DONIZETI APARECIDO LOPES FONSECA

\title{
Villa-Lobos e os metais graves sinfônicos \\ Um estudo dos elementos técnicos específicos
}

Universidade de São Paulo - Escola de Comunicação e Artes

Programa de Pós-Graduação em Artes

São Paulo, 2014 
Villa-Lobos e os metais graves sinfônicos:

Um estudo dos elementos técnicos específicos

Universidade de São Paulo

Escola de Comunicação e Artes 


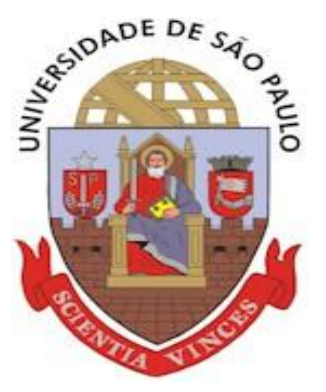

\section{UNIVERSIDADE DE SÃO PAULO}

ESCOLA DE COMUNICAÇÃO E ARTES

PROGRAMA DE PÓS-GRADUAÇÃo EM MÚSICA

PROCESSOS DE CRIAÇÃO MUSICAL

DONIZETI APARECIDO LOPES FONSECA

\section{Villa-Lobos e os metais graves sinfônicos}

Um estudo dos elementos técnicos específicos

Tese apresentada ao Programa de Pós-Graduação em Música da Universidade de São Paulo como exigência parcial obtenção do título de Doutor em Música - área de Processos de Criação Musical, sob a orientação do Prof. Dr. Gilmar Roberto Jardim

\section{Versão Corrigida}

(versão original disponível na biblioteca da Escola de Comunicação e Artes e na Biblioteca Digital de Teses e Dissertações da USP)

\section{São Paulo}




\section{FOLHA DE APROVAÇÃO}

\section{DONIZETI APARECIDO LOPES FONSECA}

Villa-Lobos e os metais graves sinfônicos - Um estudo dos elementos técnicos específicos

Tese apresentada ao Programa de PósGraduação em Música da Universidade de São Paulo como exigência parcial obtenção do título de Doutor em Música - área de Processos de Criação Musical, sob a orientação do Prof. Dr. Gilmar Roberto Jardim

Data da aprovação: 09/05/2014.

Prof. Dr. Gilmar Roberto Jardim

Prof. Dr. Marcos Branda Lacerda

Prof. Dr. Michael Kenneth Alpert

Prof. Dr. Carlos Afonso Sulpicio

Prof. Dr. Paulo José de Siqueira Tiné 


\section{AGRADECIMENTOS}

À minha querida Silvana e aos meus filhos Felipe e Julia, pelo respeito, o incentivo e o carinho; pelas inúmeras vezes que me ouviram discutir sem se aborrecer; pela compreensão da importância desta etapa na minha vida.

Ao meu orientador, Prof. Dr. Gilmar Roberto Jardim, pelas oportunidades oferecidas nos projetos sob sua tutela, pela orientação na pesquisa, pela discussão dos dados, pelas valiosas sugestões e por me acolher sempre.

Aos professores do Departamento de Música da ECA-USP, por acreditarem em minha proposta; por abrirem as portas do departamento e me receberem com respeito; por colaborarem na viabilização desta pesquisa.

A todos os meus amigos, em especial à Lúcia, que leram, palpitaram e ajudaram na elaboração deste material; pela leitura e correção deste trabalho; pelas inúmeras discussões e luzes lançadas no meu processo reflexivo, pelo apoio em todas as situações, pelo carinho e o incentivo.

A todos os alunos que estão sob minha orientação, por me ouvirem horas e horas discorrendo sobre o mundo villalobiano, por me questionarem e me incitarem à pesquisa.

A todos aqueles que, com o suor e dedicação possibilitaram a alguém estudar, refletir e escrever. 


\section{RESUMO}

A produção orquestral de Villa-Lobos é indubitavelmente grandiosa e exuberante, confrontando a nós músicos, desafios de ordem técnica e interpretativa. Este trabalho discutirá sobre algumas das partes destinadas aos metais graves e suas possíveis soluções técnicas. Escolheram-se oito peças sinfônicas de palco na intenção de se tabular uma amostra razoável dessa faceta composicional de Villa-Lobos. As sugestões interpretativas serão embasadas em análises de autógrafos e suas edições, visualizadas por meio de trechos das partes orquestrais e corroboradas por uma revisão atualizada da literatura, propondo que se busque uma compreensão maior sobre as ferramentas expressivas oferecidas ao intérprete de metal grave, inserindo-o dentro da dialética villalobiana.

Palavras-Chave: Heitor Villa-Lobos; Trombone; Orquestra Sinfônica; Interpretação; Trecho orquestral. 


\section{ABSTRACT}

The orchestral production of Villa-Lobos is certainly grand and lush. It is confronting us musicians in a technical and interpretive challenges order. This doctoral essay will discuss some of the parts composed for low brass and their possible technical solutions. It was chose eight symphonic pieces in order to major measure a reasonable sample of the compositional facet of Villa-Lobos. Interpretation suggestions are based on solid analysis from autograph and their issues, visualized by means of excerpts from the orchestral and supported by an updated literature review parts, proposing to seek a greater understanding of the expressive tools offered to low brass musician and inserting them inside of the villalobiana's dialectic.

Key words: Heitor Villa-Lobos; Trombone; Symphony Orchestra; Interpretation; Orchestral excerpts. 


\section{SUMÁRIO}

Resumo

\section{PRIMEIRA PARTE}

\section{FUNDAMENTAÇÃO E CONTEXTUALIZAÇÃO TEÓRICA, PRAGMÁTICA E METODOLÓGICA DO ESTUDO}

\section{CAPÍTULO 1 - FUNDAMENTAÇÃO TEÓRICA}

1.1 Discussão do tema: A técnica instrumental nos metais graves

1.2 Discussão do tema: Construção da interpretação

\section{CAPÍTULO 2 - CONTEXTUALIZAÇÃO METODOLÓGICA DO ESTUDO}

Introdução

2.1 Técnica de pesquisa: questionários semiestruturados

2.2 Construção do modelo analítico

2.3 Escolha e critérios utilizados para a seleção das obras e dos participantes

2.3.1 Escolha e critérios para a seleção das obras

2.3.2. Escolha e critérios para a seleção dos participantes

2.4. Procedimentos de coleta dos dados

2.5. Procedimentos de análise dos dados

\section{CAPÍTULO 3 - TRABALHOS SIMILARES}

A escassez de pesquisas relacionadas à temática e aos metais graves

\section{CAPÍTULO 4 - CONTEXTUALIZAÇÃO HISTÓRICA}

4.1 - Apresentação

\section{SEGUNDA PARTE}

APRECIAÇÃO CONTEXTUALIZADA DE OBRAS DE VILLA-LOBOS ABORDAGENS DE CARÁTER ANALÍTICO E RESULTADOS ABORDAGENS TÉCNICAS E COMENTÁRIOS SOBRE OS TRECHOS ESCOLHIDOS

$5.1-$ Balés 
Villa-Lobos e os metais graves sinfônicos:

Um estudo dos elementos técnicos específicos

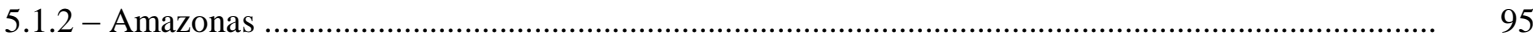

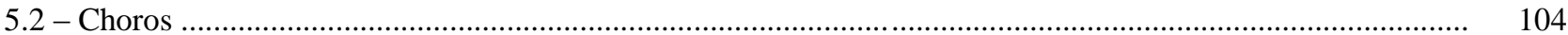

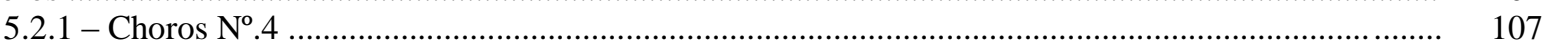

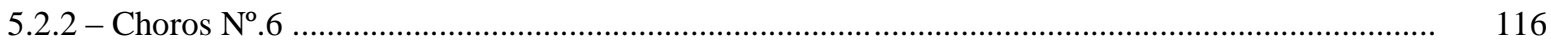

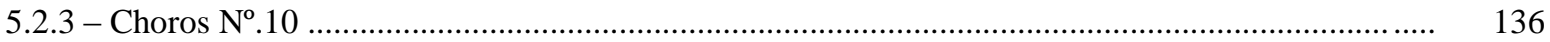

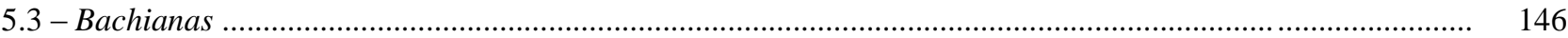

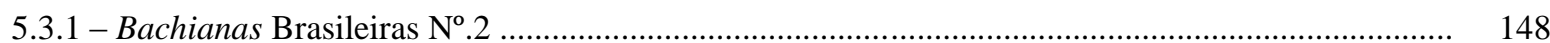

5.4 - Concerto

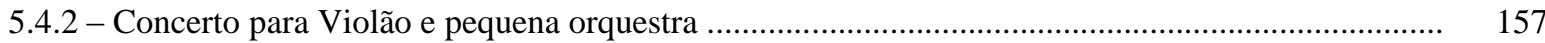

5.5 - Sinfonia ......................1.

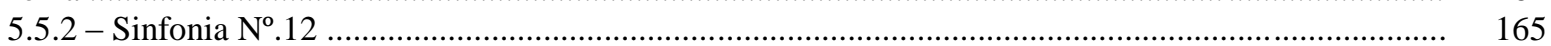

\section{CAPÍTULO 6 - ABORDAGENS DE CARÁTER ANALÍTICO E RESULTADOS}

Introdução

6.1 - Utilização dos metais graves nas peças analisadas

6.2 - Dinâmicas grafadas para os metais graves nas peças analisadas

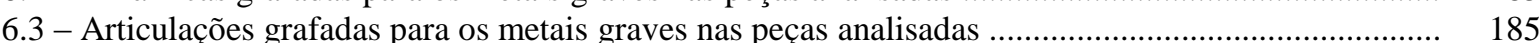

6.4 - Extensão melódica dos metais graves nas peças analisadas ........................................................... 186

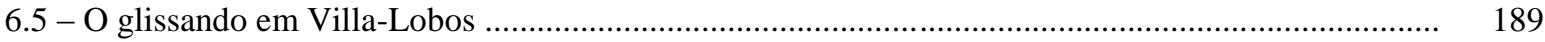

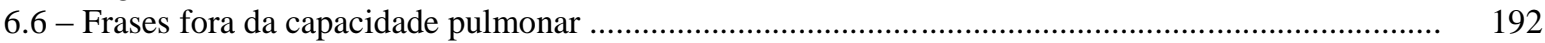

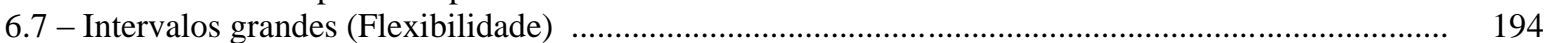

\section{CAPÍTULO 7 - ABORDAGENS TÉCNICAS E COMENTÁRIOS SOBRE OS TRECHOS ESCOLHDOS}

7.1 - Abordagens técnicas

7.1.1 - Extensão melódica …........................................................................................... 198

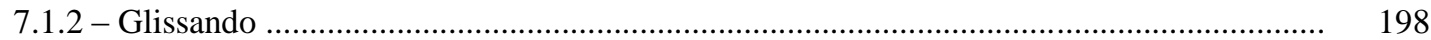

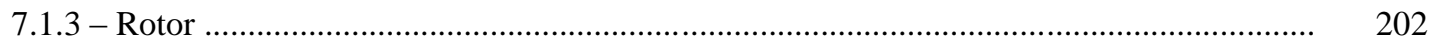

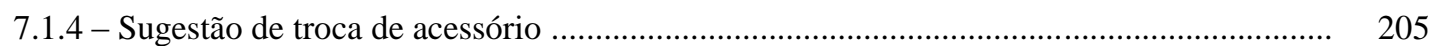

7.2 - Comentários sobre os trechos escolhidos

7.2.1 - Trechos para Trombone tenor ............................................................................... 206

7.2.2 - Trechos para Trombone baixo .............................................................................. 269

7.2 .3 - Trechos para Tuba …..................................................................................... 290

\section{TERCEIRA PARTE}

\section{CONSIDERAÇÕES FINAIS}

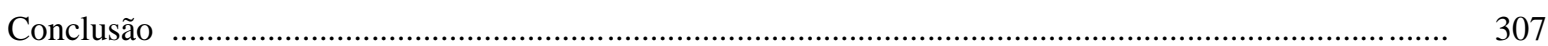

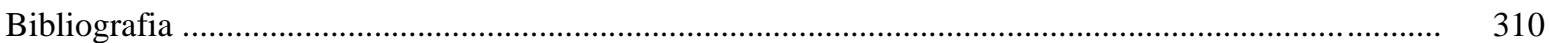

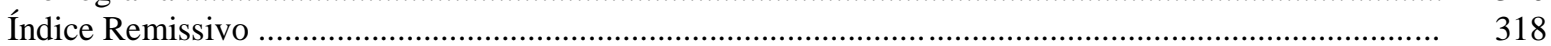

Trechos orquestrais para trombone e tuba

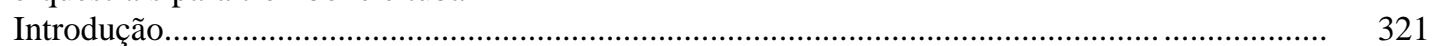

Trechos orquestrais para trombone e tuba ...................................................................... 325

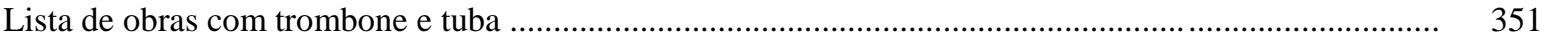




\section{Definição de termos}

Para a localização e definição das notas da extensão melódica utilizada pelo compositor para os instrumentos trombone e a tuba, adotaremos o seguinte esquema:

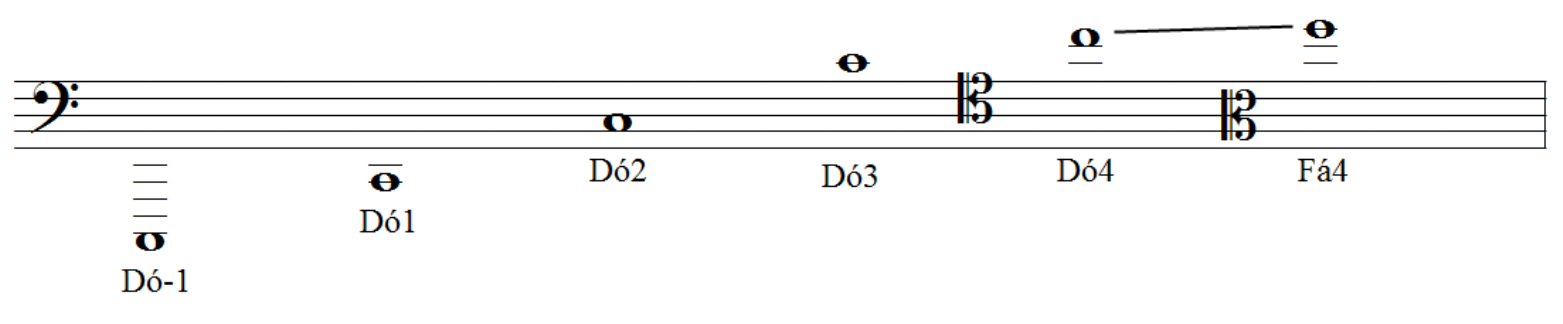

Será considerado o Dó central o Dó 3.

A localização dos trechos é definida pelas abreviaturas: c. (número de compassos) e n. (número de ensaios). Para trechos que não coincidem com números de ensaio, definimos a expressão (n. \pm x), onde “+” são os compassos após n. e "-” são os compassos anteriores à n.. " $\mathrm{x}$ " representa a quantidade de compassos anteriores ou posteriores ao número de ensaio de referência. No Choros $n^{\circ} 10$ observamos letras de ensaio e para manter o procedimento representamos por (n. \pm Letra).

No corpo do texto os exemplos mostram trechos extraídos da parte original. As alterações decorrentes das sugestões interpretativas encontram-se no Anexo - Trechos Orquestrais para Trombone e Tuba. 


\section{ABREVIATURAS}

I. - primeiro

II. - segundo

III. - terceiro

Aprox. - aproximado (a)

aum. - aumentada

$\mathbf{B x}$ - baixo

bras. - brasileira

C. - compasso

Ex. - Exemplo

EUA - Estados Unidos

Fig. - Figura

Gliss. - Glissando

Orq. - orquestra

p/ - para

Pos. - posição

Reg. - regência

Séc. - século

Tab. - Tabela

Tbn - Trombone tenor

Tbx - Trombone baixo

Ten. - tenor

Mov. - movimento 


\section{Lista de Figuras}

Fig. $1 \quad$ - $\quad$ Bartók: Mandarim Maravilhoso

Fig. 2 - Stravinsky: Pássaro de Fogo

Fig. $3 \quad$ - Debussy, Claude: Ibéria

Fig. $4 \quad$ - $\quad$ Bartók: Concerto para Orquestra

Fig. $5 \quad$ - Kodály: HaryJanos

Fig. 6 - Posições no Trombone sem e com o rotor

Fig. $7 \quad-\quad$ Villa-Lobos

Fig. $8 \quad$ - $\quad$ Quadro da Semana de Arte de 22.

Fig. $9 \quad$ - $\quad$ Diploma da Legião de Honra, 1955.

Fig. $10 \quad$ - Capa da partitura original de Uirapurú

Fig. $11 \quad$ - $\quad$ Contracapa da partitura original de Uirapurú

Fig. 12 - Joaquim A. S. Calado

Fig. $13 \quad$ - $\quad$ Ernesto Nazareth

Fig. $14 \quad$ - Viriato F. Silva

Fig. $15 \quad$ - $\quad$ Quincas Laranjeiras

Fig. $16 \quad-\quad$ Capa da partitura original de Choros $N^{\circ} 4$

Fig. $17 \quad-\quad$ Capa da partitura de Bachianas brasileiras $\mathrm{N}^{\circ} .2$

Fig. $18 \quad-\quad$ Copia manuscrita para Trenzinho Caipira - trombone

Fig. $19 \quad-\quad$ Sinfonia $\mathrm{N}^{\circ} .12$ - manuscrito

Fig. 20 - $\quad$ foto de um trombone baixo, marca Conn

Fig. $21 \quad-\quad$ Trombone baixo datado de 1920

Fig. $22 \quad-\quad$ Trombones em 1926.

Fig. $23 \quad-\quad$ Naipe de Trombones em 1920. 


\section{Lista de Tabelas}

Tab. $1 \quad$ - Configuração da Base de Dados das Peças

Tab. 2 - Instrumentação para Uirapurú

Tab. 3 - Instrumentação para Amazonas

Tab. $4 \quad$ - $\quad$ Instrumentação para Choros $N^{o} .4$

Tab. $5 \quad-\quad$ Estrutura Choros $N^{o} .6$

Tab. $6 \quad$ - Instrumentação para Choros $N^{o} .6$

Tab. $7 \quad-\quad$ Instrumentação para Choros $N^{o} .10$

Tab. $8 \quad-\quad$ Instrumentação para Bachianas brasileiras $N^{o} .2$

Tab. $9 \quad$ - $\quad$ Utilização do Trombone nas Bachianas $N^{o} .2$

Tab. 10 - Instrumentação para Concerto para Violão e Pequena Orquestra

Tab. $11 \quad$ - $\quad$ Instrumentação para Sinfonia $N^{o} 12$

Tab. $12 \quad$ - $\quad$ Utilização dos metais graves nas peças analisadas

Tab. $13 \quad$ - $\quad$ Dinâmicas grafadas para os metais graves nas peças analisadas

Tab. $14 \quad$ - $\quad$ Articulações grafadas para os metais graves nas peças analisadas 


\section{Lista de Exemplos Musicais}

Ex. 1- Uirapurú c. 1

Ex. 2- Uirapurú c. 18

Ex. 3- Uirapurú c. 25-48

Ex. 4- Uirapurú c. 29, 32 e 33.

Ex. 5- Uirapurú c. 144-146

Ex. 6 - Uirapurú c. 147

Ex. 7 - Uirapurú c. 153

Ex. 8 - Uirapurú c. 230

Ex. 9 - Uirapurú c. 239-256

Ex. 10 - Uirapurú c. 290-327

Ex. 11 - Uirapurú c. 354-355

Ex. 12 - Uirapurú c. 350-356

Ex. 13 - Uirapurú c. 362-364

Ex. 14 - Amazonas c. 6

Ex. 15 - Amazonas c. 8

Ex. 16 - Amazonas c. 24

Ex. 17 - Amazonas c. 28

Ex. 18 - Amazonas c. 37

Ex. 19 - Amazonas c. 81

Ex. 20 - Amazonas c. 89

Ex. 21 - Amazonas c. 93

Ex. 22 - Amazonas c. 127

Ex. 23 -Amazonas c. 150

Ex. 24 -Amazonas c. 269

Ex. 25 - Amazonas c. 286

Ex. 26 - Amazonas c. 289

Ex. 27 - Amazonas c. 317

Ex. 28 - Amazonas c. 330

Ex. 29 -Choros $N^{o} .4$ c. 2-4

Ex. 30 - Choros $N^{o} .4$ c. 7-9

Ex. 31 -Choros $N^{o} .4$ c. 11-12
Ex. 32 -Choros $N^{o} .4$ c. 13-19

Ex. 33 -Choros $N^{o} .4$ c. $22-25$

Ex. 34 -Choros $N^{o} .4$ c. $28-36$

Ex. 35 -Choros $N^{o} .4$ c. $37-40$

Ex. 36 - Choros $N^{o} .4$ c. 41-42

Ex. 37 -Choros $N^{o} .4$ c. $43-45$

Ex. 38 - Choros $N^{o} .4$ c. $46-51$

Ex. 39 -Choros $N^{o} .4$ c. 54-57

Ex. 40 - Choros $N^{o} .4$ c. $58-61$

Ex. 41 -Choros $N^{o} .4$ c. $62-63$

Ex. 42 -Choros $N^{o} .4$ c. $65-66$

Ex. 43 -Choros $N^{o} .4$ c. $69-70$

Ex. 44 -Choros $N^{o} .4$ c. 81-82

Ex. 45 -Choros $N^{o} .4$ c. 83

Ex. 46 - Choros $N^{o} .4$ c. $87-89$ e $99-101$

Ex. 47 -Choros $N^{o} .4$ c. $92-95$

Ex. 48 -Choros $N^{o} .4$ c. $102-104$

Ex. 49 - Choros $N^{o} .4$ c. 109-111

Ex. 50 - Choros $N^{o} .4$ c. 111

Ex. 51 - Choros $N^{o} .4$ c. 114

Ex. 52 - Choros $N^{o} .4$ c. $117-121$

Ex. 53 - Choros $N^{o} .6$ c.22 (n.3) entrada dos violinos

Ex. 54 - Choros $N^{o} .6$ c.23-29 (n.3)

Ex. 55 - Choros $N^{o} .6$ c. $30-33$

Ex. 56 - Choros $N^{o} .6$ c.34-37

Ex. $57-$ Choros $N^{o} .6$ c. $36-45$

Ex. 58 - Choros $N^{o} .6$ c. $34-35$

Ex. 59 - Choros $N^{o} .6$ c. $38-40$

Ex. 60 - Choros $N^{o} .6$ c. $38-41$

Ex. $61-$ Choros $N^{o} .6$ c.50-53 
Ex. $62-$ Choros $N^{o} .6$ c. $54-55$

Ex. 63 - Choros $N^{o} .6$ c.54-56

Ex. $64-$ Choros $N^{o} .6$ c. $63-65$

Ex. 65 - Choros $N^{o} .6$ c.63-65

Ex. 66 - Choros $N^{o} .6$ c. $76-78$ e c. $86-88$

Ex. $67-$ Choros $N^{o} .6$ c.90-93

Ex. 68 - Choros $N^{o} .6$ c.117-123

Ex. $69-$ Choros $N^{o} .6$ c. 126

Ex. 70 - Choros $N^{o} .6$ c. $138-144$

Ex. 71 - Choros $N^{o} .6$ c. $160-167$

Ex. 72 - Choros $N^{o} .6$ c. $168-169$

Ex. 73 - Choros $N^{o} .6$ c. $183-192$

Ex. 74 - Choros $N^{o} .6$ c.193-194

Ex. 75 - Choros $N^{o} .6$ c.205-208

Ex. 76 - Choros $N^{o} .6$ c. $217-222$

Ex. 77-Choros $N^{o} .6$ c.255-256, 257-258, 280-

281 e $281-283$

Ex. $78-$ Choros $N^{o} .6$ c.326-341

Ex. $79-$ Choros $N^{o} .6$ c. $363-364$

Ex. 80 - Choros $N^{o} .6$ c. 365

Ex. 81 - Choros $N^{o} .6$ c.409-416

Ex. 82 - Choros $N^{o} .6$ c.417-424

Ex. 83 - Choros $N^{o} .6$ c.433-441

Ex. 84 - Choros $N^{o} .6$ c. $443-448$

Ex. 85 - Choros $N^{o} .6$ c. $472-480$

Ex. 86 - Choros $N^{o} .6$ c.464-524

Ex. 87 - Choros $N^{o} .6$ c.513-519

Ex. 88 - Choros $N^{o} .6$ c.529-534

Ex. 89 - Choros $N^{o} .6$ c.617-618

Ex. 90 - Choros $N^{o} .6$ c.675-680

Ex. 91 - Choros $N^{o} .6$ c.689-696

Ex. 92 -Choros $N^{o} .6$ c.697-698
Ex. 93 - Choros $N^{o} .6$ c.755-758

Ex. 94 - Choros $N^{o} .10$ c.1-4

Ex. 95 - Choros $N^{o} .10$ c. 15-21

Ex. 96 - Choros $N^{o} .10$ c. $15-21$

Ex. 97 -Choros $N^{o} .10$ c.23-26

Ex. 98 - Choros $N^{o} .10$ c.30-31

Ex. 99 - Choros $N^{o} .10$ c.36-53

Ex. $100-$ Choros $N^{o} .10$ c.57-61

Ex. 101 - Choros $N^{o} .10$ c.64-67

Ex. $102-$ Choros $N^{o} .10$ c. $70-76$

Ex. 103 -Choros $N^{o} .10$ c.109-114

Ex. $104-$ Choros $N^{o} .10$ c.135-137

Ex. 105 -Choros $N^{o} .10$ c. 165

Ex. 106 -Choros $N^{o} .10$ c. $174-177$

Ex. 107 -Choros $N^{o} .10$ c.190-195

Ex. 108 - Choros $N^{o} .10$ c.197-202

Ex. $109-$ Choros $N^{o} .10$ c.221-228

Ex. $110-$ Choros $N^{o} .10$ c.234-237

Ex. 111 - Choros $N^{o} .10$ c.264-268

Ex. $112-$ Choros $N^{o} .10$ c.282-285

Ex. 113 - Choros $N^{o} .10$ c. $286-290$

Ex. $114-$ Choros $N^{o} .10$ c.292

Ex. 115 - Bachianas brasileiras $N^{o} .2$ - $\mathrm{I}^{\mathrm{o}}$.mov. c. $15-20$

Ex. 116 - Bachianas brasileiras $N^{o} .2$ - II $^{\circ}$. mov. c. $1-5$

Ex. 117 - Bachianas brasileiras $N^{o} .2$ - $\mathrm{II}^{\mathrm{o}}$.mov. c. $47-51$

Ex. 118 - Bachianas brasileiras $N^{o} .2$ - III'.mov. c. $3-11$

Ex. 119 - Bachianas brasileiras $N^{o} .2$ - $\mathrm{III}^{\mathrm{o}}$.mov. c. $12-20$ 
Ex. 120 - Bachianas bras. $N^{o} .2$ - c.24-29

Ex. 121 - Bachianas bras. $N^{o} .2$ - IV ${ }^{\mathrm{o}}$.mov. c. $20-21$

Ex. 122 - Bachianas bras. $N^{o} .2-\mathrm{IV}^{\mathrm{o}}$.mov. c. $24-26$

Ex. 123 - Bachianas bras. $N^{o} .2-\mathrm{IV}^{\mathrm{o}}$.mov. c. 33-34

Ex. 124 - Bachianas bras. $N^{o} .2-\mathrm{IV}^{\mathrm{o}} . \mathrm{mov} .-$ c. $41-48$

Ex. 125 - Bachianas bras. $N^{o} .2-\mathrm{IV}^{\mathrm{o}}$.mov. c. $58-62$

Ex. 126 - Bachianas bras. $N^{o} .2$ - IV $\mathrm{IV}^{\mathrm{o}}$ mov. c. $71-75$

Ex. 127 - Bachianas brasileiras $N^{o} .2$ -

IV ${ }^{\circ}$.mov. - c.101-110

Ex. 128 - Bachianas brasileiras $N^{o} .2$ -

IV ${ }^{\circ}$.mov. - c. $146-158$

Ex.129 - Concerto para Violão - I. mov. c.1

Ex.130 - Concerto p/Violão - I. mov. c.27-38

Ex. 131 - Concerto para Violão - I. mov. c.102105

Ex.132 - Concerto para Violão - I. mov. c.109112

Ex. 133 - Concerto p/Violão - I. mov. c.125

Ex. 134 - Concerto p/Violão - II.mov. c.5-16

Ex. 135 - Concerto para Violão - II.mov. c.47-

60

Ex. 136 - Concerto para Violão - II.mov. c.7880

Ex. 137 - Concerto para Violão - III. mov. c.3138

Ex. 138 - Concerto para Violão - III. mov. c.4345

Ex. 139 - Concerto para Violão - III. mov. c.5260

Ex.140 - Concerto p/Violão - III. mov. c.86-87

Ex. 141 - Concerto para Violão - III. mov. c. $102-103$
Ex. 142 - Concerto para Violão - III. mov. c. $109-114$

Ex. 143 - Concerto para Violão - III. mov. c. $127-128$

Ex.144 - Concerto para Violão - III. mov. c. $131-134$

Ex. 145 - Concerto para Violão - III. mov. c. $147-151$

Ex. 146 - Concerto para Violão - III. mov. c. $156-158$

Ex. 147 - Sinfonia $N^{o} .12$ - I. mov. c.1-3

Ex. 148 - Sinfonia $N^{o} .12$ - I. mov. c.9-20

Ex. 149 -Sinfonia $N^{o} .12$ - I. mov. c.36-40

Ex. 150 - Sinfonia $N^{o} .12$ - I. mov. c.51-57

Ex. 151 - Sinfonia $N^{o} .12$ - I. mov. c.56-64

Ex. 152 - Sinfonia $N^{o} .12$ - I. mov. c. $74-77$

Ex. 153 - Sinfonia $N^{o} .12$ - I. mov. c.84-96

Ex. 154 - Sinfonia $N^{o} .12$ - I. mov. c.90-108

Ex. 155 - Sinfonia $N^{o} .12$ - I. mov. c.110-125

Ex. 156 -Sinfonia $N^{o} .12$ - I. mov. c.142

Ex. 157 - Sinfonia $N^{o} .12$ - I. mov. c.151-152

Ex. 158 - Sinfonia $N^{o} .12$ - I. mov. c.159-160

Ex. 159 - Sinfonia $N^{o} .12$ - I. mov. c.169-174

Ex. 160 - Sinfonia $N^{o} .12$ - II. mov. c.15-24

Ex. 161 - Sinfonia $N^{o} .12$ - II. mov. c. $45-51$

Ex. 162 -Sinfonia $N^{o} .12$ - II. mov. c.61-71

Ex. 163 - Sinfonia $N^{o} .12$ - III. mov. c.43-45

Ex. 164 - Sinfonia $N^{o} .12$ - III. mov. c.57-67

Ex. 165 - Sinfonia $N^{o} .12$ - III. mov. c.78-84

Ex. 166 - Sinfonia $N^{o} .12$ - III. mov. c.93-96

Ex. 167 - Sinfonia $N^{o} .12$ - III. mov. c.125-128

Ex. 168 - Sinfonia $N^{o} .12$ - III. mov. c.165-168

Ex. 169 - Sinfonia $N^{o} .12$ - III. mov. c.200-204 
Ex. 170 - Sinfonia $N^{o} .12$ - III. mov. c.237-239

Ex. 171 - Sinfonia $N^{o} .12$ - IV. mov. c.1-8

Ex. 172 - Sinfonia $N^{o} .12$ - IV. mov. c.13-16

Ex. 173 - Sinfonia $N^{o} .12$ - IV. mov. c.33-37

Ex. 174 - Sinfonia $N^{o} .12$ - IV. mov. c.33-40

Ex. 175 - Sinfonia $N^{o} .12$ - IV. mov. c.44-46

Ex. 176 - Sinfonia $N^{o} .12$ - IV. mov. c.62-74

Ex. 177 - Sinfonia $N^{o} .12$ - IV. mov. c.97-104

Ex. 178 - Sinfonia $N^{o} .12$ - IV. mov. c.118-120

Ex. 179 - Sinfonia $N^{o} .12$ - IV. mov. c.117-121

Ex. 180 -Sinfonia $N^{o} .12$ - IV. mov. c.128-136 


\section{Lista de Quadros}

\begin{tabular}{|c|c|c|}
\hline Quadro 1 & - & Objetivos de Pesquisa \\
\hline Quadro 2 & - & Geração de Dados \\
\hline Quadro 3 & - & Peças ordenadas por data de criação \\
\hline Quadro 4 & - & Quadro comparativo entre Debussy, Stravinsky e Bartók \\
\hline Quadro 5 & - & Comparativo de composição entre Debussy, Stravinsky e Bartók \\
\hline Quadro 6 & - & Extensão melódica geral utilizada por Villa-Lobos \\
\hline Quadro 7 & - & Extensão melódica do Trombone utilizada por Villa-Lobos \\
\hline Quadro 8 & - & Extensão melódica do Trombone baixo utilizada por Villa-Lobos \\
\hline Quadro 9 & - & Extensão melódica da Tuba utilizada por Villa-Lobos \\
\hline Quadro 10 & - & Glissando em Villa-Lobos \\
\hline Quadro 11 & - & Glissandos (não lineares no êmbolo) nas peças de Villa-Lobos \\
\hline Quadro 12 & - & Frases fora da capacidade pulmonar \\
\hline Quadro 13 & - & Intervalos grandes (flexibilidade) \\
\hline Quadro 14 & - & Tabulação total dos tópicos técnicos analisados (incidência) \\
\hline Quadro 15 & - & Listagem das composições por gênero \\
\hline Quadro 16 & - & Numeral geral para cada gênero das composições \\
\hline
\end{tabular}


Villa-Lobos e os metais graves sinfônicos:

Um estudo dos elementos técnicos específicos

\section{INTRODUÇÃO}

“(...) Todo povo tem o direito de apreciar e sentir a sua arte musical, oriunda da expressão popular, mas nunca julgá-la definitiva em relação ao universo", Villa-Lobos 
Ao participar de uma orquestra sinfônica, todo trombonista ou tubista vê suas capacidades interpretativas serem postas em xeque em qualquer peça colocada em sua frente. Para amenizar essa condição de stress, um estudo prévio e direcionado de trechos orquestrais é um tópico importante do estudo individual para músicos profissionais e estudantes em todos os continentes. Professores de instrumentos orquestrais têm dedicado especial atenção a esse quesito em particular, inserindo em seus programas curriculares trechos orquestrais de preparação para concursos de ingresso nas cadeiras sinfônicas.

O trombone se efetivou na orquestra sinfônica na $5^{a}$. Sinfonia em dó menor, de Beethoven, escrita entre 1804 e 1808. No entanto, o livro mais antigo que se tem notícia, essencialmente direcionado a trechos orquestrais, foi escrito em 1957: Anthology of Symphonic and Operatic Excerpts for bass trombone, com trechos compilados por Julian Menken e editado em Nova Iorque / EUA pela editora Carl Fischer Inc. Atualmente está disponível no periódico trimestral editado pela International Trombone Association ${ }^{1}$ um capítulo especialmente dedicado a esse assunto. No entanto, em nenhuma dessas fontes se localizou trecho algum endereçado às peças de Villa-Lobos.

Com a mesma exclusão, temos:

- O volume único de Orchester-Probespiel posaune, compilado por Armin Rosin $^{2}$ e Eberhard Pleyer ${ }^{3}$, com copyright de 1993 e editado pela C. F. Peters.

- O volume único de Orchesterstudien für Solo-Posaune, compilado por Johann Doms ${ }^{4}$, Johann. com copyright de 1985 e editado na Alemanha pela Musikverlag/ Edition Johann Doms.

- Os dez volumes da coleção Orchestral Excerpts - from the Symphonic Repertoire - for trombone and tuba, compilados por Keith Brown e editados em Nova Iorque pela International Music Company.

\footnotetext{
${ }^{1}$ http://www.trombone.net/journal/

2 Trombonista na Orquestra Sinfônica de Bamberg, Rádio de Stuttgart e Staatliche Hochschule f. Musik Stuttgart.

${ }^{3}$ Trombonista na Saarländisches Staatsorchester Saarbrücken.

${ }^{4}$ Trombonista na Berliner Philharmoniker e professor na Staatlichen Hochschule de Künste, Berlin.
} 
A única exceção encontrada foi o volume único de 20th Century Orchestra Studies for trombone, compilado por Henry Charles Smith, com copyright em 1969 e editado pela $G$. Schirmer, Inc. Na página 88 pode se encontrar um exemplo da parte completa do trombone do $4^{\circ}$. Movimento das Bachianas Brasileiras $N^{o} .2$ (Trenzinho Caipira).

Em terras brasileiras, a literatura especializada que discorre sobre a relação entre Villa-Lobos e os metais graves ${ }^{5}$ se orienta pela compreensão e interpretação de atributos que favorecem ou dificultam a separação de trechos a partir de abordagens teórico-metodológicas variadas. Pelo que já foi exposto, a pesquisa por partes individuais para trombone/tuba para a construção inicial deste projeto não foi uma tarefa simples. Mesmo com pouco acesso às partes individuais, a análise empreendida não se restringiu à utilização dos resultados da investigação. A intenção final será a criação de um material que sirva de fonte básica de pesquisa, uma vez que não está disponível para aquisição individual.

Após um processo longo de digitalização das partituras originais em partes individuais para trombone e tuba - fornecidas pelo Museu Villa-Lobos -, estas foram finalmente analisadas sob o ponto de vista da execução musical. De posse das partes individuais, foi possível esclarecer, dentro da execução instrumental tópica, termos abstratos usados muitas vezes pelo compositor ou por musicólogos para orientação do caráter da peça, estabelecendo com isso uma unidade de procedimentos em relação ao universo villalobiano.

Quanto ao procedimento composicional de Villa-Lobos, amplamente analisado por musicólogos, as soluções alcançadas não carecem de reafirmações neste trabalho. Também não será possível dar contribuição alguma em relação ao campo da orquestração, tampouco da análise musical, pois o nosso foco é o da pedagogia e da participação do trombonista como músico executante dentro de grupos sinfônicos. Informamos ainda que não será propósito de nossas análises, a não ser para contextualização de questões em foco, criticar os objetivos políticos ou ainda discutir a obra pedagógica difundida por Villa-Lobos. O tema central desta pesquisa se situará em MÚSICA - TROMBONE/TUBA e o estudo escolhido é um ensaio formal musical definido.

\footnotetext{
${ }^{5}$ Entendem-se metais graves, como sendo os instrumentos de bocais grandes e nesse grupo encontraremos a família dos trombones e tubas (grifo nosso).
} 
Este trabalho terá como objetivo principal desvelar as soluções técnicas e interpretativas direcionadas aos metais graves - mais especificamente ao trombone-tenor, ao trombone-baixo e à tuba-baixo, que são exatamente os instrumentos mais utilizados em orquestras - com base nas obras sinfônicas do compositor Heitor Villa-Lobos. Todo relato contido neste trabalho diz respeito à nossa experiência pessoal neste universo técnicoinstrumental, que é exatamente a participação, como músico-instrumentista e por 34 anos, atrás de estantes de música em orquestras sinfônicas na cidade de São Paulo e pelo interior paulista. Este estudo se situa especificamente no âmbito técnico-instrumental e se discorrerá sobre os seguintes tópicos da execução: glissandos, respiração, extensão sonora e soluções rítmicas.

\begin{tabular}{|l|l|c|}
\hline \multicolumn{2}{|c|}{ OBJETIVOS DE PESQUISA } & Enfoques \\
\hline 1 & Produzir soluções técnicas e interpretativas & Pesquisa \\
\hline 2 & Investigar a existência de possíveis erros em ritmo, notas e acessórios & Pesquisa \\
\hline 3 & $\begin{array}{l}\text { Explicitar as estratégias e táticas utilizadas por trombonistas/tubistas para a } \\
\text { resolução de passagens de difícil execução }\end{array}$ & Pesquisa \\
\hline 4 & $\begin{array}{l}\text { Identificar as especialidades desses instrumentos em paralelo com outros } \\
\text { instrumentos de mesmo sistema técnico }\end{array}$ & Pesquisa \\
\hline 5 & Estabelecer uma unidade de procedimentos em tópicas & Execução \\
\hline 6 & $\begin{array}{l}\text { Distinguir entre a partitura e parte, ponderando elementos que possam afetar } \\
\text { a representatividade de uma amostra em relação à respectiva peça }\end{array}$ & Pesquisa \\
\hline 7 & Identificar e minimizar possíveis fontes que distorçam a recolha dos dados. & Pesquisa \\
\hline
\end{tabular}

QUADRO 1

A observação atenta desses objetivos revela o desafio na investigação do repertório sinfônico de Villa-Lobos, embasado numa abordagem técnica dinâmica para a qual elegeremos o caráter processual da reconstrução de estratégias de pesquisa e execução como seu principal atributo. Para tanto, uma abordagem analítico-musical irá de encontro às necessidades desses músicos, por eleger técnicas que tratem da execução de uma forma global. Atualmente são consideradas globais as técnicas específicas para cada instrumento, de 
forma que um tratamento linear feito em especial para outro compositor, em mesma época, poderá ser utilizado num estudo de Villa-Lobos.

A disponibilização das partes de estudo para músicos profissionais ou estudantes pode melhorar a execução final dessas peças em concertos ou gravações? Para a solução desta situação-problema pouco se tem feito: partes individuais para estudo não se encontram disponibilizadas pelas editoras - mesmo que em menor resolução de impressão; orquestras profissionais, mesmo possuindo essas peças em seu arquivo musical, também não as disponibilizam; e as editoras de estudos de Trechos orquestrais, que deveriam resolver o problema, não incluem estudo das peças de Villa-Lobos. Portanto, esta pesquisa se propõe a solucionar o problema de estudo das peças aqui analisadas e ainda criar um paralelo com estudos teóricos para o aprimoramento da execução final dessas peças. 
Villa-Lobos e os metais graves sinfônicos:

Um estudo dos elementos técnicos específicos

Primeira Parte:

Capítulo 1: Fundamentação Teórica

Universidade de São Paulo

Escola de Comunicação e Artes 


\subsection{DISCUSSÃO DO TEMA: A TÉCNICA INSTRUMENTAL NOS METAIS GRAVES}

Antes de iniciarmos as discussões, deixaremos claro que nossa intenção será a de explanação de dados para especialistas em Villa-Lobos e metais graves, conjuntamente. Não haverá durante o trabalho tópicos elementares, muito menos sua explanação. Para tanto, as ferramentas que suportaram esta pesquisa e utilizadas como fonte básica foram:

- Partituras fornecidas pelo Museu Villa-Lobos.

- 10 volumes Orchestral Excerpts - from the Symphonic Repertoire - for trombone and tuba da International Music Company.

- Low Brass Excerpts da Cherry Classics.

Esta pesquisa é devedora principalmente às seguintes contribuições teóricas. No campo da técnica instrumental nos metais graves, o primeiro contribuidor foi o trombonistabaixo da sinfônica de Chicago/EUA Edward Kleinhammer (The Art of Trombone Playing, 1963), que juntamente com Philip Farkas (trompa) e Arnold Jacobs (tuba) formaram a tríplice base teórica dos instrumentistas de metais, na segunda metade do século XX. Suas definições da técnica básica irão embasar todos os trabalhos feitos a posteriori como Douglas Yeo e Charles Vernon.

Kleinhammer esclareceu sobre todos os aspectos da técnica contemporânea do trombone, desde a compra até as possíveis alterações em sua estrutura, porém sua contribuição será no campo das definições sobre a técnica específica tais como extensão melódica e glissando, que nos servirão de base para comparações sobre as proposições escritas por Villa-Lobos.

Outro contribuidor importante para essa tese foi o teórico inglês Denis Wick (Trombone Technique, 1971).. Este produziu textos clássicos sobre a técnica do trombone, que juntamente com Kleinhammer completam todos os tópicos da técnica do trombone. Este nos forneceu contribuição no campo da válvula rotora e sonoridade orquestral.

O teórico norte-americano Leonard Ratner, aluno de Schoenberg e Ernest Bloch. Professor aposentado em Stanford com seus tratados em teoria de tópicas no livro Classic 
Music (1985). O embasamento para transformação da execução musical em dados para uma pesquisa nos foi fornecido por CHAFFIN e IMREH (na teoria de "prática deliberada"), Weinstein e Mayer (sobre estratégias de estudo), Susan Hallam (habilidades significativas, autoavaliação e de elaboração de estratégias de estudo para solucionar problemas técnicomusicais) e Stefan Reid (benefícios de pesquisas para estudantes de música).

\subsubsection{EXTENSÃO MELÓDICA NO ÂMBITO ORQUESTRAL}

Os extremos ou o número de notas que o trombonista / tubista deve ter habilidade em executar são dependentes da força muscular, da destreza, e do uso correto da embocadura e do sistema respiratório, segundo informou Kleinhammer (Kleinhammer, pp.45-47, 1963). Portanto, essa extensão varia de indivíduo para indivíduo. Considerando-se que o registro

médio do trombone tenor é

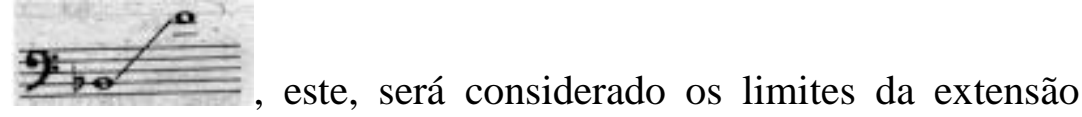
sonora do trombone tenor.

O registro agudo é a parte mais difícil da extensão a ser adquirida, mantida e tocada plenamente a qualquer momento. Nessa região estão as notas que mais dependem de força muscular e precisão extrema de embocadura. Consideraremos o registro agudo as seis notas acima do Fá3, não maiores que um intervalo de tom inteiro.

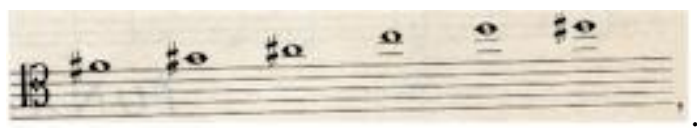

Por outro lado, elegeremos a nota Mi1 como sendo

a nota mais grave atingida por um trombone-tenor ${ }^{6}$

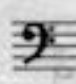

Suplantações da extensão melódica no trombone e tuba são pouco corriqueiras, mas acontecem. Exemplos desses extremos na literatura sinfônica indicam a necessidade de uma extensão ampla e prática. O exemplo mais antigo foi encontrado na $5^{a}$ Sinfonia de Beethoven, na qual a parte do primeiro trombone (possivelmente executado no trombone alto) tem como

\footnotetext{
${ }^{6}$ Trombone-tenor será aquele com afinação em sib e sem rotor em fá.
} 
nota mais aguda um Fá4

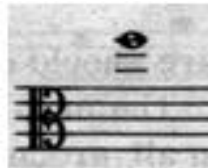

[125] de ensaio, encontramos um Mi4
quantidade de Mib4 tanto no I.Präludium no mesmo III movimento.
Encontramos um Mib4 do primeiro trombone, e na passagem do coral, em Berg/Wozzeck $2^{\circ}$, Ato $-1^{\mathrm{a}}$ cena. Há também uma passagem de solo do naipe de trombones no quarto movimento da Sinfonia Renana de Schumann. Alguns trombonista preferirão tocar essas passagens em um trombone alto para maior segurança de execução.

O trombonista-tenor também deve ter domínio de extensão extra-grave (pedal), delegada costumeiramente aos trombonistas-baixo porém utilizadas na literatura sinfônica universal. Um exemplo de extensão grave para primeiro trombone é a encontrada em Mavra, de Stravinsky, e em Prokofiev, na sua $5^{a}$ Sinfonia, na qual está grafado um Sib-1

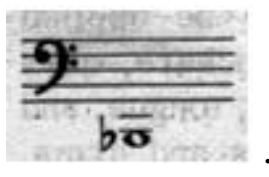

Em Berlioz / Sinfonia Fantástica está grafado um Lá-1 para o segundo trombone

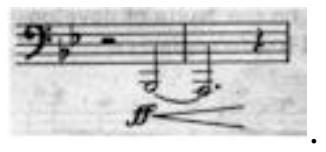

Exemplos de extensão melódica ampliada poderão ser conferidos em Also Sprach Zarathustra, de Richard Strauss, obra que requer uma extensão de Mi1 até Ré4:

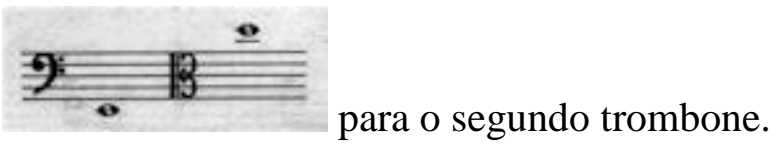


$\mathrm{Na}$ literatura orquestral para trombone baixo, a extensão atinge um Dó4

Petrouchka, de Stravinsky, e se estende na direção do grave até Fá-1 exemplo de extremos na região aguda pode ser encontrado em Berlioz / Sinfonia Fantástica $5^{\circ}$. Movimento - Ronde Du Sabbat: a $1^{\text {a }}$ tuba necessita alcançar um quase impossível Sib3

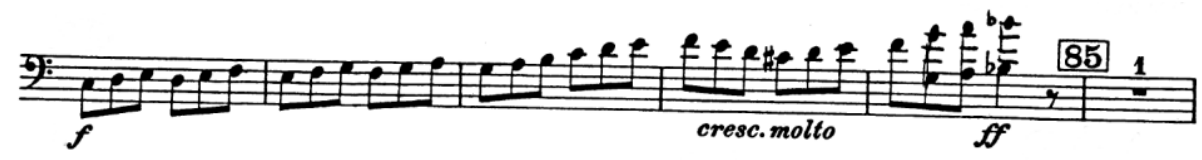

Definitivamente, a extensão de um bom primeiro trombonista deveria incluir, ao

menos Fá4
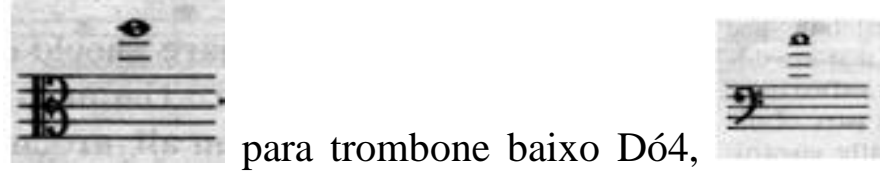

e um Sib3

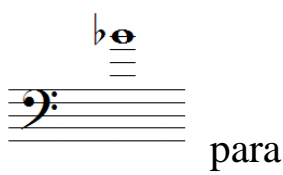

tuba. Na direção dos pedais, Lá-1

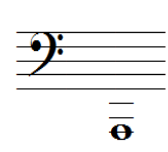

para trombone tenor, Ré-1

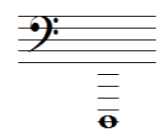

para trombone baixo e Dó-1

$\frac{\text { 9: }}{\frac{\overline{\overline{\overline{\mathbf{o}}}}}{}}$ para a tuba. 


\subsubsection{GLISSANDOS}

Todos os glissandos possíveis no trombone estão dentro das fundamentais de uma série harmônica de Sib, abaixando cromaticamente até a nota mi. No caso da existência de uma válvula rotativa, haverá mais opção para a melhora desse glissando enganoso. Um bom exemplo é a passagem escrita para trombone baixo no Mandarim Milagroso, de Bartók:

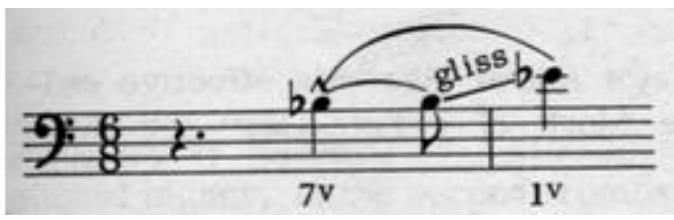

Fig. 1 - Bartók: Mandarin Maravilhoso

Um glissando completo só será possível quando todas as frequências entre duas notas grafadas puderem ser tocadas em um único modo de ressonância ou com um único movimento do êmbolo. Caso queira, o compositor pode escrever completamente o glissando dentro do tempo:

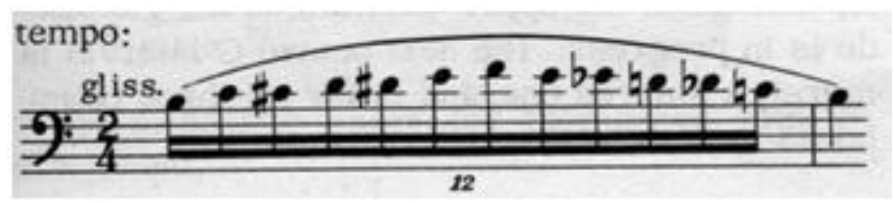

Porém, se a grafia dos glissandos for menos significante, a escrita será a seguinte:

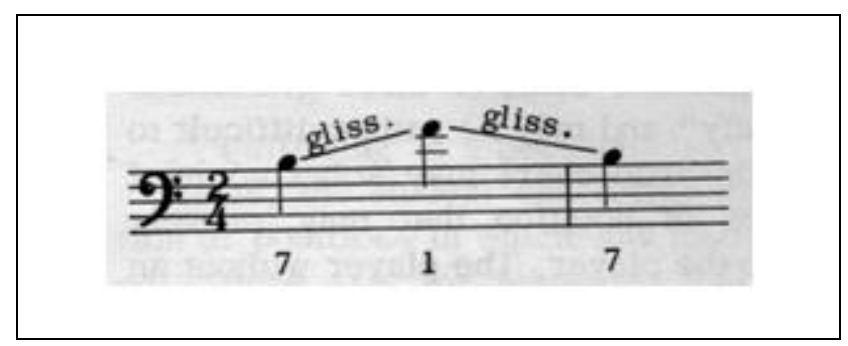

Segundo Kleinhammer: "No trombone é possível se executar um glissando de até $4^{\mathrm{a}}$ aum. Isso é devido aos atributos do sistema de êmbolo do trombone. Acima desse intervalo, considera-se um engano acometido por compositores ou maestros, que esperam o impossível; será necessária uma atuação ‘falsa’ com a ajuda do lábio”. (Kleinhammer, 1963 p. 63). 
A seguir, alguns glissandos existentes na literatura orquestral universal:
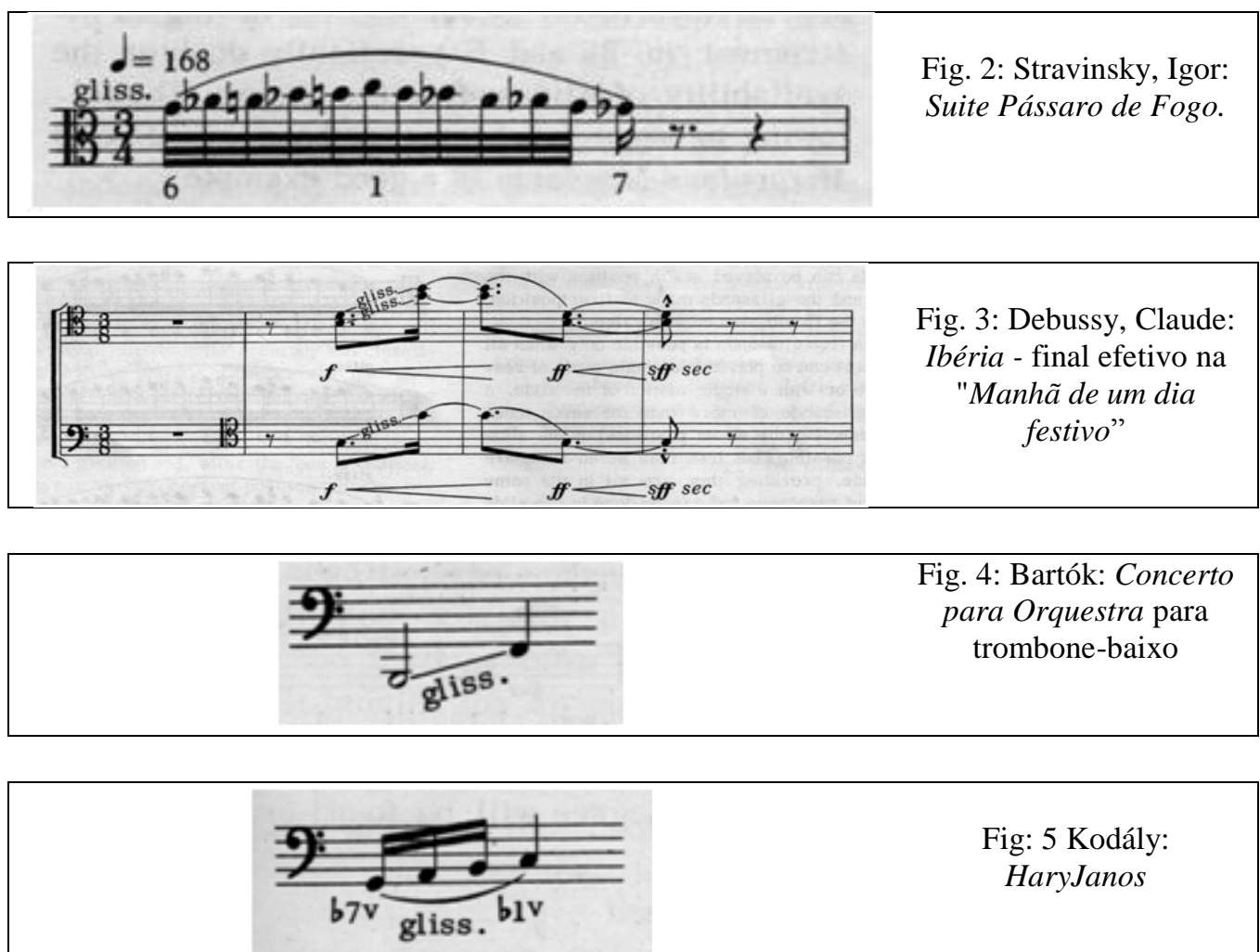

Fig: 5 Kodály:

HaryJanos

\subsubsection{Dimensões e rotor no trombone}

Segundo Wick (1971, p. 1), os anos imediatamente após a Segunda Guerra Mundial trouxeram uma mudança de estilo não só na execução como, mais importante ainda, no equipamento usado pelos naipes de trombone das orquestras sinfônicas. Até então, os instrumentos que se encontraram em uso por, no mínimo, meio século, possuíam um calibre muito pequeno ( 0.450 de polegada), com campanas pequenas de aproximadamente 6.5 polegadas para os $1^{\circ}$ s e $2^{\circ}$ s trombones; Além disso, tínhamos o trombone-baixo em "Sol". Em consequência desse quadro não soavam com clareza as dinâmicas "pp".

O primeiro estágio na revolução na maneira de se tocar trombone na Europa foi a aceitação de instrumentos de calibres maiores. Pelos meados dos anos de 1950, os novos trombones de grande calibre entraram em uso por causa de sua sonoridade mais ampla. As 
tubas pequenas afinadas em "Fá" foram substituídas, nos idos de 1960, pelas tubas afinadas em Dó de grande calibre. Há tantas e diferentes exigências ou requisitos de estilo no trombone sinfônico moderno que é necessário que o músico se interaja dessas mudanças e as incorpore.

A invenção da válvula rotativa e sua adoção na Europa Central do séc. XIX tornou o trombone, segundo Wick (Trombone Technique, pp.70-73), em "Sib" e "Fá" aceito por todos e um desenvolvimento natural. A tubulação Fá é acrescentada ao tubo principal do instrumento acionando a válvula rotativa por meio do polegar da mão esquerda. Com o advento da válvula rotora, o trombone tenor se tornou hábil a executar mais 4 notas na direção grave:

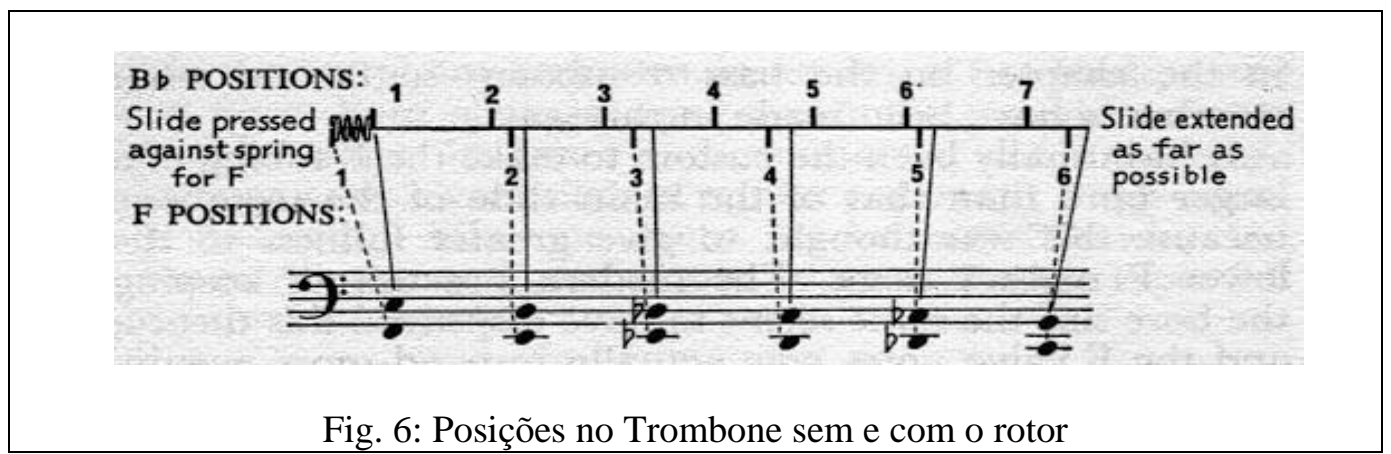

A válvula em "Fá" será mais útil se utilizada abaixo do Fá2 e evita-se usá-la acima dessa extensão.

\subsection{4 . Respiração contínua ou circular}

Respiração circular é uma técnica usada por músicos de sopro para produzir notas contínuas, sem interrupção. Isso é possível através da respiração nasal, enquanto, simultaneamente, empurra-se o ar para fora através da boca, utilizando o ar armazenado nas bochechas.

No séc. XIII, fabricantes asiáticos de joias, especializados em ouro e prata, usaram técnicas de respiração circular para a elaboração de vários artigos decorativos e ornamentais. Na elaboração desses itens, os artesãos foram obrigados a soprar continuamente para a chama através de um tubo com uma agulha e buracos, a fim de fundir o metal duro e amolecê-lo. A partir dessa necessidade, passaram a dominar um sistema circular de 
respiração, inspirando simultaneamente através do nariz enquanto assopravam para o processo de fundição, sem qualquer pausa. A introdução da técnica de respiração circular na arte dos instrumentistas de sopro antigos era uma invenção produtiva na sua realização técnica ${ }^{7}$.

Há vários instrumentistas que se utilizam dessa técnica. Podemos citar: o oriental Zurna, o mongol limbe, os sardos launeddas, o egípcio arghul, o australiano didgeridoo, assim como muitos oboés e flautas tradicionais da Ásia e do Oriente Médio. Apesar de muitos músicos de sopro não reconhecerem a respiração circular com sendo de grande utilidade, alguns trechos musicais compostos antes do séc. XX só são possíveis mediante sua utilização.

A técnica específica informa que o músico deve respirar normalmente, porém, quando os pulmões estiverem quase vazios, o último volume de ar é soprado para dentro da boca, ficando armazenado nas bochechas. As bochechas devem ser comprimidas para o ar sair na direção dos lábios, enquanto o músico rapidamente enche os pulmões pela inalação através do nariz. Essencialmente, a respiração circular preenche a lacuna entre as exalações.

\subsection{5 . Flexibilidade extrema}

Flexibilidade é uma técnica usada por instrumentistas de bocal que possibilita a execução de um intervalo grande em uma fração curta de tempo. Segundo a afirmação de Samuel Woodhead ${ }^{8}$, em seu artigo "Pershing's $O w n^{\prime}$, existem vários livros da técnica do trombone ou tuba que fornecem exemplos de flexibilidade, mas é importante o reconhecimento das fraquezas e dos limites de qualquer trombonista ou tubista. Uma falha corriqueira é a tendência de se fazer a progressão de uma nota grave para outra muito aguda, ou seja, intervalos maiores que uma $8 \mathrm{~J}$ - o deslocamento da embocadura pode comprometer o restante da frase.

\footnotetext{
${ }^{7}$ Moschner. S. Circular Breathing A New Approach

8 http://iss.schoolwires.com/cms/lib4/NC01000579/Centricity/Domain/3261/TromboneRangeExtension-1.pdf (acessado em 21/01/2014).
} 


\title{
1.2 DISCUSSÃO DO TEMA: CONSTRUÇÃO DA INTERPRETAÇÃO
}

Alf Gabrielsson (2003) mostra que as primeiras pesquisas na área da interpretação musical só aconteceram por volta de 1900. Destaca que somente na última metade do séc. $\mathrm{XX}$, com o estudo da psicologia cognitiva, pesquisas empíricas sobre essa temática foram desenvolvidas. Com isso, pôde-se entender melhor como os músicos se preparavam para tocar e, finalmente, comprovar que a excelência musical pode ser conquistada. Para Chaffin e Lemieux (2004), o nível de excelência de uma execução musical está diretamente relacionado à quantidade e à qualidade de tempo aplicado em sua elaboração.

Uma prática eficaz não é simplesmente uma questão de repetição. O exercício repetido de uma habilidade, ainda que para fins profissionais, não conduz necessariamente a uma melhoria. $\mathrm{O}$ desenvolvimento de habilidades para num plano estável quando o desempenho atinge o nível necessário para fazer o trabalho. Melhoria exige incentivo adicional para motivar o trabalho árduo necessário (BRYAN e HARTER, 1897, p. 1899 apud CHAFFIN e IMREH, 2001, p.40) ${ }^{9}$.

A melhora de uma execução musical exige a definição de objetivos específicos e adequados ao nível de habilidade que conduziu ao desenvolvimento de estratégias eficazes. $\mathrm{O}$ progresso deve ser monitorado e novas rotas para a melhoria devem ser continuamente exploradas, sendo esse um trabalho caracterizado como "prática deliberada" (ERICSSON et al., 1993 apud CHAFFIN e IMREH, 2001, p.40).

Chaffin e Imreh mostram que autores como Ericsson et al. (1993), Ericsson e Charness (1994), Howe (1990) e Sloboda (1996) acreditam que a prática deliberada

\begin{abstract}
é essencial para o desenvolvimento de altos níveis de habilidade em qualquer área das ciências humanas. Em todas as áreas da realização humana que têm sido pesquisadas, as biografias daqueles que alcançaram eminência indicaram que no mínimo dez anos de prática intensiva precederam as conquistas que os tornaram famosos (CHAFFIN e IMREH, 2001, p.39) ${ }^{10}$.
\end{abstract}

Chaffin e Lemieux (2004) acreditam que organizar uma execução musical é uma tarefa complexa e que as habilidades necessárias para essa preparação são desenvolvidas ao

\footnotetext{
${ }^{9}$ Effective practice is not simply a matter of repetition. The repeated exercise of a skill, even for professional purposes, does not necessarily lead to improvement. Skill development typically stops at as table plateau when performance reaches the level required to get the job done. Further improvement requires some additional incentive to motivate the hard work required.

${ }^{10}$ Deliberate practice is essential for the development of high levels of skill in any field. In every area of human achievement that has been examined, the biographies of those who have attained eminence indicate that a minimum of ten years of intensive practice preceded the achievements that made them famous.
} 
longo de muitos anos de prática musical. Aaron Williamon (2004) complementa que é inevitável uma combinação entre empenho mental e físico para um estudo mais proveitoso, o qual cria estratégias de estudo, maximizando o tempo de estudo.

Partindo da definição feita por Weinstein e Mayer (1986) sobre "estratégias de estudo", Harald Jorgensen (2004) as define como:

pensamentos e comportamentos que os músicos realizam durante a prática e que se destinam a influenciar o seu estado motivacional ou afetivo, ou a maneira em que selecionam, organizam, integram e ensaiam novos conhecimentos e habilidades. (JORGENSEN, 2004, p.85) ${ }^{11}$.

A capacidade de detectar e corrigir erros é uma habilidade de extrema importância para o músico, visto que somente com essa identificação é que se desenvolverá as habilidades necessárias sua correção. Susan Hallam (2001) mostra que os músicos são capazes de desenvolver habilidades significativas, assim como de se auto avaliar e de elaborar estratégias de estudo para solucionar problemas técnico-musicais. As estratégias de estudo, segundo Jorgensen (2004), são normalmente aplicadas pelos músicos de uma maneira consciente; entretanto, podem ser empregadas automaticamente por meio das repetições, mostrando assim que o tempo de estudo é bastante influente na aplicação de estratégias para a solução de problemas e/ou dificuldades.

Em outras pesquisas, Hallam (1995a, 1995b apud CHAFFIN e LOGAN, 2006, p.114) mostra que músicos experientes demonstram um entendimento mais específico dos fatores que determinam as suas decisões durante o estudo. Por outro, as informações obtidas por meio de pesquisas revelam que essa expertise gerariam um banco de dados fundamental à uma melhor interpretação.

Com isso, passamos a perceber que o emprego dessas estratégias de estudo de forma consciente é um fator determinante para um músico de excelência, considerando que esse apresenta mais informações sobre as suas dificuldades e habilidades e, consequentemente, maior capacidade de utilização dessas estratégias para facilitar a preparação de uma execução

\footnotetext{
11 thoughts and behaviors that musicians engage in during practice that are intended to influence their motivational or affective state, or the way in which they select, organize, integrate, and rehearse new knowledge and skills.
} 
musical. Stefan Reid (2006) mostra que estudantes e músicos amadores são beneficiados por pesquisas que versem sobre o trabalho de músicos profissionais e professores de instrumento, induzindo-os a uma real concentração durante seu estudo individual, tornando-a dessa forma ainda mais produtiva ao final da seção.

Entendemos que para se tornar um músico de excelência, o músico deve ter a seu dispor as técnicas e estratégias necessárias para um estudo eficaz. Dessa forma, ao entender melhor nossas próprias características, identificando e analisando as estratégias utilizadas por outros, é possível que a nossa compreensão sobre técnicas do instrumento, e até mesmo sobre a parte pedagógica, sejam ampliadas. Reid (2006) explica que, mesmo sabendo que as maneiras de estudar de um músico evoluem ao longo dos anos, enriquecendo assim a sua experiência musical, não é incomum observar que diferentes músicos apresentam diferentes formas de praticar o mesmo instrumento, especialmente na construção interpretativa. Compreendemos, portanto, que, se observarmos apenas um músico, não poderemos ter uma visão diferenciada de diferentes maneiras de se estudar o instrumento e de construir uma execução musical.

Nossos questionamentos são os seguintes: Quais são as estratégias de estudo utilizadas por trombonistas ou tubistas que atuam em orquestras ou bandas sinfônicas? Os modelos que foram construídos em outras pesquisas sobre planejamento da execução musical são válidos para este trabalho? As estratégias são as mesmas, apesar do trombone e tuba serem distintos, ou existem diferenças?

Sendo assim, a presente pesquisa tem como objetivo geral compreender o processo de construção de uma execução musical por meio da observação do estudo de músicos de orquestras brasileiras, além de objetivos específicos, como entender como esses músicos estudam e preparam suas execuções, investigar as estratégias que cada um utiliza durante o seu estudo preparatório e também descrever como se cria um arquétipo para a construção da interpretação musical individualmente.

Nossa proposta não é a de comparar estudos de diferentes músicos, mas sim entender como cada um, a sua maneira, constrói sua execução musical para que possamos entender esse processo interpretativo musical. 
Villa-Lobos e os metais graves sinfônicos:

Um estudo dos elementos técnicos específicos

Capítulo 2:

PROCEDIMENTOS METODOLÓGICOS

Universidade de São Paulo

Escola de Comunicação e Artes 


\section{INTRODUÇÃO}

A metodologia utilizada nesta pesquisa foi construída estrategicamente de modo paulatino, desde o momento do planejamento da proposta até o instante no qual os resultados foram postos em planilha. Isso não significou que os questionamentos, o objeto de investigação, se esgotaram; afinal, o conhecimento é sempre inacabado, construído continuamente. Procuramos adotar uma abordagem que considerasse a investigação como inserida em um processo técnico-musical mais amplo, ressaltando a complexidade das relações técnicas nos diferentes momentos da execução.

Sob o ponto de vista do delineamento metodológico, a presente pesquisa abordará perspectivas do estudo individual do músico induzido por pontos técnicos previamente relatados. Houve ainda a nossa interferência na investigação, pois interagimos com o objeto desta pesquisa há 34 anos. Dessa forma, preferimos o método indutivo, exploratório e descritivo dos dados reais e fiáveis, ferramenta utilizada na observação da execução individual e transcrição documental para a planilha.

Os dados inicialmente adquiridos alimentarão a pesquisa e foram obtidos em dois planos de análise: os momentos da relação e a apropriação dos resultados da investigação. No que diz respeito ao primeiro plano, os dois momentos da relação foram identificados - a elaboração do projeto de pesquisa e seu desenvolvimento - e apresentados à luz de variáveis na busca desses instrumentos nas peças determinadas, igualmente, da atuação dessas dentro da composição e das formas de relacionamento entre os aspectos técnicos de execução que acabaram por influenciar os rumos da pesquisa. Quanto ao segundo - a apropriação de resultados da pesquisa -, as especificidades do projeto em questão exigiram a proposição de um modelo analítico que considerasse, por um lado, os diferentes tipos de resultados que a pesquisa poderia aportar e, por outro, os condicionantes da relação entre as peças investigadas e os trechos que podem influenciar a apropriação (ou não) dos resultados.

Tendo por base os escritos das pesquisadoras Cristina Gerling e Regina Santos, que afirmam que "a pesquisa se direciona para o universo amostrado, o tamanho da amostra, a forma de coleta, o tratamento dos dados. A coleta de dados, na dimensão qualitativa, pode ser realizada a partir do relato das experiências dos participantes, que descrevem seus processos 
de prática instrumental, os problemas e as soluções provenientes da própria experiência, sua compreensão do texto musical" (GERLING e SANTOS, 2010, p.100). Para compreendermos melhor o percurso metodológico construído, criamos dois agrupamentos para os dados produzidos na investigação focalizada: "dados aproveitados" e "dados produzidos". A Tab. abaixo representa tais agrupamentos:

\section{GERAÇÃO DE DADOS}

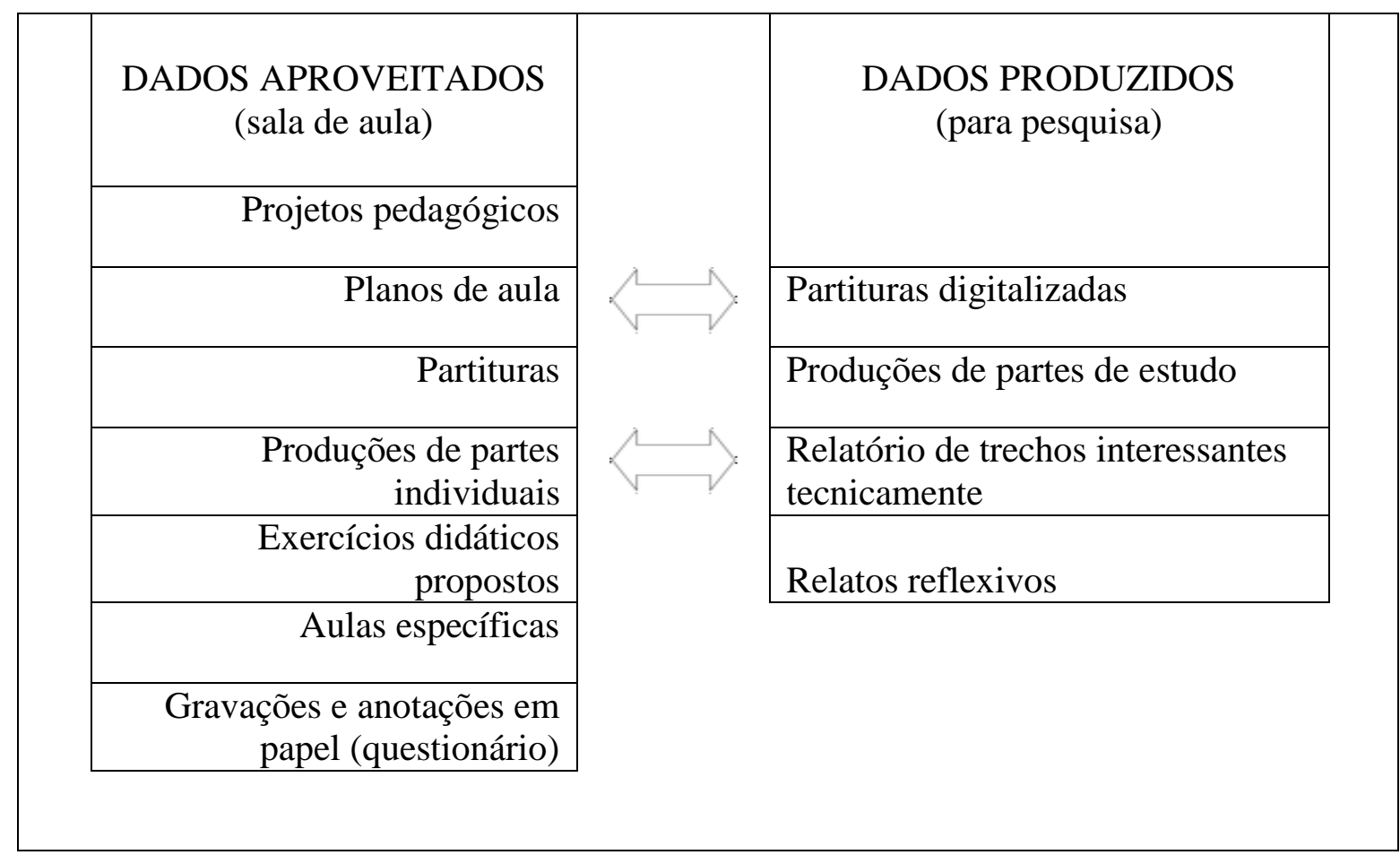

\section{Quadro 2}

No agrupamento "dados aproveitados", encontram-se os registros produzidos a partir de materiais ou situações existentes na sala de aula ou mesmo anteriormente a ela. Independentemente da pesquisa operacionalizada, as práticas dos músicos e dos alunos produziram anotações; relatórios foram elaborados, criou-se partes de estudos individuais; aulas específicas sobre Villa-Lobos foram ministradas, tornando-se passíveis de registros em áudio. Para tanto, foi solicitado aos alunos que tocassem determinados trechos utilizados para focalizar determinadas técnicas exigidas pelo compositor. A pedido dos próprios músicos, as gravações em áudio serviram apenas para criar grupos de assuntos técnicos transpostos para a pesquisa (dados), não servindo como aporte sonoro a este trabalho. 
No agrupamento "dados produzidos", encontram-se registros que não fazem parte das atividades pedagógicas cotidianas, ou seja, são produtos de atividades realizadas especificamente para fins de geração de dados para a pesquisa. As situações de trabalho em campo foram registradas mediante anotações feitas no momento da execução. Quando produzidas por graduandos em estágio supervisionado na instituição de ensino focalizada, essas anotações passaram por uma re-textualização, transformando-se em relatos reflexivos do relatório. Para o processo de coleta de dados, foram utilizados dois instrumentos: a parte de estudo e o questionário.

A perspectiva de estudo de caso foi escolhida pelo fato de possuir 30 participantes (músicos graduandos e em cursos regulares) e teve como objetivo mostrar suas respectivas soluções interpretativas, apontando para suas dificuldades e conhecimentos na preparação de um trecho orquestral. Far-se-á referência para "características pessoais ou particulares, cujo destaque possibilita o aumento da compreensão do fenômeno, uma vez que o estudo de caso visa, sobretudo, à profundidade" (Laville e Dione, 1999). E ainda o experimento, que por sua vez afirma que "a observação de um fenômeno leva o pesquisador a supor tal ou tal causa ou consequência: é a hipótese. Somente o teste dos fatos, a experimentação, pode demonstrar sua precisão.” (Laville e Dione, 1999, p.27).

Buscamos, portanto, por meio dos questionários identificar os problemas e/ou dificuldades que cada participante encontrou durante a execução dos trechos escolhidos e as estratégias que empregaram para as soluções. Os trechos foram estudados individualmente e lhes foi pedido que relatassem os pontos positivos e negativos de sua execução, muito embora saibamos que músicos profissionais de orquestra apresentam um tempo limitado para a preparação de uma obra sinfônica.

Técnicas de amostragem probabilística foram utilizadas e debruçou-se sobre as inserções do naipe de metais graves nas peças escolhidas, explicitando a análise estatística dos dados. As análises das peças basearam-se no estudo individual de cada pesquisado com base no referencial técnico do trombone ou tuba das resoluções interpretativas de cada instrumento. A discussão sob o ponto de vista pedagógico foi feita a partir de uma revisão da literatura no âmbito interdisciplinar na área de práticas orquestrais, nas quais os trechos de estudo das peças orquestrais são consideradas matérias-primas do curso. 


\subsection{TÉCNICA DE PESQUISA: QUESTIONÁRIOS SEMIESTRUTURADOS}

\section{Questionários semiestruturados}

Para esta investigação, que tem como objetivo entender as estratégias de interpretação que músicos de metais graves utilizam durante o estudo de um trecho orquestral, a técnica de pesquisa que se mostrou mais adequada foi o questionário semiestruturado. A definição de Laville e Dione (1999, p. 188) é clara: uma "série de perguntas abertas na qual o entrevistador pode acrescentar perguntas de esclarecimento". Essa técnica é consequência da necessidade de o pesquisador ter liberdade, indispensável no caso, para explicar algumas questões durante a coleta dos dados ou reformulá-las para se adaptarem melhor às condições de cada entrevistado.

Araújo (2010, p.28) demonstrou que essa técnica permite que "o entrevistado se sinta mais à vontade para citar suas experiências particulares, e dar respostas espontâneas que podem ser decisivas para o resultado da pesquisa, trazendo a perspectiva do entrevistado em relação às estratégias de estudo". Sendo assim, esse modelo de questionário foi escolhido por permitir maior esclarecimento durante a coleta de dados e um aprofundamento em questões e temas, muitas vezes particulares, que pudessem surgir durante as respostas. O roteiro continha perguntas referentes à trajetória musical de cada participante, assim como questões relacionadas ao tempo e à organização de estudo para a execução do trecho. Foram apresentadas perguntas direcionadas, em alguns casos, às estratégias de estudo utilizadas pelos músicos na preparação de cada obra.

\subsection{CONSTRUÇÃO DO MODELO ANALÍTICO}

Para a construção do modelo que utilizamos na identificação das estratégias de estudo neste trabalho foram coletados dados em pesquisas empíricas que fazem parte dessa temática. Neste trabalho, mobilizamos os estudos de Hallam, 1995a, 1995b; Williamon e Valentine, 2002; Jorgensen, 2004; Chaffin e Imreh, 1997, 2001, 2002; Barros, 2008; e Araújo, 2010. No entanto, no decorrer da coleta de dados, compreendemos a necessidade de acrescentar outras estratégias identificadas pelos participantes desta pesquisa que muitas vezes se relacionavam com as particularidades do instrumento estudado. 
Devido a essas variáveis, optamos por construir um modelo de análise misto. Para Laville e Dione (1999), este modelo é caracterizado por sua natureza mutável, o que proporciona ao pesquisador liberdade para não se prender a um molde fechado e predeterminado.

Em suas análises e interpretações, o pesquisador não quer se limitar à verificação da presença de elementos predeterminados; espera poder levar em consideração todos os elementos que se mostram significativos, mesmo que isso o obrigue a ampliar o campo das categorias, a modificar uma ou outra, a eliminá-las, a aperfeiçoar ou precisar as rubricas (LAVILLE e DIONE.1999, p.222).

As estratégias de estudo que compõem o modelo analítico e são selecionadas por meio das pesquisas empíricas já mencionadas são:

1 - Exercícios de aquecimento e exercícios técnicos motores.

2 - Estudo por meio de repetições.

3 - Estudo por meio de seções musicais.

4 - Estudo da análise e estrutura da obra musical.

5 - Estudo em andamentos diferentes.

6 - Estudo de seções difíceis.

7 - Exercícios de alongamento, relaxamento e de finalização do estudo.

8 - Estudo por meio de gravações de outras execuções.

9 - Estudo com metrônomo.

10 - Fixação de metas e objetivos.

Além dessas, apresentamos algumas estratégias utilizadas pelos participantes para solucionar problemas específicos do instrumento e que também compõem o nosso modelo de análise:

11 - Estudo com afinador.

12 - Estratégia de emissão do ar para controle da afinação.

13 - Estratégia de utilização de respiração circular. 


\subsection{ESCOLHA E CRITÉRIOS PARA A SELEÇÃO DAS OBRAS E DOS PARTICIPANTES}

Barros (2008, p.63) aponta alguns critérios para a escolha da obra a ser utilizada nas pesquisas empíricas a partir de uma pesquisa de Barry (1992, p.114), na qual são indicadas algumas características para essa opção. $\mathrm{O}$ autor nomeia alguns critérios para a seleção:

- ser apropriada ao nível de dificuldade do indivíduo;

- ter extensão moderada;

- conter variedade rítmica;

- $\quad$ ser relativamente curta;

- não fazer parte do repertório padrão.

Vimos que apenas o último critério serviria como regra geral para as peças de VillaLobos; os outros foram estabelecidos de acordo com o que se pretendia nesta pesquisa, não estando inclinado à generalização para a escolha do repertório das pesquisas empíricas. Desse modo, para a seleção realizada para esta pesquisa, elencamos apenas os seguintes critérios:

1. Conter pelo menos um dos metais graves na orquestração;

2. Servir para apresentações ao vivo em concertos de palco;

3. Não fazer parte do repertório padrão;

4. Nunca ter sido executada pelos participantes em orquestras sinfônicas.

Sendo assim, os trechos escolhidos poderiam ter sido extraídos de muitas obras que tivessem uma importância técnica e interpretativa para os metais graves, já que os participantes são instrumentistas ativos em uma orquestra sinfônica. Com isso, a maioria das obras orquestrais de Villa-Lobos estaria compatível com os critérios acima. Sabemos da importância, para esta pesquisa, de a obra já ter sido executada pelo menos uma vez em um concerto sinfônico para que pudéssemos investigar também as dificuldades no momento dos ensaios e na sua execução, além das estratégias que cada participante usou para solucionar os possíveis problemas.

Para a escolha das obras, levamos em consideração a intenção de ampliar o repertório no estudo do instrumento, além de aumentar as possibilidades de pesquisas nessa área. Gabrielsson (2003, p.235) mostra ainda que "diferentes instrumentos oferecem diferentes 
possibilidades de execução; portanto, há necessidade que o repertório desse instrumento seja mais abrangente para uma melhor investigação"12.

Sendo assim, o substrato que será utilizado para essa pesquisa, são as peças dos grupos mais relacionados aos concertos sinfônicos de palco, ou seja, as sinfonias, os Concertos, as Bachianas, os Balés, Quarteto e os Chôros. As Suítes, as músicas para cinema, as composições para banda de música, o Oratório e a Ópera estarão excluídos por não pertencerem ao grupo acima informado. O mesmo se aplica às peças exclusivamente para cordas, piano, violão e voz, por não conterem metais graves em sua orquestração.

Não houve intenção em definir um número geral ou específico para cada grupo, mas o máximo de três peças por grupo, pois a totalidade nos traria um trabalho muito extenso. A exceção de peça única foi o Choros $N^{\circ}$, que, embora esteja no grupo sinfônico dos Choros, será considerada nesta pesquisa como Música de Câmara $^{13}$ por conter apenas 4 instrumentos em sua composição. A escolha também não se preocupou com extensão ou dificuldade de cada peça. Separamos apenas as peças de mais execuções no cenário brasileiro de concertos sinfônicos.

$\mathrm{O}$ ato de analisar uma peça sob uma perspectiva interpretativa e estrutural é possível graças a padrões teóricos estabelecidos nos parâmetros da análise musical. Graças às esses parâmetros, as soluções tópicas não serão consideradas definitivas; no entanto, tornam uma análise interpretativa de considerável relevância. Dessa forma, a separação dos trechos permitiu-nos construir tabulações e inferências que nos revelaram padrões úteis para posteriormente serem considerados na classificação de novos elementos. Optamos por trabalhar nesta pesquisa com o tópico Tratamento de dados, o que incluiu a organização, análise e interpretação de dados, o estudo dos compassos e as dinâmicas.

Levando em consideração a tarefa de classificação dos trechos musicais, tornou-se claro que a criação de uma base de dados com um conjunto de atributos específicos seria de grande utilidade. Essa base de dados musicais deveria compreender um conjunto de gêneros

\footnotetext{
${ }^{12}$ As different instruments offer different possibilities in performance, there is a need for an extended repertoire of instruments in performance research.

${ }^{13}$ Será assumida nesta pesquisa a limitação de três a oito executantes, com uma parte específica para cada executante, informada no Dicionário Grove de Música, Jorge Zahar Editor, p.634.
} 
musicais que poderiam a princípio ser diferenciados pelos métodos apresentados. Parece evidente que a distinção entre gêneros musicais seria tanto mais facilitada quanto mais distintos fossem os gêneros envolvidos.

Assim, o primeiro passo para a sua construção foi a escolha de uma amostra que representasse, e fosse possivelmente menos distorcida, cada um dos grupos a considerar; por conseguinte, os gêneros seriam facilmente identificáveis. Essa associação, apesar das diferenças entre os estilos serem claras e evidentes, criou uma classificação possível: metais graves em concertos sinfônicos de palco.

Apesar de não ser totalmente unânime, essa base comum teria, mais adiante, um suporte justificado dentro dos gêneros musicais. Portanto trabalharemos com os seguintes gêneros:

- Balé;

- Câmara Choros;

- Concertante;

- Orquestral Choros, Bachianas ou Sinfonia.

Por meio desse conjunto de músicas, determinou-se de uma forma útil suas características comuns para que o seu tratamento a nível estatístico foi possível. A primeira abordagem a esse problema pretendeu ser principalmente a tentativa de descortinar um método fundamentalmente estatístico de tratar os dados, sem aprofundar o tratamento da música como um sinal sonoro. 
Portanto, o processo esquematizado ficou da seguinte forma: (a) Após a decisão de quais peças seriam trabalhadas (num total de 12), limitou-se a ação de pesquisa dentro desse grupo; (b) Decidiu-se quais trechos seriam interessantes para a análise: decidiu-se pelos que mais têm recebido apresentações nos últimos anos; (c) A peças foram separadas num arquivo para posterior agrupamento; (d) Os trechos semelhantes foram apagados; (e) Separou-se os trechos remanescentes, de modo a classificá-los por dificuldade técnica dentro dos gêneros; (d) Foram criados arquivos digitais em programa musical específico; (e) Posterior inserção ao texto da pesquisa. Por fim, a configuração dos elementos de dados, com base nos gêneros, apresentou-se da seguinte forma:

\begin{tabular}{c|c}
\hline Gêneros & Peças \\
\hline Balé & 2 \\
\hline Câmara/Chôro & 1 \\
\hline Orquestral/Chôro & 2 \\
\hline Concertante & 1 \\
\hline Orquestral/Bachianas & 1 \\
\hline Orquestral/Sinfonias & 1 \\
\hline
\end{tabular}

Tab. 1: Configuração da Base de Dados das Peças

Embora a justificativa para a adoção dessa ordenação e escolha tenha se baseado nos estilos orquestrais de palco desenvolvidos por Villa-Lobos, sabe-se da existência de metais graves na música de cinema, em suítes e orquestras de sopro (bandas). No entanto, por não se confirmar experiência profissional suficiente que nos licencie a defender uma tese nesses gêneros, eles foram deixados de lado. Esse procedimento de escolha nos possibilitou o encontro de um número expressivo de trombonistas e tubistas em atividade nas orquestras sinfônica. 
Com base nessa configuração, foram extraídas do universo composicional de VillaLobos as peças com caracterização da amostra adiante relacionada e ordenada por data de criação, tipo, instrumental, movimentos e duração aproximada:

\begin{tabular}{|c|c|c|c|c|c|c|}
\hline & Peça & Data criação & Tipo & Instrumental & Movimentos & $\begin{array}{l}\text { Duração } \\
\text { aprox. }^{14}\end{array}$ \\
\hline 1 & Uirapurú & 1917/e. 1935 & Balé & 2 ten -1 tbx -1 tuba & único & 19 min. \\
\hline 2 & Amazonas & 1917/e. 1929 & Balé & 2 ten -1 tbx -1 tuba & único & $12 \mathrm{~min}$. \\
\hline 3 & Choros $\mathrm{N}^{\circ} .4$ & 1924 & Câmara & 1 ten $/ 1$ tbx $(?)-0$ tuba & único & $6 \mathrm{~min}$. \\
\hline 4 & Choros $\mathrm{N}^{\circ} .6$ & 1926/e. 1942 & Orquestral & 3 ten -1 tbx -1 tuba & único & $25 \mathrm{~min}$. \\
\hline 5 & Choros $\mathrm{N}^{\circ} .10$ & 1926 & Orquestral & 2 ten. -0 tbx -0 tuba & único & 12 min. \\
\hline 6 & Bachianas $\mathrm{N}^{\circ} .2$ & 1930 & Orquestral & 1 ten. -0 tbx -0 tuba & 4 & 22 min. \\
\hline 7 & $\begin{array}{c}\text { Concerto para violão e } \\
\text { pequena orquestra }\end{array}$ & 1951 & Concertante & 1 ten. -0 tbx -0 tuba & 3 & $18 \mathrm{~min}$. \\
\hline 8 & Sinfonia $^{\circ} 12$ & 1957 & Orquestral & 3 ten -1 tbx -1 tuba & 4 & $24 \mathrm{~min}$. \\
\hline
\end{tabular}

Quadro 3 - Peças ordenadas por data de criação

Dentro do microuniverso composicional de obras escolhidas do compositor VillaLobos, as peças foram analisadas segundo os seguintes tipos de variáveis:

- utilização do rotor,

- glissandos,

- frases além da capacidade pulmonar humana,

- extensão melódica

- $\quad$ superação de flexibilidade e

- posicionamento dos metais graves dentro da orquestração.

${ }^{14}$ Média simples das gravações orquestrais pesquisadas neste trabalho. 
Villa-Lobos e os metais graves sinfônicos:

Um estudo dos elementos técnicos específicos

\begin{tabular}{|c|c|c|c|c|c|c|c|}
\hline Peça & $\begin{array}{c}\text { Data } \\
\text { criação }\end{array}$ & Tipo & $\begin{array}{l}\text { Necessidade de } \\
\text { rotor no } \\
\text { trombone tenor }\end{array}$ & $\begin{array}{c}\text { Glissandos } \\
\text { além da } \\
\text { 4 a aum. }^{\text {(para tbn) }}\end{array}$ & $\begin{array}{c}\text { Frases } \\
\text { além do } \\
\text { limite do } \\
\text { ar }\end{array}$ & $\begin{array}{c}\text { Superação } \\
\text { de } \\
\text { extensão } \\
\text { melódica }\end{array}$ & $\begin{array}{c}\text { Intervalos } \\
\text { maior que } \\
10^{\mathrm{a}} \mathrm{M}\end{array}$ \\
\hline Uirapurú & $1917 / 35$ & Balé & Não & Tbn 1 & - & - & - \\
\hline Amazonas & $1917 / 29$ & Balé & Não & Tbn & Tbx & Tuba & Tbn \\
\hline Choros $\mathrm{N}^{\circ} 4$ & 1924 & Câmara & $\operatorname{Sim}^{15}$ & Tbn & Tbn & $\operatorname{Sim}^{16}$ & Sim \\
\hline Choros $\mathrm{N}^{\mathrm{o}} .6$ & $1926 / 42$ & Orquestral & $\operatorname{Sim}^{17}$ & Tbn & $\begin{array}{l}\text { Tbx e } \\
\text { Tuba }\end{array}$ & Tuba & Tuba \\
\hline Choros $\mathrm{N}^{\circ} 10$ & 1926 & Orquestral & Não & Sim & Sim & Tbn & Sim \\
\hline Bachianas $\mathrm{N}^{\circ} 2$ & 1930 & Orquestral & $\operatorname{Sim}^{18}$ & Tbn, & Tbn, & Tbn, & Sim \\
\hline $\begin{array}{c}\text { Concerto para } \\
\text { violão e pequena } \\
\text { orquestra }\end{array}$ & 1951 & Concertante & Não & Não & Sim & Sim & Não \\
\hline Sinfonia $\mathrm{n}^{\circ} 12$ & 1957 & Orquestral & Não & Não & Não & Não & Sim \\
\hline
\end{tabular}

Quadro 4 - Peças ordenadas por técnicas específicas

Pesquisas embasadas em músicos sinfônicos interferem e acrescentam positivamente qualidade ao ensino dos instrumentos orquestrais e as estratégias de preparação seriam uma opção de estudo. Se valendo dessa filosofia, a escolha dessas obras, serviriam como incremento ao repertório de estudo para esses instrumentos, tornando-se, dessa forma, possível a discussão de como se estuda e se prepara esse tipo de repertório com o respaldo dos músicos consultados.

\footnotetext{
${ }^{15}$ Se executado num trombone-barítono com 0.547 de polegada.

${ }^{16}$ Haverá a superação melódica se optar pela execução com um trombone-baixo.

${ }^{17}$ Para o $3^{\circ}$. Trombone.

${ }^{18} \mathrm{O}$ rotor será necessário para se executar plenamente o glissando no $4^{\circ}$ Movimento (Trenzinho Caipira). 


\subsubsection{Escolha e critérios para a seleção dos participantes}

As pesquisas na área do planejamento da execução, as quais têm como objetivo a análise do estudo individual e a verificação do tipo de prática utilizada por cada participante, apresentam evidentemente características metodológicas semelhantes entre si e interesse por variáveis iguais, como, por exemplo, a relação dos grupos de sujeitos envolvidos na pesquisa. Barros faz algumas considerações a respeito desse tema:

\footnotetext{
Constatei que, em relação aos grupos de sujeitos, a maioria das pesquisas apresentou coerência no gerenciamento desses grupos, havendo nivelamento de acordo com vários critérios, como idade, nível de habilidade e tempo de estudo (BARROS, 2008, p.31).
}

O público formador de dados, e escolhido para esta pesquisa, foi composto por músicos (trombonistas e tubistas) oriundos de cursos superiores e técnicos no estado de São Paulo. A escolha por graduandos em curso regular se deu principalmente pela inexistência de pesquisas nacionais e internacionais sobre o tema, não obstante o fato que, na graduação, o aluno mostrar-se receptível à prática de trechos orquestrais, o que permitiu a extração de forte indicador do grau de conhecimentos adquiridos. Esses alunos têm ainda a disponibilidade de absorção novos aprendizados, demonstrando grande interesse na resolução de questões técnicas de execução para incorporação de novos conhecimentos ou mesmo para sua afirmação profissional.

Do ponto de vista dos procedimentos técnicos, esta pesquisa se apresenta como levantamento de dados (survey). O universo da pesquisa foi constituído por 23 trombonistastenor, 6 trombonistas-baixo e 3 tubistas, matriculados na Universidade de São Paulo (6 Ten 1 Tbx - 1 Tuba), nas Faculdades Integradas Cantareira (1 Ten - 1 Tbx), na Escola de Música de São Paulo (11 Ten - 1 Tbx - 1 Tuba) e no Instituto Baccarelli (4 Ten - 2 Tbx - 1 Tuba). Todos se apresentavam na época, ano letivo de 2013, devidamente matriculados em cursos regulares e bacharelados desses respectivos instrumentos. E ainda contamos com a contribuição profissional de OSESP (1 Ten - 1 Tuba) e OSB (1 Tbx). 


\subsection{PROCEDIMENTO DE COLETA DOS DADOS}

Inicialmente buscamos fazer um levantamento dos profissionais de orquestras e alunos graduandos no instrumento que estivessem disponíveis para participar da pesquisa. A partir de então, selecionamos os participantes pelo nível de domínio técnico avançado pra que fossem mais confiáveis suas observações. O primeiro contato com os participantes foi por meio de emails, nos quais descrevíamos as intenções da pesquisa. Em seguida, foram novamente enviados e-mails contendo o trecho a ser estudado.

Pediu-se que os e-mails fossem respondidos pelos músicos profissionais com as dificuldades encontradas em cada trecho e suas sugestões. Para os graduandos a coleta de depoimentos aconteceu em seu próprio local de estudo: a entidade onde estavam matriculados. As entrevistas semiestruturadas aconteceram em horário extra-aula e buscavam conhecer não só a trajetória musical de cada um, como também um aprofundamento no estudo e na preparação para uma execução. A intenção era entender as estratégias de estudo que cada instrumentista utilizava para resolver determinados problemas.

Durante essa sessão, o instrumentista tinha 30 minutos para executar o trecho, sendo incentivado a expor os problemas e as dificuldades que identificava no decorrer da execução. Salientamos a importância dessa explicação das estratégias a serem utilizadas para a solução de algum problema técnico. As entrevistas foram realizadas durante o $2^{\circ}$ Semestre de 2013 e gravadas num gravador digital SONY (modelo PCM 50). O tempo de duração da gravação foi exatamente o tempo dos trechos; não foi incluído o período de estudo de preparação de cada participante e as entrevistas.

Os instrumentistas que participaram da pesquisa receberam um termo de consentimento, no qual concordavam com o objetivo deste estudo e se colocavam à disposição para revisar a parte da pesquisa destinada à sua participação, com o intuito de concordarem ou não com a publicação do trabalho. Ficariam, assim, responsáveis pelo que seria publicado neste estudo. 


\subsection{PROCEDIMENTOS DE ANÁLISE DOS DADOS}

Para iniciar o processo de análise dos dados, foi necessário, conforme Laville e Dione (1999, p.197) mencionam, “organizá-los, poder descrevê-los, transcrevê-los, ordená-los, codificá-los, agrupá-los em categorias”, para, em seguida, iniciar as análises e interpretações que conduziriam às conclusões. Para Bogdan e Biklen (1994, p.205), durante a análise dos dados existe um processo de busca e organização sistemática das transcrições das entrevistas, na qual o pesquisador visa compreender profundamente os dados que coletou e transmitir de forma organizada às outras pessoas a sua descoberta.

Por esses dados terem sido originados de entrevistas semiestruturadas, outros temas não previstos foram discutidos, sendo necessário também categorizá-los. A fase seguinte contou com a análise do conteúdo, sendo utilizado o modelo misto que, segundo Laville e Dione (1999), permite ao pesquisador selecionar categorias no início do processo, porém com liberdade de modificá-las em função da análise que apontará para a identificação dos problemas e dificuldades de cada participante, assim como a estratégia utilizada por cada um na sua solução.

Para a análise e interpretação dos dados coletados para este estudo, adotamos uma abordagem qualitativa, o que, muitas vezes, implica em prender-se

às nuanças de sentido que existem entre as unidades, aos elos lógicos entre essas unidades ou entre as categorias que as reúnem, visto que a significação de um conteúdo reside largamente na especificidade de cada um de seus elementos e na das relações entre eles, especificidade que escapa amiúde do domínio do mensurável (LAVILLE e DIONE, 1999, p.227).

Nesse processo, essas nuances de sentido se confundem, o que não quer dizer que o procedimento seja subjetivo ou acidental. Para Laville e Dione (1999), é necessário que o processo continue estruturado, rigoroso e sistemático, buscando sempre apresentar clareza no procedimento. Assim, a objetividade será encontrada na explicitação, na explicação e na justificativa das etapas do processo de análise. 
$\mathrm{Na}$ fase de análise e interpretação dos dados coletados para a pesquisa, buscamos discutir as dimensões relacionadas em cada momento do aprendizado e as escolhas das estratégias de estudo durante a construção da execução de cada participante. Utilizamos, o quadro apresentado por Chaffin e Imreh (2001), que se relaciona às dimensões de aprendizagem e execução, para buscar compreender, a partir dos autorrelatos coletados durante as entrevistas semiestruturadas, se o processo de aprendizado e a dimensões apresentadas durante cada estudo é recorrente ou se ocorre alguma modificação.

Para a nossa análise interpretativa, utilizamos a estratégia de emparelhamento, que "supõe a presença de uma teoria sobre a qual o pesquisador apoia-se para imaginar um modelo do fenômeno ou da situação em estudo" (Laville e Dione, 1999, p.227). Sendo assim, esse paralelo com o estudo de Chaffin e Imreh (2001) nos permitiu verificar se houve recorrência entre a situação teórica e a observável, comparando o modelo apresentado por Chaffin e Imreh com os dados coletados nesta pesquisa. Laville e Dione (1999) esclarecem que nesse procedimento

a qualidade da organização lógica do quadro operacional mostra-se aqui primordial, pois a grade da análise que dela emerge torna-se não só o instrumento de classificação, mas também o de toda a análise e interpretação dos conteúdos (LAVILLE E DIONE, 1999, p. 227).

$\mathrm{Na}$ presente pesquisa, o nome dos participantes, das orquestras e instituições serão mantidos em sigilo. Utilizaremos porcentagens para a elucidação de cada quesito pesquisado. 
Villa-Lobos e os metais graves sinfônicos:

Um estudo dos elementos técnicos específicos

CAPITULO 3.

TRABALHOS SIMILARES

Universidade de São Paulo

Escola de Comunicação e Artes 


\section{INTRODUÇÃO}

Para a criação desta pesquisa, fizemos, sobretudo numa fase prévia, a visualização de documentários similares nos quais se buscou o fornecimento da linguagem e das características do que já se explanou sobre o objeto da pesquisa. Com vista a sistematizar essas visualizações, realizamos um estudo comparativo, no qual recolhemos informações dos documentários observados, tais como aprofundamento técnico específico, relação com qualquer obra pertencente ao objeto dessa pesquisa ou resoluções para entraves de execução, por exemplo. Ao final, decidiu-se que a posição científica seria a produção de dados e interpretação de resultados para a obtenção de conclusões.

Dos 23 trabalhos revisados, encontramos para instrumentistas orquestrais (6), para teclados (7), para instrumentistas em geral apenas (1), trechos orquestrais (2) e dentro da área de musicologia (6). Fez-se uma classificação em duas categorias, apenas para cunho metodológico: para a área da musicologia ou mesmo assuntos que influenciaram em ponto algum nossa pesquisa, encontramos 21 trabalhos, de 1997 a 2012, no entanto encontrou-se somente 2 trabalhos que abordaram diretamente os procedimentos interpretativos, que é nossa área de atuação .

\subsection{ESCASSEZ DE PESQUISAS RELACIONADAS À TEMÁTICA E AOS METAIS GRAVES}

Apesar da importância de trabalhos que buscam compreender como Villa-Lobos escreveu para os metais graves em suas peças orquestrais, existem poucas pesquisas que envolvem os referidos instrumentos.

Encontramos estudos em que o foco são os trombonistas (DUKE, 2001, NADAI, 2007; ALLEN, 2011), os tubistas (LISBOA, 2005), os trompetistas (CARDOSO, 2009), os violoncelistas (AQUINO, 2000), os pianistas (CHAFFIN e IMREH 1997, 2001, 2002; CHAFFIN, IMREH, LEMIEUX e CHEN 2003; BARROS, 2010), os violonistas (MELLO, 2009), os instrumentistas em geral (HALLAM, 1995), Trechos orquestrais (FLETCHER, 2008; MOYER, 2009), Choros (FREITAS, 2005; DAMASCENO, 2009; LACERDA, 2011; 
ALBUQUERQUE, 2012; MOREIRA, 2013;), Amazonas (Acácio PIEDADE, 2009), os organistas (NIELSEN, 1997, 1999), entre outros.

No estudo realizado por Susan Hallam (1995),Approaches to the Learning and Interpretation of Music, fez-se a investigação de abordagens de músicos profissionais durante o aprendizado e a interpretação de uma obra. Hallam mostrou que as implicações educacionais e os critérios para a formulação de futuros modelos que buscam explicar a aprendizagem e a execução musical de uma obra. Contudo, apesar de não apresentar como objetivo a análise específica de um instrumento, a pesquisa não menciona os diferentes instrumentos e o estudo dos diversos músicos envolvidos, deixando como consequência a indefinição do aprendizado da obra.

Sendo assim, até o presente momento encontramos apenas dois trabalhos que envolvem instrumentistas e o estudo do repertório sinfônico. O primeiro é a tese de Allison M.F FLETCHER (2008), que tem como objetivo afirmar que todo membro de orquestra sinfônica deve ser capaz de ser músico de estante e solista ao mesmo tempo. Acrescenta ainda que, embora existam várias coleções de livros de Trechos orquestrais, essas literaturas omitem informações referentes à parte histórica e ao estilo da peça. Fletcher disponibilizou uma edição dos trechos de algumas peças que foram comparadas para possível identificação de erros e propôs uma possibilidade interpretativa para esses solos, tais como: tendências para uma melhor afinação, dificuldades rítmicas, opções de alterações técnicas, dinâmicas, de articulação $^{19}$ e de timbre. Ao final, creditou a utilidade desse trabalho para pesquisa de professores da área, estudantes e músicos de orquestra.

Moyer (2009), em sua tese direcionada ao violoncelo, compilou trechos orquestrais retirados do repertório internacional. Sua intenção foi a de criar material de estudo para estudantes com foco especial no entendimento do trechos orquestrais em particular. Vale ressaltar que esta tese sobre 15 Trechos orquestrais para Violoncelo foi perfeitamente elaborada. A importância deste trabalho reside numa pesquisa realmente voltada para violoncelistas. A intenção da autora de dividir as técnicas exigidas para cada Trecho em

\footnotetext{
${ }^{19}$ A articulação das notas será um tema recorrente nesta pesquisa. A técnica específica dos metais brinda-nos com a possibilidade da não existência da língua (uma articulação) e de sua interferência (seis articulações). Para o deleite dos metais graves, Villa-Lobos deixou grafado nas peças analisadas, 3.658 notas articuladas $(71,06 \%)$.
} 
dificuldade primária e outros aspectos foi didática. Ela descreveu com precisão cada Trecho e ainda especificou elementos técnicos e musicais (tópicas de interpretação).

No entanto, ao invés de uma análise abrangente, a autora limitou-se a poucos compositores. Além disso, apoiou-se apenas nas partes em que o Violoncelo faz solo descoberto, não considerando partes de difícil execução, mesmo que em meio a orquestrações pesadas. Baseou-se nos compositores Beethoven, Mozart, Debussy, Mendelssohn, Brahms, Verdi e Strauss.

A autora lembra que não tão somente os trechos são uma forma de demonstrar as habilidades de um instrumentista, como os violoncelistas devem estar perfeitamente preparados para demonstrar essas habilidades.

Trabalhos encontrados com foco no trombone foram respectivamente DUKE, 2001; NADAI, 2007; e ALLEN, 2011. Neles, o foco central das pesquisas foram peças de música de câmara. Em sua tese, Duke (2001) revelou-nos que nos últimos 40 anos há uma tendência entre os compositores de transformar o instrumento solista num ator sobre o palco. A intenção do autor foi focar e realçar o repertório que se encaixa na tendência teatral.

No entanto, o autor preferiu não adentrar o repertório orquestral. Seu trabalho apoiouse em compositores modernos, tendo como base Bernstein, Folke Raba e Vinko Globokar não teve espaço para compositor algum abaixo do equador, inclusive Villa-Lobos.

O autor estendeu a possibilidade de utilização de princípios contidos nesse trabalho a outros instrumentos orquestrais ocidentais. Compositores de sonatas e concertos receberam especial atenção, e o autor acredita que uma nova era fará do trombone uma figura brilhante. O aprofundamento técnico específico na área do trombone obteve uma análise em nível avançado de técnica com resoluções de entraves de execução.

Por sua vez, Nadai (2007) revelou-nos as semelhanças e diferenças entre duas peças contemporâneas escritas para trombone. A importância de seu trabalho está nas sugestões de exercícios técnicos muito bem elaborados, contendo notas longas e estudos intervalares muito bem tratados. No entanto, a intenção do autor em criar capítulos de contextualização, análise 
da obra - direcionada especificamente a compositores, e ainda um capítulo de análise comparativa - destinada a teóricos -, deixou pouco espaço para o instrumento analisado.

Em vez de se aprofundar mais na informação técnica do trombone, ele preferiu ficar no nível superficial. Esse trabalho apoia-se num nível elementar da técnica específica e não tem como meta o profissional do instrumento. A base de dados dos capítulos Sugestões Interpretativas foram os seguintes tópicos: considerações, aspectos da técnica, comentários sobre a instrumentação e importância da análise no processo de execução musical, no qual foi mostrada a importância da elaboração de estudos com base nas dificuldades técnicas encontradas nas peças.

O autor conclui que a elaboração de estudos e sua prática seriam condutas importantes no auxílio ao músico na preparação e na execução de obras. O final do trabalho mostrou que, graças ao processo de análise, foi possível realizar uma interpretação mais consciente da obra, aprimorando a sua execução.

Finalmente, a tese de ALLEN (2011) é uma continuação da tese de Robert Gifford (1978), que por sua vez se baseou num estudo de Robert Gray (1957), no qual se discutiu o uso do trombone na música de câmara. Esse trabalho foi importante para nós por confirmar que o uso do trombone na música de câmara teve um aumento expressivo entre 1900 e 1978. O Choros No 4 de Villa-Lobos foi composto nesse período - em 1926. A intenção do autor foi a de nomear várias peças, a contar de Heinrich Ignaz Franz Biber (1640-1704) e chegar em Stravinsky (Octeto para sopros), John Cage (Ryoanji) e Vincent Pershichetti (Serenade No. 6).

No capítulo de técnicas específicas, discutiu-se magistralmente sobre trilos de lábios e de válvula, alteração do timbre e quarto de tom, além de fornecer análise formal, interpretativa e também sobre polirritmias. Embora a base de dados do autor enumere 331 peças escritas para trombone, ele se apoiou apenas em 3 peças e suas citações pouco ajudarão um trombonista que necessite realmente estudar algum trecho dessas peças.

A pesquisa conclui com a afirmação de que compositores continuam a escrever para trombone em grupos de câmara, mas reclama do pequeno número de peças que chegam à fase 
final de uma gravação em áudio. $\mathrm{O}$ autor informa ainda que a listagem de peças recém composta para o trombone continuará a crescer em sua página de internet.

Neste trabalho o aprofundamento técnico específico e as resoluções para entraves de execução foram magistralmente apresentados, porém a relação das obras com o objeto de nossa pesquisa não foi de utilidade alguma. Pelos resultados apresentados no trabalho e por não citar Villa-Lobos em sua lista de obras para o século XX, essa pesquisa não interferiu em ponto algum de nossa pesquisa.

O único trabalho localizado e destinado ao instrumento tuba foi o artigo de LISBOA (2005). Nesse artigo, o autor nos revela que desde seu surgimento no século XIX, as bandas "de retreta" 20 têm provido não apenas entretenimento e serviços à população de pequenas cidades em datas sociais importantes, mas também são polos formadores de significativa parcela dos músicos das bandas militares e dos naipes de sopros das orquestras sinfônicas do Brasil. A importância desse trabalho residiu em demonstrar como a tuba recebeu um tratamento solístico inusitado nas peças de João Cavalcante ${ }^{21}$, exercendo um papel de destaque em meio a uma escrita sinfônica (instrumentação, timbres e texturas).

A intenção do autor em destacar a escrita influenciada pelo tratamento sinfônico na instrumentação e timbre, a utilização sistemática de dinâmicas, acentos, ligaduras, a utilização do contraponto e, especialmente do ponto de vista do instrumentista, a exploração mais refinada das possibilidades técnico-musicais da Tuba. No entanto, o artigo centra-se apenas no gênero dobrado, no qual geralmente a tuba recebe a mera função de acompanhamento, fazendo os baixos dos acordes em ritmos simples, enfatizando a pulsação ou partes fortes do tempo. A base de dados foram apenas as peças de João Cavalcanti.

A partir disso, observou-se na escrita para tuba de João Cavalcante a mesma variedade de funções e a mesma sofisticação encontradas nas partes graves do gênero choro. De fato,

\footnotetext{
${ }^{20}$ Bandas essencialmente compostas por metais, madeiras e percussão. Participam da comunidade, tocando em festas e solenidades. Apresentam-se geralmente em praças ou coretos.

${ }^{21} \mathrm{O}$ compositor e maestro João Cavalcante (1902-1985), nascido em Passagem de Mariana/MG, estado brasileiro com o maior número de bandas de retreta, destacou-se por mesclar elementos populares e eruditos em suas composições para bandas (23 dobrados). Iniciou sua vida profissional em Ouro Preto, transferindo-se depois para Belo Horizonte, onde se formou no Conservatório Mineiro de Música, atual Escola de Música da Universidade Federal de Minas Gerais.
} 
João Cavalcante não se esqueceu do papel de acompanhamento tradicional da tuba na música de banda de retreta.

Com relação ao instrumento Trompete, apenas localizamos a tese de CARDOSO (2009). Nela, o ponto central foi análise técnica e interpretativa da série Choros escrita exclusivamente para Trompete. A importância desse trabalho é que várias soluções técnicas direcionadas ao Trompete foram reveladas e possuem paralelo com a técnica dos metais graves. A intenção do autor em analisar as partituras, visualizá-las por meio de gráficos e de uma revisão da literatura específica, ofereceu ferramentas bem claras aos leitores.

Porém, ao invés das indicações de extensão melódica estarem acompanhadas de notação em pauta, estas apenas foram citadas em forma de nomenclatura em relação ao dó central. Esse trabalho ainda se apoiou em demonstrações gráficas dos envelopes gerados pela intervenção e afirmou que a informática é parte integrante de disciplinas teóricas tanto como das práticas interpretativas, nas quais uma visualização sonora destinada a intérpretes seria uma possibilidade. Inclusive ao citar o trombone (p.90), o envelope gerado para um tenuto, não condiz com o demonstrado.

E, por fim, sugeriu notas mais curtas que as originalmente escritas pelo autor, como justificativa a um "balanço" (sic) nacional. Embora tenhamos citado alguns temas que precisariam de mais averiguações técnicas, essa pesquisa foi a mais próxima, em termos técnico-instrumental, da proposta desta nossa pesquisa. $\mathrm{O}$ aprofundamento técnico específico foi avançadíssimo e as resoluções para entraves de execução receberam atenção adequada.

Perante a promessa das sugestões em corroboração (via visualização sonora) com uma melhor interpretação dos Choros de Villa-Lobos, decidiu-se que este trabalho nos serve de material de pesquisa apenas para o capítulo dos Choros e nas soluções técnicas específicas desse mesmo capítulo, porém não interfere nos pontos técnicos da área dos metais graves. Logo, a relação das obras com a totalidade dos gêneros escolhidos não interfere na validade de nossa pesquisa.

O único trabalho encontrado no qual o foco é o Violoncelo foi o de AQUINO (2000). Essa tese revelou elementos nacionalistas no Concerto $N^{o} 2$ para Violoncelo. A intenção do autor foi apontar os elementos que influenciaram a partitura final e como foram grafados no 
processo composicional. Fez ainda uma comparação entre o instrumento e os padrões rítmicos do berimbau. Considerou, em particular, a influência do violão na escrita villalobiana.

No entanto, o autor não se aprofundou na parte prática do instrumento, mesmo que sua pesquisa tenha sido centrada na área de execução musical, como ele mesmo denominou. Esse trabalho apoiou-se no campo composicional das escritas de Villa-Lobos para Concerto $N^{\circ} 2$ para Violoncelo. Sua base de dados foram os manuscritos fornecidos pelo Museu Villa-Lobos e a localização de algumas semelhanças entre certas peças folclóricas nacionais.

Por fim, o autor conclui o trabalho reforçando a ideia de que o concerto exibe algumas "apropriações" de temas folclóricos nacionais, comentando sobre o número de vezes que esse concerto foi gravado e utilizando frases do violoncelista homenageado pela peça.

O aprofundamento técnico específico do Violoncelo manteve-se em nível intermediário, contando com poucas sugestões de entraves de execução. A relação desse trabalho com o objeto de nossa pesquisa é totalmente pertinente no capítulo destinado ao Concerto $N^{o} 2$ para Violoncelo, tornando-se fonte de pesquisa.

Com foco no instrumento violão, localizamos a dissertação de MELLO (2009), que mostra um estudo comparativo entre dois manuscritos e três edições da obra Concerto para violão e pequena orquestra. Foi realizada nesse trabalho uma edição crítica desta peça de $\mathrm{H}$. Villa-Lobos. A intenção do autor era que a partir dessa análise das divergências, poderiam ser elaborados comentários acerca de cada uma delas e apontadas soluções para a construção de uma melhor interpretação.

Nesse trabalho foram feitas inferências sobre cada um dos três aspectos que poderiam ser abordados em uma obra de arte: poético, neutro e estésico. Na segunda (Edição crítica), foram expostas algumas informações referentes ao embasamento teórico e à metodologia utilizada no estudo comparativo, juntamente com alguns exemplos das partes do violão e dos comentários críticos subsequentes, que demonstram como foi realizada a construção. Foram encontradas divergências entre as versões, perfazendo um total de 189 possibilidades distintas de execução, que foram devidamente identificadas e comentadas visando a possíveis soluções. 
A partir daí, tanto o aprofundamento técnico específico quanto as resoluções para entraves de execução ficaram centradas no violão. Portanto, a relação das obras com os metais graves não se pode firmar paralelo algum. Pelos resultados apresentados neste trabalho, os assuntos técnicos do instrumento violão não interferem em ponto algum em nossa pesquisa.

Com foco central em "Choros", localizamos os seguintes trabalhos: FREITAS (2005), DAMASCENO (2009), LACERDA (2011), ALBUQUERQUE (2012) e MOREIRA (2013). Porém, a quase totalidade está no campo da musicologia. A única exceção ficou com a dissertação de MOREIRA (2013), dissertação que desvelou a construção de um processo interpretativo por meio da observação do estudo individual de outros flautistas. Esses flautistas foram incentivados a apontar os problemas com os quais se deparavam e a maneira como os resolviam, mas a própria autora alerta que algumas das estratégias são específicas para o instrumento centro da pesquisa. A importância desse trabalho reside nos tópicos pesquisados: estratégias de estudo instrumental, construção da interpretação e o direcionamento a músicos de orquestra.

Nesse trabalho encontramos a opinião pessoal de três flautistas profissionais, entrevistados durantes a pesquisa. A base de dados foi o solo de flauta do início do Choros $N^{o} 6$, com transcrição das particularidades interpretativas de cada entrevistado. A partir desse conjunto de atributos, a autora afirma ser de grande relevância a construção de uma estratégia interpretativa associada à psicologia cognitiva.

Por fim, pode-se confirmar um aprofundamento específico de alto nível técnico no qual as resoluções para entraves de execução foram muito bem explanadas. A relação deste trabalho com o objeto da nossa pesquisa é totalmente pertinente e, pelos tópicos de execução apresentados no trabalho de MOREIRA, concluímos que esta pesquisa nos serve como bibliografia de apoio para o assunto de Procedimentos Interpretativos. Porém o instrumento flauta e o tamanho do repertório (apenas o Choros $N^{o}$.6) não será útil pela diferença de objeto da pesquisa.

Os outros trabalhos focados no tema Choros mantiveram seu foco no âmbito musicológico. Em sua dissertação, FREITAS (2005) confirmou que o tema Choro, gênero instrumental originalmente brasileiro, tem merecido mais pesquisas no meio acadêmico. Um 
ponto importante desse trabalho foi a descrição da trajetória do Choro ao chegar à capital do Estado de Minas Gerais, desde a sua vinda do Rio de Janeiro, passando pelos programas ao vivo dos chorões nas antigas rádios da cidade. Por fim, o autor exibe traços biográficos de seus principais compositores e a catalogação de suas obras.

No entanto, esse trabalho centra-se apenas na cidade de Belo Horizonte, apoiando-se em entrevistas com personalidades ligadas ao gênero nessa cidade. Como base de dados, o autor optou por escolher algumas dessas personalidades mais reconhecidas e outros que atuaram ou ainda estão atuando em grupos regionais.

Em sua conclusão o autor se utiliza da definição villalobiana para Choro: "a essência musical da alma brasileira"(sic) - ao mesmo tempo gênero musical e forma de tocar que representa o Brasil em toda diversidade e virtuosidade.

Como não existiu qualquer aprofundamento técnico específico e muito menos foram encontradas resoluções para possíveis entraves de execução, essa dissertação não servirá como fonte de pesquisa. Vale apenas citar a intenção do autor em optar pelo recorte em considerar apenas os músicos que atuaram regularmente tanto como instrumentistas quanto compositores. Villa-Lobos se encaixaria perfeitamente nesse grupo. O tema central dessa dissertação foi o Choro, mas Villa-Lobos foi apenas citado no final e o raio de atuação da pesquisa ficou restrito à capital mineira.

De mesma forma, em seu texto DAMASCENO (2009) tratou das mediações sociais que possibilitaram a legitimação de Villa-Lobos como o grande compositor que implementou as ideias modernistas no campo da música brasileira. Por meio da concepção de negociação simbólica que desenvolveu ao longo do texto, explicitou como se processaram tais mediações sob a ótica da pesquisa e como elas foram formalizadas esteticamente na obra do musicista, tendo o Choros $N^{\circ} 10$ como obra paradigmática do seu percurso.

A importância desse texto foi o desenvolvimento de uma ideia diferenciada da trajetória de Villa-Lobos junto à pesquisa sociológica mais relevante até aqui publicada de Guérios (2003), mas define o início da modernidade de Villa-Lobos na própria Semana de 22. O texto apresenta um Villa-Lobos como um negociante simbólico de sua arte com diferentes públicos, músicos e críticos musicais em busca de uma personalidade brasileira. Considera 
ainda que a produção musical de Villa-Lobos não pode ser vista de maneira linear ou unívoca por ser ele um compositor compulsivo.

Dentro dessa conjuntura, mostrou como Villa-Lobos lidou com as influências estrangeiras, já que a música erudita nacional, segundo o autor, tinha uma notória dependência estética externa que não poderia ser desconstruída da noite para o dia. No caso de Villa-Lobos, tal "angústia" seria superada por meio da sua dupla atuação entre o erudito e o popular. Concluímos que o texto, por não conter aprofundamento técnico específico algum e carecer de qualquer resolução para entraves de execução não serve como fonte de pesquisa.

No caso específico de LACERDA (2011), embora seu trabalho esteja centrado na musicologia e tenha realizado uma discussão sobre o conceito de gênero harmônico a partir de obras de Debussy e Stravinsky, suas conclusões acerca do Choros $N^{o} .4$ serviram de bases para o capítulo de ABORDAGENS DE CARÁTER ANALÍTICO. Em seguida, foram apreciados todos os momentos que compõem a primeira parte do Choros $n^{\circ} 4$. O estudo nos revelou as semelhanças na escolha das fontes de construção harmônica e ainda a maneira de articulação formal dessas fontes. O trabalho propõe que se busque uma compreensão maior do desempenho do compositor no diálogo que manteve com a arte contemporânea.

Esse estudo ainda mostrou que há equivalência na forma de emprego de sonoridades orientais e de escalas arcaizantes ou advindas de músicas tradicionais populares comuns a uma boa parte dos compositores modernistas. Defendeu que a tonalidade sobreviveu em quatro novas significações: sistemas complexos (Bartók) e justaposição, superposições e combinações controladas (Debussy).

Chamou atenção o emprego do tetracorde pentatônico, vestido e articulado na forma de largos saltos intervalares no trombone. A partir desse conjunto de atributos acima expostos, o aprofundamento técnico específico ficou no âmbito da musicologia; por conta disso, não se encontra aí resoluções para entraves de execução. A relação da obra com o objeto da pesquisa limita-se às poucas citações recebidas pelo instrumento trombone. No entanto, pelo fato da pesquisa estar centrada nos Procedimentos Interpretativos, esse trabalho não servirá como fonte de pesquisa. 
Nos dois artigos de ALBUQUERQUE (2012) primeiramente discutiu-se o uso de eixos de simetria como fator estrutural importante na peça Choros $n^{\circ} 4$ (1926) por apresentar diversos procedimentos envolvendo tal recurso composicional. Também foram abordados centricidade, polos do eixo simétrico, simetrias inerentes às coleções referenciais, eixo fixo e polarização por exclusão e tipos de movimento axial do eixo. O autor demonstra como VillaLobos utilizou os eixos de simetrias entre intervalos de alturas em diversos níveis estruturais, marcação formal da obra, geração de centros sonoros em seções ou trechos melódicos.

A intenção do autor foi observar o processo de amadurecimento desse procedimento, que surgiu primeiramente a partir de simetrias inerentes de coleções referenciais - diatônica, octatônica, acústica e tons-inteiros. Mas logo o compositor encontrou, na oposição entre notas "brancas" e "pretas" e também na relação entre ciclos intervalares, outras fontes muito prósperas para geração de simetrias intervalares.

Em seu segundo artigo, ALBUQUERQUE discutiu o uso de eixos de simetria como fator estrutural importante nos Choros $n^{\circ} 4$ (1926) e Choros $n^{\circ} 7$ (1924) por apresentarem diversos procedimentos envolvendo tal recurso composicional. Também abordou centricidade e os polos do eixo simétrico; simetrias inerentes às coleções referenciais; eixo fixo e polarização por exclusão; e tipos de movimento axial do eixo. No entanto, este artigo não tem o foco direcional aos Procedimentos Interpretativos. Portanto não servirá como fonte de pesquisa.

Por não estar dentro da linha interpretativa, o aprofundamento técnico específico e as resoluções para entraves de execução não foram tratadas nesse trabalho. A relação das obras com nosso objeto da pesquisa apenas encontra ligação na peça Choros $n^{o} .4$.

Finalmente, o último trabalho localizado na área da musicologia foi o artigo de Acácio PIEDADE (2009). Nesse, fez-se um mapeamento preliminar dos universos de tópicas musicais na música de Villa-Lobos. Após uma breve descrição teórica do universo de tópicas musicais da musicalidade brasileira, o texto apresentou análises de trechos de diversas peças selecionadas com objetivo de exemplificar o uso de tópicas. Concluiu afirmando a importância de Villa-Lobos para a música brasileira, destacando ainda sua inventividade nas tópicas indígenas e amazônicas. 
O autor nomeou algumas tópicas em Villa-Lobos, tais como: época de ouro, nordestinas, selvagens, floresta tropical, indígenas, caipiras, impressionistas. No artigo não se encontrou aprofundamento técnico específico algum, nem sequer resoluções para entraves de execução, pois não estava centrado na linha da interpretação. Embora este trabalho trate do assunto TÓPICAS, as ideias contidas nessa pesquisa não serviram de fonte para nosso trabalho. 
Villa-Lobos e os metais graves sinfônicos:

Um estudo dos elementos técnicos específicos

Capítulo 4:

CONTEXTUALIZAÇÃO HISTÓRICA:

Universidade de São Paulo

Escola de Comunicação e Artes 


\section{1 - APRESENTAÇÃO}

Este capítulo apresentará uma breve contextualização histórica e suas variantes formais a partir de acontecimentos ligados estritamente à evolução da escrita villalobiana. Para se chegar a essa meta, serão levantadas questões históricas e se considerará os personagens que possibilitaram a trajetória do músico ao compositor, inclusive um paralelo entre as peças analisadas e suas páreas pertencentes à compositores de outros países, que tenham reconhecida influência.

Como pilar dessa contextualização, localizam-se três aspectos relevantes: o primeiro foi o cenário musical vigente, tanto na época de Villa-Lobos quanto na anterior à sua formação. Fatos como as guerras mundiais, os acontecimentos políticos e os patrocínios serão citados como um pressuposto evolutivo, pois por seu intermédio Villa-Lobos transpôs os muros do regionalismo e difundiu sua ideia de música da Terra do Brasil.

Como segundo aspecto, serão citados os fatores que o levaram a pesquisar as fontes folclóricas nacionais e os personagens que possibilitaram essa empreitada. Esse será um dos pontos relevantes da pesquisa: a transformação do Villa-Lobos moderno, um compositor passível de influências europeias, o orgulho e a defesa da temática sonora brasileira.

Por último, o terceiro aspecto trata-se do seu processo de maturidade, com as influências que sofreu e a convivência e a projeção internacionais que foram o sustentáculo da consolidação de sua nova forma de compor. Toda informação nos servirá de base no transcorrer dos acontecimentos por meio de relações interpessoais, políticas e culturais que permitiram a Villa-Lobos mostrar uma linguagem exótica e ameríndia, com todas as evidências modernas da nova era.

A cronologia se iniciará em 5 de março de 1887 com seu nascimento e findará no ano de 1959, dia 17 de novembro, data do seu falecimento. Os anos não apontados na cronologia não significam, de forma alguma, uma inatividade de Villa-Lobos. Apenas foram subtraídos por não interferirem em seu pensamento ou por não desencadearem consequências sobre as peças analisadas neste trabalho. 


\section{2 - CONTEXTUALIZAÇÃO HISTÓRICA}

Villa-Lobos nasceu no Rio de Janeiro - bairro das Laranjeiras - e não por acaso na Rua Ipiranga (que nos remete à independência). Seu período mais profícuo em atividade composicional foi de 1915 a 1958 (43 anos), quebrados com seu falecimento aos 72 anos. Também nasceu em 1887 e foi seu conterrâneo o compositor, regente e professor Oscar Lorenzo Fernandez (1887-1948), que, além de sua carreira artística e didata, esteve ao lado de Villa-Lobos, Luciano Gallet ${ }^{22}$, Camargo Guarnieri e Francisco Mignone na consolidação do nacionalismo musical. Além deles, Brasílio Itiberê da Cunha também foi um dos precursores dessa corrente com sua rapsódia, A Sertaneja, escrita para piano entre 1886 e 1869.

Ainda nesse mesmo ano de 1887, o Brasil deixou de ser uma monarquia, mas a população, de forma geral, hesitava em aceitar a República. Houve então um acontecimento de extrema importância na área cultural da época: logo após a proclamação da República, em 1899, um decreto extinguiu o Imperial Conservatório de Música e criou, em seu lugar, o Instituto Nacional de Música. A alteração no nome indicava a mudança de estrutura e de ênfase estética no Instituto, o grande centro musical do país. Seu primeiro diretor, Leopoldo Miguéz, fez questão de impor uma estética moderna ${ }^{23}$ para combater o "conservadorismo" reinante.

Outro defensor de nossa música nacionalista nasceu em São Paulo, capital do estado, seis anos após Villa-Lobos, mais exatamente em 1893. Um dos mentores do modernismo brasileiro nas artes: o poeta, escritor, crítico literário, pesquisador de folclore, ensaísta e professor Mário Raul de Moraes Andrade. Foi nesse ambiente cultural que Heitor VillaLobos se formou como músico. Seu pai, Raul Villa-Lobos, havia-lhe ensinado a tocar Violoncelo desde a mais tenra idade e já em 1904 trabalhava nas orquestras das Sociedades Sinfônicas do Rio de Janeiro.

\footnotetext{
${ }^{22}$ Luciano Gallet (1893-1931), pianista, compositor e folclorista de ascendência francesa. É companheiro de Villa-Lobos, como instrumentista, nas orquestras de salão do início do século XX.

${ }^{23}$ Para Miguéz, modernas eram a estética alemã de Richard Wagner e a francesa de Camille Saint-Saëns (Guérios, 2004, pp. 52-56).
} 


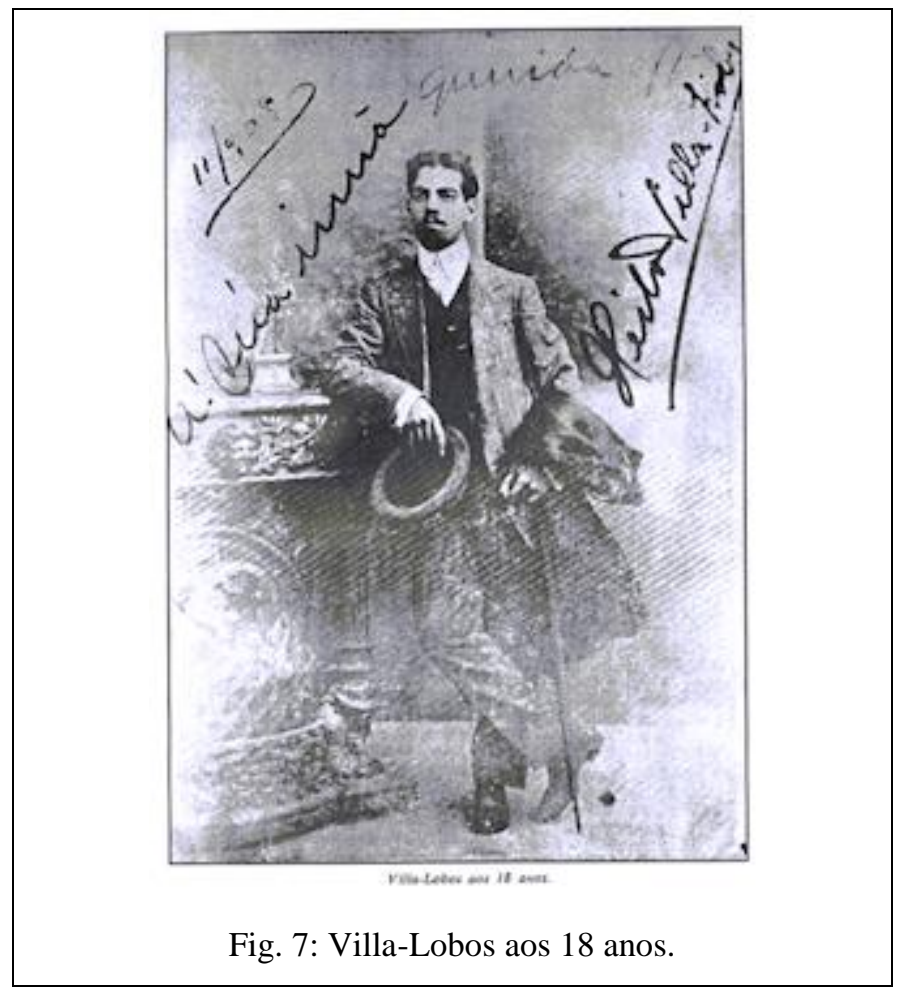

Passados 18 anos de seu nascimento, Villa-Lobos detinha uma coleção de livros raros herdados de seu pai, os quais resolveu vender. Com o dinheiro, em 1905 ele viajou para o Espírito Santo e chegou até os estados da Bahia e de Pernambuco. Além das respectivas capitais desses estados, embrenhou-se em seus sertões, passando pequenas temporadas em engenhos e fazendas. Nos anos seguintes, mais viagens: para o sul, o centro-oeste e, ainda especula-se, para a Amazônia ${ }^{24}$, que, por sua exuberância, o teria impressionado vivamente.

Voltando à cidade do Rio de Janeiro, adiantados três anos, com a inauguração do Theatro Municipal da cidade, a 14 de julho de 1909. A Prefeitura resolveu financiar as temporadas de óperas, convidando cantores e maestros mundialmente reconhecidos. Nesse novo momento da ópera, financiada pelo poder público, essas se diferenciariam das apresentadas na primeira metade do séc. XIX - promovidas por companhias e empresários estrangeiros. A produção operística aumentou em número a cada ano. Ainda em 1909, nasceu em Portugal a cantora, atriz e dançarina Carmen Miranda (seu falecimento ocorreu em 1955), que, a partir da década de 1940, se tornaria, ao lado de Villa-Lobos e na área da cultura, uma das peças-chave da política de "boa vizinhança” criada pelos EUA.

\footnotetext{
${ }^{24}$ Contemporâneo de Villa, nasceu no estado do Pará, o compositor e pianista Waldemar Henrique (19051945), que se destacou, sobretudo, como autor de canções baseadas no folclore amazonense.
} 
Villa-Lobos finalmente se estabeleceu no Rio de Janeiro no ano de 1912. Formado no ambiente musical erudito da década de 1910, compreendeu as diferentes estéticas musicais de acordo com o panorama traçado por seus antecessores: a "antiguidade" e a "nobreza" da ópera italiana, em confronto com a "modernidade" de Wagner e Saint-Saëns. Longe das praias cariocas e mais especificamente na Áustria, a modernidade teria um novo compositor: Arnold Schönberg (13/09/1874 - 13/07/1951). Este compõe o Op. 21 Dreimal sieben Gedichte aus Albert Girauds 'Pierrot lunaire', (Três vezes sete poemas do 'Pierrot Lunaire' de Albert Giraud), mais conhecido como Pierrot Lunaire ("Pierrot lunático" ou "Pierrot da lua"). Ciclo de canções baseadas num conjunto de 21 poemas, selecionados e traduzidos para o alemão por Erich Hartleben, do ciclo de poemas homônimo escrito por Albert Giraud. A obra estreou no Berlin Choralion-saal em 16 de outubro de 1912, com Albertine Zehme (1857-1946).

No ano seguinte, em Paris, Claude Debussy estreou, a 15 de maio de 1913, Jeux, sua última obra orquestral. Apresentada no Théâtre des Champs-Élysées e conduzida por Pierre Monteux mas não bem recebida pelo público da época. Nesse mesmo ano e mesmo compositor, destacou-se ainda Syrinx, para flauta solo, La boîte à joujoux, Prèludes, Poèmes de Stéphane Mallarmé. Na cidade de Paris, no mesmo ano e no mesmo teatro, viu-se a estreia do balé A Sagração da Primavera - com subtítulo de Quadros da Rússia pagã em duas partes - em 29 de maio. Composta por Igor Stravinsky em seu período russo ${ }^{25}$ e coreografado originalmente por Vaslav Nijinsky. A concepção de cenografia e os figurinos foram de Nicholas Roerich; a produção, de Sergei Diaghilev para a sua companhia de Ballets Russes. Stravinsky ainda terminou a composição para voz de Trois petites chansons, mas esta não se tem informação da influência sobre Villa-Lobos.

No ano de 1915, ou seja, dois anos após a estreia da Sagração de Primavera, deu-se o início das apresentações oficiais de Villa-Lobos como compositor. No dia 29 de janeiro realizou-se no Teatro Dona Eugênia (Salão Nobre da Associação dos Empregados do Comércio), em Nova Friburgo, estado do Rio de Janeiro, o primeiro recital com obras de sua autoria. Ao violoncelo tocou o próprio compositor, e ao piano, Lucília Villa-Lobos, num concerto que causou reações de espanto em críticos de renome da época pelo tratamento harmônico ousado empregado por Villa-Lobos. Ainda no mesmo, Villa-Lobos iniciou a composição do ciclo dos 17 quartetos de cordas, concluídos em 1957.

${ }^{25}$ Que perdurou até 1910. 
Numa tentativa de se encontrar algum paralelo das orquestrações realizadas por VillaLobos e outros compositores internacionais em mesma época, nada se pode relacionar. Exemplos dessa constatação se confirmou na França, onde Debussy compôs a série de Doze Études para piano - peças de extrema dificuldade, que, segundo o próprio autor, apenas os pianistas com "mãos notáveis" 26 deveriam tocá-la. Ainda do mesmo Debussy, As três sonatas (1915-1917) são parte de um ciclo para instrumentos diversos que ficou incompleto. A mais importante é a Sonata para piano e violino, obra avançada com asperezas inéditas e por fim Sonata para flauta, viola e harpa.

No ano anterior à composição, informada por Villa-Lobos, de Amazonas e Uirapurú, exatamente no ano de 1916, Debussy terminou a composição da peça Ode à La France, escrita para soprano, coro e orquestra. Stravinsky, por sua vez e na fase suíça, completava coincidentemente duas peças para voz: Renard e Berceuses Du chat. Finalizando esse ano profícuo, Bartók terminou as composições: Five Songs e Slovak Folksong (voz e piano).

As composições Amazonas e Uirapurú (balé com orquestra completa) ocorreram ambos em $1917^{27}$. Villa-Lobos, ainda no Rio de Janeiro, foi apresentado ao compositor francês Darius Milhaud - então secretário de Paul Claudel na Legação da França -, de quem ficou amigo e apresentou os terreiros de macumba, os chorões ${ }^{28}$ e a música carnavalesca. Nesse mesmo ano Villa-Lobos ainda estreou:

- Sonata $N^{o} 1$ para violino

- Sonata $n^{o} .2$ para Violoncelo

- Louco (W079)

- Memorare (W128)

- Sinfonia $n^{\circ} .2$, Op. $160(\mathrm{~W} 132)$.

\footnotetext{
26 "A warning to pianist not to take up the musical profession unless they have remarkable hands". In Www.pianosociety.com/cms/idex.php?section=156. Acessado em 17/12/2013.

${ }^{27}$ Amazonas (1917/e. 1929) e Uirapurú (1917/e. 1935).

${ }^{28}$ Villa aproximou-se da estética boêmia carioca desde seus 12 anos, mais exatamente em 1899.
} 
1917 foi indiscutivelmente um ano muito produtivo para a composição erudita mundial. Longe das terras brasileiras, outros compositores terminaram as seguintes peças:

\begin{tabular}{|c|c|c|}
\hline Debussy & Stravinsky & Bartók \\
\hline $\begin{array}{l}\text { Opereta Les soir illuminés } \\
\text { par l'ardeur Du charbon }\end{array}$ & Balé Le Noces & $\begin{array}{l}\text { Romanian Folkdances para } \\
\text { piano e pequena orquestra }\end{array}$ \\
\hline Ode à La France & Peça orquestral Le chant du rossignal & $\begin{array}{l}\text { Five Slovak Folksongs para } \\
\text { coro masculino e orquestra }\end{array}$ \\
\hline Sonata para violino e piano & Three Tales for Children & Quarteto de Cordas $N^{o} .2$ \\
\hline La chute de La Maison Usher & Peça vocal Four Russian Peasant Songs & \\
\hline & Pour Pablo Picasso - clarinete solo & \\
\hline & Canon para duas trompas & \\
\hline & Cinq pièces faciles & \\
\hline & Valse pour les enfants, para piano. & \\
\hline
\end{tabular}

Graças à qualidade de suas composições, Villa-Lobos conseguiu driblar a falta de recursos financeiros para a divulgação de suas obras. Organizou ainda um concerto no Teatro Municipal, em 1918, com a participação de 80 músicos, que trabalharam contando com o lucro da bilheteria. O concerto foi um fracasso de público, mas um sucesso de crítica, tornando o compositor conhecido.

O falecimento em Paris do compositor Claude Debussy em 25 de março de 1918 pôs fim a uma bela trajetória daquele em quem primeiramente Villa-Lobos se espelhara. Ainda em Paris, Stravinsky reformulou a ópera Le Rossignol, transformando-a em uma peça de concerto e rebatizando-a de Le chant du Rossignol, eliminando os cantores, assim como a maioria das músicas do $1^{\circ}$ ato. Também compôs Histoire du soldat (com sete instrumentos em sua orquestração, com parte para um trombone-tenor); sua segunda peça para teatro experimental, Le chant du Rossignol; a peça vocal Berceuse; Ragtime para onze instrumentos; e, por fim, Dueto para fagote. Bartók, em impressionante produção, terminou as seguintes peças: Fifteen Hungarian Peasant Songs e Studies (piano) e a Suite do Mandarin Maravilhoso (orquestra). 
"Choros $N^{\circ} 1$ " - para violão - escrito por Villa-Lobos em 1920, dá início à criação do monumental ciclo dos 14 "Choros" (concluído em 1929), escritos para as mais diversas formações camerísticas e sinfônicas, e com dedicatórias a figuras importantes do mundo das artes: Ernesto Nazareth, Mário de Andrade, Tarsila do Amaral, Oswald de Andrade, Arthur Rubinstein e Tomás Terán. Enquanto isso, em 15 de maio de 1920, na Ópera de Paris, o Ballets Russes estreou Pulcinella, de Igor Stravinsky, e, ainda nesse mesmo ano, a Sinfonia de Sopros, com 24 músicos de sopro e de metal. Bartók terminou a composição da peça para piano Eight Improvisations on Hungarian Peasant Songs.

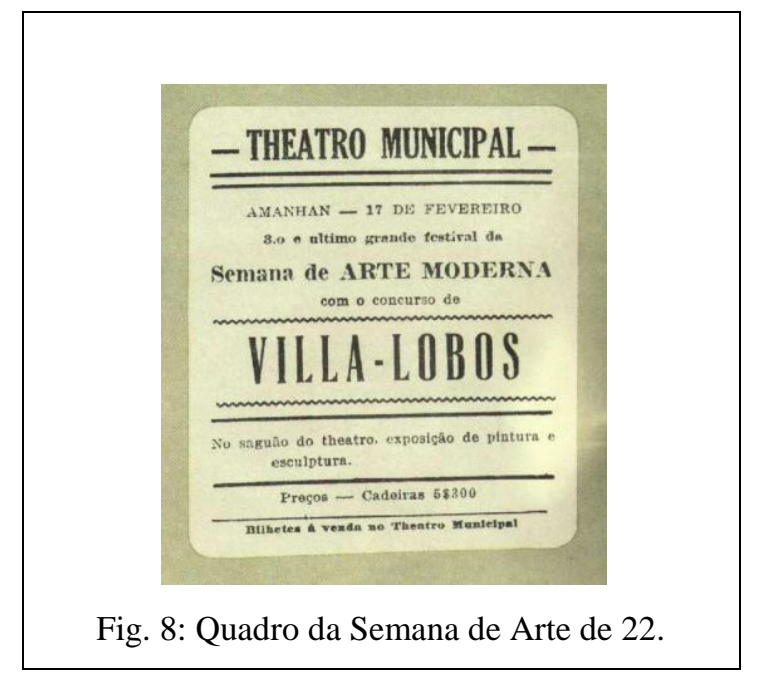

A convite do escritor e diplomata Graça Aranha, Villa-Lobos participou, como único compositor, da Semana de Arte Moderna, ou Semana de 22, como também ficou conhecida. Realizada no Theatro Municipal de São Paulo com o objetivo de mudar conceitos estéticos e lançar as sementes de uma arte genuinamente brasileira, a Semana de Arte Moderna foi de extrema importância para Villa-Lobos por lhe proporcionar a oportunidade de apresentar suas obras fora do Rio de Janeiro. Dela tomaram parte, entre outros, artistas e intelectuais, como Mário de Andrade, Tarsila do Amaral, Oswald de Andrade, Menotti Del Picchia $^{29}$, Ronald de Carvalho ${ }^{30}$ e Guilherme de Almeida ${ }^{31}$.

\footnotetext{
${ }^{29}$ Paulo Menotti del Picchia (1892-1988), poeta, jornalista, político, romancista, contista, cronista e ensaísta. Considerado precursor do Movimento Modernista na literatura.

${ }^{30}$ Nasceu no Rio de Janeiro (1893-1935). Poeta, ensaísta e memorialista. Em viagem à Lisboa em 1914, entrou em contato com o modernismo português. Essa relação com os modernistas portugueses marcou sua obra e o aproximou dos modernistas brasileiros.

${ }^{31}$ Guilherme de Almeida (1890-1969), poeta e ensaísta. Foi redator de O Estado de São Paulo, diretor da Folha da Manhã e da Folha da Noite, fundador do Jornal de São Paulo e redator do Diário de São Paulo.
} 
No Theatro Municipal do Rio de Janeiro, em 1922, Arthur Rubinstein fez a estreia da "Prole do Bebê $N^{\circ} 1$ ". Enquanto isso Bartók, na Hungria, terminou a composição da Sonata $N^{o} 2$ para violino e piano, sonata escrita em dois movimentos contínuos complexos. Essa obra estreou no ano seguinte na cidade de Berlim e foi dedicada à violinista Jelly d'Arányi, sobrinha do famoso violinista, Joseph Joachim.

Villa-Lobos fez sua primeira viagem à Europa em julho de 1923, subsidiado pelo Congresso Brasileiro e tendo como destino final Paris, onde permaneceu por um ano. Também obteve ajuda financeira de um grupo de amigos: Carlos e Arnaldo Guinle, Laurinda Santos Lobo, Graça Aranha, Olívia Guedes Penteado, Paulo Prado, Conselheiro Antônio Prado e Geraldo Rocha.

Ao chegar a Paris, presenciou uma cidade movimentada musicalmente: o sucesso de "A Sagração da Primavera" transformou um jovem compositor russo, Igor Stravinsky, em uma celebridade. Segundo nos relatou Guérios: "Villa-Lobos saiu do Rio de Janeiro como um compositor de vanguarda. (...) Era um dos poucos a ousar compor de acordo com as revolucionárias ideias de Debussy. Em Paris, porém, Debussy já não era mais sinônimo de vanguarda" (GUÉRIOS, 2003, p. 128).

A viagem a Paris e principalmente o contato com o compositor russo redefiniu a estética composicional de Villa-Lobos. Segundo Mariz “(...) assistiu ao vivo o Sacre du Printemps, de Stravinsky, e se sentiu abalado. Confessou-me ainda que foi a maior emoção musical de sua vida (MARIZ, 2005b, p. 98)". Se ocultarmos o nome das obras e dos compositores, as transcrições descrevem características comuns às obras de ambos ${ }^{32}$. Ainda segundo Mariz, "O comentário sobre o Noneto 33 (W191, 1923) se confunde com o comentário sobre a Sagração da Primavera 34 ”. A confirmação viria de Luis Heitor: "era, sobretudo, do Stravinsky daquele tempo que as suas obras se aproximavam (...).

\footnotetext{
${ }^{32}$ Tais como ênfase no ritmo (o que se reflete no destaque que dava aos instrumentos de percussão) e combinação ousada de timbres.

${ }^{33}$ Escrito para flauta, oboé, clarinete, saxofone alto, fagote, celesta, piano, harpa, percussão e tímpanos.

${ }^{34}$ Obra essa que utiliza uma orquestra sinfônica completa e um naipe de três trombones e tuba em sua orquestração.
} 
Na Salle des Agriculteurs, sob o patrocínio da Embaixada do Brasil na França, aconteceu no ano de 1924 o primeiro concerto em solo francês dedicado exclusivamente a obras de autoria de Villa-Lobos. Desse evento participou, entre outros, Arthur Rubinstein. Nessa ocasião, duas obras escritas em 1923 foram estreadas: o "Poème de l'Enfant et sa mère" e o "Noneto". Paralelamente mas sem conexão alguma em termos de orquestração, em Paris, Stravinsky compôs Les Noces. No ano seguinte, 1924, Villa-Lobos conheceu o violonista espanhol Andrés Segóvia. A partir da composição dos Choros, na fase "pós-Paris", VillaLobos estabeleceu a série como a possibilidade de síntese da música brasileira.

O ano anterior ao término da composição dos Choros $N^{o} .4$ e $N^{o} .6$, mais precisamente em 1925, Stravinsky terminou a composição das peças: Suite $N^{o} .1$ para orquestra de câmara, Suite on themes, fragments and pieces by Giambattista Pergolesi (violino e piano), Serenata em Lá (piano). No mesmo ano de 1925, Varèse apresentou ao público a composição de Intégrales for Wind and percussion, e Bartók compôs Village Scenes (Falún), cinco canções eslovacas (para voz feminina e piano).

Villa-Lobos organizou, em 1926, uma série de concertos na cidade do Rio de Janeiro último ano do governo Arthur Bernardes. Paralelamente a esses concertos, ele ainda continuou a composição da série dos Choros com o Choros $n^{o} 4$ (W218), o Choros $N^{\circ} \boldsymbol{6}$ (W219) e estreou o Choros $n^{\circ}$ 10, Alma brasileira, Três poemas indígenas (W224). Iniciou ainda a composição das "Serestas", para canto e piano. Sua segunda viagem à capital francesa ocorreu em dezembro do mesmo, 1926. Novamente patrocinado pela família Guinle, levou na bagagem os Choros e o projeto de “(...) conquistar espaço para sua nova música brasileira (GUÉRIOS, 2003, p. 147).” Segundo Peppecorn, “Ele estava bastante consciente de que era o colorido nacional que interessava aos parisienses (PEPPECORN, 2000, p. 90).” E continua ainda: "Seus novos objetivos exigiam uma nova postura como compositor" (ibdem).

No âmbito das artes internacionais, o ano de 1926 ainda presenciou a morte de Claude Monet. Compositores eruditos finalizariam as seguintes composições:

- $\quad$ Anton Webern - Zwei lieder, Op. 19;

- $\quad$ Béla Bartók - Concerto para piano No .1 , Sonata para piano, Out of Doors para piano;

- $\quad$ Darius Milhaud - Le pauvre matelot (ópera);

- $\quad$ Igor Stravinsky - Pater Nostrer;

- Jean Sibelius - Tapiola. 
Villa-Lobos prolongou sua segunda viagem a Paris até 1930. Novamente a figura de Arthur Rubinstein tentou convencer Guinle a patrocinar a publicação das obras de VillaLobos pela editora francesa Max Eschig. A revisão das mesmas e o trabalho para captar recursos para a realização dos concertos na capital francesa exigiram tempo e dedicação de Villa-Lobos, que, por conta de toda essa atribulação, não acrescentou peça alguma à série dos Choros. O Choros $n^{\circ} 4$, já composto e dedicado ao mecenas Carlos Guinle, foi interpretado pela primeira vez em um concerto dedicado às obras do compositor em 24 de outubro de 1927, na Salle Gaveau (Paris). Já Stravinsky, este em seu período neoclássico, estreou no ano de 1927 a peça Oedipus Rex, e Varèse terminou as peças orquestrais Amériques e Arcana. Bartók, por sua vez, concluiu a peça para piano Three Rondeaux on Slovak Folk Tunes e o Quarteto de cordas $N^{o} .3$.

No ano anterior à composição de Momoprecoce, Stravinsky compôs o balé em dois quadros Apollo (1928) - escrito para orquestra de câmara com apenas 34 instrumentos de cordas - e ainda a peça orquestral Quatre études for orchestra, com a curta duração de 9 minutos, feita a partir de um arranjo de Três Peças curtas para quarteto de cordas e dividida em 4 movimentos. Por outro lado, Bartók terminou a Rapsódia para violino e piano $N^{o} 1$.

A primeira audição do bailado ou poema sinfônico $\boldsymbol{O}$ Amazonas aconteceu no dia de 30 de maio de 1929 em Paris, na Salle Gaveau, interpretado pela Orchestre du Concert Poillet acrescida de músicos, num total de 120 executantes. Villa também estreou nesse mesmo ano a fantasia Momoprecoce (W240), para piano e orquestra, baseada em sua série para piano solo "Carnaval das Crianças". Momoprecoce foi dedicado a Magda Tagliaferro. Ainda concluiu os 12 Estudos para violão, Chôros $N^{o} .9$ (W232), Chôros $N^{o} .12$ (W233), Introdução aos Chôros (W239) e Suíte sugestiva (W242). Stravinsky, por sua vez, compôs Capriccio for piano and Orchestra, e Bartók fez nova orquestração da Rapsódia $N^{o} .1$ para violino (1927), retirando o piano e, em seu lugar, agregando uma orquestra (1929).

A Sinfonia dos Salmos (para coro), de Stravinsky, estreou no ano de 1930 em Paris. Nesse ano, Villa-Lobos regressou ao Brasil e dirigiu-se ao interior de São Paulo, onde iniciou um marco em sua vida: a composição das nove "Bachianas Brasileiras", que ocorreu de 1930 a 1945. Ainda em 1930, Villa-Lobos compôs as Bachianas Brasileiras $\boldsymbol{N}^{\boldsymbol{o}} \mathbf{2}$ (W247) e o Quinteto em Forma de Choros. Bartók, por sua vez, terminou a composição das seguintes 
peças: Cantata Profana (9 Enchanted Stags) para 2 vozes, coro duplo e orquestra; Sonatina para violino e piano; e o Concerto $N^{o} .2$ para Piano e Orquestra.

Em 1931, ano seguinte à estreia da Bachianas Brasileiras $N^{o} .2$, Stravinsky estava relutante em compor o Concerto em ré para violino ${ }^{35}$. Alegou falta de familiaridade com o violino à Willy Strecker ${ }^{36}$, mas o próprio Strecker o autorizou a consultar Dushkin ${ }^{37}$ sobre questões técnicas do instrumento. $\mathrm{O}$ concerto composto em estilo neoclássico foi divido em 4 movimentos e teve duração aproximada de 20 minutos. Varèse, por sua vez, compôs a peça Ionisation for 13 percussion: primeira composição para conjunto de percussão-solo ${ }^{38}$. Bartók terminou, nesse mesmo ano, os seguintes trabalhos: 44 Duetos para Violinos e as peças orquestrais Danças Transilvanias e Hungarian Sketches.

Enquanto passava férias na França, Schoenberg foi alertado de que seu retorno para a Alemanha seria perigoso. Sem outra opção, viajou com a família para os $\mathbf{E} \mathbf{U A}^{39}$, porém isso só aconteceu após tentativas de se transferir para a Grã-Bretanha. Dessa forma, Schoenberg mudou-se para os EUA no ano de 1934. Seu primeiro cargo nos EUA foi o de professor no Conservatório Malkin, em Boston; depois se mudou para Los Angeles, onde lecionou na Universidade do Sul da Califórnia. Foi nomeado professor visitante na Universidade da Califórnia no ano de 1935.

Em 1937, Stravinsky foi diagnosticado com tuberculose. Ainda de luto pela morte de familiares, juntamente com a eclosão da Segunda Guerra Mundial, foi obrigado a deixar a Europa definitivamente. No período suíço (1915-1920) e francês (1920-1939), escreveu os dois primeiros movimentos da peça orquestral Symphony in $C$; o terceiro movimento, quando em Cambridge / Massachusetts; e o último e quarto movimento, já na cidade de Hollywood/Califórnia, logo após sua emigração para os EUA no ano de 1939. Stravinsky ainda compôs em 1940, a peça para piano intitulada Tango. Com a piora da situação política europeia e após a eclosão da Guerra, mesmo relutante, Bartók emigrou, como Stravinsky, para os EUA em outubro de 1940, onde terminou o Concerto para dois pianos.

\footnotetext{
${ }^{35}$ White, 1979, p.368.

${ }^{36}$ Willy Strecker da B. Schotts Söhne, editora de música das obras de Stravinsky.

${ }^{37}$ Samuel Dushkin (13/12/1891 - 24/06/1976) violinista, compositor e pedagogo americano.

${ }_{38}$ Muito embora Alexander Tcherepnin dedicasse um movimento completo para solo de percussão em sua Sinfonia $\mathrm{N}^{\circ} .1$, datada de 1927

${ }^{39}$ Friedrich 1986 , p.31.
} 
No ano de 1941 Villa-Lobos fez sua primeira visita à cidade de Los Angeles/Califórnia - EUA - um ano após a emigração de Bartók e dois anos após a de Stravinsky. Nessa ocasião recebeu o título de Doutor Honoris Causa pelo Occidental College. Ainda nesse ano, Villa-Lobos compôs as Bachianas Brasileiras $n^{o} .4$, Sinfonia $n^{o} .6$ e estreou as Bachianas Brasileiras $n^{\circ}$.7. Bartók não forneceu peça nova; apenas fez revisões nas seguintes peças: Three Hungarian Folksongs e a Suite para dois pianos. No ano seguinte, Stravinsky compôs, em 1942, o balé Danses concertantes para orquestra de câmara, Circus Polka, a peça orquestral Four Norwegian Moods. Bartók, por sua vez, iniciou a composição do monumental Concerto para orquestra (que terminou em 1943 e ainda o revisou em 1945). No ano de 1943, Villa-Lobos foi novamente agraciado com o título de Doutor Honoris Causa pela Universidade de Nova York.

Sabe-se que a composição da Sinfonia $N^{\circ} 6$, de Villa-Lobos, ocorreu em 1944 e que, no ano anterior, Stravinsky tinha terminado as composições do balé Ode for Orchestra e da Sonata para dois pianos. A partir do ano de 1944 a notoriedade internacional de Villa-Lobos, principalmente norte-americana, vinda do pós-guerra, transformou-o num incansável viajante. Suas bases operacionais se encontravam em Nova York no primeiro trimestre do ano; em Paris, no segundo trimestre; e no Rio de Janeiro, em todo o segundo semestre.

O ano de 1944 foi o ano da composição da $\sigma^{a}$ Sinfonia de Villa-Lobos e seu último ano de uma longa permanência no Brasil - iniciada em 1930. Nesse ano, Stravinsky compôs o balé Scènes, a peça para coral Babel e a peça para viola-solo, Elegy. Bartók também compôs uma peça para cordas em quatro movimentos, nesse caso para solo de violino, e a nomeou Sonata. Dedicou-a a Yehudi Menuhin.

O final da II Guerra Mundial, em 1945, não melhorou a precária situação financeira de Stravinsky, em parte por conta da perda dos royalties de suas obras na Europa e por sua mudança para os EUA. Sua peça Scherzo à la russe ${ }^{40}$ foi composta como trilha do filme The North Star. Como o filme foi abortado, Stravinsky decidiu orquestrá-la para a Big Band de Paul Whiteman. Por conta do pouco sucesso obtido, ele novamente a orquestrou, no mesmo ano de 1945, para a Orquestra Sinfônica de São Francisco / EUA. Stravinsky ainda compôs

${ }^{40}$ Tchaikovsky também compôs em 1867 uma peça homônima, para dois pianos. 
Sinfonia em três movimentos e Ebony Concerto para clarinete. O Brasil, recebeu a triste notícia da morte de Mário de Andrade em 25 de fevereiro de 1945, na cidade de São Paulo. Mesmo com a perda desse grande aliado, Villa-Lobos compôs o Concerto para violão, estreou Erosão e seu Quarteto $n^{o} 2$. Bartók terminou a composição das seguintes peças:

- A férj keserve (Goat Song) - para voz e piano;

- Três Canções Folclóricas Ucranianas - para voz e piano;

- Concerto para Viola e orquestra (apenas esboços);

- Concerto para Piano e Orquestra No 3.

No âmbito político-nacional, a 31 de janeiro de 1951 Getúlio Vargas assumiu o $2^{\circ}$ mandato como presidente do Brasil, desta vez por voto direto. Infelizmente, a 13 de julho faleceu, em Los Angeles - Califórnia / EUA, Arnold Schoenberg. Ainda nesse mesmo ano Stravinsky estreou em Veneza sua última obra neoclássica, a ópera The Rake's Progress. Nessa década de 1950, Stravinsky usou técnicas de composição seriais não dodecafônicas em pequena escala - o Septeto e Três Canções de Shakespeare são exemplos dessa nova fase.

Dois anos à frente, exatamente em 1952, ano anterior à composição do Concerto para Violoncelo e orquestra $N^{o}$. 2, Stravinsky compôs a peça Cantata for mezzo-soprano, tenor, coro feminino, sopros e Violoncelo. Villa-Lobos terminou a composição do Concerto para Violoncelo e orquestra $N^{o} 2$ em 1953 e ainda estreou o Concerto $n^{o} .4$ para piano e o Quarteto $n^{o} 11$. No universo musical, houve os falecimentos, a 5 de março, do compositor Sergei Prokofiev (nascido em 1891), e a 4 de julho, do compositor Marcelo Tupinambá (nascido em 1899). Stravinsky compôs nesse mesmo ano as peças Tango para orquestra de câmara; Três canções de William Shakespeare para voz, Septeto para cordas, piano, clarinete, trompa e fagote; e finalmente Concertino $^{41}$ para um grupo de câmara de 12 instrumentos - na verdade essa peça foi um arranjo do mesmo Concertino para quarteto de cordas (1920).

Entre os anos de 1954 a 1958 Villa-Lobos gravou para a EMI francesa uma série contendo diversas obras de sua autoria. As obras gravadas foram:

- As nove "Bachianas Brasileiras";

- As 4 suítes do "Descobrimento do Brasil";

${ }^{41}$ Stravinsky compôs 3 concertinos: Quarteto de cordas (1920), para piano (1923) e grupo de câmara (1953). 
Villa-Lobos e os metais graves sinfônicos:

Um estudo dos elementos técnicos específicos

- "Choros $N^{\circ} 10 "$;

- "Momoprecoce";

- "Concerto $N^{o} 5$ para Piano e Orquestra".

Houve a participação de solistas como o soprano Victoria de Los Angeles ${ }^{42}$, Magda Tagliaferro e Felicja Blumental ${ }^{43}$. Essas gravações fizeram parte de uma coleção de discos intitulada "Villa-Lobos par Lui-Même". No ano de 1954 - primeiro ano da gravação desse disco, Stravinsky compôs a peça vocal Four Russian Songs, e o compositor Edgar Varèse, a peça para sopros, percussão e fita eletrônica, Deserts. Villa-Lobos estreou, nos dois últimos anos da gravação - entre 1955-1956 -, o "Concerto para Harpa e Orquestra" e o "Concerto para Violão e Pequena Orquestra", escritos para dois dos mais importantes instrumentistas de todos os tempos: o harpista Nicanor Zabaleta (1907-1993) e o violonista Andrés Segóvia (1893-1987), que foram os solistas dos concertos dirigidos por Villa-Lobos à frente, respectivamente, da Orquestra da Filadélfia e da Sinfônica de Houston.

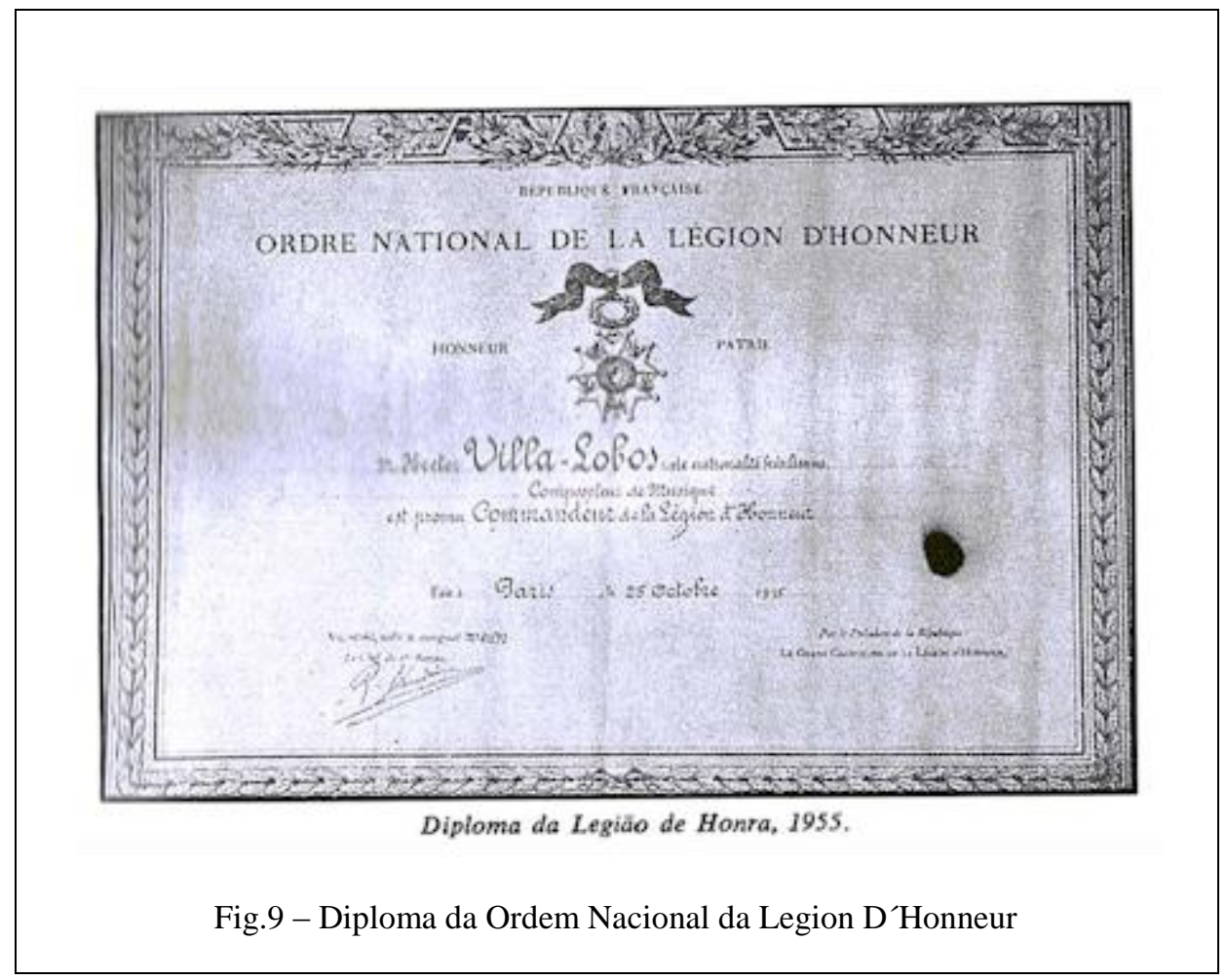

\footnotetext{
42 1/11/1923 - 15/1/2005. Soprano lírico catalão. Foi classificada como a número 3 na lista dos vinte maiores sopranos de todos os tempos do BBC Music Magazine (2007)

43 28/12/1908 - 31/12/1991. Pianista, nascida em Varsóvia/Polônia. Em 1938 mudou-se para o Brasil, em fuga do crescente antissemitismo na Europa. Defendeu a música e os compositores brasileiros por toda a sua vida.
} 
O ano de 1957 foi declarado pelo governo brasileiro como o Ano Villa-Lobos. Seus 70 anos de idade foram comemorados num editorial no jornal The New York Times e com a declaração de cidadão honorário da cidade de São Paulo, onde se organizou uma "Semana Villa-Lobos". Numa fase produtiva, Villa-Lobos escreveu a trilha sonora para o filme Green Mansions, de Mel Ferrer, que mais tarde se tornou a suíte Floresta do Amazonas. Ainda compôs nesse ano a ópera Yerma, estreou a Sinfonia $n^{o} .10$, o Concerto $n^{o} .3$ para piano e orquestra e terminou a composição da Sinfonia $N^{\boldsymbol{o}}$. 12. Paralelamente, Stravinsky compôs o balé Agon e, no ano seguinte (1958), terminou a peça para coral Threni. Varèse compôs o Poeme eletronique, peça de 8 minutos escrita para o pavilhão da empresa Philips, na Feira Mundial de Bruxelas.

Um ano mais tarde ocorreu na cidade de Nova Iorque, em 12 de julho de 1959, o Empire State Music Festival. Nesse evento, Villa-Lobos foi o regente da Symphony of the Air, naquele que foi seu último concerto. Fez parte do programa:

- $\quad$ Choros $N^{o}$ 6";

- "Papagaio do Moleque";

- "Uirapurú";

- "Descobrimento do Brasil - $1^{a}$ Suíte";

- Quatro canções da "Floresta do Amazonas" (em primeira audição mundial em concerto), interpretadas pelo soprano Ellinor Ross ${ }^{44}$.

Em exatos 128 dias após esse evento, Villa-Lobos faleceu no Rio de Janeiro, em 17 de novembro e aos 72 anos. Foi velado no Theatro Municipal e enterrado no Cemitério São João Batista. Na lápide de seu túmulo, lê-se:

"Considero minhas obras como cartas que escrevi à Posteridade sem esperar resposta".

\footnotetext{
44 Nascida a 01/08/1932 em Tampa/Flórida - EUA. Soprano dramática, especializada em repertório italiano. Teve sua aposentadoria forçada em 1979 devido à doença.
} 
Villa-Lobos e os metais graves sinfônicos:

Um estudo dos elementos técnicos específicos

Segunda Parte:

Capítulo 5:

\section{APRECIAÇÃO CONTEXTUALIZADA DAS OBRAS}

“[...] Na floresta virgem eu tagarelava com os pássaros. Tinha eu uma flauta e cantava as mesmas canções dos passarinhos. Então eles me reconheciam: um homem, um animal raro que entendia a sua própria linguagem. Eles me respondiam e eu também lhes respondia [...]" Villa-Lobos. 


\section{INTRODUÇÃO}

Villa-Lobos tinha uma enorme capacidade de trabalho que resultou numa imensa produção $^{45}$. Entre as sinfonias, concertos, os Trios e Quartetos, as Bachianas, os Chôros, os Balés, Suítes, Músicas para cinema, composições para banda de música, o Oratório, peças para piano, canto e violão, poemas sinfônicos, música de câmara, quartetos de cordas e as Óperas, seu opus chega à casa dos mil. O que nos vale lembrar ainda, é que Villa-Lobos é o compositor brasileiro que tem o maior número de obras editadas, gravadas e difundidas pelo mundo, quer seja em registros históricos ou em gravações mais recentes.

O livro "The Study of Orquestration", de Samuel Adler, nos trás luz à questão e explicitam as seis técnicas básicas que nasceram na literatura. Para Adler, muitos livros de orquestração têm recomendado que o acompanhamento orquestral fosse atribuído principalmente ao naipe das cordas, uma vez que tem, de forma geral, uma tendência a não "roubar a cena" inteiramente. No entanto, o autor considera esta tática uma mera simplificação que não provém da literatura orquestral, ao contrário de suas técnicas.

Em alguns casos, o enunciado dessas técnicas, por fazer uso de metáforas, como a palavra "cor", por exemplo, ou por fazer uso de termos muito amplos, como "contraste", pode não comunicar imediatamente a ideia central da técnica e até para alguns parecer vago. Entretanto, com as explicações e exemplos, esses termos serão esclarecidos e seu entendimento mais consistente.

Vale esclarecer que, nesse livro, Adler usa as expressões Foreground, Middleground e Background, para se referir, respectivamente, ao primeiro plano, segundo plano e terceiro plano quando trata da orquestração em seus exemplos e explicações.

${ }^{45}[\ldots]$ "Minha inspiração são oito, dez horas, doze horas de trabalho por dia" [...] Villa-Lobos. 


\subsection{BALÉS}

Segundo Zanon, além de Choros, Bachianas e Sinfonias, Villa-Lobos ainda compôs cerca de 20 peças orquestrais. Geralmente concebidas como poemas sinfônicos ou balés. (Zanon, 2009, p.67). Juntas, elas praticamente formaram um ciclo, de coerência comparável ao das Bachianas. Com outro foco, Damaceno afirmaria que em perspectiva, as peças da juventude de Villa-Lobos, estariam dentro de sua fase dionisíaca (Damaceno, 2009, p.114), e soariam como um prelúdio às importantes realizações dos anos 20. Amazonas (1917/e. 1929) e Uirapurú (1917/e. 1935) já mostra a preocupação com texturas características.

Os poemas sinfônicos Uirapurú e Amazonas têm características em comum que os tornam obras especiais inseridas na imensa produção villalobiana (Salles, 2009, p.25). Tratase de dois de seus maiores êxitos incorporando-se ao repertório das principais orquestras. Ao converter histórias da Antiguidade em lendas amazônicas, Villa-Lobos investe uma imensa carga semântica na sonoridade, na configuração e reiteração de motivos, no jogo de densidades, no conceito de ambientação. O Villa-Lobos de Amazonas e Uirapurú estava totalmente afinado com as preocupações da vanguarda europeia de sua época.

Acredita-se que ambos tenham sido reescritos em Paris, quando ganharam seus títulos definitivos. Tanto Uirapurú quanto Amazonas apresentam características de transição entre Villa-Lobos formado pelo academicismo franco-wagneriano dominante no Brasil no início do século XX e o modernismo stravinskiano/varèsiano que o compositor brasileiro efetivamente conheceu em Paris.

De acordo com a tradição romântica do poema sinfônico, em ambas as composições Villa-Lobos procura dar conotação sonora à matéria literária. Porém ele se manteve aberto para transplantar a música de um contexto para outro, fazendo ligeiras alterações ou ainda alguns acréscimos. Nesse caso, a adaptação não deve ter apresentado grandes problemas porque ambos fazem referências a canto de pássaros e ruídos da mata (Salles, 2009, p. 26). 
Segundo Acácio Piedade (2009) sua diversidade constitui um universo que perpassa por várias tópicas: tópicas selvagens (aspecto selvagem da natureza) que tratam da brutalidade dos fenômenos naturais; tópicas animais, que retratam tipicamente pássaros habitantes da floresta, como o uirapurú, geralmente utilizando princípios de iconicidade.

De fato, as tópicas indígenas em Villa-Lobos merecem um estudo aprofundado. A questão é antropologicamente importante, pois se trata da representação do outro através do que se chamou de "estética primitivista", criando artisticamente a dualidade modernocivilizado e primitivo-selvagem, e expressando o mal-estar da civilização pela perda de vínculo com o mundo natural. Como em Camargo Guarnieri (Acácio PIEDADE; BENCKE, 2009), Villa-Lobos teve frequência garantida em tópicas caipiras, tanto na melodia do trenzinho caipira como nos acordes de viola no Plantio do Caboclo. 


\subsubsection{UIRAPURÚ}

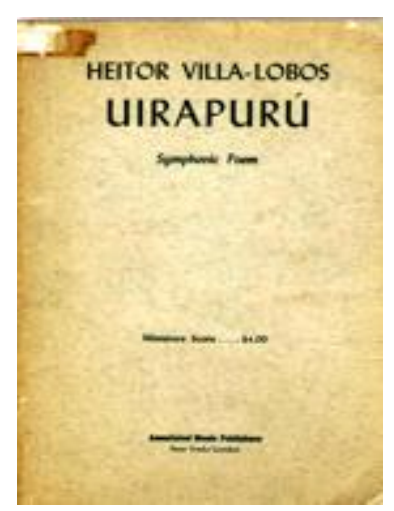

Fig. 10 - Capa da partitura original de Uirapurú

O Bailado ou poema sinfônico "O uirapurú”, foi composto por Villa Lobos no Rio de Janeiro em 1917, com argumento de sua própria autoria a partir de uma lenda indígena. De acordo com a partitura, "O uirapurú" foi reformado em $1934^{46}$, ano em que a peça foi dedicada a Serge Lifar, que a dançou no Rio de Janeiro. A estreia se deu no ano seguinte em 25 de maio de 1935, com a orquestra e o corpo de baile do Teatro Cólon em Buenos Aires, sob a regência do compositor e coreografia assinada por Ricardo Nemanov.

O libreto que consta da própria partitura original, nos informa o seguinte:

Conta uma lenda que a magia do canto noturno do uirapurú era tão atraente que as índias se reuniam a noite a procura do trovador mágico das florestas brasileiras. Porque as feiticeiras lhes contaram, que o uirapurú era o rei do amor e o mais belo cacique da terra.

Em uma floresta calma e silenciosa, aparece um índio feio tocando flauta. Em um grupo alegre surgem as mais belas silvícolas da região do Pará, que se decepcionam ao descobrirem o índio feio. Indignadas, enxotam-no brutalmente com pancadas, empurrões e pontapés. Por entre as folhagens das árvores as índias ansiosas procuram o uirapurú, certas de encontrarem um lindo jovem. Esta ansiedade é testemunhada pelos grilos, corujas, bacuraus, sapos-intanhas, morcegos e toda a fauna noturna. Ouvem-se ao longe de quando em quando alguns grilos suaves que anunciam o uirapurú e irradiam contentamento todo aquele ambiente.

Seduzida pelo mavioso canto do uirapurú, aparece uma linda e robusta índia de flecha e bodoque em punho, como uma adestrada caçadora de pássaros noturnos. Vendo o pássaro encantado, lança lhe a flecha, prostrando-o por terra. Surpreende-se, porem, ao

\footnotetext{
${ }^{46}$ Uirapurú provavelmente foi refeito por volta de 1930 (Lima, 2002, p. 6).
} 
vê-lo transformar-se num belo índio que é disputado pelas índias. A caçadora que o ferira sai vitoriosa.

No auge da contenda ouve-se o som fanhoso e agoureiro da flauta de osso. Temendo uma vingança, as índias procuram esconder o belo índio que é, porém surpreendido pelo índio feio, feroz e vingativo, que atirando-lhe a flecha fere-o mortalmente. Pressurosas, as índias carregam o belo índio em seus braços para a beira de um poço, onde subitamente ele se transforma num pássaro invisível, deixando-as tristes e apaixonadas ao ouvir apenas o seu canto maravilhoso que desaparece no silencio da floresta $^{47}$.

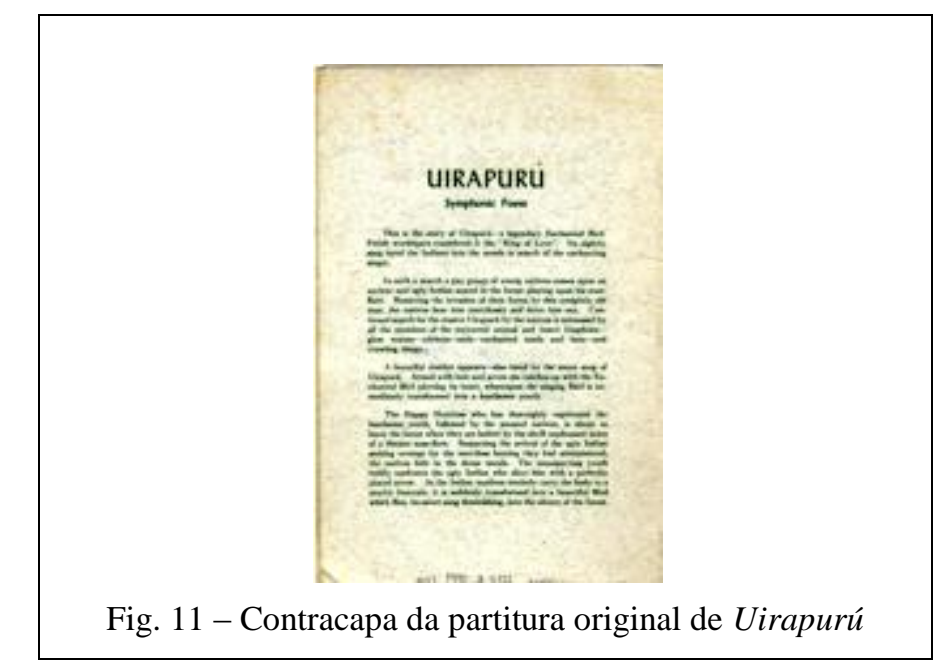

O Uirapurú fará parte do concerto ocorrido na cidade de Nova Yorque, em 12 de julho de 1959, onde acorreu o Empire State Music Festival. Neste evento Villa-Lobos conduziu a Symphony of the Air em seu último concerto em vida ${ }^{48}$.

Uirapurú está entre as obras mais representativas do "paisagismo modernista" de Villa-Lobos segundo Volpe (2009, p.36), cuja reformulação do Indianismo, embora tenha dado continuidade a duas convenções românticas (a identificação do índio com a natureza e a oposição entre o noble sauvage e o índio primitivo), estabeleceu novas convenções, particularmente a representação do mundo mágico e primevo do indígena, da natureza "maravilhosa", integrando o motivo metamórfico, da "Amazônia imaginária", do éden mítico. A releitura do Indianismo cunhada por Villa-Lobos, a partir de um imaginário edênico, constitui aspecto fundamental para a compreensão do nacionalismo modernista.

\footnotetext{
${ }^{47}$ Texto extraído da última página da partitura original de Villa-Lobos.

${ }^{48}$ Em exatos 128 dias após esse evento, Villa-Lobos faleceu no Rio de Janeiro.
} 


\section{CONSIDERAÇÕES DA ORQUESTRAÇÃO EM UIRAPURÚ}

A instrumentação utilizada por Villa-Lobos nessa peça é, segundo ALENCAR (2010, p.6) caracteristicamente europeia, não tendo nenhuma grande diferença; o destaque, porém, cabe à sua diferenciada utilização de instrumentos como o oboé, o corne inglês e o próprio piano para reproduzir os "sons da floresta" (pequenos pássaros, roedores, insetos - todos claramente ilustrados pelo compositor), não se esquecendo da utilização da flauta para reproduzir o canto do uirapurú.

Outra característica fundamental são as modulações rítmicas e tonais que perpassam a música. A não utilização de um ritmo constante pode ter duas razões: uma é a tentativa de romper com o modelo europeu - ou melhor, tentativa de se apropriar do modelo europeu e passar a moldá-lo conforme as características da própria música brasileira - e outra seria a retratação da heterogeneidade dos ritmos da floresta (os animais, a flora, os índios, etc.). Quanto à tonalidade, esta foge bastante do modelo tradicional europeu: Villa-Lobos cria modulações não tradicionais para dar mais vivacidade e ineditismo à sua música ${ }^{49}$, mas também dotada de "erudição" e características notadamente brasileiras na música de concerto.

Utilizaremos a edição editada da Associated Music Publishers - New York, com copyright de 1948. Com um efetivo orquestral completo, constando os seguintes instrumentos:

\begin{tabular}{c|c|c}
\hline \multirow{4}{*}{ Madeiras } & 1 & Flauta Piccolo \\
\cline { 2 - 3 } & 2 & Flautas \\
\cline { 2 - 3 } & 2 & Oboés \\
\cline { 2 - 3 } & 1 & Corne Inglês \\
\cline { 2 - 3 } & 2 & Clarinetes \\
\cline { 2 - 3 } & 1 & Clarone \\
\cline { 2 - 3 } & 2 & Saxofone soprano \\
\cline { 2 - 3 } & 1 & Fagotes \\
\hline
\end{tabular}

\footnotetext{
${ }^{49}$ A peça foi escrita sem acidente algum, tornando-a tradicional e fácil para leitura, porém esta modula à vontade de Villa-Lobos, chegando a vários momentos à bitonalidade (como ocorre no penúltimo acorde) ou à atonalidade (o que acontece no último compasso da composição).
} 
Villa-Lobos e os metais graves sinfônicos:

Um estudo dos elementos técnicos específicos

\begin{tabular}{c|c|c}
\hline \multirow{4}{*}{ Metais } & 4 & Trompas $^{50}$ \\
\cline { 2 - 3 } & 3 & Trompetes \\
\cline { 2 - 3 } & 3 & Trombones \\
\cline { 2 - 3 } & 1 & $\begin{array}{c}\text { Tímpano, xilofone, glockenspiel, chimes, } \\
\text { côco, tamborim, tambor surdo, pratos, } \\
\text { bumbo, tam-tam e reco-reco }\end{array}$ \\
\hline \multirow{3}{*}{ Percussão } & 2 & Harpas \\
\cline { 2 - 3 } & 1 & Celesta \\
\cline { 2 - 3 } & 1 & Piano \\
\hline Exótico & 1 & Violinofone \\
\hline Cordas & & Violinos 1 e 2, Viola, Violoncelo e \\
& & Contrabaixo \\
\hline
\end{tabular}

Tab. 2: Instrumentação para Uirapurú

Sobressai-se nessa composição a escrita marcada pela pesquisa de novos timbres principalmente em relação aos instrumentos tradicionais de percussão, como o reco-reco e o coco. A influência de Richard Wagner (1813-1883) em Villa-Lobos é reconhecida por muitos estudiosos de sua obra. Essa admiração por Wagner foi sem dúvida despertada pelos mentores de Villa-Lobos no Rio de Janeiro, como Francisco Braga e Alberto Nepomuceno (Carvalho, 2003a). Salles dedica um capítulo para explanar o arquétipo wagneriano em Uirapurú (Salles, 2009, p. 28-36).

Segundo Bruno Kieffer ao abstrair-se da evolução de Villa-Lobos no tocante ao domínio de seu métier de compositor, deixando de lado ainda a evolução de eventuais sombras pessoais em obras ainda marcadamente francesas, a análise das composições anteriores a 1922, força a impressão de que o aparecimento da personalidade que se tornaria muito marcada de Heitor Villa-Lobos bem como de características telúricas ou populares veiculadas por uma linguagem típica do século XX, processou-se de um modo incorruptível e não evolutivo linear. O poema sinfônico "O Uirapurú" é uma das manifestações de tal erupção. De fato a obra possui e já em sua plenitude a personalidade de seu autor e

\footnotetext{
${ }^{50}$ As trompas são detentoras de solos e partes importantes no repertório villalobiano, porém suas participações importantes não serão analisadas nesta pesquisa. Apenas receberão citação quando seus escritos interferirem na atuação dos metais graves (grifo nosso).
} 
características telúricas realizadas aqui em parte por elementos descritivos como, por exemplo, o canto do uirapurú.

Por fim podemos vislumbrar certos elementos stravinskianos ${ }^{51}$ que corroboram a hipótese de que Uirapurú (juntamente com Amazonas) tenham sido retrabalhadas em Paris. Daí conclui-se que nem toda inovação percebida em Uirapurú se deve ao impacto causado pela audição de Le Sacre (Guérios, 2003).

Os trombones são utilizados em uma extensão que compreende do Sib1 ao Mi3 (tenor), do Sol1 ao Dó2 (baixo) e do Sib-1 ao Dó2 (tuba). Com dinâmicas que variam do mezzo-forte ( $\mathrm{mf}$ ) ao fortississimo (fff) em sem nomear o mezzo-piano (mp). O primeiro momento onde os trombones 1 e 2 entram, juntamente com toda a orquestra ${ }^{52}$, será exatamente no primeiro compasso e a partir da segunda metade do $3^{\circ}$. tempo, em um glissando possivelmente integral no $2^{\circ}$. trombone, mas não no $1^{\circ}$. trombone:

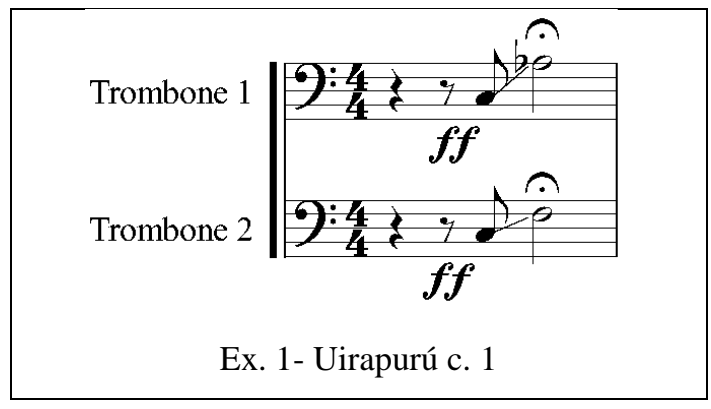

Após esse glissando, os metais graves ficarão por 16 compassos sem tocar, e farão se retorno numa semibreve em dinâmica $f f$ e crescendo. Isso em conjunto com toda a orquestra (c. 18).

\footnotetext{
${ }^{51}$ (...) apresentando melodias que expandem o sistema tonal, com timbres ousados, no uso da politonalidade, da polirritmia, da síncope e de instrumentos de percussão de origem popular. (Damasceno, 2007 p.147)

${ }^{52}$ Em verdade, apenas os teclados (xilofone, glockenspiel e piano) e as cordas (violinos, violo e Violoncelo) fazem esse glissando. Para as madeiras (flautas, clarinetes e fagotes), Villa-Lobos escreveu arpejos.
} 


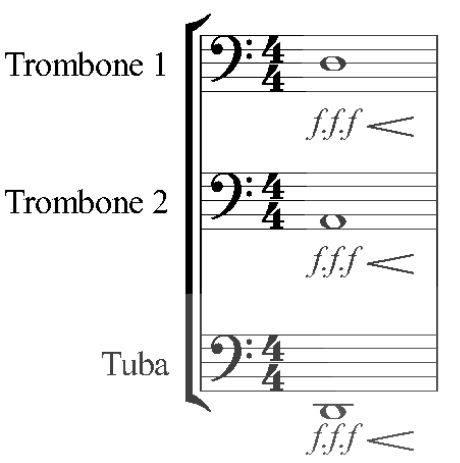

Ex. 2- Uirapurú c. 18

Novamente o naipe fica em contagem de espera por seis compassos, no entanto o trecho que se segue, no número [7] traz o $1^{\circ}$. trombone em contratempo ${ }^{53}$ (Villa-Lobos demarca esse trecho em Tempo di marcia), ostinato em contratempo também executado pelos violinos 1 e viola. Essa ideia se inicia no c.25 e perdurará até o c.48. Mais tarde o $2^{\circ}$. trombone também participará deste ostinato, mas a partir do c.37.

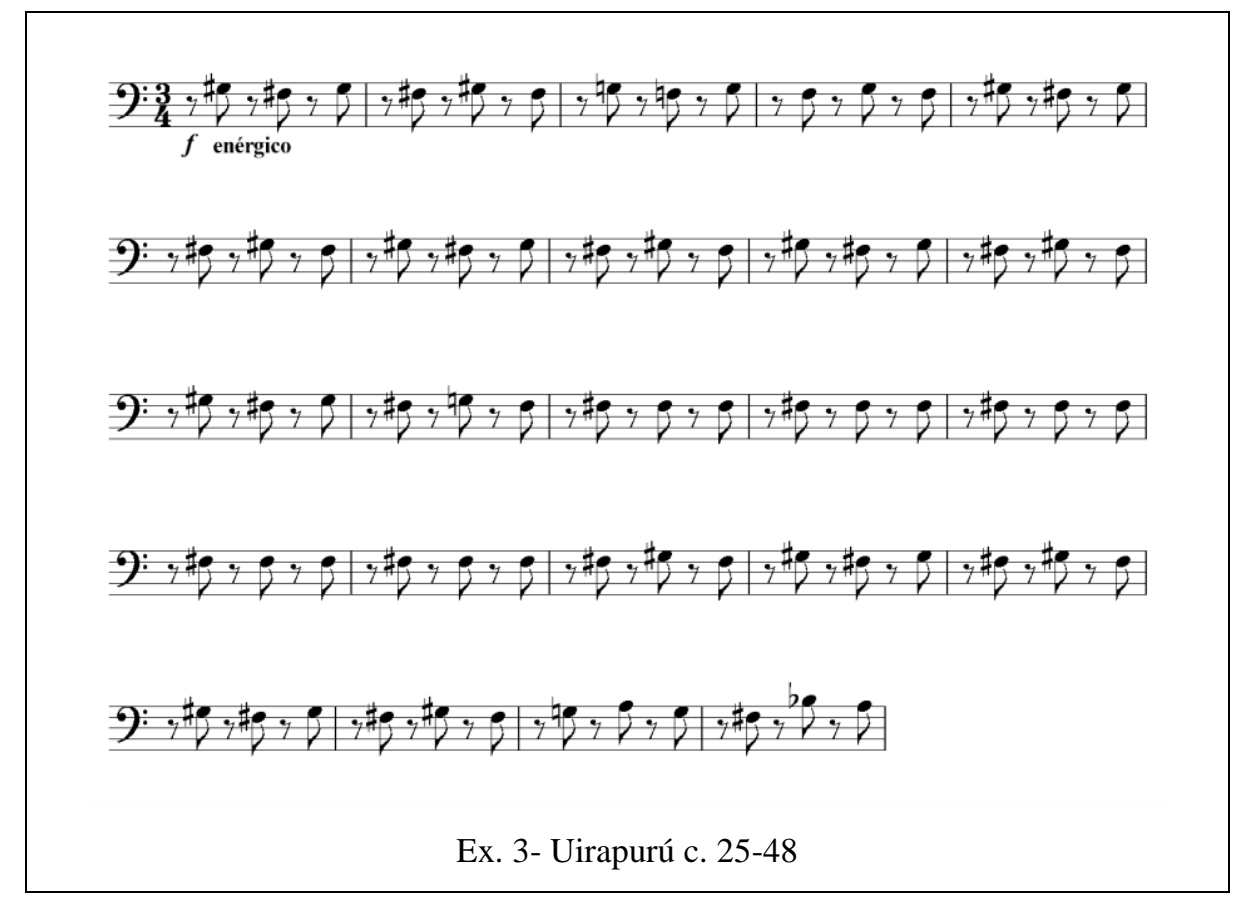

Nesse inciso cabe aos metais graves, com exceção do $1^{\circ}$. trombone, a observância da precisão rítmica imposta pela orquestração de Villa-Lobos. Este inciso também será executado pelos fagotes, tímpano e piano:

${ }^{53}$ Esse ostinato em contratempo é muito comum nas marchas brasileiras. 


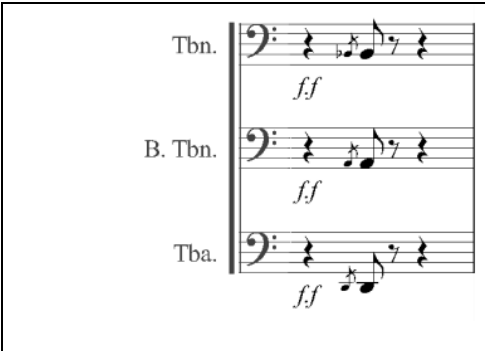

Ex. 4- Uirapurú c. 29, 32 e 33.

Como esse motivo, o $3^{\circ}$. Trombone e a tuba retornam à música no c.144-146, juntamente com fagotes, contrafagotes, tímpano, piano, surdo, Violoncelo e contrabaixo, porém a partir do c.146 apenas continuam em ostinato a tuba, os fagotes, contrafagote e o contrabaixo:

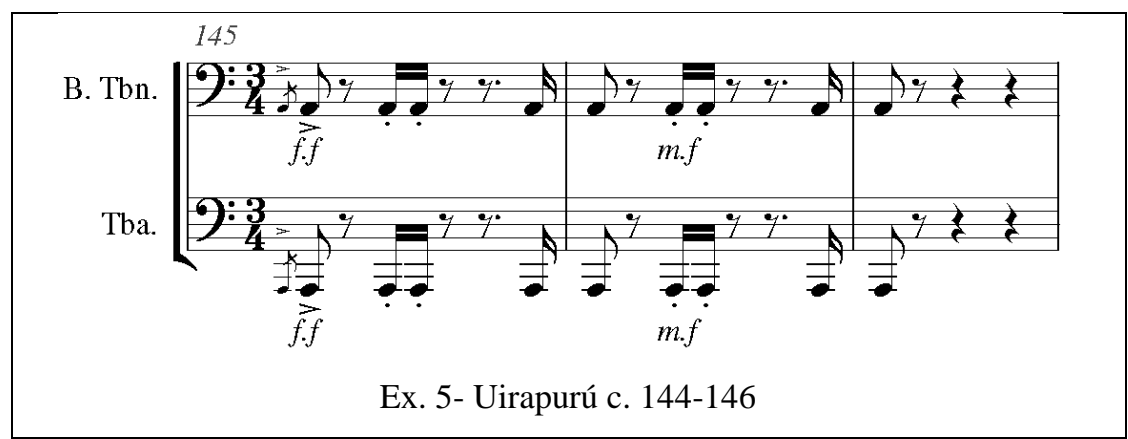

Sobre este ostinato, todos os trombones são responsáveis por um inciso de difícil execução, em conjunto com viola e Violoncelo, iniciado por uma pausa de semicolcheia. Porém os trombones descansam um compasso e tocam no próximo - a viola e o Violoncelo repetem ciclicamente esse ostinato por 11 compassos, sem parada alguma:

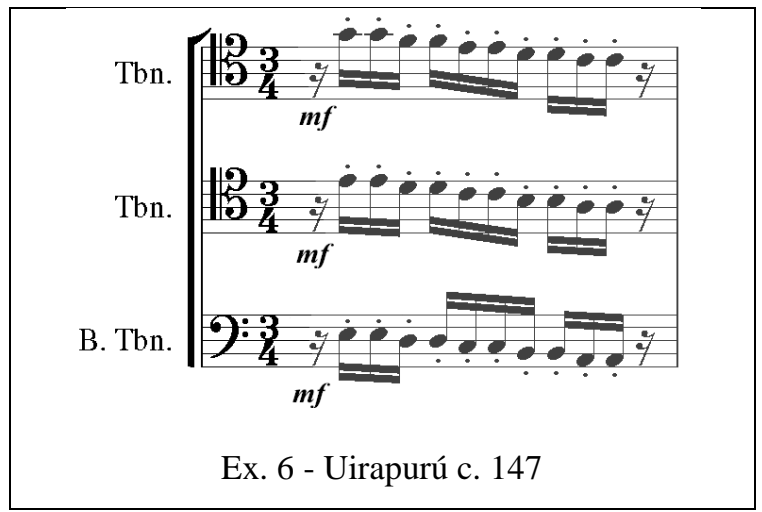

A tuba terá um soli no c.155 juntamente com o clarone, fagotes, contrafagotes e contrabaixos. Todos os instrumentos estão em dinâmica $m f$ : 
Villa-Lobos e os metais graves sinfônicos:

Um estudo dos elementos técnicos específicos

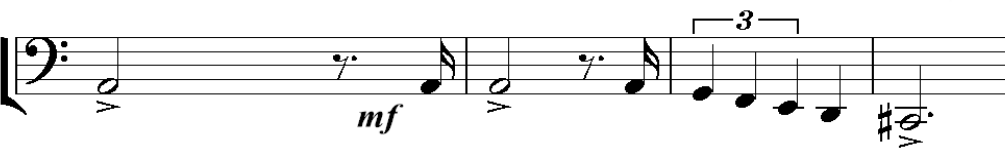

Ex. 7 - Uirapurú c. 153

O trecho que se segue, faz com que os trombones (em surdina straight) sintam-se solista, pois Villa-Lobos o escreveu apenas para o naipe:

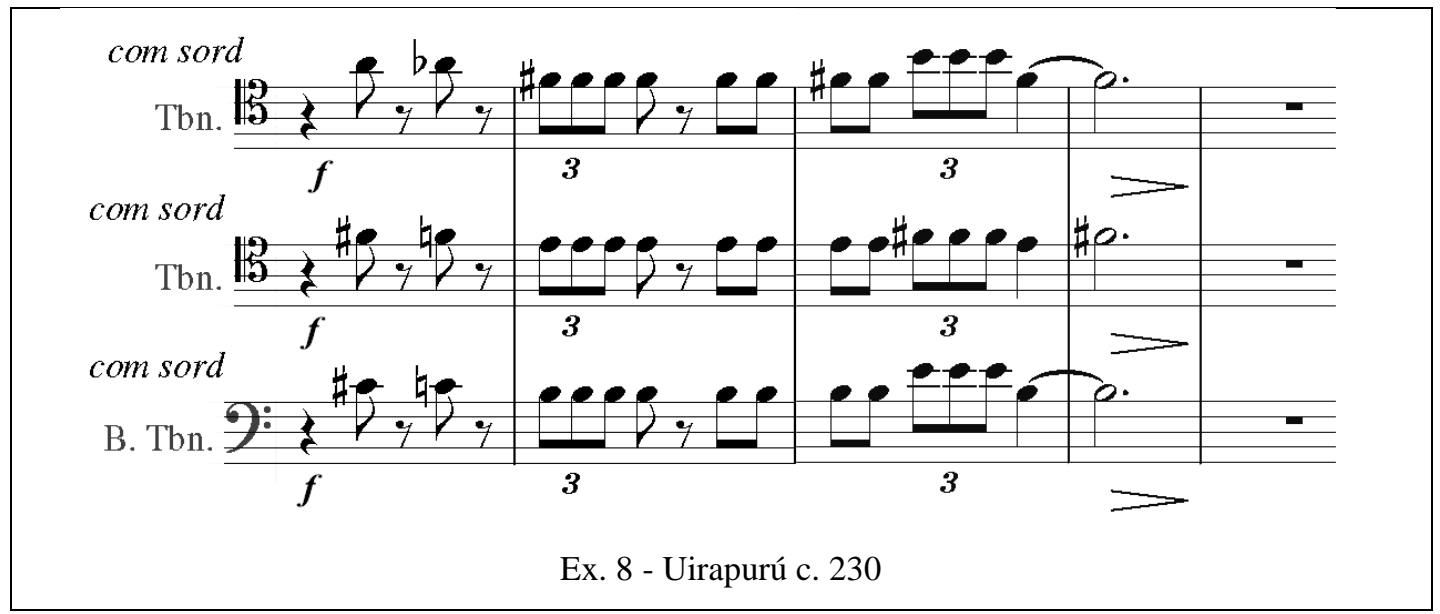

O próximo trecho será feito apenas pelo $3^{\circ}$. Trombone, mas é um espelho do período executado pelos Violoncelos e contrabaixos no c. 227, exatamente um período de 12 compassos:
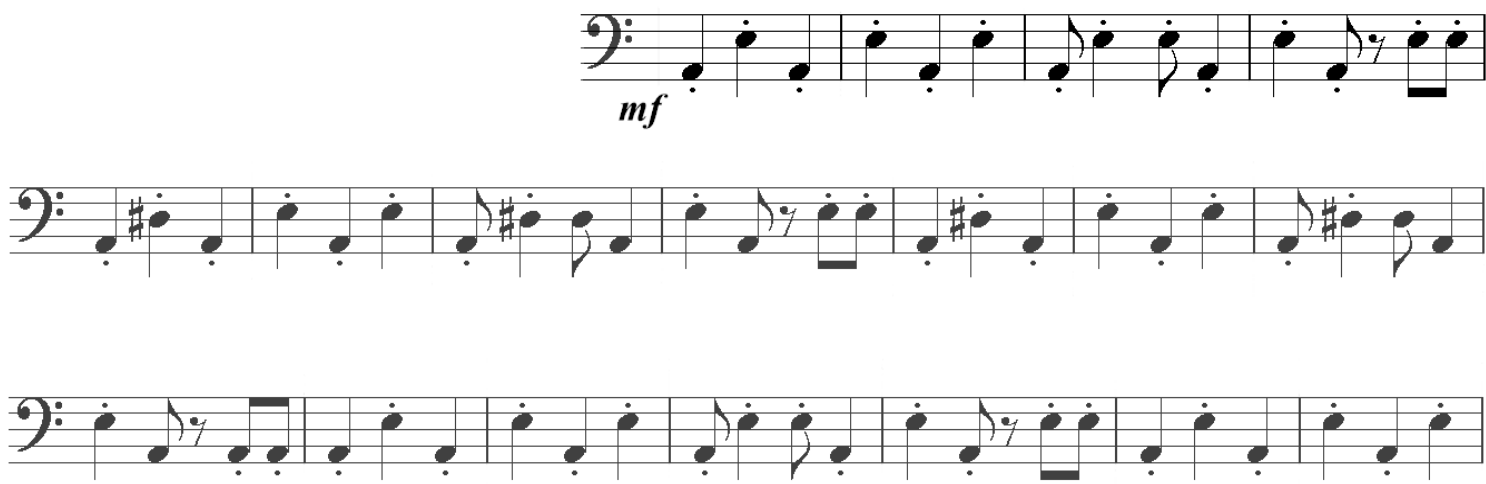

Ex. 9 - Uirapurú c. 239-256 
A partir do c.290 o $2^{\circ}$. Trombone inicia a exposição do tema, onde se executará em completo, porém outros instrumentos participarão desse solo mas numa participação seccionada (tocam apenas 2 compassos cada um):

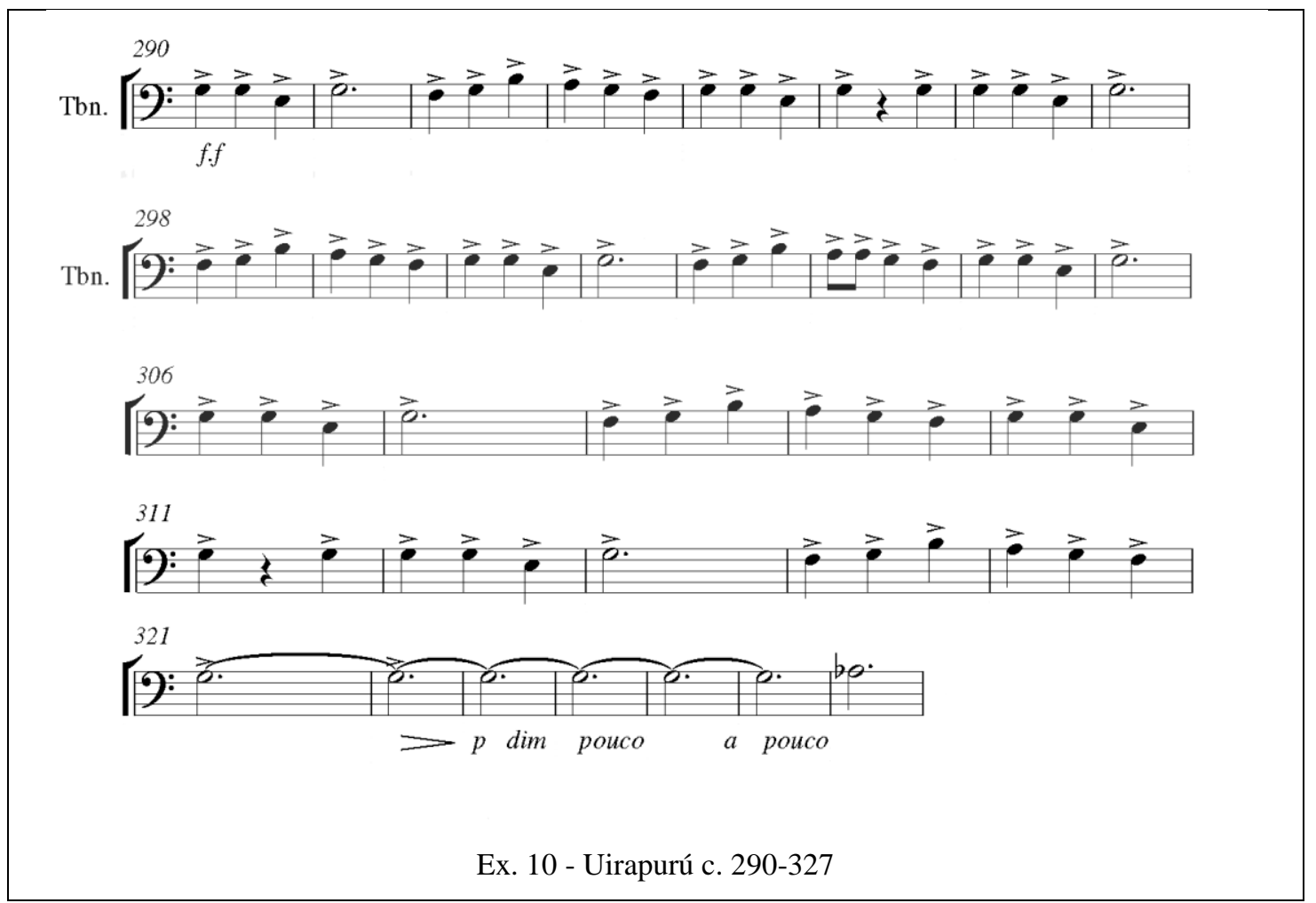

Antes de executar o trecho que se segue, os trombones e a tuba ficaram por 22 compassos sem tocar, e no c. 354 o $1^{\circ}$. Trombone fará um solo (com glissandos) na região aguda e com surdina straight. Esse solo mais se assemelha ao grito de algum animal.

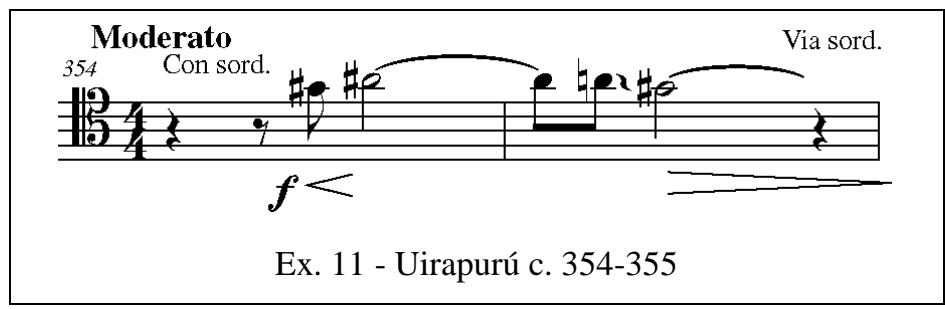

Dois compassos após o solo do $1^{\circ}$. Trombone, mais precisamente no c.358, a tuba e o $3^{\text {o }}$. Trombone (juntamente com fagotes, contrafagote, tímpano e contrabaixo) executarão uma figuração puramente rítmica na nota Fá: 


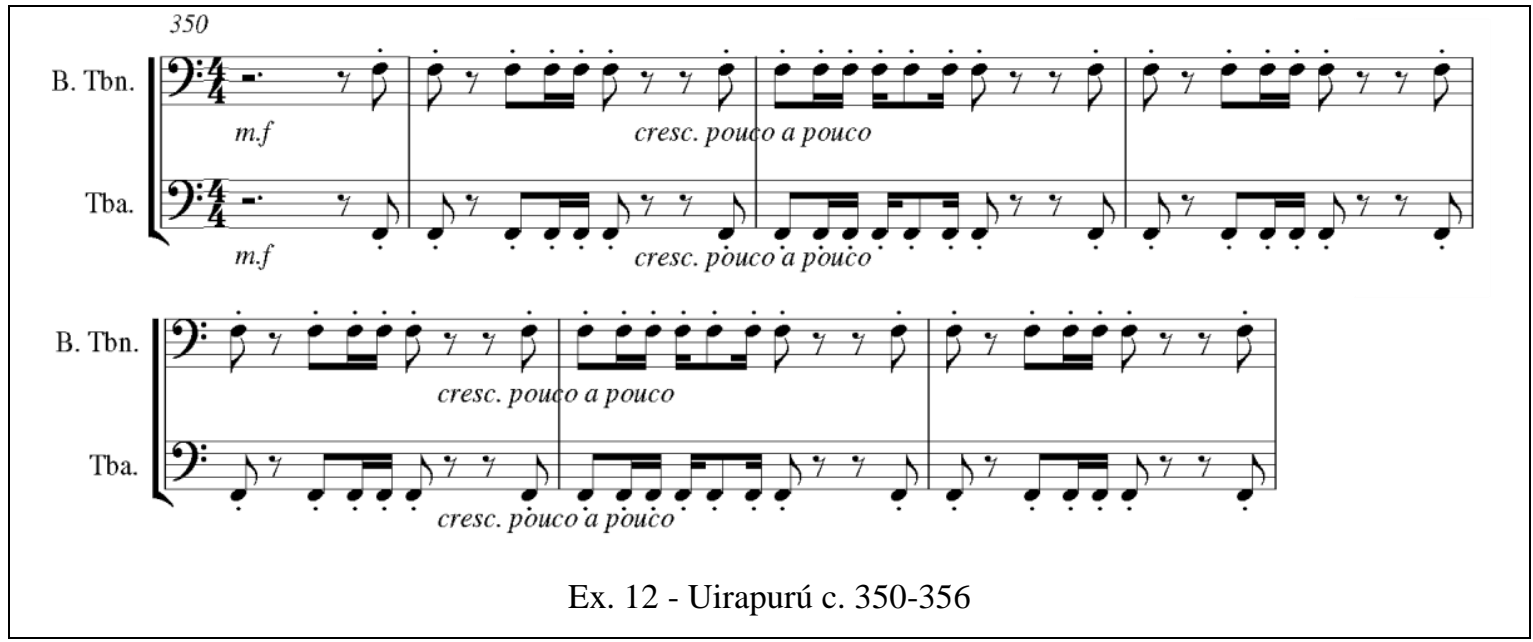

E por fim, o $1^{\circ}$. Trombone fará uma escala ascendente em conjunto com os Trompetes e o naipe de cordas (sem o contrabaixo) no c. 362:

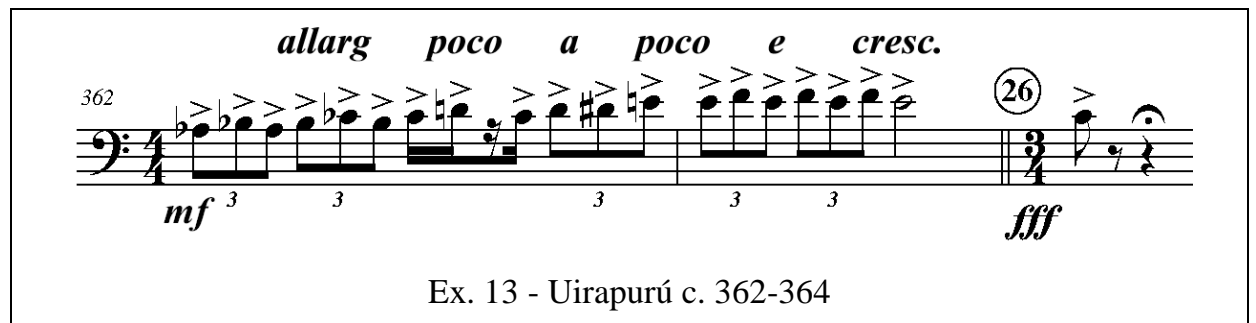

Os trombones não tocam no final da peça Uirapurú: estes ficam em espera pelos 17 compassos finais.

Em termos de utilização dos metais graves na peça Uirapurú entre os 381 compassos existentes na peça, encontramos os metais graves em 215 compassos $(56,43 \%)$ e os mesmos ficarão em pausa por 166 compassos (43,57\%). Teremos ainda 47 compassos em soli (4 para trombones, 2 para $1^{\circ}$. trombone, 39 para o $2^{\circ}$. trombone e 4 para tuba) e 2 compassos solo para o $1^{\circ}$. trombone. Nesta peça estão escritos 3 glissandos possíveis e 2 glissandos fora da extensão do êmbolo.

Em relação às dinâmicas utilizadas por Villa-Lobos para os metais graves, nos trechos anteriormente apresentados, não se encontrou dinâmica abaixo do $\boldsymbol{m p}$. Porém nos nível fortes, encontrou-se as seguintes ocorrência: $\boldsymbol{m f}(5), \boldsymbol{f}(3), \boldsymbol{f f}(4)$ e $\boldsymbol{f f f}(2)$. Quanto às articulações escritas por Villa-Lobos, encontramos 117 notas com ponto de diminuição e 90 notas com acento. 


\subsubsection{AMAZONAS}

"Depois de Amazonas perdi o pudor e a timidez de escrever coisas arrojadas" ${ }^{54,}$, Villa-Lobos.

Como ainda era violoncelista da orquestra do Theatro, Villa estudou profissionalmente os balés do repertório da companhia, fato que o influenciou a compor bailados (Peppecorn, 2000 p.48). O Bailado ou poema sinfônico O Amazonas, foi escrito por Villa- Lobos no Rio de Janeiro, em 1917/e. 1929. Sua primeira audição se deu em Paris na Salle Gaveau, a 30 de maio de 1929, em desempenho da Orchestre du Concert Poillet, acrescida de músicos, num total de 120 executantes.

O material melódico de Amazonas baseou-se em temas indígenas desenvolvidos por Villa-Lobos. O ambiente harmônico, rítmico e a atmosfera criada pelos timbres obedecem a um princípio de forma original de instrumentação, calcada nos efeitos e sugestões do próprio compositor. As florestas, os rios, as cascatas, os pássaros, os peixes e bichos ferozes, os silvícolas, os caboclos e as lendas marajoaras, tudo influiu psicologicamente na confecção dessa obra (apud Horta, 1987:8).

Para o compositor seus principais motivos melódicos são os que representam o tema da invocação, o da surpresa da miragem, o do rastejar e galope dos monstros lendários do Rio Amazonas, o da sedução, da volúpia, da sensualidade da índia sacerdotisa, o do canto heroico dos guerreiros indígenas e do precipício.

Assim é o libreto deste balé (Pereira, 2003, p.117-118):

Uma linda virgem e moça consagrada pelos Deuses das florestas amazônicas, costumava saudar a aurora, banhando-se nas águas do Amazonas, o rio marajoara, o qual às vezes ainda mostrava os efeitos de sua cólera contra as filhas da Atlântica, mas que em homenagem a beleza delas, de vez em quando também, acalmava as ondas de sua própria corrente eterna.

A moça selvagem diverte-se alegremente, ora invocando o sol com gestos rituais, ora contornando o corpo divino em gestos graciosos para que seu corpo possa inteiramente ser contemplado pela luz do astro rei, ou se refletir na ondulante superfície do rio. E quanto mais vê sua sombra desenhar na tela dolente e fria aos

\footnotetext{
${ }^{54}$ Villa-Lobos. Amazonas tem argumento de Raul Villa-Lobos, pai do compositor.
} 
traços de sua beleza, tal como ninguém a idealizara, mais ela se orgulha de si mesma, numa sensualidade brutal.

Enquanto a virgem cisma, o Deus dos ventos tropicais a perfuma com seu sopro caricioso e amoroso, mas a moça, desprezando essas implorações de amor, dança entregando-se loucamente a seus prazeres como uma criança ingênua.

Indignado de tanto desprezo, o ciumento Deus dos ventos, leva o perfume casto da filha dos marajós até as regiões profanas dos monstros. Uns desses monstros sente a moça, e na ansiedade de possuí-la, tudo destruindo ao passar, avança e sem ser percebido, aproxima-se da índia. Impulsionado pela força dos instintos, que a natureza depositou nos seres vivos, ele vai realizar o capricho incontrastável do imã invisível.

A pequena distancia da virgem, o monstro para de caminhar e principia rastejando. Já de perto ele contempla a moça, extasiado e a deseja, sem ser percebido por ela, o monstro procura esconder-se, porém sua imagem é refletida pela luz do sol sobre a mancha cinzenta da sombra da índia, é então que vendo sua própria imagem transformada, cheia de terror e sem destino, a virgem consagrada, seguida pelo monstro, precipita-se no abismo do seu próprio desejo.

\section{CONSIDERAÇÕES DA ORQUESTRAÇÃO EM AMAZONAS}

Utilizaremos a edição revisada e editada pelo maestro Roberto Duarte, sob encomenda da Academia Brasileira de Música ABM, em 2010. Com um efetivo orquestral completo, constando os seguintes instrumentos:

\begin{tabular}{|c|c|c|}
\hline \multirow{10}{*}{ Madeiras } & 2 & Flautas Piccolo \\
\hline & 2 & Flautas \\
\hline & 2 & Oboés \\
\hline & 1 & Corne Inglês \\
\hline & 1 & Requinta (Clarinete em Mib) \\
\hline & 2 & Clarinetes \\
\hline & 1 & Clarone (Clarinete baixo) \\
\hline & 2 & Fagotes \\
\hline & 1 & Contrafagote \\
\hline & 1 & Sarrusofone \\
\hline \multirow{4}{*}{ Metais } & 4 & Trompas \\
\hline & 4 & Trompetes \\
\hline & 3 & Trombones \\
\hline & 1 & Tuba \\
\hline
\end{tabular}


Villa-Lobos e os metais graves sinfônicos:

Um estudo dos elementos técnicos específicos

\begin{tabular}{c|c|c}
\hline \multirow{3}{*}{ Percussão } & & $\begin{array}{c}\text { Tímpano, xilofone, glockenspiel, chimes, côco, tamborim, } \\
\text { tambor surdo, pratos, bumbo, tam-tam e reco-reco }\end{array}$ \\
\cline { 2 - 4 } & 1 & Celesta \\
\cline { 2 - 3 } & 2 & Harpas \\
\cline { 2 - 3 } & 1 & Piano \\
\hline Exótico & 1 & Citara de arco ou Violinofone \\
\cline { 2 - 3 } & 1 & Viola D'amore \\
\hline Cordas & & Violinos 1 e 2, Viola, Violoncelos e Contrabaixo \\
\hline
\end{tabular}

Tab. 3 - Instrumentação para Amazonas

Em um estudo sobre os elementos, Vasco Mariz afirma que Amazonas é uma obra acentuadamente programática, onde contém efeitos orquestrais surpreendentes e combinações audaciosas de timbres, bem como o emprego do violinofone e da viola de amor, como instrumentos solistas, tudo isso numa definitiva libertação tonal. Bem anterior a Mariz, Mario de Andrade (1933) afirmou que Amazonas:

"é a música da natureza, aprendida com os passarinhos e as feras, com os selvagens e os tufões, com as águas e as religiões primárias, música da natureza, junto da qual a $6^{\mathrm{a}}$. Sinfonia de Beethoven ou Siegfried ${ }^{55}$, não como beleza, está claro, mas como significação cósmica. Não passam de amostras bem educadinhas da natureza, para expor nas vitrinas, natureza já comercializada, limpinha e vestida na civilização cristã ${ }^{n 56}$.

O relato de Le Frem ${ }^{57}$ nos põe a par do ocorrido durante a primeira audição mundial dessa peça afirmando lembrar-se muito bem da audição plena de tumulto e de veemência, dada na Salle Gavos de Amériques de Varèse e de Amazonas de Villa-Lobos, sob a regência de Gaston Poulet. O concerto transformou-se em motim na sala, e colocou, frente a frente, partidários e adversários, mas a audição contribuiu para difundir o nome de Villa-Lobos entre os melômanos ${ }^{58}$, muitos dos quais se iriam tornar seus partidários decididos.

\footnotetext{
${ }^{55}$ De Richard Wagner.

${ }^{56}$ Música, Doce música, 1932.

${ }^{57}$ Paul Le Frem, compositor francês.

${ }^{58}$ Melómano é considerado aqui como sendo um indivíduo amante e conhecedor de música, intérpretes e estilos musicais.
} 
A cidade de Paris e a peça Amazonas realmente tem um forte elo: foi nessa cidade onde Villa-Lobos realizou seu projeto de reorquestração. Inicialmente batizado de Myremis ${ }^{59}$, o poema sinfônico ambientado na Antiguidade foi transplantado para a floresta amazônica, permitindo a Villa-Lobos a chance de atualizar e ampliar determinados processos composicionais.

Há em Amazonas resíduo das influências de Wagner- e Stravinsky. Assim se justifica a discrepância entre a data de composição fornecida por Villa-Lobos, 1917, e a efetiva estreia da obra em 1929 (Guimarães, 1972, p. 219). Essas referências a Richard Wagner demonstram a interação de Villa-Lobos com o ambiente musical mais sofisticado do Rio de Janeiro, que via no compositor alemão um símbolo da música moderna ou da renovação musical em relação à ópera italiana. Em termos de tópicas, Acácio Piedade (2009) citaria que outro exemplo das tópicas de floresta tropical é sua enunciação como lugar da teofania, onde deuses, demônios ou espíritos da natureza habitam e têm sua voz musical.

Os trombones são utilizados em uma extensão que compreende do Ré2 ao Mi3 (tenor), do Dó1 ao Si2 (baixo) e do Fá-1 ao Réb2 (tuba). Com dinâmicas que variam do pianississimo (ppp) ao fortissississimo (ffff) em sem nomear o mezzo-piano (mp). Tuba e $3^{\circ}$. trombone aparecem pela primeira vez em c.6 num motivo cromático descendente, na forma de quiálteras de colcheia e em conjunto com o contrafagote e o sarrusofone, em dinâmica fff e estacato:

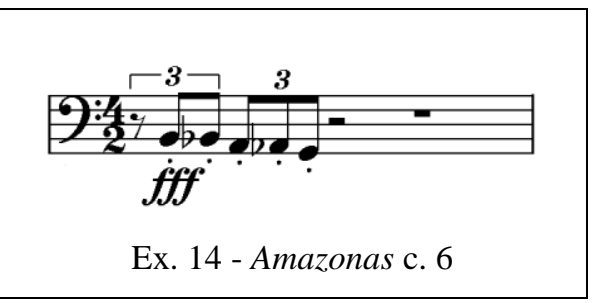

Haverá outro motivo cromático descendente, porém em semicolcheias mas com a mesma orquestração, dinâmica e articulação no c. 8:

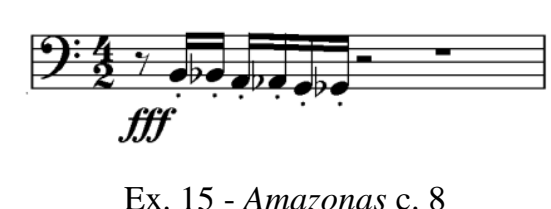

\footnotetext{
${ }^{59}$ Mario de Andrade (1963) refere-se a essa peça como obra medíocre apresentada no Brasil em 1918. Salles, 2009, p. 27.
} 
Em c.24 todos os trombones tocam em mesmo ritmo, porém harmonizados, num movimento de semínimas, onde flautas e clarinetes estarão fazendo mesmo motivo, porém as madeiras mudam notas a cada tempo e estarão em dinâmica superior ( $\boldsymbol{m} \boldsymbol{f}$ contra $\boldsymbol{p p}$ ):

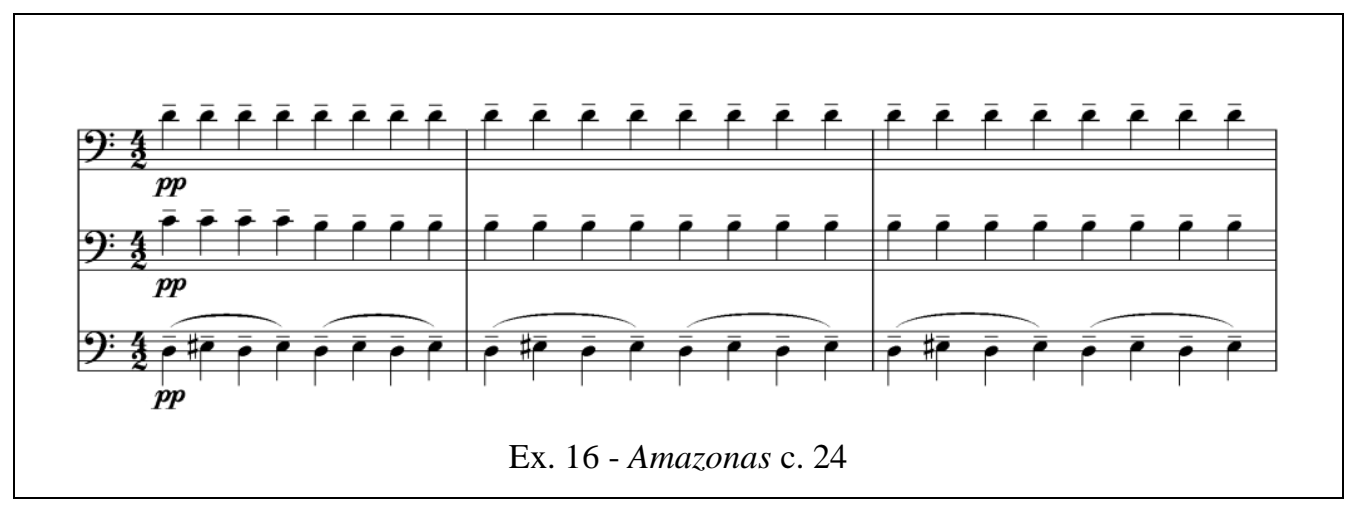

Nessa ideia de tercina dobrada no c.28, cabe aos trombonistas observarem atentamente a dinâmica a dinâmica escrita em $\boldsymbol{m} \boldsymbol{f}$, pois farão o complemento da ideia melódica iniciada nas cordas no c.27, e estas também estão grafadas em $\boldsymbol{m f}$ :

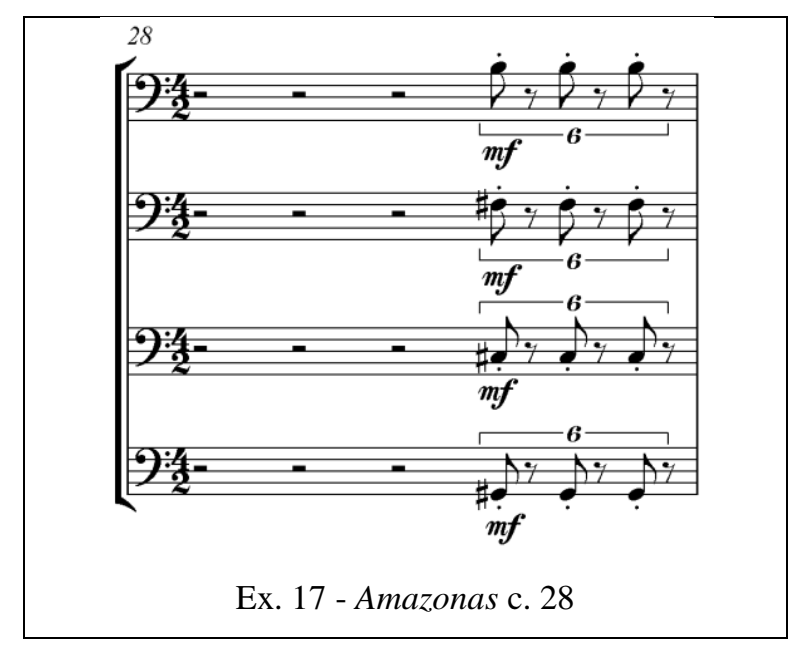

O trecho que se segue, no número 5 (c.37), traz os trombones juntamente com a clarinete, trompas e Trompetes no tema principal que perdurará por 4 compassos. Atenção especial deve ser dada a parte rítmica desta seção: 


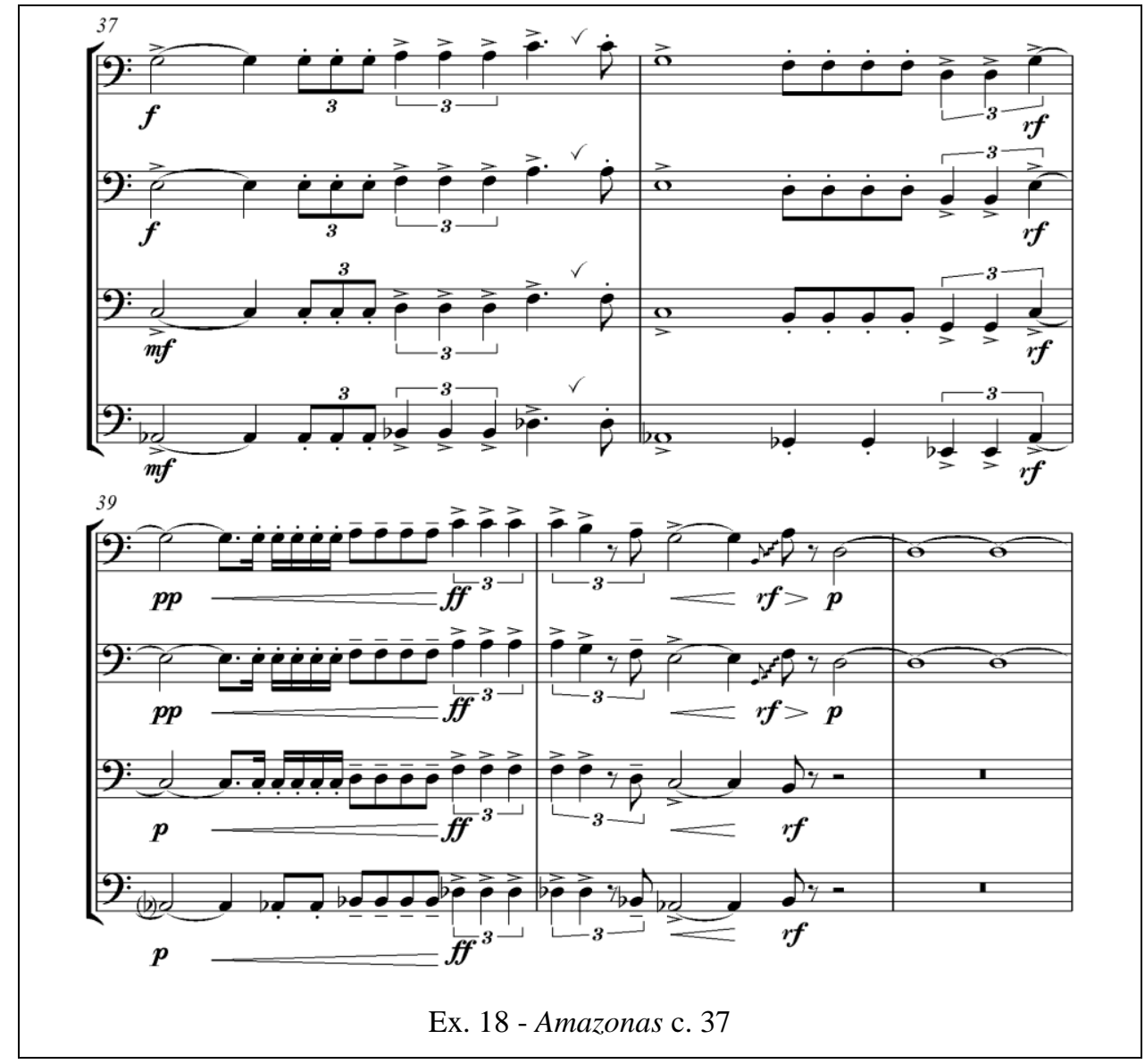

Praticamente toda a orquestra (com exceção da requinta e do flautim) faz uma figura rítmica intermeada de várias pausas e uma alteração rítmica em duína no c. 81 e na fórmula de compasso 2/4 no c.89:

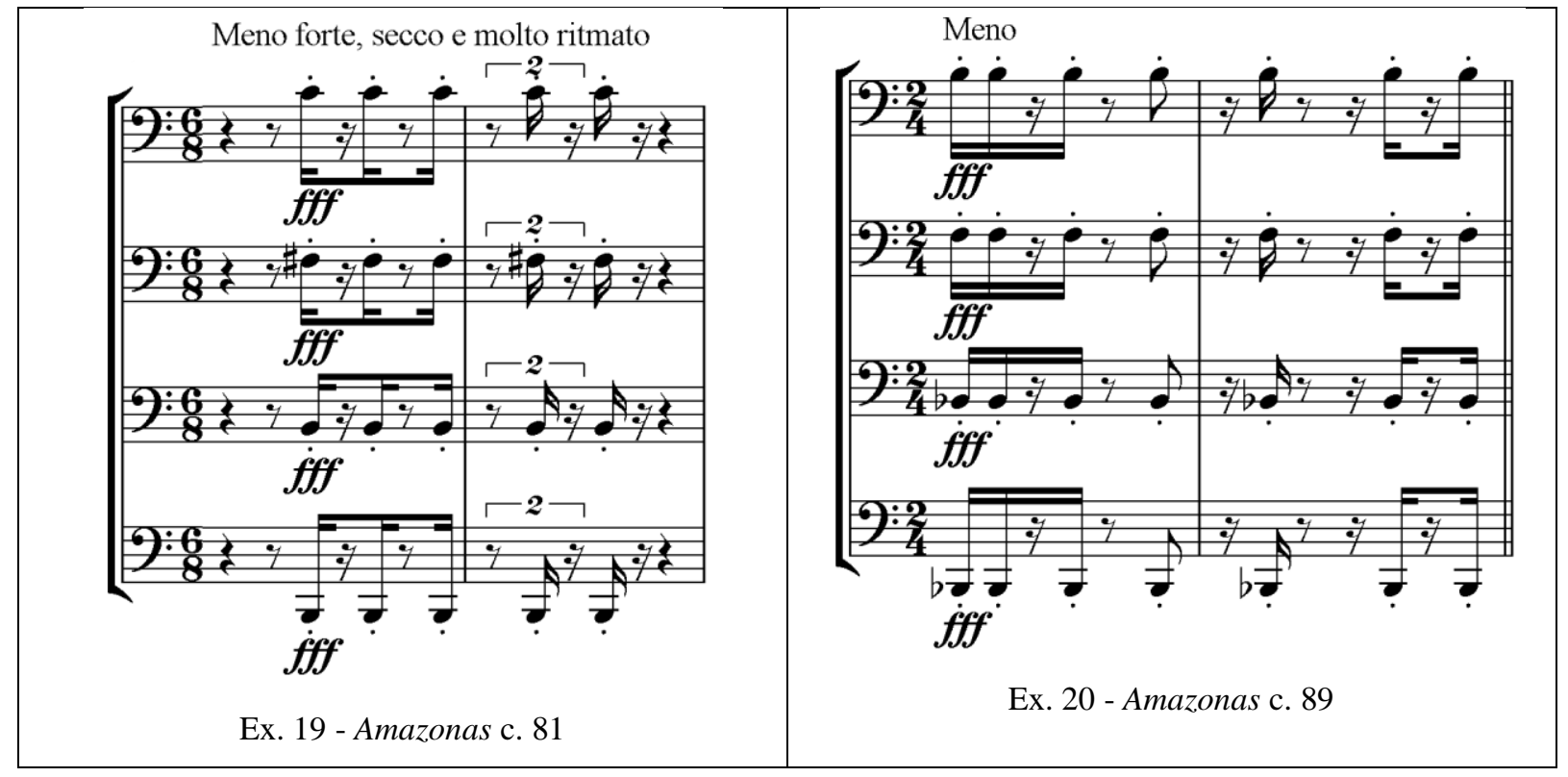


Villa-Lobos e os metais graves sinfônicos:

Um estudo dos elementos técnicos específicos

Clarone, fagotes, contrafagote, sarrusofone, trompas, trombones e tuba fazem, no c.93, um incisivo escalar descendente e decrescente:

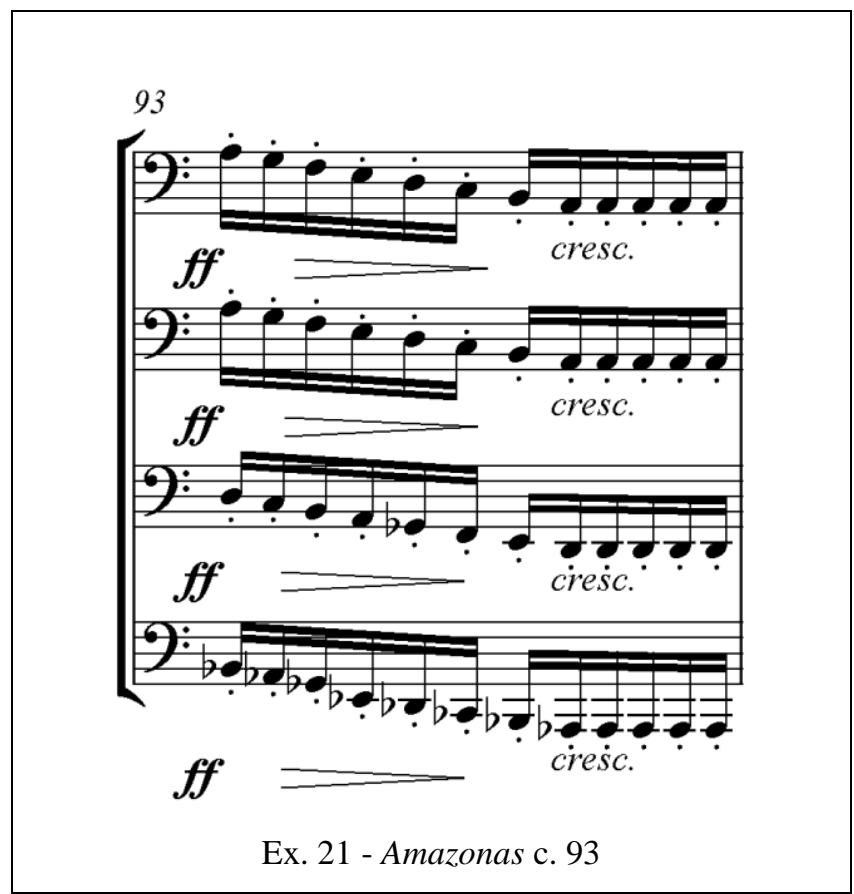

Enquanto o clarinete sola o tema em c.127, os trombones 1 e 2 farão um glissando possível no $2^{\circ}$. tempo dos compassos 128,130 e 132 :

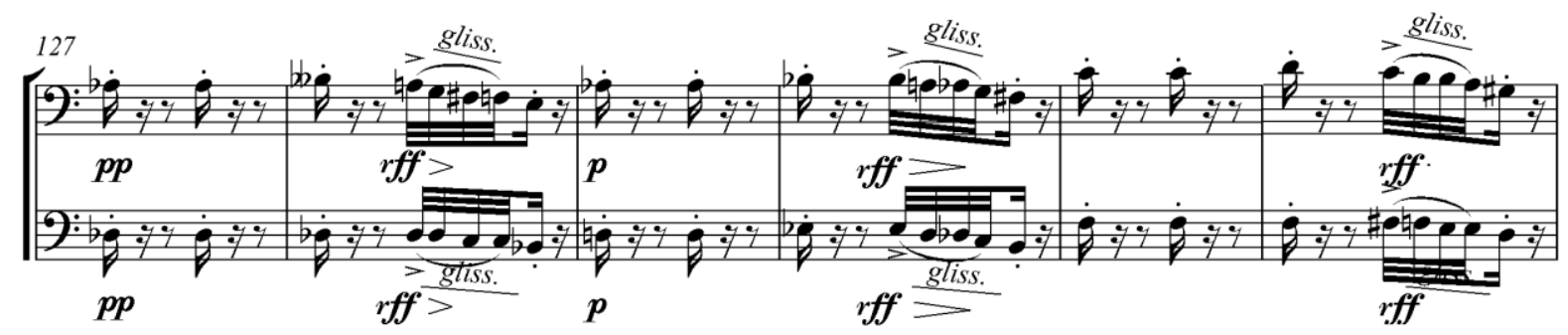

Ex. 22 - Amazonas c. 127

A partir do c. 150 os metais (Trompetes 3-4, trompas 2-4 e trombones 1-2) repetirão o tema já exposto pelos clarinetes (c.127), violinos (c.131) e flautas e oboés (c. 135): 


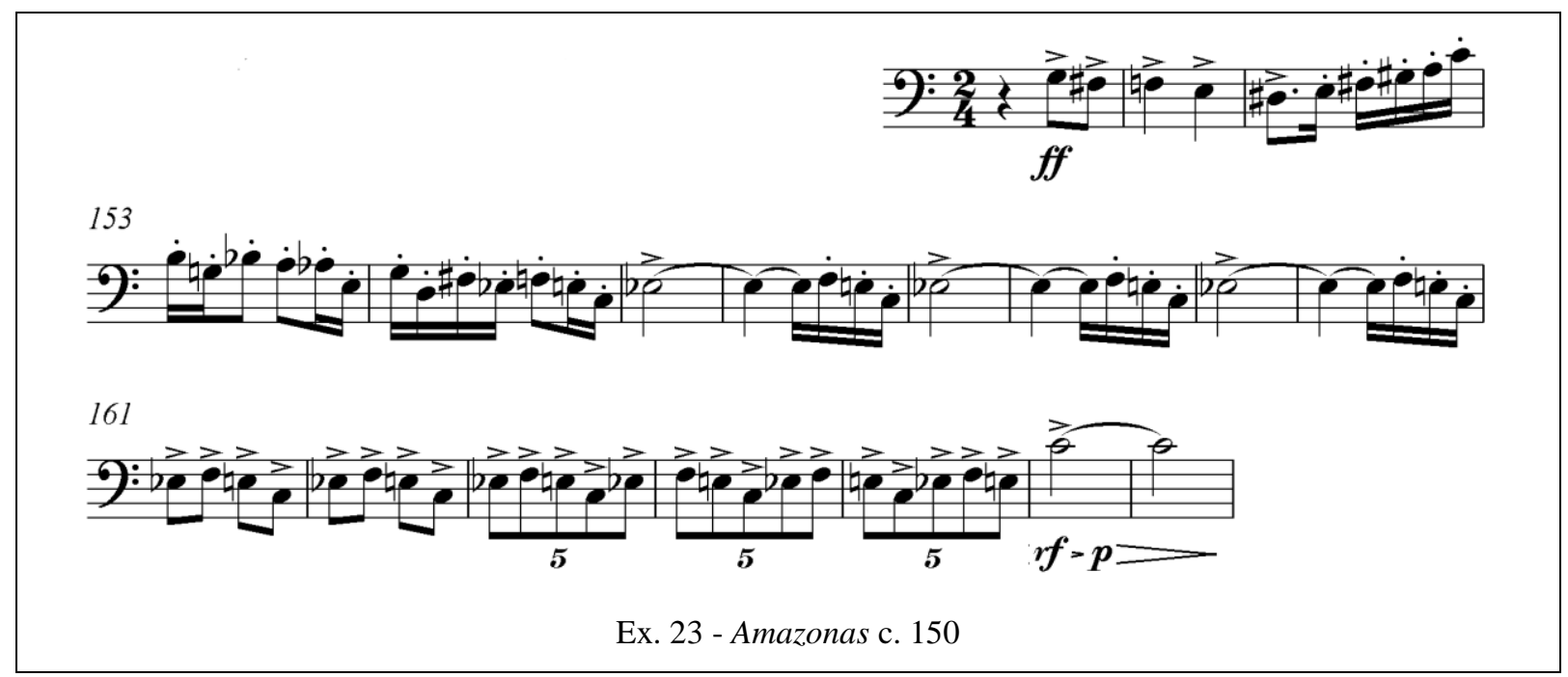

Após uma sequência de mínimas, que iniciaram no c.215, os metais graves farão um fragmento do tema exposto no c.37, porém este se iniciará em c.269 e estará em 2/4:

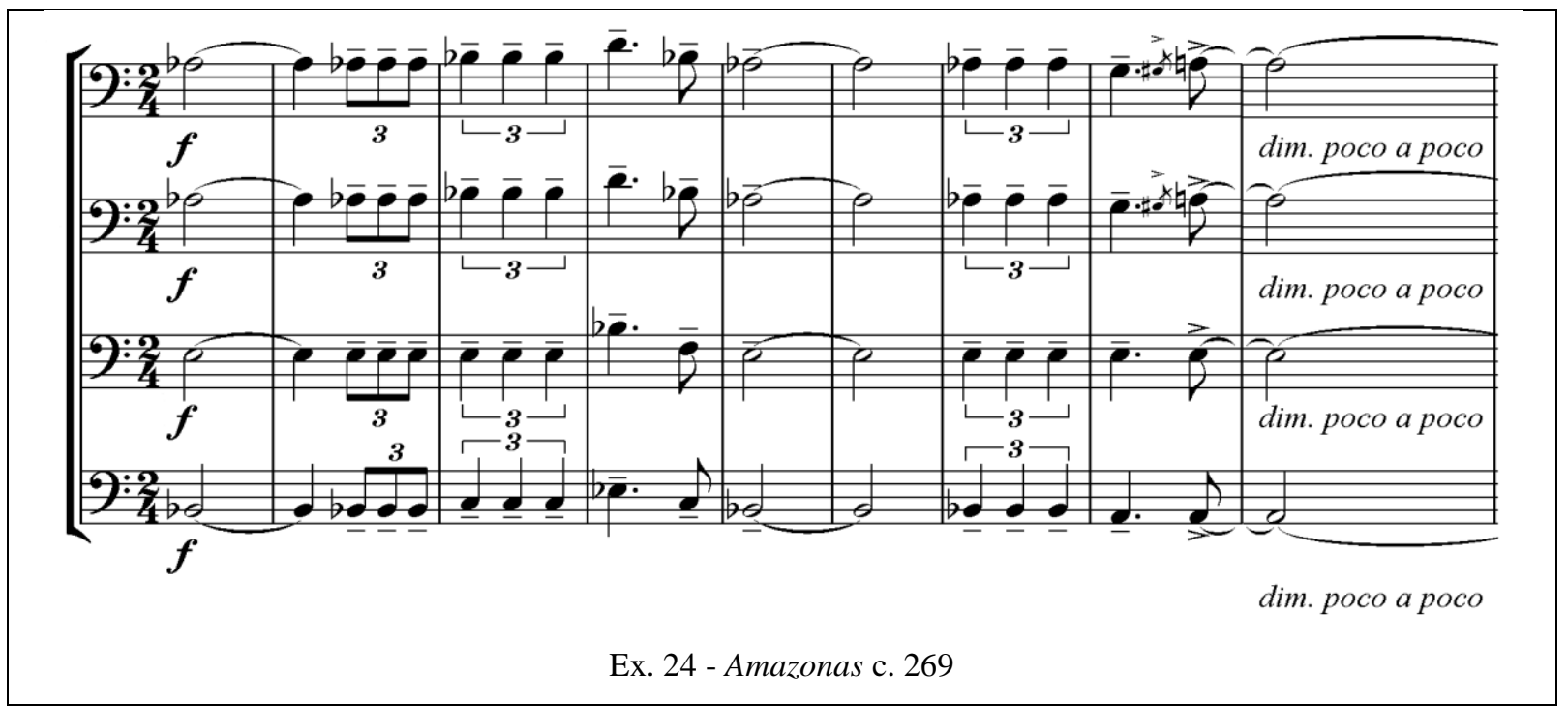

A célula rítmica (em tercinas de mínimas) apresentada pelo $3^{\circ}$. Trombone em conjunto com a tuba é curiosa, pois ser esta apenas apresentada por esses 2 instrumentos até o c.290. A partir de c.291 as 2as. e 4as. trompas participarão deste inciso que finda-se no c. 293.

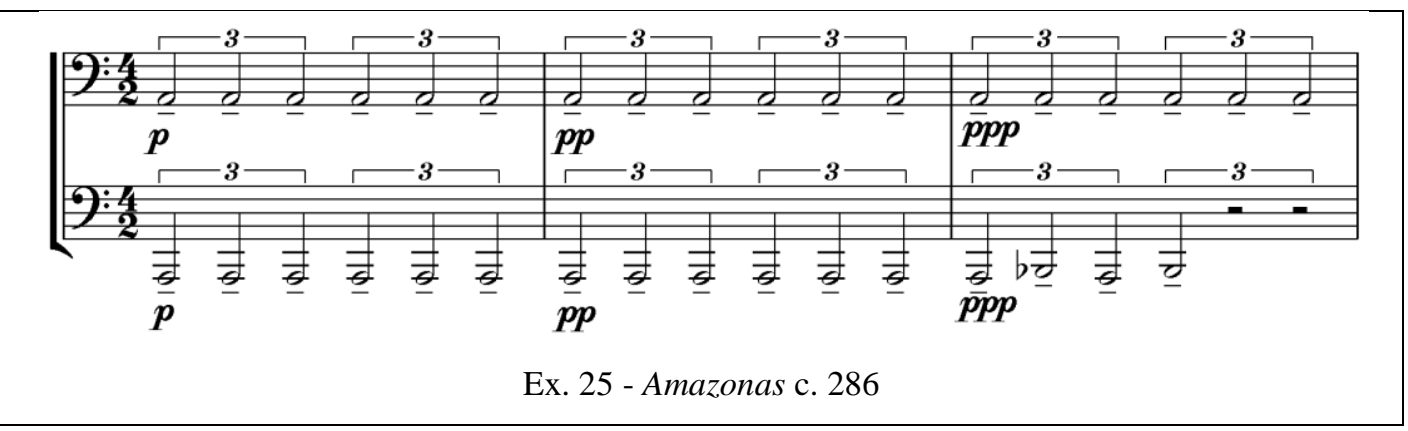

Universidade de São Paulo

Escola de Comunicação e Artes 
Em meio a essa célula rítmica enunciada acima, o $1^{\circ}$. Trombone fará um glissando no c. 289 , acompanhado pelas trompas e $1^{\circ}$. e $2^{\circ}$. Trompetes:

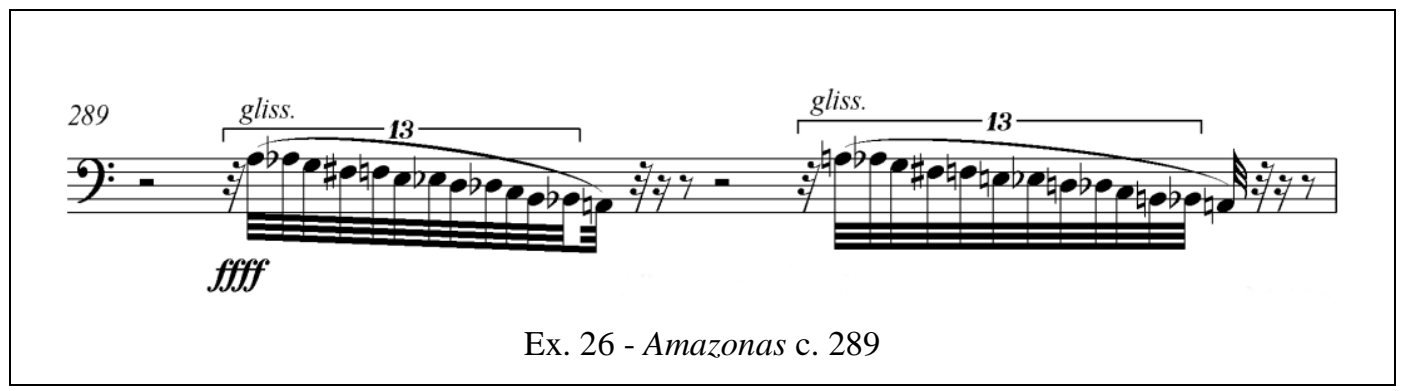

Em c.317 a tuba apresenta, em dinâmica $f f$ e em conjunto com o contrafagote, um inciso e sua variação:

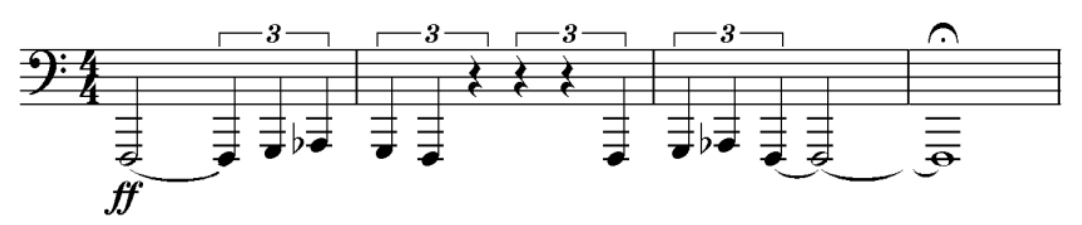

Ex. 27 - Amazonas c. 317

No final da obra, os trombones fazem no c. 330 um fragmento tercinado em conjunto com o clarinete, clarone, fagote, contrafagote, trompas e Trompetes. No c. $3311^{\circ}$. E $2^{\circ}$. trombones farão um glissando complementando as cordas e em conjunto com as harpas. A tuba ficará encarregada, juntamente com o contrafagote, tímpano, celesta, piano e contrabaixo de tocar a última nota soada nesta peça.

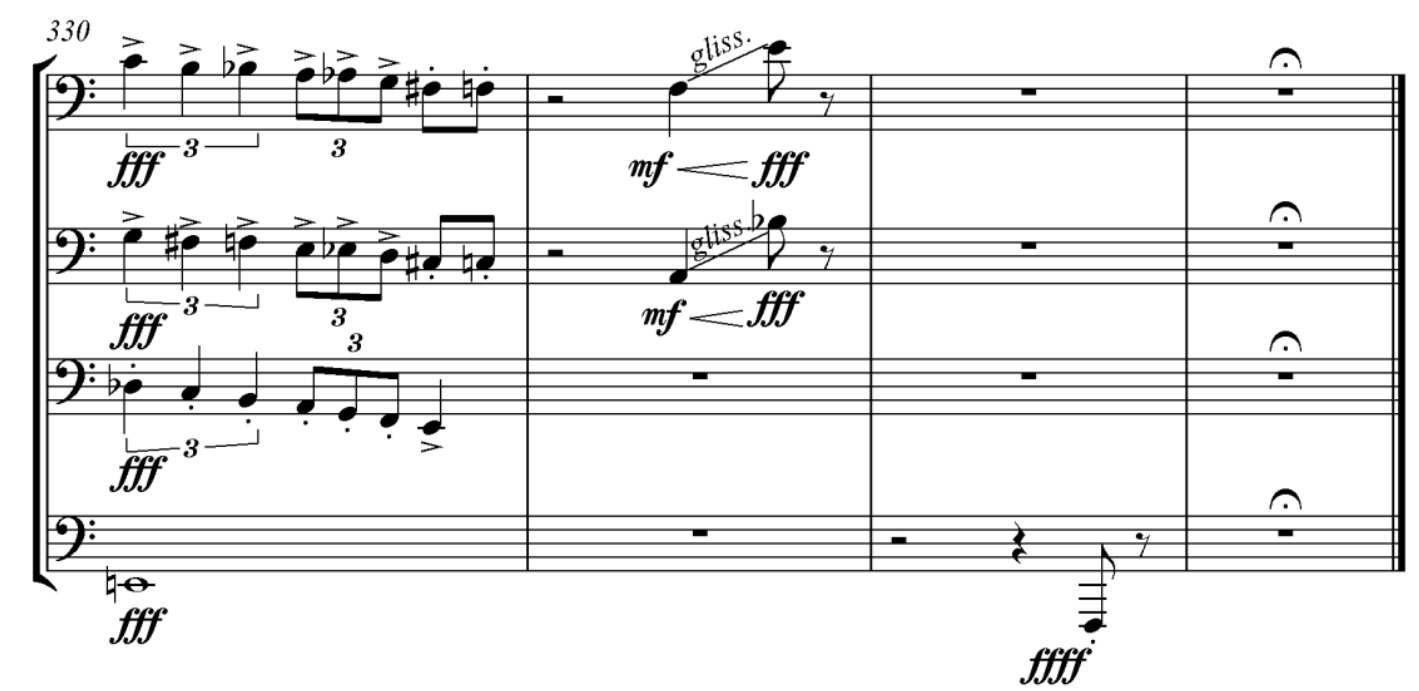

Ex. 28 - Amazonas c. 330 
Em termos de utilização dos metais graves na peça Amazonas, dos 333 existentes na peça, encontramos os metais graves em 207 compassos $(62,16 \%)$ e os mesmos ficarão em pausa por 126 compassos (37,84\%). Teremos ainda 33 compassos em soli (15 para metais graves, 18 para $1^{\circ}$. e $2^{\circ}$. trombone) e não haverá solo algum para metais graves. Nesta peça estão escritos 3 glissandos possíveis e 4 glissandos fora da extensão do êmbolo.

Em relação às dinâmicas utilizadas por Villa-Lobos para os metais graves, nos trechos anteriormente apresentados, não se encontrou a dinâmica $\boldsymbol{m p}$. No entanto, com 1 ocorrência encontramos ppp; 2 ocorrências de ffff; 5 de $\boldsymbol{m f} ; 7$ de $\boldsymbol{f f} ; 8$ ocorrências de $\boldsymbol{p p}$ e $\boldsymbol{f} ; 10$ ocorrências de fff; e por fim, a dinâmica mais utilizada por Villa-Lobos no peça Amazonas foi $\boldsymbol{p}$ com 16 ocorrências. Quanto às articulações, localizamos 102 notas com acento ( > ), 110 com tratina em tenuto ( - ) e com ponto de diminuição encontrou-se 170 notas.

\subsection{CHOROS}

Segundo Alejo Carpentier ${ }^{60}$, Villa-Lobos foi um dos poucos artistas latinos que se orgulhou de sua sensibilidade americana e não tratou de desnaturalizá-la. Nesse caso específico, continua Carpentier, "é palmeira que pensa como palmeira, sem sonhar com pinheiros nórdicos. Daí o sucesso realmente extraordinário: sucesso de público, de crítica e de apreciação pelos profissionais, obtido em Paris pelas obras do compositor com suas páginas cheias dessa rítmica trepidação, desse colorido formidável, que só se conhece nas terras americanas cujos elementos autóctones foram enriquecidos com a contribuição dos navios negreiros" ("El Nacional” - Caracas. Maio de 1953; pp. 45-47).

O reconhecimento internacional de Heitor Villa-Lobos viria graças a sua associação aos Choros. Lembremos a narrativa de Alexandre Pinto ${ }^{61}$ sobre os chorões da terceira década do século XX:

\footnotetext{
${ }^{60}$ (26/12/1904 - 24/04/1980) Romancista, ensaísta e musicólogo que muito influenciou a literatura latinoamericana. Nascido em Lausanne, na Suíça, Carpentier cresceu em Havana, Cuba.

${ }^{61}$ Circa 1870-1940: Rio de Janeiro. Carteiro e músico amador (violonista, cantor e cavaquinista) de música popular.
} 


\begin{abstract}
"Os músicos na sua maioria faziam pontos nas casas de chá da Rua do Ourives, 50 de propriedade de Buschhman Guimarães \& Bevilacqua. No Moreira, à Rua Gonçalves Dias, no Cavaquinho de Ouro, na Rua da Carioca, e na Rebeca de Ouro na mesma rua. Nos botequins encontravam-se frequentemente os malandros chorões cantando modinhas e assobiando ao ouvido de outros entusiastas do chôro.
\end{abstract}

Fim do baile, alta madrugada, o chôro saía tocando uma polca dengosa e o pessoal mergulhava no primeiro botequim que encontravam aberto. Cada um escolhia a bebida de sua predileção, havendo quem preferisse o rabo-de-galo, que era uma mistura de parati, mel de abelha e canela. E o chôro continuava. O sol invadia o botequim e flauta se fazia ouvir acompanhada do cavaquinho e do violão. $O$ botequim enchia-se de seresteiros que vinham de outros forrobodós, e o chôro continuava até 9, 10, 11 horas.”( PINTO, Alexandre G., "O choro", 1936 - p.127).

Villa-Lobos pertenceu a um grupo de Seresteiro de Escola. Seu quartel general foi o Cavaquinho de Ouro, na Rua da Carioca, onde recebeu convites de toda a espécie para tocar nos lugares mais diversos. Faziam parte do grupo, cujo chefe era Quincas Laranjeiras ${ }^{62}$ entre outros, Luiz de Souza e Luiz Gonzaga da Hora, Anacleto de Medeiros ${ }^{63}$, Zé do Cavaquinho $^{64}$ e Felisberto Marques. O repertório abrangia peças de Joaquim Antônio da Silva Callado ${ }^{65}$, Ernesto Nazareth, Luiz de Souza e Viriato Figueira da Silva (MARIZ, 1983, p.32).

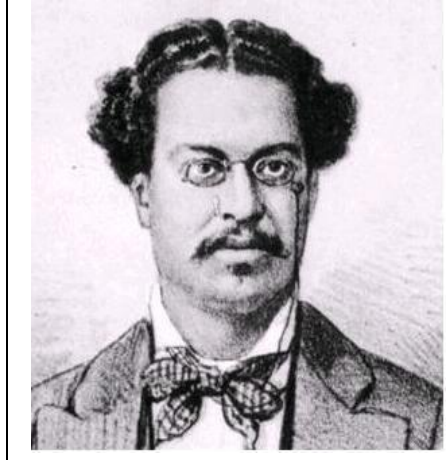

Fig. 12 - Joaquim A. S. Calado

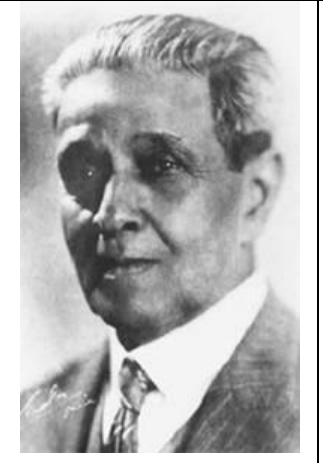

Fig. 13 - Ernesto Nazareth

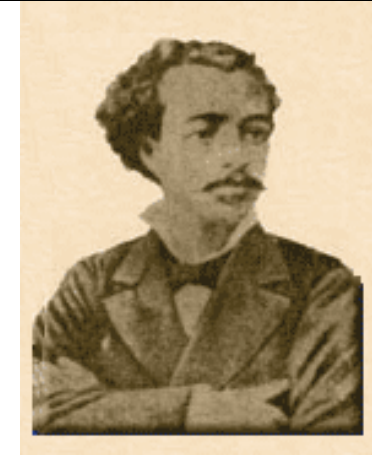

Fig.14 - Viriato F. Silva

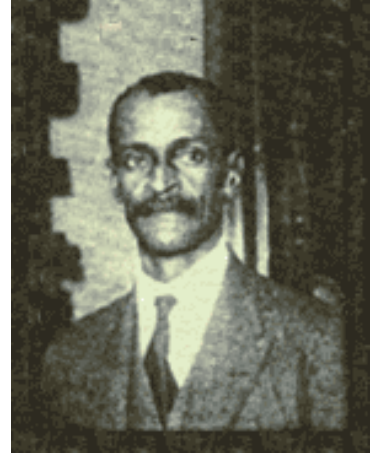

Fig. 15 - Quincas Laranjeiras

\footnotetext{
62 Joaquim Francisco dos Santos (1873-1935). Músico, compositor e violonista.

63 Anacleto de Medeiros (1866-1907), chorão, instrumentista versátil e organizador da primeira Banda do Corpo de Bombeiros do Rio de Janeiro.

${ }^{64}$ José Rodrigues de Moura (1911-1981) músico.

65 Joaquim Antônio da Silva Callado (1848-1880) - considerado o "pai" dos chorões - forma seu mais famoso conjunto, o Choro Carioca. No final do século XIX a palavra "choro" designava apenas "conjunto musical". Somente na década de 1910 é utilizada para definir o gênero musical.
} 
Faz-se necessário aqui, retornar ao panorama dos seresteiros cariocas, segundo Luiz Edmundo $^{66}$ :

No Rio da assomada do século não se compreende lua no céu sem serenata, sem violão e sem cantigas. Atenção, porém que a serenata está na rua, quando a música adormece por ermas ruas e revés caminhos, andam grupos de seresteiros a cantar. Em grupos numerosos, lá vão eles ferindo violões, cavaquinhos, bandurras ${ }^{67}$ e bandolins com os chapéus desabados nos sobrolhos, nos bolsos dos paletós, francos da branca e da vinhaça. Andam léguas e léguas assim a tocar, a cantar até que venha a luz do dia.

De dois gêneros são as serenatas que se fazem entre nós: a serenata de cantigas e a que se denomina chôro. Na primeira avulta a voz humana, na segunda não se escuta a voz e só os instrumentos é que criam... uns as melodias, outros as harmonias, que se conjugam em original e íntimo concerto (EDMUNDO Luiz - em "Rio de Janeiro de meu tempo"; 1957 - p 166).

Villa-Lobos, segundo Vasco Mariz, retirou dos chorões ambiente para criar uma atmosfera nova de música. Naquele ambiente formou uma faceta de sua personalidade composicional, aproveitando o que havia de original: melodias e o estilo de alguns dos músicos chorões. Entre estes, Villa-Lobos era conhecido como o "violão clássico" (MARIZ, 1983, p.32) e chegou mesmo a influenciá-los, pois à sua sugestão, Nazareth escreveu batuques, fantasias e estudos (NEVES, 1977, p.24).

No caso de Villa-Lobos, segundo Ênio Skeff ${ }^{68}$, sua recusa a adesão à música de consumo, juntamente com a companhia de alguns chorões famosos como Pixinguinha ${ }^{69}$, não teria se dado como um acidente de sua formação. O jovem violoncelista, familiarizado com repertório clássico ensinado pelo pai, poderia não ter assumido a consciência da música de concerto. A posição de Villa-Lobos foi, em todo caso, coerente com o tipo de princípio artesanal à que se filiou e que foi bem além da simples pratica musical. É aqui certamente que se vislumbram os princípios de uma consciência histórica específica, que não se explicam somente por um grau maior de erudição.

\footnotetext{
${ }^{66}$ Terceiro ocupante da Cadeira 33 da Academia Brasileira de Letras. Luis Edmundo de Melo Pereira da Costa, jornalista, poeta, cronista, memorialista, teatrólogo e orado, nasceu no Rio de Janeiro, RJ, em 26 de junho de 1878, e faleceu na mesma cidade em 8 de dezembro de 1961. Fonte: site da Academia Brasileira de Letras.

${ }^{67}$ Espécie de bandolim curto com seis pares de cordas

${ }^{68}$ Nascido em Porto Alegre (RS). Jornalista, crítico de música, ilustrador e artista plástico.

69 Flautista, saxofonista e compositor Alfredo Vianna da Rocha Filho, o Pixinguinha (1897-1973). Rio de Janeiro.
} 
O intervalo entre os quartetos e as sinfonias demonstra como o compositor dedicou atenção à série $\operatorname{Choros}^{70}$ e aos novos desafios na busca pelo reconhecimento internacional de suas obras. Sobre os Choros, o próprio Villa-Lobos nos deixou o Estudo Técnico, Estético e Psicológico:

Sendo os Choros construídos segundo uma forma técnica especial, baseada nas manifestações sonoras dos hábitos e costumes dos nativos brasileiros, assim como, nas impressões psicológicas que trazem certos tipos populares, extremamente marcantes e originais, foi o Choros $\mathrm{N}^{\circ} 1$ escrito propositadamente como se fosse uma produção instintiva da ingênua imaginação desses tipos musicais populares, para servir de simples ponto de partida e alargar-se proporcionalmente, mais tarde, na forma, na técnica, na estrutura, na classe e nos casos psicológicos que encerram todos esses gêneros de música.

O tema principal, as harmonias e modulações, apesar de pura criação, são moldados em frequências rítmicas e fragmentos celulares melódicos dos cantores e tocadores populares de violão e piano, como Sátiro Bilhar, Ernesto Nazareth e outros (VILLALOBOS, 1950).

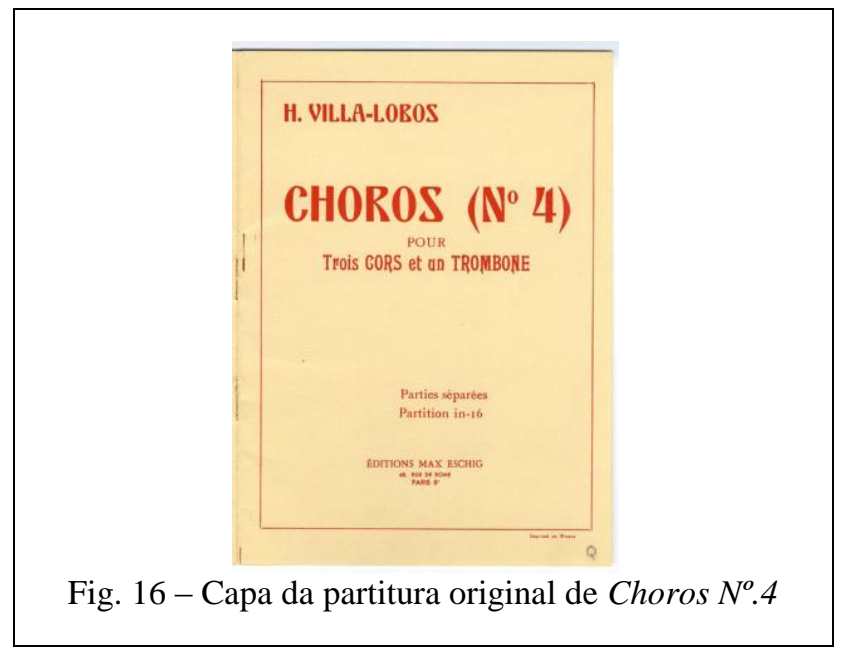

\subsubsection{CHOROS N $N^{o} 4$}

Sob o ponto de vista da estruturação formal, Villa-Lobos considerava o Choros $n^{o} .4 \mathrm{o}$ mais característico. Sua opinião se baseou em função da ousadia na utilização de glissandos e efeitos em surdina (NOBRE, 2013, p. 3). No entanto Rob Barnett ${ }^{71}$ irá adicionar outros adjetivos não autorizados pelo compositor, tais com: mal-humorado, sutil, ansioso e ao final

\footnotetext{
70 Até a composição do Choros $n^{\circ} 1$, em 1920, Villa-Lobos escreveu cinco sinfonias, a sexta sinfonia foi composta vinte e quatro anos depois.

${ }^{71} 1953$ - Birmingham/Inglaterra. Comentarista de gravações clássicas para a MusicWeb Internacional.
} 
nos arrasta para um carnaval de rua $(. . .)^{72}$. Mas o que se sente como autêntico brasileiro, Carvalho declarou em seu estudo: “O Choros $n^{\circ} 4$ é de uma representação clara das músicas e danças de uma sociedade: exemplo típico de um Choro autêntico (CARVALHO, 1987, p. 66)".

A obra foi composta no Rio de Janeiro, em 1926, e teve sua estreia em Paris, em concerto na Salle Gaveau, a 24 de outubro de 1927. Neste ano Villa-Lobos retorna à capital francesa onde se hospeda no apartamento de Carlos Guinle à Place Michelle, $n^{\circ}$. 11. Graças à hospitalidade, Villa-Lobos dedicou o Choros $n^{\circ} .4$ à esse amigo.

Dentro do gênero de música de câmara, este Choros, escrito para 3 trompas e 1 trombone, foi descrito pelo próprio Villa-Lobos como sendo "relacionado à vida musical popular e suburbana das grandes cidades, cuja melodias possuem um lirismo irônico, baseado na forma tradicional das músicas populares, de danças da sociedade oriundas do estrangeiro. É talvez o mais significativo dos Choros na sua forma e significação elevadas" (Villa-Lobos em Estudo técnico, artístico e psicológico, 1950).

\section{CONSIDERAÇÕES DA ORQUESTRAÇÃO DO CHOROS Nº.4}

Utilizaremos a edição impressa pela Editions Max Eschig, com copyright de 1928. Estando inserido no grupo Câmara/Chôro, esta peça conta com um efetivo instrumental, determinado pelos seguintes instrumentos:

\begin{tabular}{c|c}
\hline 3 & Trompas \\
\hline 1 & Trombone-baixo (ou barítono) \\
\hline
\end{tabular}

Tab. 3 - Instrumentação Choros $N^{o} .4$

Villa-Lobos explorou potencialidades sonoras a partir de propriedades acústicas que lhe possibilitaram novos meios de expressão. O Choros $n^{o} .4$ se organiza de maneira bem clara. "Em uma primeira seção, o compositor dá ingresso de maneira contínua em momentos

\footnotetext{
72 "Choros 4 is for four brass instruments - grumpy, subtle, anxious, and at last swept into the carnival with popular street music (...)".

In: http://www.musicweb-international.com/classrev/2011/Mar11/villalobos_biscd1830.htm
} 
bem demarcados a três estruturas harmônica e melodicamente diferenciadas, que se estendem até o surgimento de uma pausa geral" (Lacerda, 2011, p.287).

O trombone foi utilizado em uma extensão que compreende do Ré1 ao Lá3. Com dinâmicas que variam entre o pianíssimo (pp) ao fortíssimo(ff) em sem nomear o mezzo-piano $(\boldsymbol{m p})$. Nos dois primeiros compassos, vemos o estabelecimento de um diálogo entre as ressonâncias de um bloco de quatro tricordes tocados pelas trompas (motivo a) ${ }^{73}$ e ao final deste inciso e com a duração de uma nota longa feita pelas trompas, teremos a entrada do trombone servindo de reafirmação da coleção de tons inteiros já apresentada pelas trompas, [Réb,Mib,Fá,Sol,Lá,Si], citando os baixos de um violão (Ex.29). O mesmo acontecerá no c.58, porém Villa-Lobos fará uma pequena variação nesse inciso e o trombone sofrerá uma transposição para mais agudo (Ex.30):

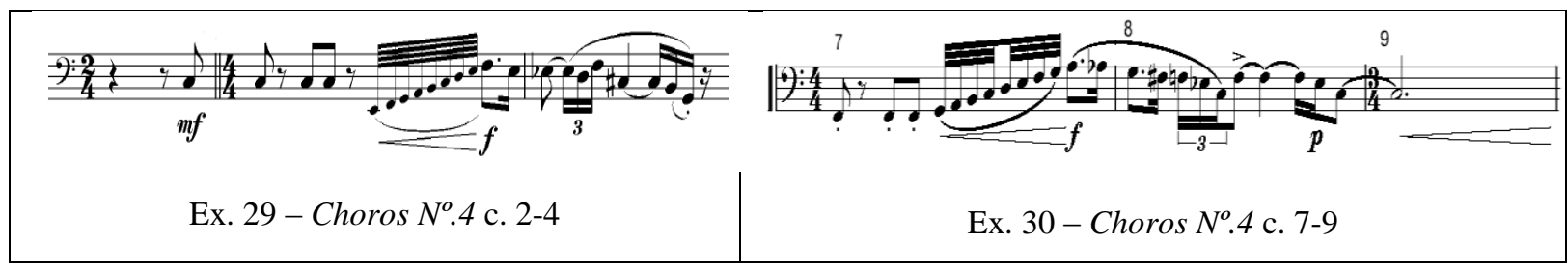

Para os dois próximos compassos, Villa-Lobos repete um melisma em torno da nota Réb. Esse melisma sempre ocorrerá como preenchimento da nota longa das trompas (segunda vez que Villa-Lobos se utiliza desse princípio contrapontístico, onde uma voz de movimenta enquanto a outra repousa):

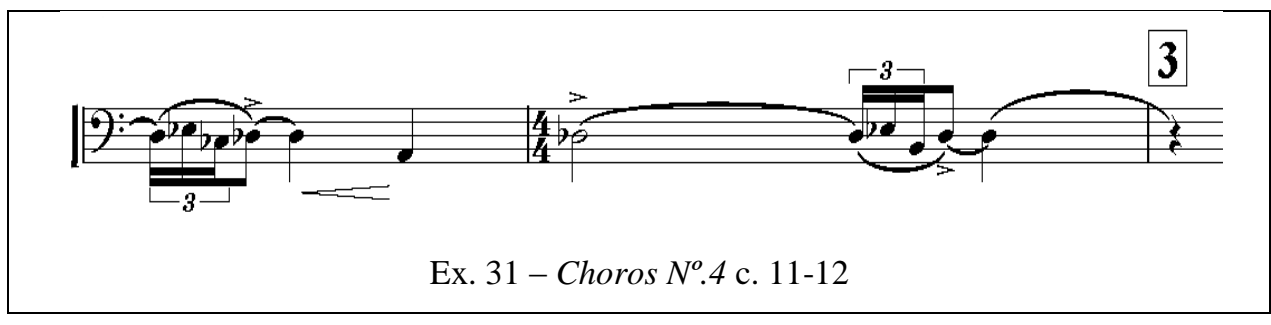

A partir de [3] (c.13), o trombone inicia uma sequência de colcheias, citando os bordões do violão. Os Bordões são tocados pelo polegar e as notas agudas (neste caso apenas uma nota aguda) são tocadas em contratempo com o bordão:

\footnotetext{
${ }^{73}$ As trompas "tocam uma sequência de quatro acordes, em que aparecem 11 sons da escala cromática, com exceção do Sib" (SALLES, 2009: 153). Esse procedimento harmônico é chamado por Salles de "polarização por exclusão" e é uma prática comum na música de Villa-Lobos.
} 


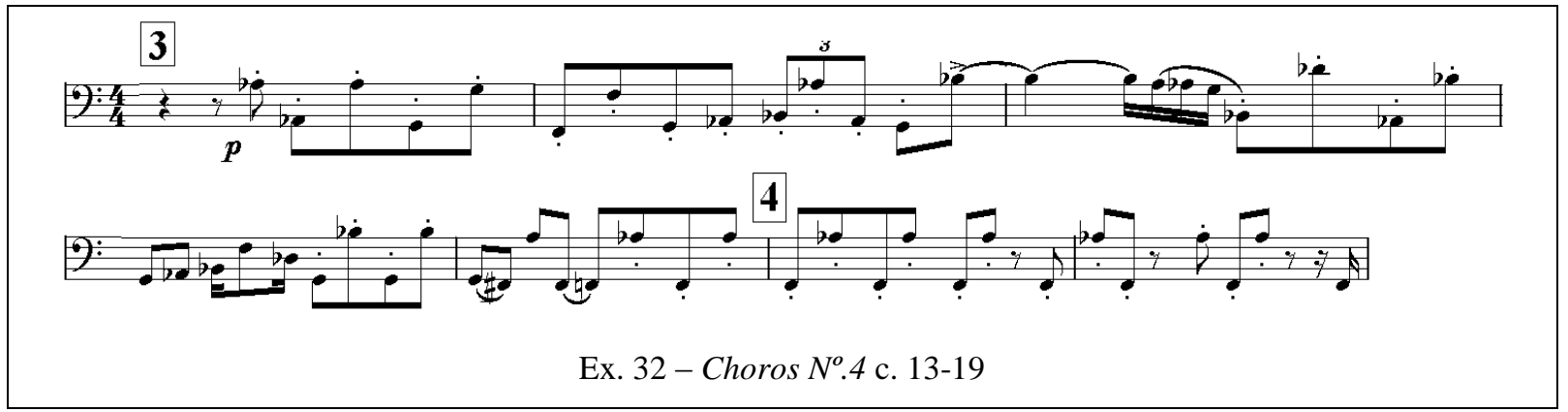

No próximo trecho - início da parte B -, Villa-Lobos fará uma inversão de posições: a $3^{\text {a }}$. trompa ficará incumbida de tocar os baixos, enquanto o trombone será transformado numa trompa grave, em apoio paralelo à $2^{\mathrm{a}}$. trompa:

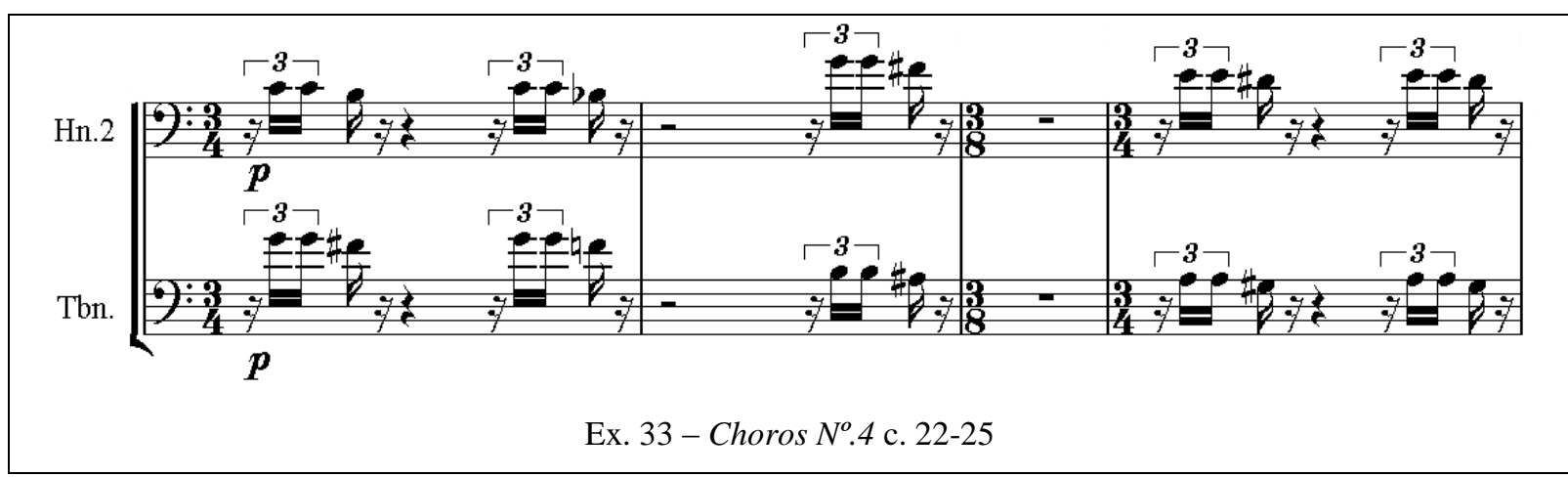

Villa-Lobos retoma a ideia da sequência de colcheias feitas no c.13, recapitulando ao estilo do bordão/tricorde violonístico, porém desta vez será do c.28 ao c.36, mas será mantido a quadratura de oito compassos:

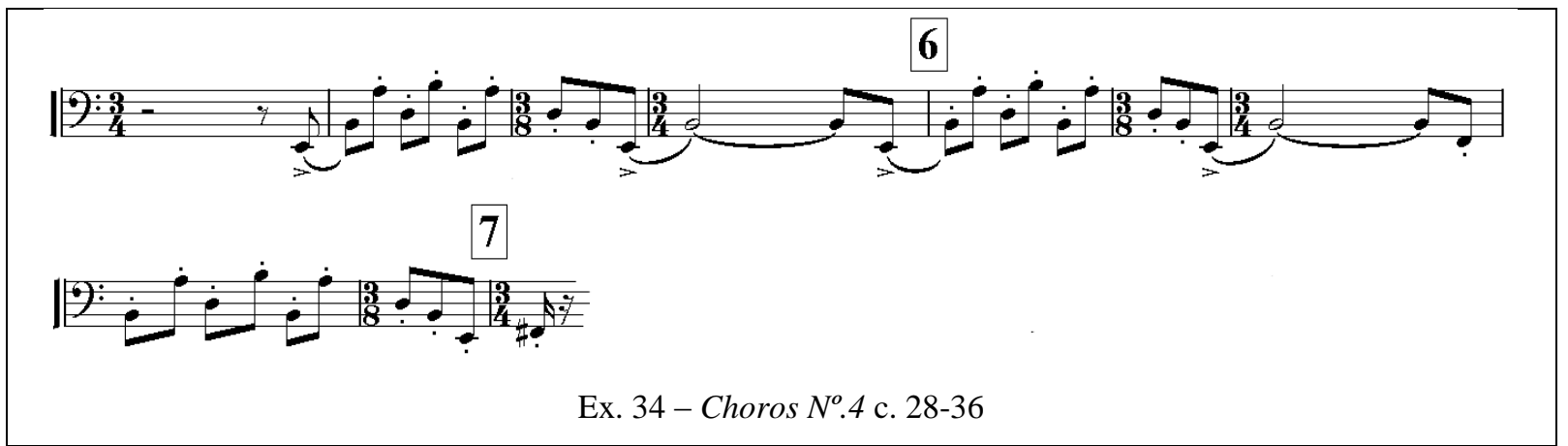

A partir de c.37 (n.7), Villa-Lobos mantém o trombone dentro da ideia de baixo condutor, porém não mais como bordão/tricorde. Nesta semifrase (na verdade, dois compassos repetidos, mas com quadratura de quatro compassos) o trombone ficará a cargo apenas do baixo sem a adição das notas agudas/tricorde (lembrando, em muito, o estilo do baixo no jazz): 


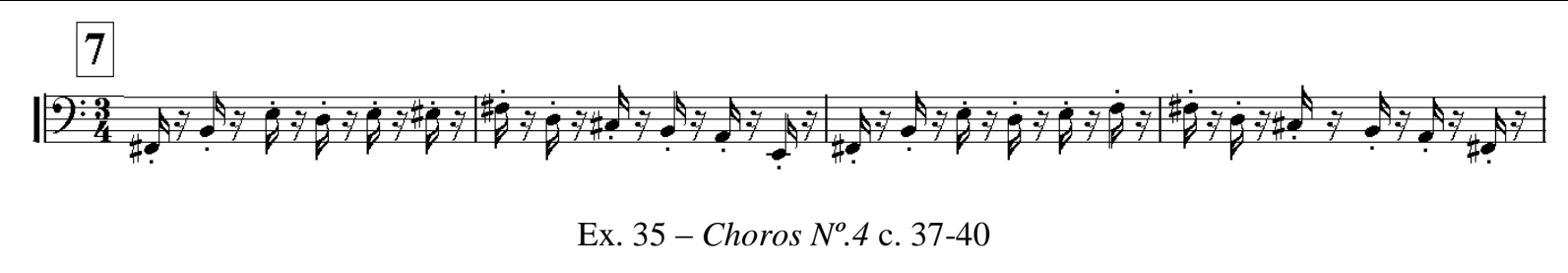

O trombone ainda será mantido dentro da ideia de baixo condutor no c.41-42, porém num movimento cromático descendente partindo da nota Sól:

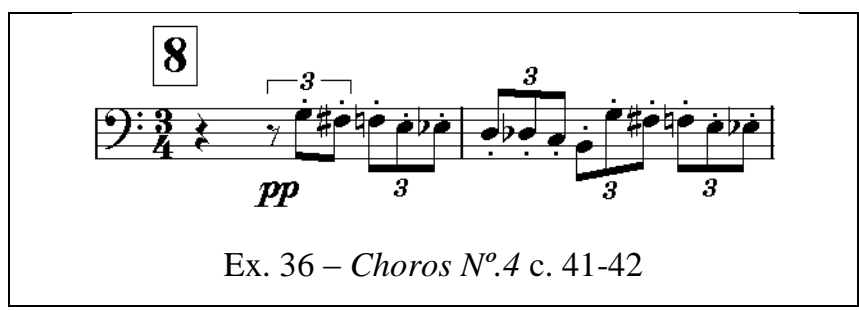

O inciso-solo feito pelo trombone no c.43-44 é um eco do inciso feito pela $2^{\mathrm{a}}$. trompa no c.41-42:

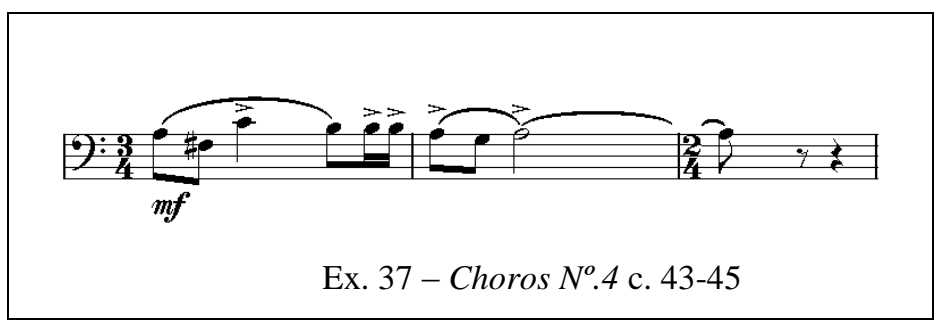

Os c.46-51 terão ideia de recapitulação do início, porém o trombone será considerado como uma $3^{\text {a }}$. trompa:

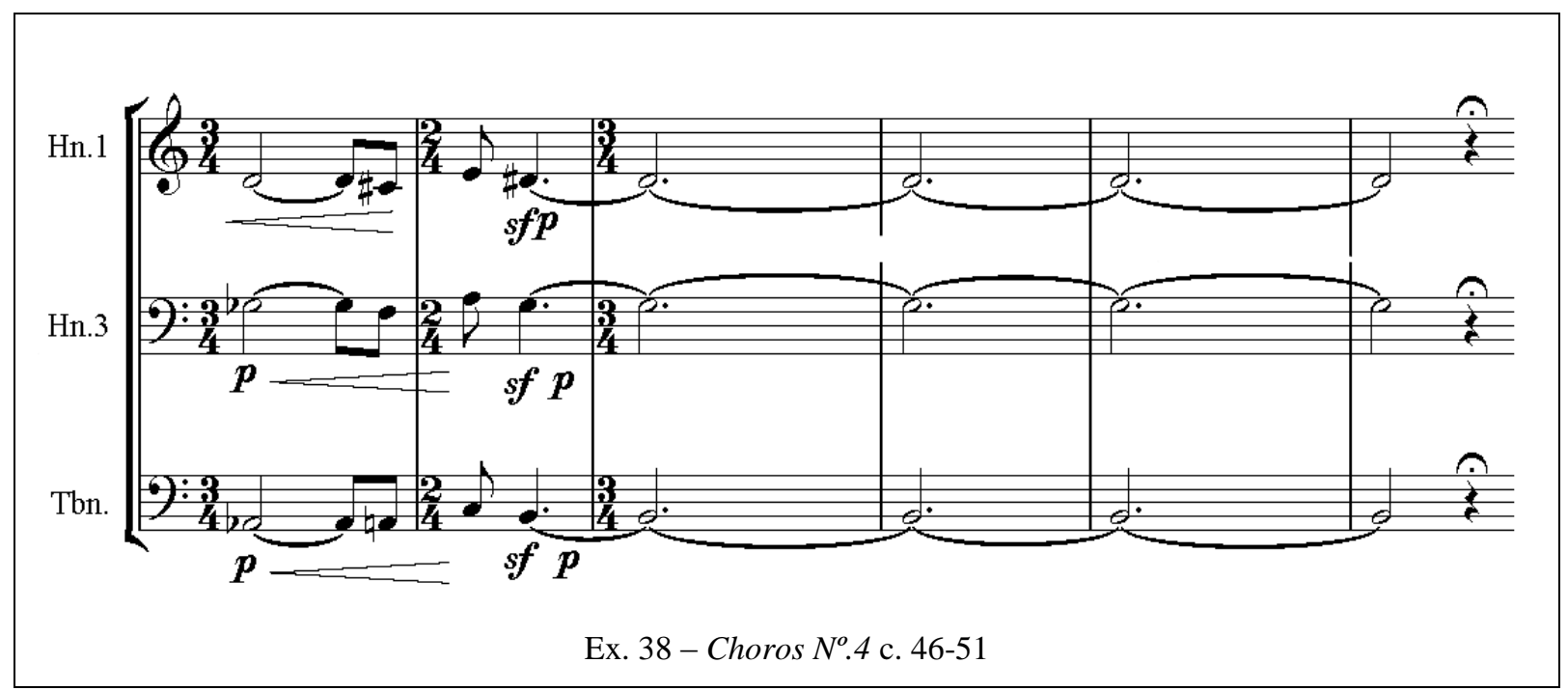


No c. 54-57 o trombone fará seu $2^{\circ}$. inciso-solo, utilizando de um material intervalar novo, com duração de 2 compassos. Os próximos 2 compassos serão uma variação por ampliação da segunda parte desse mesmo inciso:

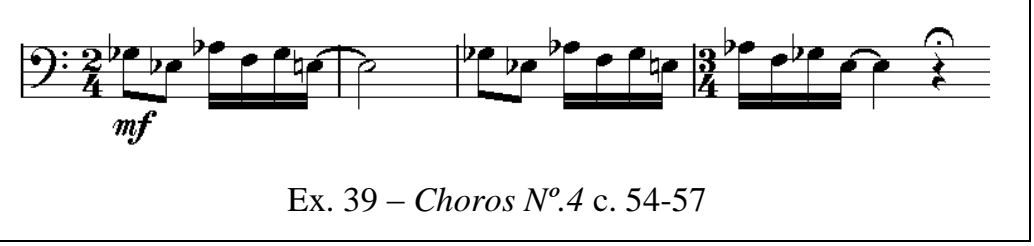

A partir de n.11 (c.58) Villa-Lobos tratará todo o quarteto como um grupo coeso. O período será harmonizado a 4 vozes, e todos tocam em paralelo rítmico. Esse caráter harmônico perdurará por 4 compassos. Exceção ficará com a pirâmide do c.59-60:

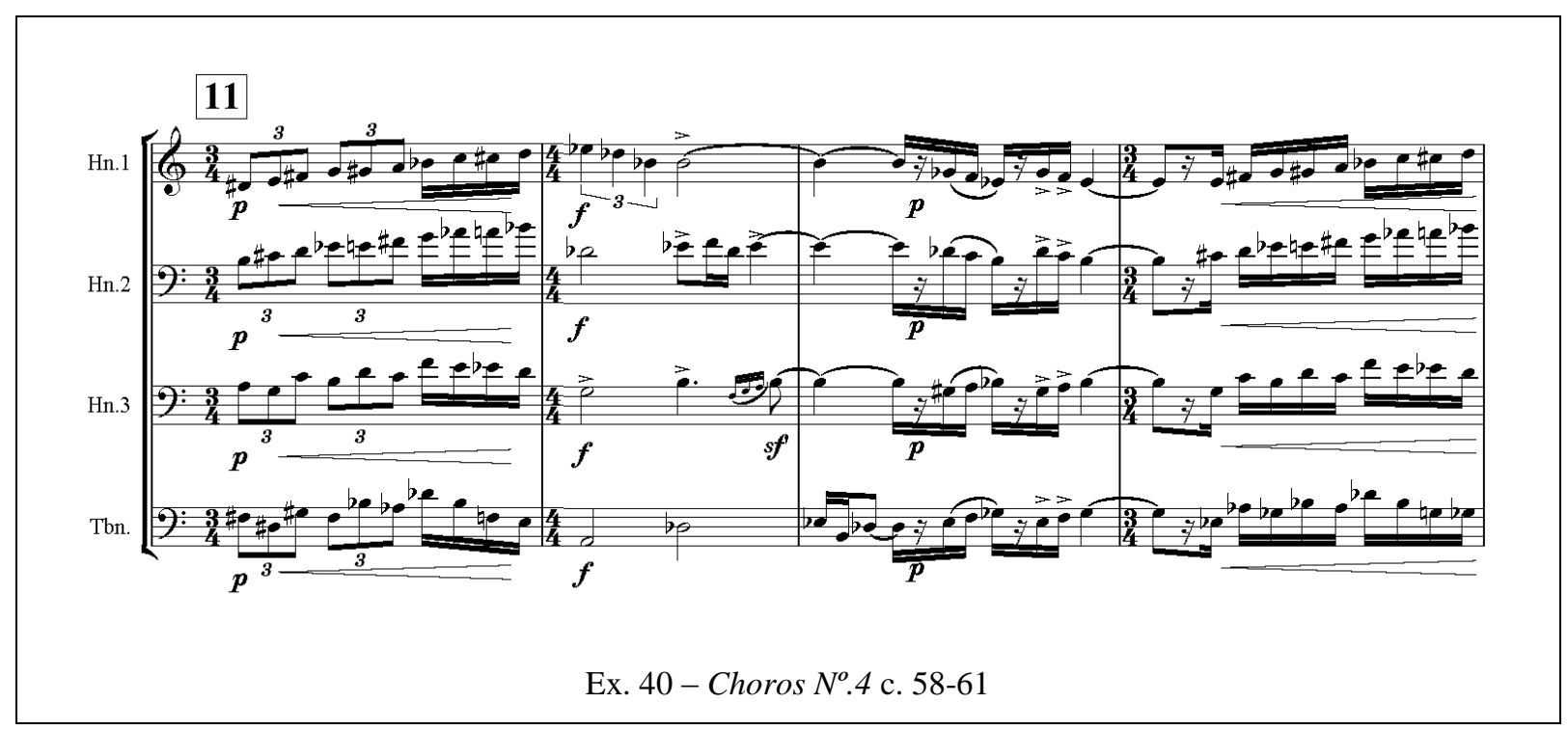

Em n.12 (c.62) o trombone estará compondo naipe com a $2^{\mathrm{a}}$. e $3^{\mathrm{a}}$. trompa, num ostinato de um inciso de tercina entre semínima e colcheia, enquanto a $1^{\mathrm{a}}$. trompa sola. Esta semifrase ainda será harmonizada a 3 vozes:

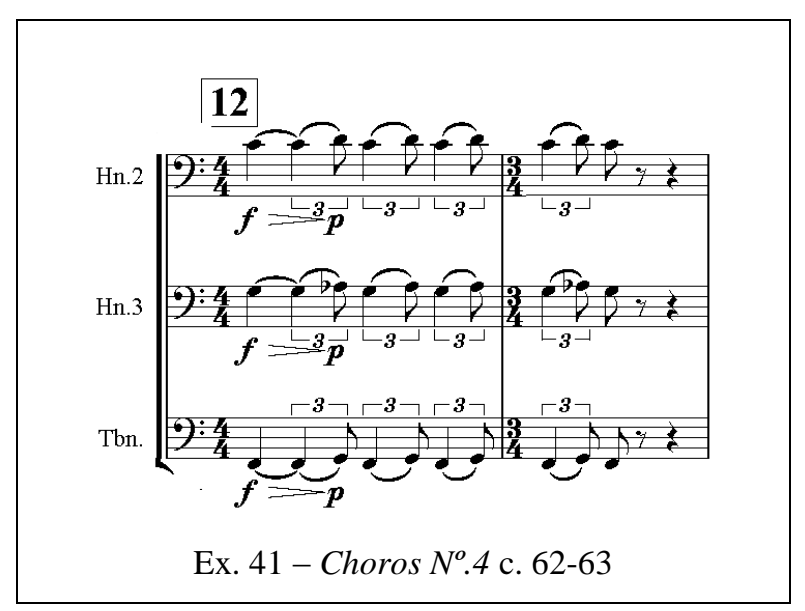


Após dois compassos de espera, o trombone tocará a terminação do tema solado pela $2^{a}$. trompa (última semicolcheia) e novamente mostrará a ideia de baixo condutor em movimento cromático descendente (motivo d), como no c.41-42:

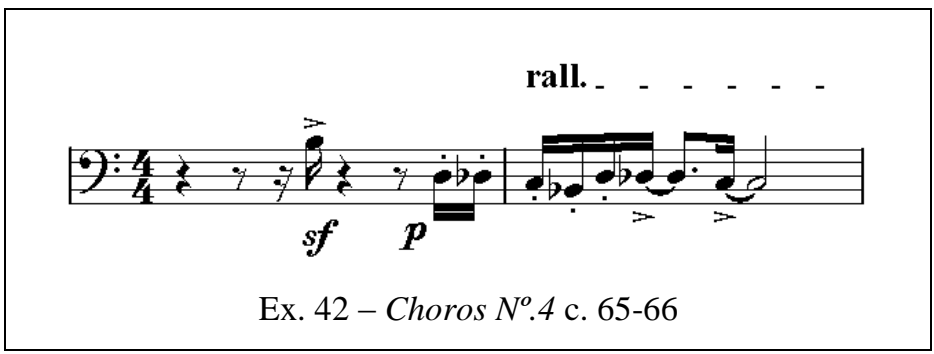

Em n.13 (c.67) o trombone iniciará um ostinato de 4 semínimas que se repetirá por 11 vezes até o c.78. Há uma exceção no c.77 onde essa sequência de notas é quebrada com a existência de um Sib no $1^{\circ}$. Tempo (Ex.43):

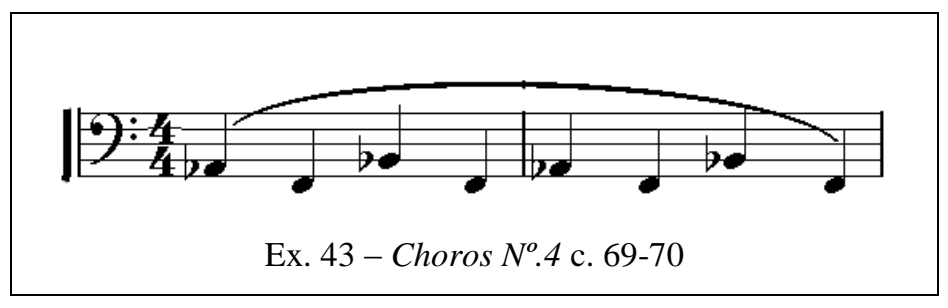

O trombone ainda continuará, nessa segunda seção do Choros $N^{o} .4^{74}$ em forma de dança e com referência direta às tradições urbanas da música popular do início do século XX. com a ideia de ostinato, porém este inciso-ostinato terá a duração de 2 compassos e acontecerá nos compassos 82-83, 84-85, 89-90, 91-92, 92-93, 96-97, 97-98105-106, 107-108. Aqui denominaremos de baixo movimentado, ou baixo melódico, em contraponto à voz principal (NEVES, 1977, p. 22):

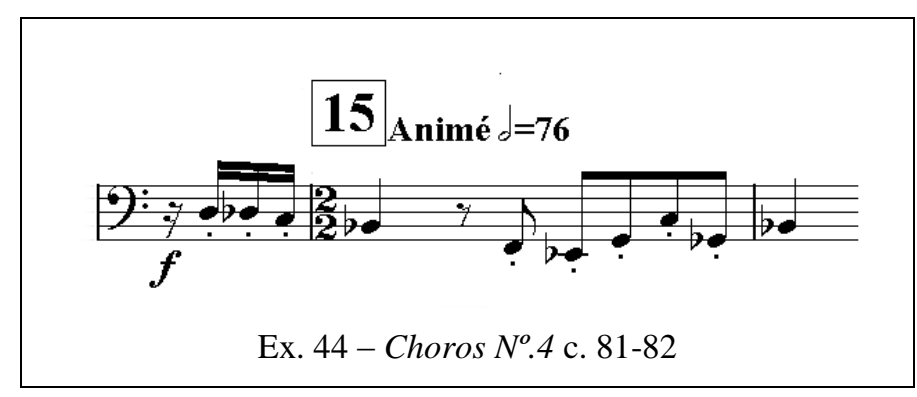

\footnotetext{
${ }^{74}$ Albuquerque (2009, p.1013) defende a semelhança entre o tema principal da segunda seção da obra (a partir do c.82) e o fandango nordestino Rema que rema, coletado por Mario de Andrade na década de 1920 em viagem pelo interior do país.
} 
Para fechar essa ideia de ostinato, Villa-Lobos escreveu para o trombone um glissando possível de $3^{\mathrm{a}}$.m (Ex.45). Este glissando se repetirá em c. 83, 85, 91, 97, 106 e 108:

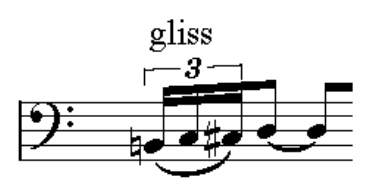

Ex. $45-$ Choros $N^{o} .4$ c. 83

Como conclusão das frases, Villa-Lobos escreveu, para o trombone, arpejos descendentes em colcheias no n.16 (c.87-89; Ex. 46). Essa terminação de frase ainda terá mais duas ocorrências (Ex. 47 e Ex. 48), mas estas sofrerão alterações:
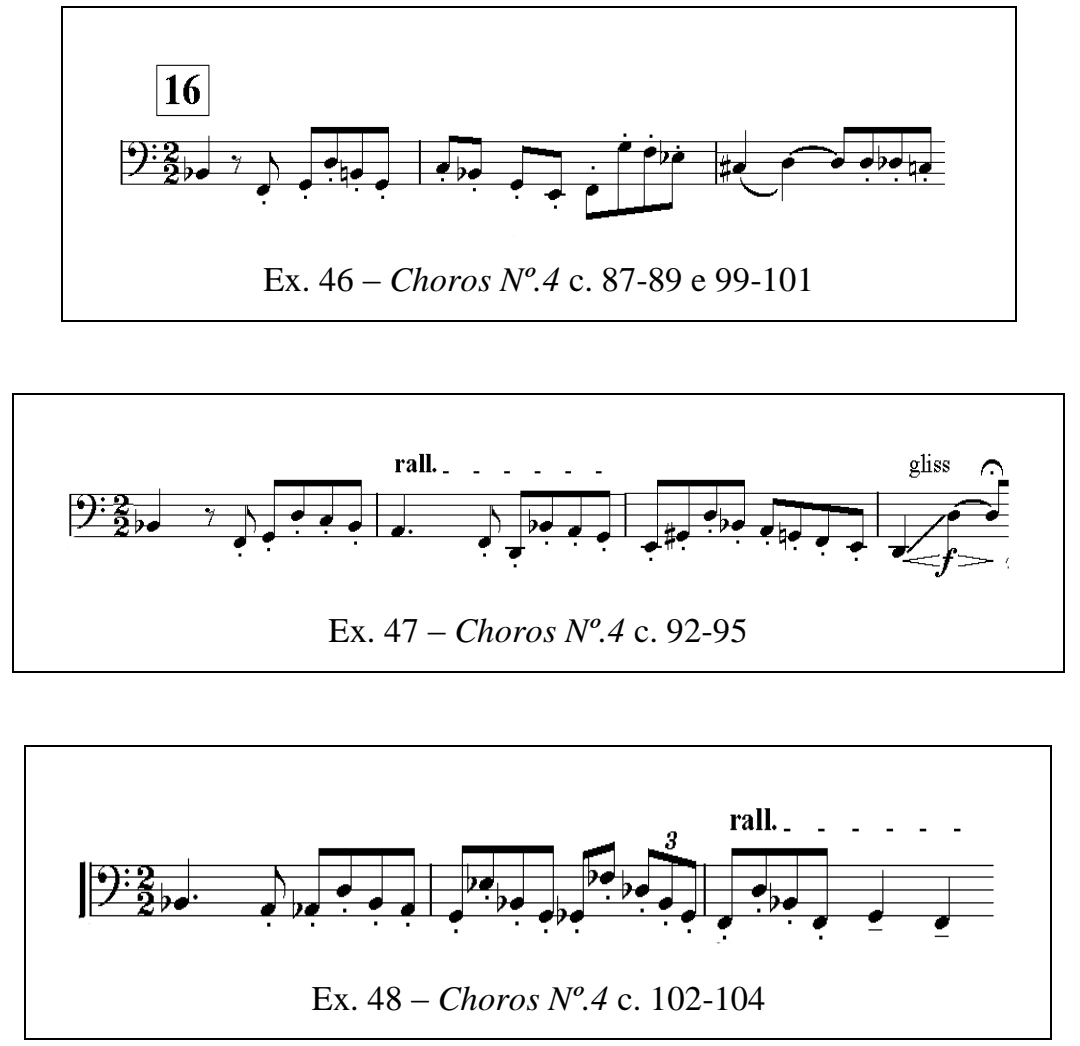

A partir de n.19 (c.109) o quarteto fará uma sequência de três compassos em pirâmide (repetidos ainda mais duas vezes) onde após um inciso de semínima pontuada e colcheia, inicia-se pirâmides contendo quatro colcheias para cada instrumento (Ex. 49): 


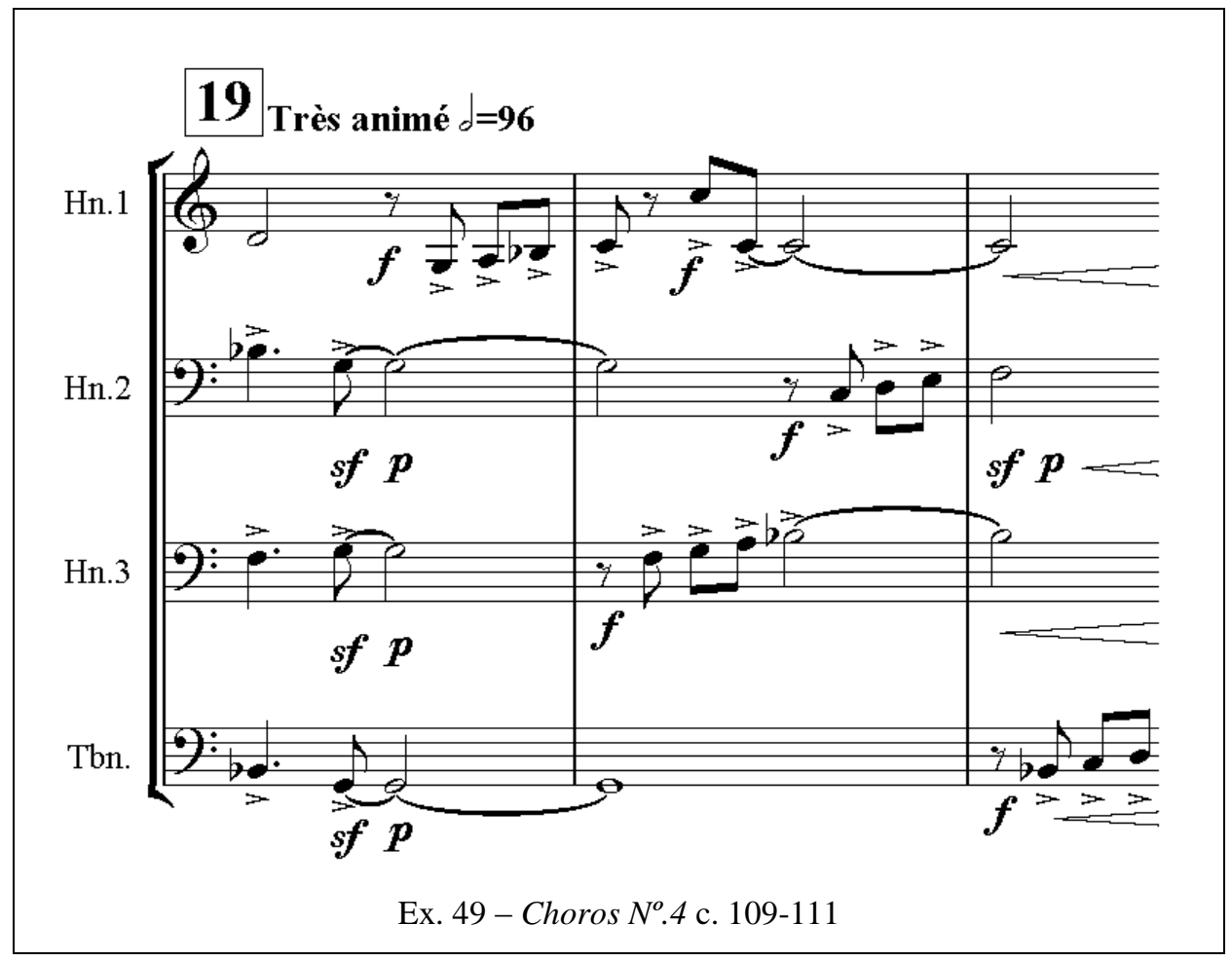

As terminações para essa seção de pirâmide seguem um padrão ABA:

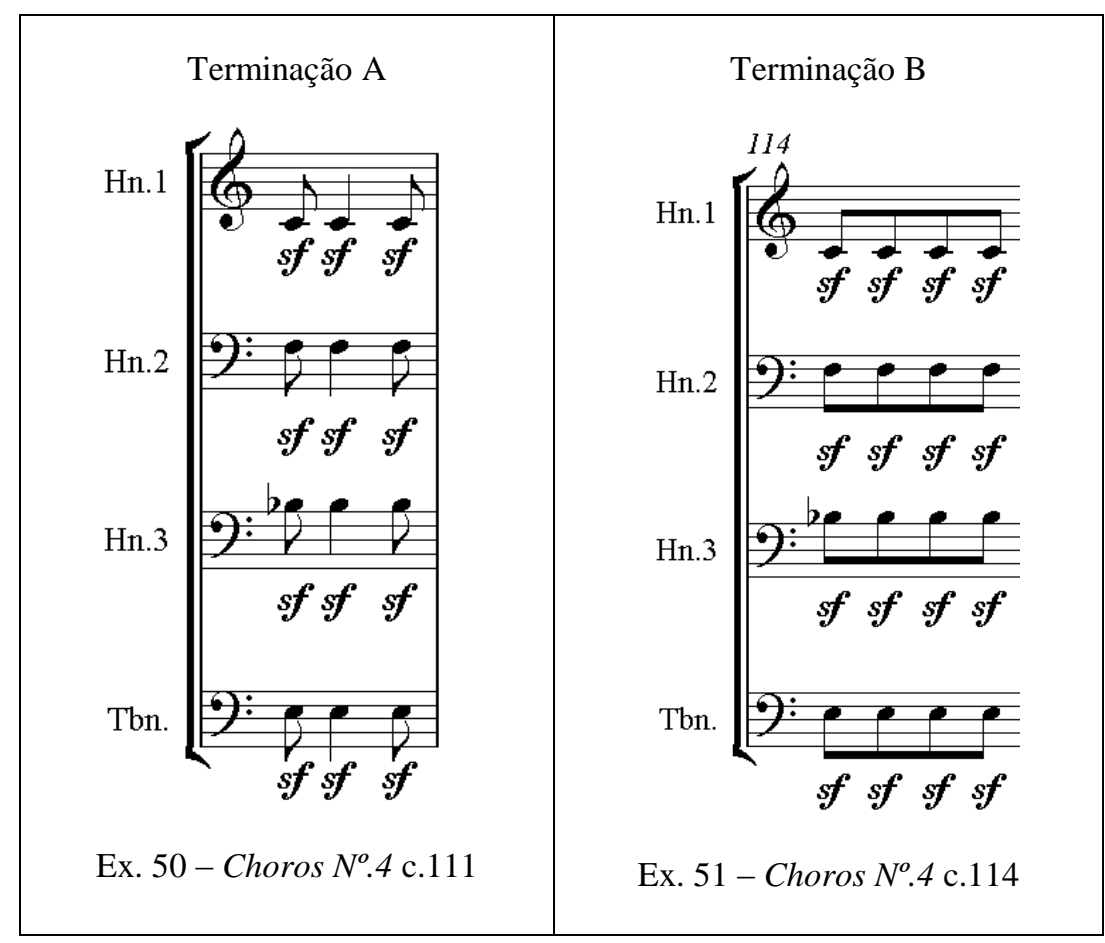

A coda será feita em colcheias harmonizadas e em paralelo, com um descanso de fermata a cada dois compassos e o final fica por conta de uma nota longa (semibreve) em fermata: 


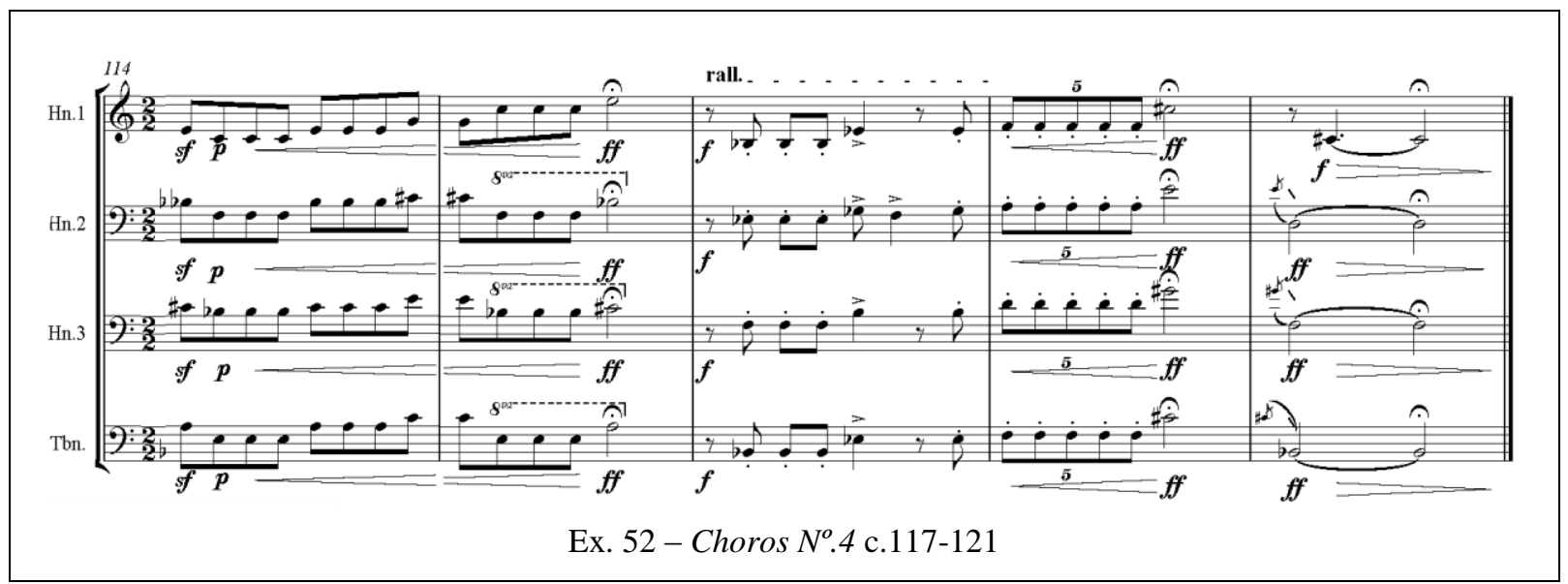

Em termos de utilização do trombone na peça Choros $N^{o} .4_{s}$ este, dos 121 compassos da peça, encontramos trombone em 116 compassos $(95,87 \%)$ e este ficará em pausa por 5 compassos (4,13\%). Não teremos compasso algum em soli, porém o trombone sola em 12 compassos (todos na primeira parte da peça). Nesta peça estão escritos 6 glissandos possíveis e 3 glissandos fora da extensão do êmbolo.

Em relação às dinâmicas utilizadas por Villa-Lobos para os metais graves, na peça Choros $N^{o} .4$ localizou-se 2 ocorrências para as dinâmicas $f \boldsymbol{f}$ e $\boldsymbol{p p} ; 6$ ocorrências para $\boldsymbol{m f} ; 9$ para $\boldsymbol{f}$ e 13 ocorrências para $\boldsymbol{p}$. Quanto às articulações escritas por Villa-Lobos, encontrou-se 2 ligaduras com ponto; 3 tratinas/tenuto; 33 acentos e por fim, 263 notas com ponto de diminuição.

\subsubsection{CHOROS No.6}

Os Choros $N^{o}$. 6 foi composto em 1926 porém sua estreia ocorreu a 18 de julho de 1942 na cidade do Rio de Janeiro. Este dedicado à Arminda Neves de Almeida e executado pela primeira vez pela Orquestra do Theatro Municipal do Rio de Janeiro, sob a regência do próprio autor. Essa peça ainda fez parte do programa do último concerto em que Villa-Lobos regeu, na cidade de Nova Iorque, a 12 de julho de 1959 durante o Empire State Music Festival com a Symphony of the air $^{75}$.

\footnotetext{
${ }^{75}$ Durante o período, o catálogo de suas obras ainda registra mais três apresentações dessa obra sob regência do autor:- 26/11/1942. Em Los Angeles, no Philarmonic Auditorium, com a Janssen Symphony of Los Angeles; 
Segundo o próprio Villa-Lobos em 1950, este Choros $N^{o} .6$ pode ser considerado a poesia dos sons, por possuir, na maior parte de sua construção, ambientes de doçura e melancolia. Sua atmosfera harmônica, na maior parte das vezes, possui uma espécie de ficção do ambiente sertanejo do nordeste brasileiro. Outra citação viria de Nóbrega, "Villa-Lobos aproveitou mais em extensão, intensidade e elementos técnicos, de que se nutriam os Choros anteriores". (NÓBREGA, 1974, p. 55).

No entanto, Seixas (2001b, p. 30) observou em seu estudo sobre os elementos texturais do Choros $n^{\circ}$ 6, que os pedais (baixos integrados) e ostinati (função harmônica) são presentes e definem todas as seções onde a "textura ${ }^{76}$ é constituída por camadas". Salles, em seu livro nos confirma que "as combinações texturais de Villa-Lobos resultam em estruturas harmônicas não sendo raro haver atrito entre as camadas constituintes. Nas combinações mais ousadas desses elementos, estão subvertidas as noções tradicionais de melodia e acompanhamento, dada a autonomia que cada parte assume" (SALLES, 2009, p. 101).

Seixas (2001) em sua dissertação Procedimentos Composicionais no Choros $\mathrm{n}^{\circ}$ 6, de Heitor Villa-Lobos, apresentou um estudo sobre a obra e busca esclarecer a sua estrutura composicional. O autor mostrou que a série Choros foi considerada por muitos estudiosos como sendo "a parte mais criativa e característica de sua criação" (2001, p.8). Além disso, segundo Seixas, o compositor consagrou-se na crítica nacional e ganhou destaque internacional ao executar sua série dos Choros em Paris, no ano de 1920, quando surpreendeu o público com vitalidade e originalidade. O pesquisador de Villa-Lobos mostrou ainda que:

(...) no plano estético, ao combinar de forma única elementos da música moderna europeia com brasileirismos de várias procedências, integrando-os em processos pessoais de composição, os Choros foram fundamentais para a afirmação do estilo maduro de Villa-Lobos. (SEIXAS, 2001, p. 8)

Ainda segundo Seixas, o Choros $n^{o} 6$ foi "um dos seus cavalos-de-batalha em turnês ao estrangeiro", mostrando, assim, que a obra foi bastante executada, sendo regida pelo compositor em várias ocasiões. A obra é apontada como a representante de um maior aproveitamento dos recursos de elementos técnicos que não foram empregados nos Choros

18/05/51. Na cidade de Helsink, com a Helsingfors Stadsorkester; - 11/12/53. Na cidade de Havana, Cuba, no Teatro Auditorium. Com a Orquestra Filarmônica de La Habana.

76 Texturais seriam as linhas melódicas diatônicas, os movimentos escalares ascendentes e movimentos circulares. 
anteriores. O Choros $N^{o} 6$ não conta com a participação de solistas e/ou coro, o que se diferencia de grande parte das obras de Villa-Lobos.

Em Villa-Lobos, sua obra (1965), organizado pelo Museu Villa-Lobos, o Choros $n^{\circ} 6$ é caracterizado por possuir

(...) atmosfera harmônica, na maior parte das vezes, possuir uma espécie de ficção do ambiente sertanejo do nordeste brasileiro. O clima, a cor, a temperatura, a luz, os pios dos pássaros, o perfume de capim melado entre as capoeiras, e todos os elementos da natureza de um sertão serviram de motivo de inspiração desta obra que, no entanto, não representa nenhum aspecto objetivo nem tem sabor descritivo (BARROS, 1965, p.155-156).

Seixas (2001) apresentou uma divisão da sua estrutura analítico-musical, a qual é caracterizada por possuir seis partes agrupadas em duas subseções, sendo quatro mais extensas e duas de transição:

\begin{aligned} \hline Subseção 1 : Lento \\ $\bullet \quad$ Introdução c. $1 / 17 \\ \bullet \quad$ Transição 1 c. $18 / 21 \\$\hline Subseção 2 : Allegro \\ $\bullet \quad$ Tema 1 c. $22 / 25 \\ \bullet \quad$ Transição 2 c. $54 / 66 \\ \bullet \quad$ Desenvolvimento c. $67 / 117 \\ \bullet \quad$ Tema II c. $118 / 152 \\$\hline\end{aligned}

Tab. 5 - Estrutura Choros $N^{o} .6$

\section{CONSIDERAÇÕES DA ORQUESTRAÇÃO DO CHOROS $N^{o} .6$}

Utilizaremos a edição revisada e editada pelo maestro Roberto Duarte, sob encomenda da Academia Brasileira de Música ABM, em 2008. Estando inserido no grupo Orquestral/Chôro, esta peça conta com um efetivo orquestral completo, determinado pelos seguintes instrumentos:

\begin{tabular}{c|c}
\hline 2 & Flautas \\
\hline 1 & Flautim \\
\hline 2 & Oboés \\
\hline 2 & Clarinetes \\
\hline
\end{tabular}


Villa-Lobos e os metais graves sinfônicos:

Um estudo dos elementos técnicos específicos

\begin{tabular}{c|c}
\hline 1 & Clarinete baixo (clarone) \\
\hline 1 & Saxofone soprano \\
\hline 2 & Fagotes \\
\hline 1 & Contra-fagote \\
\hline 4 & Trompas \\
\hline 4 & Trombones \\
\hline 4 & Tuba \\
\hline 1 & pratos, bombo, tartaruga, camisão grande, cuíca, \\
& roncador, reco-reco, tambú e tambí, tambores, \\
chocalho e tamborim),
\end{tabular}

Tab. 6 - Instrumentação para Choros $N^{o} .6$

Os trombones são utilizados em uma extensão que compreende do Ré1 ao Si3 (tenor), do Dó1 ao Dó\#3 (baixo) e do Fá-1 ao Dó\#3 (tuba). Com dinâmicas que variam do pianíssimo (pp) ao fortississimo(fff) em sem nomear o mezzo-piano (mp). A entrada do $1^{\circ}$ trombone ocorrerá no c.23 ( $\left.\mathrm{n}^{\circ} 3+2\right)$, logo após o término do solo do saxofone soprano (5/4), precedido por um compasso rítmico dos violinos (Ex. 53).

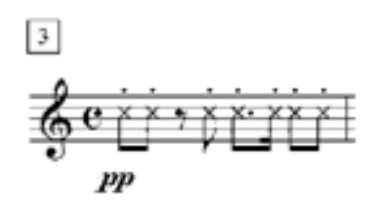

Ex. 53 - Choros $N^{o} .6$ c.22 (n.3) entrada violinos

Essa entrada será em conjunto ao $2^{\circ}$ Trompete, ambos com indicação de $s o l{ }^{77}$. Seu ritmo será o de semibreves acentuadas ( > ) em uníssono com os oboés, em $\boldsymbol{m} \boldsymbol{f}$ (Ex.54).

\footnotetext{
${ }^{77}$ Segundo o dicionário Grove's: solo é o termo que identifica, numa partitura, uma passagem que deve ser executada por um só interprete (não existe citação de exceção para dobra)... Existindo mais de um, o plural será soli.
} 


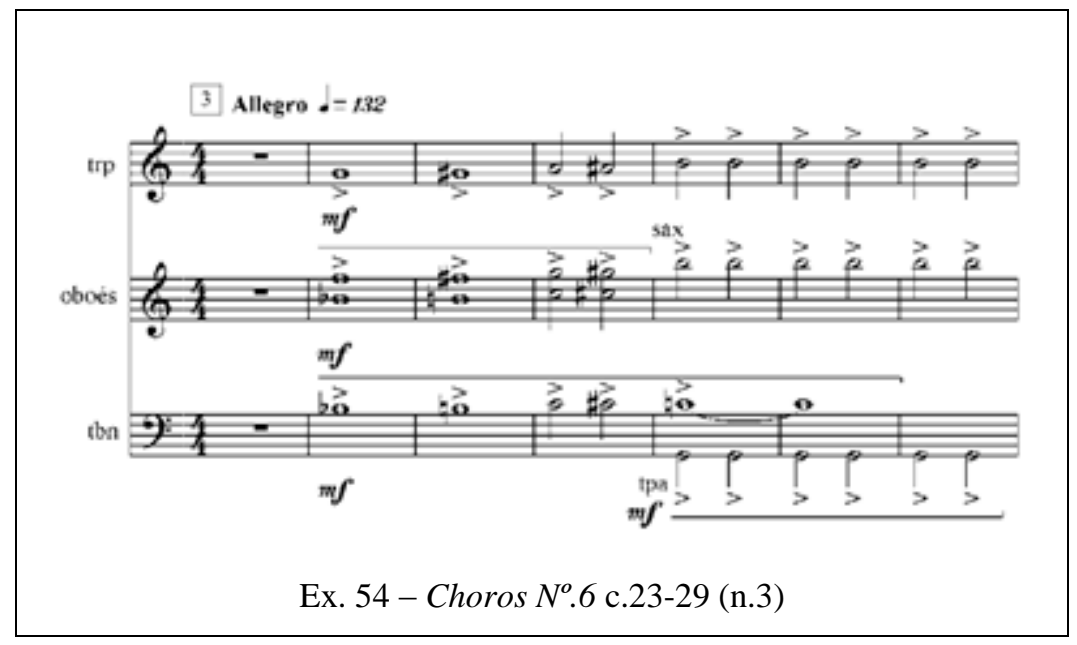

No c.25 (n.3+4), o trombone solo acompanha em mínimas acentuadas o conjunto com o Trompete, oboés e saxofone, porém no c.26 a orquestração que soará num nível mais forte, poupará o trombone, com a escrita de duas semibreves ligadas, perfazendo oito tempos. Porém, retornará no c.30 para novamente acompanhar o grupo anterior em suas semínimas acentuadas, até o c.33 (Ex. 54).

No c.30 acontecerá a primeira entrada da tuba ([4] de ensaio). Esse movimento melódico estará em uníssono com fagote e contrabaixo (Ex. 55) e em articulação estacato.

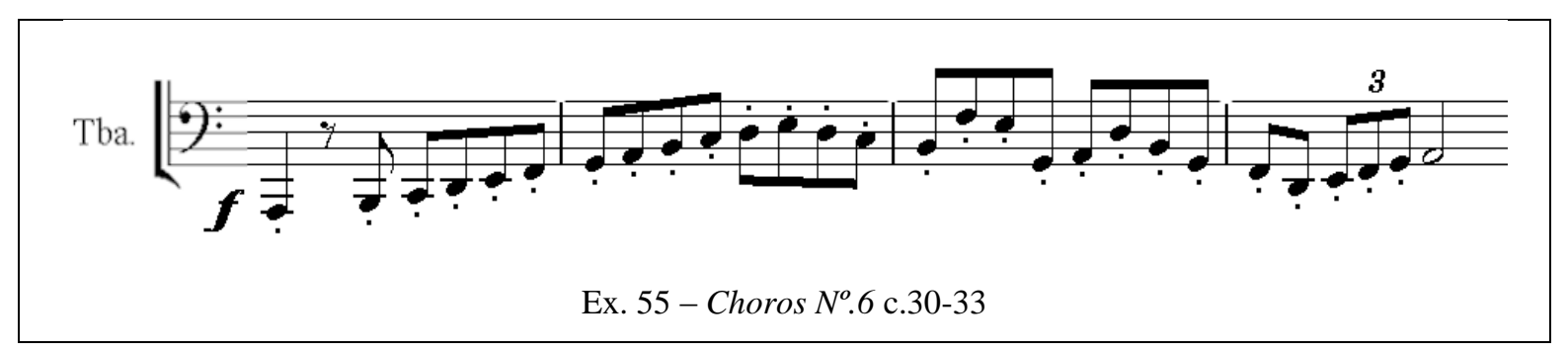

Em c.34 (n.5-4), localizou-se um equívoco na orquestração original: o $3^{\circ}$ trombone fará um ostinato rítmico, em Lá1, e não repetido por outro instrumento na orquestração. Em decorrência desse isolamento e ainda da dinâmica em $\boldsymbol{m f}$, esse movimento rítmico do $3^{\circ}$ trombone foi praticamente inaudível nas audições de gravações. Esse ostinato funciona como um importante apoio rítmico, mas Villa preferiu não expor esse elemento com duração de quatro compassos, que terá sua continuidade no tímpano, por mais oito compassos (Ex. 56).

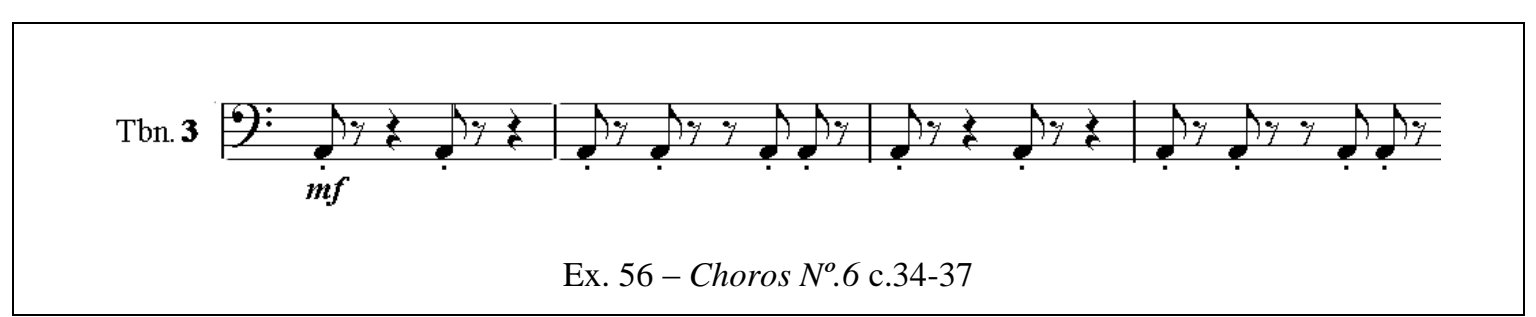


No c.36-37 o $1^{\circ}$ trombone concluirá a ideia melódica iniciada pelos fagotes. O $3^{\circ}$ trombone fará mesma melodia uma 5a.J abaixo, mas de uma forma completa (ou seja, quatro compassos). Culminando com a exposição completa do $1^{\circ}$ trombone, nos c. $42-45$ (Ex. 57).

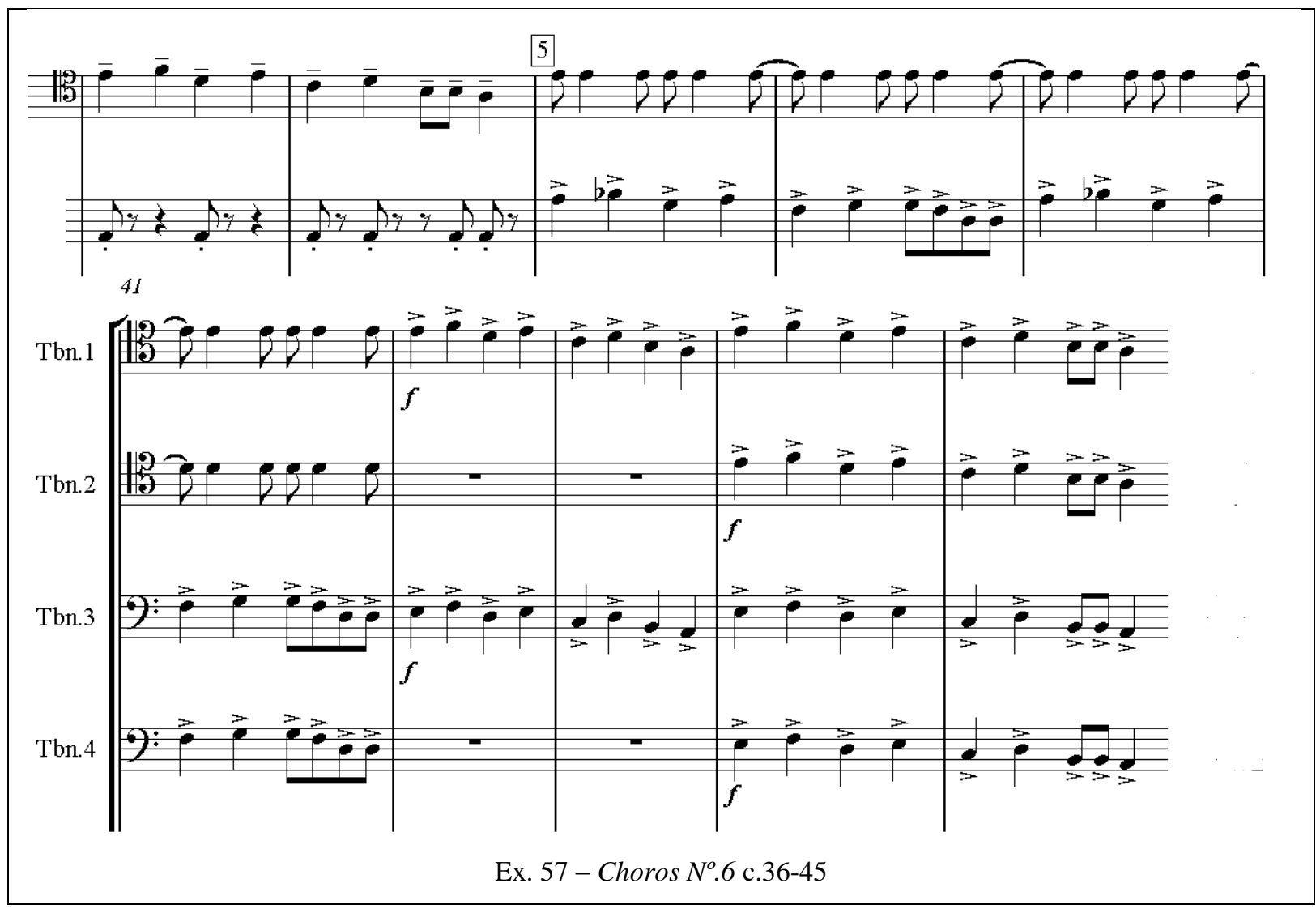

Novamente esse trecho ficará inaudível por conta da ampla orquestração, embora esse motivo servisse como base para o motivo principal executado pelo oboé, saxofone soprano, $1^{\circ}$ violino e $1^{\circ}$ Trompete, numa variação em forma de apogiatura dupla. (Ex. 58).

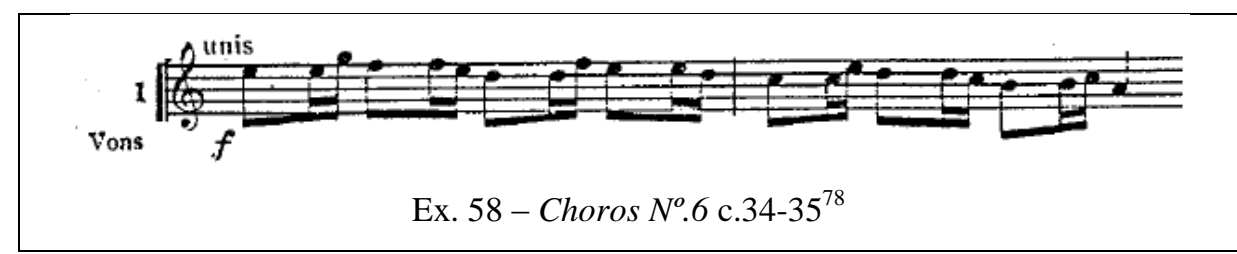

Um novo material apareceu no c.38-41 em forma de sincopa, tanto para o $1^{\circ}$ e $2^{\circ}$ trombones, e será corroborada pelas 3a. e 4a. trompas e a harpa. Essa síncopa recebeu uma ligadura de valor a cada troca de compasso, o que criou uma dificuldade de articulação para o trombonista.

${ }^{78}$ Fonte: Partitura de material de consulta do Museu Villa-Lobos; 1955 by Editions Max Eschig. 


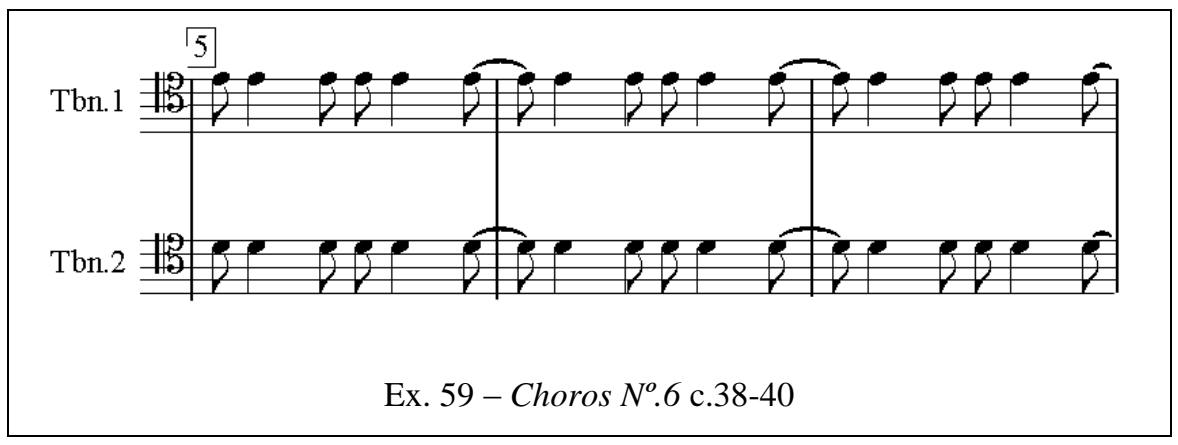

Nesse mesmo momento (número de ensaio [5]), a tuba iniciará, em conjunto com os fagotes e contrabaixos, uma sequência de arpejos em torno das notas Lá e Mi, porém pouco audível dentro da orquestração densa que Villa propôs nesse momento. A pausa de colcheia, a cada par de compassos, serviu claramente como local de respiração para o tubista (Ex. 60).

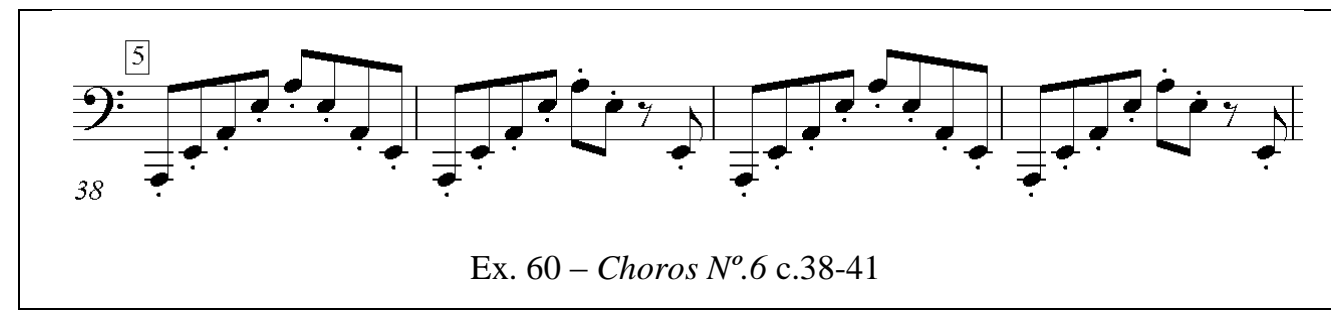

A partir de c.50, especificamente a partir de [7]-4, os trombones em conjunto com os Trompetes (realmente em dinâmica $\boldsymbol{m f}$ ), demonstraram a técnica de deslizamentos de semitons enquanto as madeiras apresentam escalas cromáticas em tercinas, um elemento novo que deve ser ouvido (Ex. 61). A articulação sempre foi em estacato apenas o descanso melódico em mínima pontuada que receberá a indicação de sforzando.

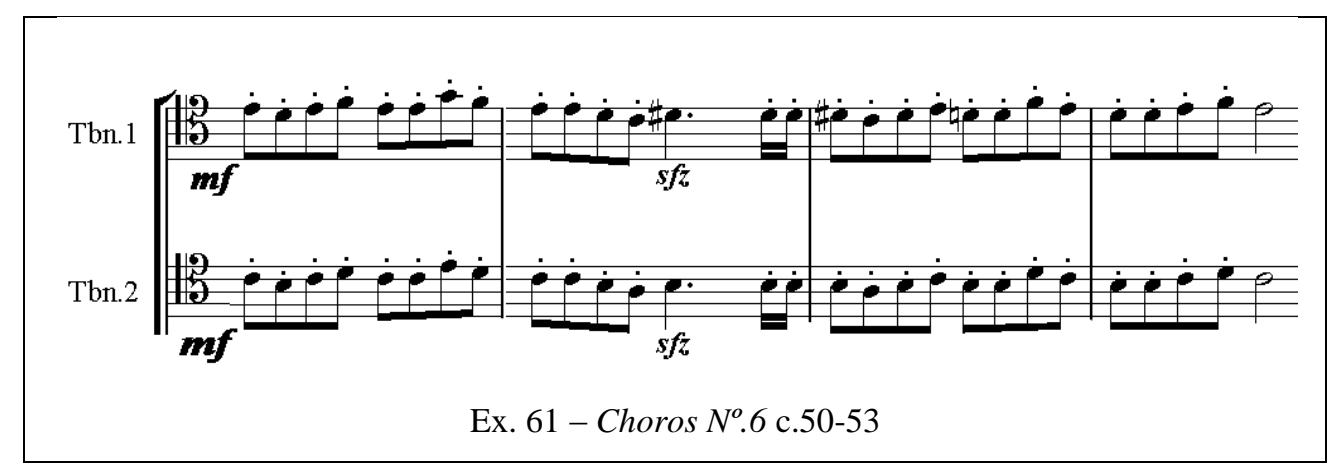

Os compassos entre os números 7 (c.54) e 8 possuem um padrão de dinâmica repetido em todos os instrumentos: $\boldsymbol{m} \boldsymbol{f}$ crescendo em cada compasso (Ex. 62). O primeiro e segundo trombones devem crescer partindo de um $\mathbf{m p}$ até atingir um forte para realçar o efeito desejado pelo compositor. O compositor ainda insistiu na articulação em estacato. 
Villa-Lobos e os metais graves sinfônicos:

Um estudo dos elementos técnicos específicos

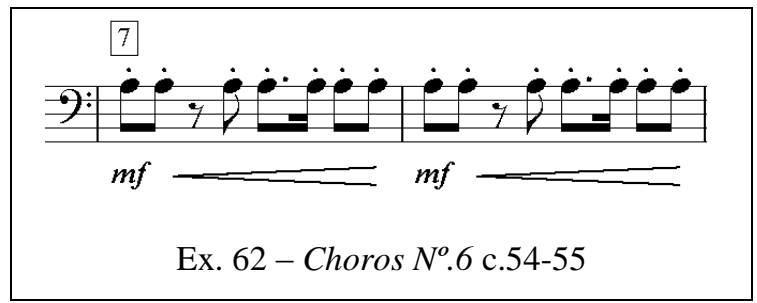

O número 7 de ensaio (c.54-62), em dinâmica $f$ para todos (excetua-se o tímpano, que na partitura está grafado em $\boldsymbol{m f}$ ), apresenta o mesmo ritmo para todos os graves da orquestra (contrafagote, trombones 3 e 4, tuba, tímpano e contrabaixo) - (Ex. 63), que é na verdade, a finalização do crescendo orquestral. A articulação dos trombones deverá ser curta (ponto de diminuição), tornando o trecho mais percussivo.

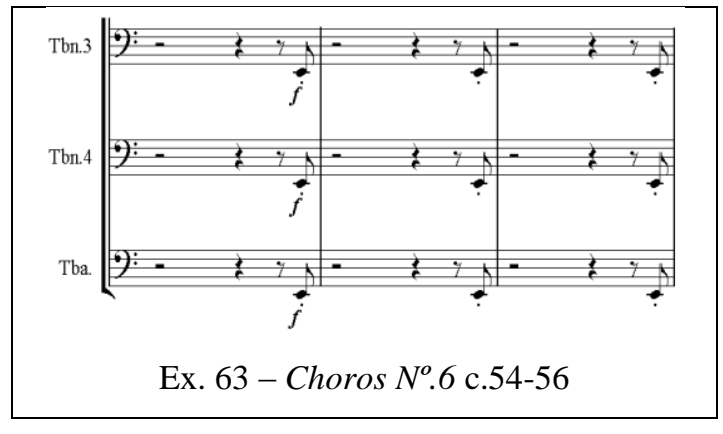

Porém essa ideia de um elemento percussivo continuará além do [8], no entanto será adicionado, ainda, as trompas, violas e Violoncelos (Ex. 64). Elemento rítmico, esse, que servirá como complemento do motivo rítmico dos Trompetes, celesta e violinos. (Ex. 65)

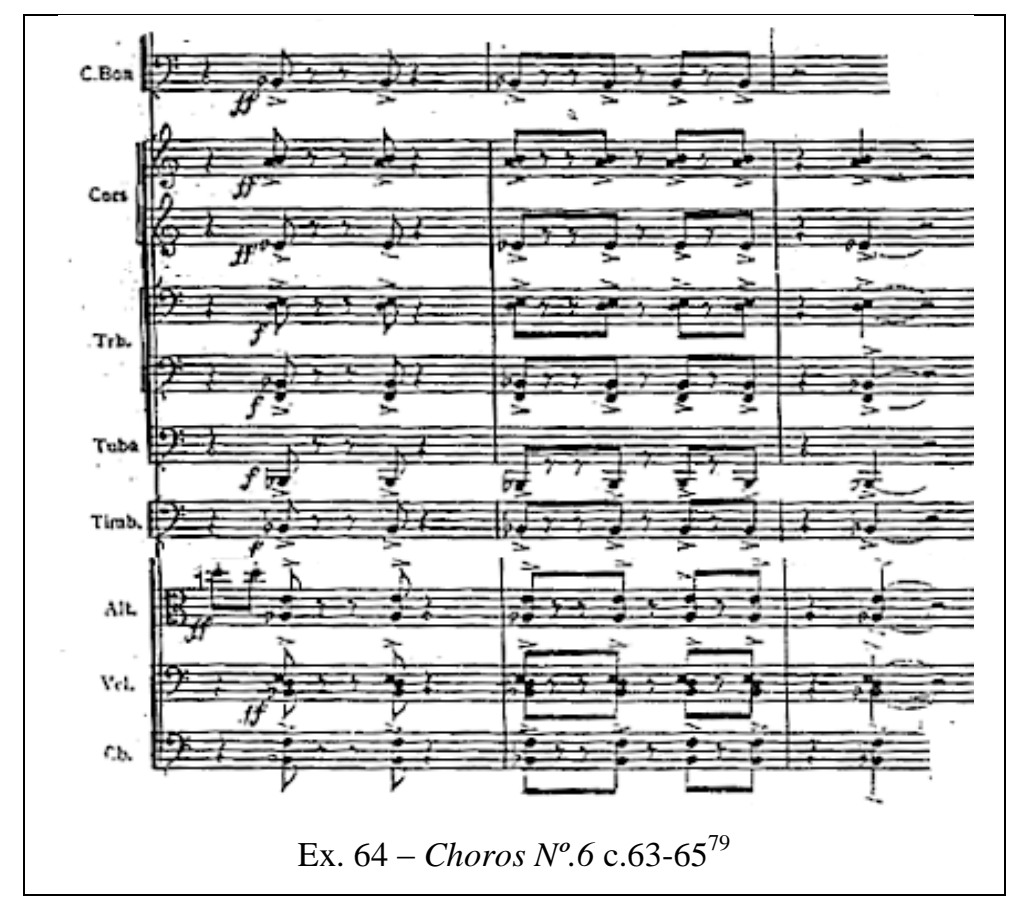

${ }^{79}$ Fonte: Partitura de material de consulta do Museu Villa-Lobos; 1955 by Editions Max Eschig. 


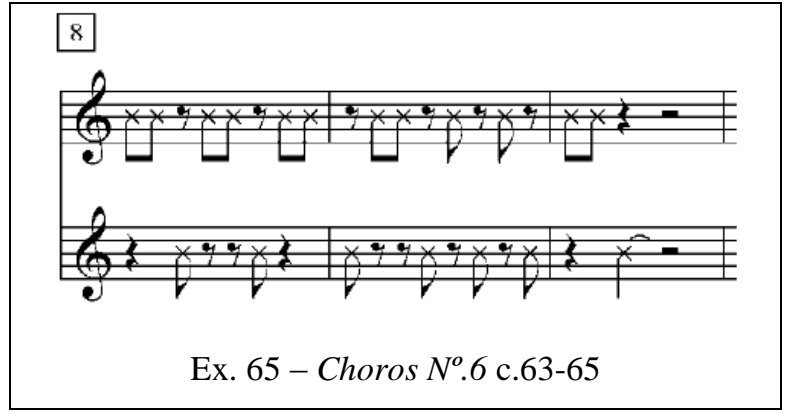

O compositor acrescentou um grau à mais na dinâmica do trombone, escrevendo forte para esse momento, e acentos $(>$ ). Embasado pelas tercinas da harpa, segundos violinos, viola e Violoncelo. (Ex. 66)

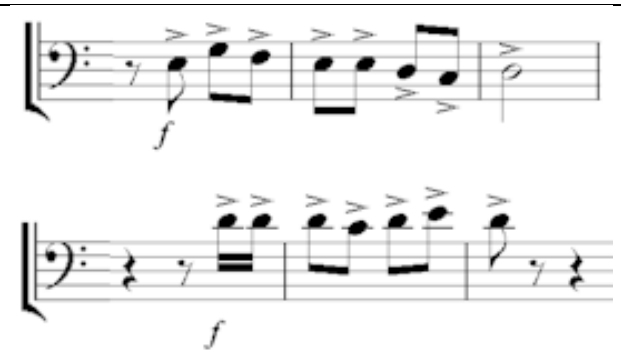

Ex. 66 - Choros $N^{o} .6$ c. $76-78$ e c. $86-88$

No c.90, Villa-Lobos criará para a sequência em semicolcheias culminando com um modo completo descendente, feitas pelas flautas e oboés, um movimento, também em semicolcheias, porém estático, nos quatro trombones e tuba. (Ex. 67)

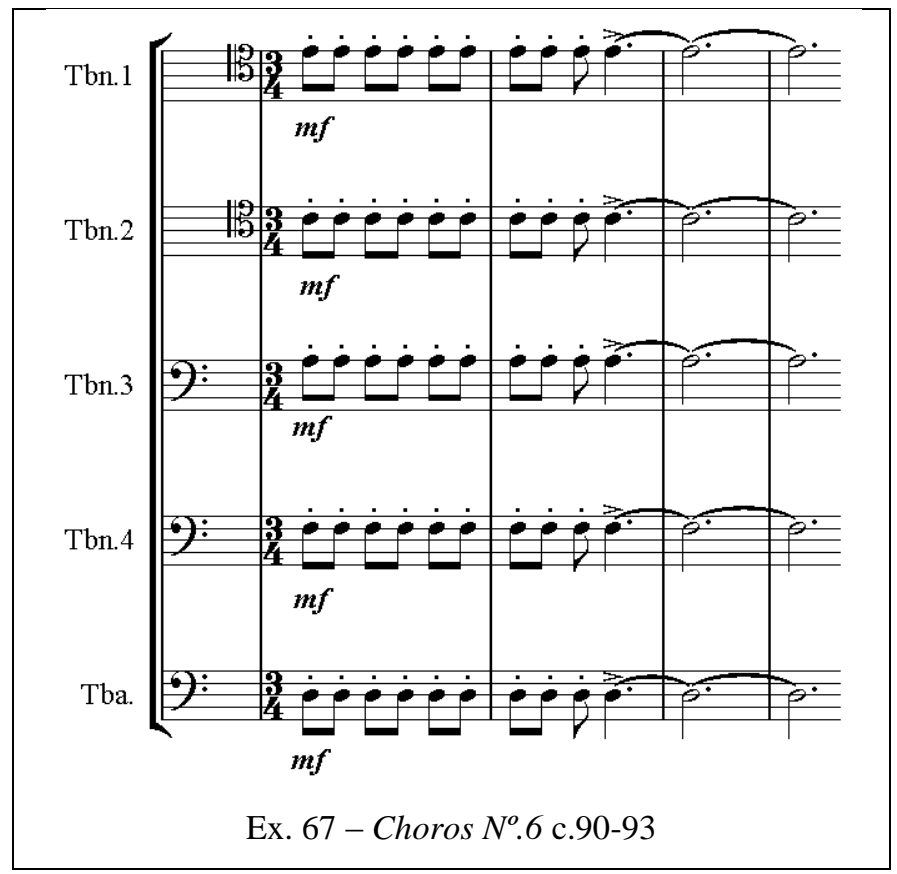


Os $3^{\circ} \mathrm{e} 4^{\circ}$ trombones, além da tuba, ficarão em espera por 26 compassos (os $1^{\circ}$ e $2^{\circ}$ ficarão, num total, 44 compassos). Os $3^{\circ}-4^{\circ}$ trombones e a tuba retornarão no c.120 fazendo uma reposta ao motivo melódico exposto pelos violinos (Ex. 68).

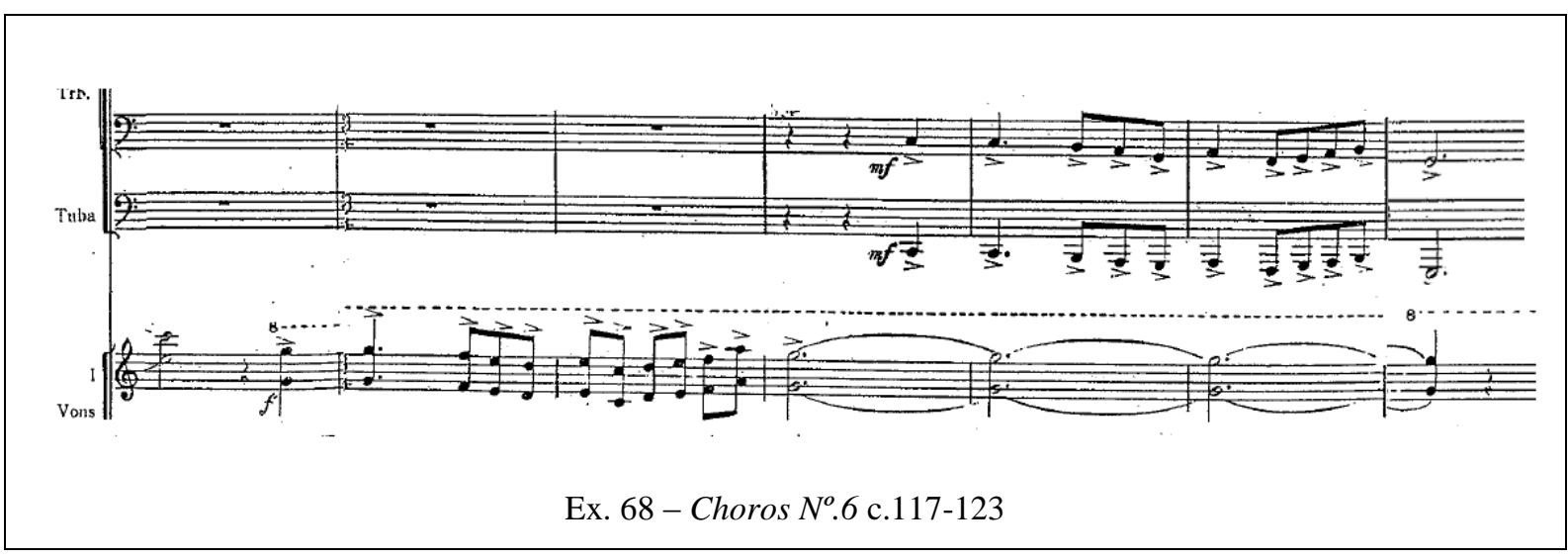

No c.126 $([13]+9)$ o $4^{\circ}$ trombone e a tuba iniciarão um ostinato rítmico que perdurará por 25 compassos consecutivos (Ex. 69). Durante os três primeiros compassos (c.126-128) a dinâmica indicada será $\boldsymbol{m f}$, mas a partir do c. 129 essa dinâmica será alterada para $\boldsymbol{p}$ e essa passagem tornar-se-á inaudível dentro da orquestra para que os fagotes, clarinetes e flautas fiquem audíveis.

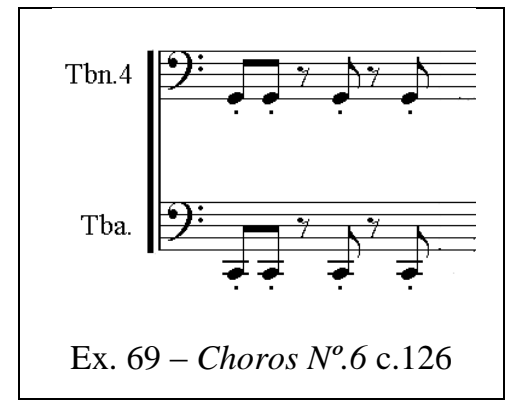

No c. 138 ([14]) os trombones 1,2 e 3 tocarão um pedal ${ }^{80}$ de 21 tempos, onde apenas o $2^{\circ}$ trombone trocará sua nota no c.142. Levando-se em consideração que Villa-Lobos enumera esse Allegro em $\mathrm{MM}=132$, teremos um pedal de aproximadamente 10 segundos ${ }^{81}$.(Ex. 70).

\footnotetext{
${ }^{80}$ Seixas (2001) observa como os pedais e os ostinati são importantes na elaboração do Choros $n^{o} 6$.

${ }^{81}$ Sabiamente Villa-Lobos indica uma dinâmica suave para o naipe, caso contrário, seríamos obrigados a uma respiração estratégica em meio a essa nota longa.
} 


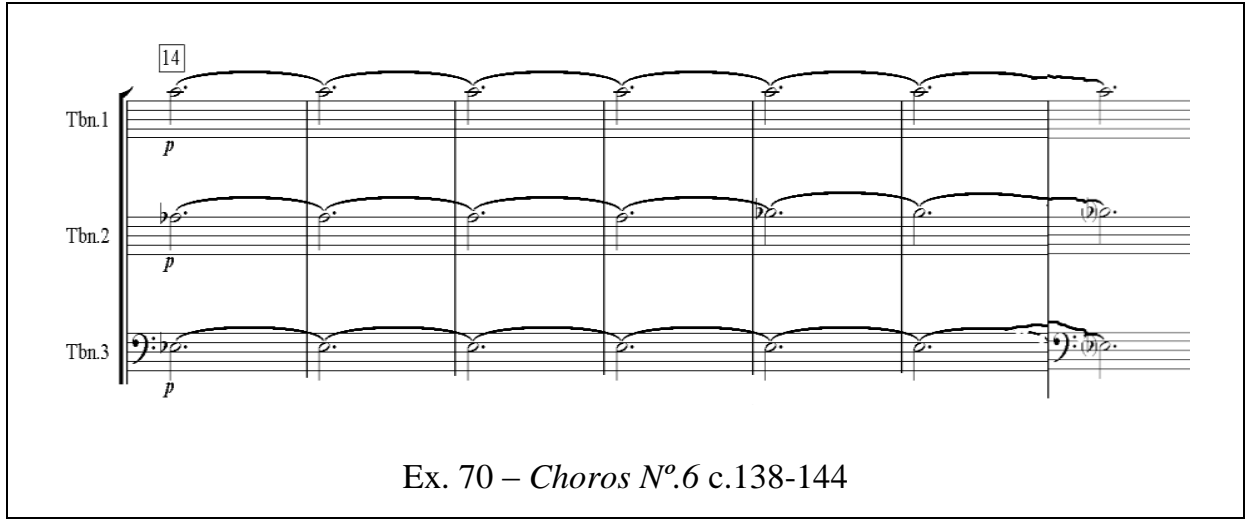

No c. $160([16]+1)$ os $1^{\circ}, 3^{\circ}$ trombones e a tuba farão uma linha melódica em conjunto com fagotes, Violoncelos e contrabaixos reforçando o contraponto ao eco melódico feito pelos violinos, $1^{\mathrm{a}}$. trompa e flautas (ex.71). Os $2^{\circ}$ e $4^{\circ}$ trombones servirão apenas para finalizar essa ideia melódica e o $1^{\circ}$ trombone não tocará a última nota, recebendo tempo hábil para colocar a surdina necessária para o ultimo tetracorde do período (Ex. 72).
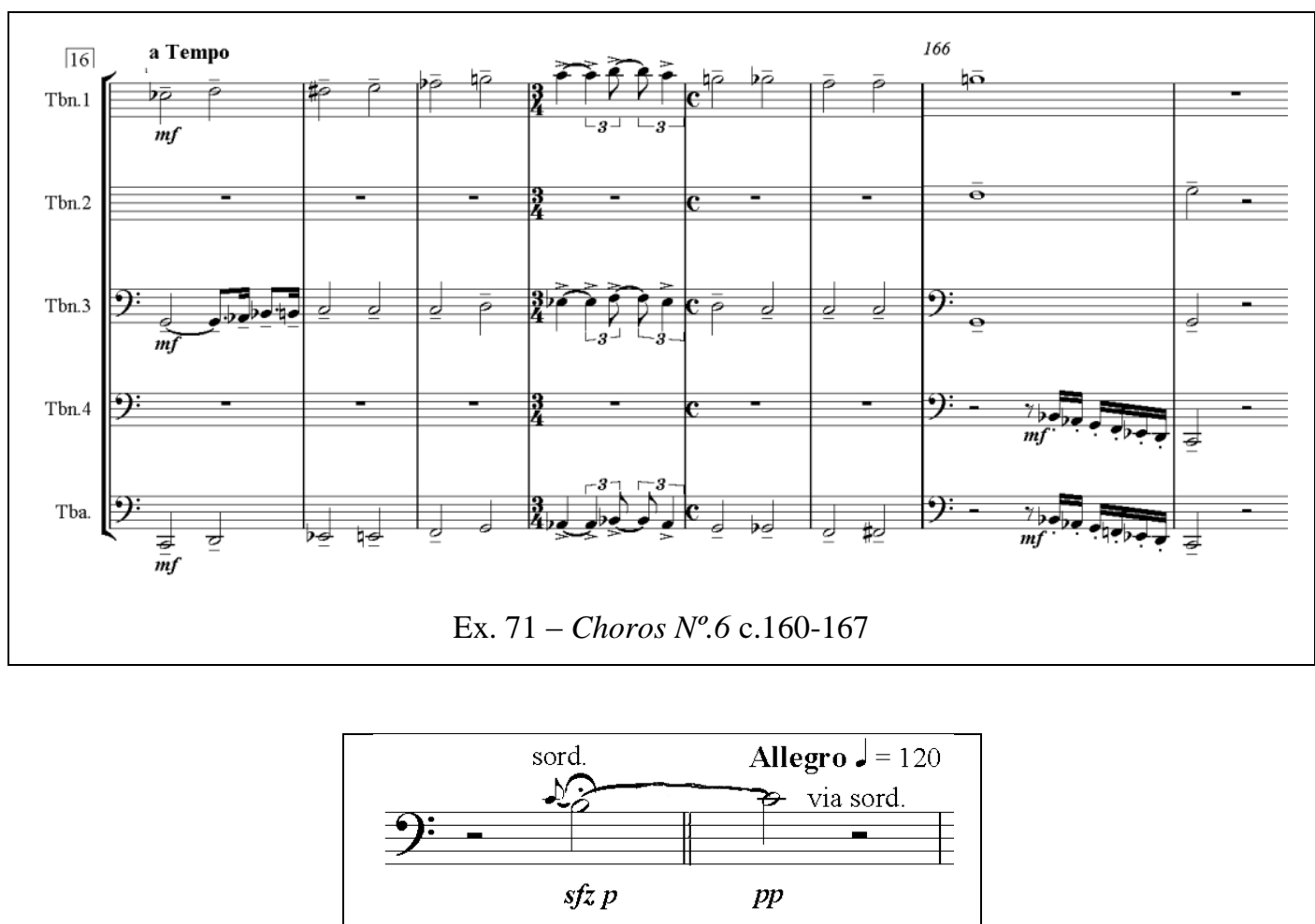

Ex. 72 - Choros $N^{o} .6$ c. $168-169$

No c. $183([18]+3)$ o $1^{\circ}$ trombone fará um solo dentro do naipe e logo após o término do solo do saxofone soprano. Essa frase tocada pelo $1^{\circ}$ trombone dará movimento a essa 
frase. Está em forma de movimento escalar ascendente ${ }^{82}$, em espelho à ideia de escala descendente das flautas. (Ex. 73).

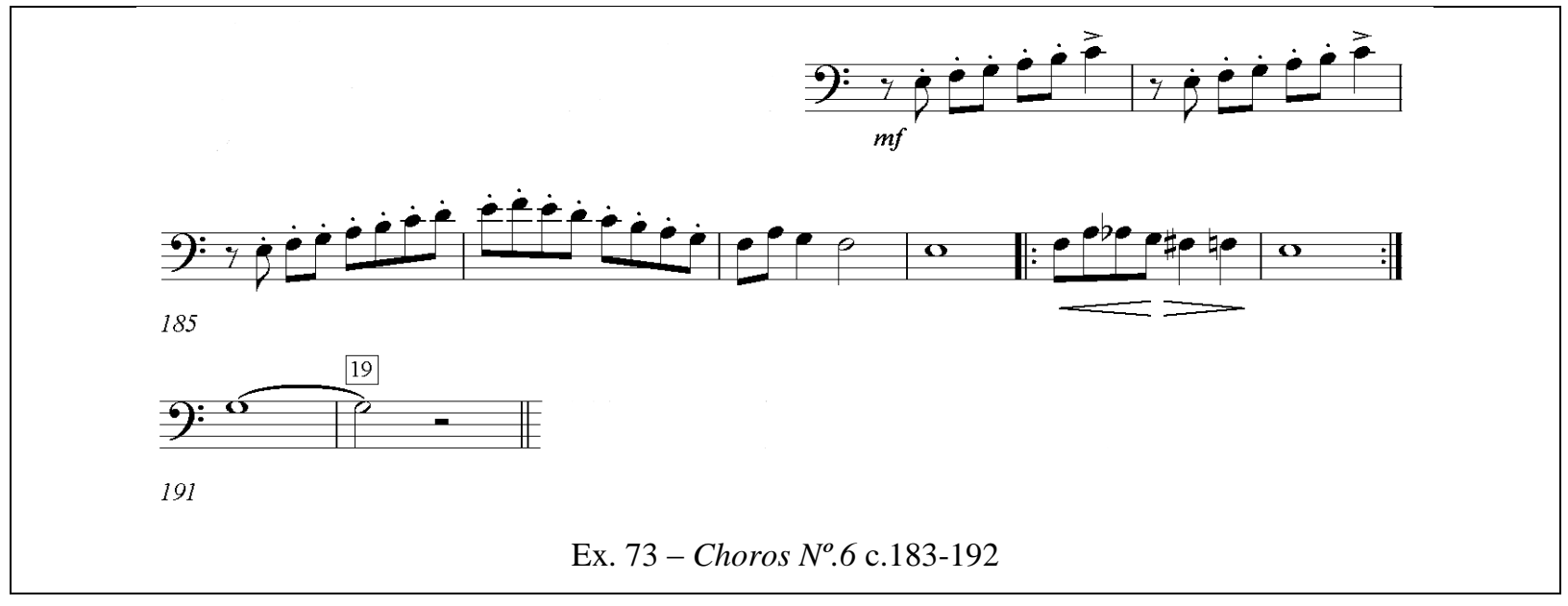

No c. $193([19]+1)$ inicia-se uma dança, com forte intenção tética. Os trombones e a tuba serão os responsáveis pela $1^{\mathrm{a}}$ semicolcheia de cada tempo. O ostinato terá duração de dois compassos e se repetirá por oito vezes - seis numa frase e dois na frase sequente. A cada cinco semicolcheias únicas, o ritmo será de duas mas a tuba será poupada desse movimento duplo de semicolcheias (Ex. 74). Entre as seis repetições haverá um movimento melódico em colcheias para finalizarmos a frase (Ex. 75)

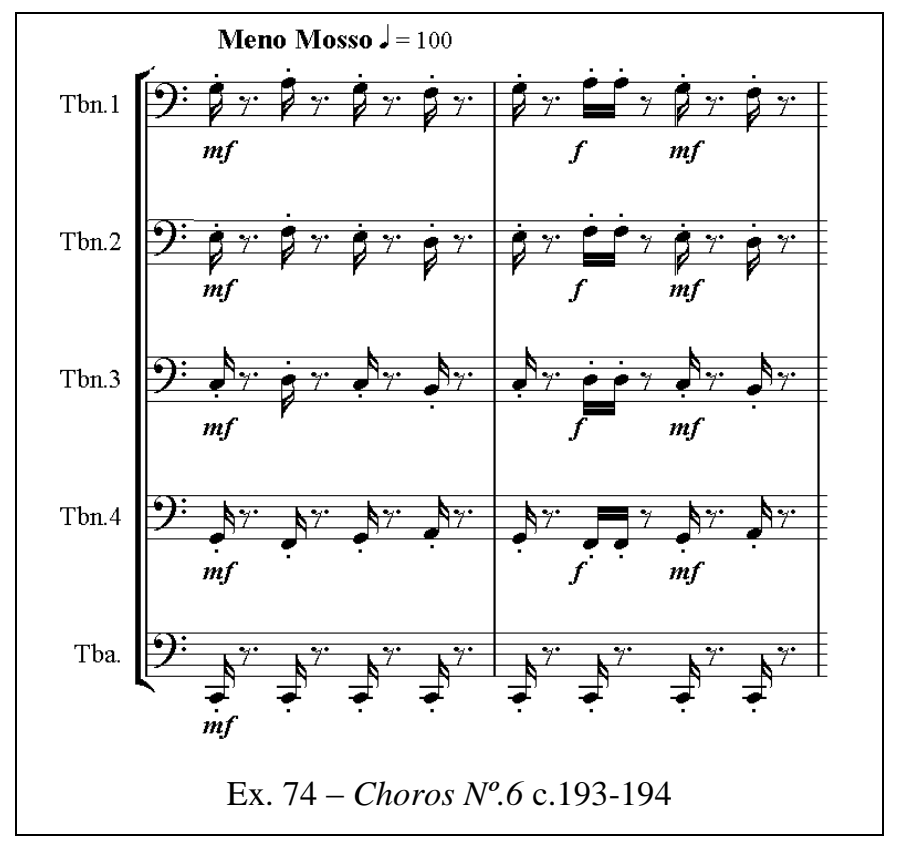

\footnotetext{
${ }^{82}$ Segundo Seixas (2001b, p.30), o movimento escalar ascendente será um dos elementos texturais do Choros $n^{o}$ 6, como subdivisão do diatonismo das linhas melódicas.
} 
Villa-Lobos e os metais graves sinfônicos:

Um estudo dos elementos técnicos específicos

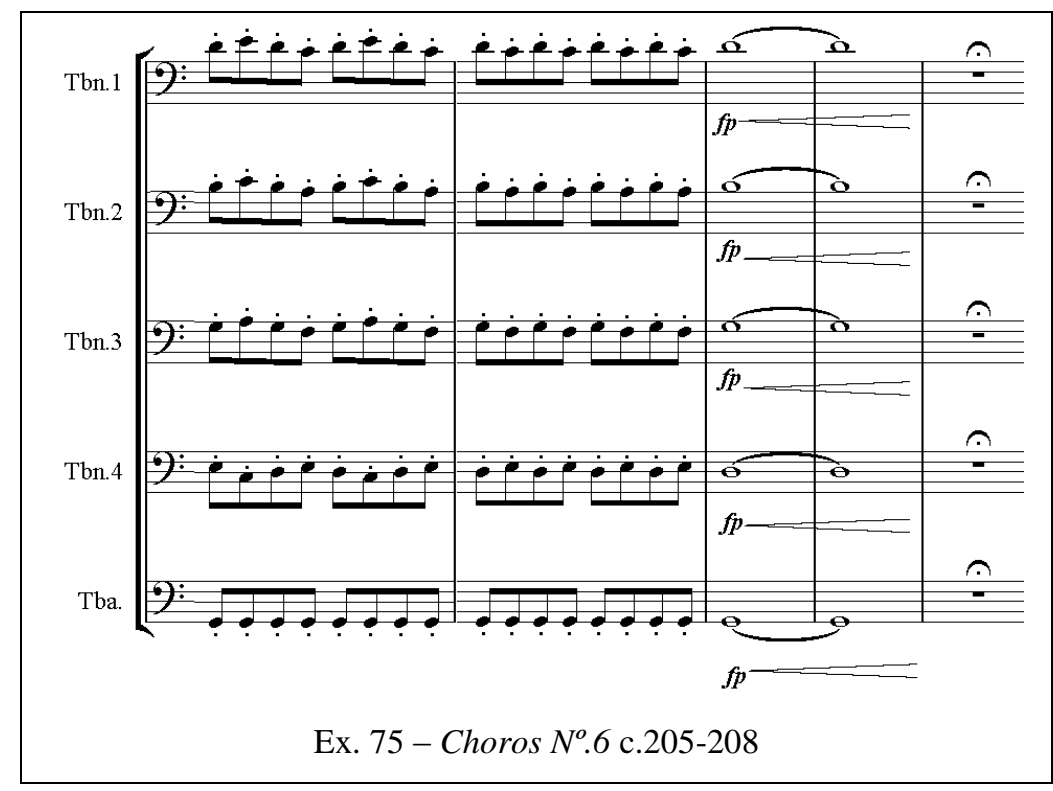

$\mathrm{Na}$ anacruse do c.218, o $1^{\circ}$ trombone fará um pedal de 16 tempos, com função de $5^{\mathrm{a}}$. trompa. (Ex. 76)

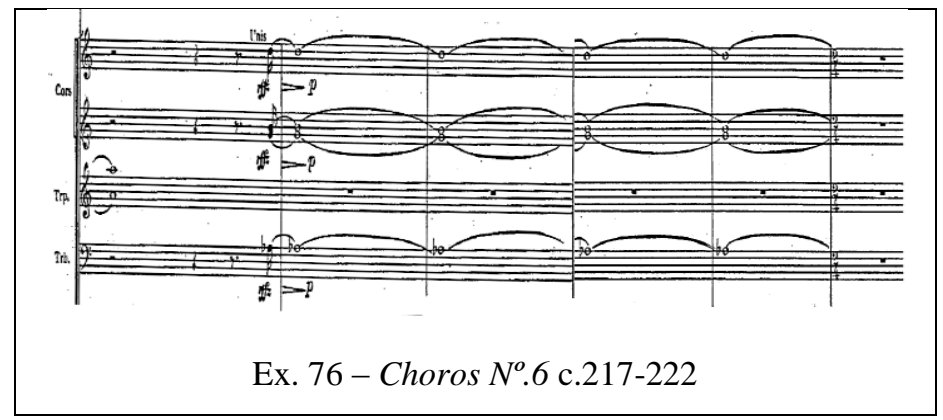

Villa-Lobos se utilizará, em todos os trombones e na tuba, de um motivo para os próximos 27 compassos. Esse motivo sofrerá ainda três alterações (Ex. 77).

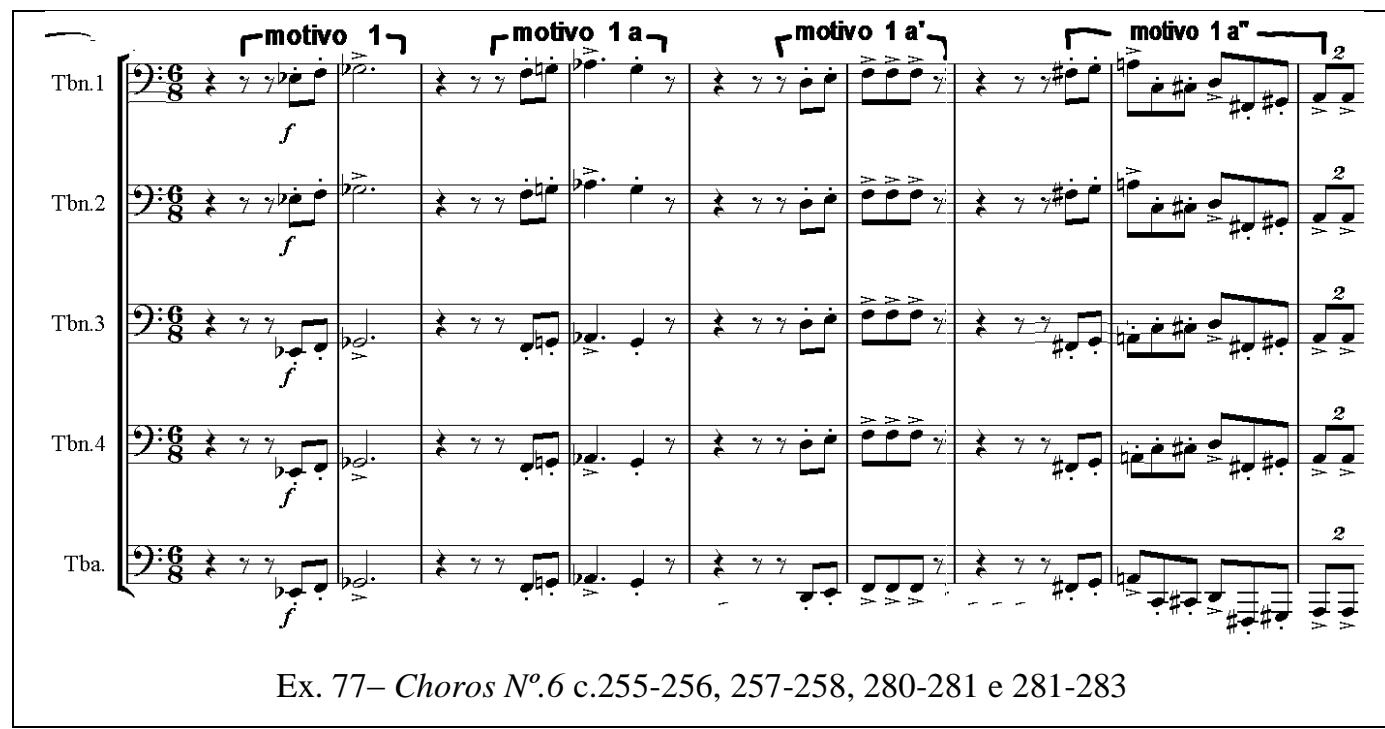


Os trombones e tuba ficarão 42 compassos em espera. Em c. 326 [31] o $1^{\circ}$. trombone (em uníssono com os fagotes) e a tuba farão um motivo descendente escalar que perdura por 15 compassos, com um compasso de fermata, e mais 15 compassos com a mesma ideia motívica, porém Villa-Lobos trocará a linha da tuba pelo $3^{\circ}$. trombone a partir do c. $348-\mathrm{e}$ ainda na partitura original, e na troca da pag. 93-94 ele nomeia, novamente, a tuba para a finalização dos c. 355-357. (Ex. 78)

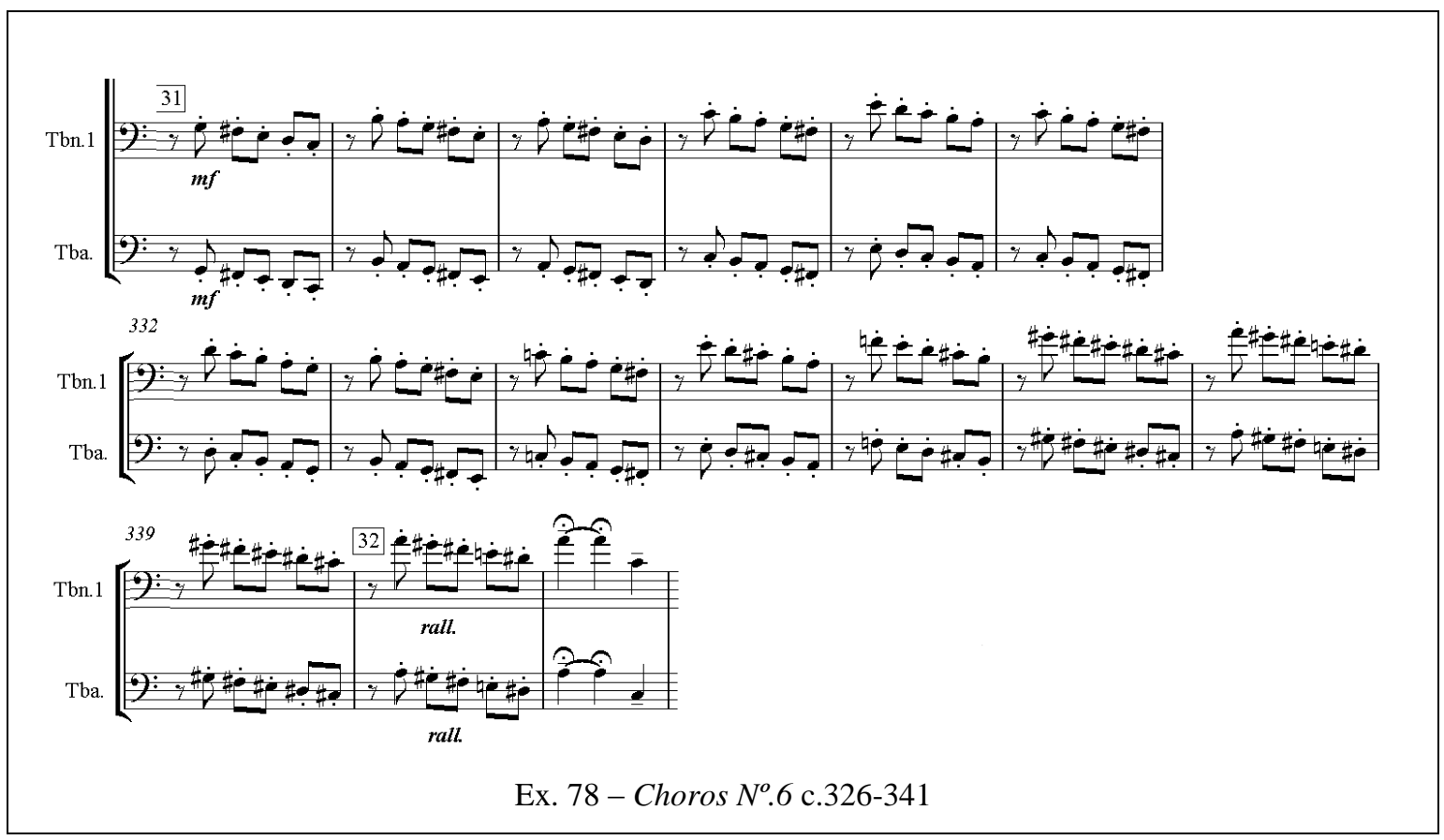

Após a valsa em andamento lento, o $1^{\circ}$. e $2^{\circ}$. trombones apresentam célula rítmica em compasso binário em contraste com o solo do trecho anterior (n.34 - c.363; Ex. 79). Segundo Neves: “(...) Nesta obra mais que em outras, encontramos o confronto entre elementos opostos: ao tema lírico segue o furioso, ao meditativo, a dança” (NEVES, 1977, p 51).

O caráter do novo ambiente musical em $\boldsymbol{m} \boldsymbol{f}$ e uníssono com Trompetes permite aos trombonistas liberdade na dinâmica nos sete primeiros compassos. O elemento apresentado, um ostinato, é descrito por Seixas: "Como introdução, seu caráter "perturbador" atua para criar expectativa” (SEIXAS, 2007, p. 135). Perturbação que deve ser finalizada no início das escalas ascendentes (c.370), quando se diminuir a dinâmica e o valor da cada nota. 
Villa-Lobos e os metais graves sinfônicos:

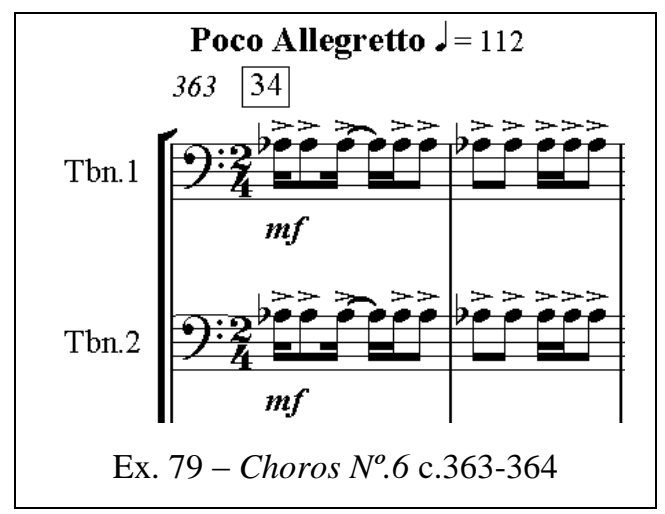

No c. $365([34]+2)$ os $3^{\circ}$. e $4^{\circ}$. trombones farão uma mínima em $s f z$. Essa intervenção servirá como apoio às quatro trompas em seis sequências de mínimas, mas a partir do $2^{\circ}$. compasso, os fagotes continuarão com em conjunto com as trompas (Ex. 80)

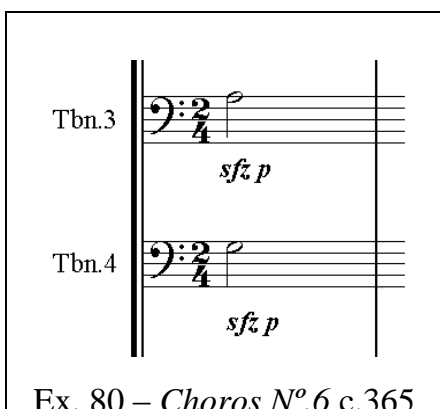

Os trombones retornarão à peça em 36 compassos numa sequência de oito mínimas no c.409. (Ex. 81)

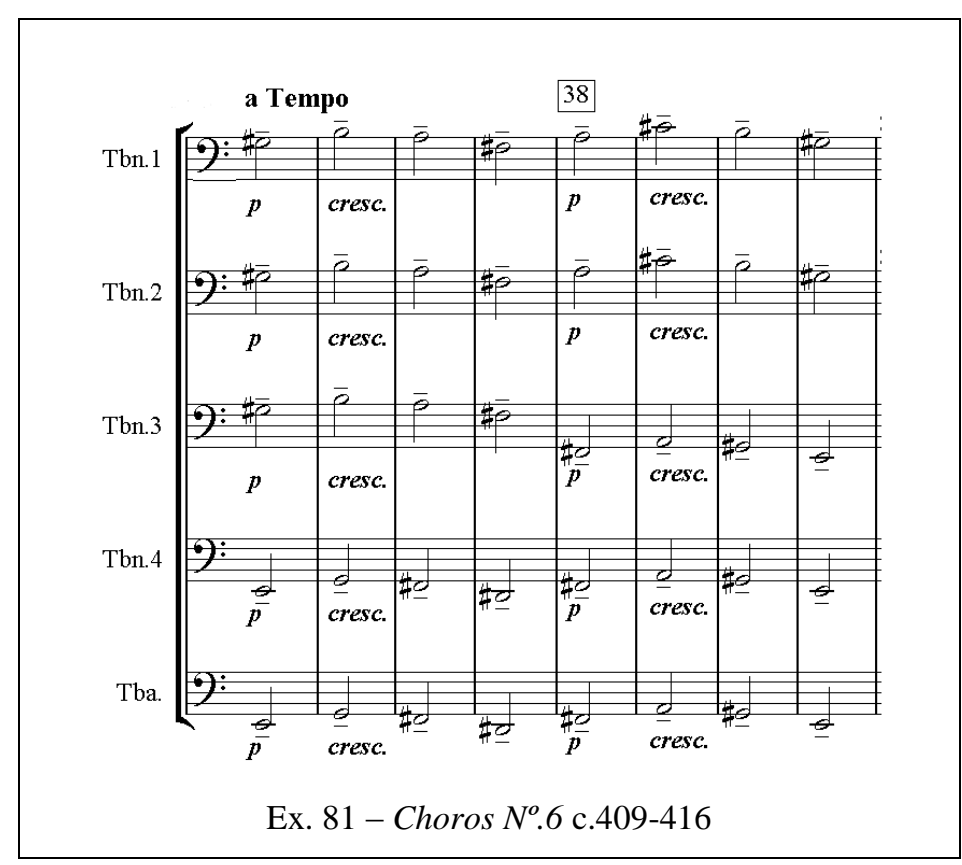


A partir do c. 417 , o $1^{\circ}$. e $2^{\circ}$. trombones iniciarão uma sequência de tercinas em conjunto com trompas e Trompetes enquanto os $3^{\circ}$. e $4^{\circ}$. trombones e a tuba farão um motivo contrastante em semicolcheias em conjuntos com clarone, fagotes, Violoncelos e contrabaixos (Ex. 82).

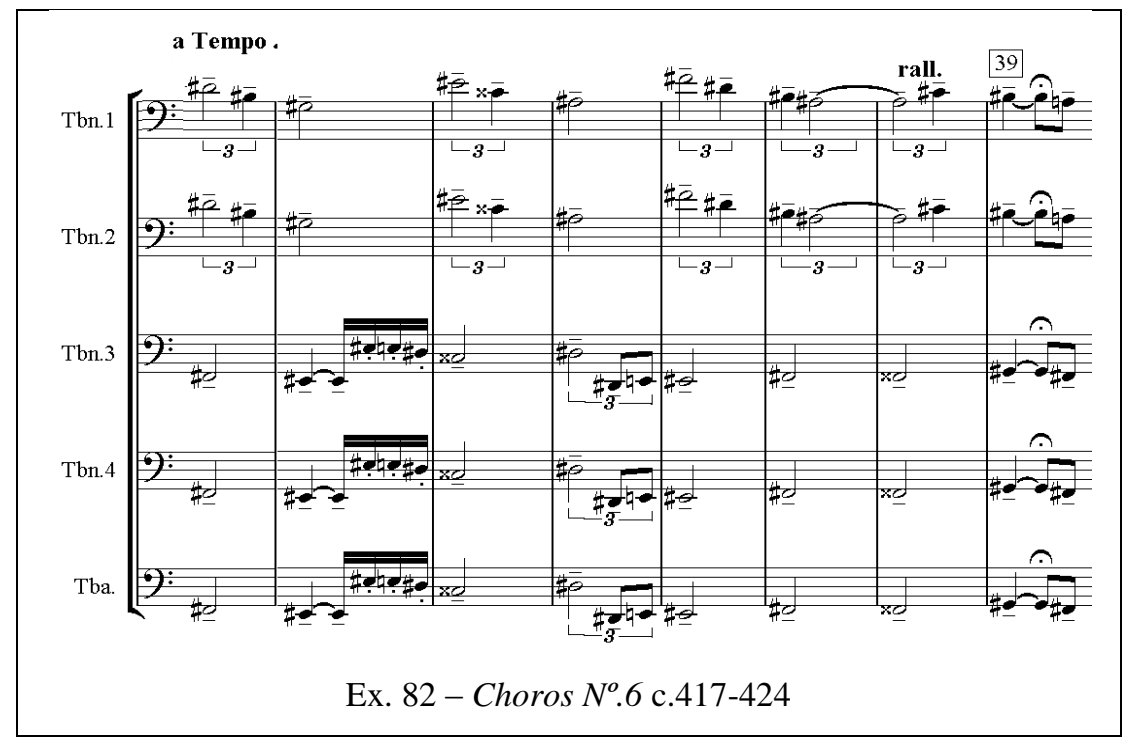

A sequência anterior, de mínimas e depois tercinas de mínimas será reprisada a partir do c.425, porém no c.433 a tuba não participará da reprise da tercinas, em vez disso, VillaLobos preferiu manter a tuba em tético de semínimas num movimento escalar ascendente e descente (Ex. 83).

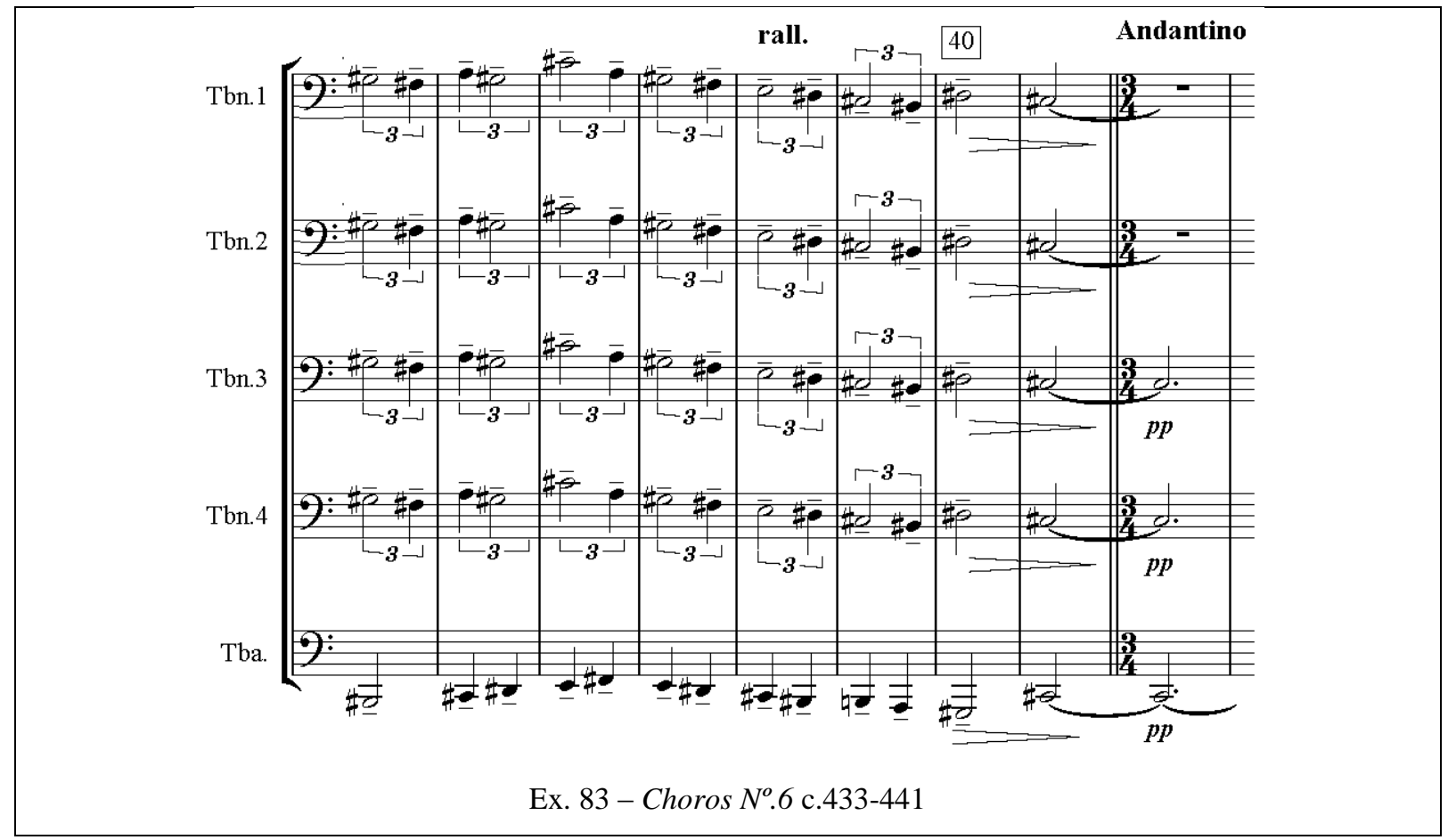


No c. 444 o $1^{\circ}$. e $2^{\circ}$. trombones estarão em conjunto com as trompas, Trompetes, oboés, clarinetes e saxofone no tema exposto (Ex. 84). Um novo ambiente em compasso ternário em c.440 (n.40+2) apresenta os metais com surdinas - trompas com bouché - em $f$. Os metais tocam a mesma parte dos oboés, clarinetas e saxofone, instrumentos cujo timbre se assemelha ao timbre dos metais com surdina. Segundo Seixas, “(...) o elemento melódico, a cargo dos Trompetes, aparece em evidência, em termos de dinâmica e timbre. No entanto, é o ostinato [como forma, nas flautas e Violoncelos] em mezzoforte que caracteriza o trecho (...)” (SEIXAS, 2007, p. 128). Apesar da importância atribuída por Seixas ao ostinato, a dinâmica forte destinada aos metais permite que os instrumentistas toquem forte. Porém, devem diminuir a partir de c.445 para que a nova melodia do primeiro oboé, requinta e saxofone possa ser ouvida. Segundo Nóbrega, neste ponto "a orquestra prepara um novo episódio" (NÓBREGA, 1974, p. 59).

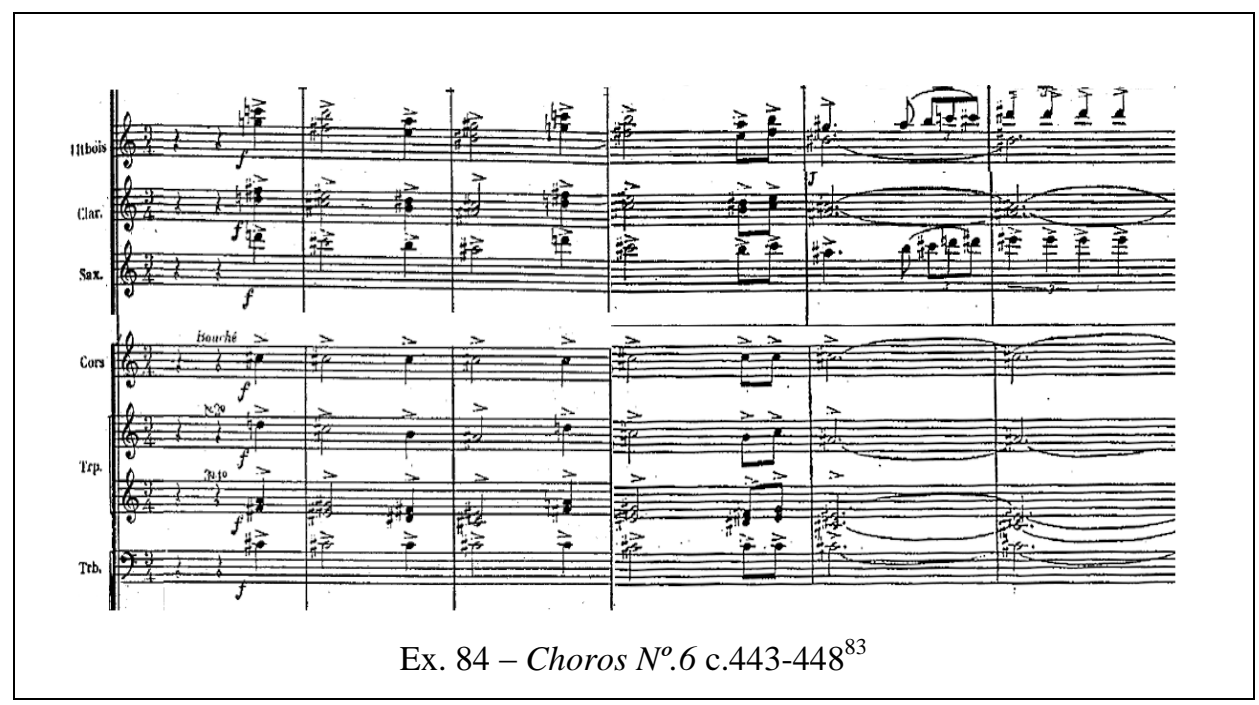

No c.472 ([42]+8) o $1^{\circ}$. trombone reforçará a melodia feita pelo corne-inglês e o saxofone (c. 468) atuando apenas na finalização da semifrase. A utilização de surdina foi uma feliz escolha de Villa-Lobos para que o timbre do trombone não alterasse a soma do corneinglês com o saxofone (Ex. 85 e ex. 86).

\footnotetext{
${ }^{83}$ Fonte: Partitura de material de consulta do Museu Villa-Lobos; 1955 by Editions Max Eschig.
} 
Villa-Lobos e os metais graves sinfônicos:

Um estudo dos elementos técnicos específicos
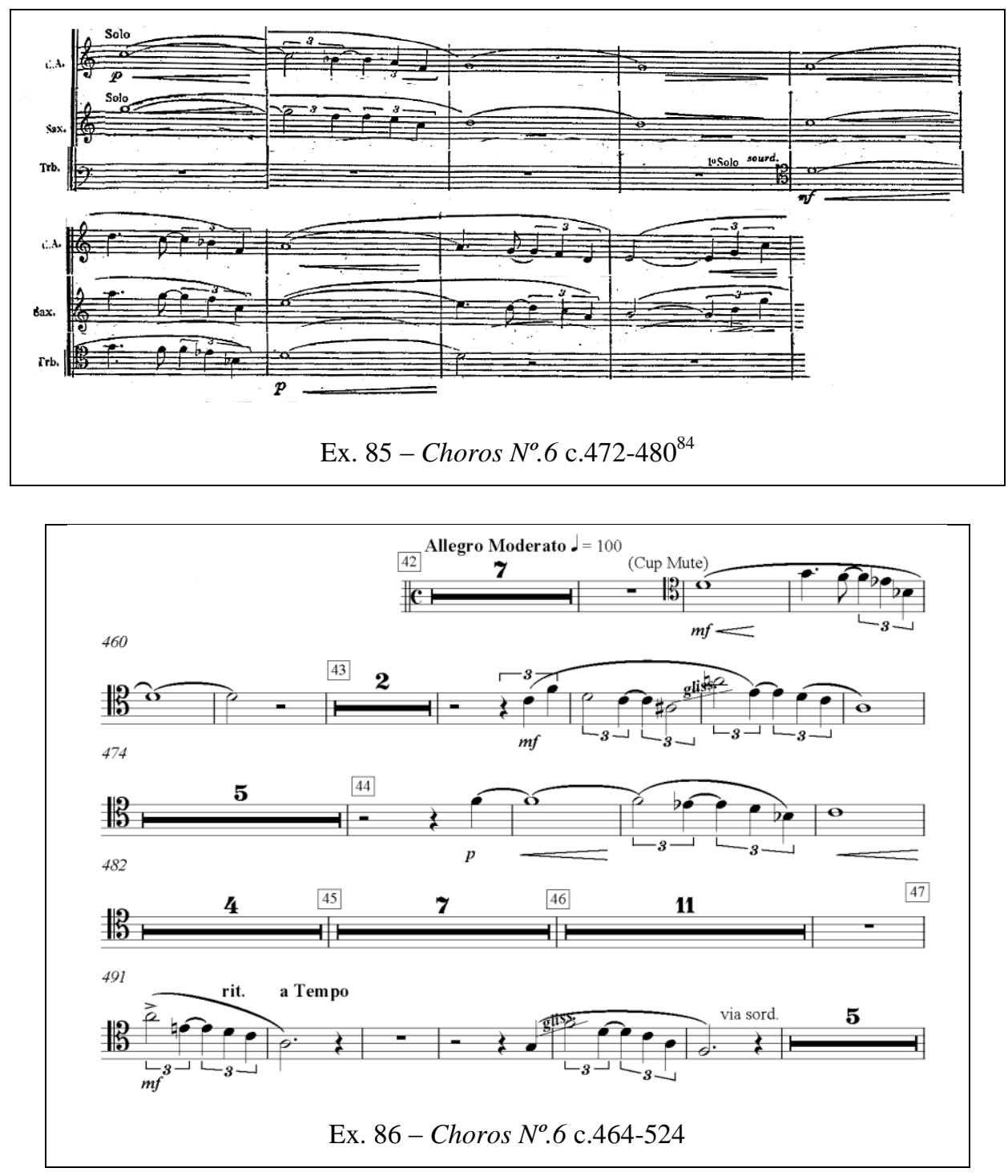

Essa ideia de complemento de semifrase também acontecerá quando os violinos expuserem o tema (c. 502 ou [46]), mas o $1^{\circ}$. trombone terá a resposta melódica com a $1^{\mathrm{a}}$. e $2^{a}$. trompas (Ex. 87)

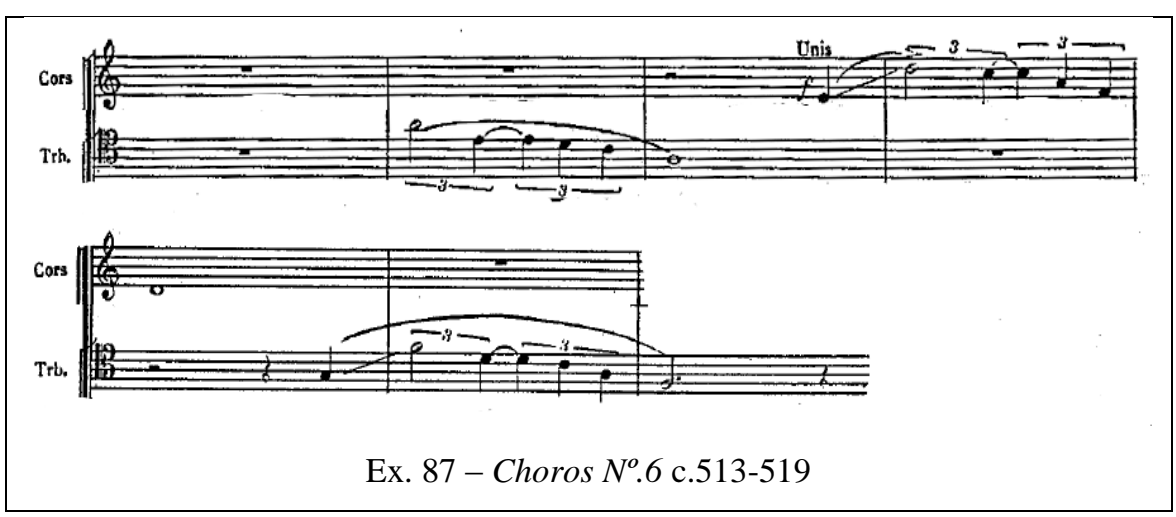

${ }^{84}$ Fonte: Partitura de material de consulta do Museu Villa-Lobos; 1955 by Editions Max Eschig. 
Após uma sequência de semibreves ligadas (c.478 ao c. 533), o $1^{\circ}$. trombone e a tuba entrarão no c. 529 com um motivo já exposto pela harpa, madeiras, trompas e Trompetes com surdina. (Ex. 88).

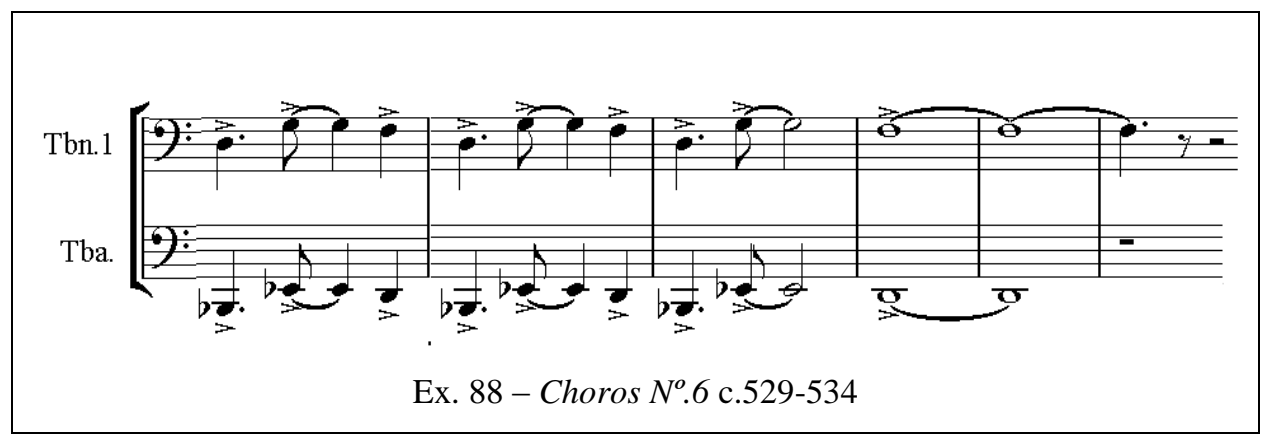

No c. 617, Villa-Lobos utilizará o naipe completo (em conjunto com as trompas, percussão e flautas) para finalizar a frase apresentada pelo clarone e o contrabaixo (c.611 ou um compasso antes de [56]), porém tanto o $1^{\circ}$. trombone, quanto a $1^{\mathrm{a}}$. trompa não farão uma semibreve: Villa preferiu uma apogiatura in bateri. (Ex. 89)

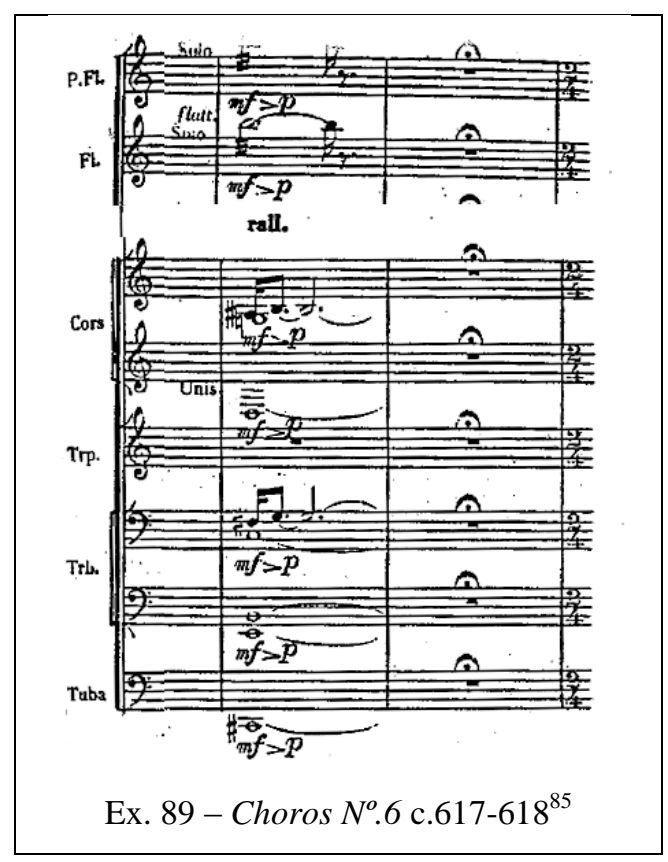

Nesse próximo trecho, Neves descreve como "[de] um breve divertimento, atingindo pouco a pouco toda a orquestra (...)” (NEVES, 1977, p. 51). Villa-Lobos grafou diversos tipos de acentos encontrados nos motivos. No c. 675 , o $1^{\circ}$. trombone fará uma sequência de mínimas ligadas em dupla. Essa ideia servirá para realçar o $1^{\circ}$. tempo de cada par de compassos, ou seja, justamente a pausa de semicolcheia do motivo dos Trompetes. (Ex. 90)

\footnotetext{
${ }^{85}$ Fonte: Partitura de material de consulta do Museu Villa-Lobos; 1955 by Editions Max Eschig.
} 


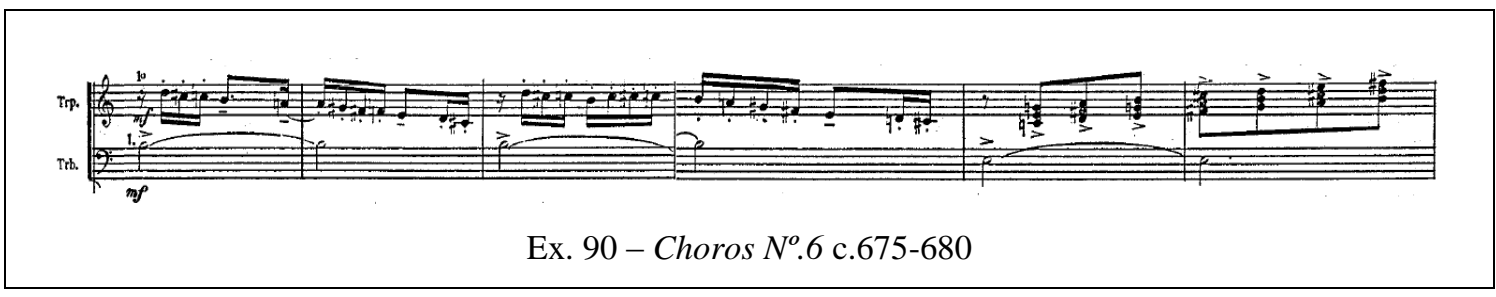

No c. 689 (dois antes [63]) os trombones 1,2 e 3 completam motivo em colcheias, iniciado pelas trompas. (Ex. 91)

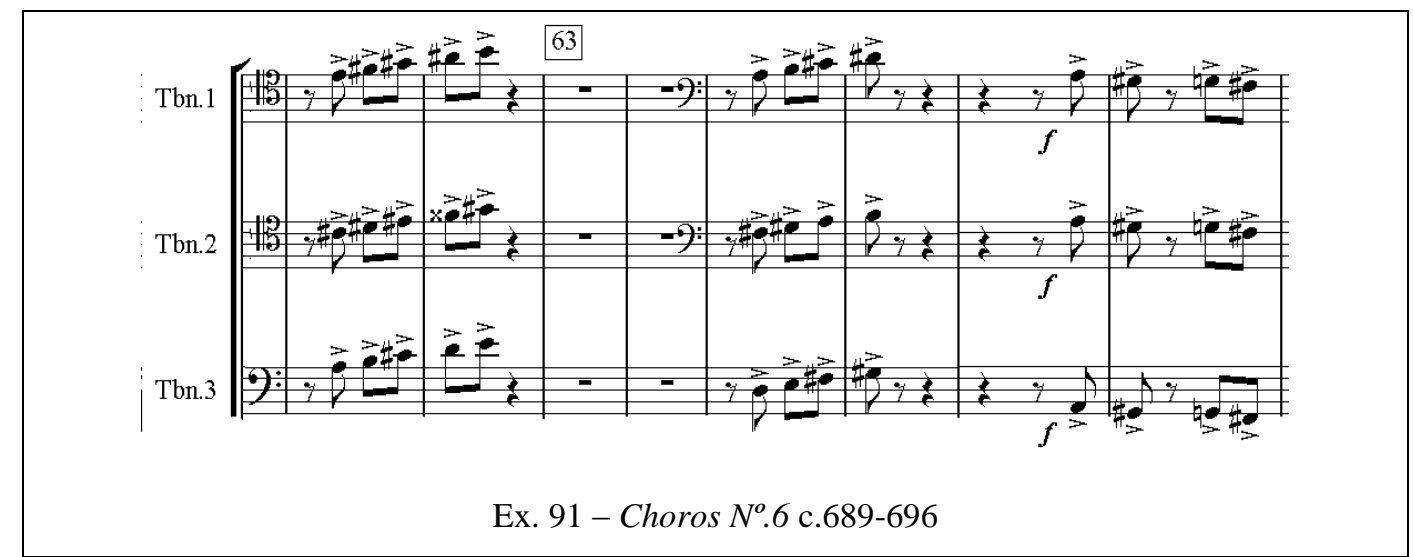

Em c. 697 ([64]) o $3^{\circ}$. trombone e a tuba iniciarão o tema já exaustivamente exposto pelas cordas (Ex. 92). Mais adiante (c. 709) tanto o $1^{\circ}$. quanto o $2^{\circ}$. trombones se juntarão ao $3^{\circ}$. trombone, porém a tuba ficará em tacet, por apenas 2 compassos, e na última vez, participará desse motivo (c. 709).

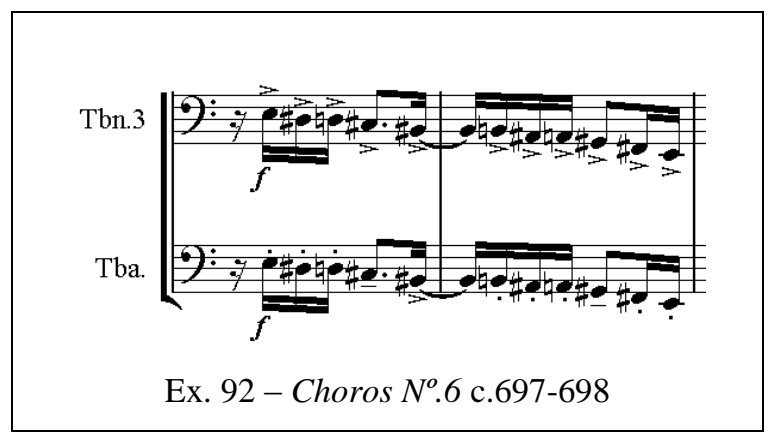

E por fim, os trombones e a tuba participarão do pedal em dó\#2 (c.755) com fermata (a tuba troca de oitava, mas acreditamos que isso não interfere na ideia de pedal). Enquanto perdure esse pedal, farão um arpejo de duas oitavas os violinos 1 e 2, Trompete, saxofone, clarinete, oboé e flauta, para ao final juntarem-se a harpa e a celesta num tetracorde cheio de sons agregados e, em seguida, soarem as oitavas "wagnerianas" como finalização. (Ex. 93). 


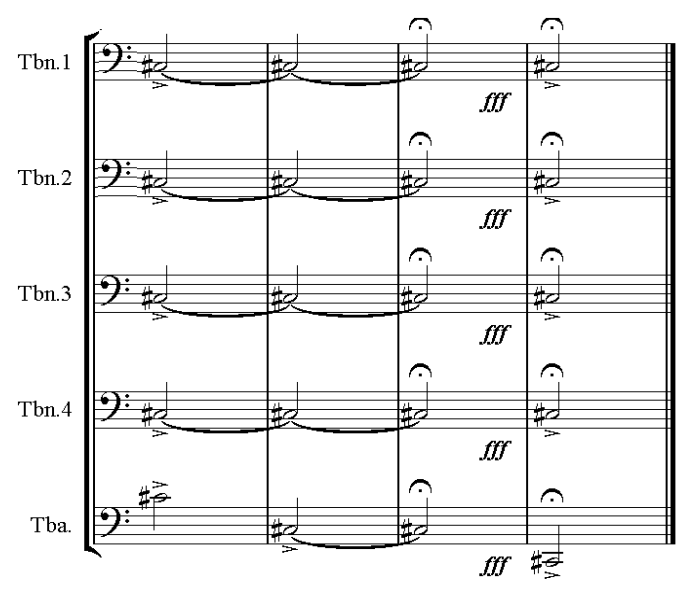

Ex. 93 - Choros $N^{o} .6$ c. $755-758$

Em termos de utilização dos metais graves na peça Choros $N^{o} .6$, este, dos 758 compassos da peça, encontramos trombones e tuba em 377 compassos $(49,74 \%)$ e este ficará em pausa por 381 compassos (50,26\%). Teremos 28 compassos em soli (c.76-77, 86-87, 121122, 363-369, 472-476, 478-481, 487-489, 514-515, 518-519), porém não haverá solo. Nesta peça estão escritos 4 glissandos fora da extensão do êmbolo (c.253, 479, 517, 546).

Em relação às dinâmicas utilizadas por Villa-Lobos para os metais graves, na peça Choros $N^{o} .6$ localizou-se apenas uma ocorrência para as dinâmicas $f f f$ e $\boldsymbol{p p}$; duas ocorrências para $\boldsymbol{f f}$; cinco para $\boldsymbol{p}$, doze para $\boldsymbol{f f}$ e 23 ocorrências para $\boldsymbol{m f}$. Quanto às articulações escritas por Villa-Lobos, encontrou-se 31 ligaduras; 54 tratinas/tenuto; 65 notas sem articulação alguma, 261 acentos e por fim, 1061 notas com ponto de diminuição.

\subsubsection{CHOROS $N^{o} .10$}

O Choros $n^{o} 10$ foi escrito no Rio de Janeiro em 1926 com o subtítulo "Rasga o Coração" e dedicado a Paulo Prado. O Choros $N^{\circ} 10$ é o primeiro da série Choros que fora estreada num formato sinfônico, no dia 11 de novembro de $1926^{86}$, no Rio de Janeiro. Dentre todos os Choros da série, este é o mais gravado, conforme registro do Museu Villa-Lobos ${ }^{87}$.

\footnotetext{
${ }^{86}$ Encontrou-se divergência para a data da $1^{\text {a }}$. apresentação em 08 de maio de 1933, como $1^{\text {a }}$. audição mundial do Choros $N^{\circ} .10$.

${ }^{87}$ No catálogo das obras do autor dos Choros, sob o título Villa-Lobos, sua obra, publicado pelo Museu VillaLobos, encontramos as seguintes apresentações do Choros $N^{o}$.10:
} 
Nóbrega (1974, p. 89) afirmou ser o Choros $N^{o} .10$ a vedete incontestável da série, “(...) há motivos justos para tal celebridade: a concisão e caráter impressivo dos temas; a ambientação sugestiva, para qual concorrem alusões melódicas a cantos de pássaros e motivos carregados da representatividade de verdadeiros símbolos da nossa psique musical; (...) a rítmica aliciadora (...); a participação coral, (...) tal é o elenco de fatores conjugados para fazer do Choros $n^{\circ} 10$ uma obra genial".

"Existe sempre um filho querido. Poderíamos dizer que o Choros $n^{\circ} 10$, o qual VillaLobos chamou de Rasga Coração, seja, entre todos o mais amado" (CARVALHO, 1987, p. 77).

O próprio Villa-Lobos nos deixou seu relato em favor desse Choros:

\begin{abstract}
A variedade de pássaros - rica em número e gênero - que existem em todo o Brasil, sobretudo os que vivem nos bosques e florestas e os que cantam à madrugada e ao entardecer nos infinitos sertões do Nordeste, serviram para alguns motivos do Choros $N^{\circ} 10$. (...) O coro misto que se adapta à estrutura desta obra está colocado no mesmo plano de valor e distinção da arquitetura orquestral. O texto é constituído de sílabas e vocalizes, sem nenhum sentido literário, nem coordenação de ideias, apenas servindo de efeitos onomatopaicos, para formar ambiente fonético característico da linguagem dos aborígines. Entretanto, quando o crescendo das vozes atinge o seu clímax, aparece, incidentalmente e já em terceiro plano, confundindo-se com a intrincada teia de um contraponto cerrado em pleno stretto, uma melodia lírica e sentimental, à maneira da modinha suburbana, extraída de uma canção popular, com letra do poeta seresteiro Catulo Cearense, denominada Rasga o Coração. (...) (VILLA-LOBOS, 1950).
\end{abstract}

Segundo Damaceno (2009, p.117) no Choros $N^{\mathrm{o}} 10$ Villa-Lobos conseguiu, para muitos, a síntese gênio/natureza/nação. "Esta foi obra mais respeitada do musicista, nos anos dos 1920, e está para essa década como a Tocata ( $O$ trenzinho do caipira) da Bachianas $N^{\circ} 2$ (1930) e a Ária (Cantilena) da Bachianas $N^{\mathrm{o}} 5$ (1938) estão para a década dos 1930 em diante".

- $1^{\text {a }}$. 11/11/26, Rio de Janeiro - Teatro Lírico. Grande Orquestra da Empresa Viggiani; Coro de artistas brasileiros e o Deutscher Mannerchor; A., reg. - 03/12/27, Paris - Salle Gaveau. Orchestre des Concerts Colonne e L'art Choral; A., reg. ( $1^{\text {a }}$ audição na França)

- 20/09/34, Rio de Janeiro - Theatro Municipal. Balé Russo de Serge Lifar; Serge Lifar, cor. e bailarino; H. Spedini, reg.. Intitulada "Jupari”.

- 17/03/36, Paris. Orquestre Symphonique Pasdeloup; Serge Lifar, Suria Magito, M. Lebecher e Corpo de Baile da ópera de Paris; Serge Lifar, cor.; J. E. Szyfer, reg.

- 10/04/42, Boston - Symphony Hall. Boston Symphony Orchestra; Cecilia Society Chorus; Serge Koussevitzky.

- 07/12/52, Bruxelas. Orchestre National de Belgique; Chorus de la Société Philarmonique et des Jeuneusses Musicales de Bruxelles; Leon Fleisher, pf; Eleazar de Carvalho, reg. (1ª audição na Bélgica). 
Damaceno ainda afirmou que neste Choros, Villa-Lobos misturou suas referências indígenas, o impressionismo de Debussy, a polirritmia stravinskiana a elementos da música popular urbana, numa síntese única, ou melhor, numa desleitura única, que Mário de Andrade chegou a considerar "o mais verdadeiro e apoteótico hino da música brasileira".

A música possui três partes claramente demarcadas numa dinâmica crescente, a partir dos elementos sonoros dispostos na primeira parte. Os acordes são ordenados em blocos, dando a impressão de um aparente caos sonoro.

A obra inicia-se em tom solene com um sol menor alicerçado por três quartas inferiores, onde se nota a melodia do "schottisch" denominado Yara, do chorão Anacleto de Medeiros - de maneira transfigurada no meio de outras melodias, dentro de sincopados ritmos que se sucedem em várias células rítmicas diferenciadas. A segunda parte apresenta-se numa espécie de "sono" impressionista na sua harmonização entre os instrumentos de sopro, encerrando-se numa expressividade máxima até chegar numa rápida pausa. A terceira parte da obra emerge logo em seguida, com um tema tocado por um fagote que vai ao mesmo tempo marcando seu ritmo, num crescente, até ganhar um ritmo maxixado, expresso por uma rica percussão popular, junto a um misto coral apoteótico - onde é alternado o tema melódico e a parte rítmica.

Esta última parte expressa os versos de Rasga Coração de Catulo da Paixão Cearense, (música de Anacleto de Medeiros) de maneira onomatopaica, cadenciados primeiro por um Trompete solo, e depois por uma flauta e um oboé solo junto, até chegar a um clímax em que as vozes parecem ir ao seu limite, encerrando junto à orquestra com um forte e terminal fá sustenido.

\section{CONSIDERAÇÕES DA ORQUESTRAÇÃO DO CHOROS $N^{\circ} .10$}

Utilizou-se a edição Max Eschig, com copyright de 1928. Inserida no grupo Orquestral/Chôro, esta peça possui o seguinte efetivo orquestral: 
Villa-Lobos e os metais graves sinfônicos:

Um estudo dos elementos técnicos específicos

\begin{tabular}{c|c}
\hline 2 & Flautas \\
\hline 2 & Oboés \\
\hline 2 & Clarinetes em Lá \\
\hline 1 & Saxofone alto (Mib) \\
\hline 2 & Fagotes \\
\hline 3 & Trompas \\
\hline 2 & Trompetes em Lá \\
\hline 2 & Trombones \\
\hline & Percussão (tímpano, tamborim de Provence, Caixa clara, tambor, caxambu, \\
& puita, caísse de bois, reco-reco, chocalho, bombo, tamtam grande) \\
\hline 1 & Piano \\
\hline 1 & Harpa \\
\hline & Côro \\
\hline & Cordas \\
\hline
\end{tabular}

Tab. 7 - Instrumentação para Choros $N^{o} .10$

Os trombones são utilizados em uma extensão que compreende do Fá1 ao Si3. Com dinâmicas que variam do pianíssimo (pp) ao fortissississimo(ffff). Com dinâmicas que variam do pianíssimo (pp) ao fortissississimo(ffff) em sem nomear o mezzo-piano (mp). Os trombones entram em tutti orquestral (excetua-se aqui flautas, percussão e côro) logo no c.1 (Ex.94). Pela configuração orquestral a que Villa-Lobos submeteu esse início, cabe aos trombonistas não sobressaírem-se ao restante da orquestra.

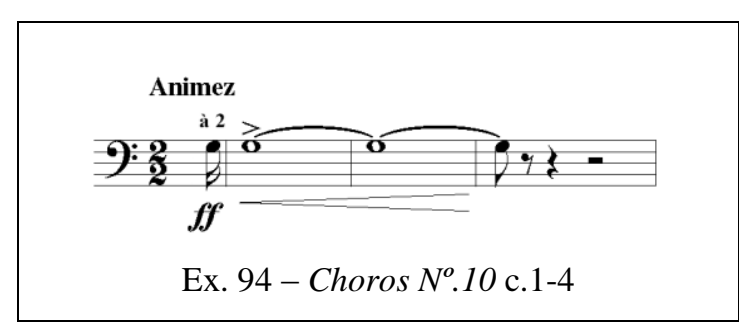

O Ex. 95 apresenta os metais, a partir da letra A (c.14), em um bloco com diferenças na grafia das articulações (acento [ > ] para Trompetes e trompas e tenuto ( - ) para trombones). Simultaneamente, oboés, clarinetes e todas as cordas tocam um movimento escalar em de semicolcheias em dinâmica suave ( $p, m p$ e $m f$ ) com crescendo. Segundo Alves: "A intervenção dos metais em c.15 tem função de tema principal, é recomendável uma dinâmica acima dos demais instrumentos" (ALVES, 2003, p. 45). 


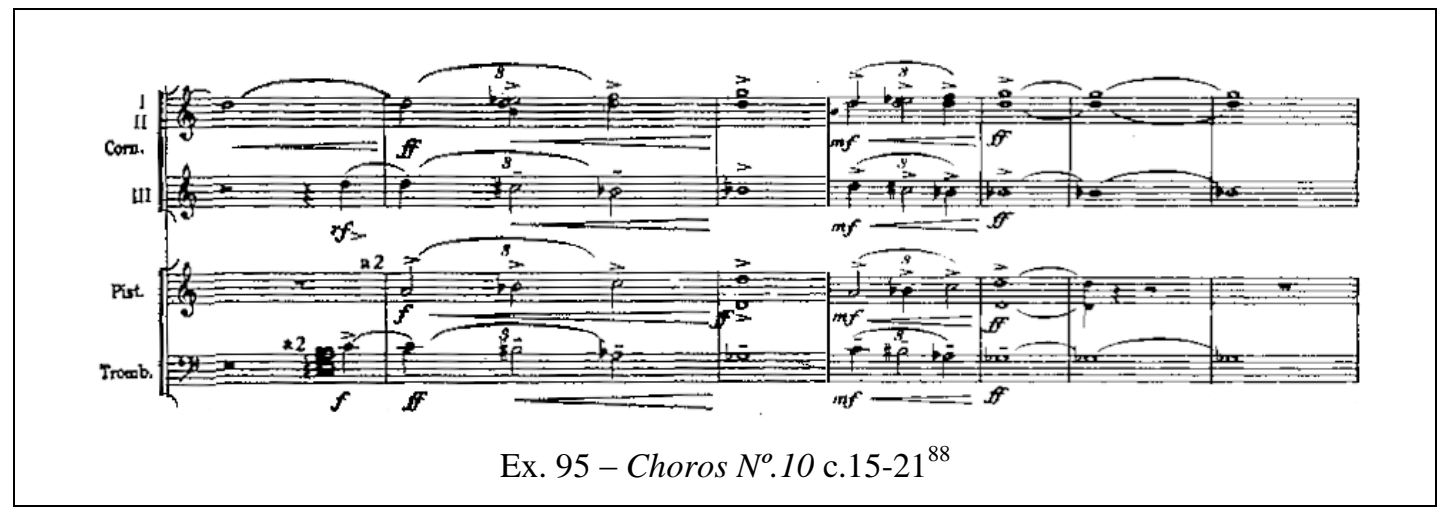

O Ex.96 mostra o trecho de acordo com o que Villa-Lobos escreveu para os trombones em articulação tenuto ( - ):

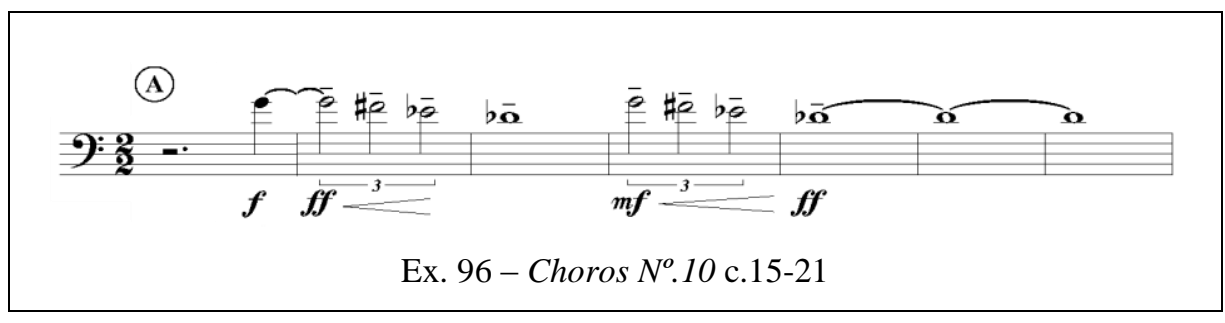

Portanto, como sugerido por Cardoso (2009), melhor será igualamos as articulações de trombones, trompas e Trompetes em acento $(>)$. Deste modo e graças à unidade de procedimentos, as notas soam mais definidas dentro da peça.

No próximo trecho (c.23-26) toda a orquestra (com exceção das flautas e clarinetes) fará um desenho harmônico, e em paralelo, de uma sequência de mínimas acentuadas e em dinâmica fff para todos. Os trombones estão inseridos nesse grupo (Ex.97):

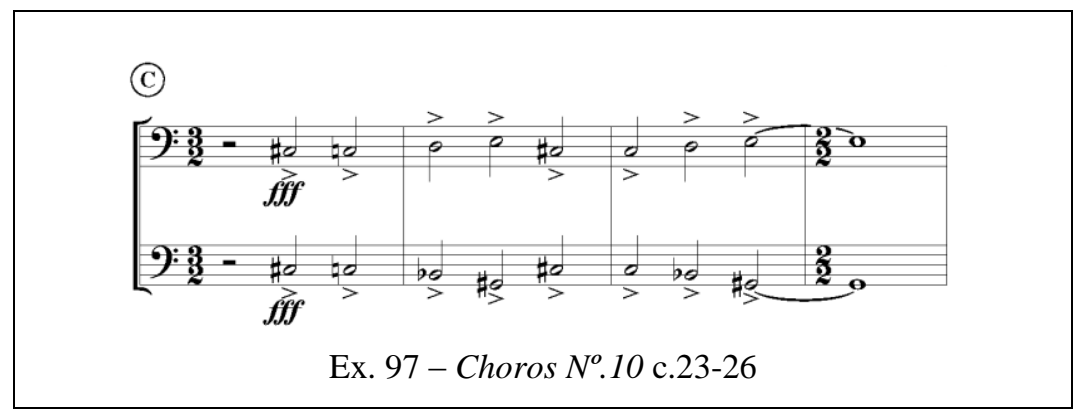

Num ataque em conjunto com madeiras (clarinete, saxofone, fagotes), trompas e contrabaixos, os trombones farão uma nota longa com queda e retorno de dinâmica ao final. Na partitura está grafado fff (para saxofone, trompas e trombones), mas localizamos ff para clarinetes, fagotes, reco-reco, piano e contrabaixo. Em números absolutos, cinco instrumentos

${ }^{88}$ Fonte: cópia da partitura editada pela Max Eschig, com copyright de 1928. 
estarão em $\boldsymbol{f f}$, e apenas três em $\boldsymbol{f f f}$. No entanto, todos terminarão seus crescendo em $\boldsymbol{f f f f}$ (com a exceção do reco-reco). Finalizando, não compete à nós emitir um veredito sobre qual dinâmica tocar, melhor será, seguir os escritos de Villa-Lobos.

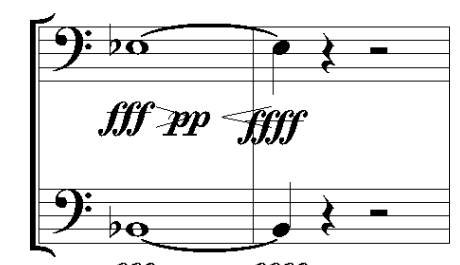

$f f f>p p \operatorname{ffff}$

Ex. 98 - Choros $N^{o} .10$ c. $30-31$

No próximo trecho acontece o primeiro solo de trombone. Escrito partindo de um glissando com a semifrase toda ligada e em dinâmica $f$ (c.36-46) e ff (c.48-53).

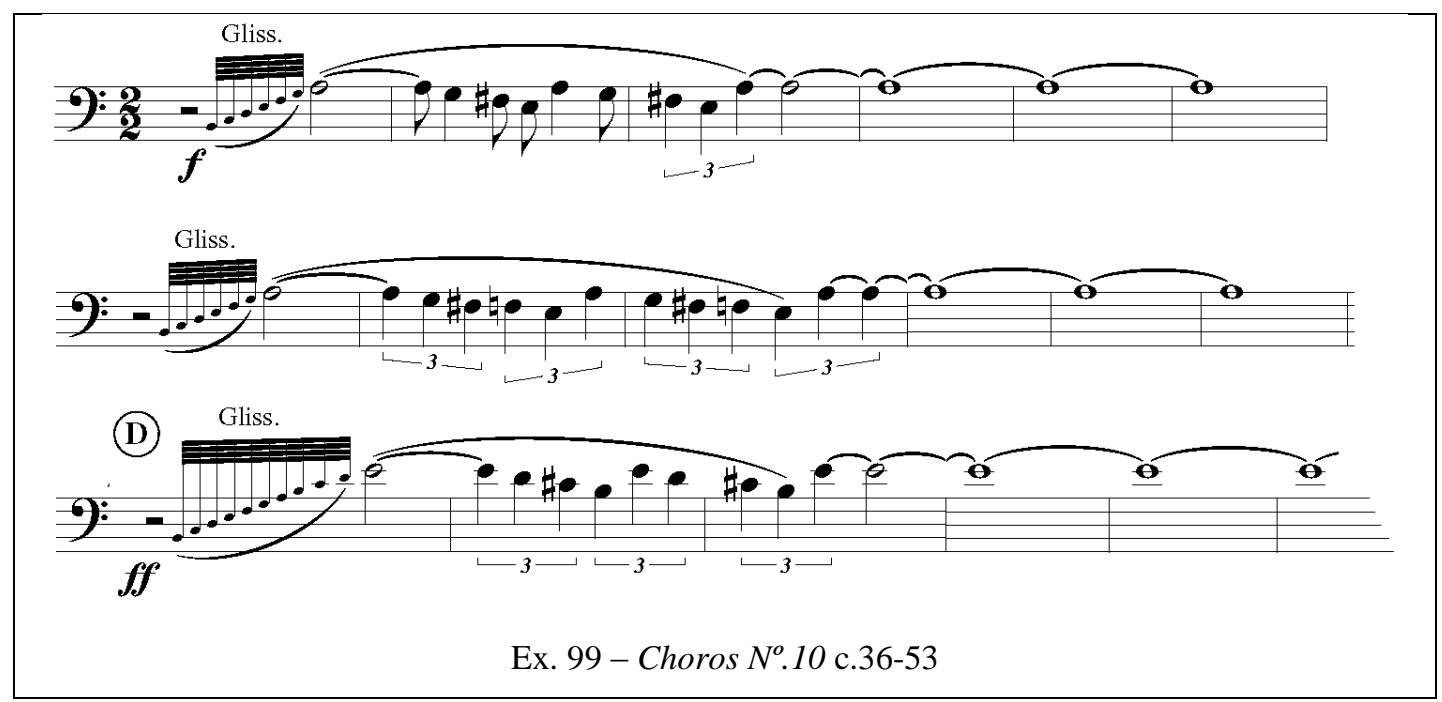

O trecho compreendido entre os c.57-61 servirá como resposta ao tema exposto pelos Trompetes. Villa-Lobos escreveu esse baixo para os trombones e conjunto com o fagote e contrabaixo, ambos em articulação acentuada ( > ) e em dinâmica $f(E x .100)$.

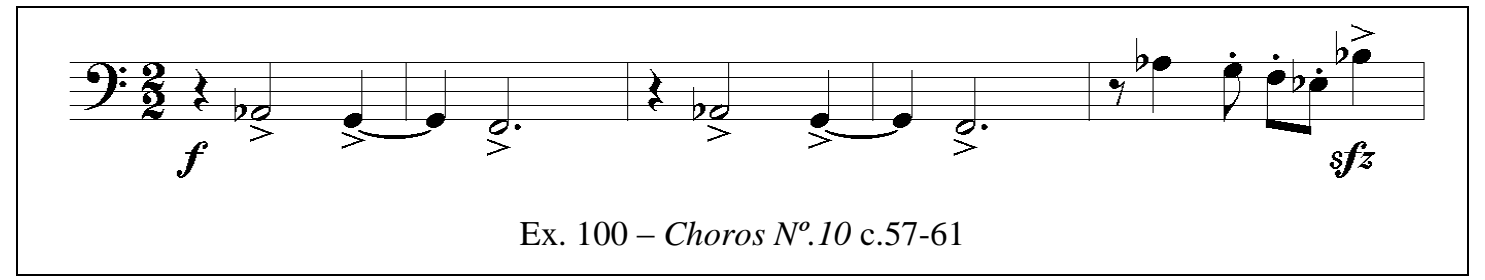

Novo soli para trombone de c.64-67. As trompas 1 e 2 estarão juntas nesse tema. A dinâmica será $\boldsymbol{f}$ e a articulação será acentuada ( > ) para ambos. 


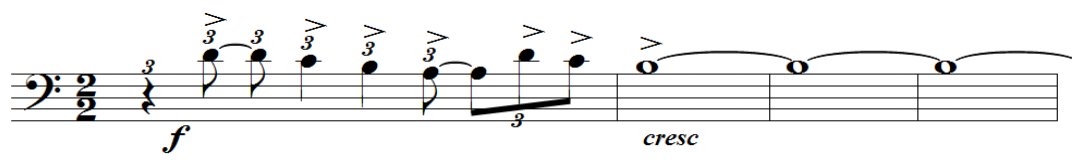

Ex. $101-$ Choros $N^{\circ} .10$ c.64-67

$\mathrm{Na}$ letra $[\mathrm{G}]$ (c.70-76) o trombone iniciará um ostinato onde a primeira colcheia em resposta rítmica ao tema exposto pelas flautas, oboés, clarinetes, fagotes, $1^{\mathrm{a}}$. trompa e violino solo (Ex.102).

(G)

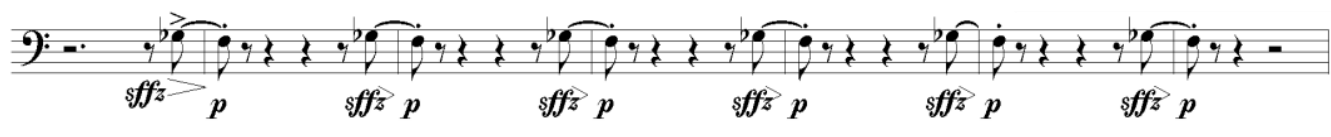

Ex. 102 - Choros $N^{o} .10$ c.70-76

Este próximo solo de trombone, com surdina (c.109-112), terá intervenções escalares descendentes do clarinete, flauta, oboé e harpa em dinâmica $\boldsymbol{m f}$ (Ex.103) .

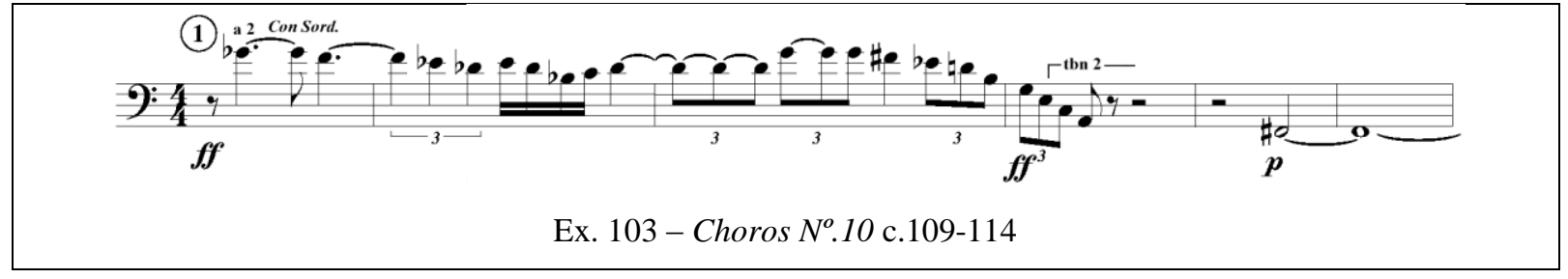

Outro soli para o trombone (c.132-152) em conjunto com todas as trompas, em dinâmica $f$ e articulação acentuada para todos. Este tema será repetido consequentemente pelos trombones em quatro vezes. Os violinos farão a resposta a esse inciso e os Trompetes reforçam esse inciso a partir do c.147-152.

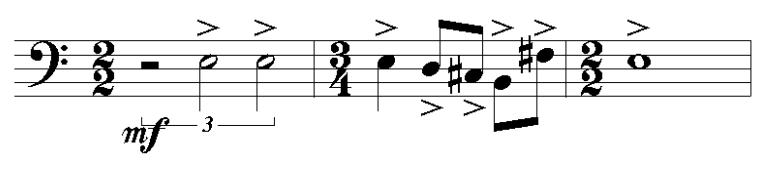

Ex. $104-$ Choros $N^{o} .10$ c. $135-137$

Trombones iniciam um baixo motívico escalar ascendente no c.165 (Ex.105) e perdurará como ostinato até o c.173 (nove compassos exatamente iguais). A dinâmica escrita é o $m f$, deixando quase inaudível esse ostinato dos trombones. O motivo é a orquestração que criou uma massa sonora de flautas, oboés, $3^{\mathrm{a}}$. trompa (também em $\boldsymbol{m f}$ ) fazem a pergunta, enquanto Trompetes, saxofone e $2^{\circ}$. violino (em dinâmica $f$ ) fazem a resposta ao tema. 


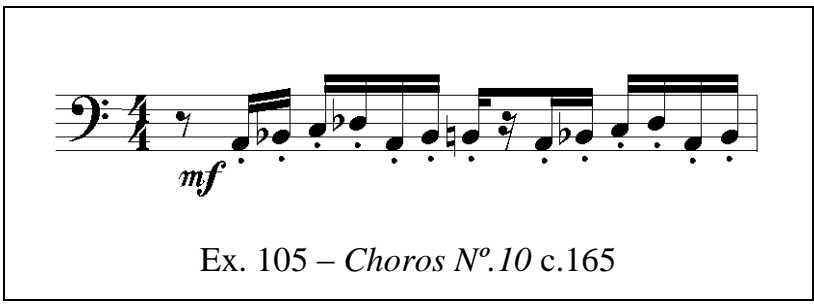

Trombones estarão no tutti rítmico (em conjunto com fagotes, trompas, tímpano, bombo e cordas) que preparará a entrada das vozes no Choros $N^{o} .10$. Todos os instrumentos terão mesma articulação (sff no c.174-175) e acento $^{89}$ ( > no c.176).

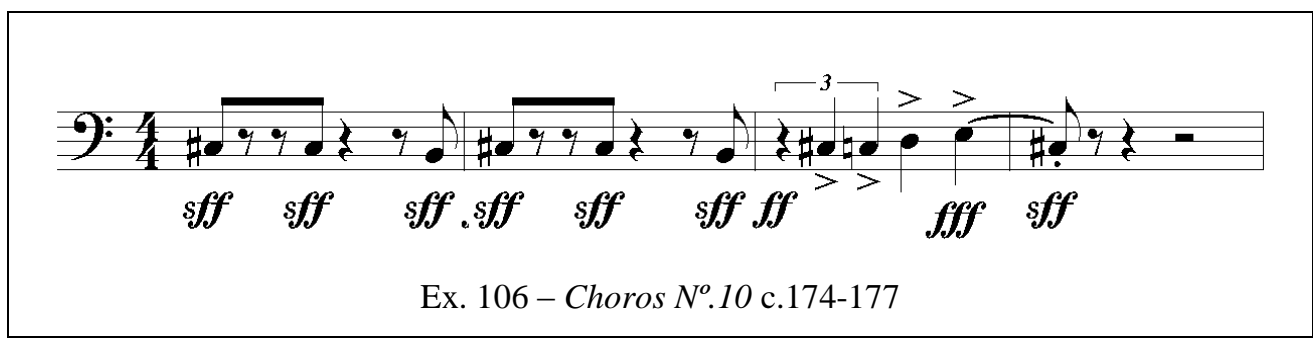

O próximo soli do trombone (c.190-195) será em conjunto com os fagotes (em dinâmica $\boldsymbol{f}$ ) e as vozes masculinas (em dinâmica $f \boldsymbol{f}$ e que realmente serão os timbres dominantes). Este trecho será uma recapitulação do tema já exposto, porém há uma variação (c.192-195) onde Villa-Lobos criou uma ideia de acelerando de figuras, sem alterar o andamento da peça (Ex.107).

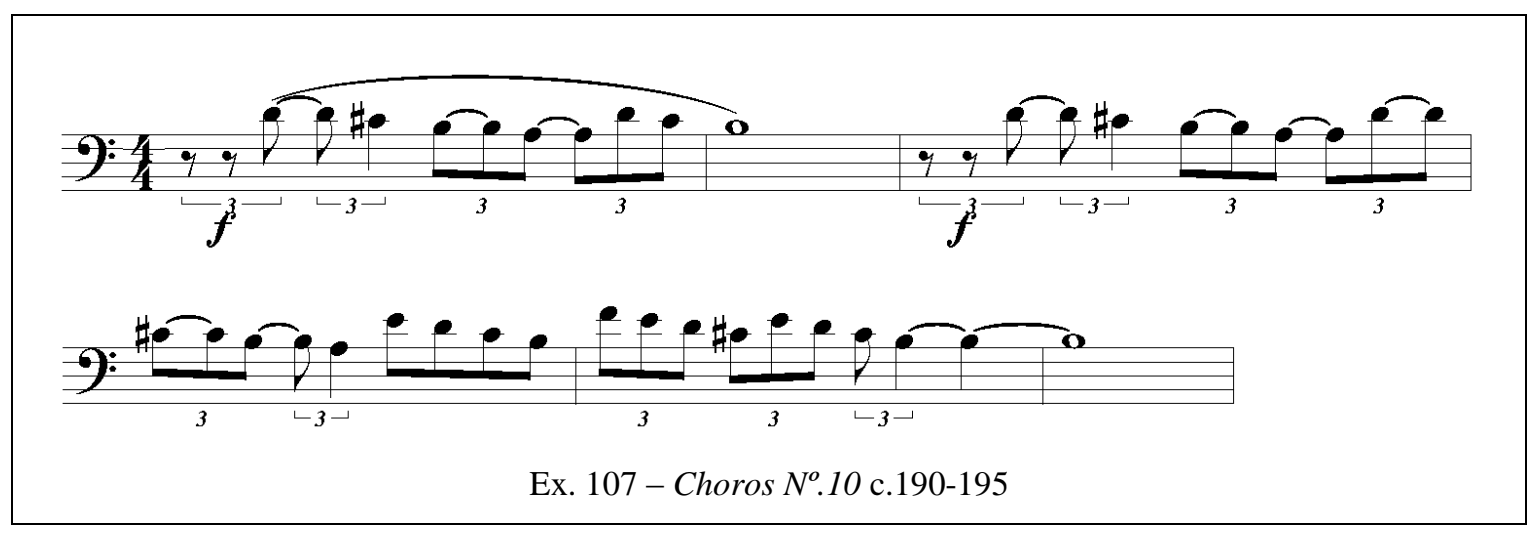

Os trombones farão dois efeitos de glissandos (c.197 e c.201) em meio a repetição do tema principal pelas vozes e a arpejos polirrítmicos nos clarinetes e fagotes. Essa intromissão do glissando deverá ser realmente forte, como Villa-Lobos grafou na parte original (Ex.108).

\footnotetext{
${ }^{89}$ Conforme palavras de Pablo Casals: "Se você continuar com o forte não ouvirá o acento. Um acento forte precisa ter um diminuendo: isto é mais poderoso e natural." (BLUM, 1977, p. 51).
} 


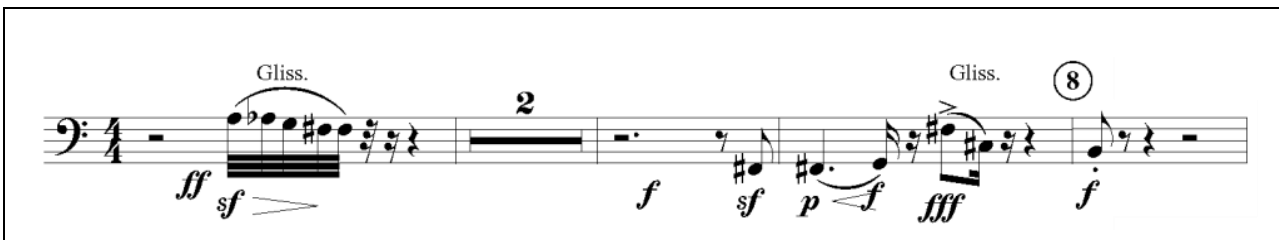

Ex. $108-$ Choros $N^{o} .10$ c.197-202

No próximo trecho (c.221-228), os trombones estão responsáveis apenas por um inciso rítmico em conjunto com os fagotes, trompas, Trompetes, barítonos e Violoncelos (Ex.109):

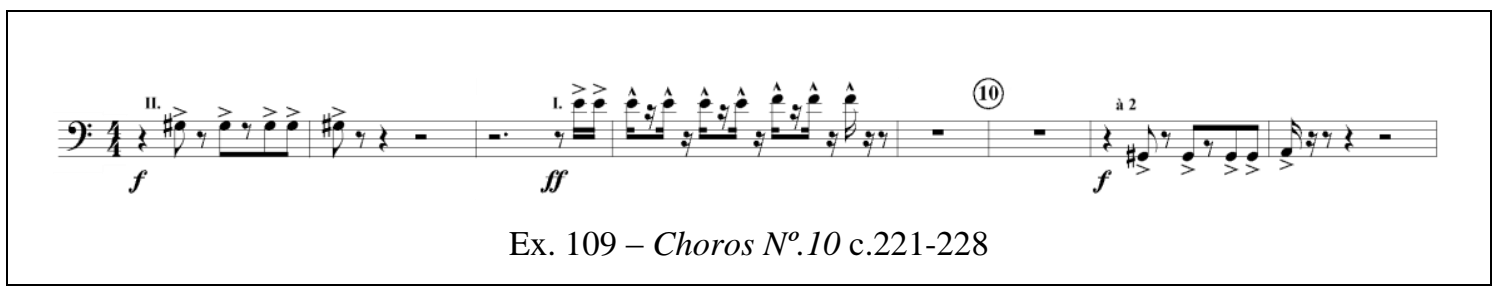

Em c.234-237 e c.250-253 os trombones farão uma semifrase em blocos harmônicos em conjunto com os clarinetes, saxofone, fagotes e trompas que servirá de apoio harmônico ao tema exposto pelas vozes masculinas do coro (Ex. 110):

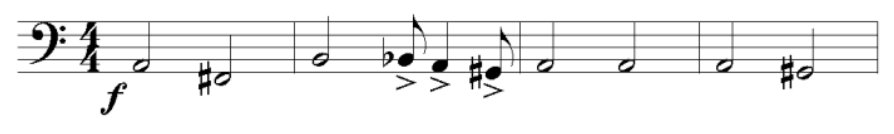

Ex. $110-$ Choros $N^{o} .10$ c. $234-237$

Os trombones expõem novamente o tema alterado de c.264-268 em conjunto com os fagotes, Violoncelos e contrabaixos. Os Trompetes ficam responsáveis pelo contracanto que se movimenta em semicolcheias e colcheias durante as notas longas do trombone (Ex. 111):

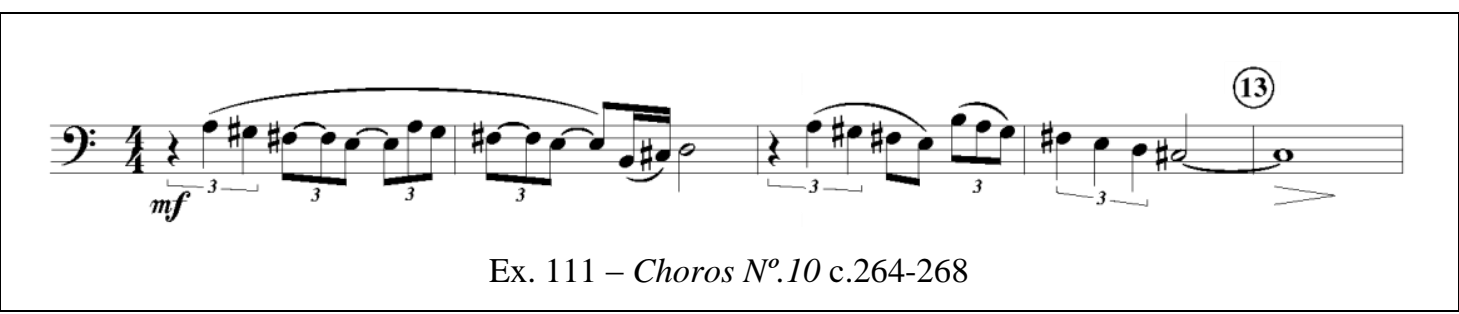

Neste trecho da peça (c.282-285) os trombones farão um desenho rítmico com cunho percussivo, embora Villa-Lobos tenha grafado no c.282 a palavra solo, estão em conjunto com o trombone, a $1^{\text {a }}$. trompa e o $1^{\circ}$. Trompete (Ex. 112): 


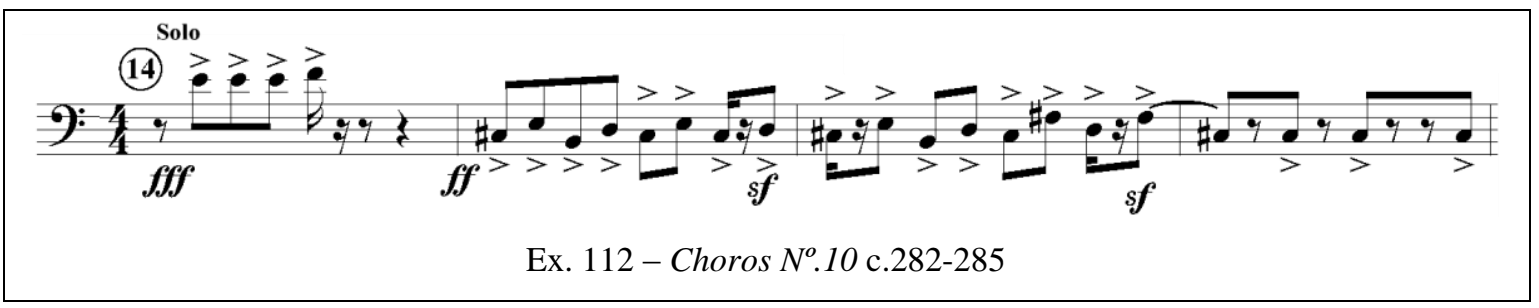

Com exceção do c.286, a partir do c.287 o trombone estará participando dos blocos harmônicos que compõem a coda do Choros $N^{o}$.10. Só não participarão desses blocos harmônicos as flautas, oboés e coro (Ex.113):

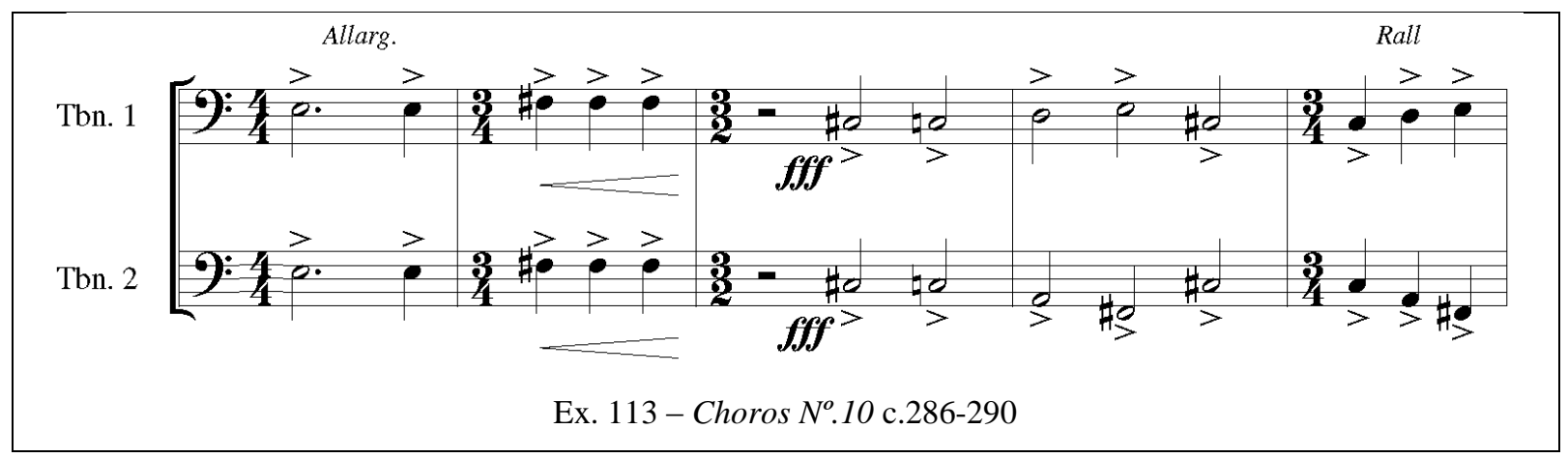

A peça termina (c.292) em um tutti orquestral, com dinâmica em fortissississimo e ainda com um discreto crescendo e a nota com sua valoração completa (Ex. 114).

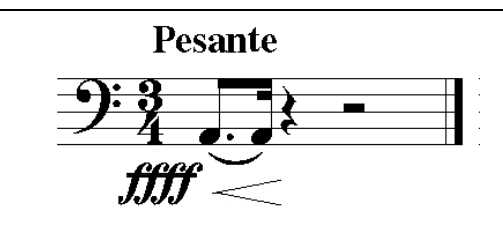

Ex. $114-$ Choros $N^{o} .10$ c. 292

Em termos de utilização dos trombones na peça Choros $N^{o} .10$ com um total de 292 compassos, o trombone atua em 154 compassos $(52,74 \%)$ e fica em espera por 138 compassos (47,26\%). Teremos 23 compassos em solo (c. 36-54; c.109-112) e 21 compassos em soli (c.64-65; c.132-152; c.190-195 e c.282). Nesta peça estão escritos um glissando executável (c.197) e quatro glissandos fora da extensão do êmbolo (c. 36, c.41, c.47 e c.201).

Em relação às dinâmicas utilizadas por Villa-Lobos para os trombones, na peça Choros $N^{o} .10$ localizou-se duas ocorrências para as dinâmicas ffff; três ocorrências para pp; seis ocorrências para $\boldsymbol{m f}$; oito para $f f f$ e $\boldsymbol{p}$; onze ocorrências para $\boldsymbol{f f}$ e finalmente 15 ocorrências para $f$. Quanto às articulações escritas por Villa-Lobos, encontrou-se 24 ligaduras; 7 tratinas/tenuto; 9 sforzatos; 9 sff; 128 notas com ponto de diminuição e por fim 152 acentos. 


\subsection{BACHIANAS}

As Bachianas Brasileiras, em numero de nove suítes e orquestradas para formações diversas, foram escritas entre 1930 e $1945^{90}$. Inspiradas nas formas pré-clássicas do estilo de Johann Sebastian Bach ${ }^{91}$ e fundidas com material folclórico brasileiro (em especial a música caipira), os movimentos das Bachianas receberam, graças a essa fusão, dois títulos: um ao estilo barroco, outro brasileiro.

Vale lembrar que "a série de Bachianas brasileiras representa em termos estéticos a adesão de Villa-Lobos a um movimento de retorno à música barroca ${ }^{92}$ (principalmente) e clássica, chamado de Neoclassicismo". Embora o neoclassicismo possa ser considerado, via de regra, como "restaurador", dificilmente se poderia atribuir a um compositor brasileiro esse tipo de restauração de uma tradição nacional que não era sua (SALLES, 2009, p.100).

Será de Luiz Heitor Correa de Azevedo a explicação dessa preferência por Bach: Essa intuição, esse extraordinário faro das fontes populares da música brasileira que caracteriza tantas páginas de Villa-Lobos, ele os recebeu seguramente do avô "pianeiro". Como também a vocação irresistível, que adolescente ainda, o impelia para a companhia, considerada duvidosa dos chorões da época. Essas impressões musicais seresteiras, combinadas com as fugas de Bach, que a tia Zizinha, irmã de seu pai, tocava ao piano, haviam de marcar profundamente a sensibilidade do garoto e resultar nessa experiência extraordinária que o compositor tentou ao atingir a plena maturidade, associando nas Bachianas Brasileiras o que podia parecer à primeira vista tão disparatado: a natureza de certa musica popular do Brasil e a polifonia barroca do adorado mestre da "Arte da Fuga" e do "Cravo Bem Temperado".

Segundo Zanon (2009, p.63) as Bachianas Brasileiras dão o tom ao Villa-Lobos dos anos 30 e 40. É um ciclo que guarda relação de complementaridade com os Choros. Na série das Bachianas o estilo é homogêneo da primeira à última peça. Também há de se notar o contraste entre a expressão seca do neoclassicismo europeu, objetivista e paródico, e um Villa-Lobos senhor de si, encaixando obras desbragadamente melodiosas nesse contexto.

\footnotetext{
${ }^{90}$ Grove's (1998), p.62.

91 Villa-Lobos considerava, em maio 1947, os trabalhos de Bach como "fonte folclórica universal - rica e profunda, com todos os materiais sonoros populares de todos os países, intermediária de todos os povos".

${ }_{92} \mathrm{Na}$ realidade eram os baixos movediços da música barroca que ressoavam no seu espírito como os do violão seresteiro.
} 
Incorporar aspectos da linguagem bachiana em suas composições foi uma forma de imprimir uma assinatura étnica, afirmou-nos Salles (2009, p.100). Porém, do ponto de vista da organização textural, as Bachianas pouco acrescentam, por apresentarem uma funcionalidade harmônica tradicional que se sobressai como a principal linha de força. Embora mantendo algumas de suas características composicionais, Villa-Lobos optou por hierarquizar o plano da composição, tornando assim a textura um elemento secundário, quando muito referencial, especialmente ao evocar organizações texturais e formais tradicionais como a fuga, a tocata ou o prelúdio bachianos.

Ainda assim em suas Bachianas, obra de resultados talvez "menos felizes", ou talvez menos ambiciosos que os Choros, percebe-se que Villa-Lobos buscava adaptar material mais tradicional, tanto do ponto de vista microestrutural (alturas, tonalidades, formações triádicas), quanto macroestrutural (forma, fuga, suíte), à sua poética desenvolvida nos anos de 1920. No entanto, segundo Salles (2009, p. 246) essa série de Bachianas lhe custou o rótulo de "fértil melodista" e praticamente sepultou o interesse especulativo por suas criações.

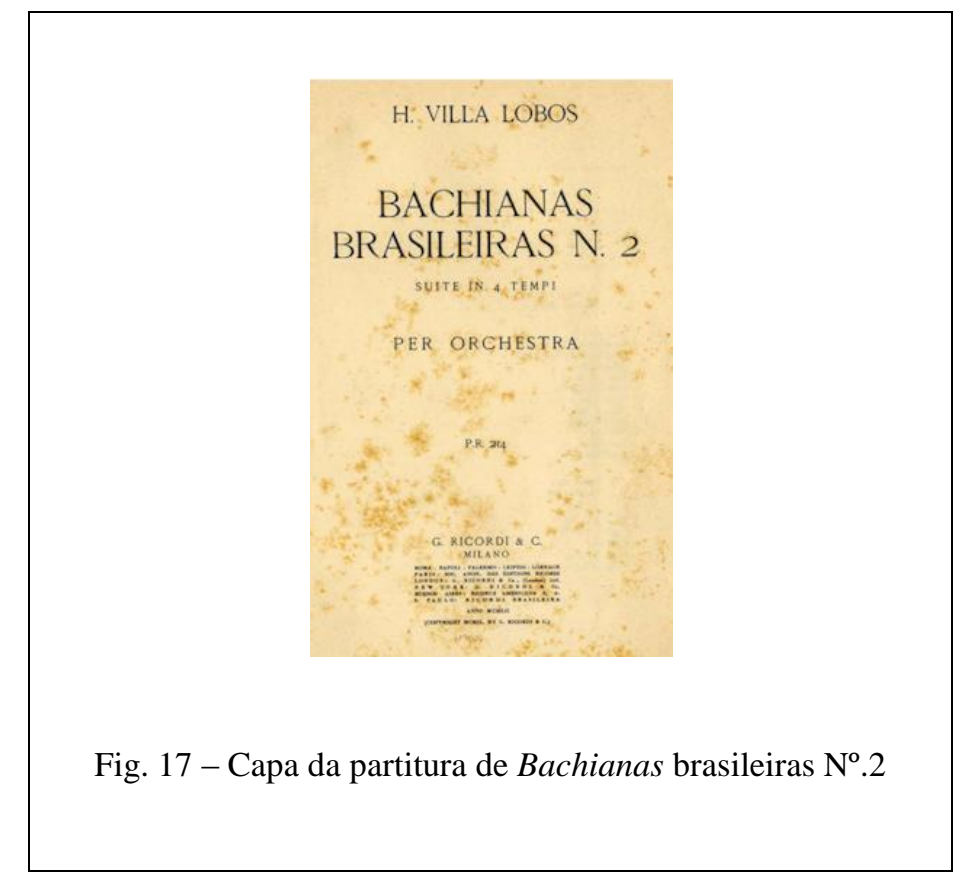




\subsubsection{BACHIANAS BRASILEIRAS $\mathrm{N}^{\circ} .2$}

Essa peça foi composta no ano de 1930 e estreada em Veneza por Alfredo Casella. Existem quatro movimentos, cada um re-explorando alguma peça mais antiga para piano ou para Violoncelo e piano.

- Prelúdio (O Canto do Capadocio) - Adágio - Andantino

- Ária (O Canto da Nossa Terra) - Largo

- Dança (Lembrança do Sertão) - Andantino moderato

- Tocata (O Trenzinho do Caipira) - Un poco moderato

O $4^{\circ}$. movimento se caracteriza por imitar o movimento de uma locomotiva com os instrumentos da orquestra. A melodia recebeu posteriormente letra composta por Ferreira Gullar.

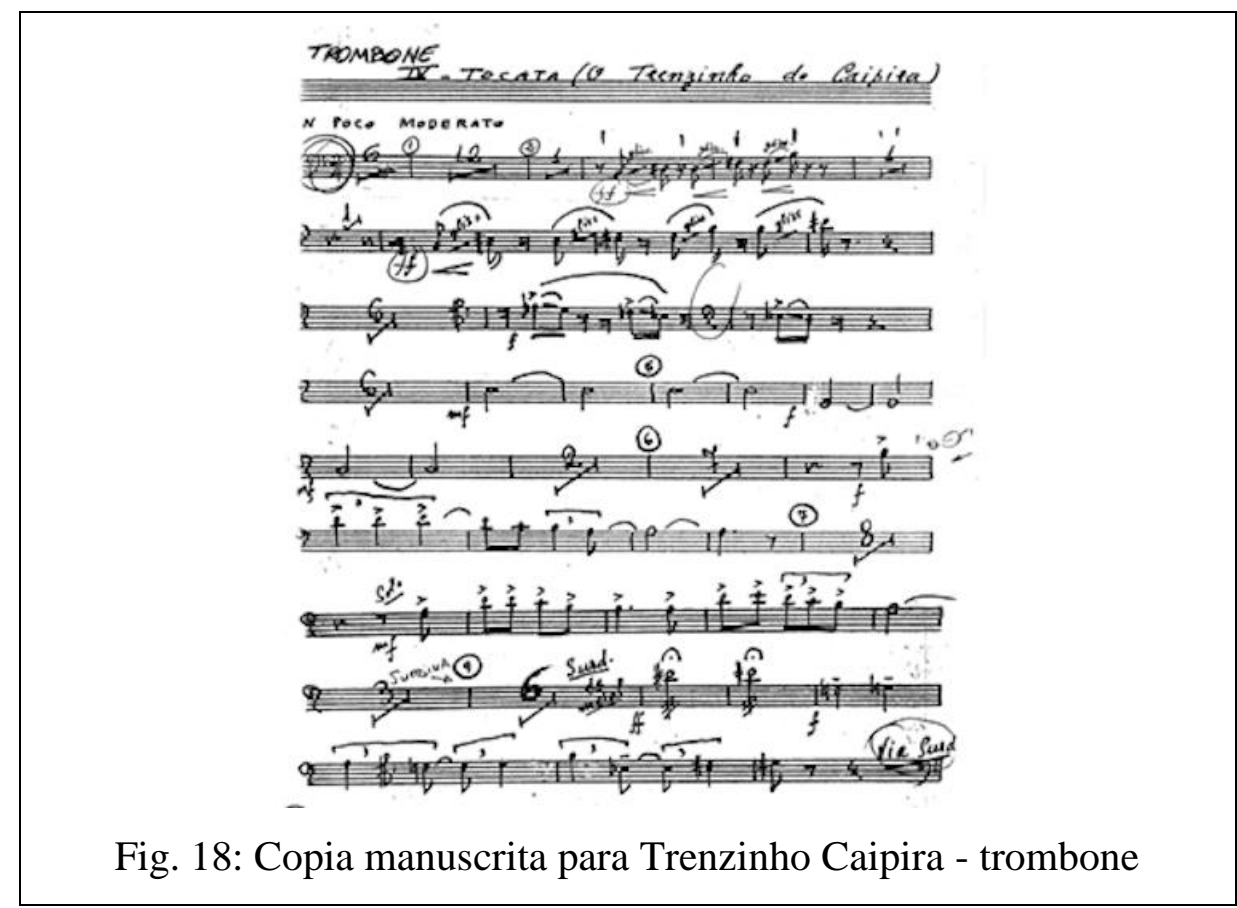

Renata Botti (2003b, p. 1144) observou que a opinião corrente, expressada por Adhemar Nóbrega, onde as Bachianas brasileiras apresentam um estilo contrapontístico, não se aplica à maioria dos movimentos das Bachianas, cujas texturas e cujos processos de justaposição se assemelham aos dos Choros. E ainda, Salles (2009, p.154) afirmou que nas Bachianas, a diferença primordial é a volta à tonalidade: nessas predomina o encadeamento harmônico tradicional (Botti, 2003a, pp. 76-77) 


\section{CONSIDERAÇÕES DA ORQUESTRAÇÃO BACHIANAS N.2}

Utilizaremos a edição impressa na Itália da editora RICORDI, de 1952. Estando inserido no grupo Orquestral/Bachianas, esta peça conta com um efetivo orquestral completo, determinado pelos seguintes instrumentos:

\begin{tabular}{c|c}
\hline 1 & Flautim \\
\hline 1 & Flauta \\
\hline 1 & Oboé \\
\hline 1 & Clarinete em Sib \\
\hline 1 & Saxofone tenor em Sib \\
\hline 1 & Conofone barítono em Mib \\
\hline 1 & Trompagote \\
\hline 1 & Trombone \\
\hline 2 & Cratos, Tam-tam e Bombo), \\
\hline 1 & Celesta \\
\hline 1 & Percussão (tímpano, ganzá, Chocalhos, Raganella, \\
\hline 1 & Piano \\
\hline & Cordas (Violino 1 e 2, Violas, Violoncelos e \\
& Contrabaixo. \\
\hline
\end{tabular}

Tab. 8 - Instrumentação para Bachianas brasileiras $N^{o} .2$

O trombone foi utilizado em uma extensão que compreende do Sól1 ao Lá3j. Com dinâmicas que variam do pianíssimo (pp) ao fortississimo(fff) em sem nomear o mezzo-piano $(\boldsymbol{m p})$. A primeira e única entrada do Trombone ocorrerá no c.15 $\left(\mathrm{n}^{\circ} .3+2\right)$, em uníssono com o Violoncelo.

Nesse tema do solo (que tem nesse local, sua primeira aparição) teremos elementos de plano criados pelas tercinas de semínima com texturas homofônica suave. O conjunto e o diálogo ficaram estabelecidos entre o solo (em uníssono com o Violoncelo) e o contraponto 
praticamente de $2^{\mathrm{a}}$. espécie (mínimas contra tercinas de semínimas). $\mathrm{O}$ tema anterior, exposto pelo Saxofone Tenor, incutiu uma cor morna ao trecho. Villa-Lobos preferiu manter a mesma cor para o solo do Violoncelo e Trombone, mas para isso, a dinâmica de acompanhamento foi equilibrada nos menores índices de projeção: Villa-Lobos manteve o solo em $\boldsymbol{m f}$ e o acompanhamento $\boldsymbol{p}$ (Oboé, Fagote e Trompa: uma parte do quinteto de sopros) e Violinos em ppp (que por estarem grafados na região aguda receberam essa dinâmica). Para distinção do solo em relação ao acompanhamento, colocou-se o Violoncelo e o Trombone numa região aguda e o acompanhamento se manteve na região grave. Exceção feita apenas ao Violino que foi grafado no agudo mas com baixa dinâmica, pelas razões já expostas.

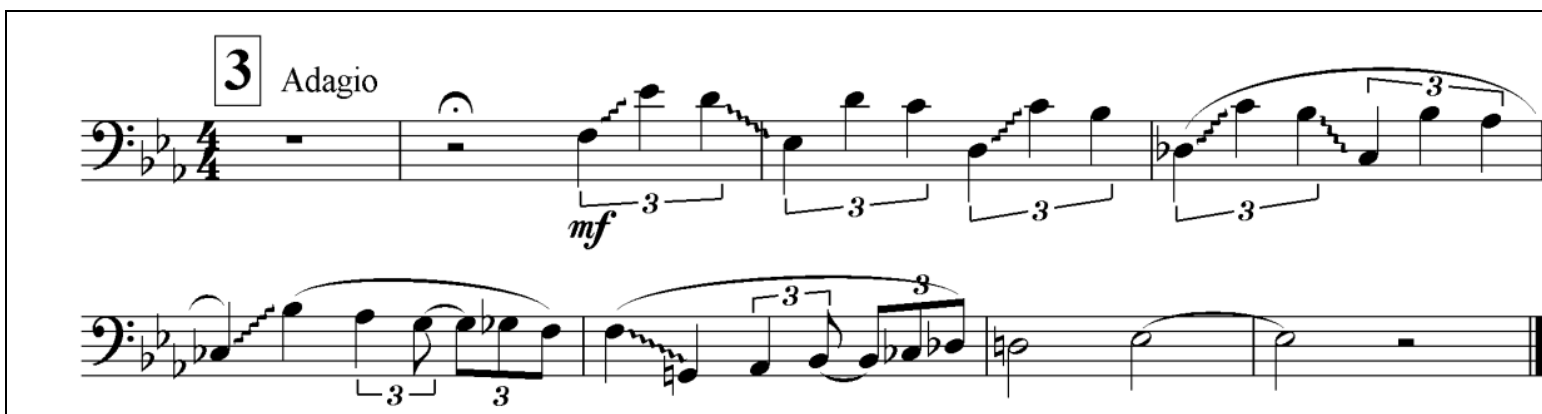

Ex. 115 - Bachianas brasileiras $N^{o} .2-\mathrm{I}^{\mathrm{o}}$.mov. - c.15-20

Próximo trecho estará alocado no $2^{\circ}$. movimento (c.1-5) onde se confirma os elementos de planos em vários sons contínuos. O Diálogo ficou estabelecidos entre o tema (praticamente paralelo entre a orquestra - mínimas e semínima) spallado pelos Violinos e Flauta, e o contrasolo feito pelo Trombone em contraponto livre. Para o equilíbrio dinâmico, Villa-Lobos preferiu não distanciar muito o solo (em dinâmica $f f$ feito pela Flauta, Saxofone tenor, Fagote e violinos ou $\boldsymbol{f}$ pelos Oboé, Clarinete e Trompas) do acompanhamento (Trombone e Trompa em $\boldsymbol{f}$ e Violoncelo e Contrabaixos em $\boldsymbol{f f}$ ). Como característica tópica indicaremos expressivo (também pela textura polifônica pesada, onde o timbre também pesado em decorrência do tutti, se dilui na direção do final da semifrase e permitindo ao Trombone um timbre menos brilhante. Indiferente da regra geral, nesse caso, o tema é menos movido que o acompanhamento, resultando, com isso, numa dificuldade na distinção da linha do solo dentro da orquestra. Dentro do campo da organologia, as combinações para o Tema foram as madeiras agudas e médias (Flauta, Oboé, Saxofone tenor) com cordofones agudos (Violino) e o acompanhamento feito tanto por aerofones, como cordofones graves. 


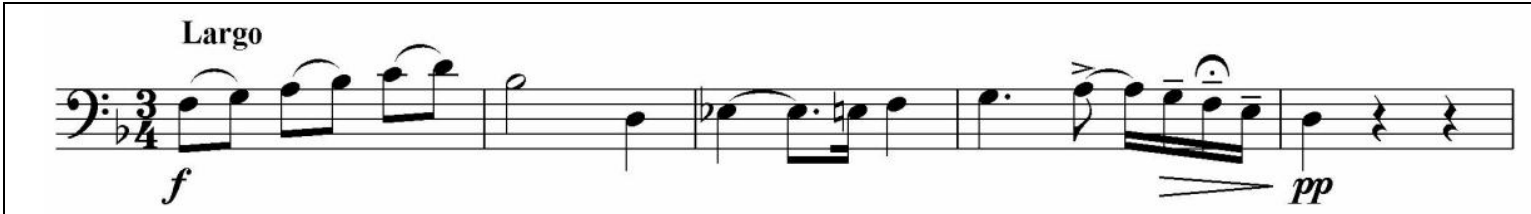

Ex. 116 - Bachianas brasileiras $N^{o} .2-\mathrm{II}^{\mathrm{o}}$. mov. - c.1-5

Próximo trecho do Trombone será a resposta a semifrase exposta pelo Saxofone tenor na região grave (c.47-50). Elementos de planos de melodia com ponto onde notas curtas geraram articulação e texturas polifônicas leve. O diálogo ficou estabelecidos entre o tema em forma consequente com tópica Lamento (Saxofone tenor em dinâmica $\boldsymbol{m f}$ e trombone $\boldsymbol{f}$ ) e o contraponto em ostinato de colcheias (cordas em $\boldsymbol{p}$ e piano não grafado dinâmica alguma) com equilíbrio da dinâmica para uma melhor distinção e independência rítmica do solo. As combinações em organologia foram Trombone e Saxofone tenor (aerofones graves no solo) e no acompanhamento cordofones (cordas e piano).

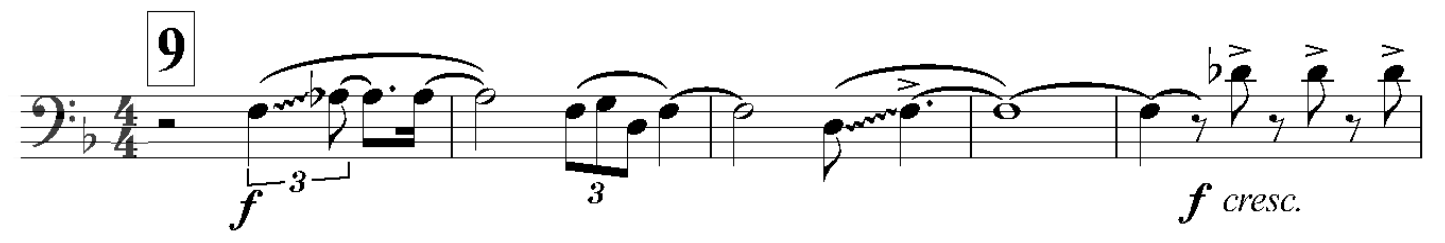

Ex. 117 - Bachianas brasileiras $N^{o} .2-\mathrm{II}^{\mathrm{o}}$.mov. - c.47-51

No terceiro movimento, o Trombone sola o tema principal em elementos de planos. Em termos de conjunto, há dois quadros criados por Villa-Lobos: o efeito de vento pelas cordas e Flauta e Oboé e a solo em forma de cantoria feito pelo Trombone. O equilíbrio dinâmico ocorreu via o solo estar em $\boldsymbol{f}$ e o acompanhamento em $\boldsymbol{m} \boldsymbol{f}$, mas as notas longas foram grafadas em $\boldsymbol{p} \boldsymbol{p}$ apenas para ambientação. Villa-Lobos aproveitou os papéis de foreground e background, tanto para o solista, quanto para o acompanhamento dentro de texturas homofônica leve. Dentro das características tópicas, podemos eleger a tópica caipira como a mais adequada. A separação entre o solista e o tutti pela independência rítmica ocorreu grafando o solo a vontade e acompanhamento em ostinato de semicolcheias. Não se localizou o uso da colocação de espaço e registro para distinguir a linha do solo da linha da orquestra. Em termos de organologia, o solo aconteceu nos aerofones graves e o acompanhamento, por sua vez e criando uma mudança de linguagem, foi grafado para os Cordofones e aerofones agudos. 


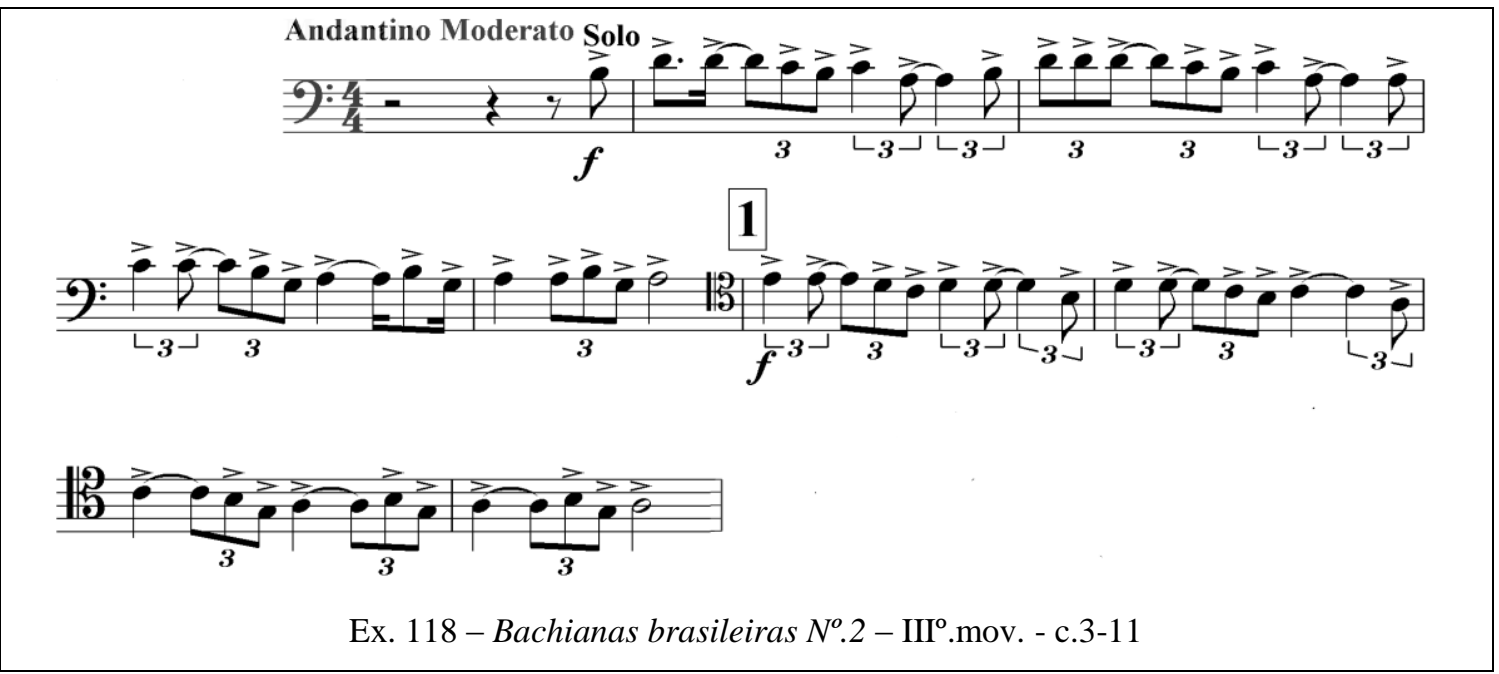

A sequência desse tema feito ainda pelo Trombone, nada será alterado. A única exceção ficará em tópicas: Villa-Lobos criará um tema em tópica época-de-ouro.

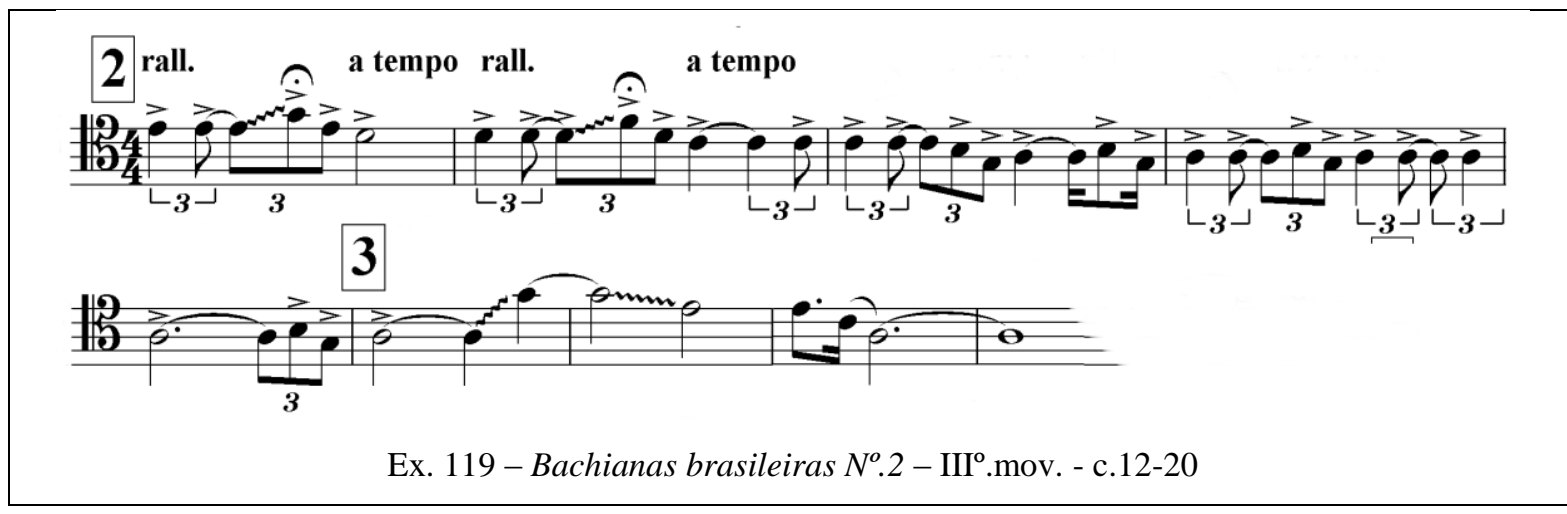

O próximo trecho compreende do c.24-29 e será formado de um inciso afirmativo e consequentemente dois incisos conclusivos. Os elementos foram de planos com vários sons contínuos. Por sua vez, o diálogo aconteceu em forma de responsório com características tópicas de dança indígena (Piedade, 2009). Não houve equilíbrio dinâmico, pois todos receberam a mesma dinâmica $f f$. A textura utilizada por Villa-Lobos foi polifônica pesada e em termos de organologia os aerofones se alternaram em pergunta e resposta com os cordofones.

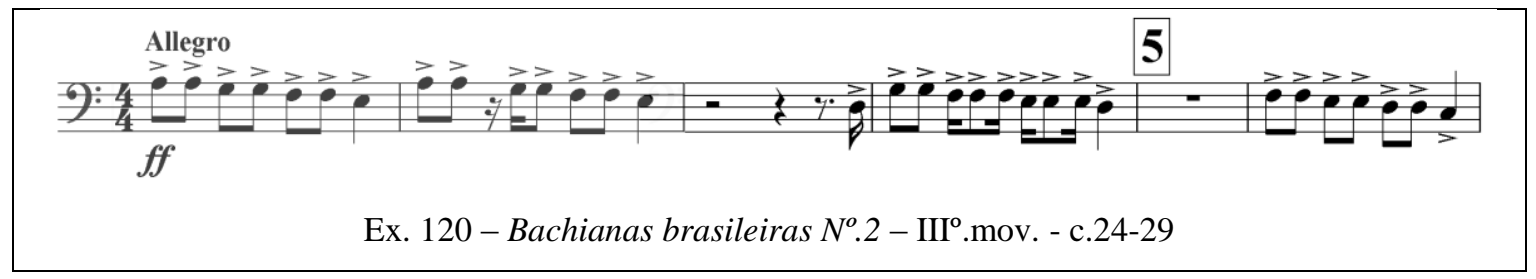


A partir desse ponto, foi localizado apenas repetições das ideias expostas anteriores até o final do movimento, não necessitando de reafirmação nesse capítulo. No quarto movimento c. 20-21 o Trombone terá sua primeira entrada com uma sequência de 3 glissandos. Os elementos de planos foram pontuais com características tópicas de selvagem. O diálogo e os contrastes de cores ficaram estabelecidos entre o solo e o ostinato sem dinâmica nas cordas. A textura utilizada foi a polifônica ríspida e dentro do campo da organologia ouve-se o solo feito pelos aerofones graves e com acompanhamento dos cordofones. Esse inciso se repetirá ampliado em c. 24-26 (Ex.121).

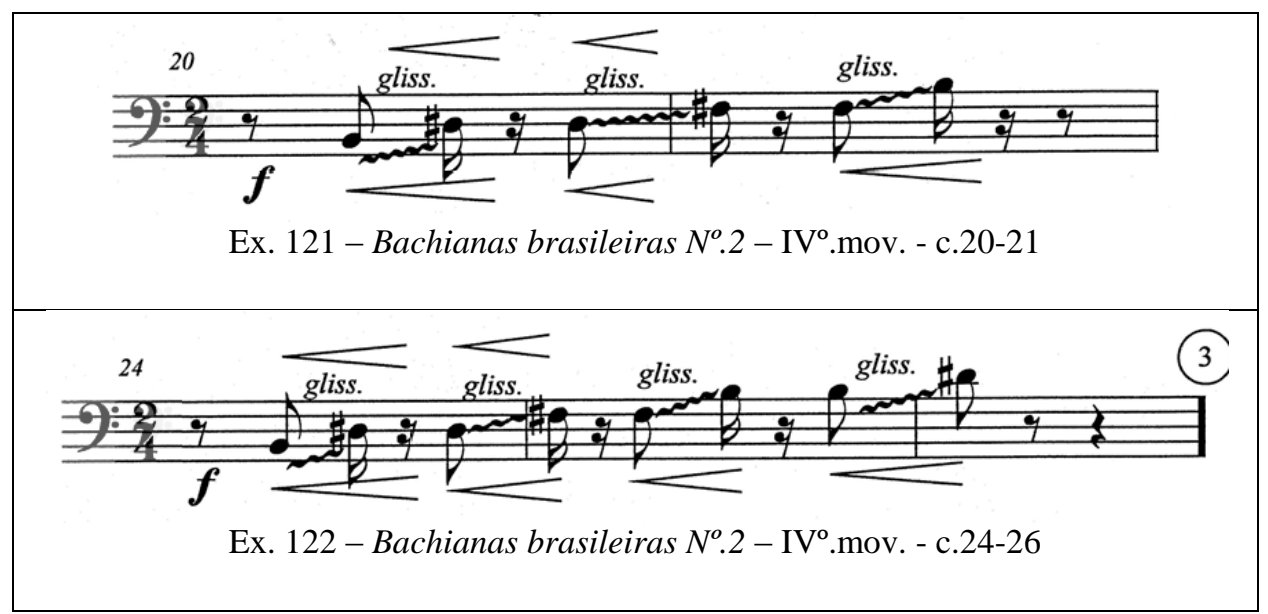

O próximo trecho escrito para o Trombone (c.33-34) é exatamente o mesmo complemento ao tema exposto pelos Violinos, iniciado em c.25 (n.3). Esse complemento se repete por seis vezes (c. 29-30; 33-34; 37-38; 41-42; 45-46; 49-50), mas o Trombone participa apenas do segundo aparecimento (c.33-34). Para todas as ocorrências teremos a ideia de elementos de planos pontual ${ }^{93}$ e o mesmo grupo de madeiras, formado pelo Flauta, Oboé, Clarinete e Fagote foram os designados por Villa-Lobos para esse inciso. Porém haverá uma exceção onde o Trombone entra para esse grupo, e toma o lugar do Fagote (c.33-34), criando uma nova combinação para o grupo ${ }^{94}$ e alterando o equilíbrio dinâmico, que recebeu de VillaLobos o nível dinâmico em $\boldsymbol{m f}$, mas para o trombone está grafado $\boldsymbol{f}$, (o Fagote ao retornar ao inciso desse grupo também receberá o mesmo $f$. A exploração de contrastes de cor para distinguir o tema do acompanhamento ficou na base rítmica onde o tema está grafado em notas longas, e o acompanhamento em notas curtas (semicolcheias). Trecho com textura polifônica pesada e característica tópica animal.

\footnotetext{
${ }_{93}$ Considera-se pontual, uma vez que a segunda nota tem aspecto de resolução por apogiatura.

94 Muito embora o timbre resultante dessa combinação de quatro sopros não sofreu alteração. O Fagote ou o Trombone não alteram o resultado timbrístico.
} 


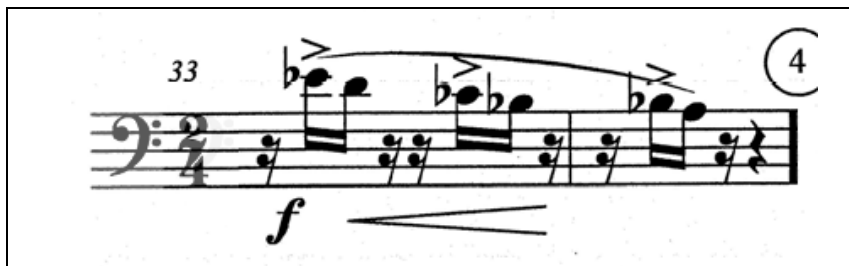

Ex. 123 - Bachianas brasileiras $N^{o} .2$ - $\mathrm{IV}^{\mathrm{o}}$. mov. - c.33-34

Para que houvesse uma diferenciação nas três ultimas repetições do tema principal, Villa-Lobos criou uma linha harmonizada de sons contínuos, dentro dos elementos de planos, e designou ao conjunto formado pelo Trombone e pelas Trompas (aerofones) a tarefa da existência de um contraste rítmico ao acompanhamento em semicolcheias. Com textura polifônica leve, o equilíbrio dinâmico ficou dentro dos padrões: o tema foi grafado em $\boldsymbol{f}$ e o acompanhamento em $\boldsymbol{m f}$, com atribuição clara de papel de background para o Trombone e a exploração de contrastes de cor e independência rítmica para que houvesse a distinção entre o tema e o acompanhamento.

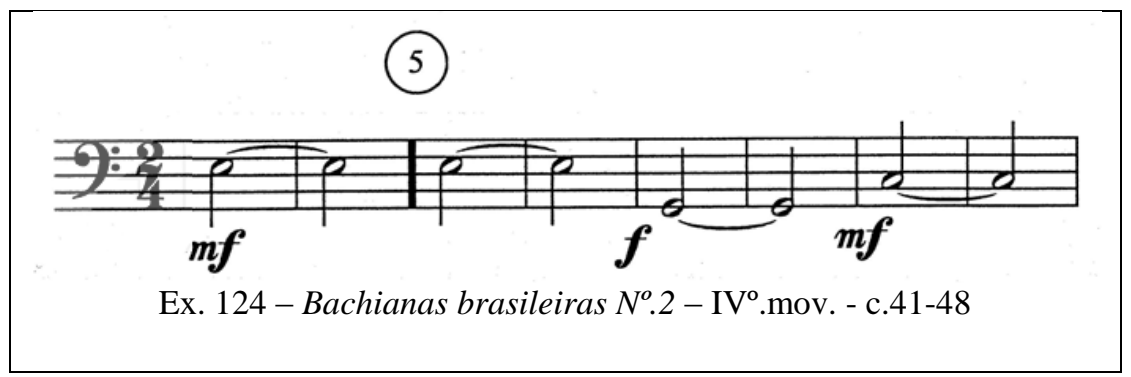

O próximo inciso, retirado do complemento do tema completo do movimento, contém quatro notas descendentes. Essas notas serão repetidas cinco vezes: o Trombone participa da $2^{\mathrm{a}}$. (c.28-32) e $4^{\mathrm{a}}$. (c.71-76) repetições. Villa-Lobos se utilizou de uma linha de som contínuo, como elementos de planos, para demonstrar a tópica de cantoria caipira. Dentro do quesito combinações instrumentais, Villa-Lobos se utilizou do tutti, sem equilíbrio dinâmico algum, uma vez que todos receberam dinâmica $f$ em suas partes e ainda apoiado numa textura monofônica pesada. Porém na $1^{\mathrm{a}}$. inserção desse inciso de complemento as madeiras não estão presentes. O diálogo na $1^{\text {a }}$. inserção ficou estabelecido entre o solo do tema (Trombone e Violino na região grave) e o acompanhamento feito pelo Trompete, Percussão e Cordofones (semicolcheias) em ostinato; para a $2^{\text {a }}$. inserção do inciso, o Trombone estará executando seu trecho em solo e o acompanhamento será o mesmo do $1^{\circ}$. Inciso, porém houve a entrada das madeiras na região aguda, executando sons da natureza. 

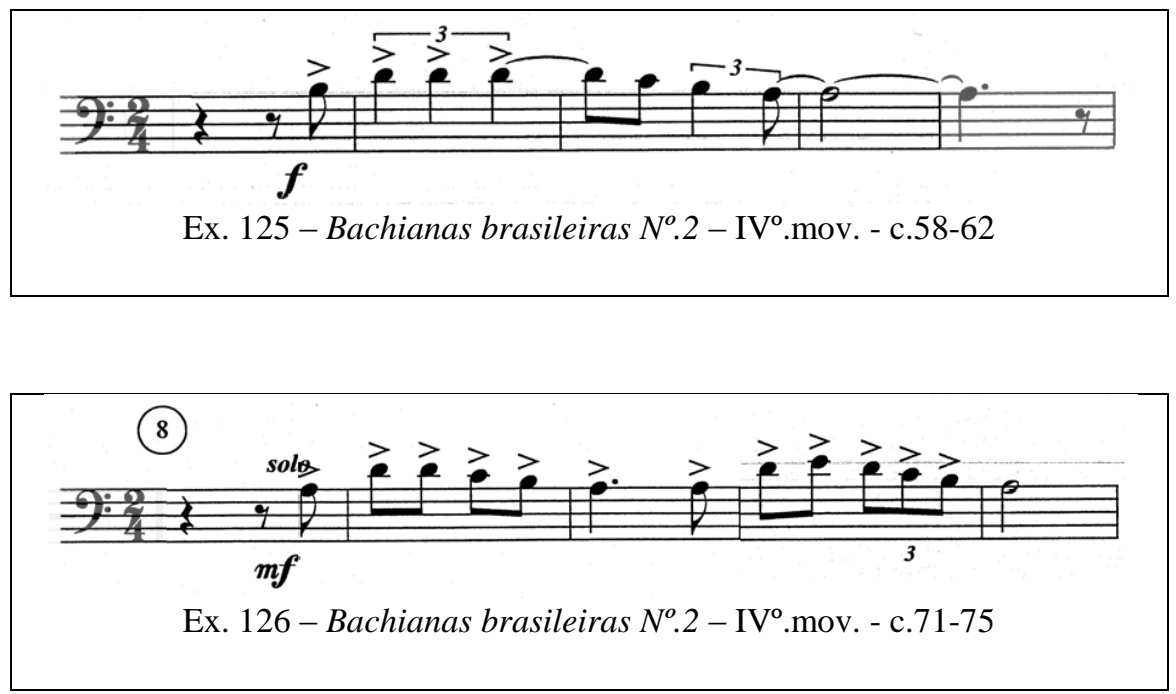

No próximo trecho (c.101-110) o Trombone participa do complemento da primeira exposição do tema feita pelas madeiras (c.95-141), sendo utilizado uma linha no parâmetro dos elementos de planos com características de tópicas caipira. O Trombone, inserido num tutti com textura polifônica pesada graças ao equilíbrio dinâmico inverso (o complemento da frase está grafado mais forte que o tema principal).

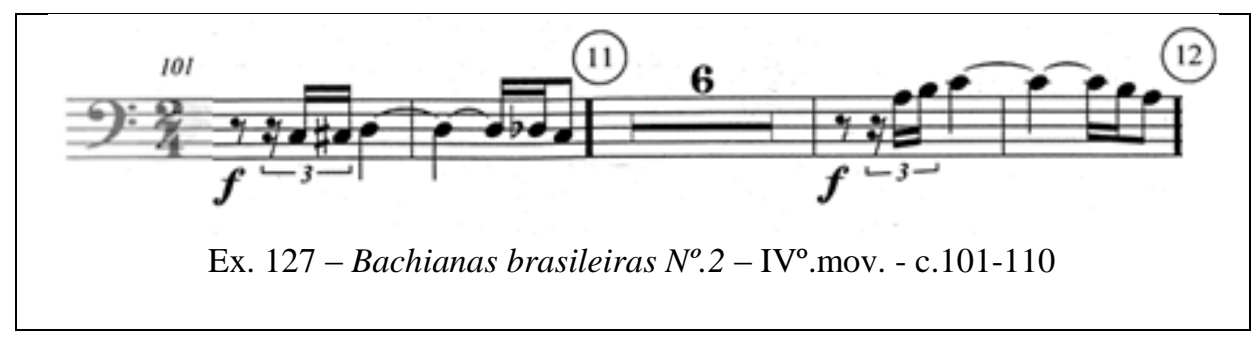

Para esse trecho, presenciamos o trombone em atuação pontuada articulada em efeito buzina, em pleno complemento à parte tética do compasso no solo da Trompa, com acompanhamento do Fagote e Trombone. Ainda é possível localizar, em $3^{\circ}$. nível, um rallentando de figuras feito pelos Violinos e Violas (c.143-175), criando a polirritmia ouvida nesse trecho. Complementando ainda se vê um tutti orquestral com textura de cluster pesado. O equilíbrio dinâmico do solo da Trompa (em $\boldsymbol{f}$ ) recebeu um acompanhamento em $\boldsymbol{m} \boldsymbol{f}$ pelos Fagote e Trombone mas não se localizou dinâmica para Percussão e cordofones. ${ }^{95}$.

${ }^{95}$ Nas gravações ouvidas, a massa do tutti praticamente encobriu o solo da trompa. 


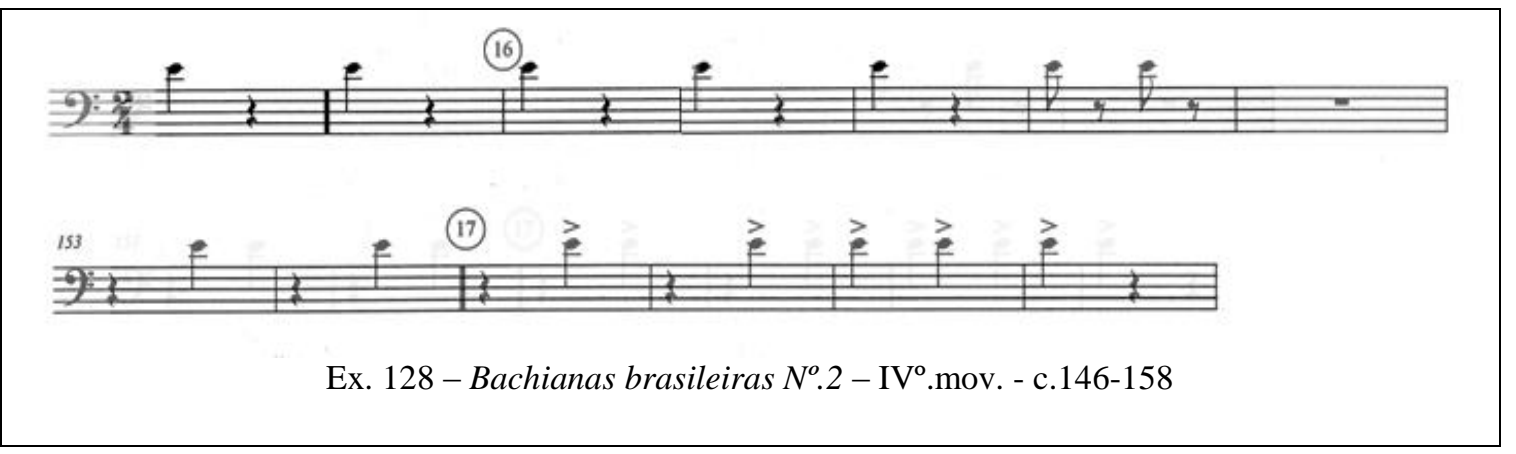

Abaixo a Tabela da utilização do Trombone na peça Bachianas brasileiras $N^{o} .2$ :

\begin{tabular}{c|c|c|c|c|c}
\hline Movimento & Total de compassos & Compassos com Trombone & Compassos sem Trombone \\
\hline $1^{\circ}$. & 99 & 7 & $7,07 \%$ & 92 & $92,93 \%$ \\
\hline $2^{\circ}$. & 77 & 19 & $24,68 \%$ & 58 & $75,32 \%$ \\
\hline $3^{\circ}$. & 106 & 87 & $82,08 \%$ & 19 & $17,92 \%$ \\
\hline $4^{\circ}$. & 182 & 50 & $27,47 \%$ & 132 & $72,53 \%$ \\
\hline \multicolumn{6}{|l|}{} \\
\hline GLOBAL & 464 & 163 & $35,13 \%$ & 301 & $64,87 \%$ \\
\hline
\end{tabular}

Tab. 9 - Utilização do Trombone nas Bachianas $N^{o} .2$

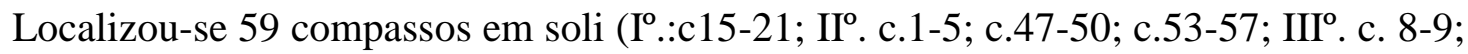
c. $12-13$; c. $24-25$; c. 27 ; c. 29 ; c. $40-43$; c. $51-55$; c. 57 ; c. $68-71$; c. $86-87$; c.90-91; IV ${ }^{\circ}$ c. $20-$ 21; c.24-25; c.33-34; c. 101-102; c.109-110) e 28 compassos em solo (III'. c. 3-7; c.10-11; c. 14-22; c.81-85; c. 88-89; IV . c. 71-75). Nesta peça estão escritos 10 glissandos fora da extensão do êmbolo ( $\mathrm{I}^{\circ}$. c15-19; III ${ }^{\circ}$. c.17; IV . c.20-21; c.24-25; ), e 7 glissandos dentro da extensão do êmbolo (II'. c47; c.49; III $^{\circ}$. c.12; c.13; IV ${ }^{o}$. c.20; c.24-25; c.33-34).

Em relação às dinâmicas utilizadas no Trombone por Villa-Lobos na peça Bachianas brasileiras $N^{o} .2$, localizou-se uma ocorrência para as dinâmicas $f f f$; duas ocorrências para $\boldsymbol{p}$; quatro ocorrências para $\boldsymbol{m f} \boldsymbol{f} \boldsymbol{f}$ e $\boldsymbol{p} \boldsymbol{p}$ e por fim dez ocorrências para $\boldsymbol{f}$. Quanto às articulações escritas por Villa-Lobos, encontrou-se quatro estacatos ( . ); oito frullatos; 20 tratinas/tenuto; 33 ligaduras; 53 notas sem articulação alguma e 332 notas acentuadas ( > ). 


\subsection{CONCERTO PARA VIOLÃO E PEQUENA ORQUESTRA}

Escrito a pedido do dedicatário Andrés Segóvia, foi composto no ano de 1951, inicialmente intitulado Fantasia Concertante, e publicado em 1955, já com o acréscimo de uma Cadência, passando então, a ser denominado Concerto para violão e pequena orquestra.

Este concerto pertence a uma etapa em que consideramos ser a última fase composicional de Villa-Lobos. Dentre as definições de alguns autores acerca de tal fase, realizadas sob diversas ópticas, salientamos a inferência de Eero Tarasti que observa que "em Villa-Lobos os estilos diferentes estão sincronicamente presentes nas mesmas épocas" (TARASTI, 1979, p. 51). Na opinião de Dudeque (1994, p.90) o Concerto para violão e pequena orquestra, é considerada como a obra "síntese da escrita violonística de H. VillaLobos".

Ainda segundo relato de Zanon (2006, p.80): "Seu Concerto para violão e orquestra é uma das poucas obras brasileiras, talvez a única, com lugar assegurado no repertório internacional do gênero. As possibilidades de reconhecimento internacional, assim abertas para um compositor brasileiro, podem ser um tremendo fator de inibição, pelo temor à epigonia".

De todos os compositores que escreveram inspirados pela arte de Segovia, Villa-Lobos é o único que parte de um conhecimento em primeira mão do arcabouço técnico do instrumento para a realização de uma linguagem individual, que incorpora uma luxuriante paleta harmônica e um compromisso com a inovação no discurso musical. Prova da qualidade visionária desta obra foi a espera que Segovia a incluísse em seus programas e até 1953 para que fossem publicados.

Com relação ao Concerto, o próprio Segovia, em carta encaminhada para Villa-Lobos, pede que o compositor "reveja bem as partes da orquestra porque na edição da parte de violão e piano passaram muitos erros" (carta, 30 jul. 1955).

Já em relação a orquestração, Mariz comenta que há um risco de o violão não ser ouvido nas grandes salas, mas acrescenta que na opinião de Turíbio Santos (apud Mariz), na verdade, o 
compositor defendia o uso do microfone para que a orquestra pudesse tocar com maior liberdade e isso garante que seja ouvido até mesmo nas maiores salas. Soma-se a isso, o fato de Villa-Lobos ter escrito a obra para uma pequena orquestra. Além disso, podemos notar o cuidado evidente na partitura da obra com relação às escolhas de dinâmicas que mostra certa cautela e zelo do autor que permitem maior destaque ao instrumento para que seja bem ouvido pelo expectador.

Assim, o resultado estético que se alcançou nesta obra provém de uma atitude composicional livre a despeito das amarras do conservadorismo, o qual eventualmente poderia condenar a utilização do microfone, restringindo a gama de possibilidades de escolhas de instrumentação e dinâmicas a serviço do compositor. Isso, pois, o violão é um instrumento com uma projeção sonora limitada se comparada à de outros instrumentos, tais como o piano, o violino e o trombone por exemplo.

\section{CONSIDERAÇÕES DA ORQUESTRAÇÃO DO CONCERTO PARA VIOLÃO}

Utilizaremos a edição revisada e editada pelo maestro Roberto Duarte, sob encomenda da Academia Brasileira de Música ABM, em 2010. Estando inserido no grupo Orquestral/Concerto, esta peça conta com um efetivo orquestral completo, determinado pelos seguintes instrumentos:

\begin{tabular}{c|c}
\hline 1 & Flauta \\
\hline 1 & Oboé \\
\hline 1 & Clarinete em Sib \\
\hline 1 & Fagote \\
\hline 1 & Trompa \\
\hline 1 & Trombone \\
\hline 1 & Violão solo \\
\hline & Cordas (Violinos, Viola, Violoncelos e Contrabaixos) \\
\hline
\end{tabular}

Tab. 10 - Instrumentação para Concerto para Violão e Pequena Orquestra

O trombone foi utilizado numa extensão que compreende do Sób1 ao Fá\#3. Com dinâmicas que variam do pianíssissimo (ppp) ao fortíssimo(ff) em sem nomear o mezzo-piano $(\boldsymbol{m p})$. 
Com relação aos processos utilizados para a composição do Concerto, podemos citar a "Teoria da intertextualidade". Esta terminologia foi inicialmente empregada na literatura, a qual se refere ao processo de produção textual, onde sua construção seria um mosaico de citações, provindas da absorção e transformação de outros textos (KRISTEVA, 1979, p. 13). A Intertextualidade designa o processo de superposição de um ou vários textos em outro.

Em música, seria o ato de se utilizar de materiais já expostos por outros compositores ou de si próprio. A primeira vez que Villa-Lobos teve a experiência de confrontar o violão com uma massa orquestral foi com a "Introdução aos Choros" (1929). Apesar dos diferentes períodos em que foram compostas, algumas questões intertextuais podem ser verificadas.

A entrada do trombone ocorrerá no próprio c. 1 do $1^{\circ}$. movimento, em meio a um motivo ritmo feito pelo fagote, trompa, $1^{\circ}$. violino e violas. Terão mesma dinâmica o grupo da estrapata $^{96}$ de quarto tempo $(\boldsymbol{f})$ a clarinete, o trombone e $2^{\circ}$. violinos (uma clara resposta a pergunta incutida pelo primeiro grupo) porém o $1^{\circ}$. grupo que faz o inciso rítmico (fagote, trompa, $1^{\circ}$. violino e violas) grafou-se $s f z$ para esse $4^{\circ}$. tempo. (Ex. 129).

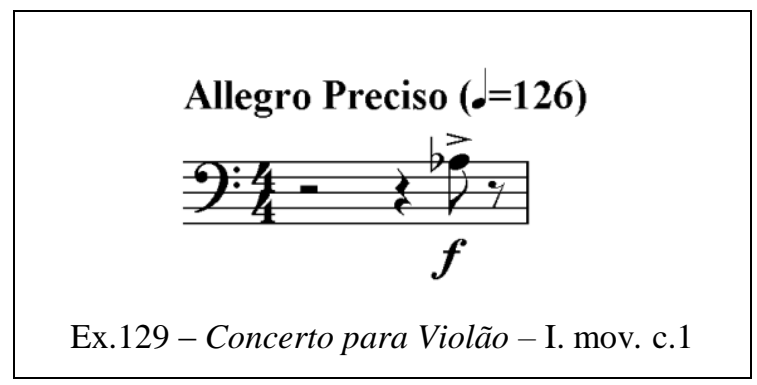

O trombone ficará em espera por 25 compassos e retorna no c.27 complementando blocos harmônicos em dinâmica $\boldsymbol{p}$, num papel claro de background e em parceria com Violoncelos, Contrabaixos, Trompa e Clarinete (Ex. 130):

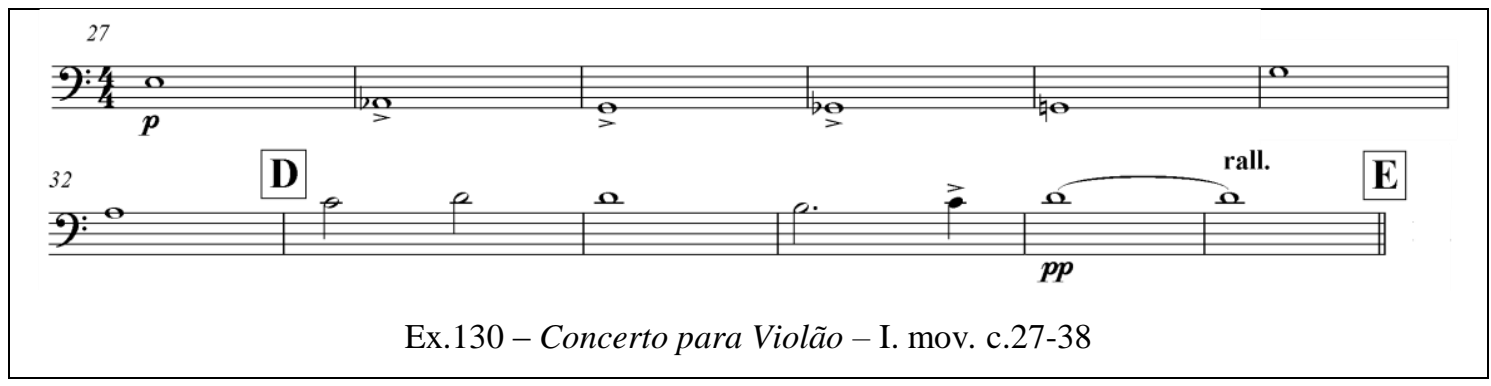

\footnotetext{
96 Termo utilizado pelos intérpretes de tango, para indicar o golpe do arco sobre as cordas, gerando um efeito sonoro particular, similar à indicação musical acadêmica de "col legno". (Música Tiempo para escuchar, 2011, p.28)
} 
O trombone ficará novamente em espera por 63 compassos e retorna no c.102 complementando blocos harmônicos em dinâmica ppp, num papel claro de background para o solo do Clarinete e em parceria com Fagote e Trompa (Ex. 131):

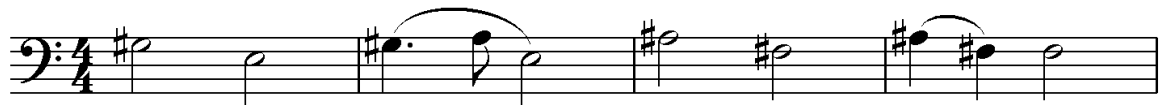

$\boldsymbol{P P p}$

Ex. 131 - Concerto para Violão - I. mov. c.102-105

O trombone ficará apenas três compassos de espera e no c.109 fará uma recapitulação do inciso rítmico do $1^{\circ}$. compasso da peça em conjunto com o Fagote. Neste inciso rítmico, que serve como conversa, o Violão e logo a seguir o oboé e a clarinete responderão ao chamamento do trombone. Villa-Lobos grafou $\boldsymbol{m} \boldsymbol{f}$ para o Trombone mas $\boldsymbol{f}$ para o Fagote e ambos terão a mesma articulação ( $\boldsymbol{s} \boldsymbol{f} z$ no $4^{\circ}$.tempo e $\boldsymbol{p}$ para a última colcheia. Nesse momento Villa-Lobos tirou o trombone da posição de background e o levou para frente da orquestração em um soli servindo de chamamento para a Coda do movimento (Ex. 132):

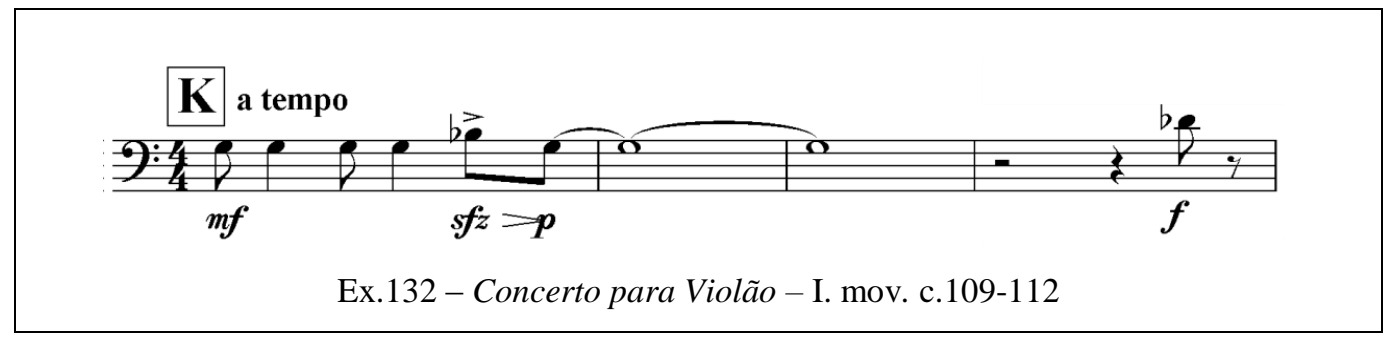

O Trombone fica em espera por 12 compassos e o movimento terminará com um tutti na nota Dó, inclusive com o solista presente (Ex. 133):

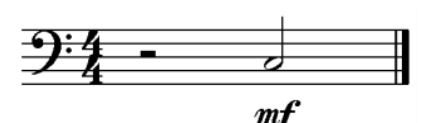

$m \boldsymbol{f}$

Ex. 133 - Concerto para Violão - I. mov. c.125

O $2^{\circ}$. Movimento se inicia com um movimento escalar ascendente do $2^{\circ}$. violino, lembrando o modo mixolídio (c.1-4) e juntamente com o Violão-solo entrarão o Trombone, Clarinete, Fagote e Trompa em blocos harmônicos e paralelos típicos de atuação em background no c.5-c.16 - inclusive em dinâmica suave (Ex.134): 


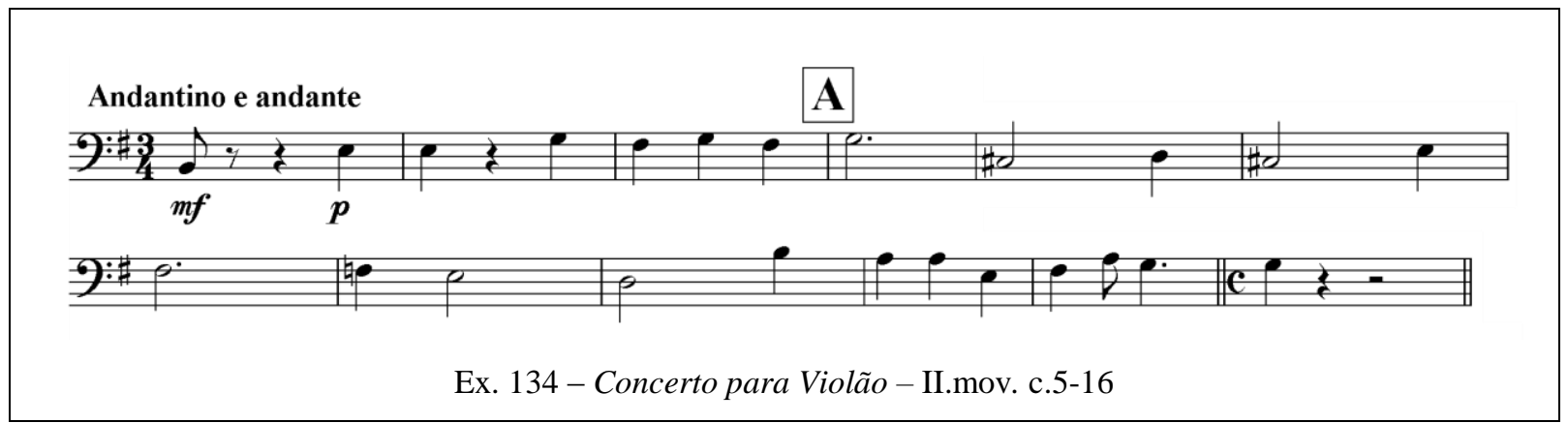

Após esse $1^{\text {a }}$. participação, o Trombone ficará 30 compassos em espera, para retornar no c.47 como $2^{\mathrm{a}}$. voz do Fagote, e em diálogo ao tema exposto pelo Clarinete e a seguir os Violinos num tutti orquestral sem a presença do solista (Ex.135):

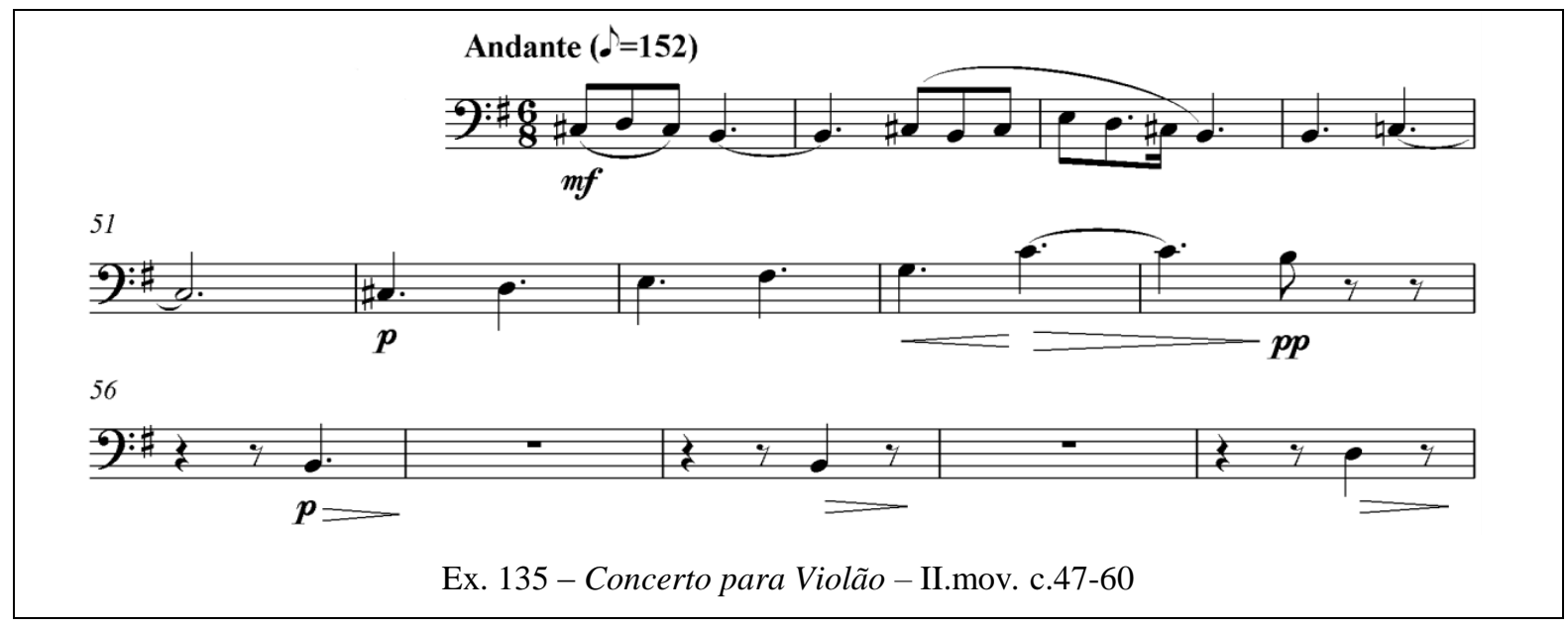

O trombone ficará em descanso por 17 compassos, e participará de três blocos harmônicos que servem de apoio em background às semicolcheias do solista e numa dinâmica muito suave e sem acentos nas notas (Ex.136):

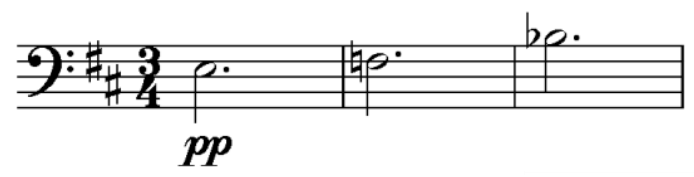

Ex. 136 - Concerto para Violão - II.mov. c.78-80

O trombone ficará em descanso por 18 compassos, não participando do término do movimento. No ultimo movimento, o Trombone entra pela primeira vez no c.31 e novamente em blocos harmônicos que servem de apoio em background ao tema exposto pelo solista e de mesma forma numa dinâmica muito suave e sem acentos nas notas (Ex. 137): 


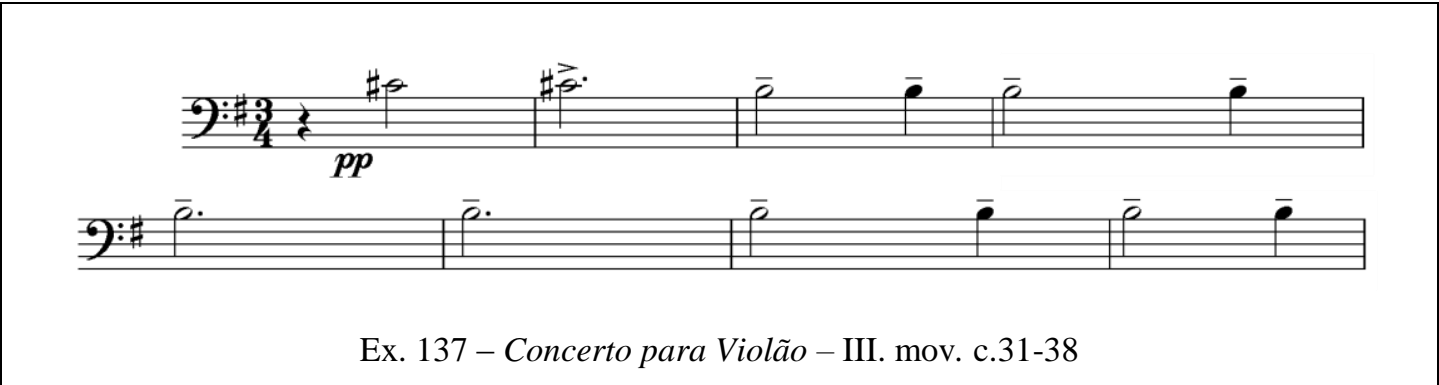

Em resposta ao inciso ascendente do Fagote, Violoncelo e contrabaixo, o Trombone fará outro descendente e em conjunto com Flauta, Oboé, Clarinete e Trompa. As madeiras estão em dinâmica $f$, enquanto Trombone e Trompa estão em $m f$. A articulação geral é a mesma: colcheias em estacato e semínima acentuada (Ex. 138):

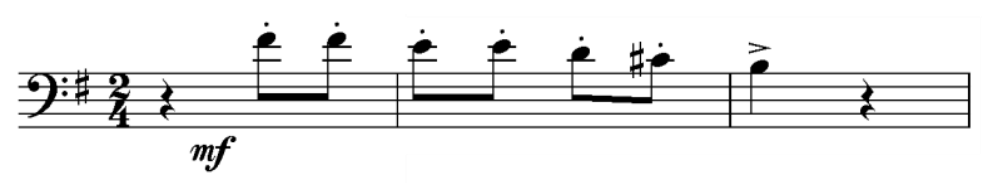

Ex. 138 - Concerto para Violão - III. mov. c.43-45

O próximo trecho será uma conversa entre a Flauta e um grupo formado pelo Oboé, Clarinete, Trompa, Trombone, Viola e Violoncelo e a finalização da frase ficou a cargo do Fagote, Trombone e Violoncelo. Todos os instrumentos estão em mesma dinâmica e articulação (Ex. 139.):

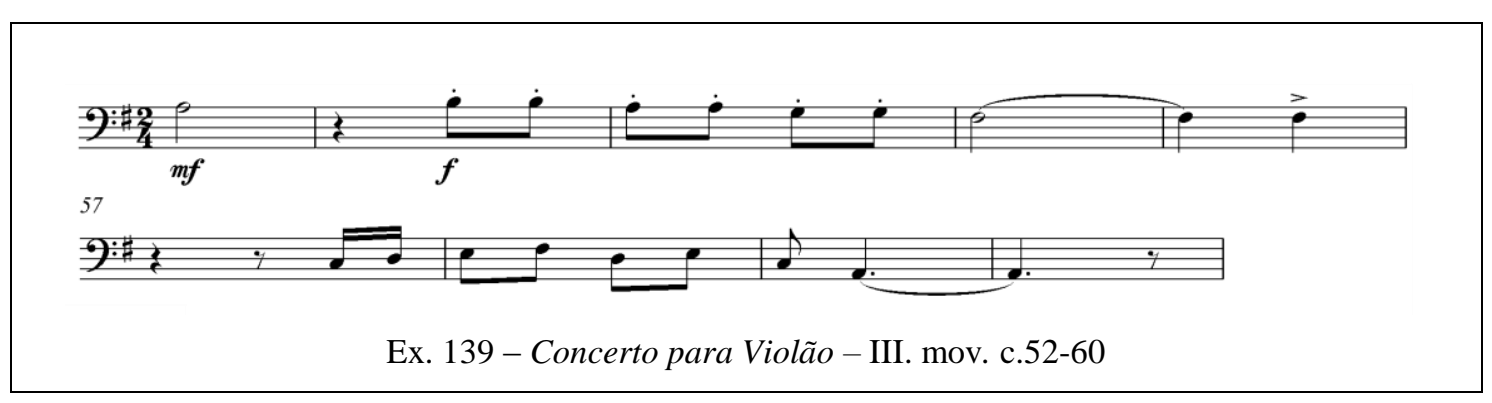

Ao final do solo do Violão, o Trombone entra no c.86-87 para em conjunto com Flauta, Oboé, Clarinete, Fagote e Trompa fechar a ideia harmônica da semifrase, em blocos harmônicos paralelos em background para o solista e numa dinâmica quase inaudível (Ex. 140). O mesmo ocorre de c.102-103 (Ex. 141):

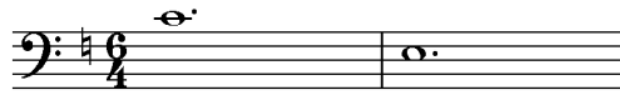

pPp

Ex.140 - Concerto para Violão - III. mov. c.86-87

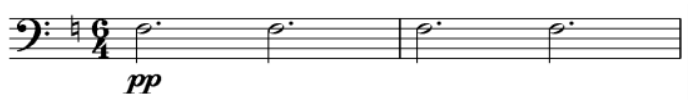

Ex. 141 - Concerto para Violão - III. mov. c.102-103 
Podemos conferir no Ex. 142 que o Trombone retorna à peça no c.109 numa nota longa em tutti orquestral (todos os sopros têm mesma dinâmica $\boldsymbol{p}$, porém as cordas iniciam um movimento escalar descendente com dinâmica $f$ ) e a partir do c.111 todos têm dinâmica $f f$. Este é o único momento em toda peça onde o trombone foi grafado em dinâmica potente e com articulação acentuada ( > ).

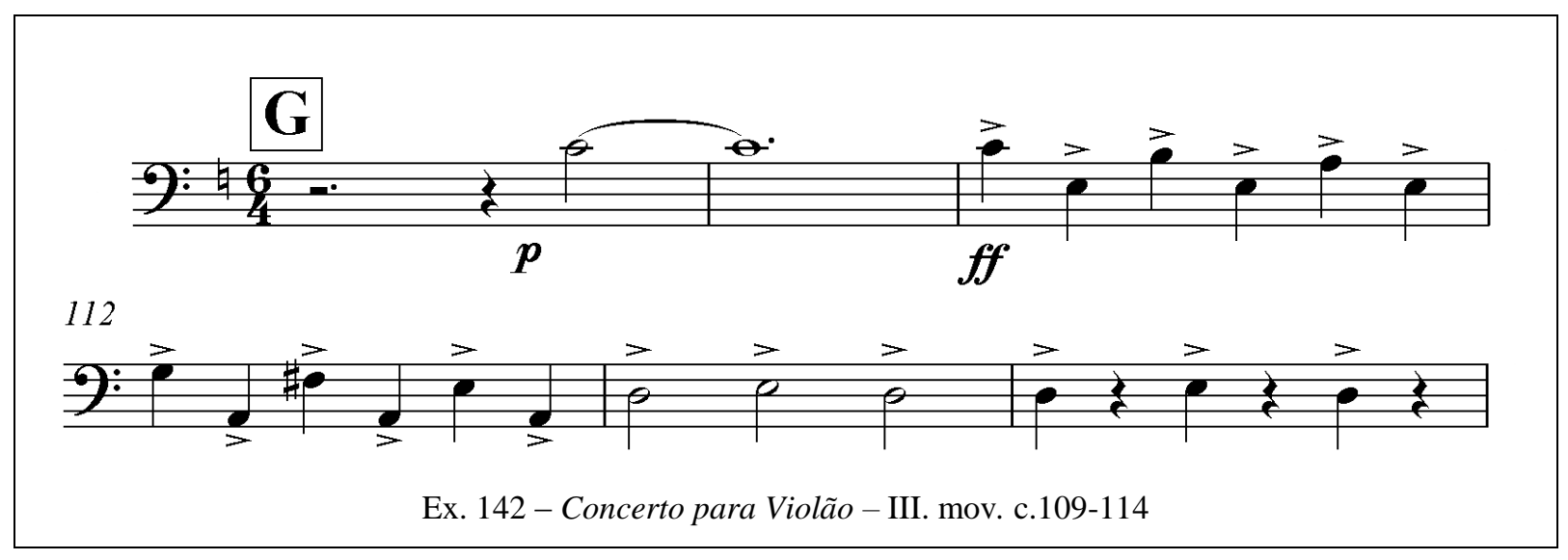

As próximas quatro participações do trombone terão a mesma configuração: em conversa com o solo do Violão, o Trombone entra em conjunto com a orquestra nos blocos harmônicos paralelos em background e numa dinâmica quase inaudível e com articulações leves (Ex.143):

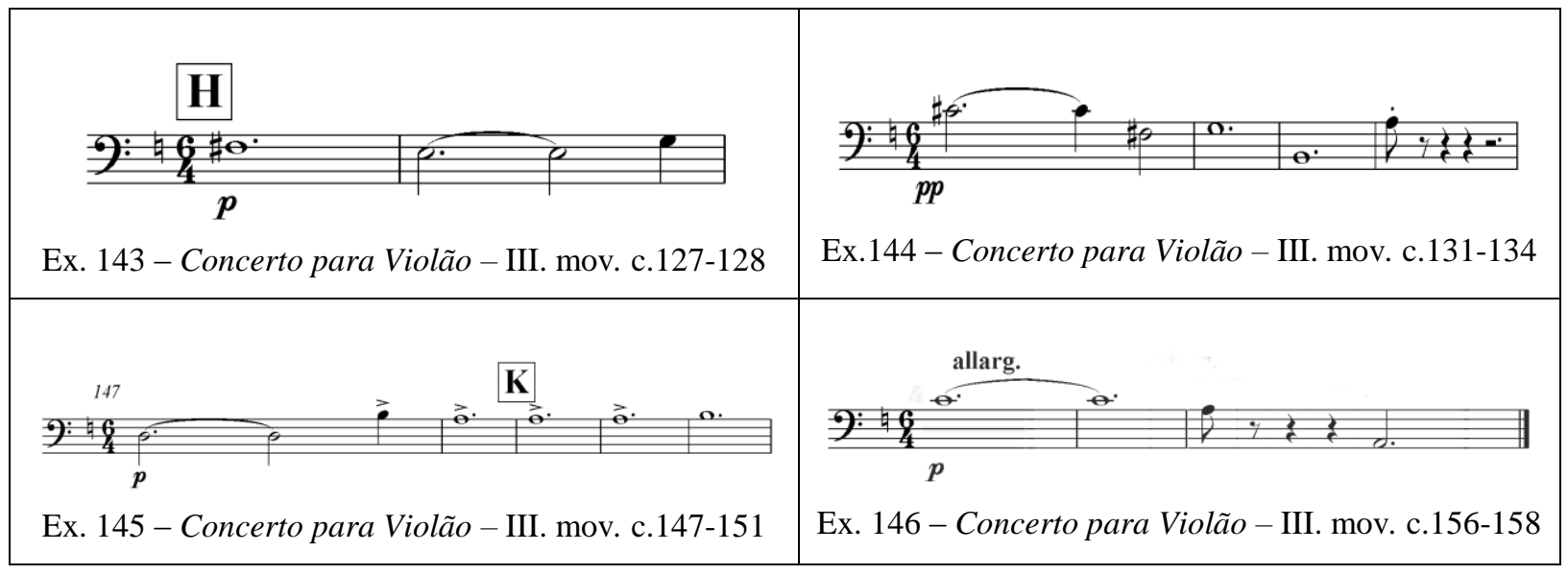

Em termos de utilização do trombone na peça Concerto para Violão e pequena Orquestra, escrita num total de compassos 162 compassos, o trombone participou de 94 compassos $(58,02 \%)$, porém ficou em pausa em 68 compassos $(41,98 \%)$. Teremos um compasso em soli (c.109). Nesta peça não houve glissando algum. 
Em relação às dinâmicas utilizadas por Villa-Lobos para o Trombone, na peça Concerto para Violão e pequena Orquestra, localizou-se uma ocorrência para a dinâmica ff; duas ocorrências para ppp; três ocorrências para $\boldsymbol{f}$; sete ocorrências para pp; oito ocorrências para $\boldsymbol{m f}$ e por fim, dez ocorrência para a dinâmica $\boldsymbol{p}$. Quanto às articulações escritas por VillaLobos, encontrou-se apenas um $s \boldsymbol{f} z$; cinco ligaduras; dez tratinas/tenuto; treze estacatos; 31 acentos e por fim, 90 notas sem articulação alguma.

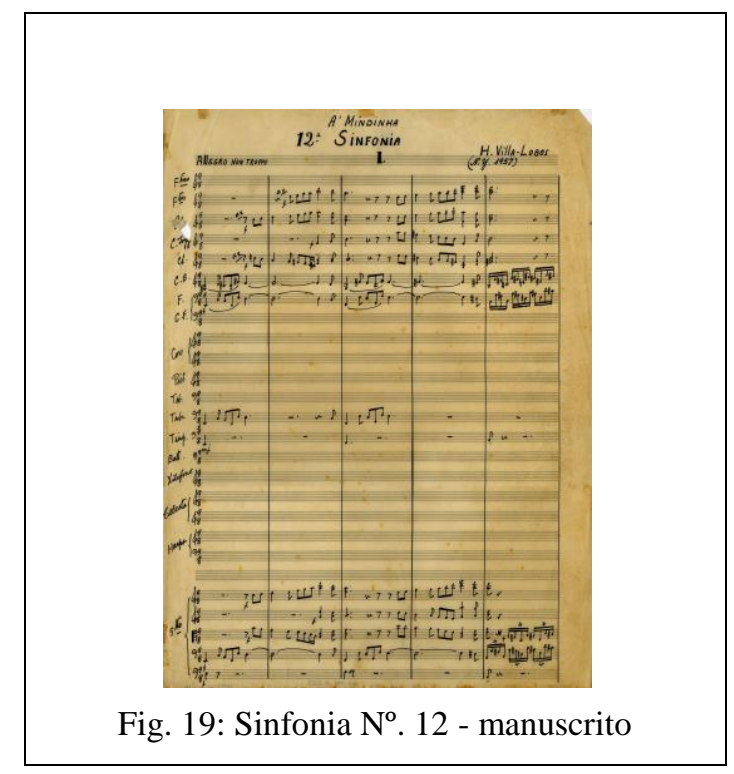

\subsection{SINFONIA}

Muitos autores defendem a ideia de que o gênero da sinfonia, saturado de carga histórica, não se adequava à indisciplina da abordagem musical de Villa-Lobos ${ }^{97}$. Vendo as coisas em retrospecto, o primeiro impacto do ciclo agora, parece justamente o contrário: chama a atenção sua homogeneidade e o papel secundário exercido por elementos descritivos ou de colorido local.

Villa-Lobos compôs suas sinfonias em dois períodos bem demarcados, separados por um hiato de 24 anos. As quatro primeiras, escritas antes de 1920, trafegam no universo do sinfonismo francês e russo; todas se conformam, de uma maneira bastante pessoal, à forma cíclica e se apoiam em texturas similares às de autores românticos como Tchaikovsky, ou pós-românticos como Scriabin.

\footnotetext{
${ }^{97}$ Ver os textos de Mariz, Muricy, Peppercorn e Tarasti, entre outros.
} 
Na segunda fase, a partir de 1944, o espaço para autoindulgência se contrai e fica evidente sua preocupação com a aderência ao cânone formal e a um plano harmônico amplo. É instigante ouvir a marca distintiva de Villa-Lobos sem a presença de material exclusivamente nacional, que não seja uma ou outra síncope. As sinfonias de $n^{\circ} .6$ a 12, compostas e estreadas entre 1944 e 1958 primam pela rara coesão arquitetônica e unicidade gestual.

\section{CONSIDERAÇÕES DA ORQUESTRAÇÃO DA SINFONIA $N^{\circ} .12$}

Para esse trabalho será utilizada uma partitura de edição desconhecida e feita manualmente, apenas com o dizer "N.Y. 1957" e também não se localizou sequer a assinatura do copista que a fez. Estando inserido no grupo Orquestral/Sinfonia, esta peça conta com um efetivo orquestral completo, determinado pelos seguintes instrumentos:

\begin{tabular}{c|c}
\hline 1 & Flautim \\
\hline 2 & Flautas \\
\hline 2 & Oboés \\
\hline 1 & Corne Inglês \\
\hline 2 & Clarinetes \\
\hline 1 & Clarinete baixo (clarone) \\
\hline 2 & Fagotes \\
\hline 1 & Trompetra-fagote (Pistões) \\
\hline 4 & Trombones \\
\hline 1 & Tuba \\
\hline & Percussão (tímpano, bateria, xilofone) \\
\hline 1 & Celesta \\
\hline 1 & Harpa \\
\hline & Cordas (Violinos, Violas, Violoncelos e Contrabaixos \\
\hline
\end{tabular}

Tab. 11 - Instrumentação para Sinfonia $N^{o} 12$ 
Os metais graves são utilizados na seguinte extensão sonora: Trombone tenor compreende do Mi1 ao Si3; Trombone baixo de Dó1 a Dó3; Tuba do Fá-1 até Sól2. Com dinâmicas que variam no $1^{\circ}$. movimento do pianíssimo (pp) ao fortíssimo(ff); no $2^{\circ}$. movimento tendo apenas piano $(\boldsymbol{p})$ e mezzo-forte $(m \boldsymbol{f})$; no $3^{\circ}$. movimento do pianíssimo (pp) ao forte $(\boldsymbol{f})$; e por fim, no $4^{\circ}$. movimento do piano $(\boldsymbol{p})$ ao fortíssimo $(\boldsymbol{f f})$. A Tuba é introduzida na Sinfonia logo no primeiro compasso, em uníssono com o Clarone, Fagote e Violoncelo. Tanto o Clarone quanto o Fagote têm suas frases ligadas, porém na partitura nem Tuba, nem Violoncelo receberam ligaduras em suas semifrases. Para o Tubista, essa pergunta em forma de sequência de intervalos longos (inciso), traz consigo uma boa dose de dificuldade técnica. Villa-Lobos usou de contrastes de cores ao colocar os instrumentinos para responder aos graves da orquestra. (Ex. 147.):

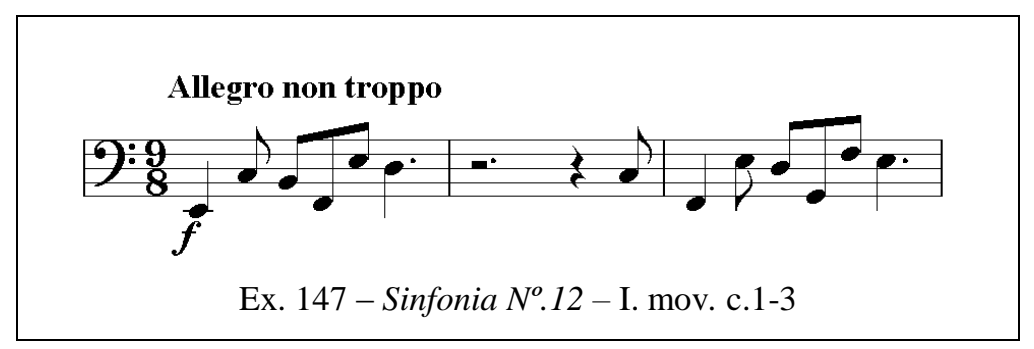

O Trombone será introduzido na peça no c.9. Em conjunto com o Trombone, VillaLobos agrupou as Trompas e Trompetes em mesmo ritmo com papéis claros de foreground com independência rítmica dos metais onde a base contrapontística do trecho foi o diálogo em forma de responsório, as madeiras e as cordas respondem ao inciso dos metais. Toda orquestra está com dinâmica $f$. Em sua frase, apenas um intervalo longo ( $7^{\mathrm{a}}$.m) foi utilizado.

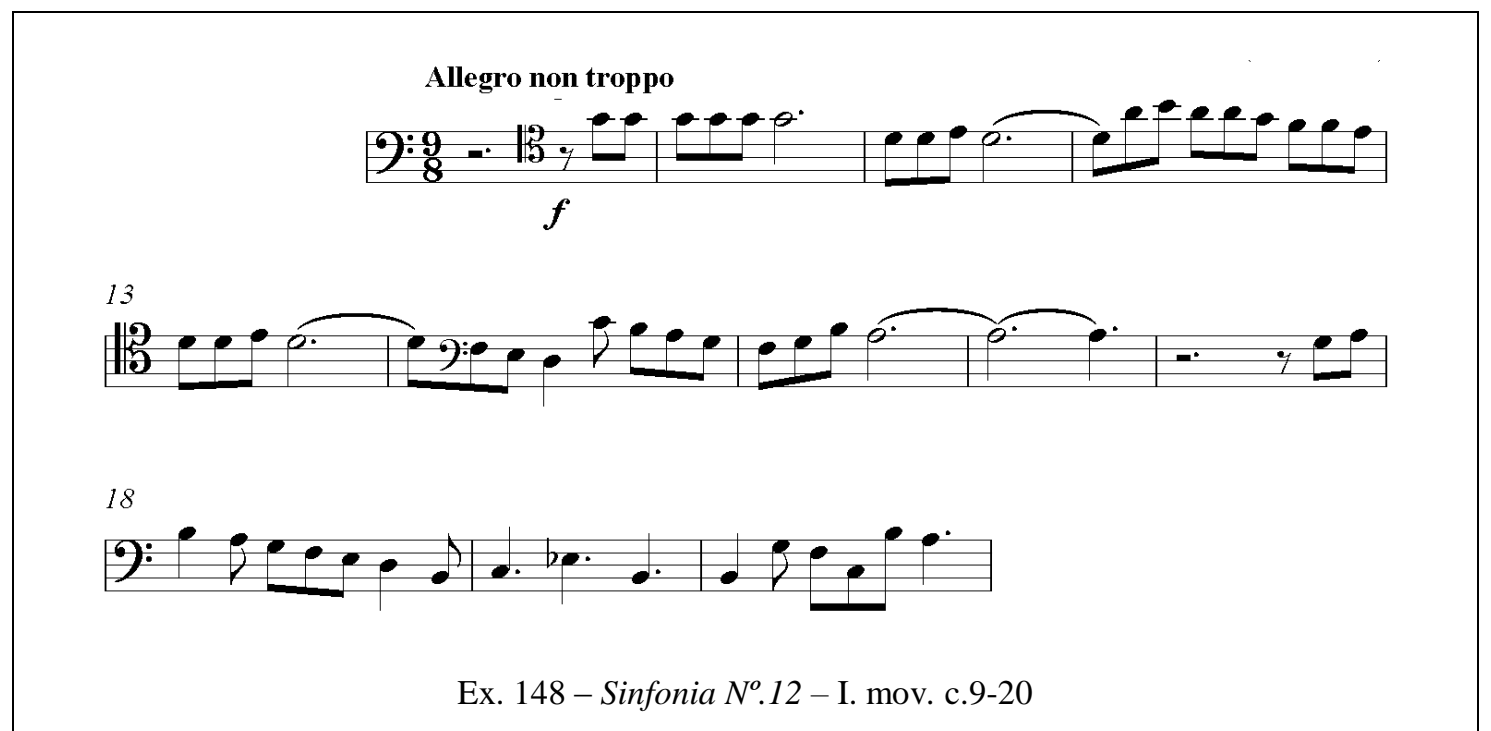


Trecho para o Trombone com características muito próximas às do trecho anterior, porém os intervalos pequenos foram amplamente usados nesse trecho. Os metais estão praticamente sozinhos nesse trecho, apenas com uma intervenção dos Violinos e Violas no c.37. Novamente o papel dos metais foi o de foreground. A semifrase finaliza com uma ideia feminina. Ex. 149:

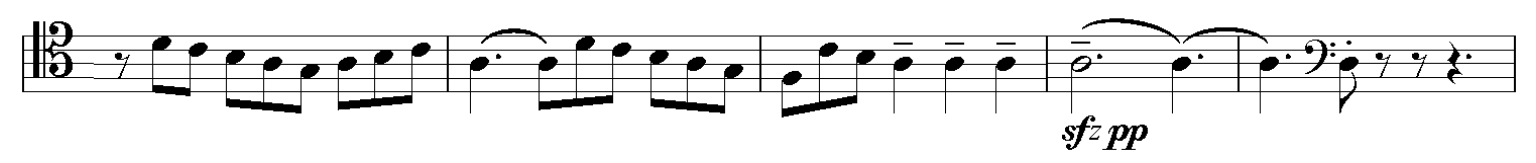

Ex. 149 - Sinfonia $N^{o} .12-$ I. mov. C.36-40

No próximo trecho, a Tuba caminha, em conjunto com Fagotes, Contrafagote e Trompas de forma isolada, ou seja, apenas ouviremos uma nota longa feita pelos Violinos e Violas. Com ritmo caracteristicamente em 9/8 onde Villa-Lobos colocou em posição de destaque na orquestração os sopros graves. Estes sem ligadura alguma em sua semifrase.

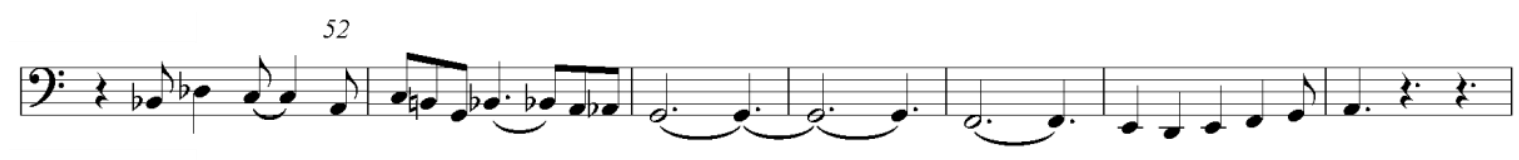

Ex. 150 - Sinfonia $N^{o} .12-$ I. mov. C.51-57

Os Trombones voltam à ativa nesse trecho. Primeiramente o Trombone baixo em conjunto com a Tuba, Fagotes, Contrafagote e trompas farão um inciso (c.56) com tendências quartenárias preparando o inciso principal do movimento - este sim ternário-, que será feito pelos Trombones com intervalos melódicos de $6^{\mathrm{a}}$. e $7^{\mathrm{a}}$. (c.57). O retorno dos Trombones quatro compassos adiante ${ }^{98}$ é uma recapitulação do inciso quartenário exposto pelo Trombone baixo.

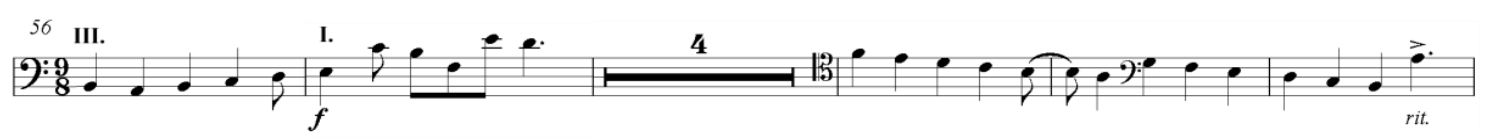

Ex. 151 - Sinfonia $N^{o} .12-$ I. mov. c.56-64

${ }^{98}$ Durante a pausa dos Trombones, as cordas fazem incisos com tendência quartenária. 
Em c.74-75 a Tuba será solista, apenas uma intervenção interrogativa das Trompas e Trompetes (c.74) e o inciso quartenário na nota Fá (c.75) feito pelo Tímpano, acompanha a Tuba nesse momento. Este inciso tocado pela Tuba será respondido em eco pelo Contrafagote nos c.76-77, logo na sequência da Tuba. Ex. 152:

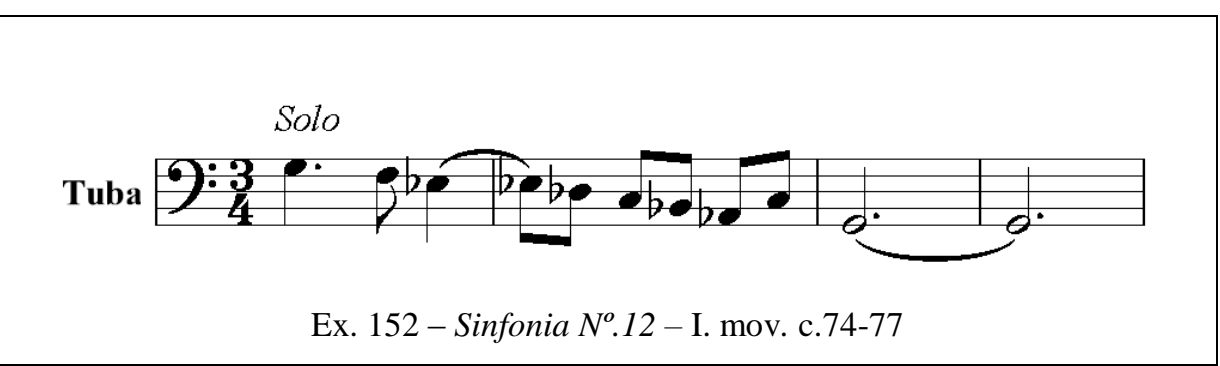

Embora no próximo trecho, Villa-Lobos grafou solo para o Trombone, encontra-se escrito na partitura, em compassos próximos, a palavra solo para Flautim e Fagote. Desta forma, não está claro quem é o solista desta frase. No entanto, o Trombone fica sozinho do c.84 até o c.88. A partir do c.88, o Trompete entra em conjunto com Trombone no inciso ternário, mas as madeiras estão movimentos melódicos em semicolcheia. Trecho com abundância de intervalos de $5^{\text {a }}$. Ex. 153:

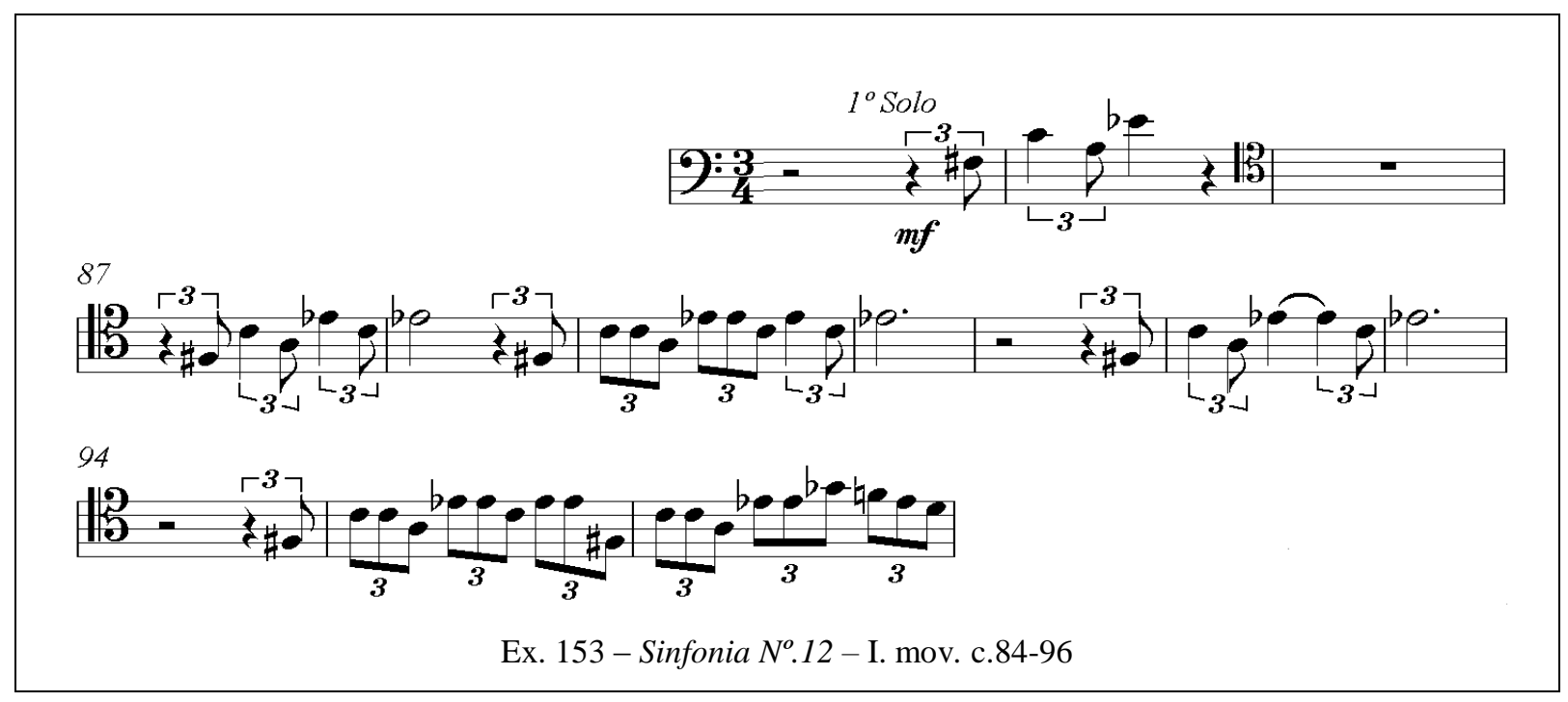

Trecho longo, onde o Trombone baixo estará em conjunto com Oboés, Corne Inglês, Clarinetes, Clarone e Trompetes, numa frase nova com ideia de background, onde a primeira semifrase é ritmicamente diferente da segunda (Ex. 154). 


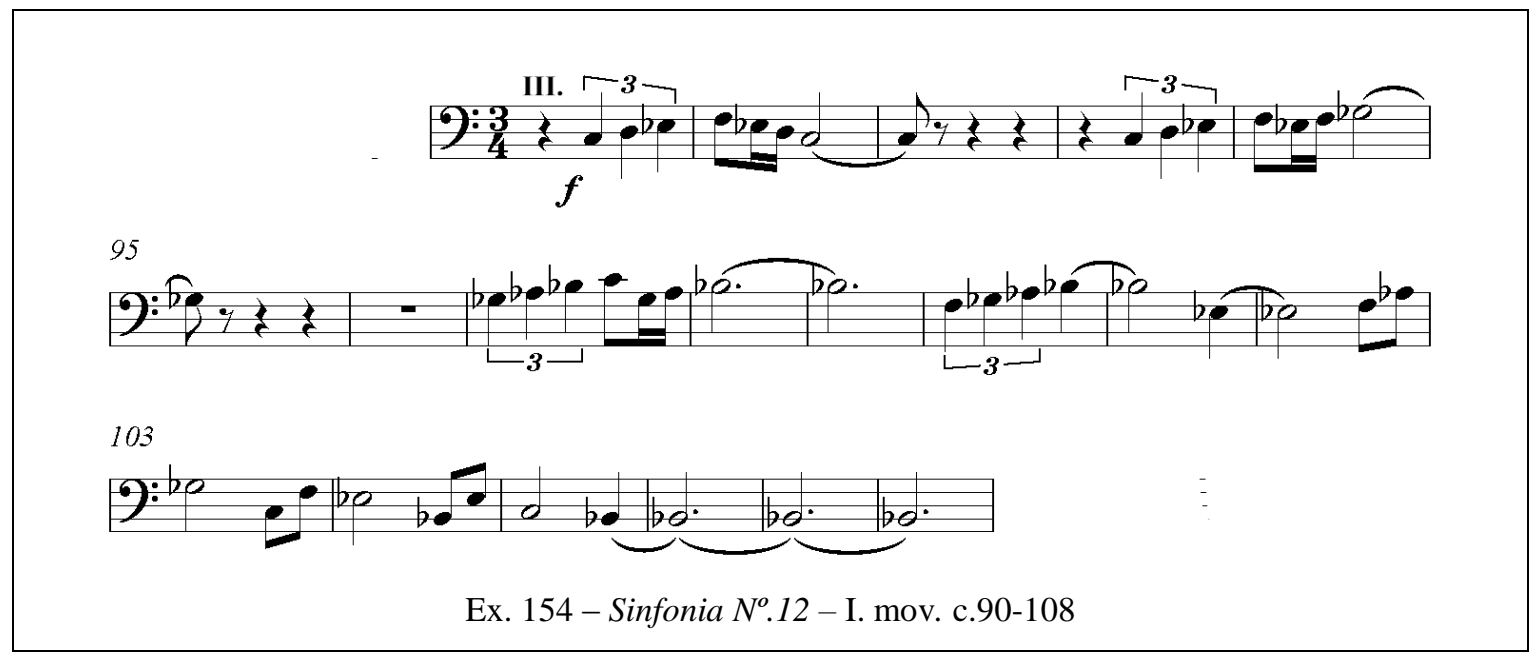

O inciso novo (com tercinas de semínima ao início e recheado de intervalos de $6^{\mathrm{a}}$. e $7^{\mathrm{a}}$.) é recapitulado pelo Trombone, num tutti orquestral em conjunto com: Trompas, Trompetes e Cordas. Não há contraponto nesse momento: a orquestra se mantém em pausas. Essa frase se divide em duas semifrases bem distintas em termos de utilização de figuras rápidas em contraponto às figuras mais longas, para a segunda semifrase (Ex. 155).

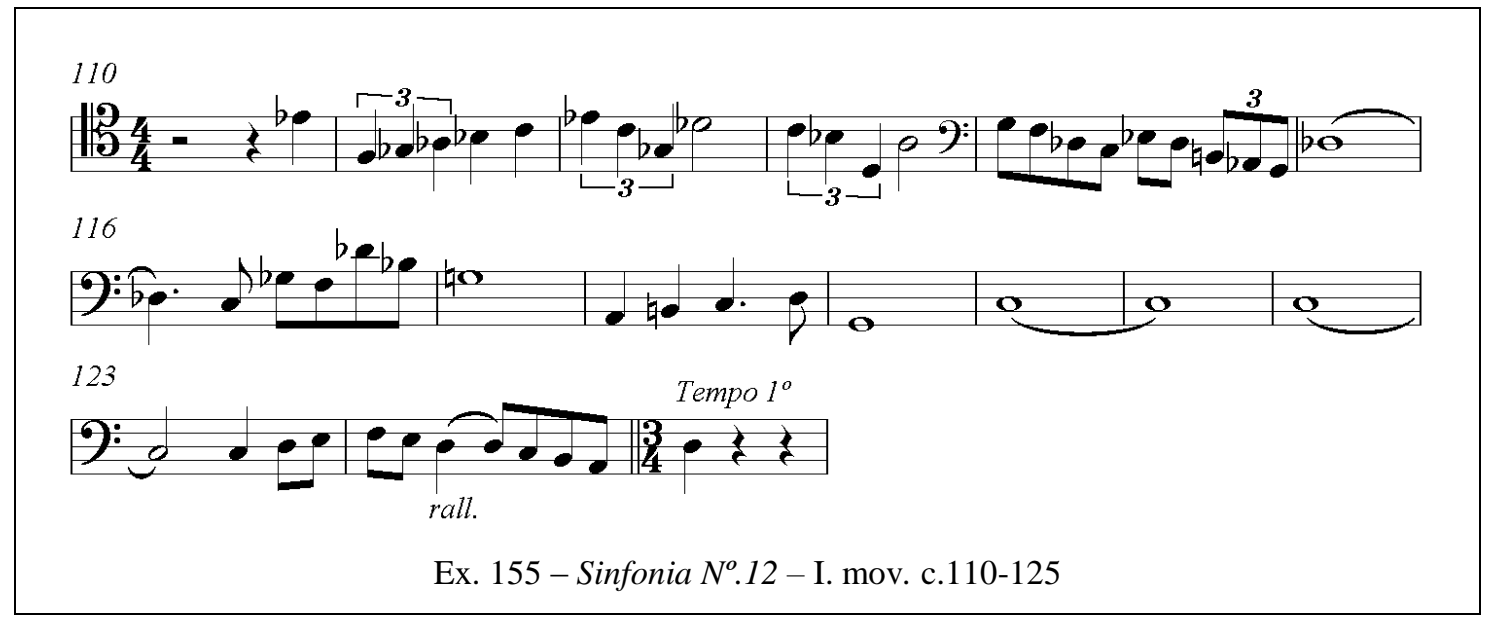

O $1^{\circ}$. Trombone recapitula em dinâmica $f$, o inciso principal desse movimento, em conjunto com Violinos e Violas. Não há acompanhamento nesse momento, apenas nota longa de base feita pelos Fagotes, Contrafagote, Violoncelo e Contrabaixo (Ex. 156).

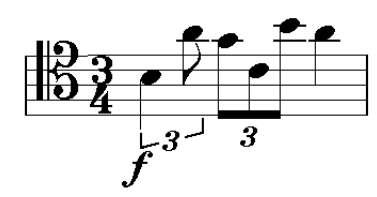

Ex. 156 - Sinfonia $N^{o} .12-$ I. mov. c. 142 
Em complemento melódico a um movimento escalar cromático descendente iniciado no c.149 pelos Oboés, Corne Inglês, Clarinetes, Fagotes e Violoncelos, a Tuba participará (c.151) dos três últimos tempos do movimento (os Trombones apenas participarão dos dois últimos). Trecho sem articulação alguma. Ex. 157:

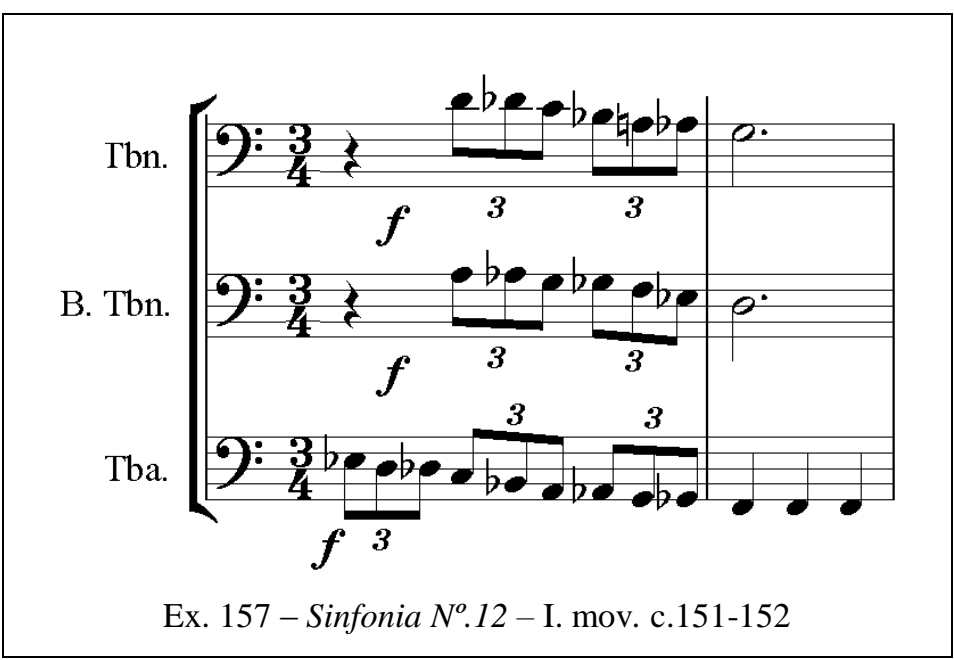

Apenas os metais graves têm esse inciso com aparência de movimento escalar ascendente (c.159-160 - Ex. 158). Concomitantemente haverá nesse momento, mais dois incisos simultâneos (arpejos descendentes nas cordas e movimento estático com mordente inferior ao final nas madeiras).

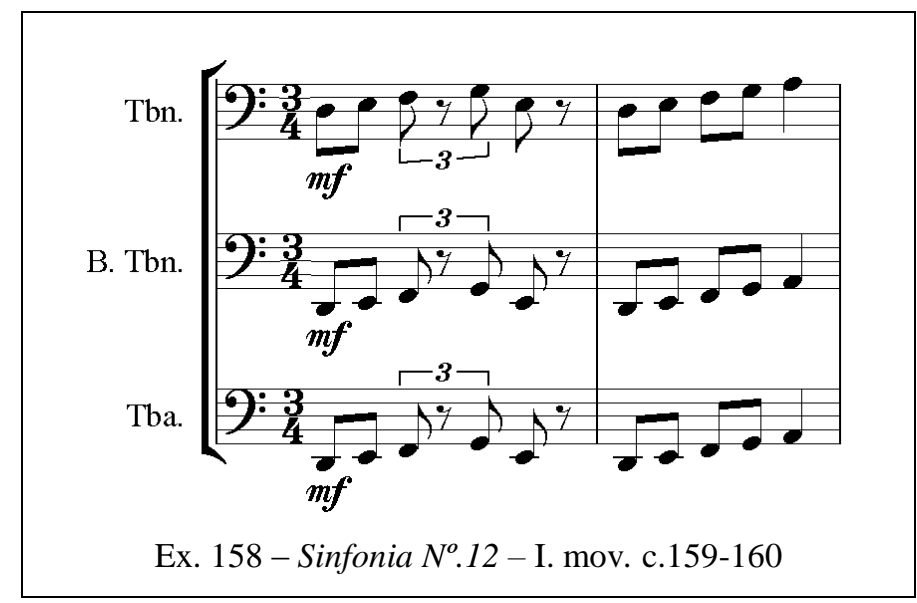

O próximo inciso, com apenas um intervalo de $6^{\mathrm{a}}$., foi escrito apenas para o Trombone. As Trompas respondem em eco esse chamamento do Trombone. No entanto, a tuba estará em conjunto com Fagotes, Contrafagote e Contrabaixo (Ex. 159). 


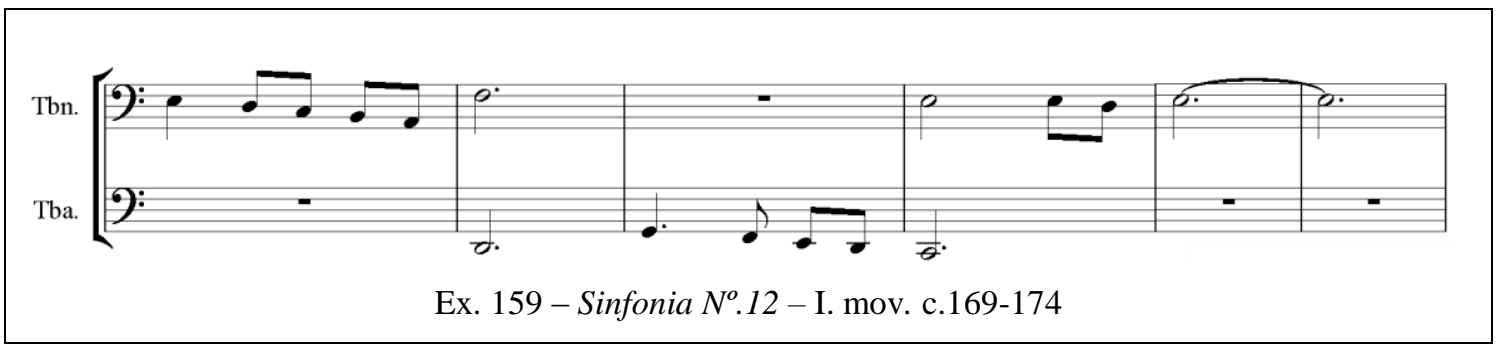

Estamos no segundo movimento. Neste, o Trombone aparece no c.15, num motivo arpejado descendente, em sestinas, como finalização (pirâmide) da ideia melódica iniciada pelas cordas e madeiras no c.14. Em igual força $(\boldsymbol{p})$ estão madeiras e metais, mas Villa-Lobos preferiu, seguramente por uma questão de equilíbrio sonoro, destinar uma dinâmica acima (mf) para as cordas. A articulação geral foi o estacato ( . ). A próxima entrada (c.23) será um eco do inciso apresentado pelas cordas em c.19-22 em conjunto com as Trompas (Ex. 160).

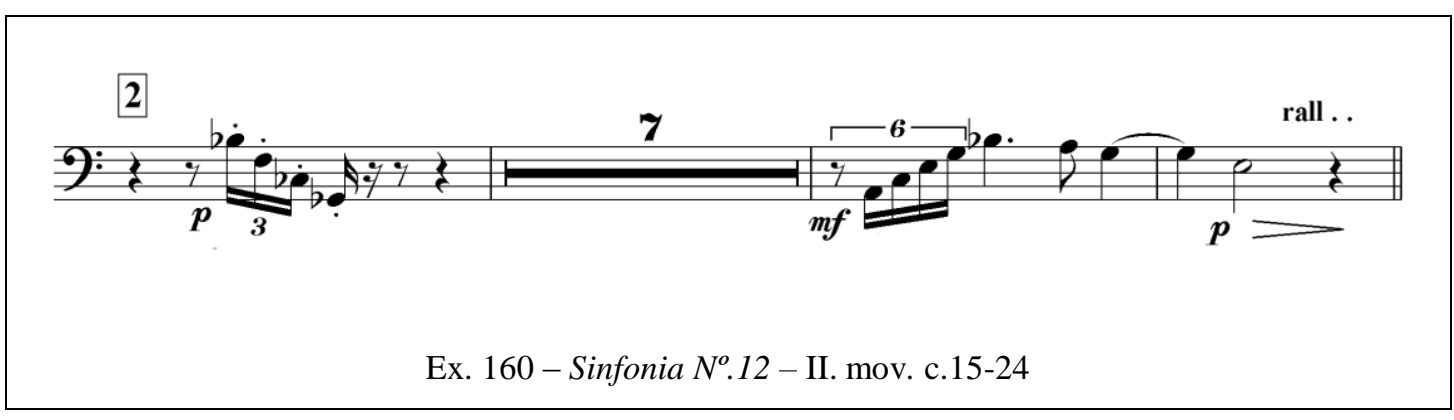

Em c.45-47, Villa-Lobos criou pirâmides de três colcheias onde o Trombone participou do segundo grupo em conjunto com as Trompas, porém a dinâmica praticada foi a mesma ( $\boldsymbol{m} \boldsymbol{f})$. Em c.48 Villa-Lobos, apenas os metais graves foram incumbidos de executar a sequência completa culminando em arpejos descendentes de tercinas em semínimas, concomitante com as cordas, no entanto em dinâmica $f$ (Ex. 161):

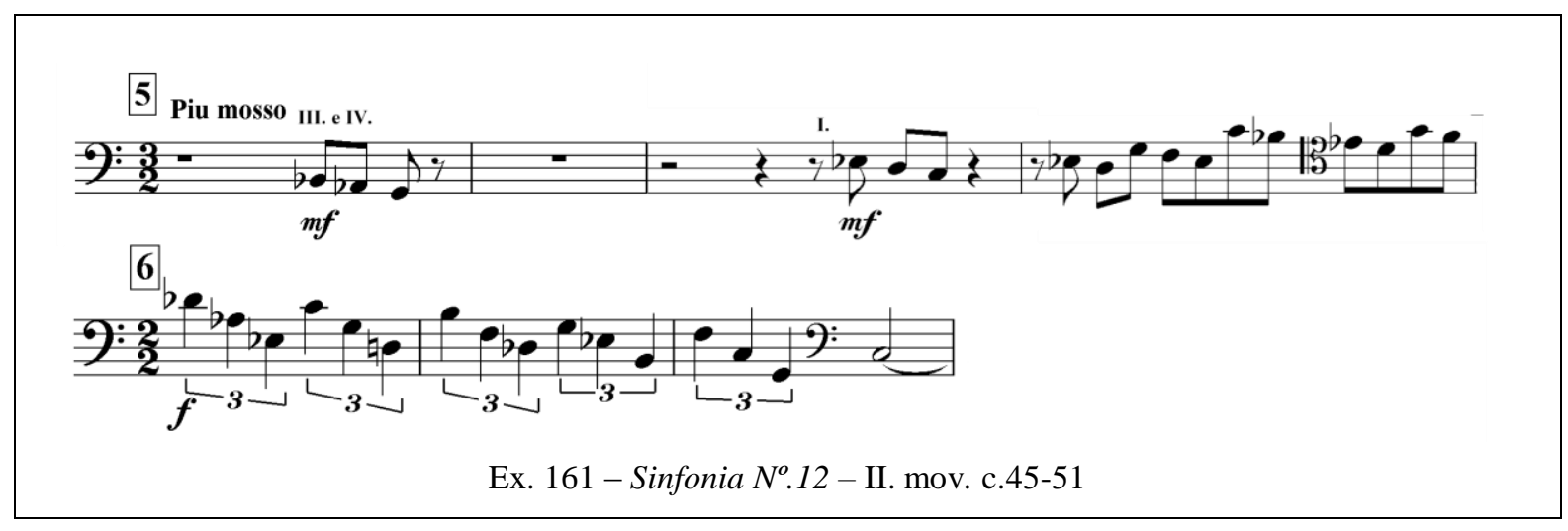


Em c.61 os metais graves fazem um contraponto, contendo dois intervalos de $6^{\mathrm{a}}$. e um de $7^{\text {a }}$, ao tema apresentado pelas Flautas, Trompa e cordas agudas (grupo 1). Junto aos metais graves estão Clarone, Fagote, Contrafagote, Violoncelo e Contrabaixo ${ }^{99}$, num claro papel de background ao tema do grupo 1 (|Ex. 162):

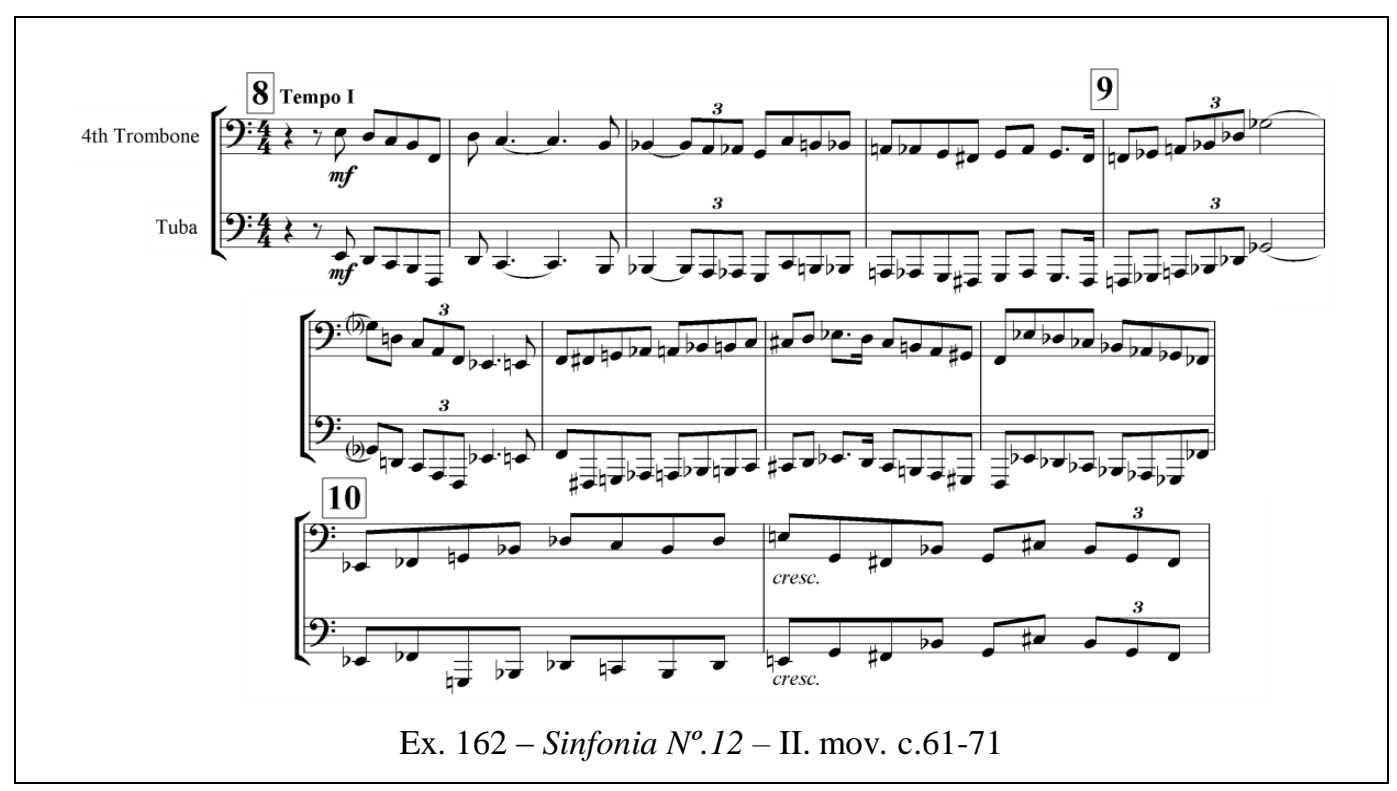

No entanto no $3^{\circ}$. movimento, os Trombones fazem sua primeira participação em foreground no c.43-44. Nesse local, Villa-Lobos grafou uma resposta em forma de eco, ao inciso em forma de arpejo, apresentado pelo Clarinete e Fagote (c.41-42) em dinâmica $f$. Estes mesmos instrumentos fazem acompanhamento ao eco dos Trombones com articulação em estacato e dinâmica $\boldsymbol{m f}$ (Ex. 163).

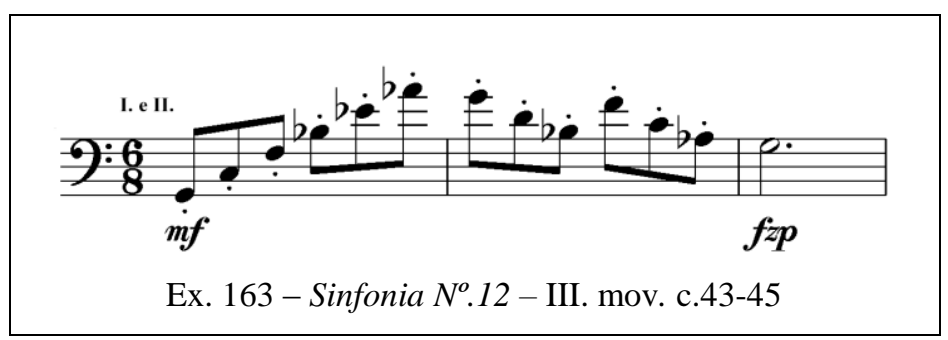

As madeiras fazem um inciso bem característico de 6/8 no c.55-56. Para esse inciso em região aguda, Villa-Lobos criou uma resposta em colcheias intermitentes onde os graves (Clarone, Fagote, Contrafagote, Tuba, Violoncelo e Contrabaixo) em clara ideia de contraste de cores, fazem três respostas ao inciso agudo (a terceira sofrerá mudança rítmica e uma ampliação). Nesse inciso dos graves teremos vários intervalos de $5^{\mathrm{a}}$. e $4^{\mathrm{a}}$. (Ex. 164):

${ }^{99}$ Em verdade, os também graves das madeiras e cordas. 


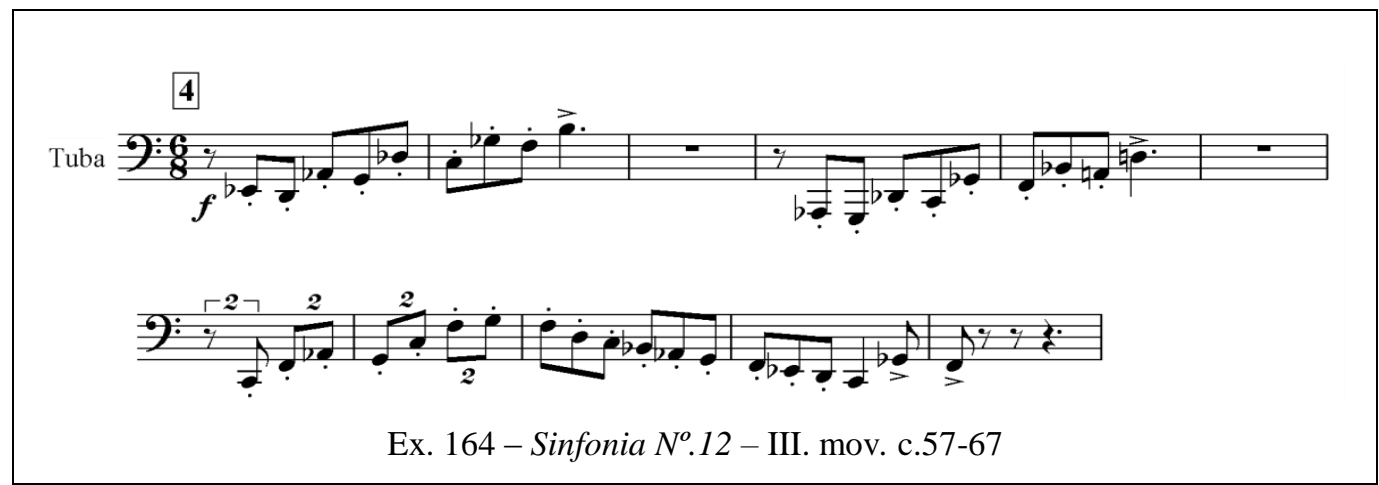

Os Trombones fazem uma resposta em eco em intervalos de $4^{\text {a }}$. (c.78-80) para o tema secundário $^{100}$ exposto em c.74-77 pelas Trompas e Trompetes. Porém o fechamento da semifrase, os Trombones estarão em conjunto com as Trompas graves (Ex. 165).

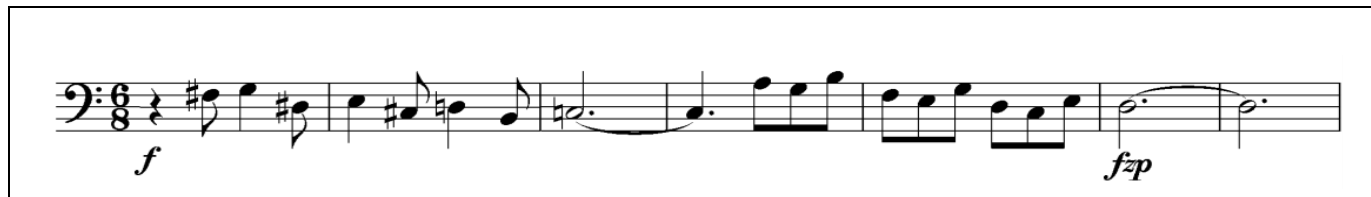

Ex. 165 - Sinfonia $N^{o} .12$ - III. mov. c.78-84

Numa sequência de incisos em forma de arpejos (c.89-103), Villa-Lobos criou um contraste melódico ao atribuir para os trombones, um inciso cromático descendente (c.93-94) em conjunto com as Trompas e em articulação estacato (Ex. 166):

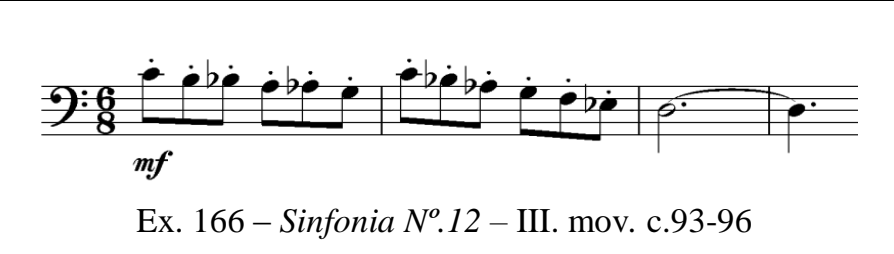

As madeiras têm o tema principal (c.117-140) em seu domínio. Villa-Lobos criou um inciso secundário polarizado na nota Dó e o designou para os Trombones (em surdina c.125-128) enquanto os Violinos fazem um eco ao tema das madeiras (Ex. 167).

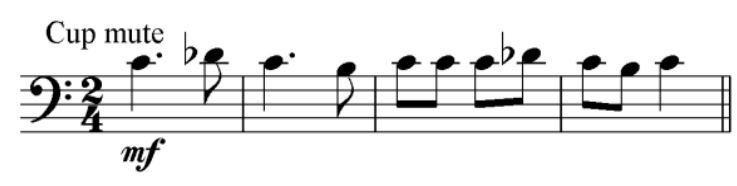

Ex. 167 - Sinfonia $N^{o} .12$ - III. mov. c. $125-128$

${ }^{100} \mathrm{O}$ tema principal foi escrito nas cordas. 
Os Fagotes iniciaram um tema secundário aos Violinos do c.141-189. Villa-Lobos copiou o inciso para os metais graves em c.157-158 e c.165-168. Para equilíbrio sonoro, Villa-Lobos grafou a dinâmica $\boldsymbol{f}$ para os fagotes e $\boldsymbol{m} \boldsymbol{f}$ para os metais graves e Tímpanos. Todos têm articulação em estacato. Destaque deve ser dado à sequência de arpejos escrita para Tuba, de difícil execução. Ex. 168:

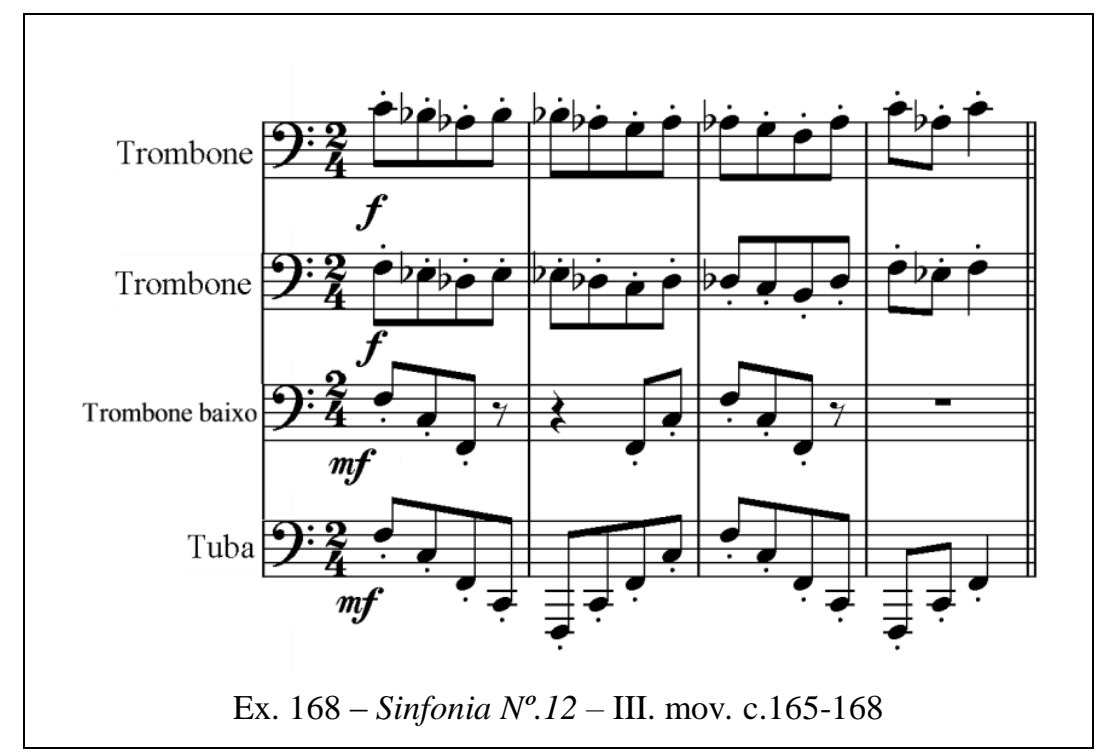

Como Coda para a parte em 2/4, Villa-Lobos deixou a cargo dos graves da orquestra (Contrafagote, metais graves, Violoncelos e Contrabaixos) um inciso em movimento escalar descendente, claramente no papel de foreground, nos c.200-204. A dinâmica ficou estabelecida em $\boldsymbol{m} \boldsymbol{f}$ e articulação estacato (Ex. 169).

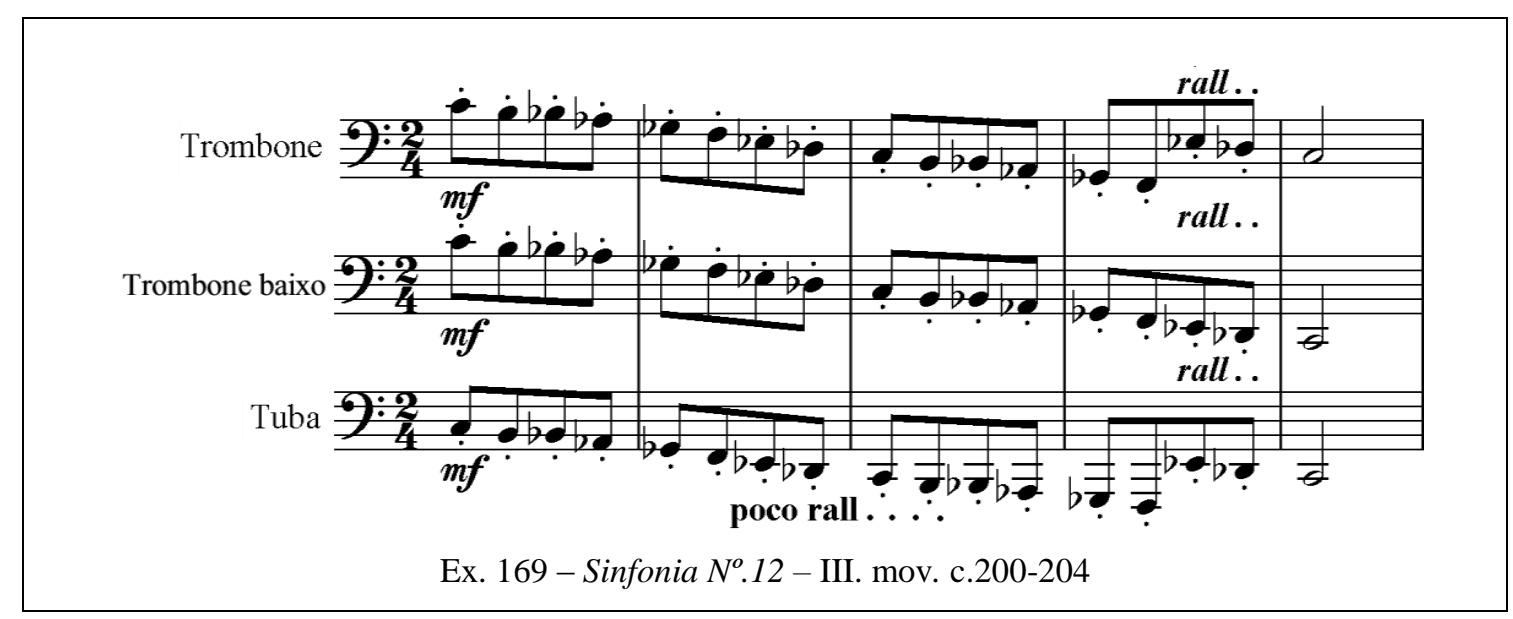

Villa-Lobos recapitula o 6/8 em c.205. A partir desse compasso, o compositor criou a ideia de dois temas antecedentes (arpejos) e um consequente (intervalar e escalar 
descendente) exposto nas cordas e depois nas madeiras, e por fim retornando às cordas (ABA). Como possibilidade composicional, Villa-Lobos aproveitará essa ideia de consequente para criar sua Coda à esse movimento, iniciando pelos graves orquestrais (Corne Inglês, Clarinete, Clarone, Fagote, Tuba, Viola, Violoncelo e Contrabaixo) e depois passando a ideia de consequente para os agudos (Flautim, Flauta, Trompete e Violinos), numa clara ideia de diálogo entre grave e agudo e o contraste de cores que essa técnica agrega. Ex. 170:

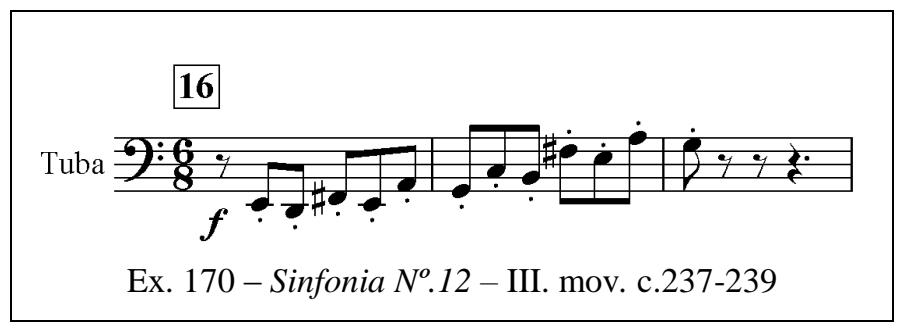

Apenas a Tuba e o Trombone baixo iniciam o $4^{\circ}$. e último movimento. Este movimento têm um inciso melódico em forma de arpejo, mas dentro de uma polirritmia simultânea criada por Villa-Lobos, onde os Violinos, Violas e Trompetes têm subdivisão binária sobre o Corne Inglês, Clarinete, Fagotes, Contrafagote, Trombone baixo, Tuba, Violoncelo e Contrabaixo com subdivisão em quiálteras de colcheia (c.1). Porém em c.4 com a entrada do restante dos Trombones, quem regerá o compasso será apenas a subdivisão por tercinas de colcheia. Em c.7, o Trombone cita o $1^{\circ}$. Inciso exposto pelos Violinos, Violas e Trompete (c.2) - Ex. 171:

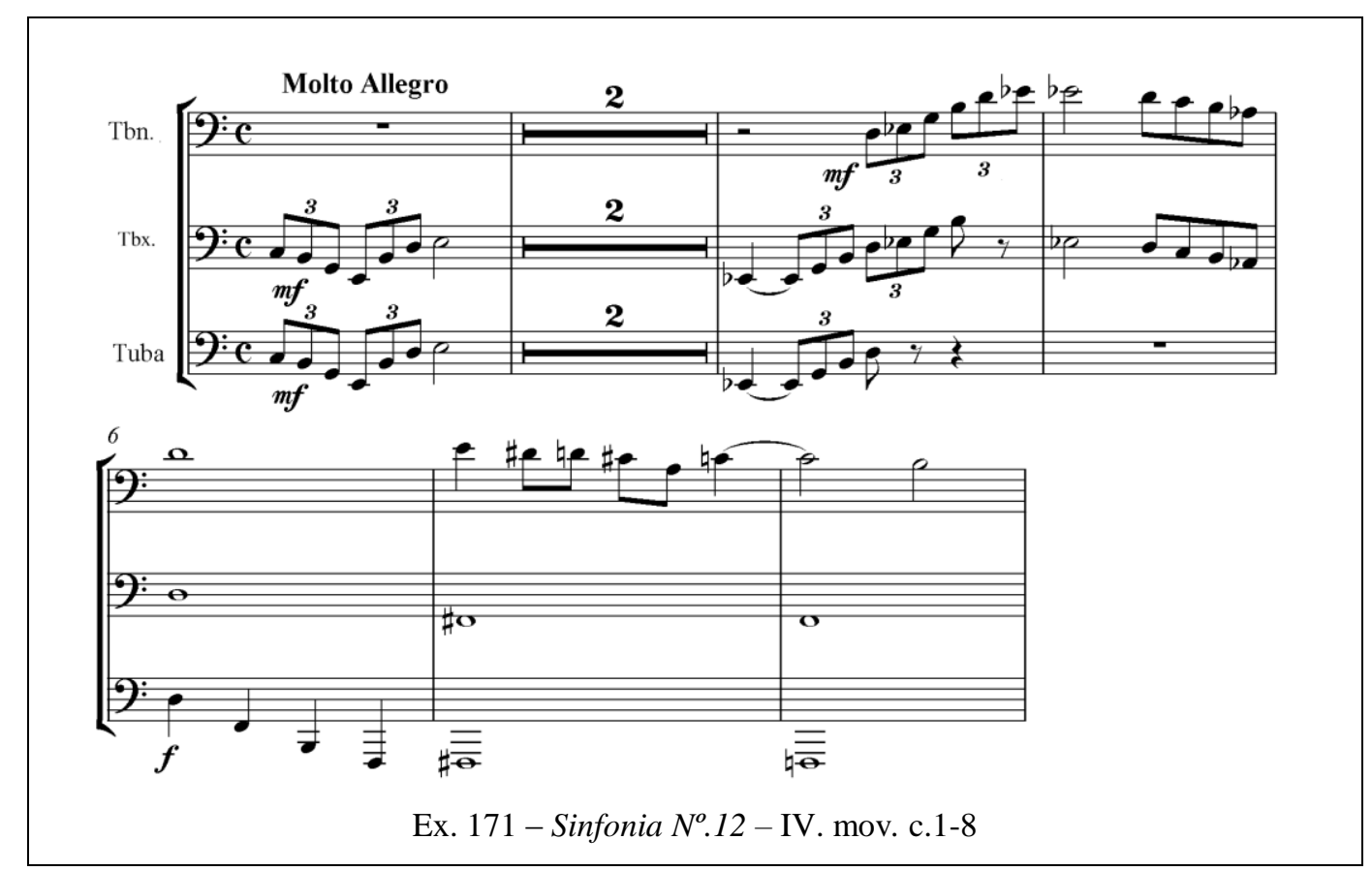


A partir do c.11, Villa-Lobos cria uma pirâmide com base no movimento escalar descendente (tetracorde) em semicolcheias, culminado no c.13. A terminação para essa semifrase será com a mesma base intervalar, porém Villa-Lobos fez com que os graves (Fagotes, Contrafagote, Trombone baixo, Tuba e Contrabaixo), mais lentos por natureza, se utilizassem de colcheias (Ex. 172).

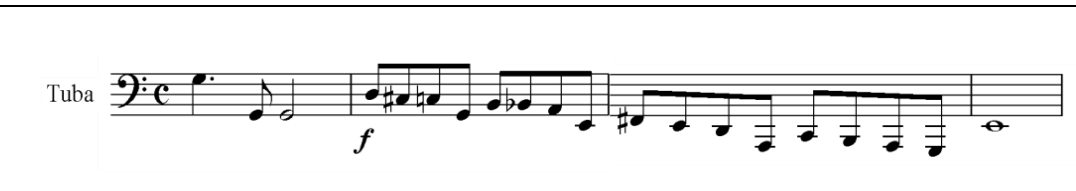

Ex. 172 - Sinfonia $N^{o} .12-$ IV. mov. c.13-16

Em c.33, Villa-Lobos criou um novo tema para cordas e madeiras. A ideia de contraponto para esse novo tema, é muito próxima do tema (sequencia de arpejos em colcheias). Os metais graves fazem esse contraponto em conjunto com Violoncelos, Contrabaixo, Fagotes e Contrafagote). Ex. 173 e 174:
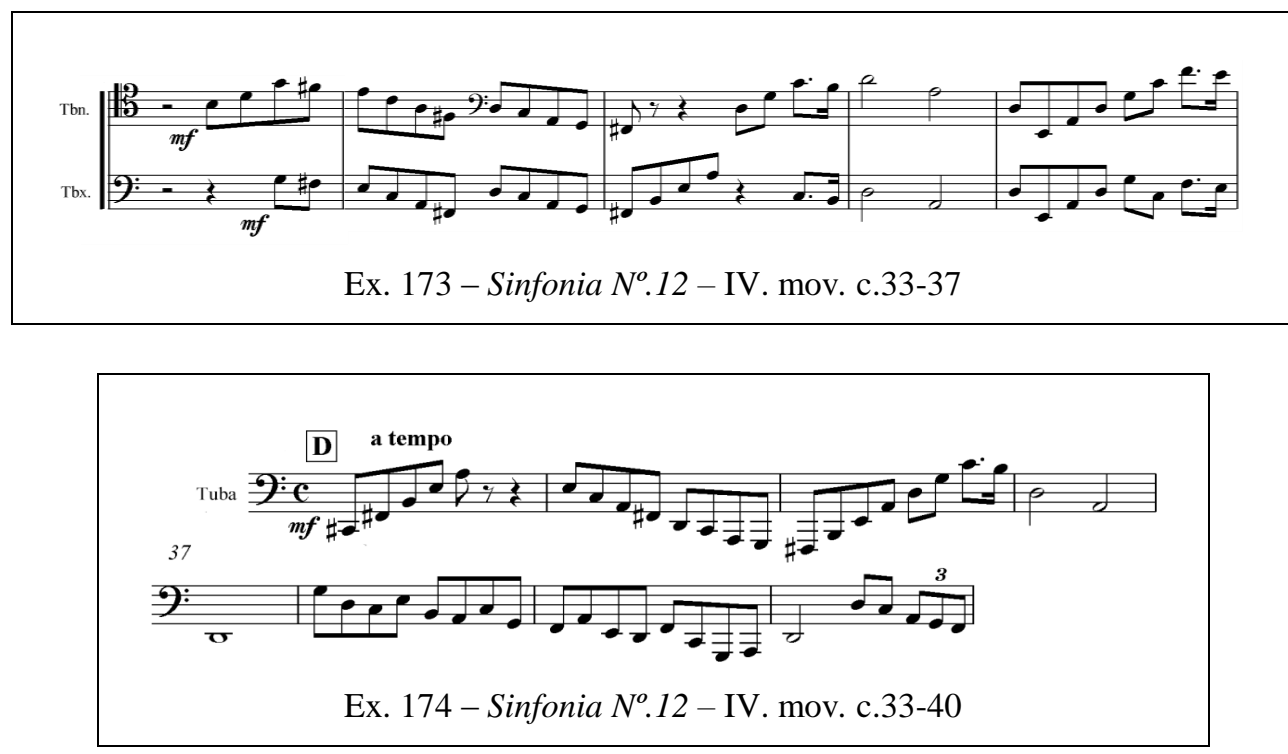

Em c.43 [5], Villa-Lobos criou para o conjunto Trompete, Violino e Viola um novo tema com base rítmica em tercina de semínima. Trombones, em solo, fazem um eco a esse novo tema em c.44 e o mesmo grupo repete, pela $3^{\mathrm{a}}$. vez, o tema em c.45 (Ex. 175).

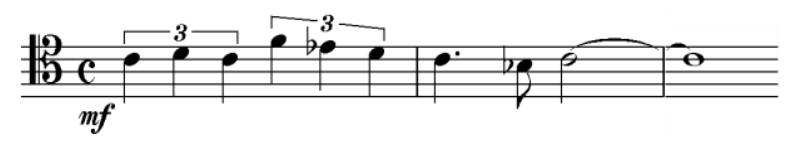

Ex. 175 - Sinfonia $N^{o} .12$ - IV. mov. c. $44-46$ 
Após uma pequena espera, os trombones foram brindados com um coral a três vozes escrito como base harmônica para o solo de Flauta (c.63-75). Um trecho onde tocam apenas Flautas, trombones e um ostinato em tercinas de semínimas feito pelos Tímpanos. Há ainda nas cordas, uma nota longa, em forma de tetracorde, mantida durante todo o coral. Nesse caso, percebe-se a técnica da separação entre o solista e o tutti pela independência rítmica (Ex. 176).

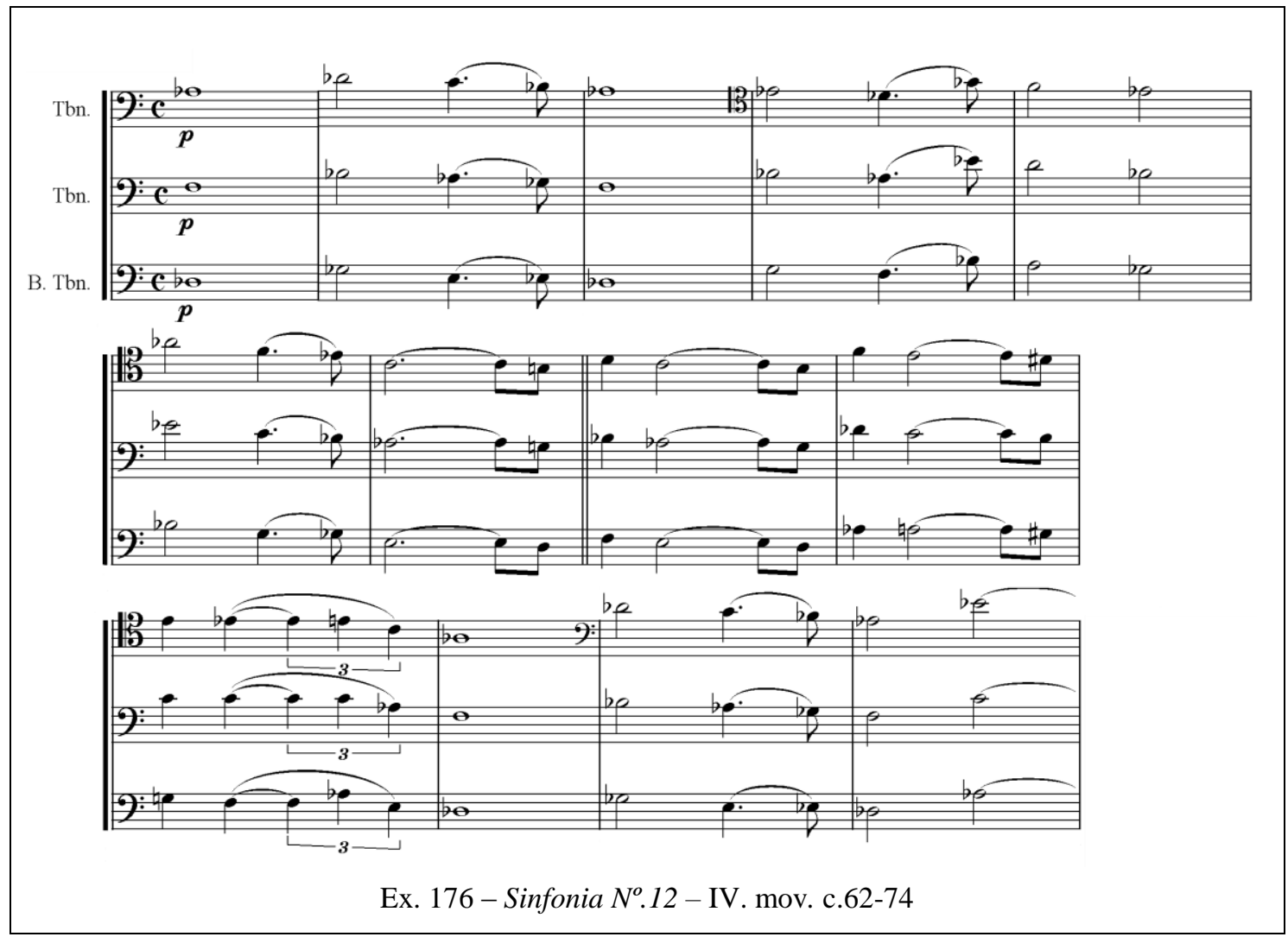

O início da Coda será marcado por polirritmias de semicolcheias (Violinos e Trompas) e tercinas de colcheia (o restante da orquestra). Como é sabido, os graves são mais lentos, logo Villa-Lobos dedicou colcheias (ao invés de semicolcheias) para esse grupo mais lento. E será dentro desse caos rítmico que os Trombones participarão do inicio da Coda (Ex. 177): 


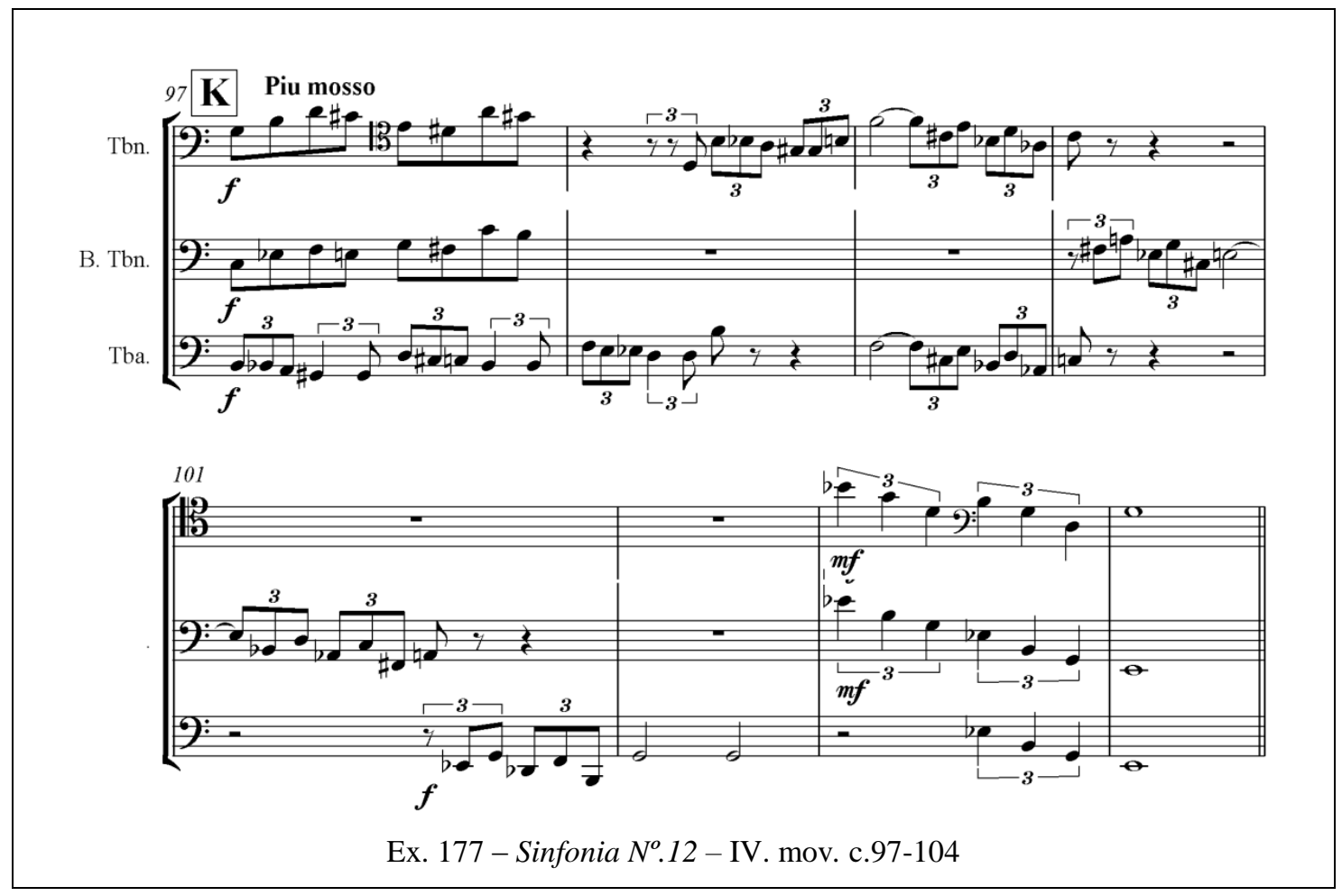

Em c.118 os Trombones fazem um eco em resposta ao tema secundário exposto pelo Clarone, Fagote, Contrafagote, Tuba, Violoncelo e Contrabaixo (c.117). Nesse trecho teremos um intervalo de $5^{\text {a }}$. e outro de $6^{\text {a }}$. (Ex. 178):

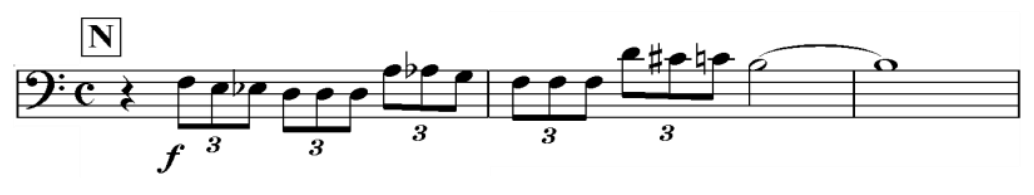

Ex. 178 - Sinfonia $N^{o} .12$ - IV. mov. c. $118-120$

Em c.117 a Tuba estará com o tema secundário, em parceria com Clarone, Fagotes, Contrafagote, Violoncelos e Contrabaixos. Nesse trecho teremos novamente intervalos de $5^{\mathrm{a}}$. e $6^{\mathrm{a}}$ (Ex.179).

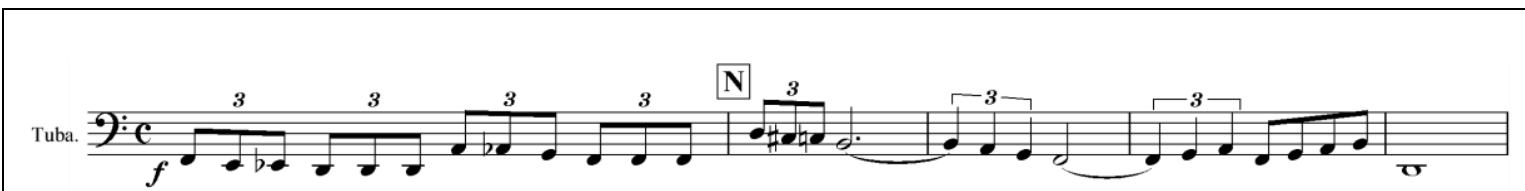

Ex. 179 - Sinfonia $N^{o} .12$ - IV. mov. c.117-121

Um novo inciso, em semínimas, que se inicia em c.129 tem como base melódica o movimento escalar descendente. Trombones e Trompas terão o mesmo desenho melódico. O 
próximo inciso se inicia em c.132 e tem como base rítmica a tercina de semínima. $\mathrm{O}$ trombone no c. 133 estará junto à Trompa com ideia de tercina de semínima na segunda metade com compasso. O responsável pelo $1^{\circ}$. grupo de tercinas, são os tímpanos (Ex. 180).

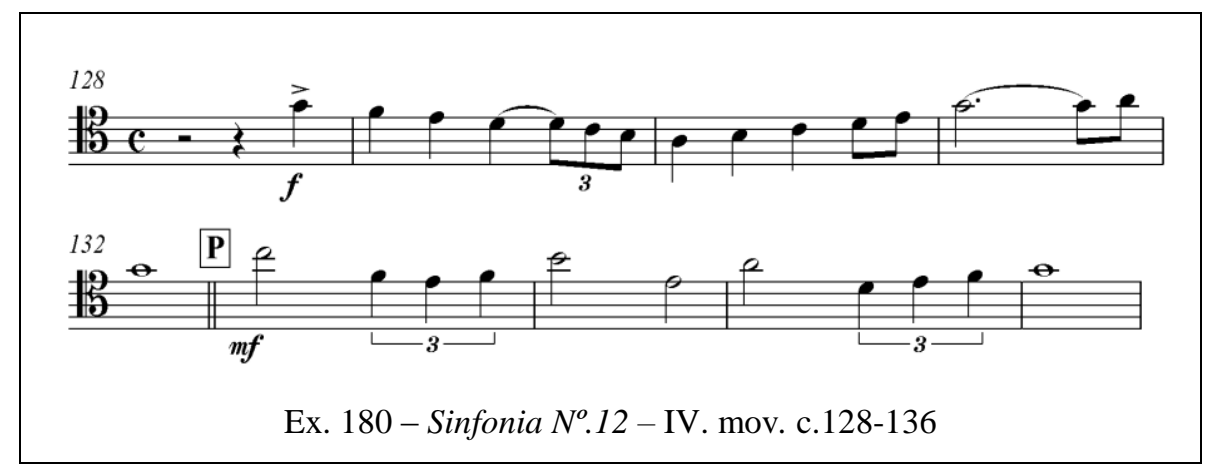

Os trombones terminarão a peça com uma série de notas longas (mínimas em tercinas ou semibreves). Em termos de utilização dos metais graves na peça Sinfonia $N^{o} .12$, num total de 687 compassos, os metais graves atuaram no $1^{\circ}$. movimento em 123 compassos $(60,89 \%)$ e ficaram em descanso por 79 compassos (39,11\%); no $2^{\circ}$. movimento em 31 compassos $(40,79 \%)$ e não tocaram por 45 compassos $(59,21 \%)$; no $3^{\circ}$. movimento em 99 compassos $(39,92 \%) 149$ compassos foram de pausas $(60,08 \%)$; e por fim no $4^{\circ}$. movimento em 103 compassos $(63,98 \%) 58$ compassos são de contagem(36,02\%). Genericamente analisando, num total de 687 compassos, os metais graves tocaram por 356 compassos $(51,82 \%)$ e ficaram em contagem por 331 compassos $(48,18 \%)$. Teremos dois compassos em soli no $1^{\circ}$. Movimento (c.84-85) e cinco compassos em solo ( $1^{\circ}$. movimento c.74-75 e $2^{\circ}$. movimento c.44-46). Nesta peça, por completo, não se localizou glissandos.

Em relação às dinâmicas utilizadas por Villa-Lobos para os metais graves, na peça Sinfonia $N^{o} .12^{101}$ localizou-se no $1^{\circ}$. movimento apenas uma ocorrência para as dinâmicas $f f$ e $p \boldsymbol{p}$; duas ocorrências para $\boldsymbol{p}$; oito para $\boldsymbol{m f}$ e onze ocorrências para $\boldsymbol{f}$; no $2^{\circ}$. movimento quatro ocorrência para a dinâmica $\boldsymbol{p}$ e cinco ocorrências para $\boldsymbol{m f}$; no $3^{\circ}$. movimento apenas uma ocorrência para a dinâmica $\boldsymbol{p p}$; sete ocorrências para $\boldsymbol{f}$; oito para $\boldsymbol{p}$ e dez ocorrências para $\boldsymbol{m} \boldsymbol{f}$; e finalmente no $4^{\circ}$. movimento apenas uma ocorrência para a dinâmica $f f$; duas ocorrências para $\boldsymbol{p}$; sete para $\boldsymbol{f}$ e onze ocorrências para $\boldsymbol{m f}$; em termos de somatória as dinâmicas ficaram com o seguinte quadro: duas ocorrências para $\boldsymbol{p}$ e $f \boldsymbol{f} ; 16$ ocorrências para $\boldsymbol{p} ; 25$ ocorrências

${ }^{101}$ Villa-Lobos compôs 12 Sinfonias. Destas, apenas a Sinfonia $N^{o} .5$ não contêm metais graves em sua orquestração. 
para $\boldsymbol{f}$; e a mais utilizada foi a dinâmica $\boldsymbol{m f}$ com 34 ocorrências. Não se encontrou ocorrência qualquer para a dinâmica $\mathbf{m p}$.

Quanto às articulações escritas por Villa-Lobos, encontrou-se no $1^{\circ}$. movimento apenas dois acentos e dois estacatos; três $\boldsymbol{s f} z$; oito ligaduras; dezoito tratinas/tenuto e por fim, 449 notas sem articulação alguma; no $2^{\circ}$. movimento apenas um $\mathbf{s f} z$; nove estacatos; e 127 notas sem articulação alguma; no $3^{\circ}$. movimento encontramos quatro $s f z$; nove acentos; 35 notas sem articulação alguma e 160 notas com articulação em estacato; e no último movimento $\left(4^{\circ}\right.$.) apenas um $s f z$ e acento; oito estacatos; onze ligaduras e 348 notas sem articulação alguma.

Totalizando todas as articulações (1.196 notas), teremos: nove $s f z(0,75 \%) ; 12$ acentos (1\%); 18 tratinas/tenuto $(1,51 \%) ; 19$ ligaduras (1,59\%); 179 estacatos $(14,97 \%)$ e 959 notas $(80,18 \%)$ sem articulação alguma.

“[...] Sou filho da natureza. Sempre senti necessidade de enfrentá-la, de aprofundar-me nela, de sondá-la.[...]", Villa-Lobos. 
Villa-Lobos e os metais graves sinfônicos:

Um estudo dos elementos técnicos específicos

CAPÍTULO 6:

\section{Abordagens de caráter analítico e resultados}

"A arte é a religião da alma humana. Os adeptos são os crentes fervorosos do milagre da arte, na divina fé das coisas misteriosas. Um submisso respeito às leis da força oculta e na certeza da sua própria bondade espiritual. A música é uma das imagens desta religião caracterizada pelos sons. É a expressão sonora de todos os seres, governada pela convenção relativa dos homens através dos séculos", Villa Lobos. 


\section{INTRODUÇÃO}

Nesta pesquisa, a delimitação do objeto, a construção dos objetivos, das hipóteses e da metodologia que a norteiam foram etapas realizadas apenas pelo pesquisador e seus alunos nos cursos de graduação e profissionalizantes. A escolha desse objeto foi referendada pelo orientador, tendo em vista a sua coerência com os propósitos gerais e o marco da investigação, relacionada às estratégias interpretativas dentro do ambiente sinfônico. No que se refere aos músicos envolvidos na pesquisa, cabe destacar algumas características do perfil: sua trajetória profissional e o perfil acadêmico dos envolvidos favoreceram o compartilhamento de visões acerca das abordagens metodológicas que deveriam ser utilizadas no projeto, propiciando que assumissem uma atribuição relevante no processo de elaboração do projeto de pesquisa.

Por outro lado, alguns músicos acumulavam experiência em didática e participação em grupos sinfônicos e tenderam a interferir nas escolhas da pesquisa. Na verdade, é bastante comum a alternância de pessoas em instituições acadêmicas e atuando em grupos sinfônicos brasileiros. Cabe também questionar se uma definição precisa de papéis não acaba sendo artificial em um modelo de pesquisa "interativa". Nesse tipo de pesquisa, a negociação entre a pesquisa e os músicos envolvidos é permanente e implica um processo contínuo de troca e aprendizado mútuo. Dessa forma, é esperado que a pesquisa, desde a sua formulação original, seja resultado das relações estabelecidas entre pesquisador e os músicos em um processo de construção coletiva, onde os diferentes grupos aportam suas vivências e diferentes visões sobre a realidade que se pretende investigar.

Por outro lado, a interferência do pesquisador em todos os momentos do desenvolvimento do projeto, incluindo o desenho metodológico da pesquisa, repercutiu, de fato, nos aportes do estudo para a tomada de decisão. A experiência analisada sugere que, mesmo buscando uma interação permanente, os conceitos e teorias em jogo, as hipóteses a serem testadas, assim como a eleição das variáveis de análise musical poderão fornecer novos e melhores insumos à pesquisa, na medida em que forem preservados alguns espaços próprios de atuação. 
O enfoque dado à análise do processo decisório dos trechos orquestrais fez com que a pesquisa se desenvolvesse pari passu a esse processo, ou seja, condicionou o andamento da investigação ao seu próprio objeto, trazendo repercussões para a relação com a pesquisa. Em primeiro lugar, fez com que as características específicas e o ponto de domínio técnico dos músicos influenciassem o desenvolvimento da pesquisa. Em segundo, assumiu-se que as contribuições e resultados da pesquisa viessem a ser consideradas ao longo do processo decisório. Esses dois aspectos implicaram ajustes frequentes dos tempos destinados a cada peça e métodos empregados, na adoção de novos rumos para a pesquisa, assim como de estratégias de articulação entre pesquisador e músicos.

O objeto da pesquisa - os metais graves em Villa-Lobos - sempre esteve acessível, mas considera-se aqui, inovadora para os estudos específicos sobre esse autor, visto que há pouca tradição em se analisar a orquestra de trás para frente: com enfoque nos instrumentos graves. Acrescente-se que as partituras, por sua própria configuração espacial, tornam bastante complexas sua visualização de baixo para cima.

Por outro lado, difícil foi disponibilizar as partes individuais no período inicial do estudo. Os motivos que explicam a fragilidade desse tópico são principalmente de ordem estrutural e institucional, com destaque para: (1) o Brasil não detém a guarda das partituras; (2) o museu Villa-Lobos e os manuscritos; (3) a baixa tradição em estudar esse compositor; (4) a baixa priorização da política pelos regentes em programar Villa-Lobos.

No entanto, fatores de ordem conjuntural, internos e externos às Orquestras Sinfônicas, também dificultaram o acesso às partes individuais. Entre os fatores externos, podemos citar as dificuldades surgidas no acesso público às partes que constavam de programações já executadas pelas mesmas. Entre os internos, os principais foram a grande instabilidade institucional, com trocas de dirigentes em momentos críticos, sejam daqueles que ocupavam posições mais estratégicas ou dos quadros mais técnicos gerando, dessa forma, descontinuidades e alterações no projeto conduzido no período. 
Esses elementos em conjunto - o caráter inicial, inovador e complexo do objeto e o contexto de instabilidade - causaram oscilações no processo de condução da pesquisa, produzindo incertezas para o projeto de investigação. Frente a tal quadro, a pesquisa buscou novas fontes e ampliaram o escopo da investigação, que envolveu a incorporação de outros referenciais teóricos, particularmente de biblioteca particular de músicos.

Com respeito às partituras, devemos elogiar o trabalho da ABM (Academia Brasileira de Música) na pessoa de seu conselho e o Maestro Roberto Duarte, pelas novas edições de algumas partituras as quais o acesso nos foi possível. Estas, além de um melhor tamanho do papel de impressão, possuem cabeças de notas muito bem visualizáveis e graças a essa nova configuração, pôde-se transcrever as partes individuais com mais precisão. Mas outra foi necessário trabalhar com os manuscritos originais - escrita manual e com cabeças de notas em fonte pequena e por vezes, dúbias em seu reconhecimento exato dentro do pentagrama.

\section{1 - Utilização dos metais graves nas peças analisadas ${ }^{102}$}

\begin{tabular}{c|c|c|c|c|c|c|c|c|c|c}
\hline & Peça & $\begin{array}{c}\text { Compassos } \\
\text { totais }\end{array}$ & $\begin{array}{c}\text { Compassos } \\
\text { tocados }\end{array}$ & $\%$ & Pausas & \% Pausas & Soli & Solo & Gliss. & $\begin{array}{c}\text { Gliss. fora } \\
\text { do êmbolo }\end{array}$ \\
\hline 1 & Uirapurú & 381 & 215 & 56,43 & 166 & 43,57 & 47 & 2 & 3 & 2 \\
\hline 2 & Amazonas & 333 & 207 & $\mathbf{6 2 , 1 6}$ & 126 & 37,84 & 33 & - & 3 & 4 \\
\hline 3 & Choros $N^{o} .4$ & 121 & 116 & $\mathbf{9 5 , 8 7}$ & 5 & 4,13 & - & 12 & 6 & 3 \\
\hline 4 & Choros $N^{o} .6$ & 758 & 377 & 49,74 & 381 & 50,26 & 28 & - & - & 4 \\
\hline 5 & Choros $N^{o} .10$ & 292 & 154 & 52,74 & 138 & 47,26 & 21 & 23 & 1 & 4 \\
\hline 6 & $\begin{array}{c}\text { Bachianas } \\
N^{o} .2\end{array}$ & 464 & 163 & 35,13 & 301 & $\mathbf{6 4 , 8 7}$ & $\mathbf{5 9}$ & $\mathbf{2 8}$ & $\mathbf{7}$ & $\mathbf{1 0}$ \\
\hline 7 & $\begin{array}{c}\text { Concerto para } \\
\text { violão }\end{array}$ & 162 & 94 & 58,02 & 68 & 41,98 & 1 & - & - & - \\
\hline 8 & Sinfonia $N^{o} .12$ & 687 & 356 & 51,82 & 331 & 48,18 & 7 & - & - & - \\
\hline
\end{tabular}

Tab.12 - Utilização dos metais graves nas peças analisadas

${ }^{102}$ Por compasso completo. 
Villa-Lobos e os metais graves sinfônicos:

Um estudo dos elementos técnicos específicos

\section{2 - Dinâmicas grafadas para os metais graves nas peças analisadas}

\begin{tabular}{c|c|c|c|c|c|c|c|c|c|c}
\hline & Peça & $\boldsymbol{p p p}$ & $\boldsymbol{p p}$ & $\boldsymbol{p}$ & $\boldsymbol{m p}$ & $\boldsymbol{m f}$ & $\boldsymbol{f}$ & $\boldsymbol{f f}$ & $\boldsymbol{f f f}$ & $\boldsymbol{f f f f}$ \\
\hline 1 & Uirapurú & - & - & - & - & $\mathbf{5}$ & 3 & 4 & 2 & - \\
\hline 2 & Amazonas & 1 & $\mathbf{8}$ & $\mathbf{1 6}$ & - & 5 & 8 & 7 & 10 & 2 \\
\hline 3 & Choros $N^{\boldsymbol{o}} .4$ & - & 2 & $\mathbf{1 3}$ & - & 6 & 9 & 2 & - & - \\
\hline 4 & Choros $N^{\boldsymbol{o}} .6$ & - & 1 & 5 & - & $\mathbf{2 3}$ & 12 & 2 & 1 & - \\
\hline 5 & Choros $N^{\boldsymbol{o}} .10$ & - & 3 & 8 & - & 6 & $\mathbf{1 5}$ & 11 & 8 & 2 \\
\hline 6 & Bachianas $N^{\boldsymbol{o}} .2$ & - & 4 & 2 & - & 4 & $\mathbf{1 0}$ & 4 & 1 & - \\
\hline 7 & Concerto para violão & 2 & 7 & $\mathbf{1 0}$ & - & 8 & 3 & 2 & - & - \\
\hline 8 & Sinfonia $N^{\boldsymbol{o}} .12$ & - & 2 & 16 & - & $\mathbf{3 4}$ & 25 & 2 & - & - \\
\hline
\end{tabular}

Tab.13 - Dinâmicas grafadas para os metais graves nas peças analisadas

\section{3 - Articulações grafadas para os metais graves nas peças analisadas}

(em notas individuais)

\begin{tabular}{c|c|c|c|c|c|c|c|c|c}
\hline & Peça & $\cdot$ & - & $>$ & - & sff & sfz & Frullato & $\begin{array}{c}\text { Sem } \\
\text { articulação }\end{array}$ \\
\hline 1 & Uirapurú & $\mathbf{2 8 6}$ & - & 189 & 6 & - & - & - & 232 \\
\hline 2 & Amazonas & $\mathbf{1 7 0}$ & 110 & 102 & 9 & 9 & 6 & - & 21 \\
\hline 3 & Choros $N^{o} .4$ & $\mathbf{2 6 3}$ & 33 & 3 & 22 & - & 21 & - & 48 \\
\hline 4 & Choros $N^{\circ} .6$ & $\mathbf{1 0 6 1}$ & 54 & 261 & 31 & - & - & - & 65 \\
\hline 5 & Choros $N^{o} .10$ & 128 & 7 & $\mathbf{1 5 2}$ & 24 & 8 & 9 & - & 22 \\
\hline 6 & Bachianas $N^{o} .2$ & 4 & 20 & $\mathbf{3 3 2}$ & 33 & - & - & 8 & 53 \\
\hline 7 & Concerto para & 13 & 10 & $\mathbf{3 1}$ & 5 & - & 1 & - & 90 \\
\hline 8 & vinfonia $N^{o} .12$ & 179 & 18 & 12 & 19 & - & 9 & - & $\mathbf{9 5 9}$ \\
\hline
\end{tabular}

Tab.14 - Articulações grafadas para os metais graves nas peças analisadas 
Villa-Lobos e os metais graves sinfônicos:

Um estudo dos elementos técnicos específicos

\section{4 - Extensão melódica}

A extensão melódica necessária para execução dos trechos orquestrais para os metais graves na atualidade são:

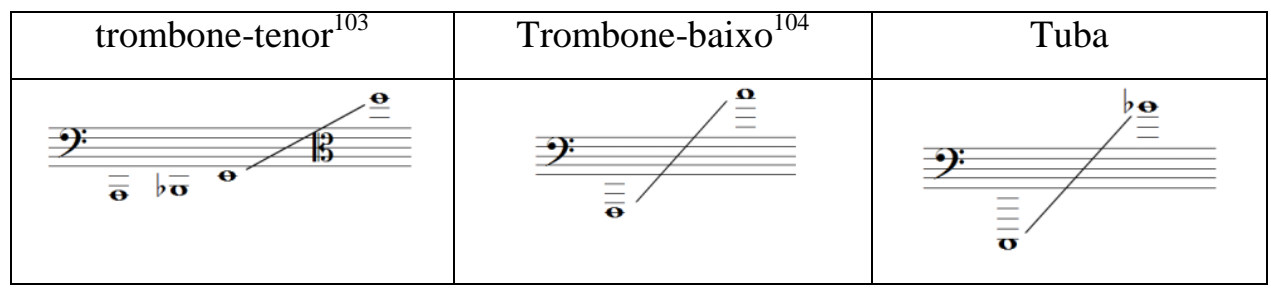

Extensão melódica utilizada por Villa-Lobos nas peças analisadas:

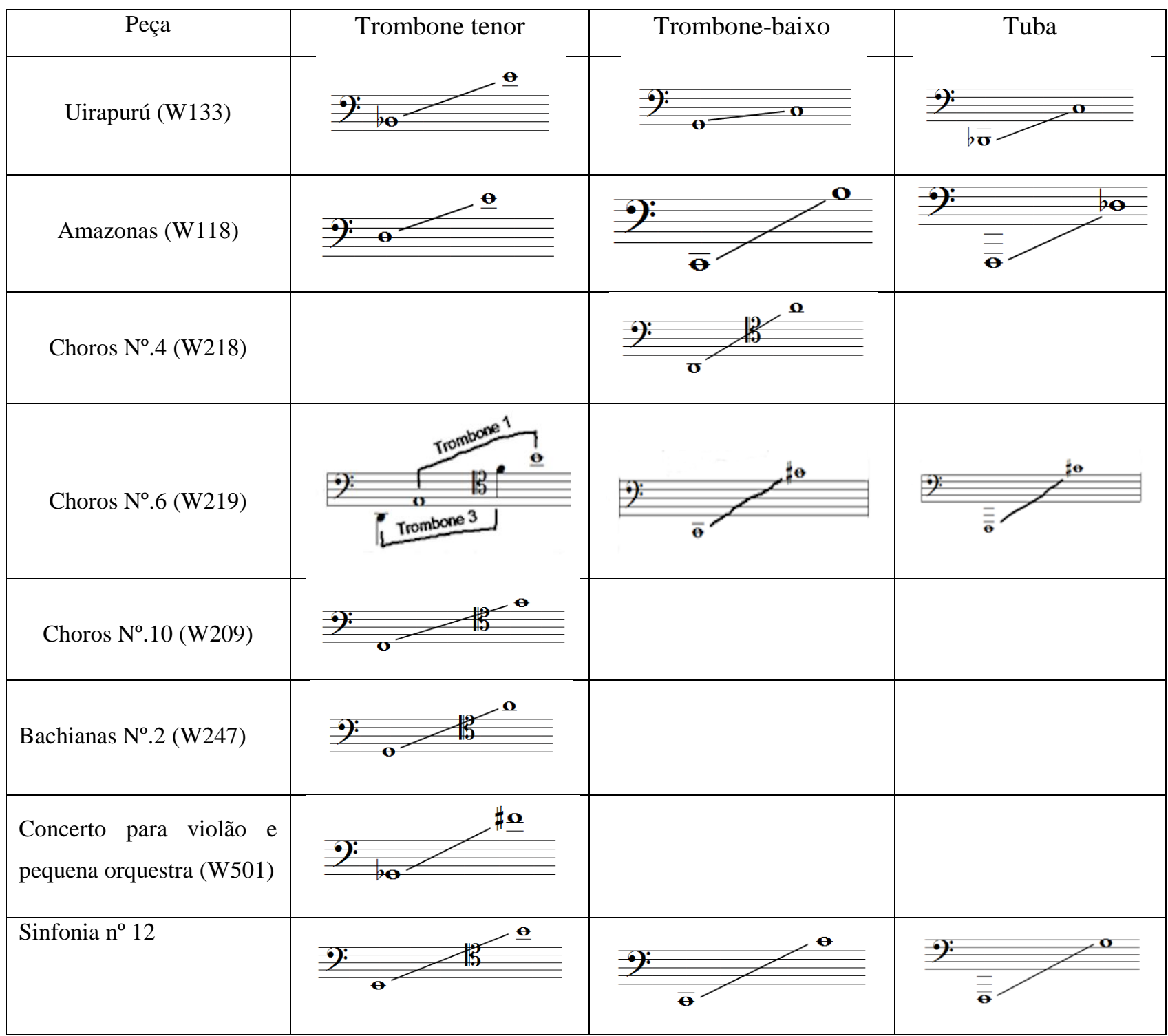

Quadro 6: Extensão melódica geral utilizada por Villa-Lobos

${ }^{103}$ KLEINHAMMER The Art of trombone playing, pp. 45, 1963.

${ }^{104}$ Ibdem, pp. 45, 1963. 
Villa-Lobos e os metais graves sinfônicos:

Um estudo dos elementos técnicos específicos

Extensão melódica utilizada por Villa-Lobos nas peças analisadas:

\begin{tabular}{|c|c|c|}
\hline Peça & Trombone tenor & Quantidade de semitons \\
\hline Uirapurú (W133) & $9)^{\circ}<$ & 1 oitava $+4^{a} \cdot \operatorname{aum}(18)$ \\
\hline Amazonas (W118) & $9 ;$ & $9^{\mathrm{a}} . \mathrm{M}(14)$ \\
\hline Choros No.6 (W219) & :): $\frac{1}{0}$ & $\begin{array}{c}1^{\mathrm{o}} .2 \text { oitavas }+2^{\mathrm{a}} . \mathrm{M}(26) \\
3^{\mathrm{o}} .2 \text { oit. }+3^{\mathrm{a}} \cdot \mathrm{m}(27)\end{array}$ \\
\hline Choros Nº.10 (W209) & $\sum_{0}^{0}$ & 2 oit. $+2^{\mathrm{a}} \cdot \mathrm{M}(26)$ \\
\hline Bachianas No.2 (W247) & $9:$ & 2 oit. $+2^{a} \cdot M(26)$ \\
\hline $\begin{array}{c}\text { Concerto para violão e } \\
\text { pequena orquestra (W501) }\end{array}$ & $\underbrace{:}_{60}$ & 2 oitavas (24) \\
\hline Sinfonia $\mathrm{n}^{\circ} 12$ (W539) & $\frac{9}{0 / 2}$ & 2 oit. $+5^{\mathrm{a}} . \mathrm{J}(31)$ \\
\hline
\end{tabular}

Quadro 7: Extensão melódica do Trombone utilizada por Villa-Lobos 
Villa-Lobos e os metais graves sinfônicos:

Um estudo dos elementos técnicos específicos

\begin{tabular}{|c|c|c|}
\hline Peça & Trombone-baixo & Quantidade de semitons \\
\hline Uirapurú (W133) & 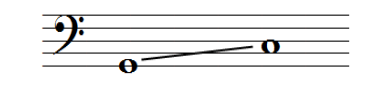 & $4^{\mathrm{a}} . \mathrm{J}(5)$ \\
\hline Amazonas (W118) & $z^{\mathbf{0}}$ & 1 oit. $+7^{\mathrm{a}} \cdot \mathrm{M}(23)$ \\
\hline Choros No.4 (W218) & 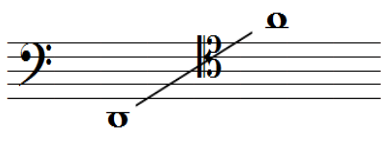 & 2 oit. $+5^{\text {a } . J ~(31) ~}$ \\
\hline Sinfonia $^{\circ} 12$ (W539) & 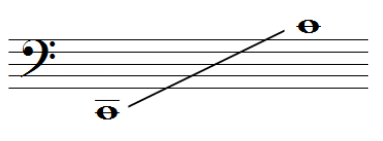 & 2 oitavas (24) \\
\hline
\end{tabular}

Quadro 8: Extensão melódica do Trombone baixo utilizada por Villa-Lobos

\begin{tabular}{|c|c|c|}
\hline Peça & Tuba & Quantidade de semitons \\
\hline Uirapurú (W133) & : & $9^{\mathrm{a}} . \mathrm{M}(14)$ \\
\hline Amazonas (W118) & $\frac{9:}{=}$ & 1 oit. $+6^{a} \cdot \mathrm{m}(20)$ \\
\hline Choros No.6 (W219) & & 2 oit. $+5^{\text {a }}$.aum (32) \\
\hline Sinfonia $^{\circ} 12$ (W539) & $\frac{\overline{2}}{\overline{\overline{\mathbf{\theta}}}}$ & 2 oitavas $+2^{\mathrm{a}} \cdot \mathrm{M}(26)$ \\
\hline
\end{tabular}

Quadro 9: Extensão melódica da Tuba utilizada por Villa-Lobos 
Villa-Lobos e os metais graves sinfônicos:

Um estudo dos elementos técnicos específicos

\section{5 - Glissando}

6.5.1 - Glissandos possíveis em Villa-Lobos

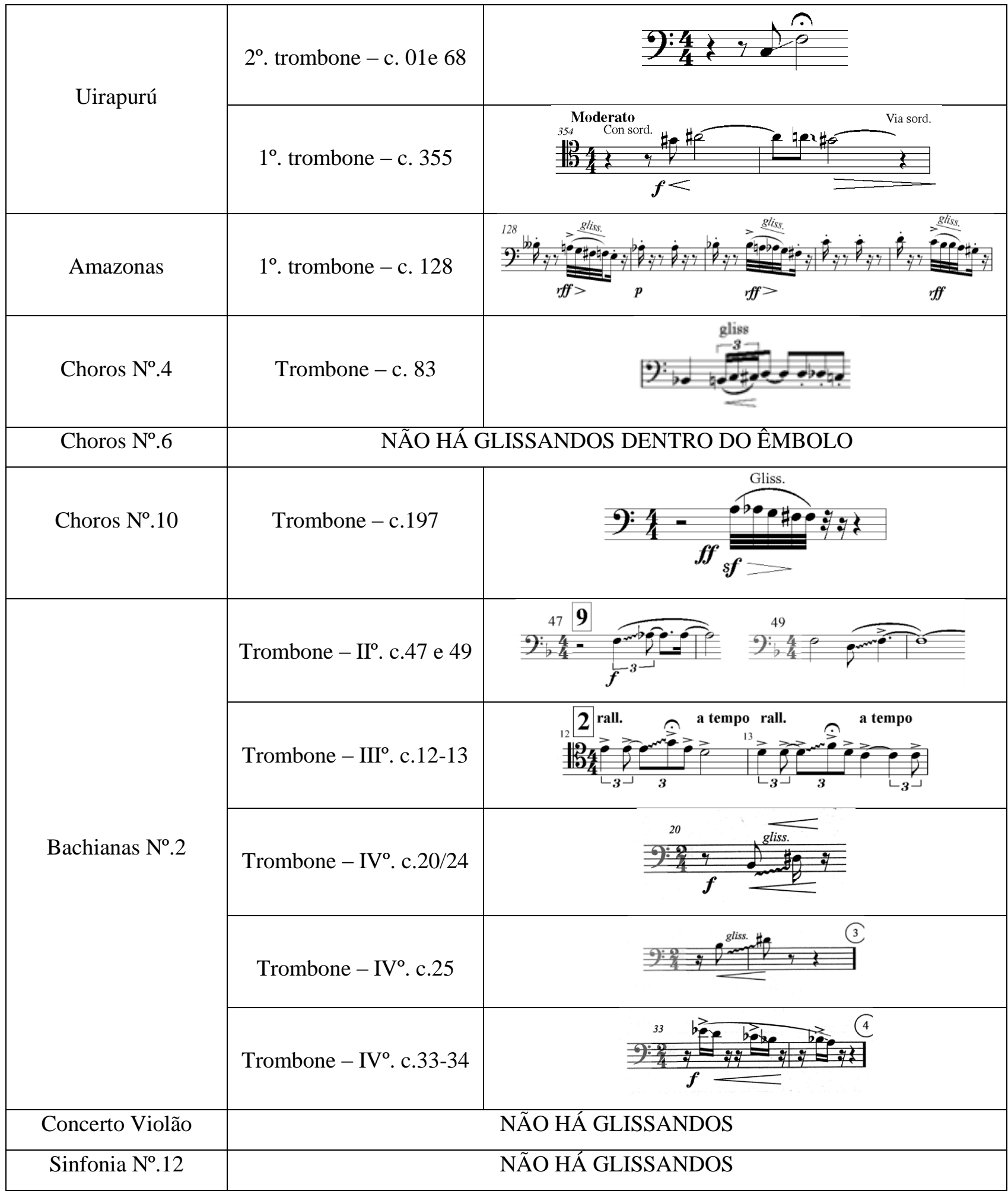

Quadro 10: Glissandos possíveis em Villa-Lobos 
Villa-Lobos e os metais graves sinfônicos:

Um estudo dos elementos técnicos específicos

\subsection{2 - Glissandos não lineares no êmbolo do Trombone (em Villa-Lobos)}

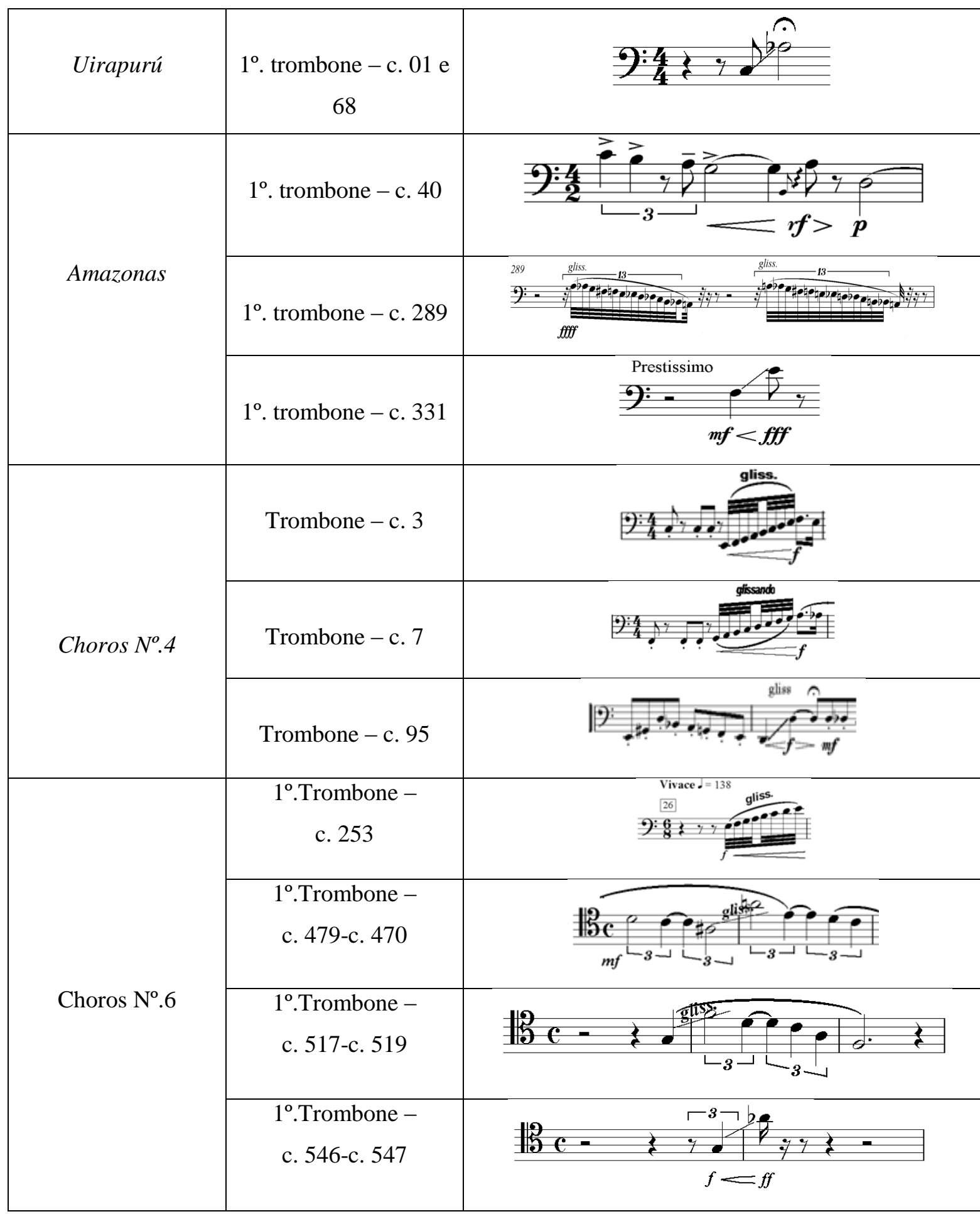


Villa-Lobos e os metais graves sinfônicos:

Um estudo dos elementos técnicos específicos

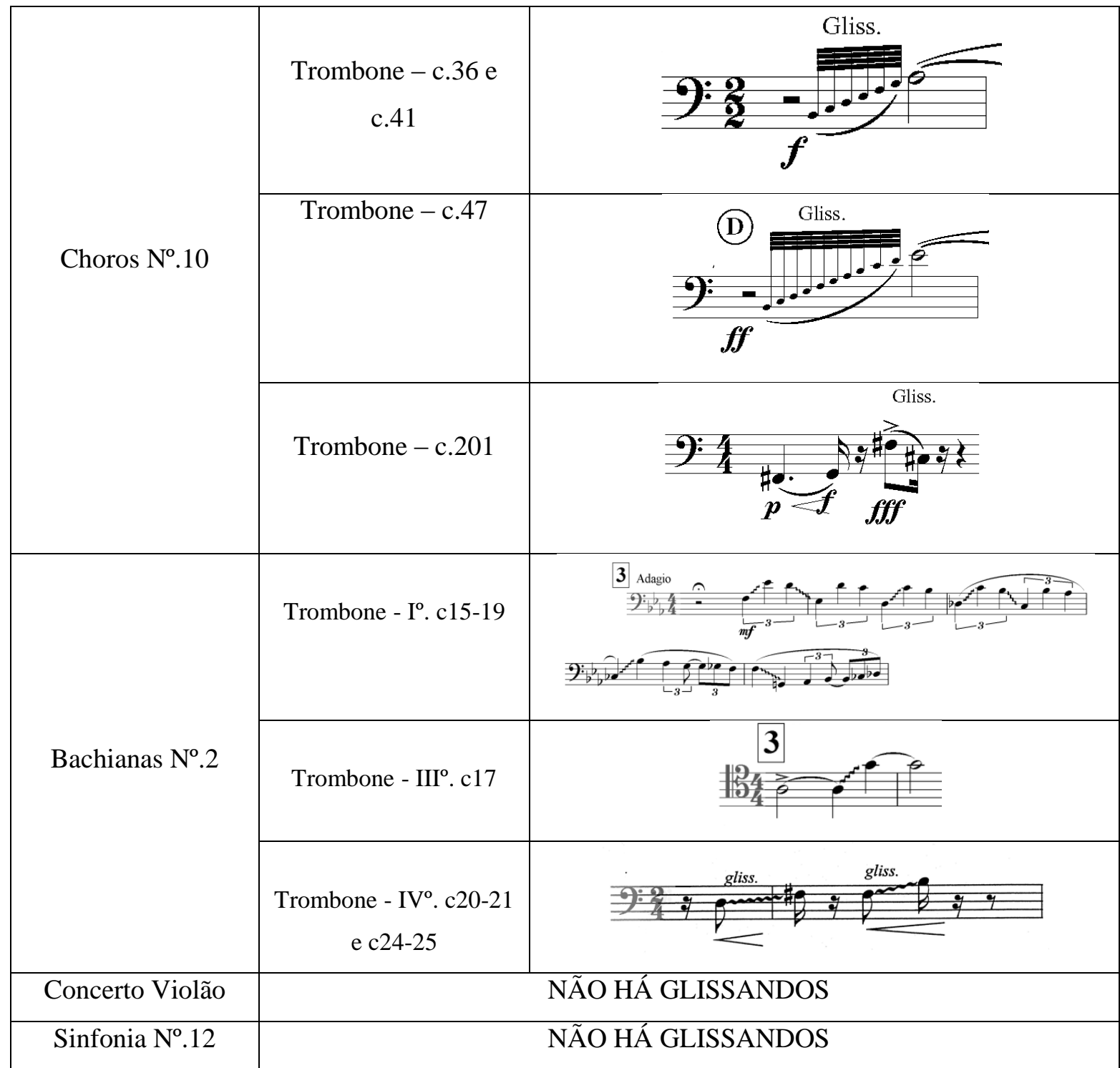

Quadro 11: Glissandos não lineares no êmbolo nas peças de Villa-Lobos 
Villa-Lobos e os metais graves sinfônicos:

Um estudo dos elementos técnicos específicos

6.6 - Frases fora da capacidade pulmonar

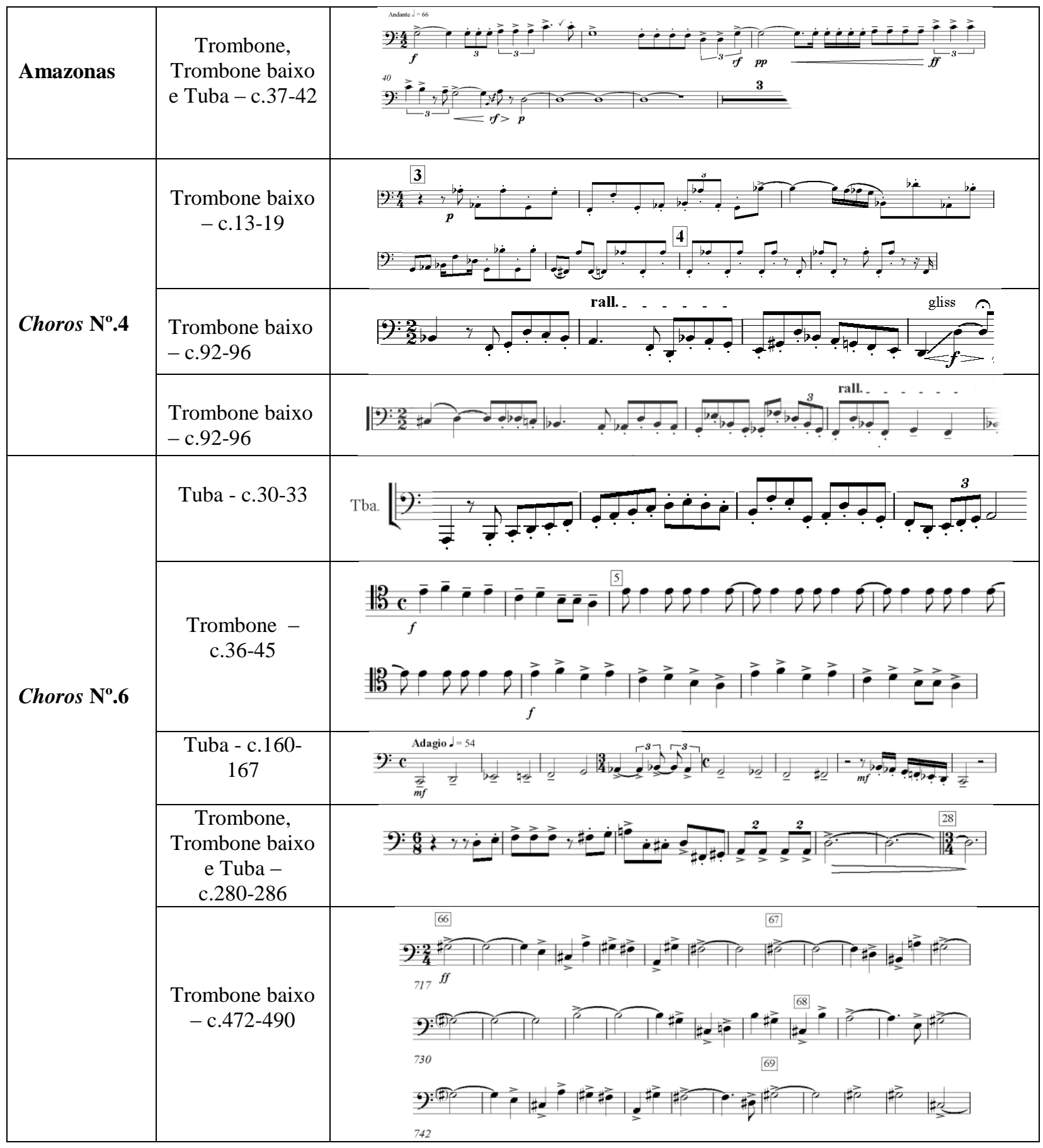


Villa-Lobos e os metais graves sinfônicos:

Um estudo dos elementos técnicos específicos

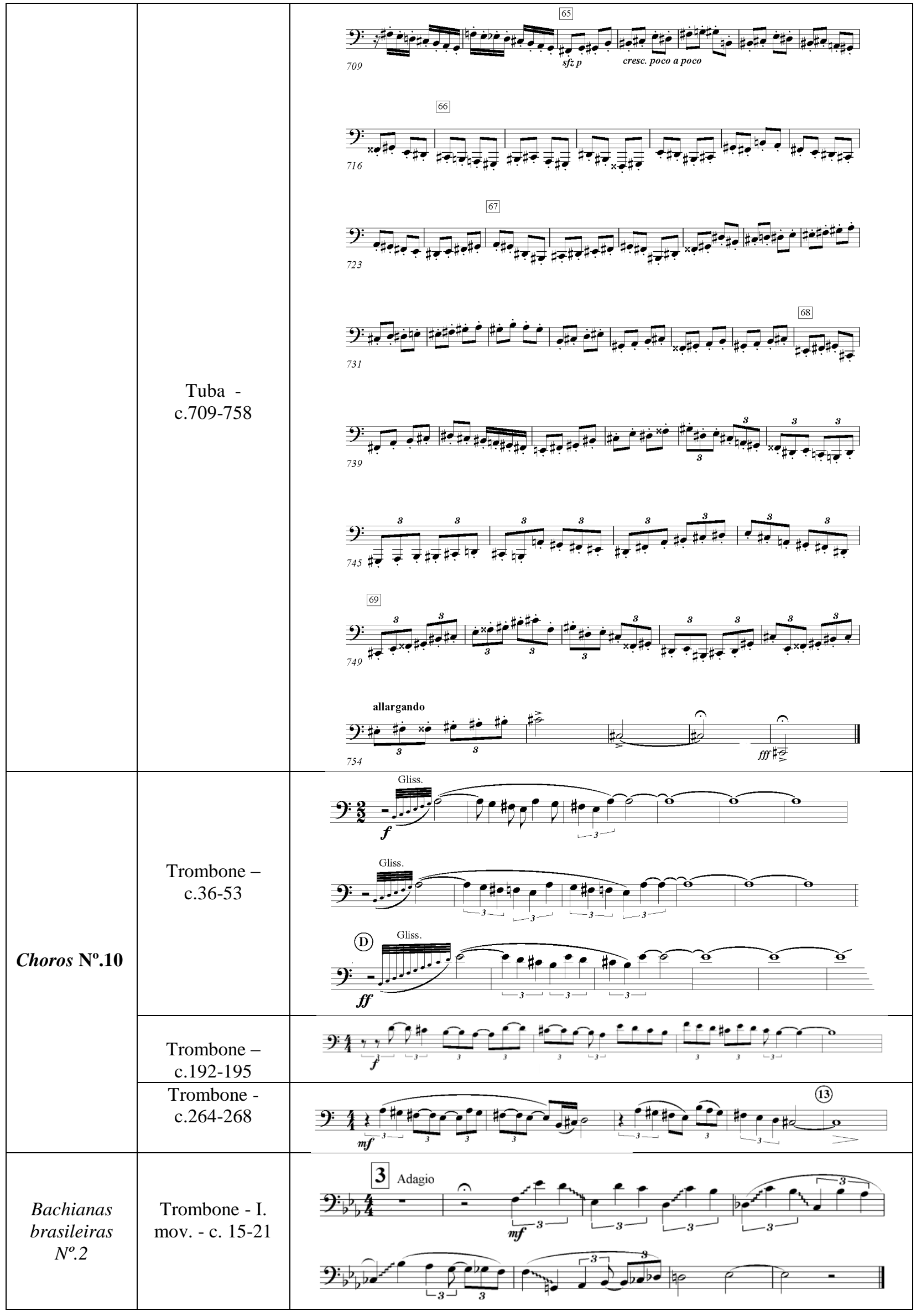

Universidade de São Paulo 
Villa-Lobos e os metais graves sinfônicos:

Um estudo dos elementos técnicos específicos

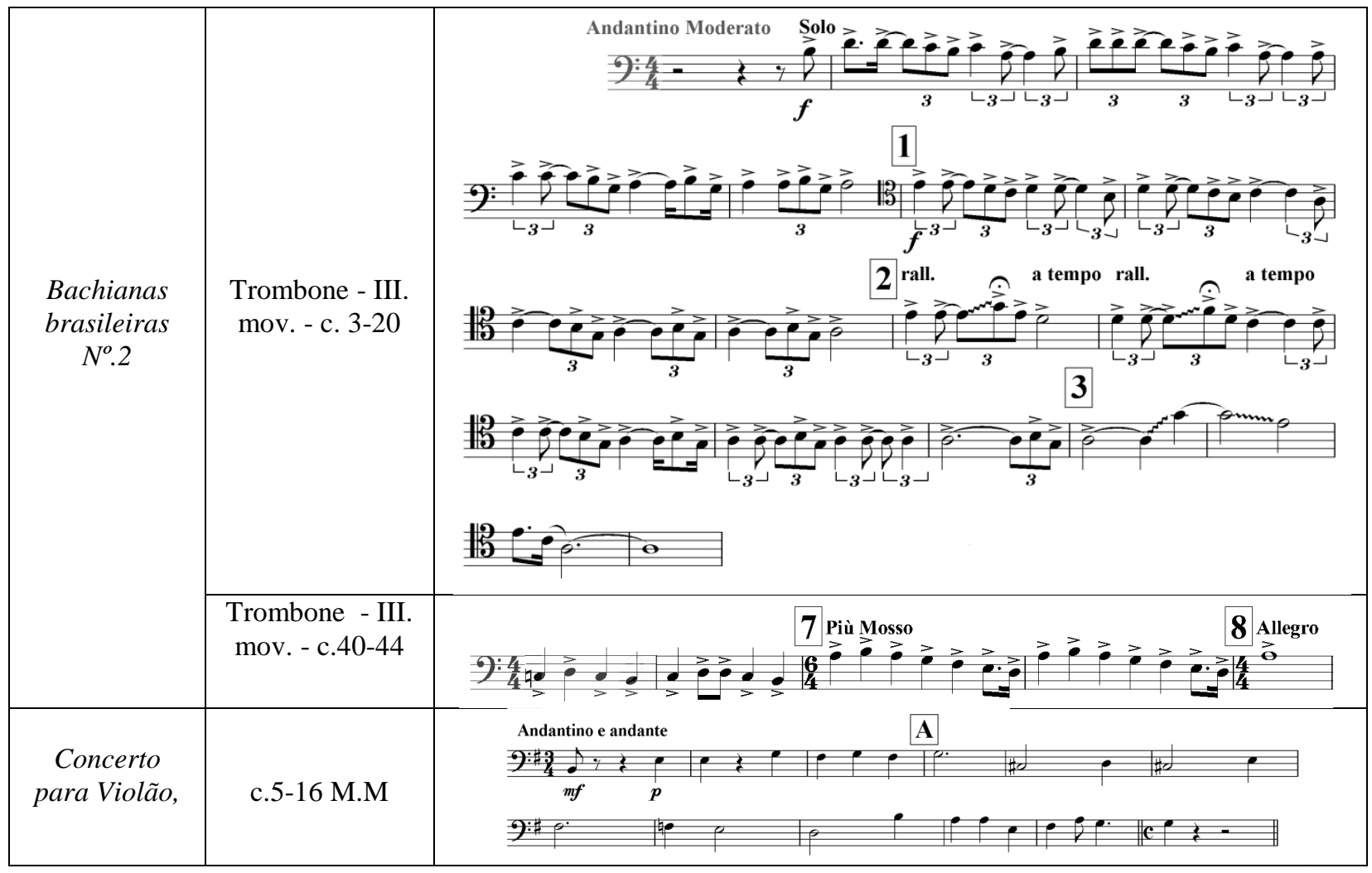

Quadro 12: Frases fora da capacidade pulmonar

\section{7 - Intervalos grandes (Flexibilidade grande)}

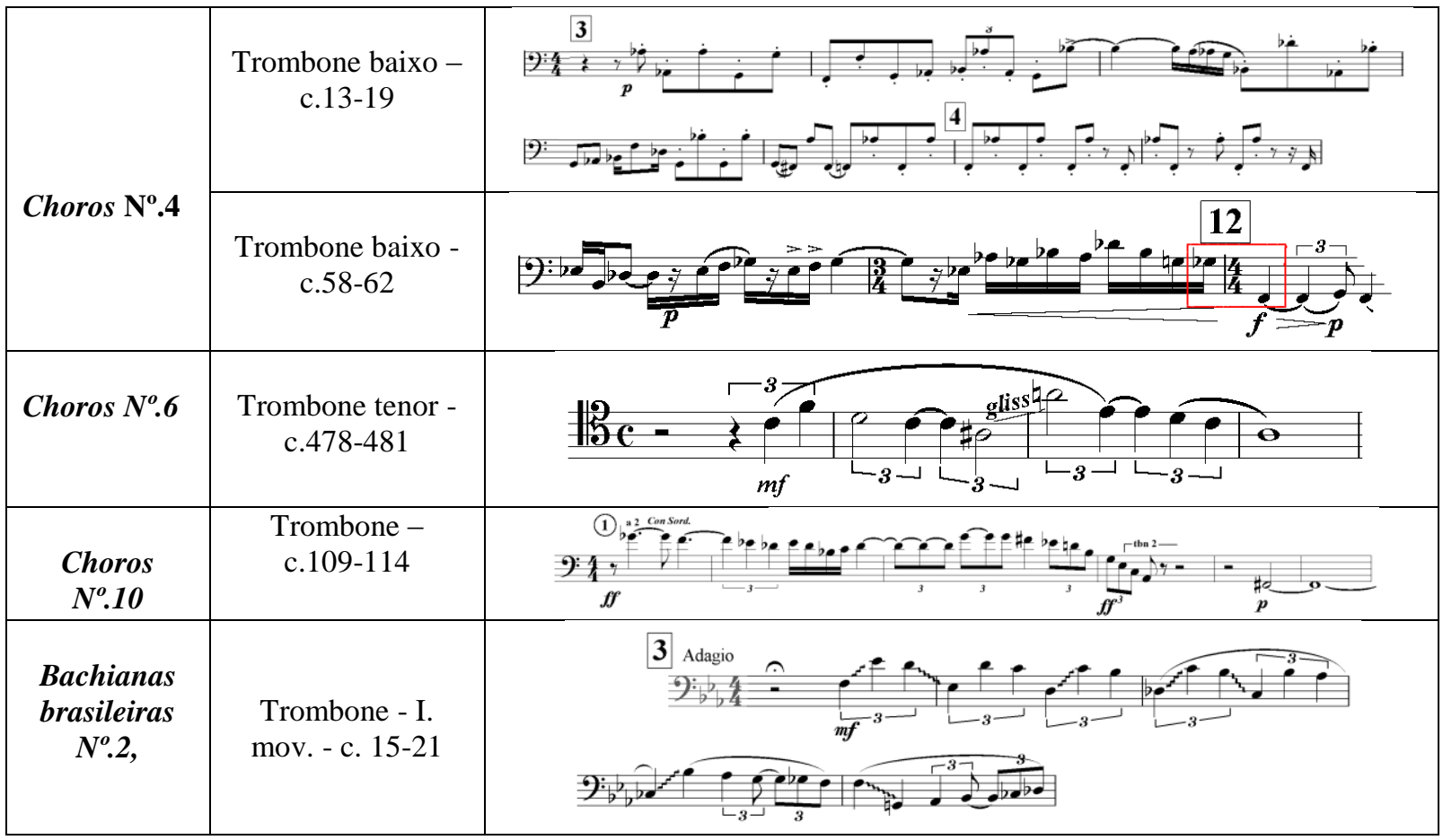

Universidade de São Paulo 
Villa-Lobos e os metais graves sinfônicos:

Um estudo dos elementos técnicos específicos

\begin{tabular}{|c|c|c|}
\hline $\begin{array}{c}\text { Concerto } \\
\text { para Violão }\end{array}$ & $\begin{array}{l}\text { Trombone - } \\
\text { c.109-114 }\end{array}$ & 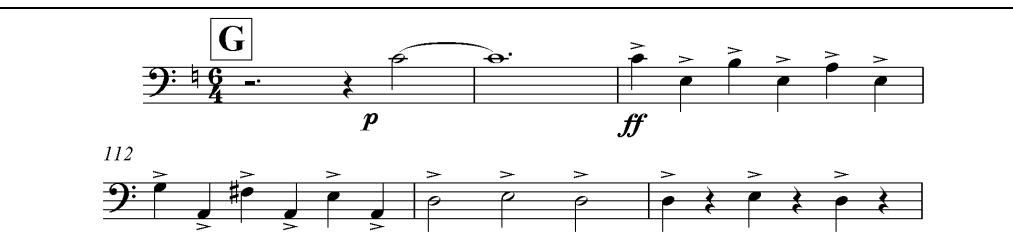 \\
\hline \multirow{7}{*}{$\begin{array}{c}\text { Sinfonia } \\
N^{o} .12\end{array}$} & $\begin{array}{l}\text { Trombone tenor - } \\
\text { I. mov. } \\
\text { c. } 9-20\end{array}$ & $y_{\cdots} \ldots \ldots \ldots$ \\
\hline & $\begin{array}{l}\text { Trombone tenor - } \\
\text { I. mov. c. } 84-96\end{array}$ & 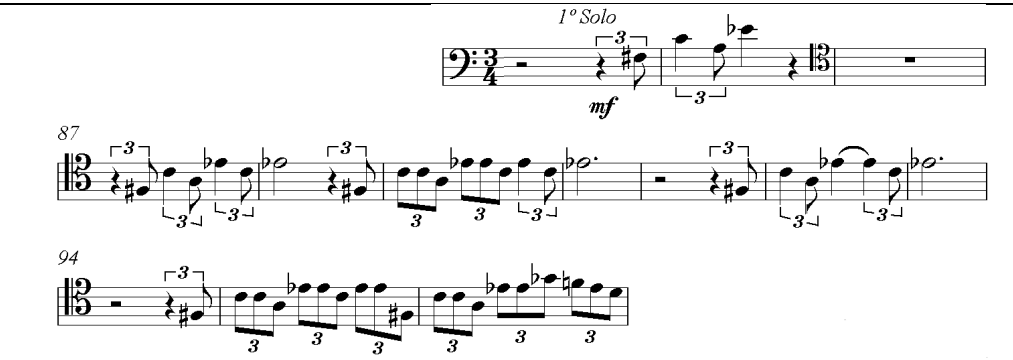 \\
\hline & $\begin{array}{l}\text { Trombone tenor - } \\
\text { I. mov. } \\
\text { c. } 110-125\end{array}$ & 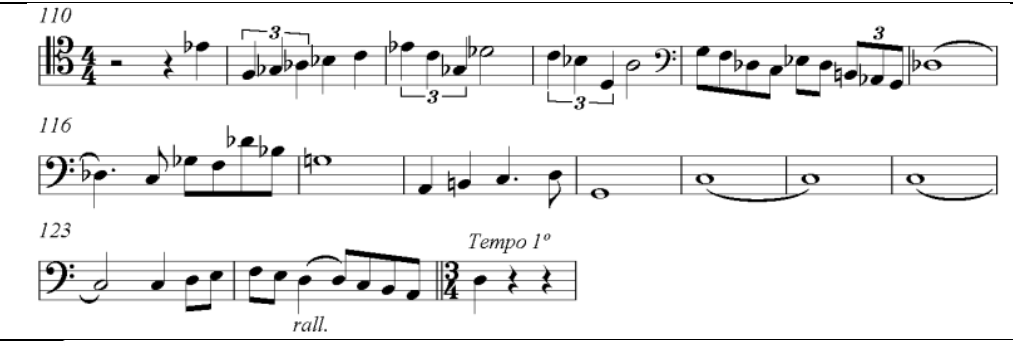 \\
\hline & $\begin{array}{l}\text { Tuba }-- \text { III. mov. } \\
\text { c. } 57-67\end{array}$ & 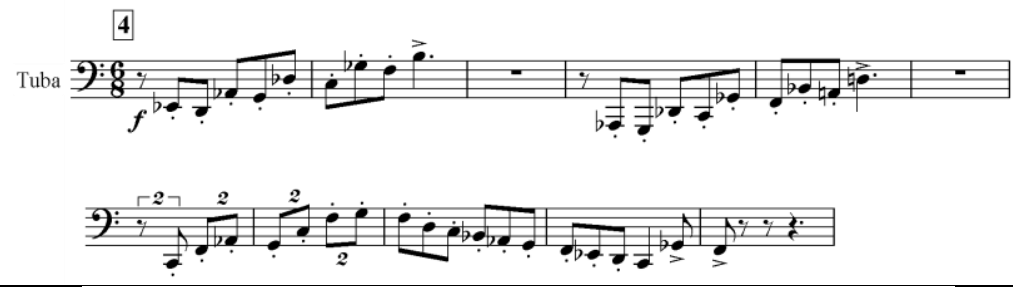 \\
\hline & $\begin{array}{c}\text { Trombone - III. } \\
\text { mov. c. } 43-44\end{array}$ & 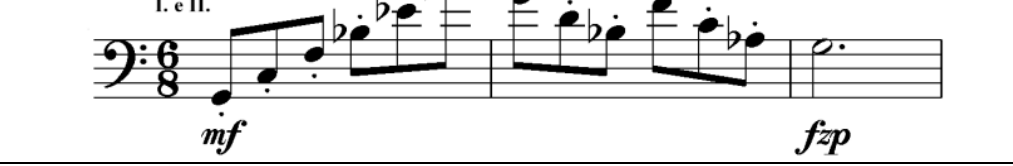 \\
\hline & $\begin{array}{l}\text { Trombone - III. } \\
\text { mov. c. } 165-168\end{array}$ & 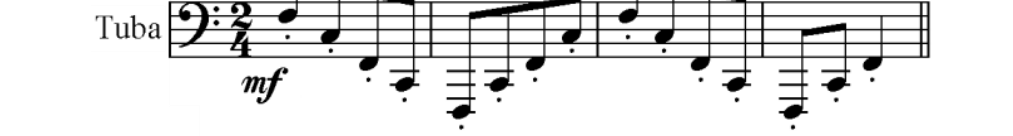 \\
\hline & $\begin{array}{l}\text { Tuba }- \text { IV. mov. } \\
\text { c. } 13-16\end{array}$ & Tuba \\
\hline
\end{tabular}


Villa-Lobos e os metais graves sinfônicos:

Um estudo dos elementos técnicos específicos

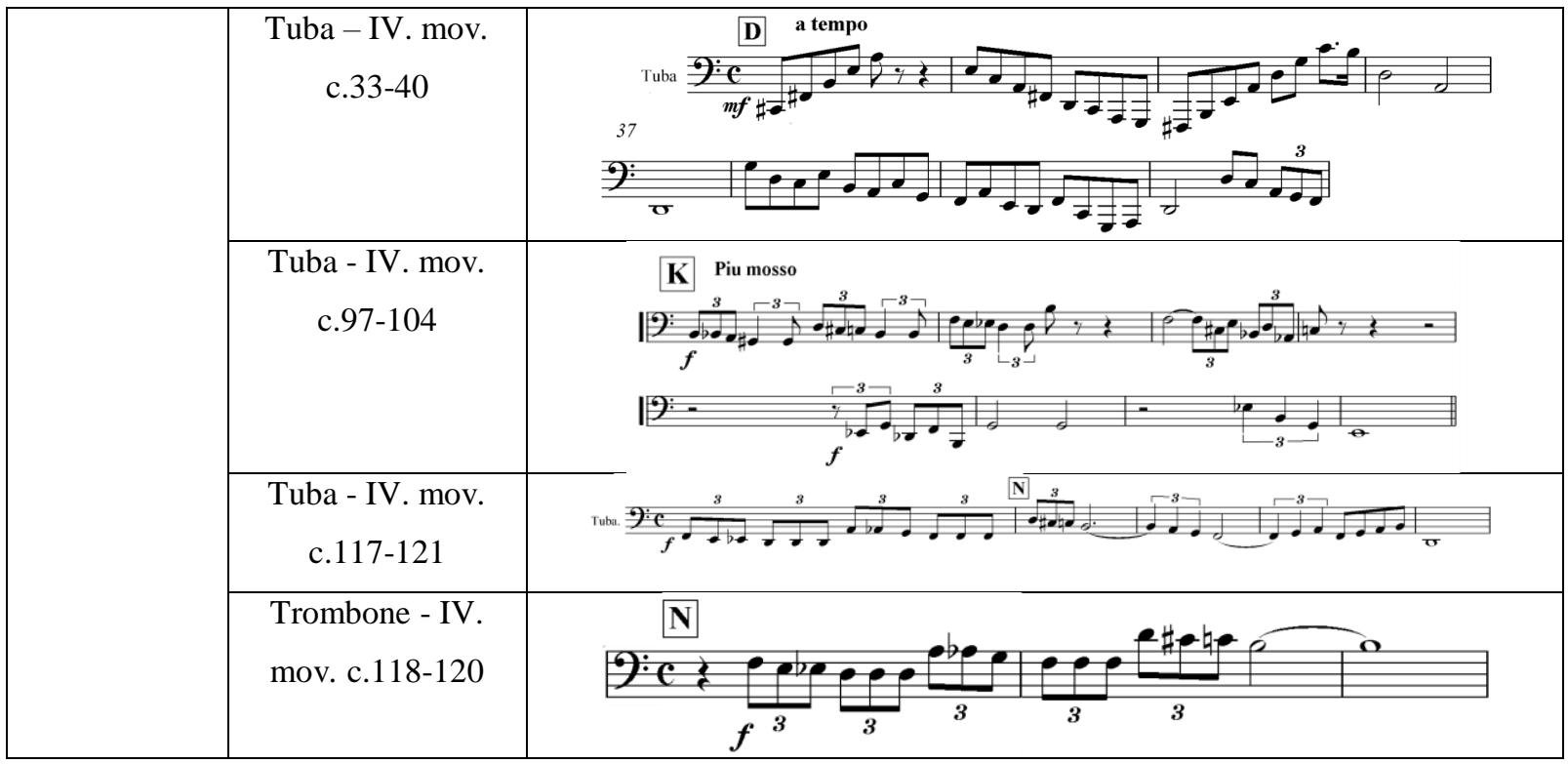

Quadro 13: Intervalos grandes (flexibilidade grande) 
Villa-Lobos e os metais graves sinfônicos:

Um estudo dos elementos técnicos específicos

7.

\section{Abordagens técnicas e comentários sobre os trechos} escolhidos

\footnotetext{
“Quem nasceu no Brasil e formou sua consciência no âmago desse país, não pode, embora querendo, imitar o caráter e o destino de outros países, apesar de ser a cultura básica transportadora do estrangeiro”, Villa-Lobos.
} 


\section{1 - ABORDAGENS TÉCNICAS}

\subsection{1 - Extensão melódica}

Pelo exposto no capítulo anterior, verificou-se a maior extensão para trombone-tenor a quantidade de 31 semitons - na Sinfonia $\boldsymbol{N}^{\boldsymbol{o}} \mathbf{. 1 2}$ - peça de maior destreza para a embocadura do trombonista. A media simples dos semitons em todas as peças ficou na casa de 25 semitons (duas oitavas $+2^{\mathrm{a}}$.m). Para o trombone-baixo, a quantidade de 31 semitons no Choros $\boldsymbol{N}^{\boldsymbol{o}}$.4, e a média simples dos semitons, para trombone-baixo, ficaram na casa de 20 semitons $\left(1\right.$ oitava $+5^{\text {a }}$ aum). Finalmente a tuba, com a quantidade de 32 semitons no Choros $\boldsymbol{N}^{\boldsymbol{o}}$.6. A media simples dos semitons no instrumento tuba, ficou na casa de 24.6 semitons (aproximadamente 2 oitavas $+2^{\mathrm{a}} \cdot \mathrm{m}$ ). Concluiu-se dessa forma que serão necessário instrumentistas em nível avançado nas peças Sinfonia $N^{o} .12$ (trombone tenor), Choros $N^{o} .4$ (trombone baixo) e Choros $N^{o} .6$ (tuba).

Tendo um pensamento inverso, confirmou-se também, no capítulo anterior, que a menor extensão para trombone-tenor foi de 14 semitons na peça Amazonas, no trombonebaixo Uirapurú, com apenas 5 semitons e na tuba Uirapurú, com apenas 14 semitons. Estes dados nos permitem a confirmação que tanto a peça Amazonas quanto Uirapurú podem ser executadas por alunos em nível médio nos instrumentos objetos dessa pesquisa.

\subsection{2 - Glissando}

Pelo exposto no capítulo anterior, nos quadros 10 e 11, pode-se confirmar que VillaLobos não se preocupou em limitar os glissandos dentro de um mesmo movimento de êmbolo. O numeral de glissandos possíveis em conjunto com os que excedem o movimento do embolo estiveram equilibrados nas peças analisadas. Desta forma, podemos afirmar que a intenção de Villa-Lobos não foi de uma execução inteiramente perfeita desse efeito, mas sim proporcionar uma sensação ao ouvinte. 
Com base nessa constatação, descreveremos algumas soluções possíveis para os glissandos que excedem o movimento do embolo.

Em Uirapurú (c.01 e c.68) há um glissando além do movimento simples do êmbolo. A execução da totalidade das notas grafadas no original não será possível. Aconselharemos aos executantes de trombone que façam um glissando com as duas primeiras notas apenas, salta-se uma $5^{\text {a }}$.dim, e termine esse glissando com as duas ultimas notas (Ex.181)

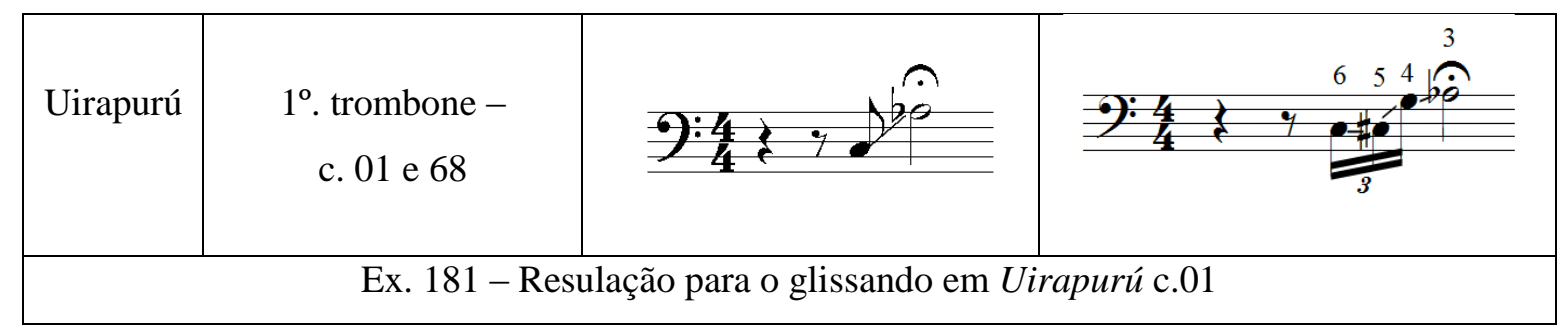

Na peça Amazonas está escrito no c.40 um glissando além do movimento simples do êmbolo. Estes, da mesma forma que o anteriormente exposto, não será possível de ser executado na totalidade das notas grafadas no original. Aconselharemos aos executantes de trombone que façam no glissando do c.40 partindo da mesma nota Síl em movimento ascendente até o Dó\#2 na $5^{\text {a }}$. posição, depois faça uma ligadura direta para a nota Sól2 e termine o efeito. (Ex.182).

\begin{tabular}{|c|c|c|c|}
\hline \multirow{3}{*}{ Amazonas } & $\begin{array}{c}1^{\circ} . \\
\text { trombone } \\
- \text { c. } 40\end{array}$ & 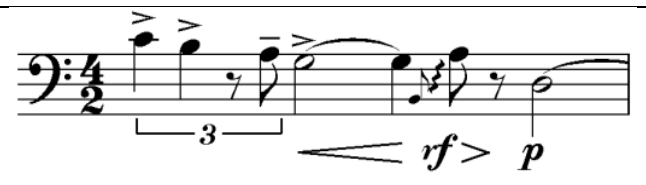 & 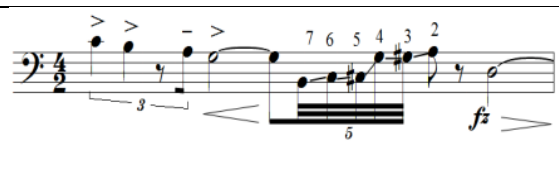 \\
\hline & $\begin{array}{c}1^{\circ} . \\
\text { trombone } \\
- \text { c. } 289\end{array}$ & 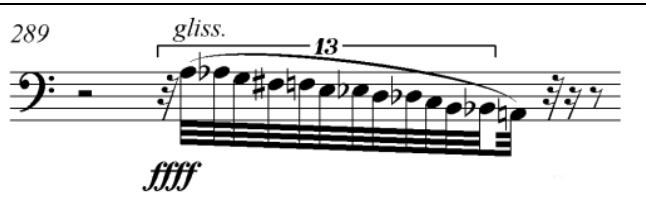 & 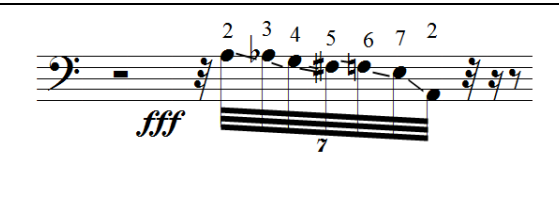 \\
\hline & $\begin{array}{l}1^{\circ} . \\
\text { trombone } \\
- \text { c. } 331\end{array}$ & $\begin{array}{c}\text { Prestissimo } \\
\boldsymbol{m}:-f_{\boldsymbol{f}}<\boldsymbol{f f f}\end{array}$ & 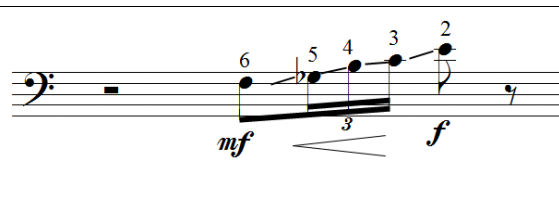 \\
\hline
\end{tabular}

Ainda na peça Amazonas está escrito no c.289 e c.331 dois glissandos além do movimento simples do êmbolo. Estes, da mesma forma que o anteriormente exposto, não 
serão possíveis de execução na totalidade das notas grafadas no original. Aconselharemos aos executantes de trombone que façam no glissando do c.289 (que se repete no mesmo compasso) partindo da mesma nota Lá e desça em glissando até o Mi na $7^{a}$. posição, depois faça uma ligadura direta para a nota final Lá grave. No segundo caso, c.331, a única opção será subir a cada 2 notas de harmônico, e chegar à nota Mi por semitom (Ex.182).

No Choros $N^{o} .4$ o primeiro glissando, escrito por Villa-Lobos no c.3, que contudo não é possível de ser executado na totalidade das notas grafadas no original. Aconselharemos aos executantes de trombone que façam um glissando com as três primeiras notas apenas, salta-se uma $5^{\mathrm{a}} . \mathrm{J}$, e termine esse glissando com as 3 ultimas notas (Ex.183). O segundo glissando, c.7, também não será possível de ser executado. Novamente aconselharemos aos executantes de trombone que façam o glissando descendente com duas notas, salta-se uma $7^{\text {a }}$.M, e termine o glissando, com as 3 últimas notas (Ex.183). Para o c.94-95 elegemos duas soluções: a superior com mais notas (e mais próximo da ideia original de Villa-Lobos) e a inferior com menos notas, mas com 50\% das notas finais tocadas em glissando (Ex.183).

\begin{tabular}{|c|c|c|c|}
\hline \multirow{4}{*}{$\begin{array}{l}\text { Choros } \\
\mathrm{N}^{\mathrm{o}} .4\end{array}$} & $\begin{array}{l}\text { Trombone } \\
- \text { c. } 3\end{array}$ & $0: 4: \ldots$ & 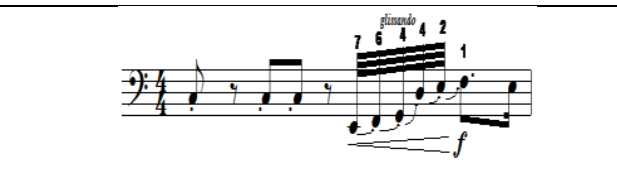 \\
\hline & $\begin{array}{l}\text { Trombone } \\
- \text { c. } 7\end{array}$ & $2: 4: \div: \ldots 00$ & 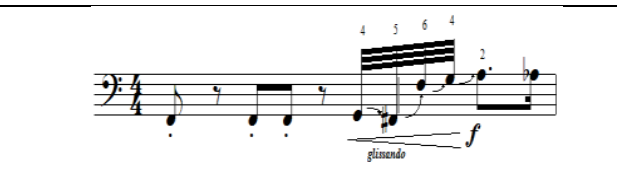 \\
\hline & \multirow{2}{*}{$\begin{array}{l}\text { Trombone } \\
\text { - c.94-95 }\end{array}$} & \multirow{2}{*}{ 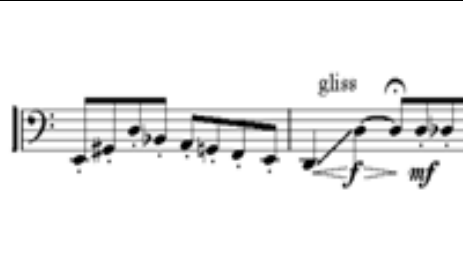 } & 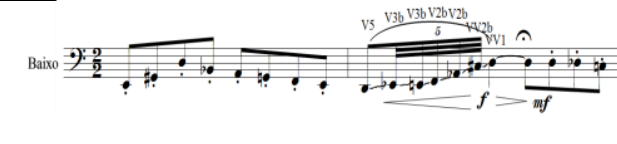 \\
\hline & & & 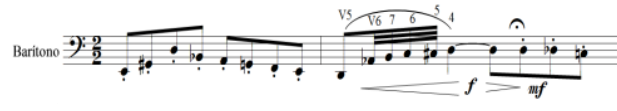 \\
\hline
\end{tabular}

A seguir, soluções práticas para os glissandos na peça Choros $N^{o}$.6. Para o glissando do c. 253 o trombonista deve ter cuidado com o glissando ${ }^{105}$ (no quadro pode-se encontrar uma sugestão para a resolução), mas este glissando não foi escrito em conjunto com os outros instrumentos da orquestra. O trombonista não deve se alongar na execução pois logo

$\overline{105} \mathrm{O}$ glissando das cordas não servirá de apoio à entrada, melhor olhar para o maestro. 
acontecerá a tercina do Trompete indicando o início de uma nova seção. Os glissandos dos c. 479 e c.517 devem ser de apenas meio tom, para um melhor refinamento da execução.

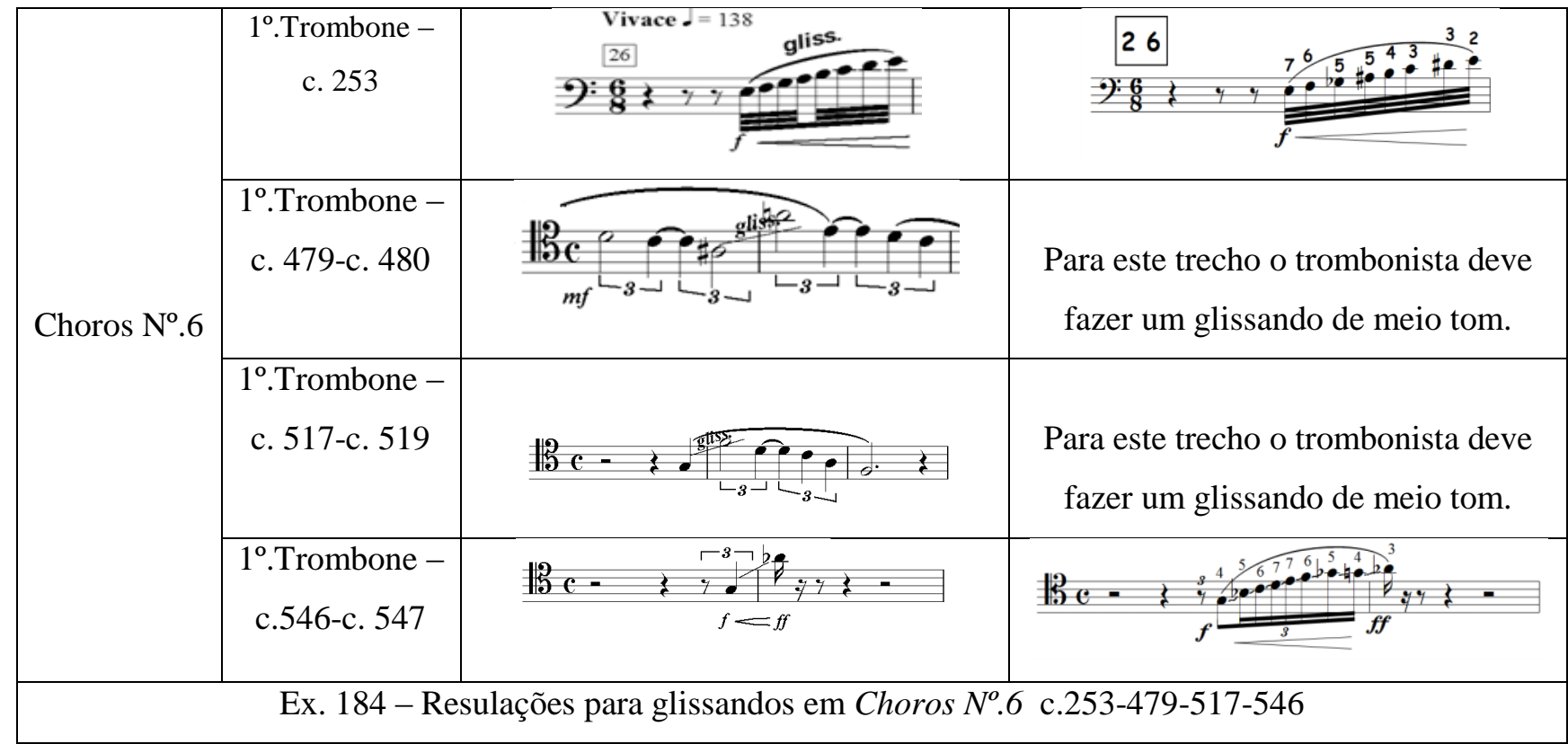

A seguir, soluções práticas para os glissandos na peça Choros $N^{o} .10$. Para o c.36 e 41, um salto de $4^{\mathrm{a}}$.J, entre Ré2-Só12, resolverá o efeito, no entanto, no c.47 serão necessários três saltos de harmônico para que se alcance a nota Mi3. Embora no c.201 o intervalo entre as notas do glissando é $4^{\mathrm{a}}$.J, o posicionamento do êmbolo não permite um glissando direto, logo o trombonista deverá quebrar o glissando com um salto de $3^{\mathrm{a}} . \mathrm{m}$ descendente na direção final da nota Dó\#2 (Ex.185).

Choros $\mathrm{N}^{\circ} .10 \quad$ Trombone-


Na peça Bachianas brasileiras $N^{o} .2$ localizou-se no $1^{\circ}$. movimento - c.15-19 uma série de glissandos além do movimento simples do êmbolo. Aconselharemos aos executantes de Trombone que façam estes glissandos da maneira descrita no Ex. 186. O mesmo valerá para os c.17 (III ${ }^{\circ}$ mov.) e c.20-21 e c.24-25 (IV . mov.).

\begin{tabular}{|c|c|c|c|}
\hline \multirow{3}{*}{$\begin{array}{l}\text { Bachianas } \\
\mathrm{N}^{\mathrm{o}} .2\end{array}$} & $\begin{array}{l}\text { Trombone }-\mathrm{I}^{\mathrm{o}} \text {. } \\
\text { c15-19 }\end{array}$ & 20, & 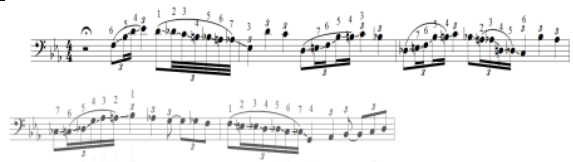 \\
\hline & $\begin{array}{l}\text { Trombone - } \\
\text { III'. c17 }\end{array}$ & 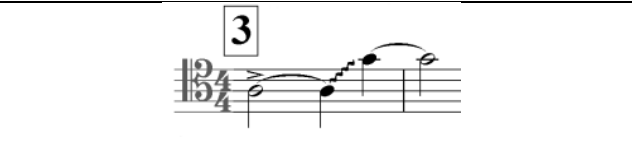 & 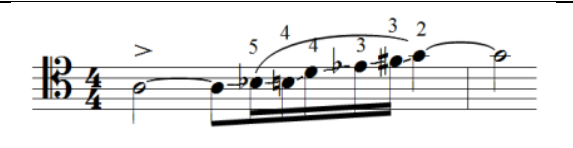 \\
\hline & $\begin{array}{l}\text { Trombone - } \\
\mathrm{IV}^{\mathrm{o}} . \mathrm{c} 20-21 \mathrm{e} \\
\mathrm{c} 24-25\end{array}$ & gliss. gliss. & $=$ \\
\hline & & 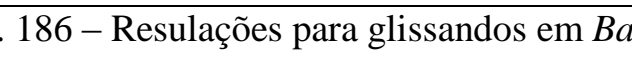 & $V^{o} .2$ \\
\hline
\end{tabular}

\subsection{3 - Rotor}

Há incongruências entre o material musical escrito e as possibilidades físicas dos trombones na época da composição do Choros $N^{o} .4$.

1. O primeiro ponto será a hipótese da existência (ou não) de um trombone com rotor em Fá, para a execução. Existem dois momentos que a extensão supera a região do trombone-tenor (a nota Mi2) feito na década de 1920. (Ex. 187)

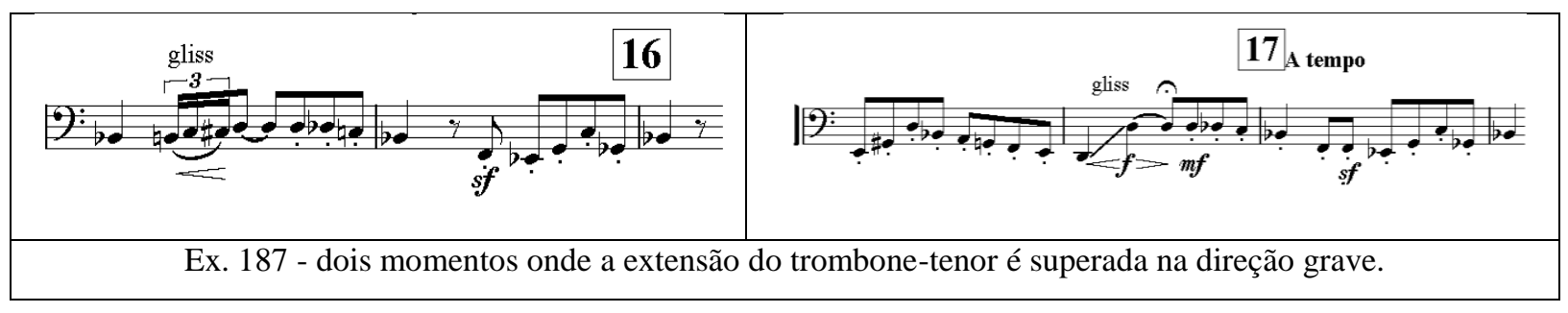


2. As fotografias de naipe de trombones das Orquestras norte-americanas, nos conduzem a resposta que somente o trombone-baixo teria essa possibilidade.

1. 1910 - A fotografia do naipe de trombones da Sinfônica de Boston / EUA nos mostra que apenas o trombone baixo seria provido de um rotor.

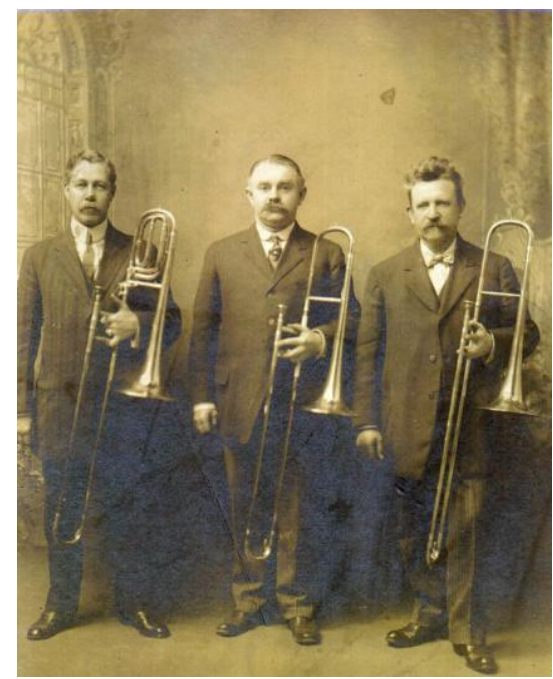

Fig. 20: 1914 - foto de um trombone baixo, marca Conn (esquerda)

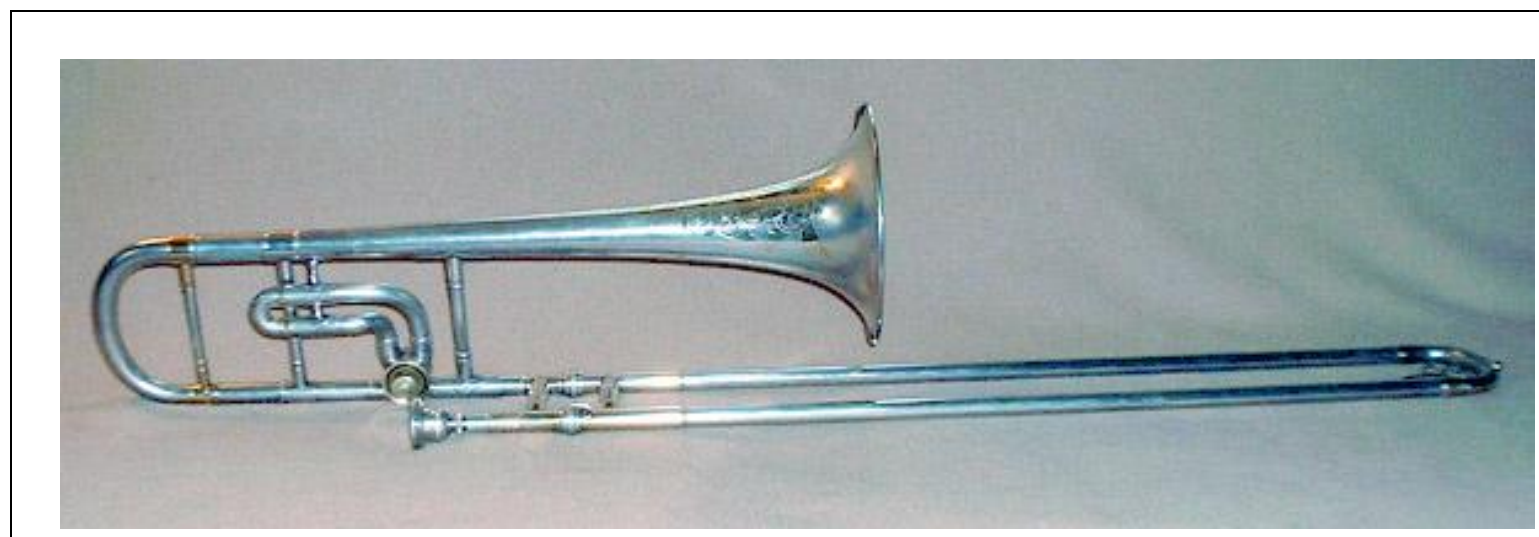

Fig. 21: Trombone baixo datado de 1920

1920 - Os trombones tenor continuam sendo fabricados sem rotor. A foto acima se refere a um trombone-baixo com tubulação curta, portanto menor que o padrão instituído para criar uma nova afinação em fá. A única ressalva aconteceu, graças a Dvorak, com relação ao trombones de válvulas que poderiam ser confeccionados em 4 rotores. 


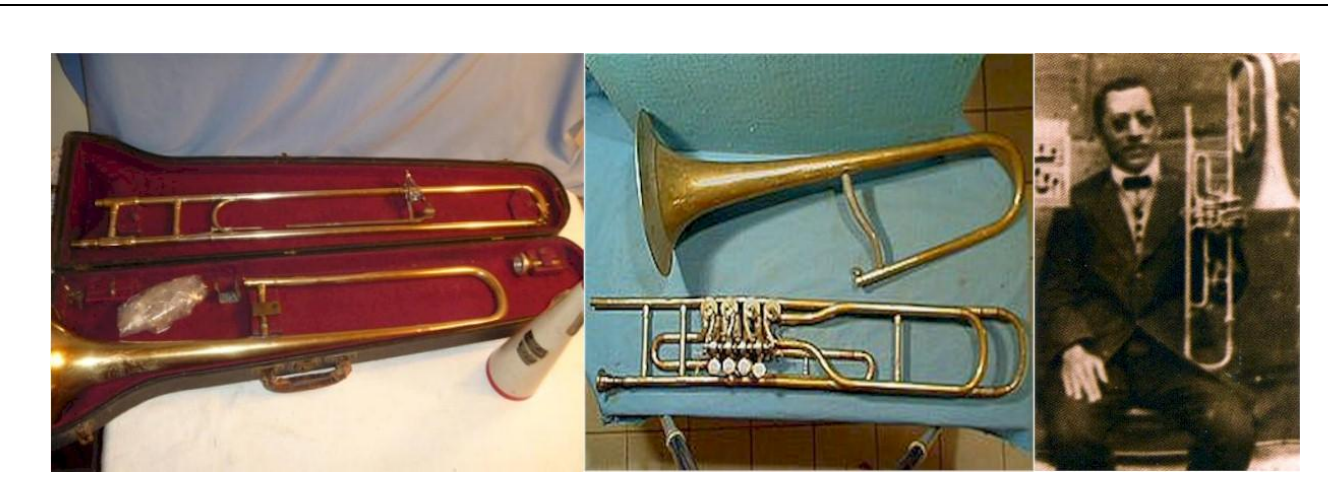

Fig. 22: Trombones em 1926

1926 - ano da composição do Choros $N^{o} .4$ baseado na disponibilidade de compra do instrumento trombone-tenor, sem rotor em fá, pela indústria instrumentista, constatamos que estes ainda não tem à disposição a opção de válvula rotora em Fá. Portanto, Villa-Lobos só teria à sua disposição um trombone-baixo para executar as notas de rotor escritas no Choros $N^{o} .4$.

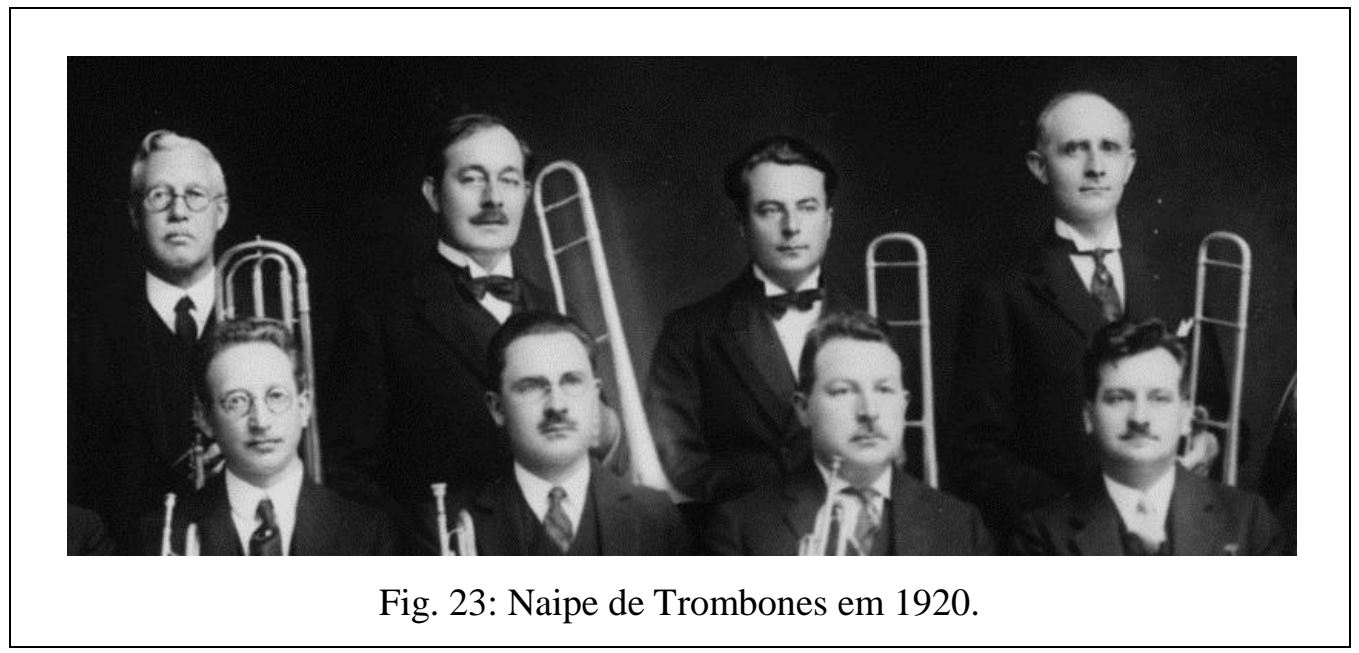

Mas ainda existirão dois problemas de execução: no c.22 e no c.118 - notas agudas, e fora da extensão provável de um trombonista-baixo na década de 1920. (Ex. 188)

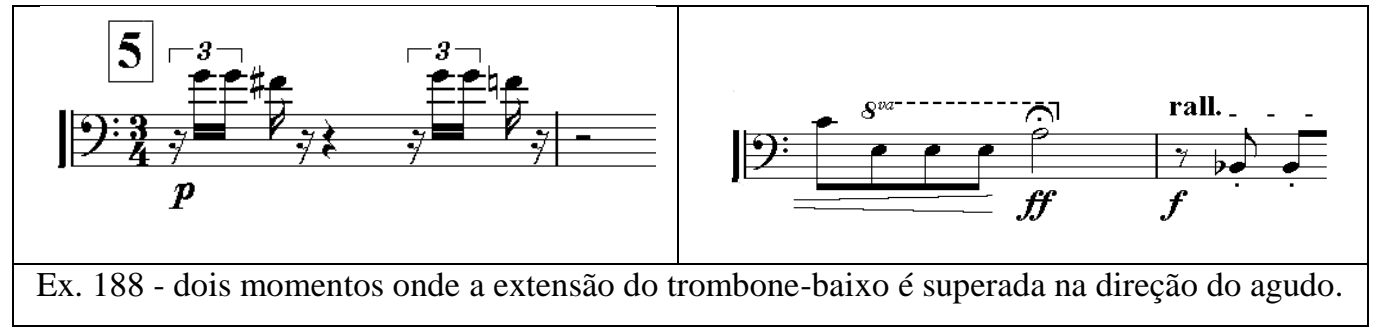




\subsection{4 - Sugestões de troca de acessório:}

No Choros $N^{o} .6$ - c.472 ([42]+8) o $1^{\circ}$. trombone reforçará a melodia feita pelo corneinglês e o saxofone (c. 468) atuando apenas na finalização da semifrase. A utilização de surdina foi uma feliz escolha de Villa-Lobos para que o timbre do trombone não alterasse a soma do corne-inglês e o saxofone (Ex. 36 e ex. 37).

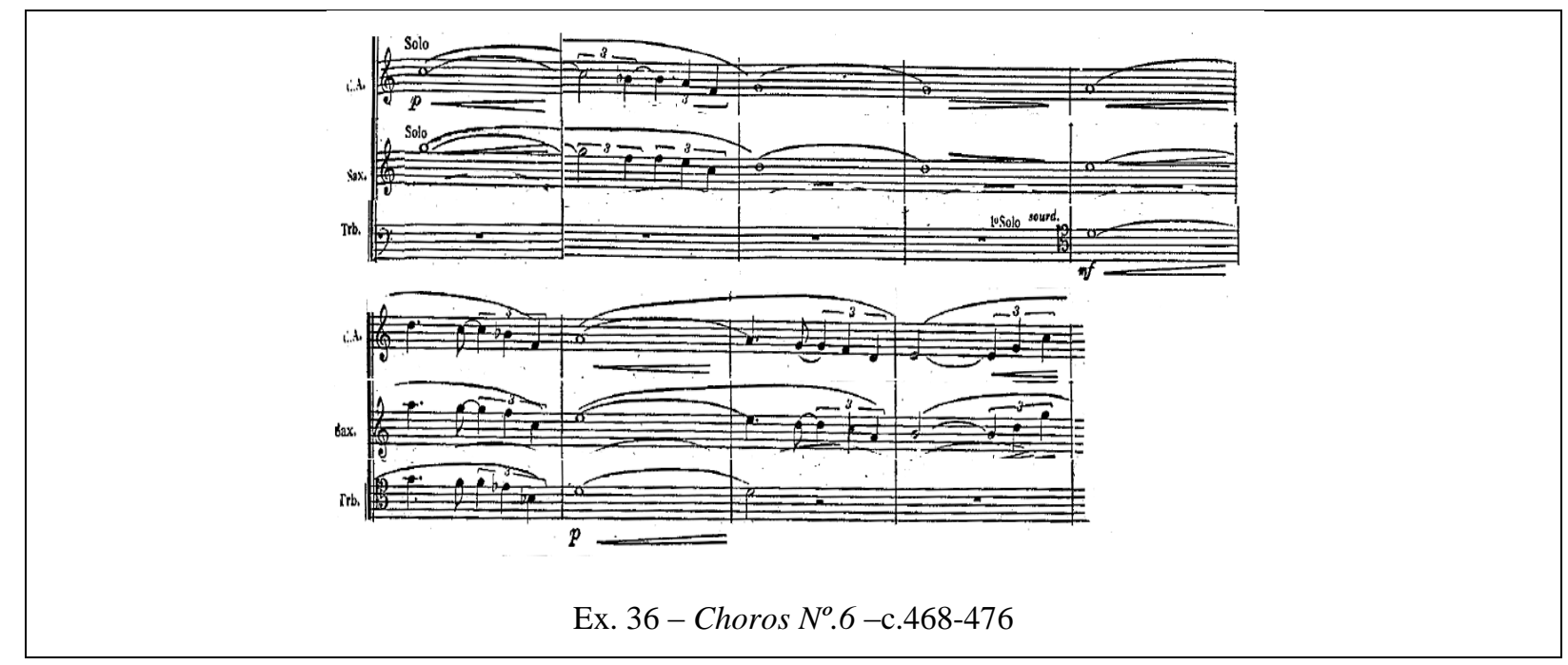

Embora Villa-Lobos tenha grafado originalmente a surdina Cup Mute, na orquestração o Trombone toca em oitava com o Saxofone Soprano, que possui um timbre mais estridente, portanto a surdina que tem o timbre mais estridente é a Straight Mute. Não encontramos exemplo de contraste timbrístico, via surdina, em peça alguma aqui analisada, portanto o mais indicado para esse trecho será a surdina Straight Mute em metal (alumínio).

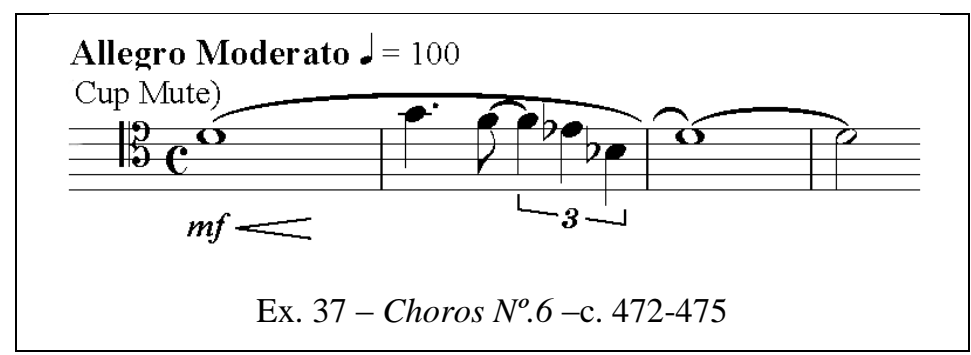




\subsection{Comentários sobre Trechos}

O objetivo deste capítulo é fornecer informações detalhadas e instruções sobre os trechos orquestrais de cada peça de Villa-Lobos aqui analisada. Os trechos escolhidos foram selecionados através das dificuldades técnicas anteriormente explanadas, indicadas pelos participantes da pesquisa. Há ainda, a pretensão de preparar o músico para realização de uma audição orquestral. Na audição, cada trecho serve para demonstrar a capacidade do candidato em uma área específica. Após a conclusão do processo de audição, a comissão terá uma visão clara de todos os aspectos técnicos dos concorrentes.

Este capítulo descreve cada trecho como um foco único e principal, bem como os elementos técnicos e musicais a serem considerados como parte da preparação para uma interpretação primorosa, considerados como "outros desafios". As soluções técnicas foram encaminhadas pelos participantes da pesquisa. Ainda para uma melhor preparação, indicou-se abaixo de cada exemplo musical, o metrônomo correspondente ao trecho.

\subsection{1 - TROMBONE TENOR ${ }^{106}$}

\section{Trecho 1: Uirapurú}

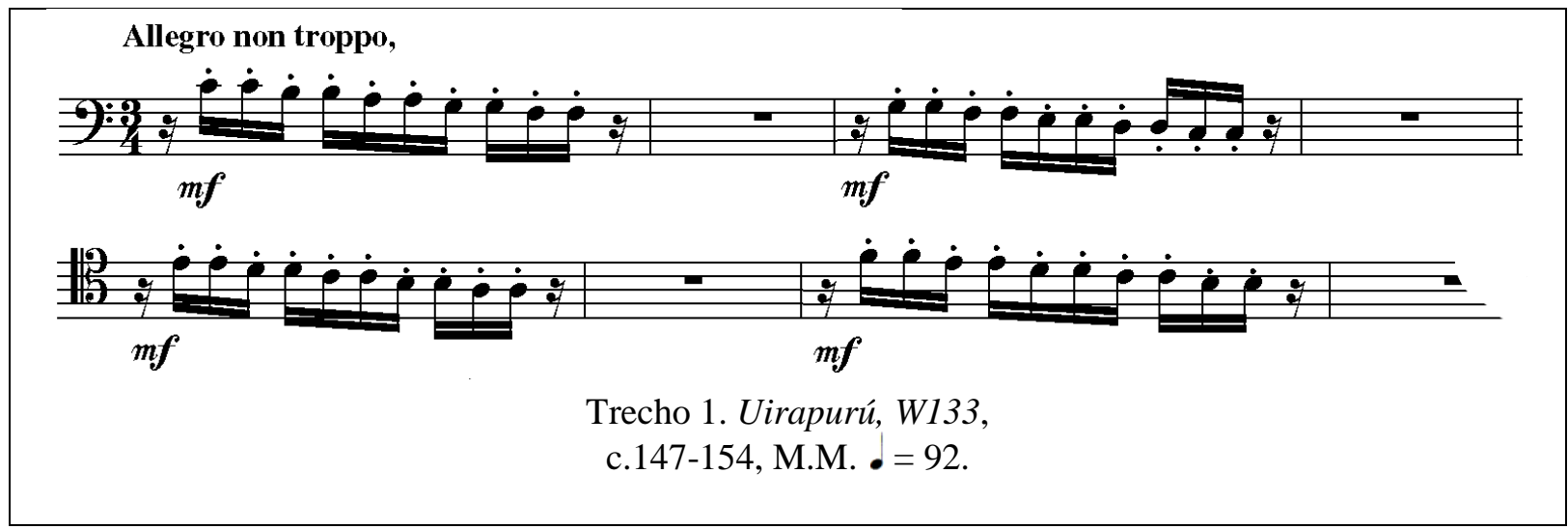

${ }^{106}$ Constatamos que Villa-Lobos tratava o naipe de trombones de forma paralela. Portanto, apenas a parte destinada ao $1^{\circ}$ trombone será explanada. O segundo trombone (ou o terceiro trombone tenor) será citado apenas se receber tratamento rítmico diferenciado (grifo nosso). 
a. Principal desafio:

Ritmo: não atrasar a entrada do inciso rítmico, por conta da pausa de semicolcheia - o tímpano toca uma nota neste $1^{\circ}$. momento do compasso. Não permitir que o ato de respirar crie atrasos de entrada.

Outros desafios:

b. Articulação: sincronizar o estacato com a velocidade do êmbolo;

c. Dinâmica: não alterar a dinâmica durante a execução do inciso.

d. Afinação: por conta da troca constante de posição do êmbolo, a afinação poderá ser comprometida.

e. Analise de estilo: não devem ocorrer acentos das notas que estão no início de cada tempo.

f. Técnicas requeridas: buscar como meta a precisão de posicionamento do êmbolo em nível avançado e boa velocidade de estacato simples.

\section{Trecho 2: Uirapurú}

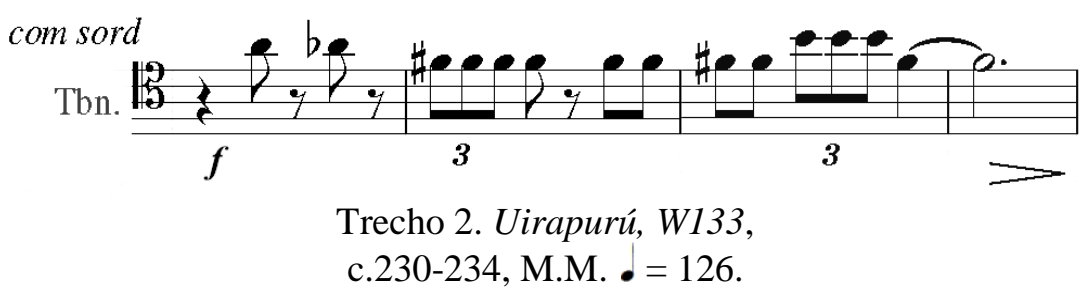

a. Principais desafios:

A colocação da surdina: o trombone terá nove tempos e o andamento da peça nesse momento estará a M.M. • = 126, portanto o trombonista terá o limite de 4 segundos para colocação da surdina. 
Outros desafios:

b. Afinação: a maioria das surdinas sobe a afinação das notas. Deve-se atentar para a afinação neste trecho.

c. Articulação: cuidado especial para que as notas - que estão grafadas na região aguda (em estacato e com surdina) não saiam ríspidas demais.

d. Ritmo: a execução da tercina em meio a colcheias regulares deve ser precisa.

e. Analise de estilo: A sonoridade da última nota não deve extrapolar o restante do inciso. Temos claramente, neste trecho, uma terminação feminina.

f. Projeção sonora: Villa-Lobos grafou a dinâmica forte $(\boldsymbol{f})$ para esse trecho. Estando com surdina, o trombonista necessariamente deverá aumentar uma dinâmica $(f f)$ para que a projeção sonora do instrumento dentro da sala de concerto aconteça no nível pretendido pelo autor.

\section{Trecho 3: Uirapurú}

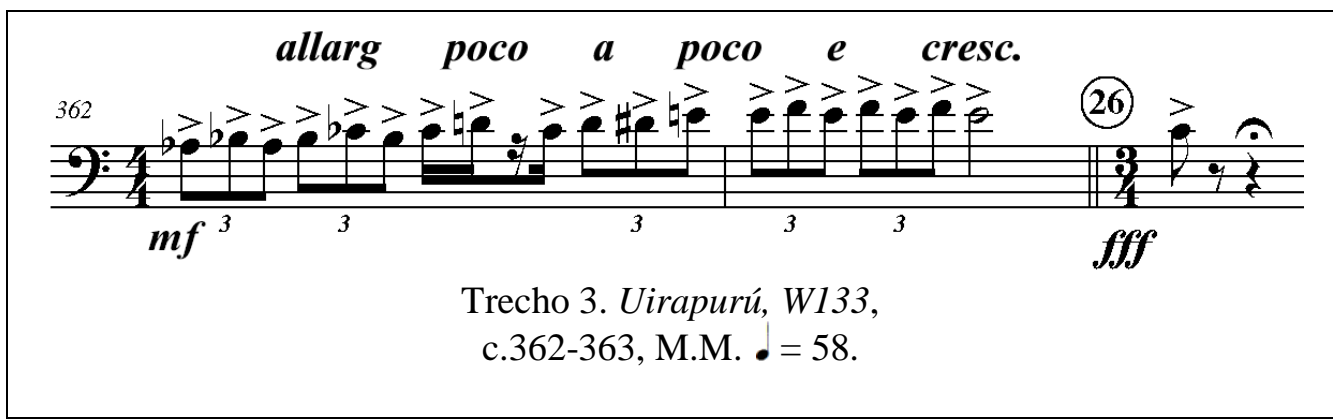

a. Principal desafio:

Projeção sonora: A sonoridade fatalmente será comprometida nesse trecho. Villa-Lobos escreveu três fatores cruciais à perda de controle sonoro: melodia na direção do agudo, crescendo autorizado a chegar a fff e um alargando de tempo. Portanto o trombonista deve ser cuidadoso em não perder o controle no final deste trecho $(\boldsymbol{f f f})$. 
Outros desafios:

b. Articulação: Este trecho está com articulação acentuada ( $>$ ), ou seja as notas devem diminuir na sustentação mas não soarem mais curtas. Não existe justificativa para uma troca de articulação (ponto de diminuição).

c. Ritmo: um trecho nitidamente em $12 / 8$, mas haverá um retorno ao $4 / 4$ no $3^{\circ}$. tempo do c. 362. Portanto o trombonista deve ter especial atenção ao ritmo deste trecho. A duração da penúltima nota deverá ser completa (outros instrumentos estarão fazendo seis colcheias em tercina enquanto perdurar essa mínima), pois esta resolverá na $1^{\text {a }}$. nota do c.364.

d. Notação diferente: Embora não grafado na partitura - e em igual circunstância para todos os instrumentos em uníssono - acreditamos que os dois Dób3 grafados no $3^{\circ}$. tempo do c.362 é na verdade Dó3 natural.

\section{Trecho 4: Amazonas}

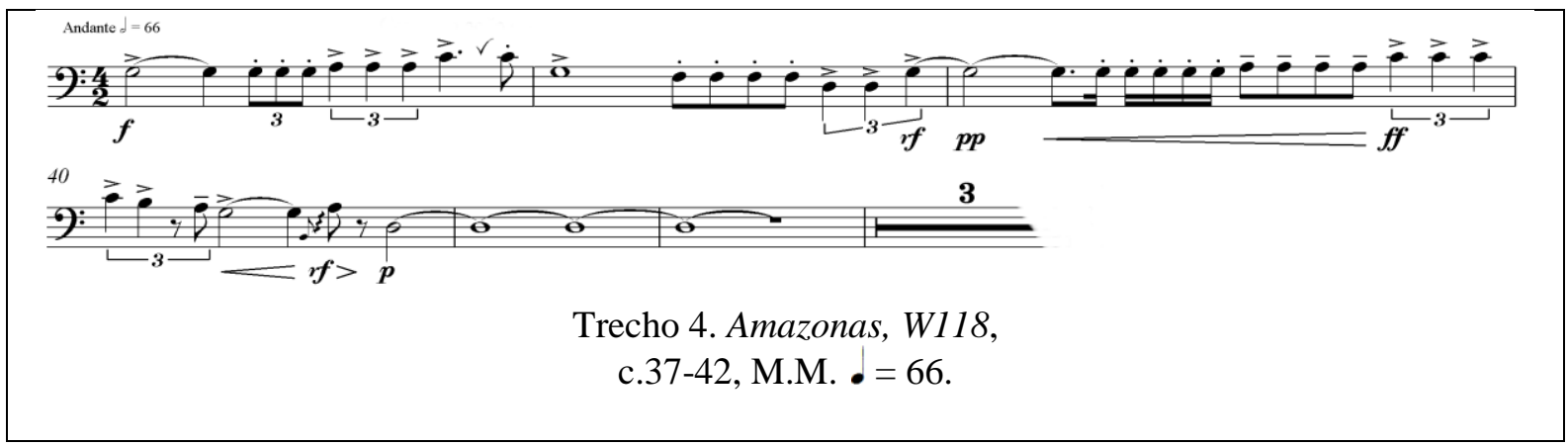

a. Principal desafio:

Ritmo: Os trombonistas devem ter especial atenção às tercinas que se posicionam em todos os compassos desse trecho. Pela própria conformação da tercina, ela tende a deixar mais lento o tempo seguinte com base de 4 colcheias em subdivisão. 
Outros desafios:

b. Dinâmica: Os trombonistas devem ficar atentos às quedas de dinâmica no c.39 e c.41.

c. Articulação: Villa-Lobos grafou estacato logo após a nota longa e no tempo seguinte acentos ( > ). Muita atenção para o c.39: está escrito estacato no $2^{\circ}$. tempo, tenuto no $3^{\circ}$. tempo ( - ) e acento ( > ) no $4^{\circ}$. tempo.

d. Analise de estilo: Villa-Lobos grafou um crescendo para o trombone $\left(\mathrm{c} .40-2^{\circ}\right.$. Tempo) e ao final glissando e rinforzando.

e. Complicações: Não há local para respiração, entre os c.39-c.42. Boa quantidade de ar deve ser armazenada nos pulmões para que esse trecho tenha sustentação sonora.

\section{Trecho 5: Amazonas}

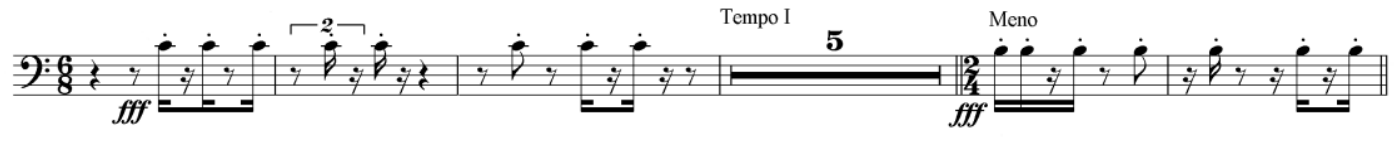

Trecho 5. Amazonas, W118, c.81-90, M.M. $\bullet=69$.

a. Principal desafio:

Ritmo: O trombonista deve estar muito seguro do local a ser tocado para cada uma dessas semicolcheias.

Outros desafios:

b. Articulação: Todas as notas deste trecho contém ponto de diminuição (estacato), portanto deverão soar curtas o tempo todo.

c. Notação diferente: A grafia desse trecho não prioriza de forma alguma a leitura do trombonista. Anotações com relação ao tempo são bem vindas para uma melhor precisão rítmica.

d. Complicações: - A alternância rítmica entre o 6/8 e as duínas deve ser precisa. 


\section{Trecho 6: Amazonas}

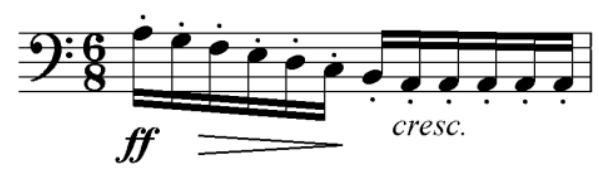

Trecho 6. Amazonas, W118, c.93, M.M. • $=66$.

a. Principal desafio:

Complicações: Após dois compassos de ritmo pouco perceptível nas cordas, o naipe de metais graves devem fazer sua entrada com segurança absoluta no $1^{\circ}$. tempo do c.93, juntamente com clarone, fagotes, contrafagotes e trompas.

Outros desafios:

a. Articulação: todas as notas estão grafadas em estacato (ponto de diminuição) portanto devem ser realmente curtas.

b. Dinâmica: Villa-Lobos grafou decrescendo no $1^{\circ}$. tempo e crescendo no $2^{\circ}$. tempo.

\section{Trecho 7: Amazonas}

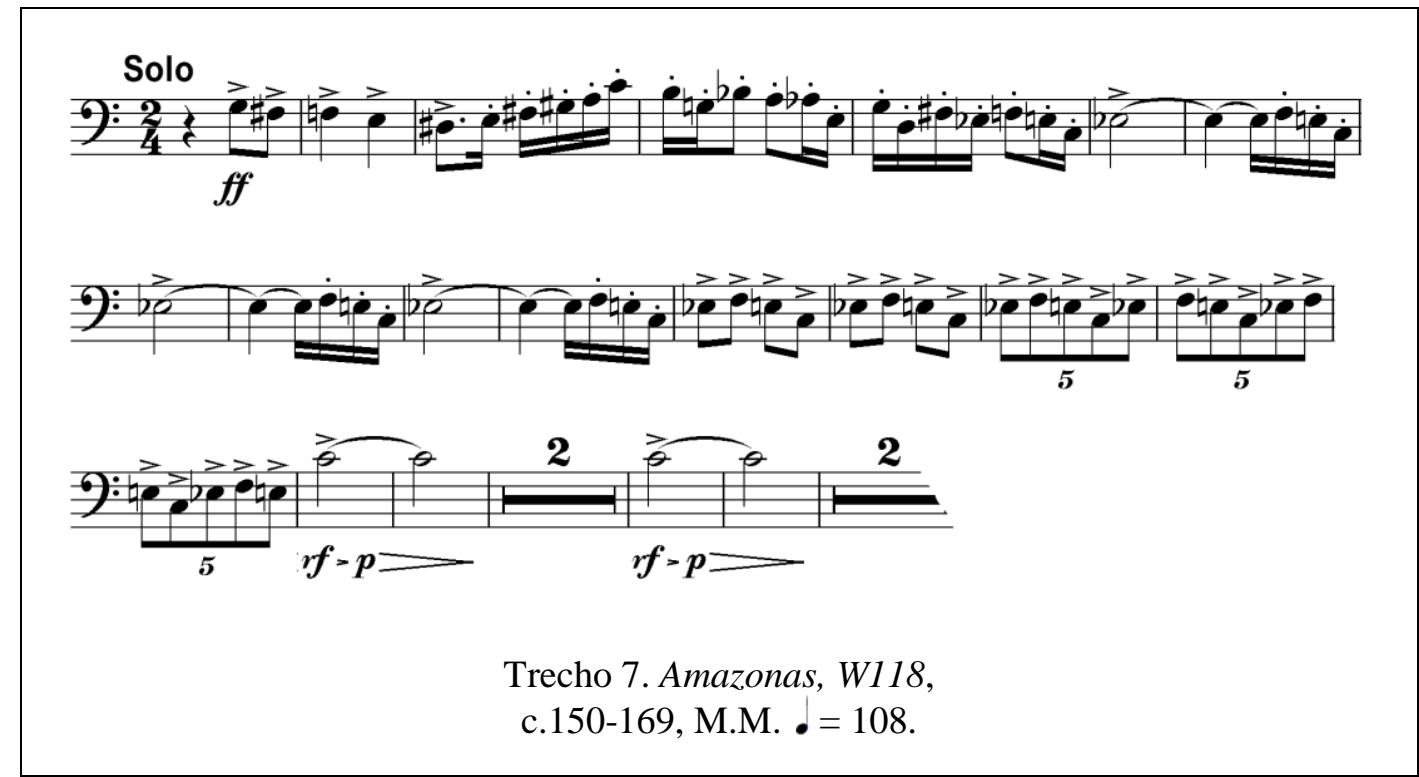


a. Principal desafio:

Técnicas requeridas: Técnica de êmbolo em nível avançado. Por conta da boa quantidade de semicolcheias e neste caso, as posições das notas no êmbolo estarem distantes, deve-se buscar um ótimo sincronismo entre a língua e o braço direito do trombonista.

Outros desafios:

b. Afinação: O trombonista deve atentar precisamente para a afinação pois este trecho estará em $8^{\mathrm{a}} . \mathrm{J}$ com a $2^{\mathrm{a}} . / 4^{\mathrm{a}}$. trompas e $3 \% 4^{\circ}$. Trompetes.

c. Articulação: Villa-Lobos foi bem claro nesse trecho - colcheias acentuadas e longas, semicolcheias curtas.

d. Ritmo: Nos c.156-158-160 ritmo acéfalo (sem a $1^{\text {a }}$. semicolcheia). Atentar para uma precisão rítmica do trombonista.

e. Complicações: Por conta do grande número de semicolcheias, os trombonistas devem ter cuidado para não aumentar a dinâmica nas semicolcheias. As quintinas nos c.163165 precisarão de um bom ajuste de proporção rítmica.

\section{Trecho 8: Amazonas}

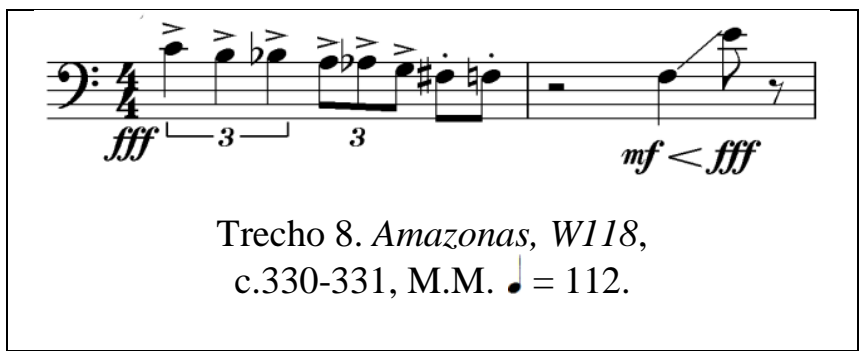

a. Principal desafio:

Ritmo: Precisão rítmica será necessária nesse trecho por conta da sequência de tercinas de mínimas e colcheias e a terminação em duína. 
Outros desafios:

a. Articulação: Atenção especial à articulação, pois Villa-Lobos grafou acentos do $1^{\circ}$. ao $3^{\circ}$. tempo, mas o $4^{\circ}$. tempo está grafado estacato.

b. Complicações: sincronização rítmica necessária entre metais e madeiras graves.

Trecho 9: Choros $N^{o} 4^{107}$

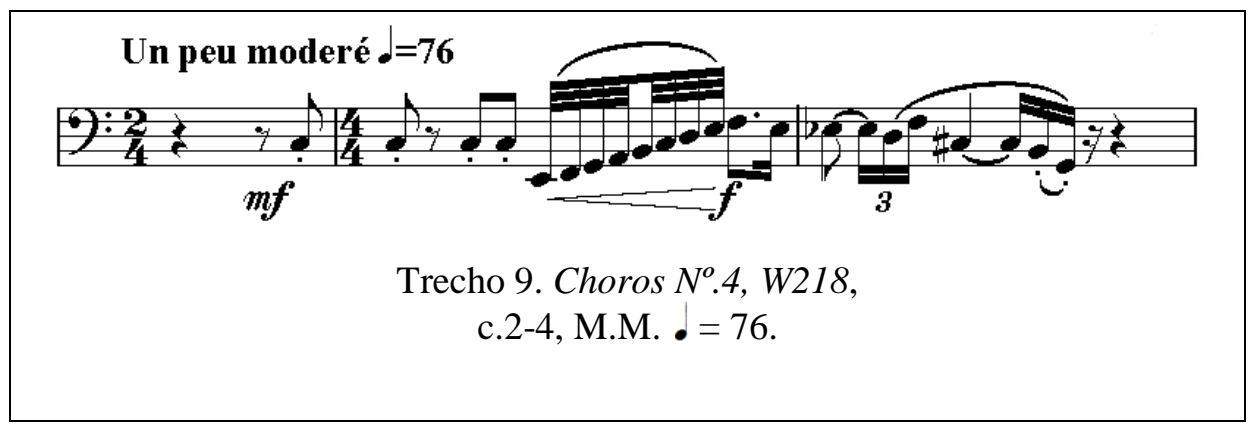

a. Principal desafio:

Complicações técnicas: Estão grafados no c.4 dois intervalos de Fá2-Dó\#2 e Si1-Sól1. Ambos são de grande dificuldade técnica para o trombonista. O motivo é a distância entre as notas quando executadas no êmbolo: Fá2 (1 $1^{\mathrm{a}}$. pos.) para Dó\#2 (5 ${ }^{\mathrm{a}}$ pos.) significam quatro posições a serem suplantadas e o outro intervalo Si1(7 . pos. ou $2^{\mathrm{a}}$.pos) para Sól1 (4 $4^{\mathrm{a}}$. pos.) que significam ( $1^{\circ}$. opção) três posições a se suplantar ou ( $2^{\mathrm{a}}$. opção) duas posições (Trecho 9a).

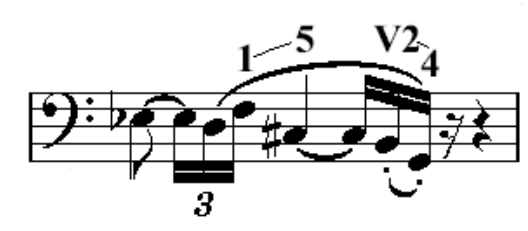

Trecho 9a. Choros No.4, W218, c.4.

${ }^{107}$ Estes trechos apenas deverão ser tocados se o trombonista possuir em suas mãos um trombone-barítono. 
Outros desafios:

b. Articulação: Como é uma articulação recorrente em Villa-Lobos, as quatro primeiras notas (Dó2) devem ser bem curtas.

c. Afinação: A quinta posição do trombone é a mais complicada para se afinar, portanto o trombonista deve concentrar-se para tocar a nota Dó\#2 bem posicionadas no êmbolo.

\section{Trecho 10: Choros $N^{o} .4$}

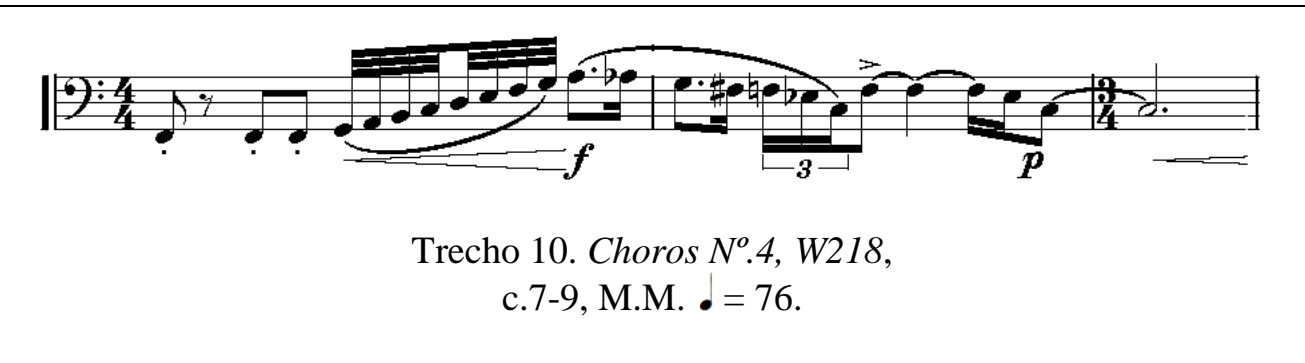

\section{a. Principal desafio:}

Complicações técnicas: Neste trecho o maior desafio será novamente a distância entre as posições do êmbolo. Está grafado no c.8 o semitom Fá\#2-Fá2. A altura não é problema alguma, porem o Fá\#2 é tocado na $5^{\mathrm{a}}$. pos. e logo a seguir teremos o Fá2 (1 ${ }^{\mathrm{a}}$. pos.). Isso significa um distanciamento de 4 posições. Essa é uma distância considerável para ser feita em tão curto espaço de tempo. Portanto, o trombonista deve buscar a habilidade em percorrer essa distância no mais curto tempo, e ainda não transpor tranco algum para a sonoridade (Trecho 10a).

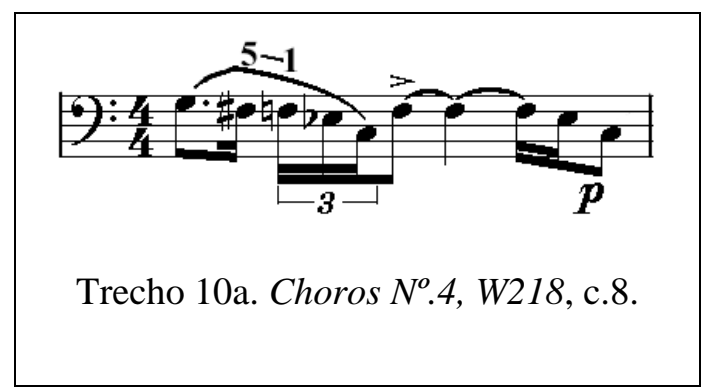

Outros desafios:

b. Dinâmica: Há uma queda brusca de dinâmica na última colcheia do c.8 - Villa-Lobos grafou um $\boldsymbol{p}$ sub. e crescendo. 
c. Articulação: As quatro primeiras notas (Fá1) devem ser bem curtas. Após o estacato, teremos duas ligaduras e ao final, Villa-Lobos grafou um acento $(>)$ na terceira colcheia do c.8.

d. Notação diferente: o glissando deve ser tocado de forma diferente (vide pg. 199).

\section{Trecho 11: Choros $N^{o} .4$}

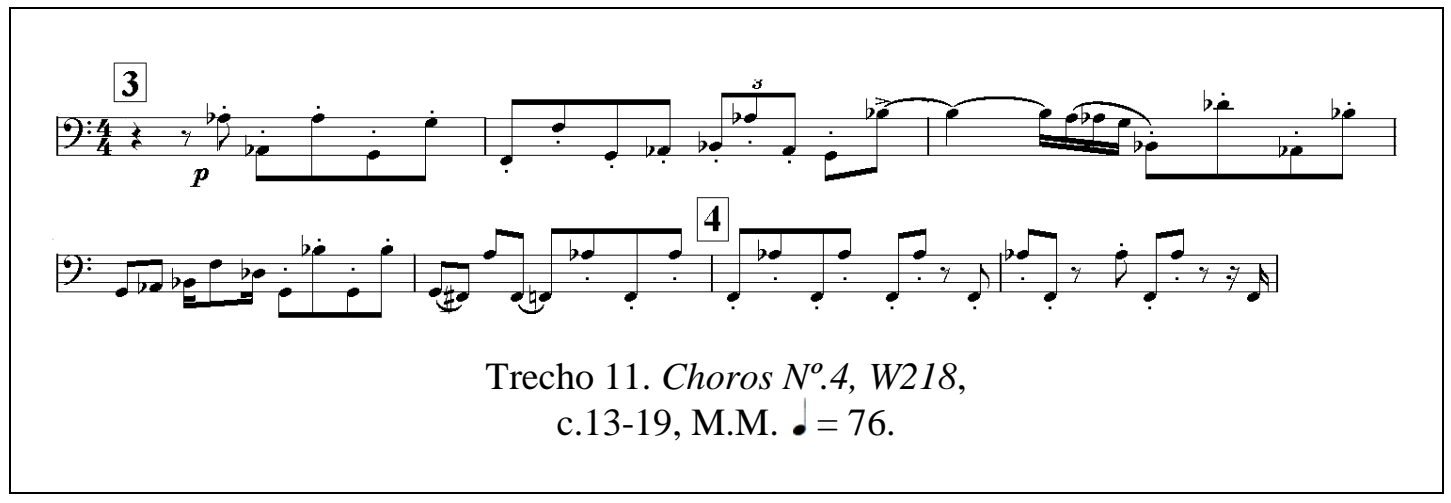

a. Principal desafio:

Respiração: Villa-Lobos não reservou um ponto específico para a respiração do trombonista. Deve-se localizar um local apropriado, que não interfira no conjunto, para esta respiração rápida.

Outros desafios:

b. Intervalos: Há nesse trecho uma expressiva quantidade de saltos melódicos grandes: doze intervalos de $10^{\mathrm{a}}$., apenas um de $9^{\mathrm{a}}$, três de $8^{\mathrm{a}}$. e finalmente um de $7^{\mathrm{a}}$, gerando uma possibilidade de erro de notas agudas.

\section{Trecho 12: Choros $N^{o} .4$}

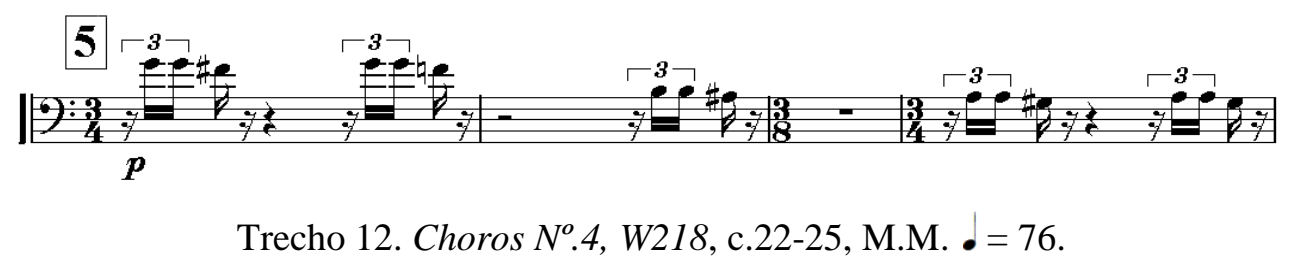


a. Principal desafio: Pelo andamento desse trecho, melhor será tocar utilizando-se da técnica de estacato duplo.

Outros desafios:

b. Sincronismo: Esse trecho é tocado em paralelo com a $2^{\mathrm{a}}$. trompa. Deve-se buscar o melhor sincronismo entre o trombonista e o trompista.

Trecho 13: Choros $N^{o} .4$

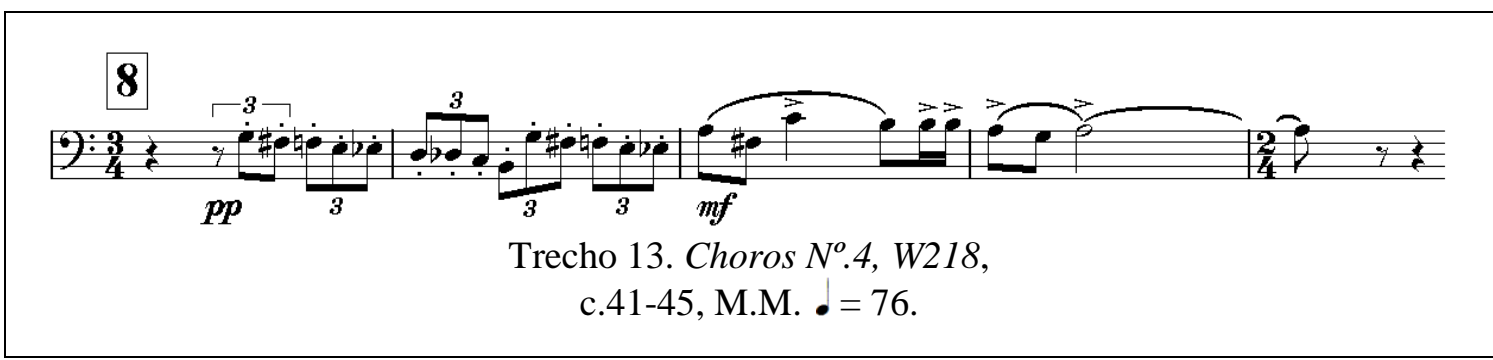

a. Principal desafio:

Analise de estilo: A troca de postura entre estar no acompanhamento (c.41-c.42) com dinâmica $\boldsymbol{p p}$ e no momento seguinte se tornar o solista (c.43-c.44) em $\boldsymbol{m f}$ requer uma habilidade técnica em nível avançado ao trombonista.

Outros desafios:

b. Ritmo: No mesmo momento que se necessita essa troca de postura de solista, o compositor fez a mesma troca no rítmico: Villa-Lobos escreveu em 9/8 os dois primeiros compassos (c.41-c.42) e retoma a ideia de 3/4 nos dois últimos compassos desse trecho (c.43-c.44), portanto o trombonista deve ter total domínio da troca em a subdivisão ternária e a binária para uma perfeita execução. 


\section{Trecho 14: Choros $N^{o} .4$}

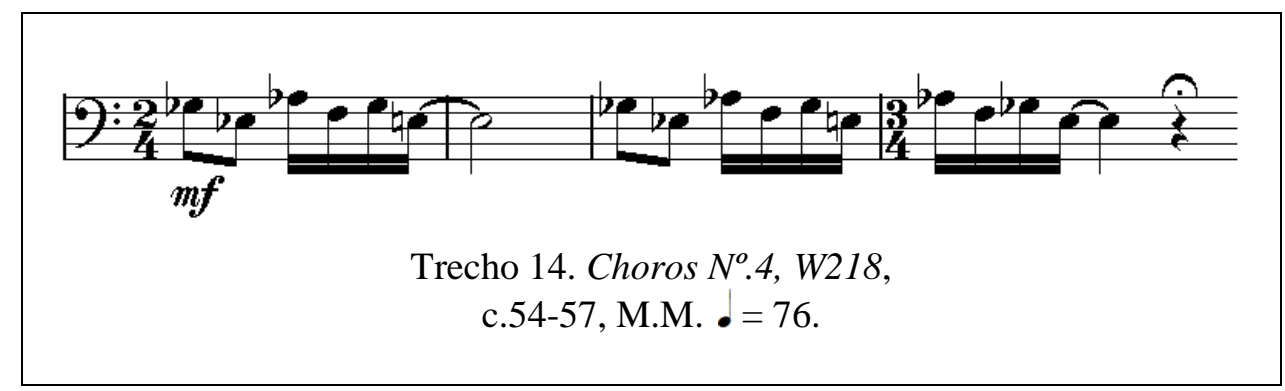

a. Principal desafio:

Complicações técnicas: O movimento do êmbolo entre a $1^{a}$. posição (Fá2) e a $5^{a}$. (Solb2) é longo o suficiente para gerar um atraso nas semicolcheias. O trombonista deve estar atento a esse movimento do êmbolo e acelerar o máximo possível (Ex. 14a).

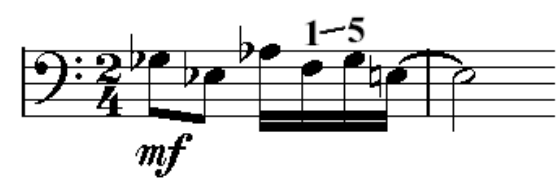

Trecho 14a. Choros $N^{o} .4$, W218, c.54.

Outros desafios:

b. Afinação: Nesse mesmo local acima mencionado, teremos além da dificuldade da distância a ser percorrida pelo êmbolo, a afinação de chegada da nota Sólb2 (5 $5^{\text {a }}$ pos.). A $5^{\text {a }}$. pos. sempre será a mais complicada, em termos de afinação, para o trombonista.

\section{Trecho 15: Choros $N^{o} .4$}

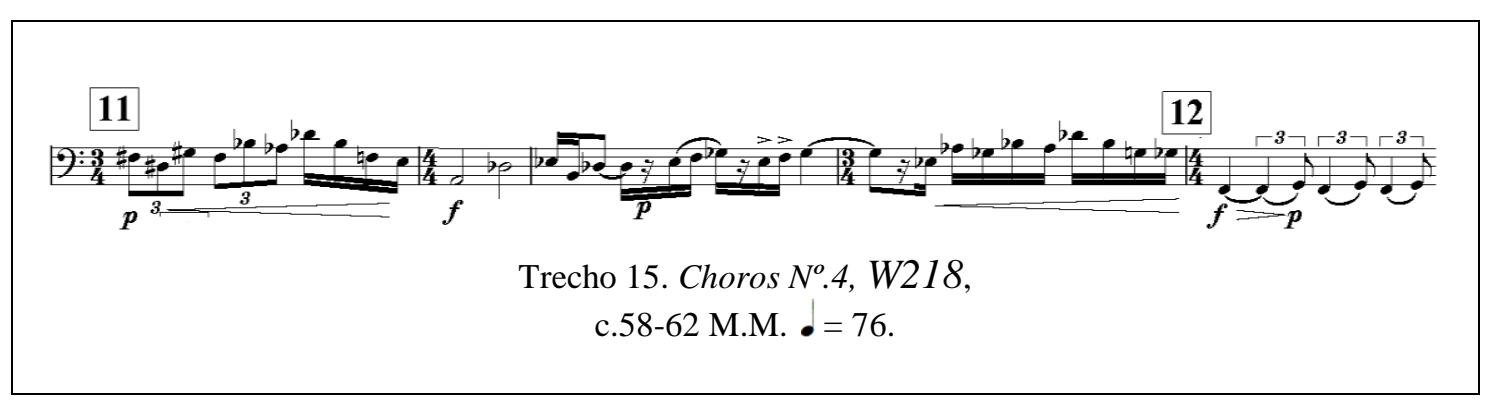


a. Principal desafio:

Intervalo grande: Villa-Lobos grafou esse intervalo de $9^{\mathrm{a}} . \mathrm{m}$ na passagem do c.61-c.62. É uma passagem realmente complicada e o trombonista será obrigado a fazer um deslocamento de embocadura para conseguir nesse espaço de tempo (apenas uma semicolcheia) essa troca de registro (Ex. 15a).

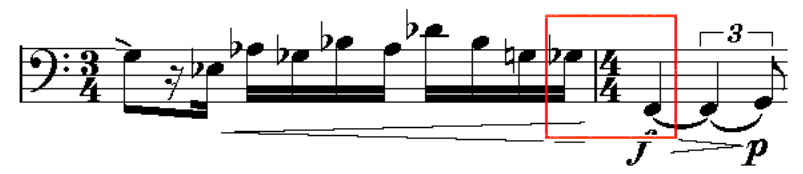

Trecho 15a. Choros $N^{o} .4$, W218, c.61-62.

Outros desafios:

b. Ritmo: A troca de tercina de colcheia com semicolcheia no c.58 cria uma dificuldade rítmica ao trombonista.

c. Dinâmica: A frase terá dois $\boldsymbol{p}$ (c. 58 e c.60) com seus respectivos cresc. (c.58 e c.61) para culminarem em dois $\boldsymbol{f}$ (c.59 e c.62). Atenção especial para essas trocas de dinâmicas.

d. Afinação: Especial atenção às notas Sólb2 durante esse trecho.

Trecho 16: Choros $N^{o} .4$

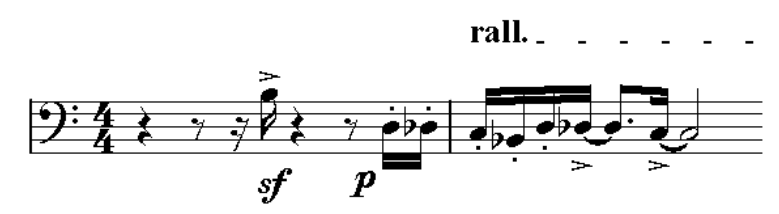

Trecho 16. Choros $N^{\circ} .4, W 218$, c.65-66 M.M. $\bullet=76$. 
a. Principal desafio:

Ritmo: Em música popular é muito comum uma nota isolada e tocada como última semicolcheia do tempo. A dificuldade para o trombonista reside no fato que ele precisará acertar perfeitamente o ritmo dessa semicolcheia precedida de uma pausa de colcheia pontuada e ainda sincronizar esse ataque de nota com as outras três trompas.

Outros desafios:

b. Articulação: Na primeira nota deste trecho há acento ( > ), estacato ( . ) nas próximas três notas e por fim, as duas últimas notas terão acento ( $>$ ) novamente.

c. Complicações técnicas: Como a distância entre a nota Dó2 e Sib1 é muito grande, sugerimos que o trombonista use a nota Dó2 feita no rotor (1 $1^{\mathrm{a}}$. posição).

\section{Trecho 17: Choros $N^{o} .4$}

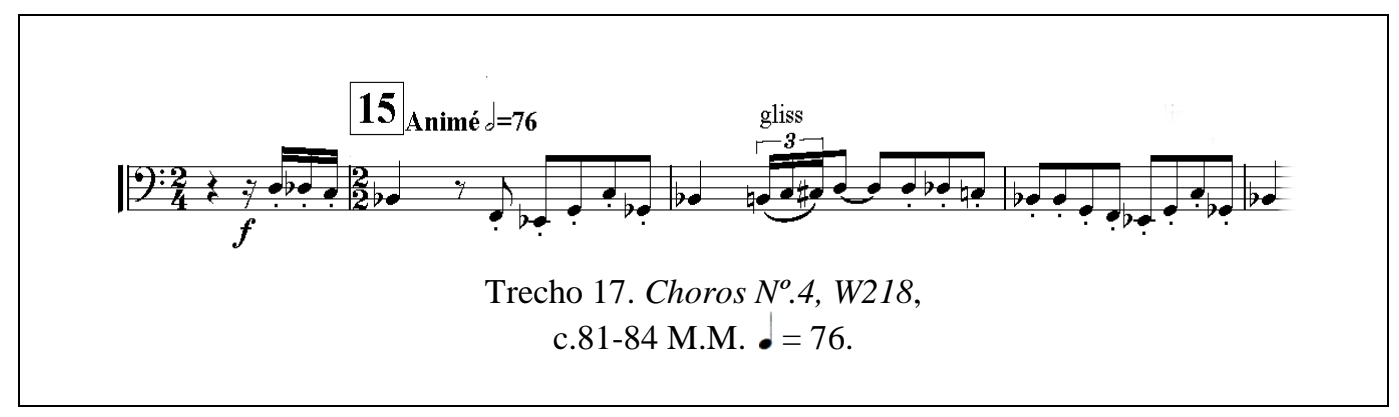

a. Principal desafio:

Ritmo: Intuitivamente todo trombonista acreditará que o glissando do c.83 o levará ao $3^{\circ}$. tempo do compasso. No entanto, Villa-Lobos antecipou esse final do glissando para a $2^{\mathrm{a}}$. metade do $2^{\circ}$. tempo. Portanto, atenção especial deve ser dada a exatidão rítmica desse c.83 (Ex.17a)

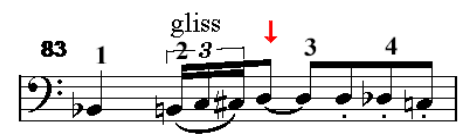

Trecho 17a. Choros $N^{o} .4$, W218, c.83. 
Outros desafios:

b. Analise de estilo: A boa execução exige que o glissando finde-se em terminação feminina. Portanto os trombonistas não devem crescer em direção ao final desse glissando.

c. Complicações - Velocidade de êmbolo: o êmbolo estará trabalhando entre a $1^{\mathrm{a}}$. e a $6^{\mathrm{a}}$. posição (duas vezes) e entre $1^{\mathrm{a}}$. e a $5^{\mathrm{a}}$. posição (duas vezes). Essa distância acarreta atrasos nas colcheias. Especial atenção à nota Sib1.

\section{Trecho 18: Choros $N^{o} .4$}

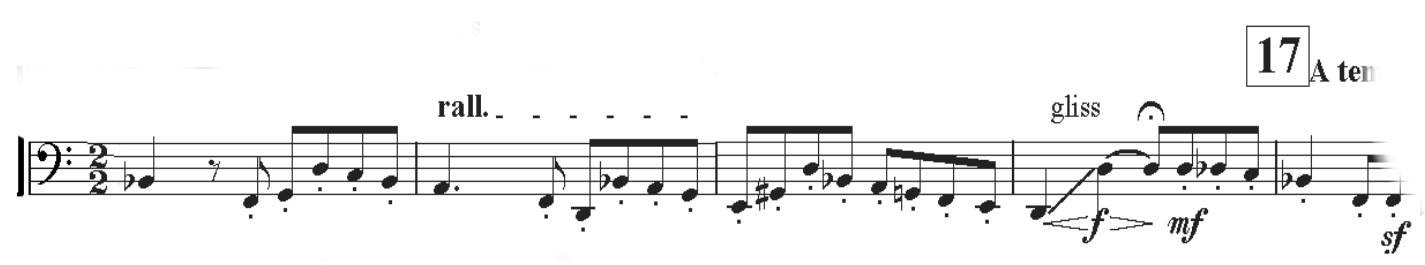

Trecho 18. Choros $N^{\circ} .4, W 218$, c.92-96 M.M. $\bullet=76$.

a. Principal desafio:

Técnica específica requerida: Villa-Lobos não deixou espaço para respiração nesse trecho durante os c.93 até c.95. O ar não será suficiente se feito de maneira natural. O trombonista deve achar um melhor local para respiração em meio a esses compassos.

Outros desafios:

b. Articulação: Especial atenção às notas curtas (ponto de diminuição) grafadas por Villa-Lobos para este trecho.

c. Complicações: Trecho com uma dificuldade técnica para o trombone tenor - a nota Ré2 (c.95) está fora da tessitura do instrumento, portanto deverá ser tocada num trombone-barítono, mesmo com a sonoridade comprometida pelo bocal inadequado a essa tessitura. 


\section{Trecho 19: Choros $N^{o} .4$}

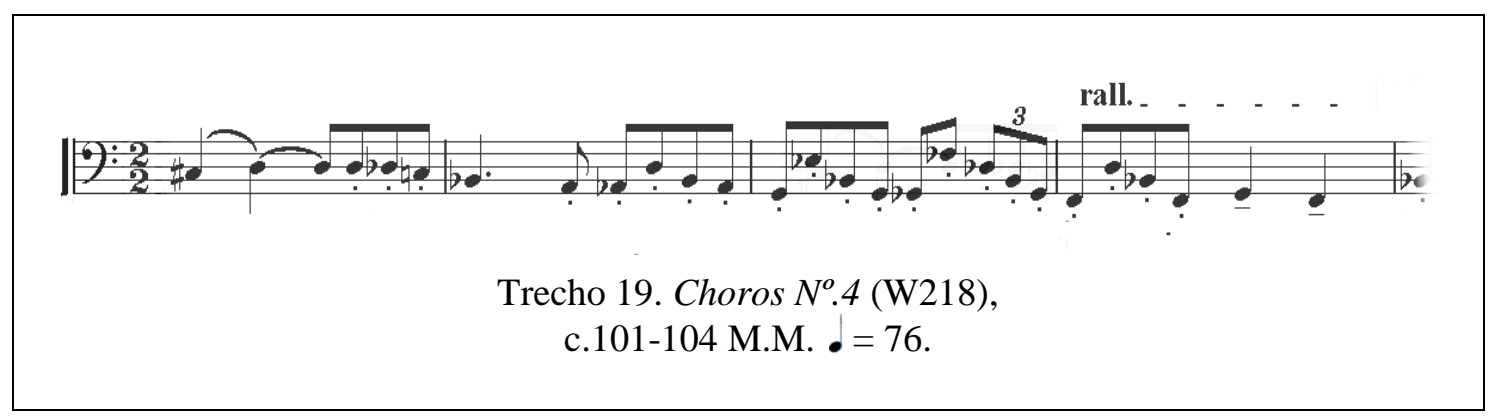

a. Principal desafio:

Técnica específica requerida: Villa-Lobos novamente não deixou espaço para respiração (de c.102 até c.104). Da mesma forma, o ar não será suficiente se o fizer de forma natural. Aconselhável será que o trombonista encontre um melhor local para respiração em meio a esses compassos, sem cortar a ideia de conjunto com os demais do grupo.

Outros desafios:

b. Força: Especial cuidado com as tercinas de colcheias escritas no c.103. Estas não devem soar mais forte que o restante do trecho.

\section{Trecho 20: Choros $N^{o} .4$}

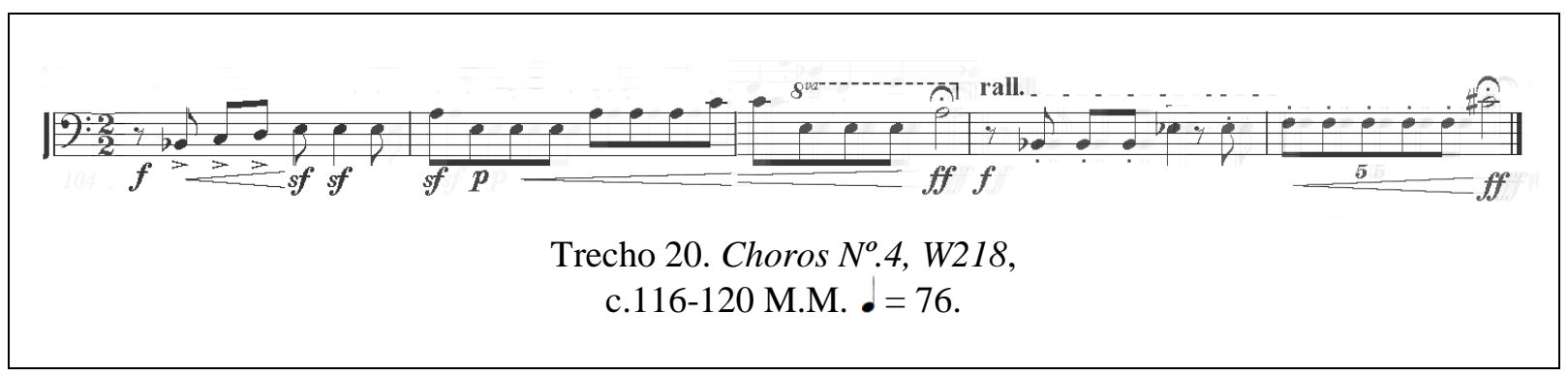

a. Principal desafio:

Ritmo: Dois locais deverão receber especial atenção: as duas colcheias da mudança do c.117c.118 (as notas sempre estarão agrupadas em 3 repetições, porém nesse local há apenas dois Dó3 - Trecho 20a) e a quintina do c.120, pois além de ser uma das mais complexas divisões, o trombonista deverá sincronizar perfeitamente com as outras trompas. 


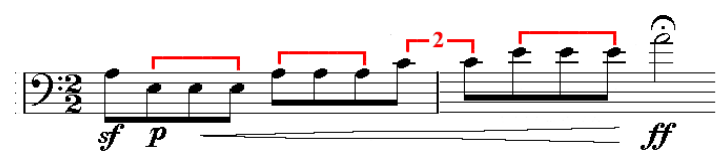

Trecho 20a. Choros N $N^{\circ}$, W218, c.117-c.118.

Outros desafios:

b. Intervalos: Não será fácil para trombonista algum terminar a $1^{\mathrm{a}}$. semifrase desse trecho na nota Lá3 em fermata e logo a seguir tocar um Sib1 (intervalo de uma oitava $+7^{\mathrm{a}} \cdot \mathrm{M}$, perfazendo 23 semitons de distância). Especial atenção a esse intervalo problemático.

c. Dinâmica: Villa-Lobos grafou um crescendo durante a quintina. Essa alteração de dinâmica não é natural, mas deve ser executada.

d. Articulação: Atentar para o fato que a $2^{a}$. semifrase desse trecho final está grafada com ponto de estacato.

e. Sincronismo: Todo o trecho está em paralelo rítmico com as trompas. Trombonistas devem manter a concentração para um perfeito equilíbrio rítmico.

Trecho 21: Choros $N^{o} .6$
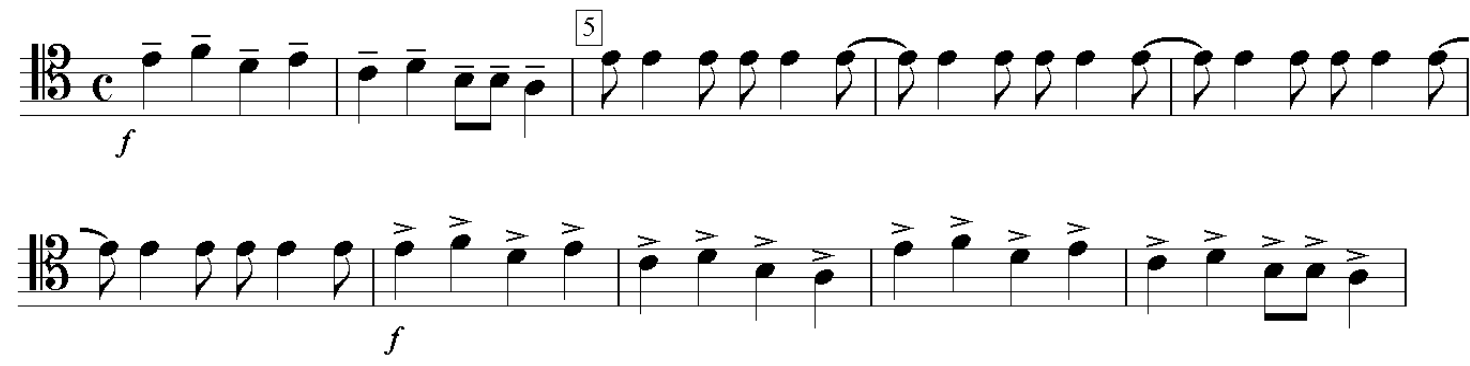

Trecho 21. Choros $N^{o} .6$, W219,

c. 36-45 M.M. $\bullet=132$.

a. Principal desafio:

Respiração: O compositor não deixou local algum para a respiração do trombonista, some-se a esse problema o fato que o acompanhamento (c.38-c.41) se junta ao soli (c.36-37 e c.42-45). Melhor será o trombonista cortar alguma nota do acompanhamento para a realização de sua respiração. 
Outros desafios:

b. Ritmo: O acompanhamento foi grafado em sincopa, porém essa sincopa não tem grafia constante - a cada barra de compasso acontece uma ligadura, que retira o bateri do compasso para o trombonista. Muita atenção deve ser investida pelo músico para que não haja oscilação da pulsação nesse trecho.

c. Articulação: Seguindo a partitura original, Villa-Lobos utilizou tratinas/tenuto no $1^{\circ}$. soli (c.36-37) e acentos ( > ) no $2^{\circ}$. (c.42-45).

Trecho 22: Choros $N^{o} .6$

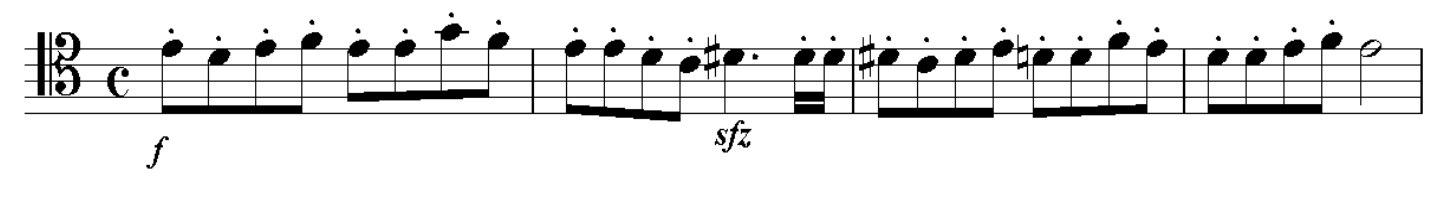

Trecho 22. Choros $N^{o} .6$, W219, c.50-53 M.M. $\bullet=132$.

a. Principal desafio:

Complicações: O cromatismo descendente ao qual Villa-Lobos incutiu nessa semifrase.

Outros desafios:

b. Articulação: Quase a totalidade do trecho está com articulação estacato, porém a única semínima pontuada recebeu $s f z$ como articulação. Logo ao meio dessa execução deve-se atentar para o $s f z$ incrustado ao meio do trecho.

c. Respiração: Villa-Lobos não deixou local possível para a respiração do trombonista. Portanto, deve-se respirar após a semínima pontuada. 
Trecho 23: Choros $N^{o} .6$

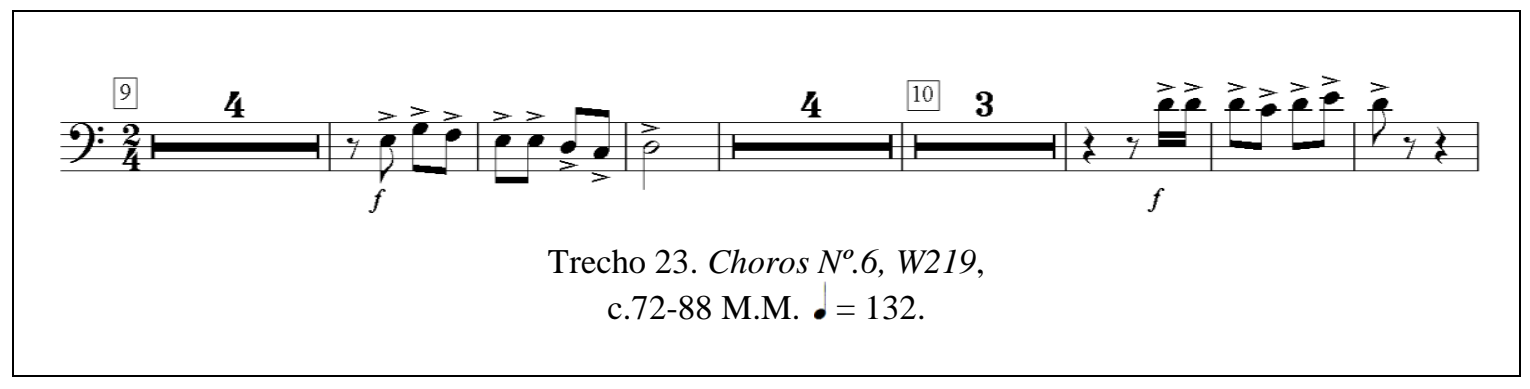

a. Principal desafio:

Complicações: Esse solo, que na verdade é o complemento da semifrase iniciada pela trompa, deve ser ainda, complementada com precisão rítmica.

Outros desafios:

b. Analise de estilo: Não se deve acentuar tempo algum durante a execução de cada inciso, principalmente o c.86 com suas semicolcheias em anacruse.

\section{Trecho 24: Choros $N^{o} .6$}

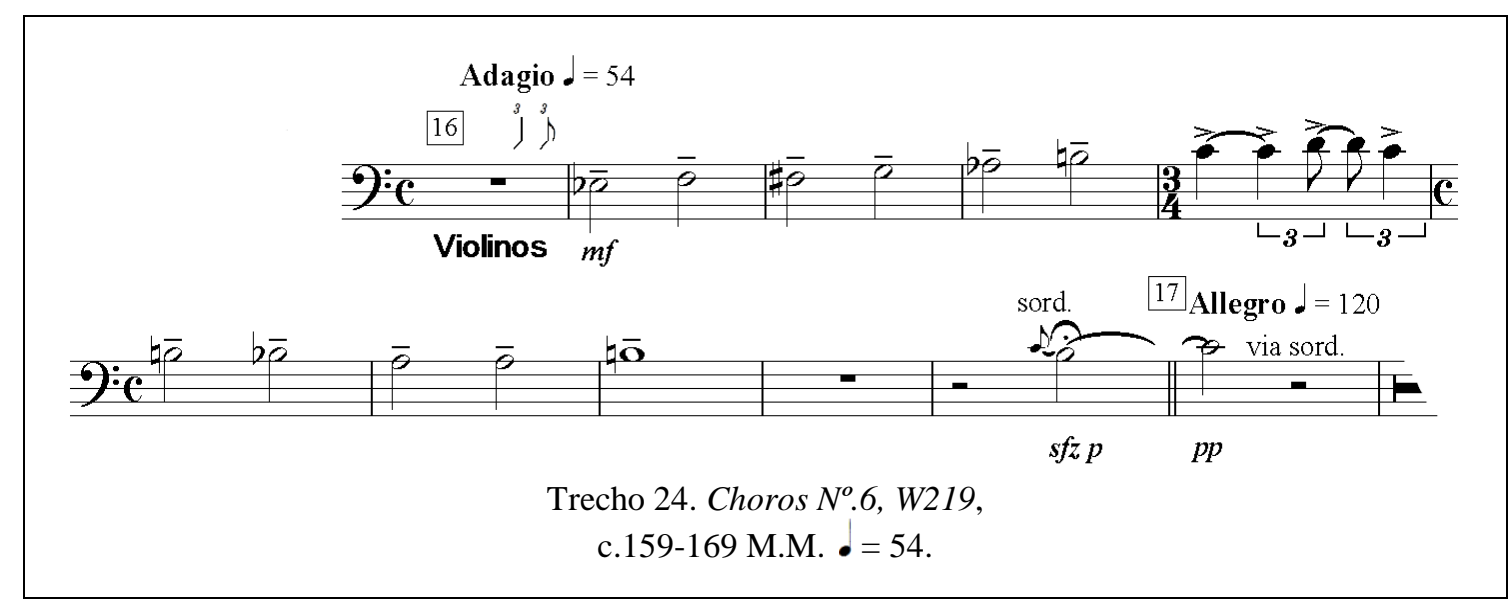


a. Principal desafio:

Ritmo: A tercina escrita por Villa-Lobos no c.163 (o único trecho que recebeu articulação em acento) deve ser executada com precisão rítmica pelo naipe completo de trombones, pois a orquestra estará com outro ritmo e o maestro não deve reger o naipe de trombones.

Outros desafios:

b. Respiração: Embora Villa-Lobos não nos deixou local algum para se respirar, e ainda em decorrência desse trecho não ser soli, o trombonista pode escolher qualquer mínima para sua respiração, desde que não atrapalhe o desenrolar das frases.

c. Complicações: Teremos seis tempos para a colocação da surdina. É tempo suficiente, mas não de forma relaxada. Faça o mais rápido possível.

\section{Trecho 25: Choros $N^{o} .6$}

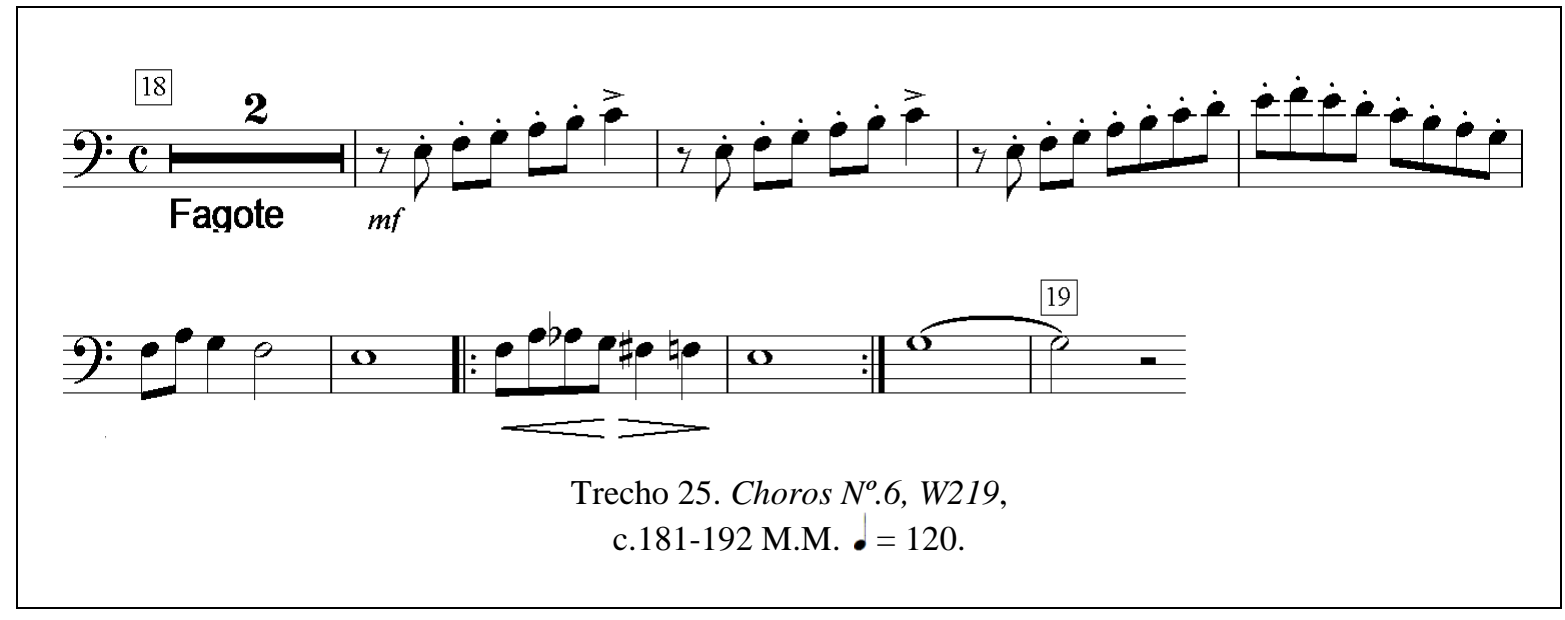

a. Principal e único desafio:

Articulação: Todo o trecho recebeu estacato como articulação, apenas a última nota de cada inciso foi grafada com acento. Pela grafia da parte original, Villa-Lobos gostaria que a última nota dos c.183-184 fossem acentuadas e mais longas. Na parte original dos c.187-192 a articulação ficou omitida. Acredita-se que a notas deveriam tornar-se mais longas ( - ). 


\section{Trecho 26: Choros $N^{o} .6$}

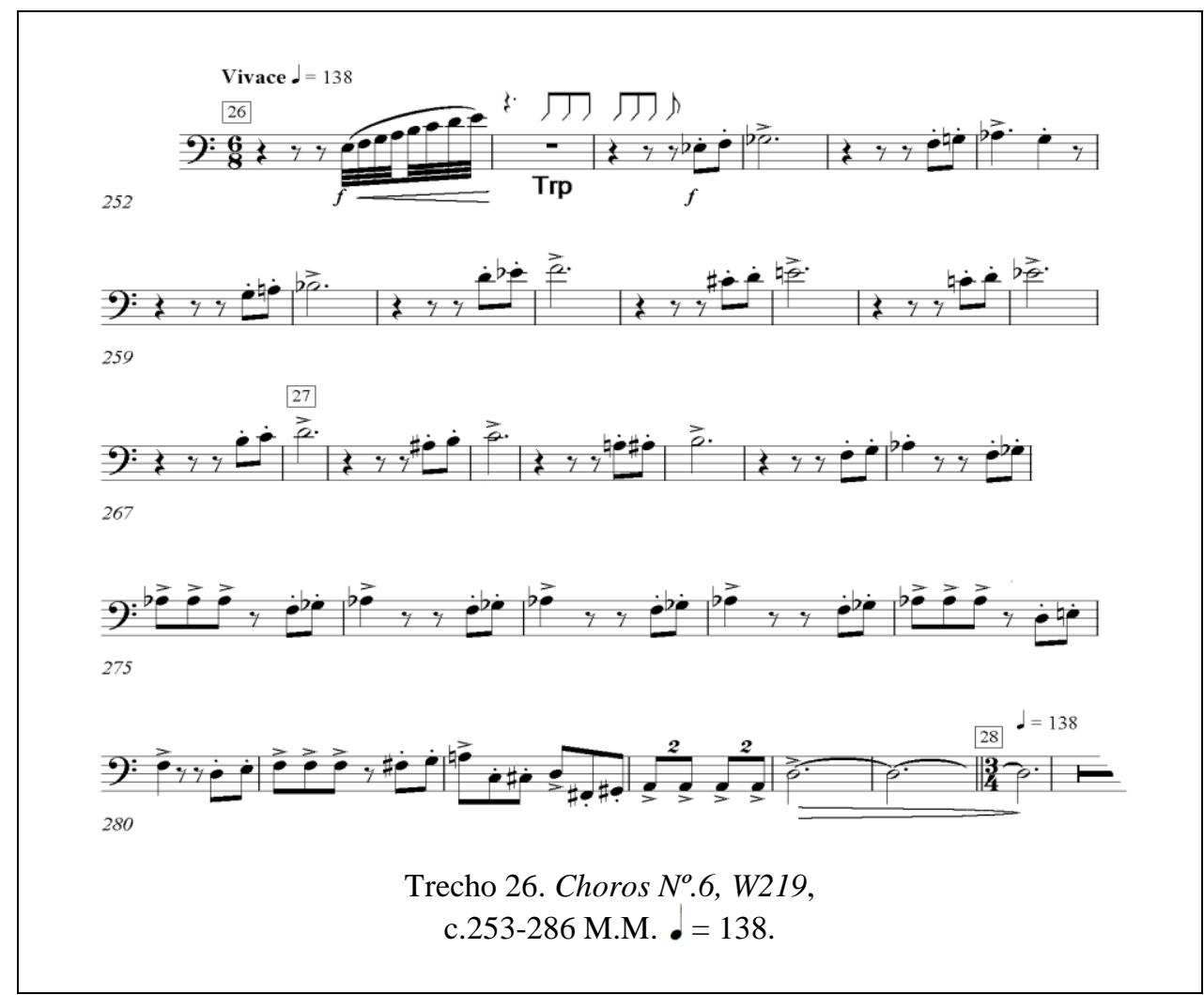

a. Principal desafio:

Ritmo: Os Trompetes entram no c. $254-2^{\circ}$. tempo, mas o ritmo destes não ajudam aos trombones em seu inciso rítmico, portanto os trombonistas devem prestar para que não aconteça atraso na sua entrada.

Outros desafios:

b. Técnicas requeridas: Após 30 compassos em 6/8, Villa-Lobos grafou para os trombones um compasso em duínas (c.283). O trombonista deve reservar especial atenção rítmica à esse local em especial.

c. Respiração: Villa-Lobos não deixou um local em especial para uma respiração, entre os c.281-286, mas em compensação, Villa-Lobos termina a frase (c.284-286) em três mínimas pontuadas, ligadas e em decrescendo. E dessa forma a escassez de ar ao final dessa frase será compensada pelo decrescendo... 
Trecho 27: Choros $N^{o} .6$

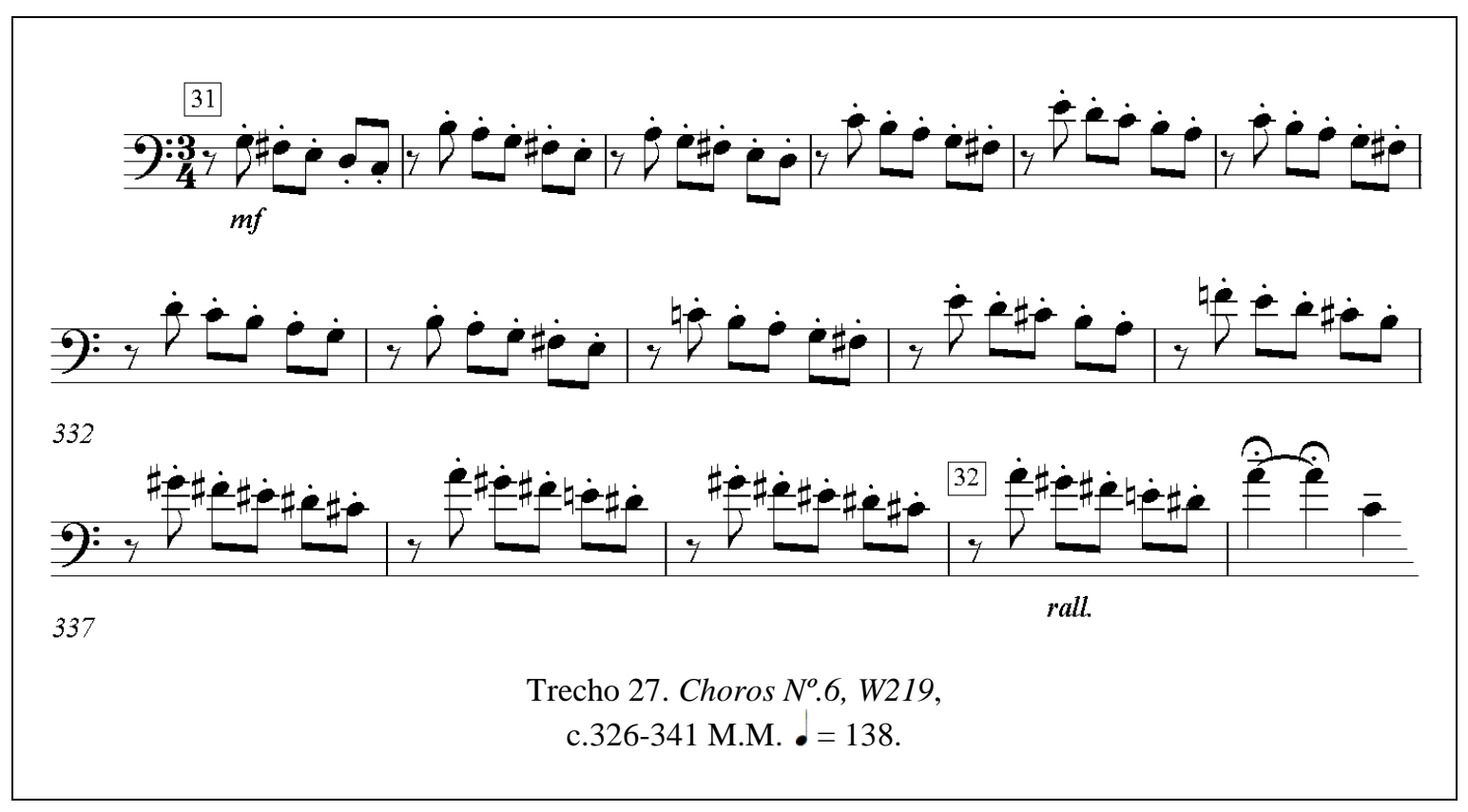

a. Principal desafio:

Extensão: Esse movimento escalar descendente que perdurará todo o trecho, não carrega consigo dificuldade alguma para o trombonista. A dificuldade reside no fato que paulatinamente a nota mais aguda do inciso torna-se mais aguda que a anterior, gerando uma fadiga muscular e criando a possibilidade de uma falha em qualquer nota aguda.

Outros desafios:

b. Articulação: Villa-Lobos grafou esse trecho inteiramente em estacato.

Trecho 28: Choros $N^{o} .6$

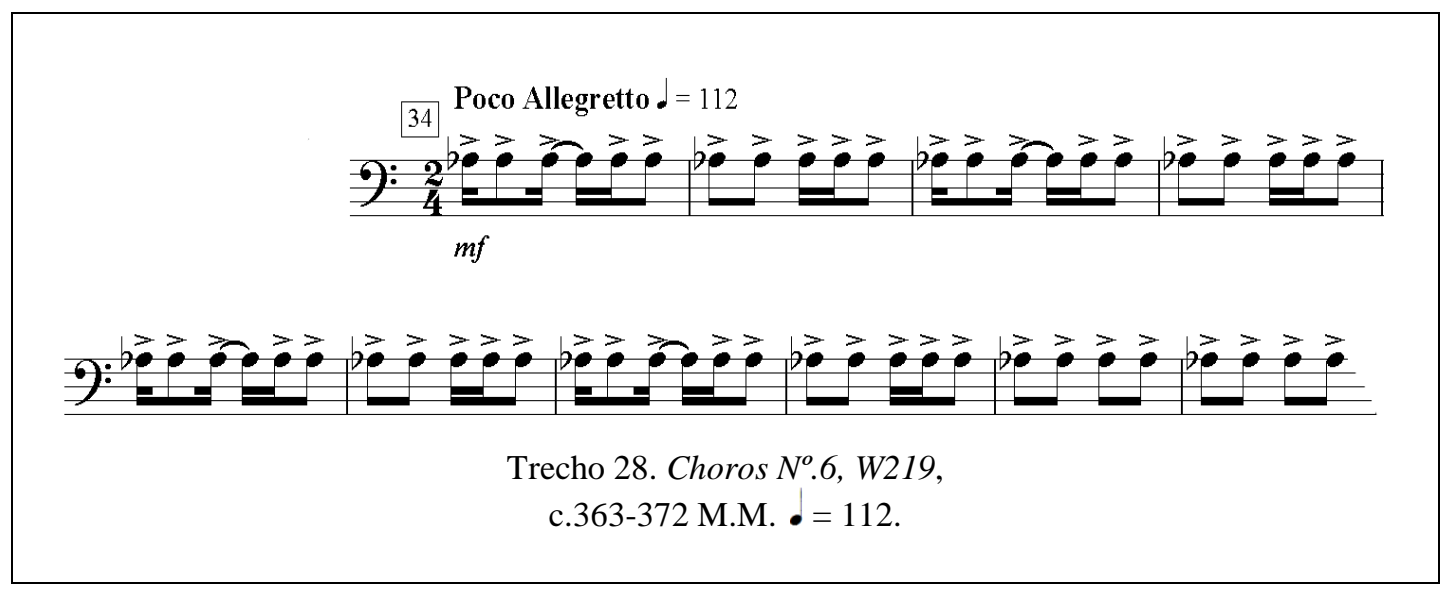

Universidade de São Paulo 
a. Principal desafio:

Ritmo: Villa-Lobos incumbiu ao Trompete e trombone a execução desse ostinato com sincopas. Foram grafadas quatro repetições deste inciso, e isso requer um alto grau de concentração por parte dos músicos para que não se cometa erros rítmicos.

Outros desafios:

b. Afinação: Este trecho foi grafado em oitava com o Trompete, logo uma perfeita afinação deve ser uma meta para o trombonista.

c. Analise de estilo: Inciso rítmico que relembra as batidas do violão num ritmo de dança. Ao violão, as notas não recebem o mesmo peso dos dedos, mas Villa-Lobos não alterou a articulação, portanto partiremos do princípio que todas as notas devem ser acentuadas e iguais em peso.

d. Articulação: Nesse trecho, retirado da edição impressa da ABM 2010, não há alteração de articulação do c.363-370. Localizamos na edição original da Max Eschig editada em 1955, a ausência de ligaduras nos c.367 e 369.

\section{Trecho 29: Choros $N^{o} .6$}

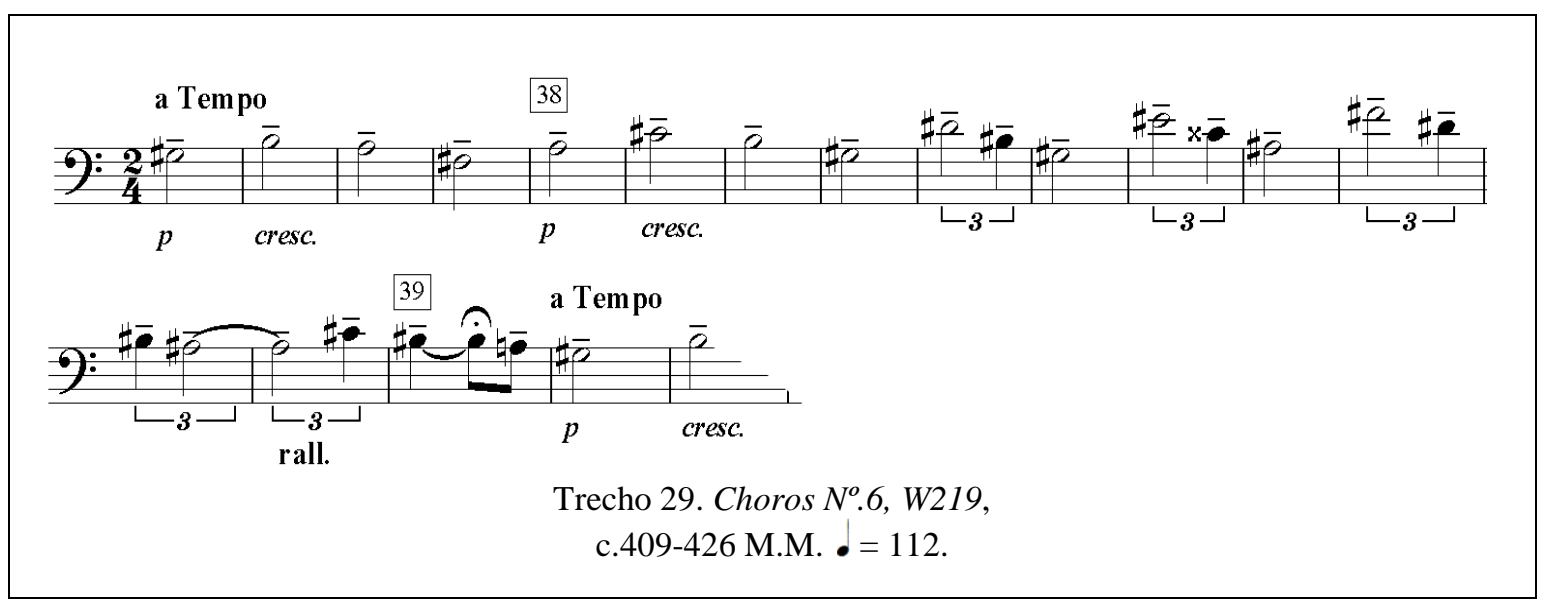

a. Principal desafio:

Ritmo: A partir do c.417 Villa-Lobos introduz, na criação de um novo motivo, a tercina de semínimas. $\mathrm{O}$ andamento não estará rápido, mas é aconselhável que o trombonista controle o tamanho das notas em quiálteras. 
Trecho 30: Choros $N^{o} .6$

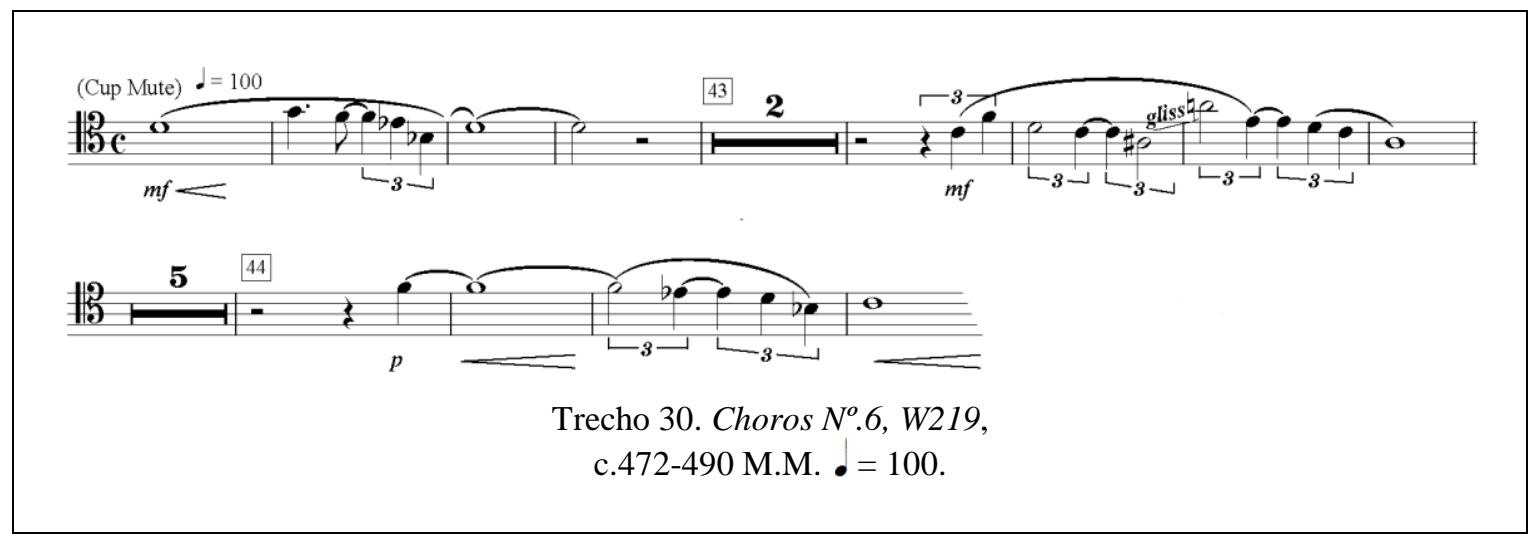

a. Principal desafio:

Análise de estilo: Esse trecho do Choros $N^{o} .6$ é dominado pelo timbre do saxofone. Para tanto, o trombonista deve se utilizar de um timbre mais suave para que combine com o saxofone.

Outros desafios:

b. Intervalos: Villa-Lobos grafou no c.479-480 um glissando de $7^{\mathrm{a}} . \mathrm{M}$, porém esse intervalo também terá o agravante do ar está na sua parte final, mas uma respiração em meio à esse inciso não será possível.

c. Dinâmica: Trecho bem suave e sem alteração de força.

d. Técnicas requeridas: Trecho totalmente escrito em surdina CUP.

\section{Trecho 31: Choros $N^{o} .6$}

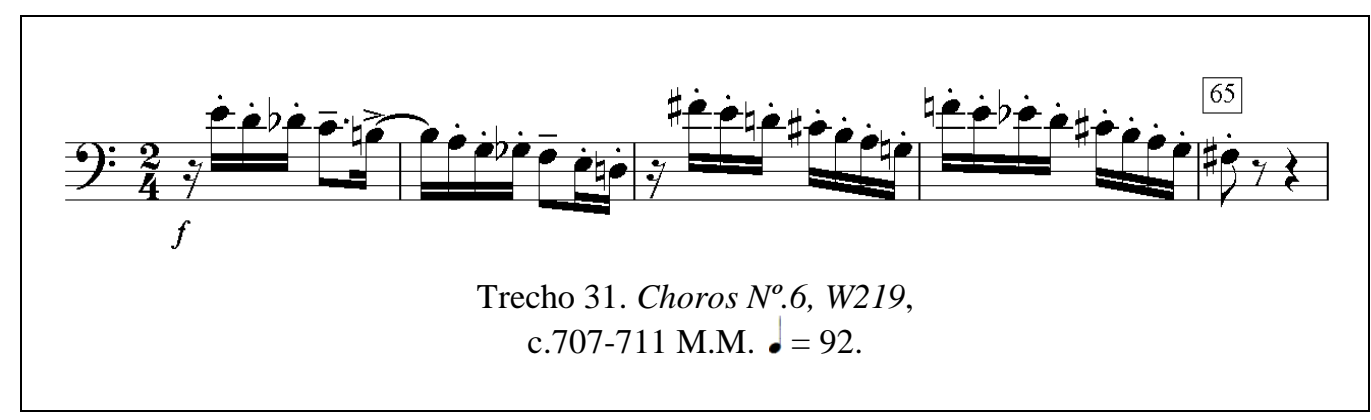


a. Principal desafio: $O$ cromatismo existente no movimento escalar descendente coloca o trombonista em estado de alta concentração.

Outros desafios:

b. Articulação: técnica bastante complicada de ser executada no c.707-708. Trombonistas devem atentar para o fato que Villa-Lobos grafou o primeiro tempo do inciso em estacato; o início do segundo tempo terá tratina/tenuto, para ao final a última nota será acentuada.

c. Técnicas requeridas: uma boa velocidade de êmbolo resolverá a maioria dos problemas dos trombonista.

\section{Trecho 32: Choros $N^{o} .10$}
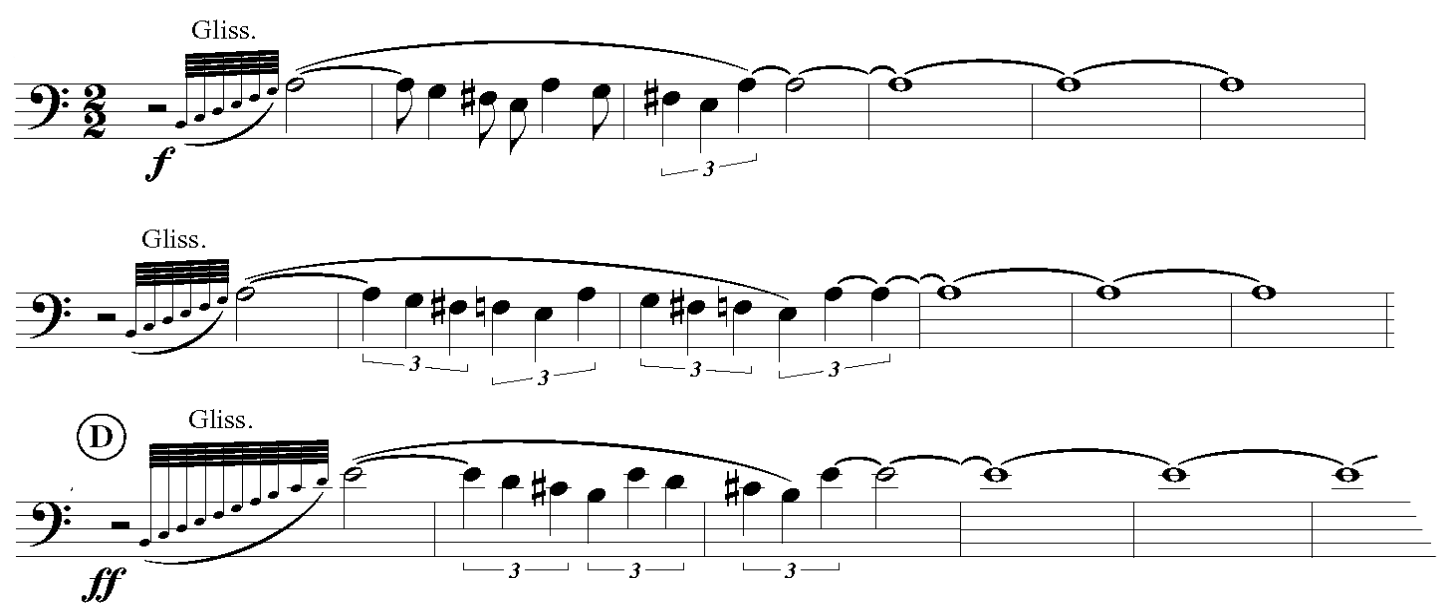

Trecho 32. Choros $N^{o} .10$, W209,

$$
\text { c.36-53 M.M. • = } 106 .
$$

a. Principal desafio:

Respiração: Villa-Lobos dedicou ao trombone frases muito longas para se executar em uma única respiração. Uma solução possível será uma profunda respiração antes da notas longa, e esta deve ser mantida com sonoridade plena até seu final. 
Outros desafios:

b. Dinâmica: Este solo foi grafado em $f$, porém a partir do c.48 Villa-Lobos eleva a dinâmica: deve-se tocar $\boldsymbol{f f}$.

c. Articulação: Uma ligadura bem executada deve ser a meta do trombonista para esse solo.

d. Complicações: Glissando fora da extensão do êmbolo, vide resolução na pg. 200.

Trecho 33: Choros $N^{o} .10$

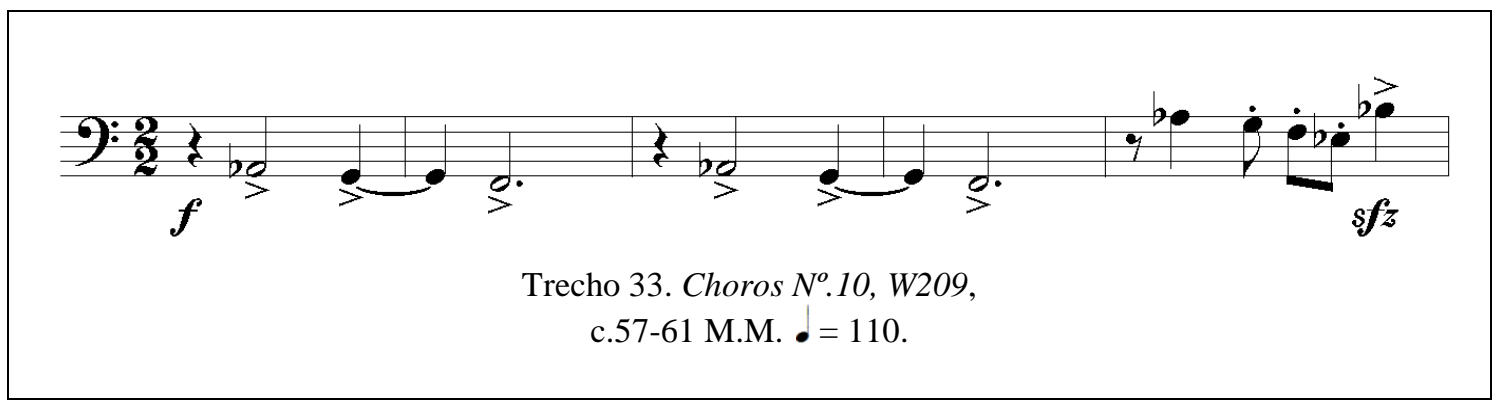

a. Principal desafio:

Sonoridade: Este solo foi escrito por Villa-Lobos dentro do limite da região grave sonora do trombone. Trombonistas devem buscar sua melhor sonoridade para esse trecho, e se for o caso, uma troca por um bocal mais fundo seria uma opção considerável. Esse trecho servirá como resposta ao tema exposto pelos Trompetes e os trombones, ainda, estarão em conjunto com o fagote e contrabaixo.

Outros desafios:

b. Articulação: Todo o trecho foi grafado com articulação acentuada ( $>$ ), porém no c.61Villa-Lobos alerta para que se toque as colcheias curtas em duração. A última nota, além de acentuada, deve receber um esforço extra por conta da notação do $s f z$.

c. Afinação: Especial cuidado com a afinação da região grave para que as notas não fiquem altas em afinação. 
Trecho 34: Choros $N^{o} .10$

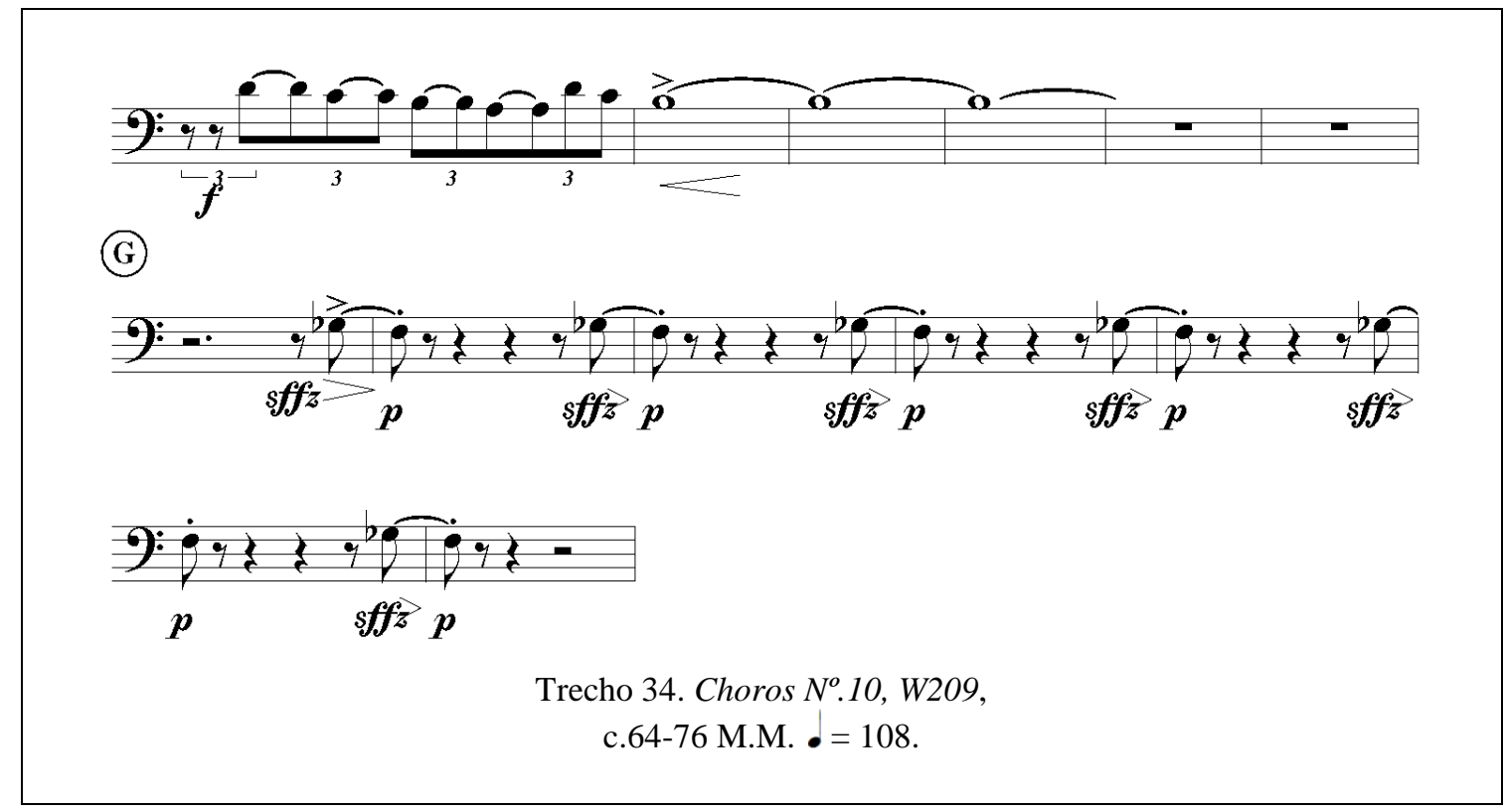

Principal desafio:

Respiração: Novamente Villa-Lobos escreveu frases muito longas para se executar em uma única respiração. A melhor solução sempre será uma profunda respiração antes da nota longa, e a manutenção sonora plena até seu final.

Outros desafios:

a. Articulação: A partir do c.70 Villa-Lobos escreveu para a ultima concheia do compasso, $s f z$ e acento ( $>$ ). Isto significa que nesse ostinato a ultima colcheia do compasso deve ser tocada sonoramente, porém para a primeira colcheia do próximo compasso, foi grafado $\boldsymbol{p}$ para que essa nota tenha quase nada de sonoridade.

b. Análise de estilo: Embora Villa-Lobos tenha escrito na partitura original, acentos para todas as notas do c.64, melhor será se o trombonista fizer esse solo com tenuto ( - ) para uma melhor junção com as trompas 1 e 2 que estarão juntas nesse tema. 
Trecho 35: Choros $N^{o} .10$

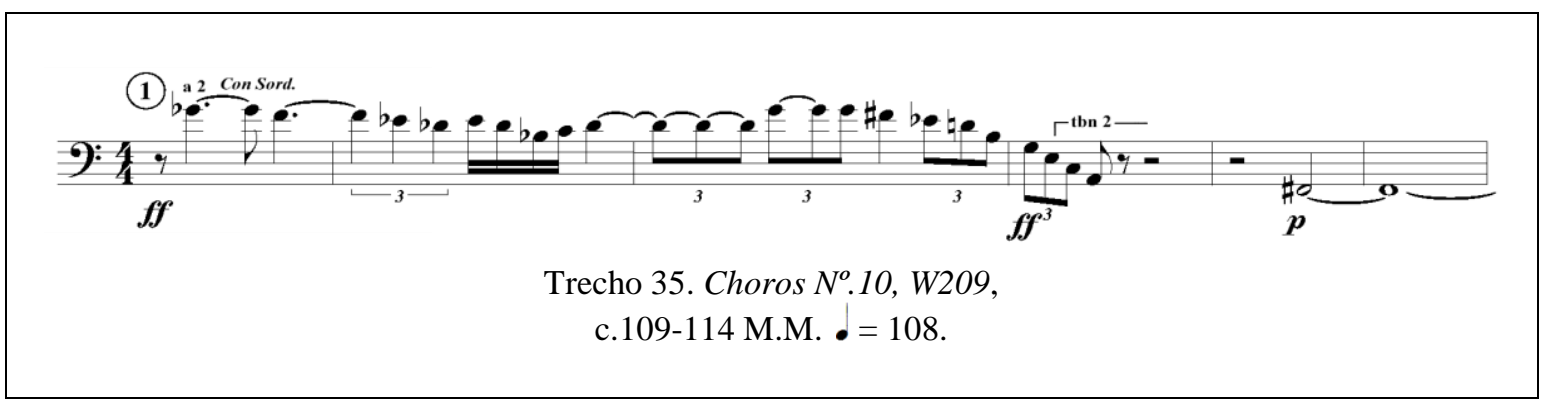

a. Principal desafio:

Complicações: A segunda parte do solo com surdina está grafada meio tom acima. Trombonistas devem prestar bastante atenção para essa alteração de altura de notas em meio ao solo.

Outros desafios:

b. Ritmo: A tercina de semínima seguida por quatro semicolcheias é um ritmo que requer bastante concentração do trombonista para uma perfeita resolução rítmica.

c. Intervalos: A sequência de arpejos descendentes ao final da frase necessitará de um leve deslocamento da embocadura para uma resolução mais fácil das notas graves.

d. Força: Um solo escrito com $\boldsymbol{f f}$ de dinâmica, mas contendo uma surdina dentro da campana, obrigará ao trombonista um esforço extra para que o resultado sonoro fique próximo da dinâmica almejada pelo compositor. 


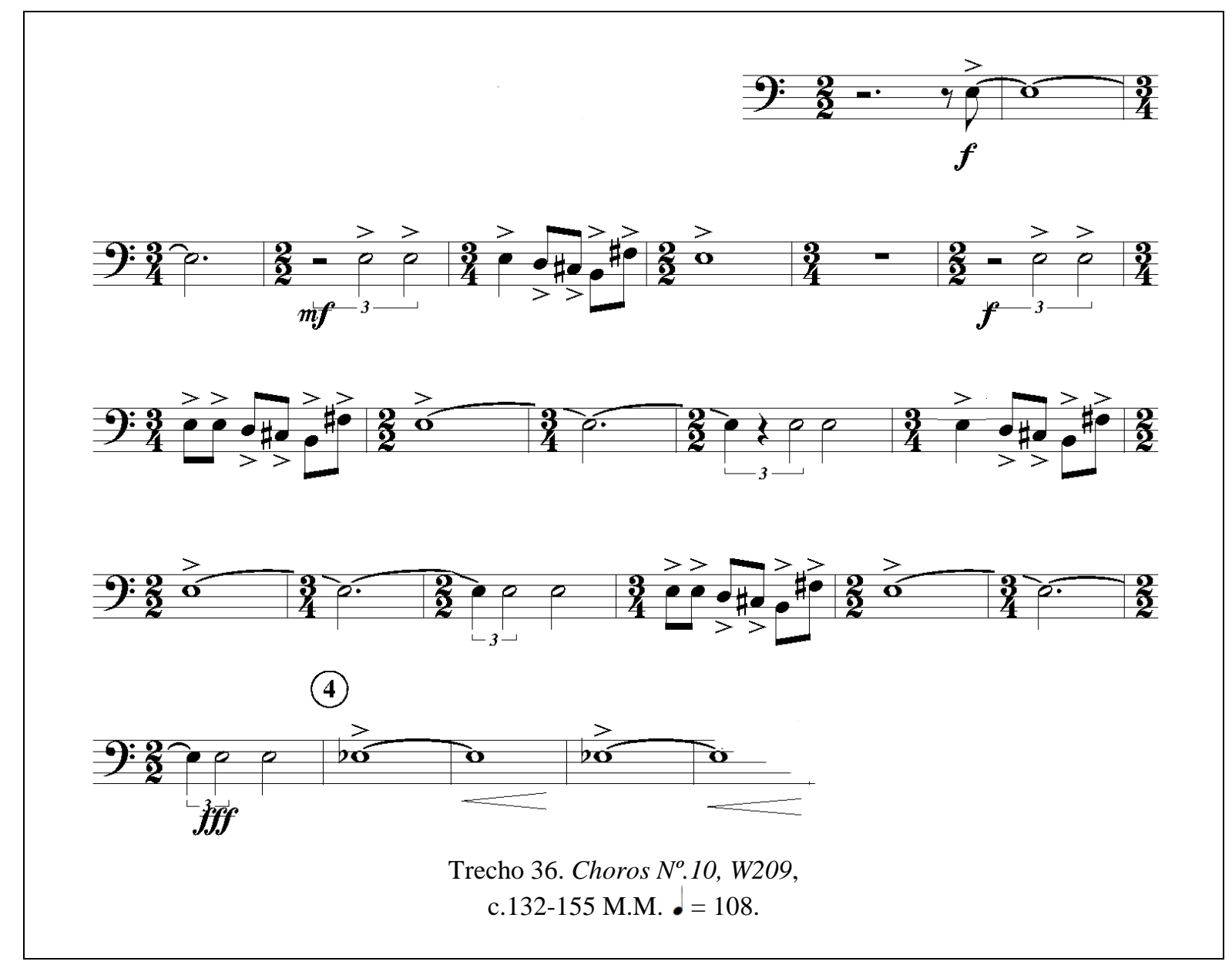

a. Principal desafio:

Articulação: Outro soli para o trombone (c.132-152) em conjunto com todas as trompas, em dinâmica $f$ e articulação acentuada para todos. As notas devem ser acentuadas ( $>$ ) porém com valoração completa. Os violinos farão a resposta a esse inciso e os Trompetes reforçam a partir do c.147-152.

Outros desafios:

a. Complicações: Muita atenção para as trocas de fórmula de compasso, principalmente o 3/4, pois a mudança de denominador sempre requer mais atenção do trombonista.

b. Técnicas requeridas: Tanto se o trombonista tocar o Si1 na $7^{\mathrm{a}}$. posição, quanto na $2^{\mathrm{a}}$. posição do rotor, essa nota terá a tendência em soar mais escura que as outras. Estando em solo, o trombonista nunca deve permitir notas com menos peso que outras. 
Trecho 37: Choros $N^{o} .10$

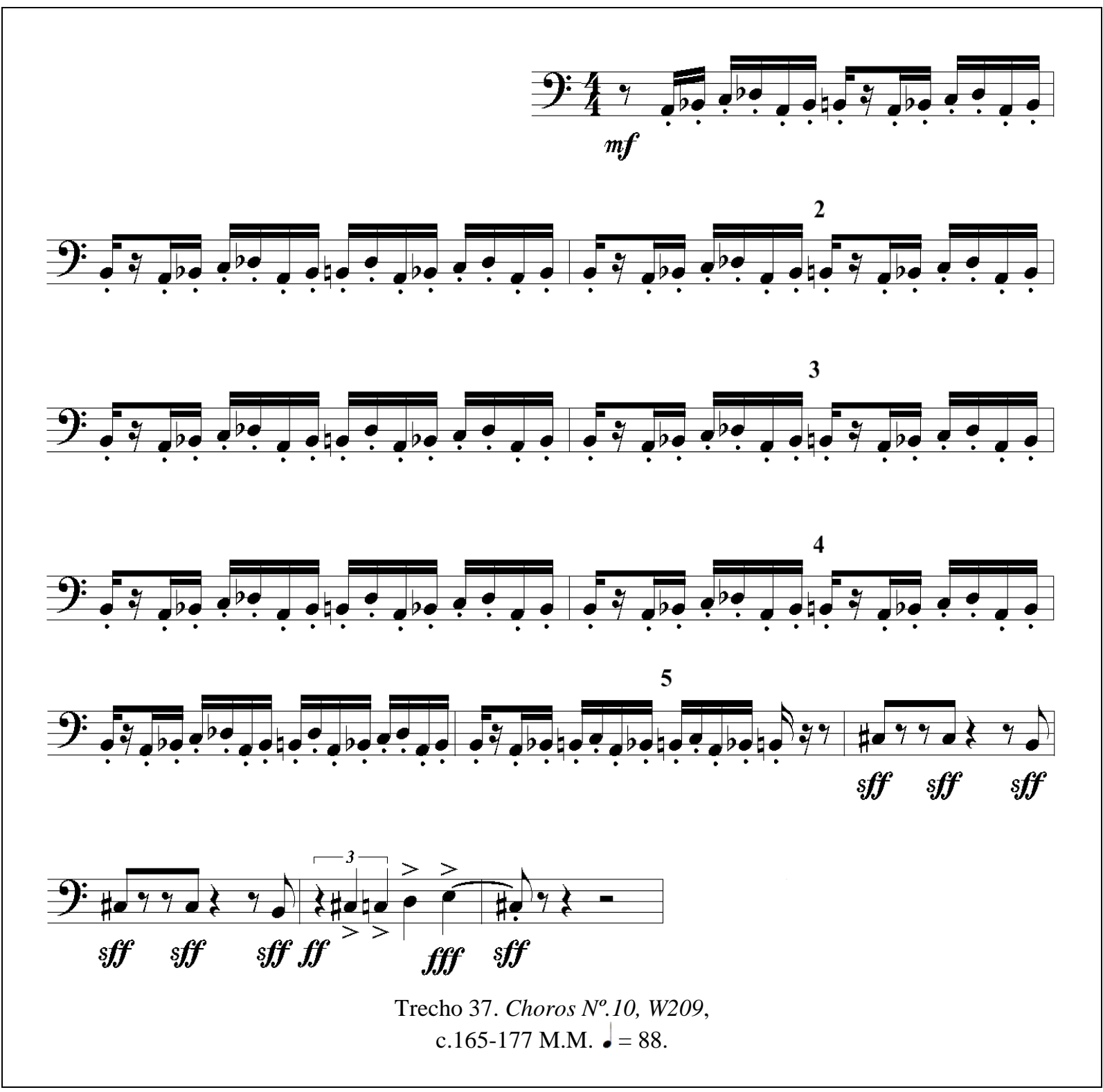

a. Principal desafio:

Complicações: Trombones iniciam um baixo motívico escalar ascendente no c.165 (em conjunto com fagotes, trompas, tímpano, bombo e cordas) e perdurará como ostinato até o c.173 (nove compassos exatamente iguais). Villa-Lobos grafou esse acompanhamento na região grave: região difícil para uma sonoridade plena no trombone-tenor ${ }^{108}$ e, por conseguinte, detentora de posições distantes no êmbolo. Este tutti rítmico preparará a entrada das vozes na peça.

${ }^{108}$ Região típica do trombone-baixo. 
Outros desafios:

b. Dinâmica: A dinâmica escrita é o $m f$, deixando quase inaudível esse ostinato. $\mathrm{O}$ motivo e a dinâmica requerida pela orquestração ficarão encobertas pela massa sonora das Flautas, Oboés, $3^{\mathrm{a}}$. Trompa (também em $m f$ ), Trompetes, Saxofone e $2^{\circ}$. Violino (em dinâmica $f$ ).

c. Técnicas requeridas: Mesmo que o trombonista seja detentor de um trombone com válvula rotora, há notas de difícil acesso escritas nesse trecho (Dó2, Si2 e Reb2). Mas a nota que será mais complicada será o Réb2, por estar alocada na $5^{\mathrm{a}}$. posição e longe de todas as outras posições (mesmo as usadas no rotor). De qualquer forma haverá muito movimento de êmbolo.

d. Sincronismo: Especial atenção às tercinas de semínima escritas no c.176. Por estarmos dentro de uma subdivisão em semicolcheias por exatos onze compassos, essa troca de subdivisão, se a necessária atenção, levará a um atraso de andamento.

Trecho 38: Choros $N^{o} .10$

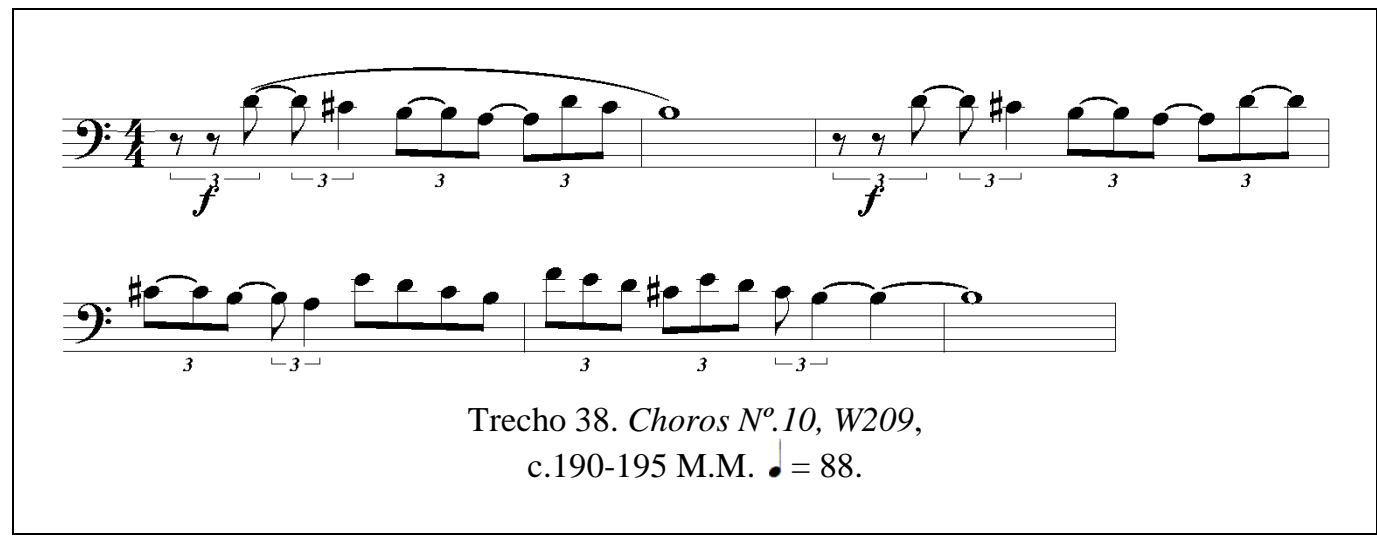

a. Principal desafio:

Respiração: Novamente Villa-Lobos escreveu frases muito longas para se executar em uma única respiração. A melhor solução sempre será uma profunda respiração antes da nota longa, e a manutenção sonora plena até seu final.

Outros desafios:

b. Análise de estilo: $\mathrm{O}$ soli do trombone será em conjunto com os fagotes (em dinâmica $f$ ) e as vozes masculinas (em dinâmica $f \boldsymbol{f}$ e que realmente serão os timbres dominantes). 
Portanto, mesmo sendo um soli, melhor será que o trombonista mescle sua sonoridade com a sonoridade dos outros músicos.

c. Ritmo: Villa-Lobos criou uma ideia de acelerando de figuras, sem alterar o andamento da peça no c.193-194. Portanto, trombonista especial atenção para que não haja acelerando algum durante a execução desse trecho.

\section{Trecho 39: Choros $N^{o} .10$}

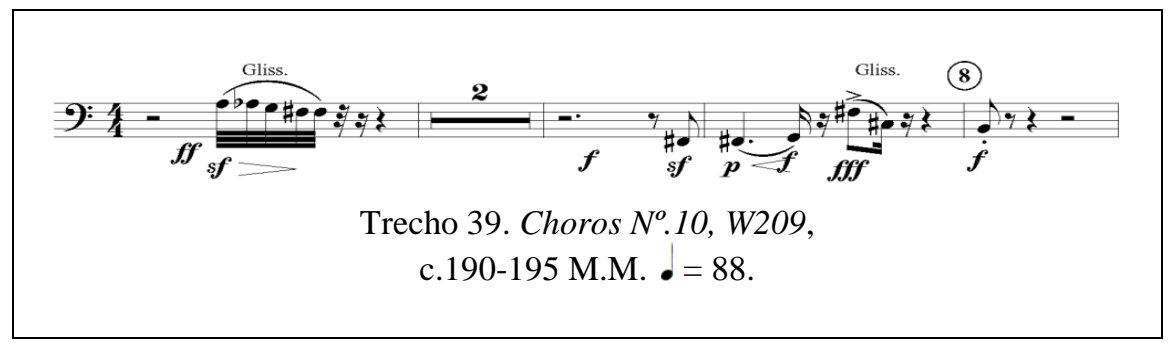

a. Principal desafio:

\section{Tercinas requeridas:}

Os trombones farão dois efeitos de glissandos (c.197 e c.201) em meio à repetição do tema principal pelas vozes e a arpejos polirrítmicos nos clarinetes e fagotes. Essa intromissão do glissando deverá ser realmente forte, tal qual Villa-Lobos grafou na parte original.

\section{Trecho 40: Choros $N^{o} .10$}

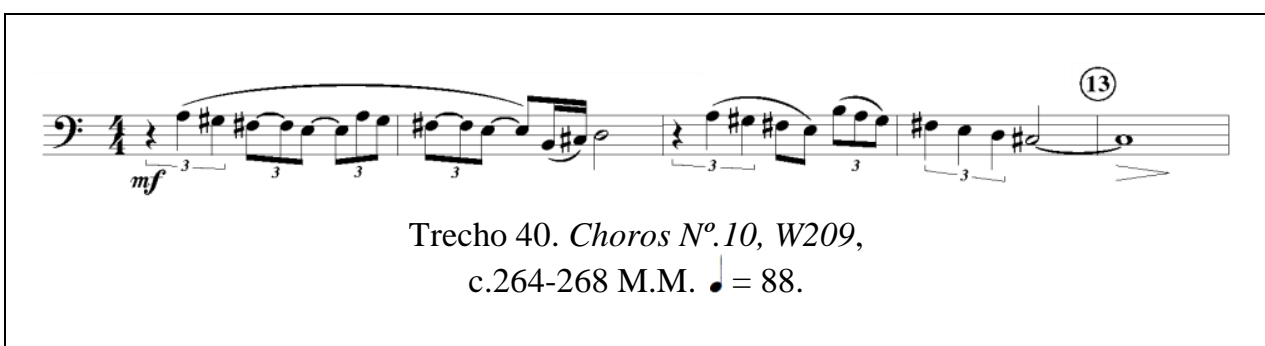

a. Principal desafio:

Respiração: Tema recorrente em Villa-Lobos. Este terá frases muito longas para se executar em uma única respiração. A melhor solução será uma profunda respiração antes da nota longa, e a manutenção sonora plena até seu final. 
Outros desafios:

Sincronismo: Os trombones expõem novamente o tema alterado de c.264-268 em conjunto com os Fagotes, Violoncelos e contrabaixos. Deve-se buscar um perfeito sincronismo rítmico desses instrumentos. No entanto, os Trompetes fazem um contraponto que se movimenta em semicolcheias e colcheias durante as notas longas do trombone.

\section{Trecho 41: Bachianas brasileiras $N^{o} .2$ - I. Prelúdio - O Canto do capadócio}

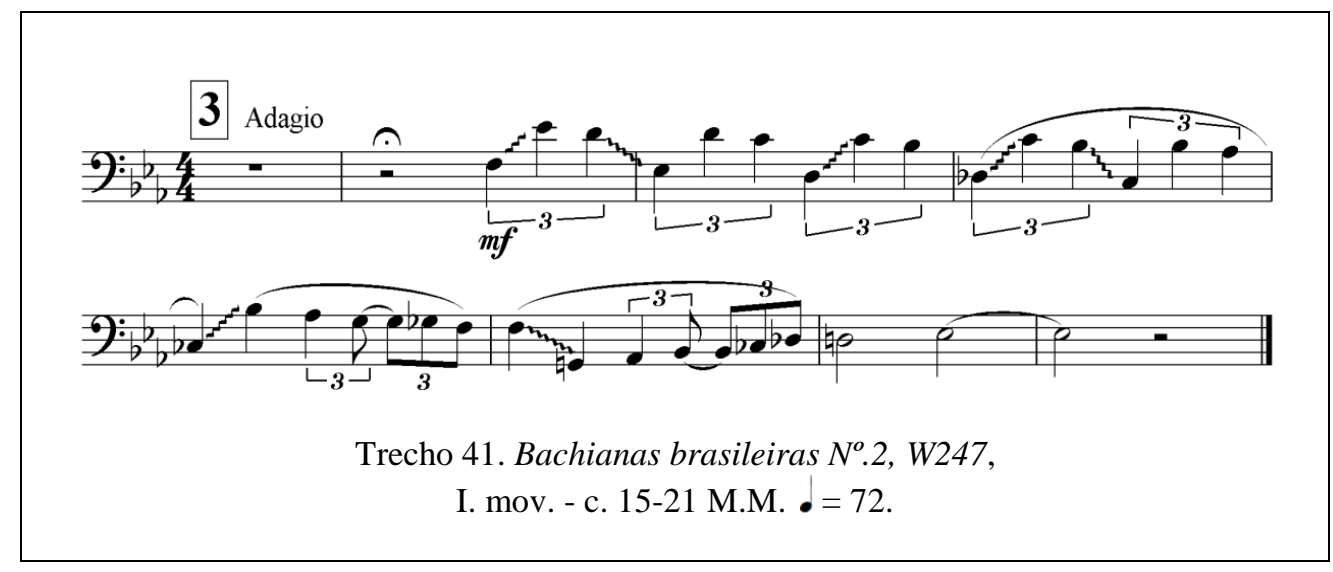

e. Principal desafio:

Complicações com a respiração: Villa-Lobos transpôs para o Trombone o mesmo tema endereçado ao Violoncelo. Por se tratar de uma linha melódica feita com base em instrumentos não dependentes de ar, não existe local próprio e relaxado para respiração. $\mathrm{O}$ Trombonista deve respirar onde não haja interferência demasiada na melodia (sugestão: $4^{\circ}$. tempo do c.18) e respirar o mais rápido e silenciosamente possível.

Outros desafios:

f. Intervalos: Trecho com boa quantidade de intervalos de $7^{\mathrm{a}}$. (10 ocorrências): atenção especial à embocadura.

g. Articulação: Trecho com frases ligadas. Para que haja equilíbrio com o ADSR do Violoncelo, deve-se manter as notas o mais ligado e sustentado possível.

h. Conjunto: O Violoncelo foi grafado em uníssono, logo o trombonista deve atentar para um perfeito sincronismo rítmico.

i. Técnicas requeridas: Além dos escritos fora da extensão do embolo, os glissandos devem ser mais dolentes por conta da tópica canção sertaneja. 
j. Analise de estilo: Por conta da terminação da frase, não se deve respirar antes da resolução (ultima nota).

Trecho 42: Bachianas brasileiras $N^{o} .2$ - II. Aria - O Canto da nossa terra

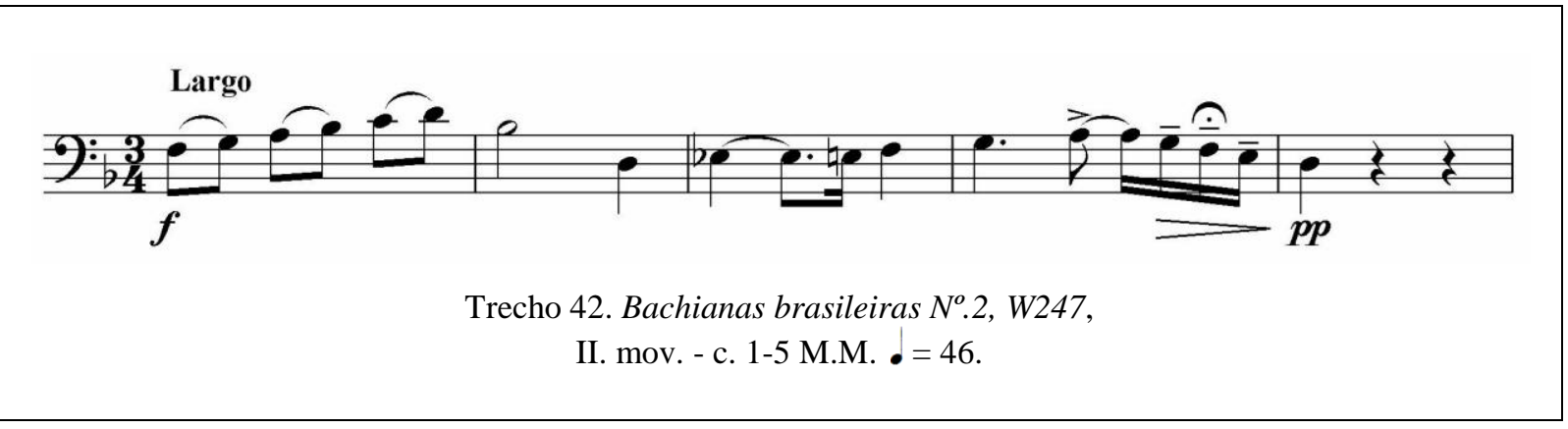

a. Principal e único desafio:

Analise de estilo: $O$ solo é do Trombone logo no início do movimento. Tecnicamente VillaLobos não escreveu dificuldades ao trombonista. O ritmo não necessita ser estritamente perfeito, porém com a indicação de fermata na conclusão da semifrase, deduz-se que um leve rallentando deva ser usado para esse final. Esse tema terá uma repetição, e nessa aconselhamos aos trombonistas que utilizem mais rubatos, para uma melhor diferenciação da recapitulação.

Trecho 43: Bachianas brasileiras $N^{o} .2-I I$. Aria - O Canto da nossa terra

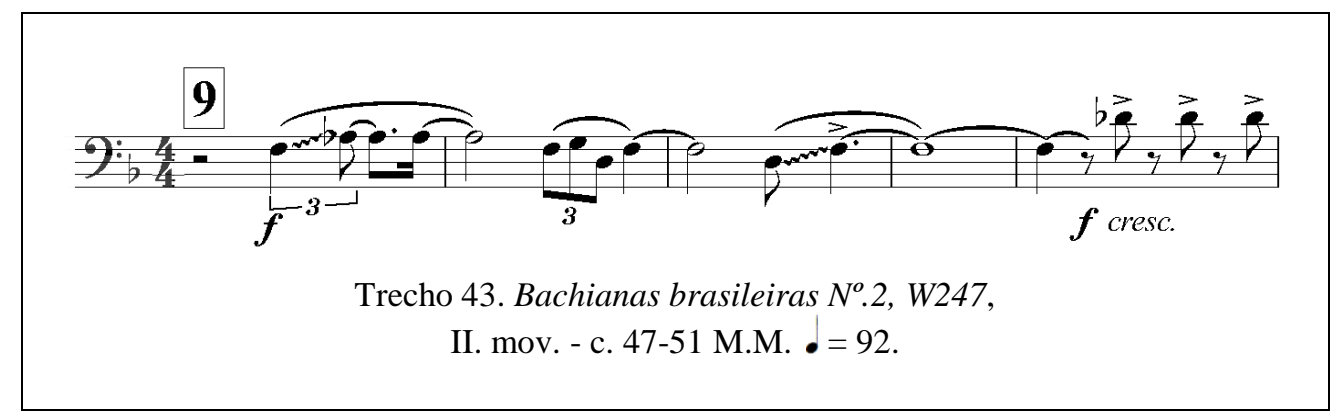

a. Principal desafio:

Articulação: Trombonista devem ficar atentos às ligaduras grafadas por Villa-Lobos, pois na $2^{\mathrm{a}}$. ligadura não há glissando e precisa-se de uma técnica bem apurada para que não haja glissandos não grafados originalmente. 
Outros desafios:

b. Técnicas requeridas: Tanto no primeiro, quanto no segundo glissando, o Trombonista deve atentar ao fato que os meios deste devem ser mais claros, e não diminuir a coluna de ar.

\section{Trecho 44: Bachianas brasileiras $N^{o} .2$ - III. Dansa - Lembrança do sertão}

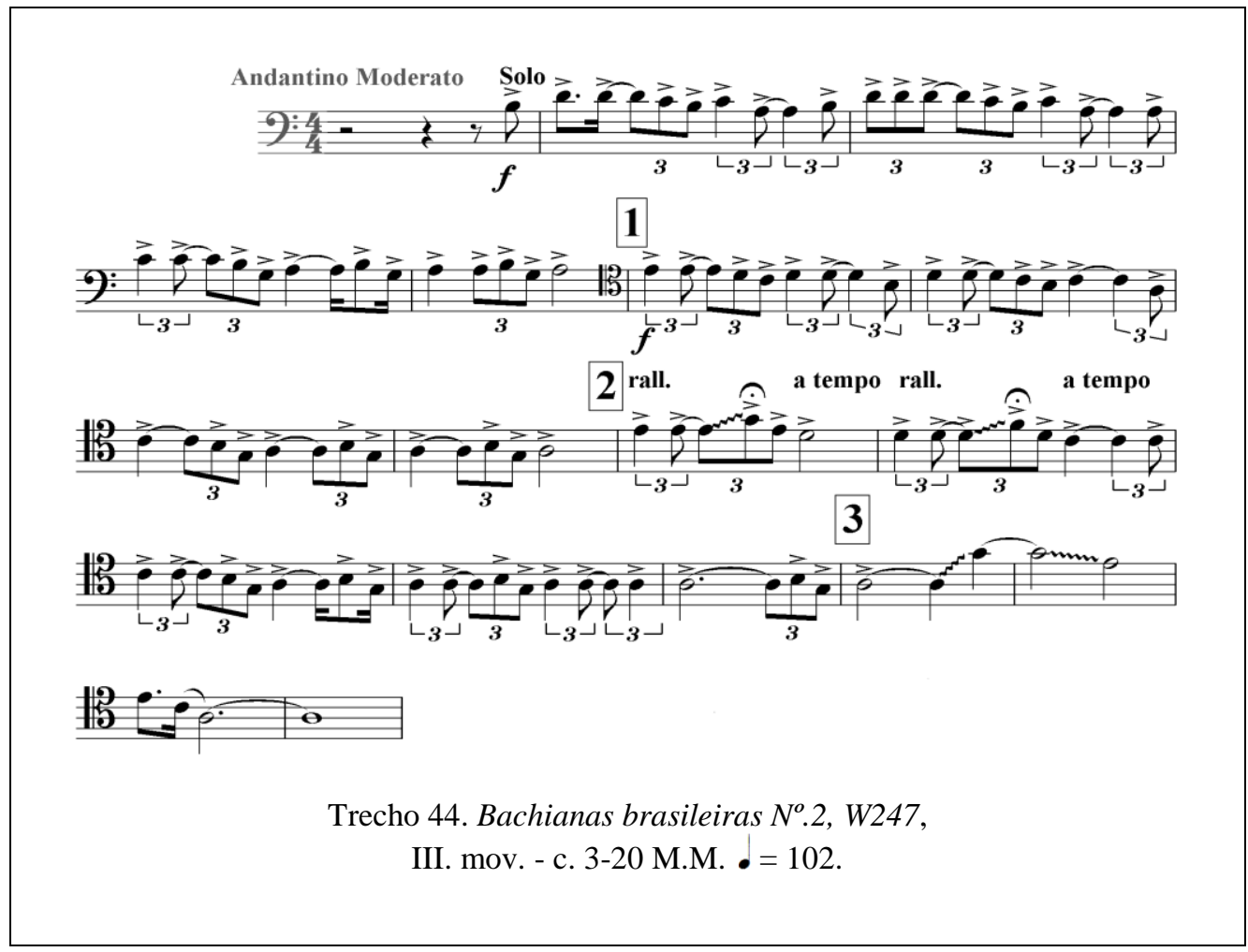

a. Principal desafio:

Respiração: Para a segunda parte do tema-solo do Trombone, Villa-Lobos não deixou espaço para respiração (e o trombonista necessita de muito ar para terminar sonoramente essa frase). Sugere-se uma respiração estratégica nos c.13 e c.16.

Outros desafios:

b. Ritmo: Trombonistas devem ficar atentos ao fato que após as fermatas (c. 12 e c. 13), o tempo continua na mesma velocidade anterior. 
Trecho 45: Bachianas brasileiras $N^{o} .2$ - III. Dansa-Lembrança do sertão

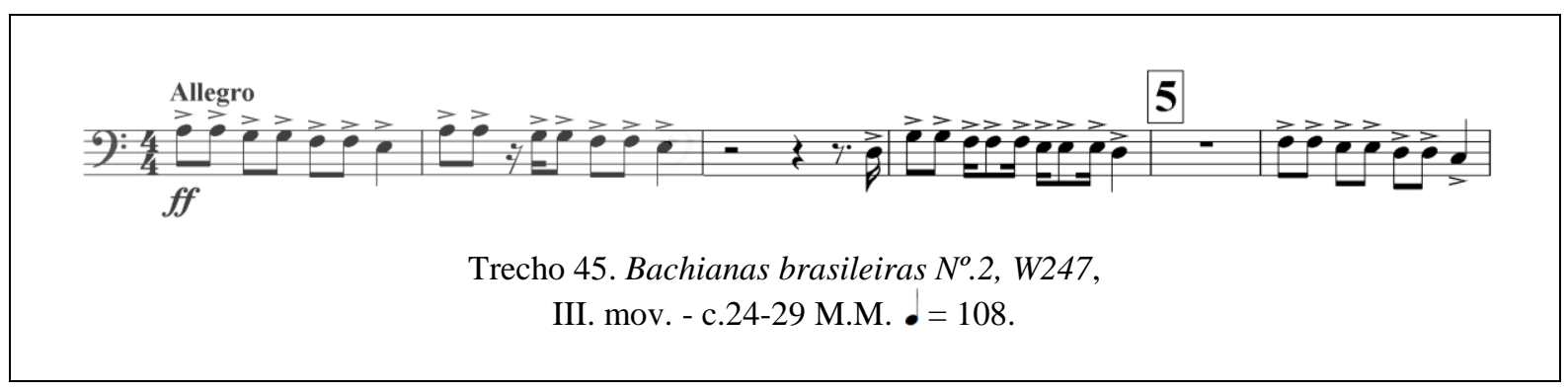

a. Principal desafio:

Ritmo: Villa-Lobos grafou para o Trombone, no c.25, um segundo tempo com um ritmo complicadíssimo para encaixe de conjunto. Muita atenção deve ser despendida pelo músico, para que não haja desencontros momentâneos.

Outros desafios:

b. Conjunto: Villa-Lobos grafou esse inciso ritmo em conjunto com as madeiras e trompas. Os trombonistas devem buscar um perfeito entrosamento com esse grupo.

Trecho 46: Bachianas brasileiras $N^{o} .2$ - III. Dansa - Lembrança do sertão

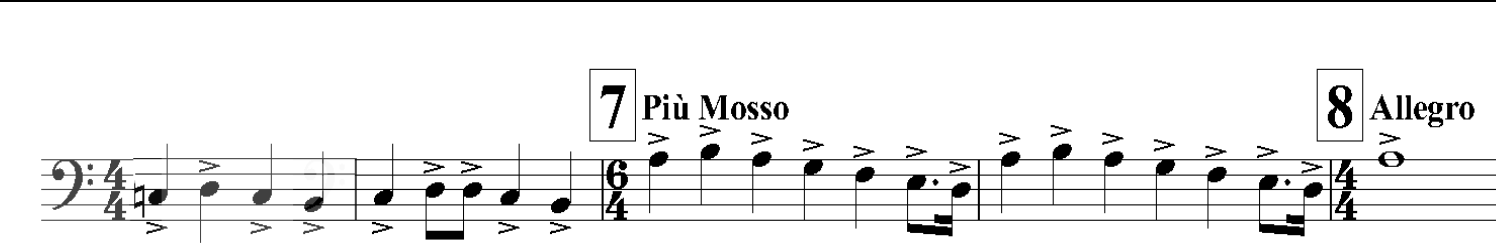

Trecho 46. Bachianas brasileiras $N^{o} .2$, W247,

III. mov. - c.40-44 M.M. • =106/152.

a. Principal e único desafio:

Respiração: Por conta da linha quase que exclusivamente em semínimas escrita por VillaLobos, não se encontra local apropriado para a respiração. Sugere-se que os trombonistas façam sua respiração na barra de compasso. 
Trecho 47: Bachianas brasileiras $N^{o} .2$-III. Dansa-Lembrança do sertão

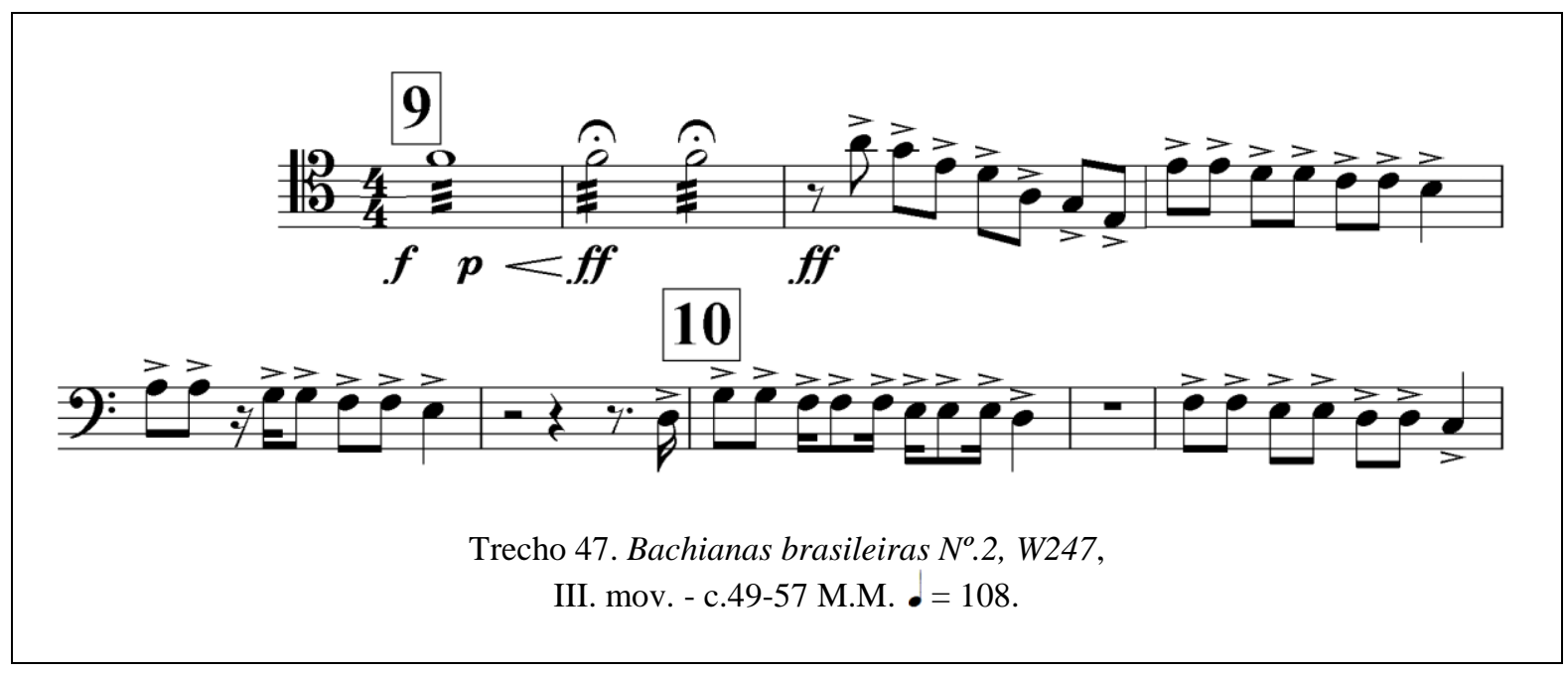

a. Principal desafio:

Técnicas requeridas: Villa-Lobos grafou frullatos nos c.49-50. Sabe-se que nem todos os Trombonistas têm essa técnica em domínio. Uma opção, para os que não conseguem, é fazer estacatos múltiplos na duração da nota.

Outros desafios

Ritmo: Villa-Lobos recapitula o ritmo do c. 25: $\log$ o mesma dificuldade e mesma solução. Devemos lembrar que novamente o trombonista deve tocar com muita atenção, para que não haja desencontros momentâneos.

Trecho 48: Bachianas brasileiras $N^{o} .2-I V$. Toccata - O Trenzinho do Caipira

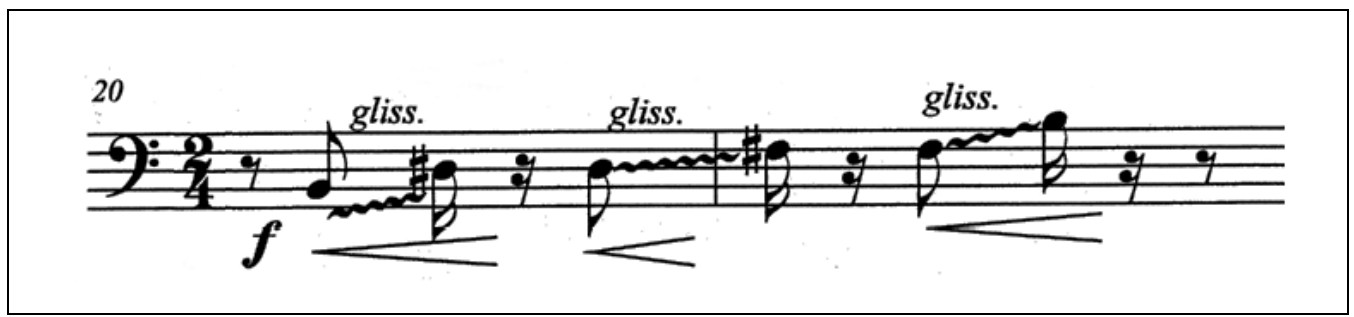


Villa-Lobos e os metais graves sinfônicos:

Um estudo dos elementos técnicos específicos

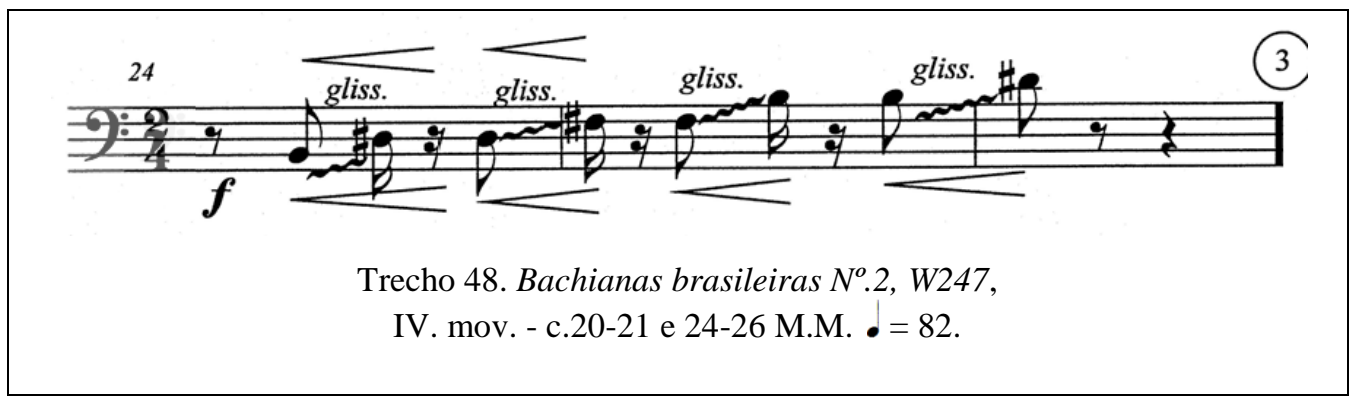

a. Principal e único desafio:

Técnicas requeridas: Nos dois exemplos (c.20-21 e c.24-26) teremos dois glissandos fora da extensão do êmbolo. Esse tipo de movimento técnico sempre requererá muita destreza da embocadura e do braço direito do trombonista.

Trecho 49: Bachianas brasileiras $N^{o} .2-I V$. Toccata - O Trenzinho do Caipira

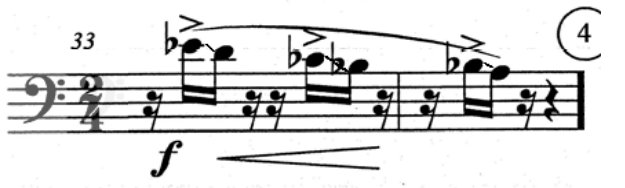

Trecho 49. Bachianas brasileiras $N^{o} .2$, W247,

IV. mov. - c.33 - M.M. $\bullet=82$.

a. Principal e único desafio:

Ritmo: O trecho escrito por Villa-Lobos não carrega consigo dificuldade alguma. Porém, sua entrada, exatamente na segunda semicolcheia de cada compasso, obriga ao trombonista a se focar para que não aconteça atrasos rítmicos em sua entrada. 
Trecho 50: Bachianas brasileiras $N^{o} .2-I V$. Toccata - O Trenzinho do Caipira

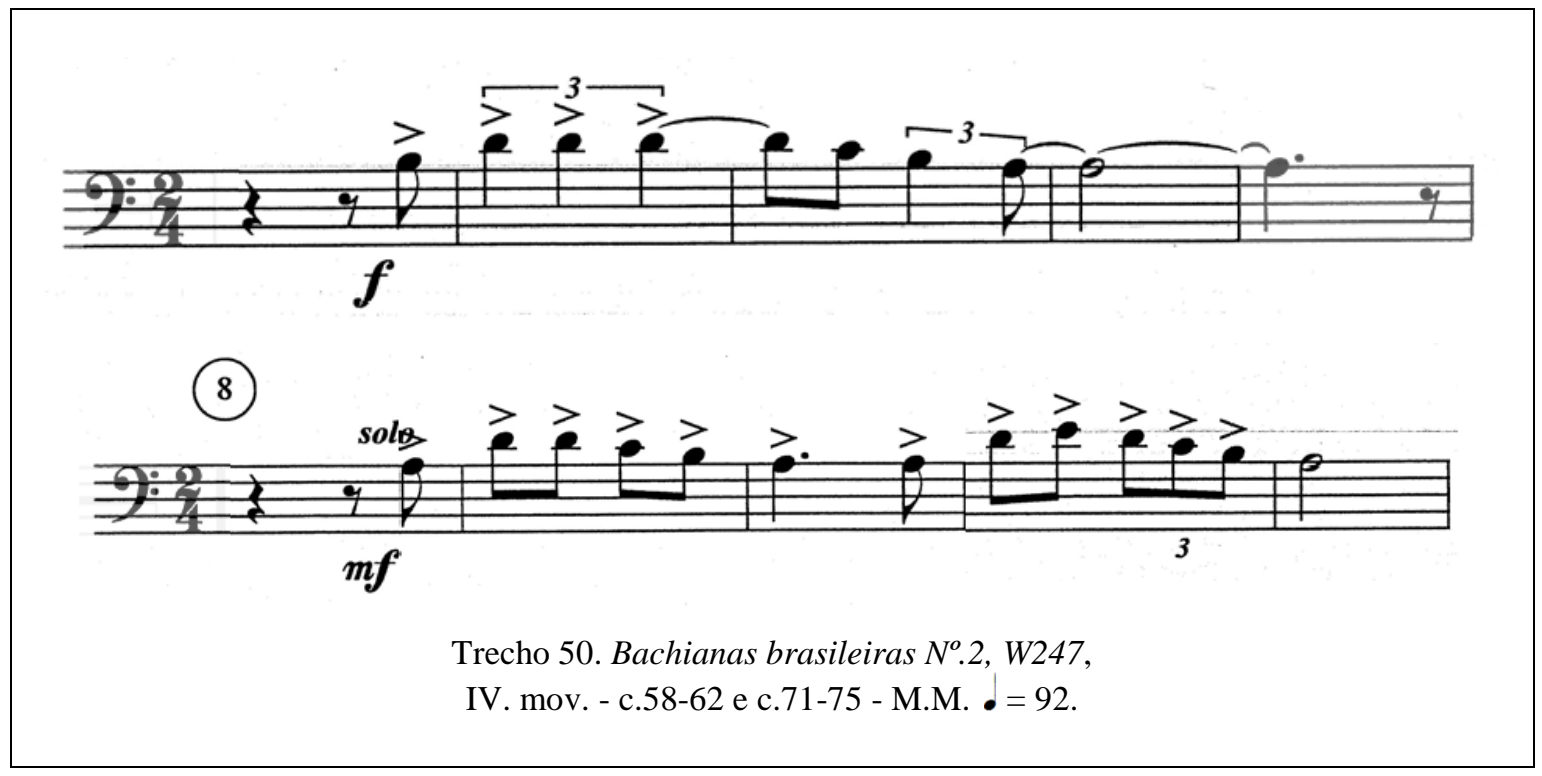

a. Principal desafio:

Respiração: Trecho grafado no limite operacional do ar do trombonista. Este, não deve esbanjar ar logo de início, pois lhe faltará ao final da frase.

Outros desafios:

b. Ritmo: O primeiro tema (c.58-62) tem subdivisão ternária, porém no c.60 - primeiro tempo, a subdivisão grafada foi binária, obrigando o trombonista a trocar mentalmente sua subdivisão. Atenção especial ao c. 60.

c. Articulação: O primeiro tema (c.58-62) termina sem articulação alguma escrita. Sugere-se que o trombonista continue com a articulação acentuada ( > ).

Trecho 51: Bachianas brasileiras $N^{o} .2-I V$. Toccata - O Trenzinho do Caipira

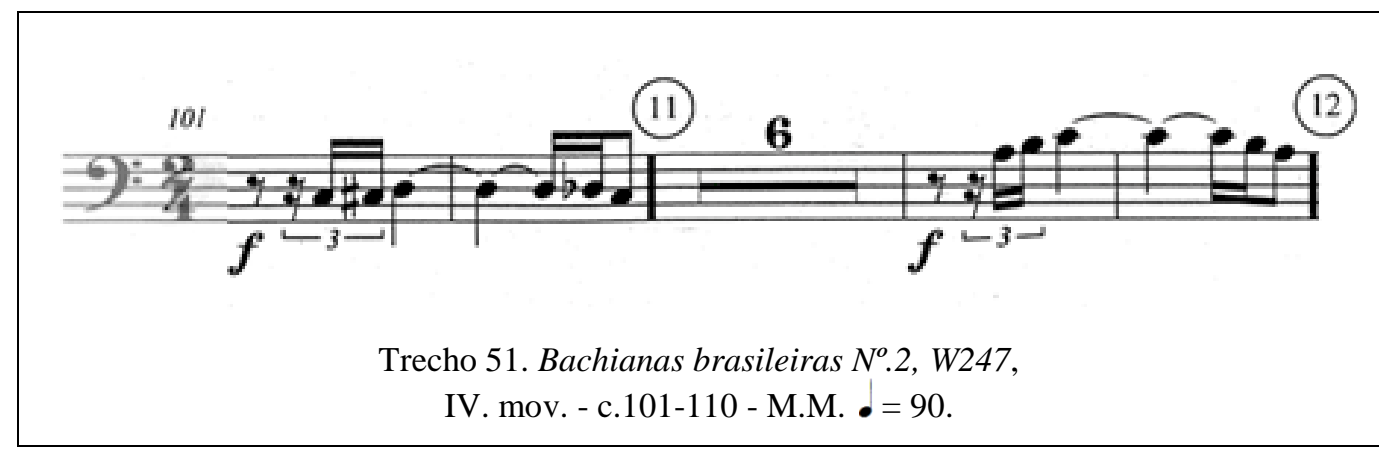


a. Principal desafio:

Técnicas requeridas: As apogiaturas duplas, escritas por Villa-Lobos terão suas execuções com melhor acabamento, se realizadas num trombone barítono com rotor em Fá. Vide solução abaixo:

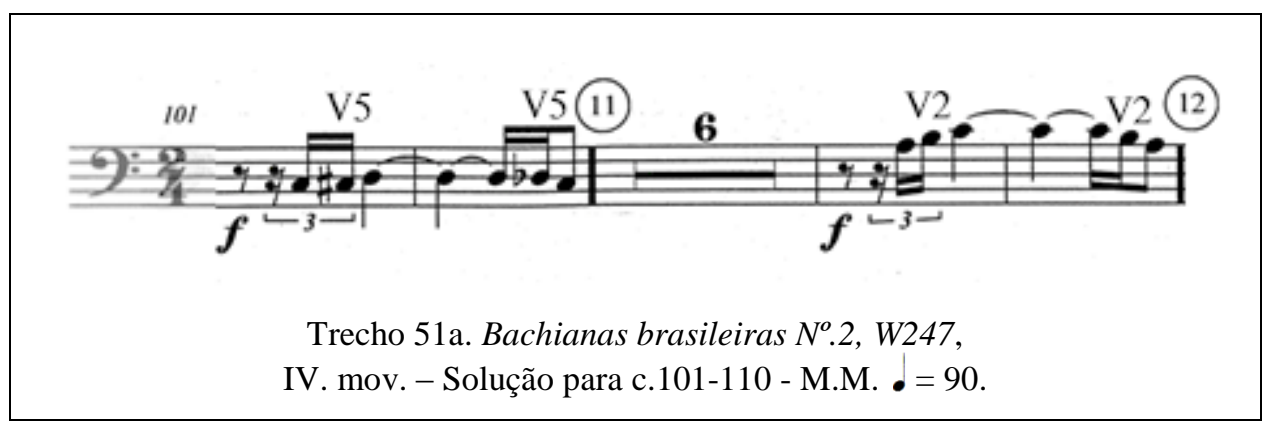

Outros desafios:

b. Ritmo: A posição dentro do tempo, escrita por Villa-Lobos, transformam essa tercinas de semicolcheias, em praticamente uma apogiatura. Trombonistas devem fazê-las como sendo realmente apogiaturas e se preocupar em terminá-las a tempo.

\section{Trecho 52: Concerto para Violão e Pequena Orquestra - I. Allegro Preciso}

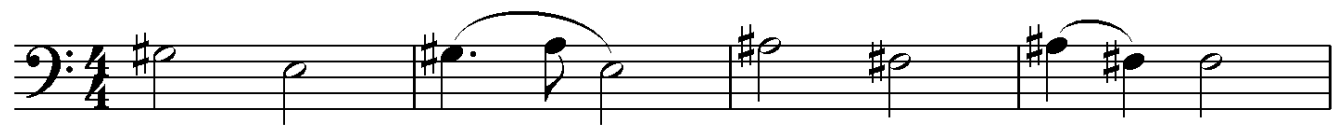

PPp

Trecho 52. Concerto para Violão, W501,

c.102-105 M.M. $\bullet=66$.

a. Principal desafio:

Dinâmica: Villa-Lobos grafou para esse trecho a dinâmica de ppp. Para o trombonista, esse nível de volume é praticamente impossível, pois carregará consigo falhas nas notas e algum chiado junto ao som. Portanto o nível baixo em decibel dependerá mais das habilidades individuais do músico do que propriamente uma técnica em específico. A solução seria tocar com a campana o mais rebaixada possível ou ainda tocar na direção da estante de música. 
Outros desafios:

b. Valoração da notas: Nos dois primeiros compassos (c.102-103) o trombone faz background para o Clarinete e nos próximos (c.104-105) será vez de acompanhar o Oboé. Em ambos os casos as notas precisam de valoração total e pouco ataque, melhor buscar uma articulação em tenuto/tratina.

c. Técnicas requeridas: Há duas ligaduras escritas por Villa-Lobos. Os trombonistas devem executá-las sem interrupção, na tentativa de imitar as ligaduras das madeiras.

Trecho 53: Concerto para Violão e Pequena Orquestra - I. Allegro Preciso

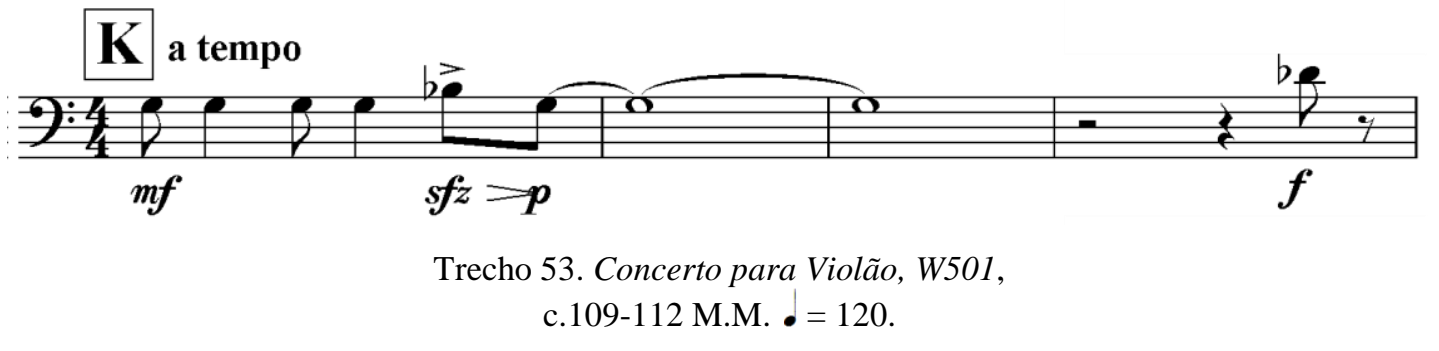

Principal desafio:

Afinação: Este trecho será o único soli do Trombone nessa peça, mas está escrito em conjunto com o Fagote. Portanto o trombonista deve buscar uma afinação perfeita junto ao Fagote.

Outros desafios:

a. Dinâmica: Villa-Lobos grafou $\boldsymbol{m} \boldsymbol{f}$ para o Trombone mas $\boldsymbol{f}$ para o Fagote. Essa forma de escrita nos indica a intenção do compositor em se buscar um perfeito equilíbrio, ou seja, o Trombone não pode sobrepor o Fagote.

b. Articulação: Tanto o Trombone quanto o Fagote receberam a mesma articulação ( $s f z$ no $4^{\circ}$.tempo e $\boldsymbol{p}$ para a última colcheia). A última nota do c.109 deve ser muito suave, mesmo a nota anterior tendo sido a mais forte do compasso. 
c. Analise de estilo: Neste inciso rítmico, que serve como conversa, o Violão e logo a seguir o oboé e a clarinete responderão ao inciso do trombone. Portanto o inciso deve ser executado de forma que as madeiras possam imitá-lo logo a seguir.

\section{Trecho 54: Concerto para Violão e Pequena Orquestra - II. Andantino}

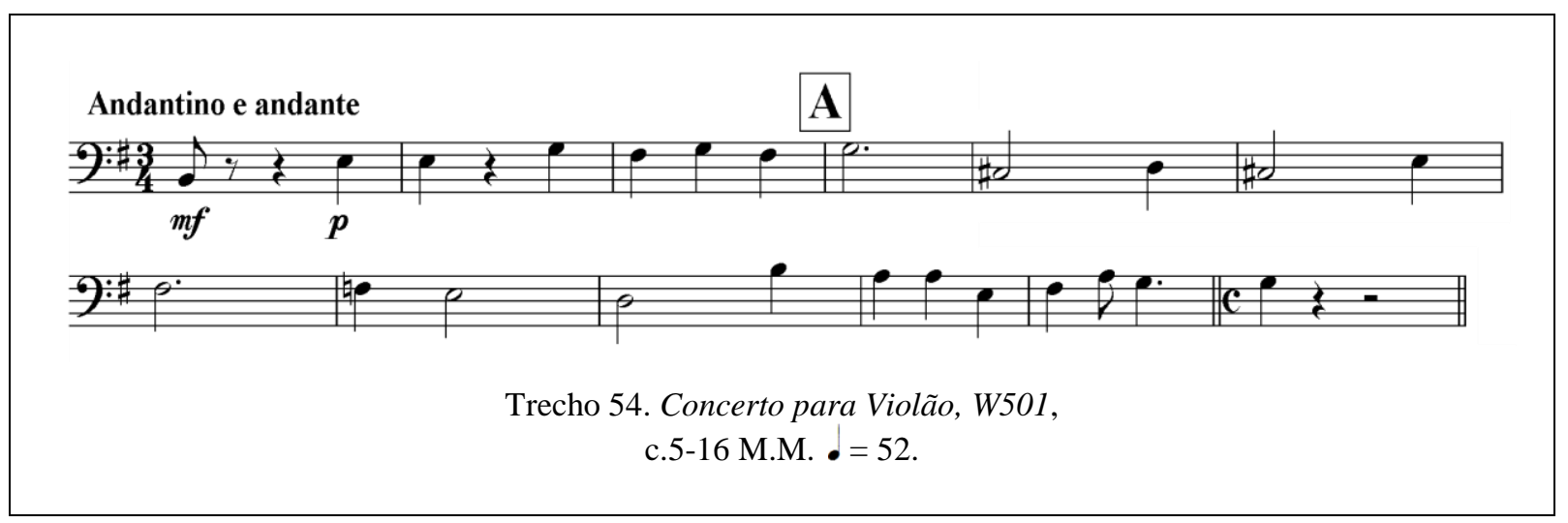

a. Principal desafio:

Complicações: Este trecho está em andamento lento. Dessa forma o sincronismo da troca de notas deve ser alcançado quase em sua perfeição.

Outros desafios:

b. Ritmo: A colcheia do c. 15 está realmente no $2^{\circ}$. tempo. Muita concentração para não cometer enganos durante a execução.

c. Respiração: não há lugares pré-estabelecidos para respiração, portanto deve-se buscar locais possíveis onde não interfiram na linearidade da frase.

d. Dinâmica: a primeira nota é $\boldsymbol{m} \boldsymbol{f}$, mas o restante é realmente suave ( $\boldsymbol{p}$ ).

e. Articulação: embora não grafada, melhor se o trombonista utilizar a articulação em tenuto (tratina).

f. Analise de estilo: $\mathrm{O} 2^{\circ}$. movimento se inicia com um movimento escalar ascendente do $2^{\circ}$. violino, lembrando o modo mixolídio (c.1-4) e juntamente com o Violão-solo entrarão o Trombone, Clarinete, Fagote e Trompa em blocos harmônicos e paralelos típicos de atuação em background. A sonoridade do trombone deve fundir-se aos instrumentos do background. 
Trecho 55: Concerto para Violão e Pequena Orquestra - II. Andantino

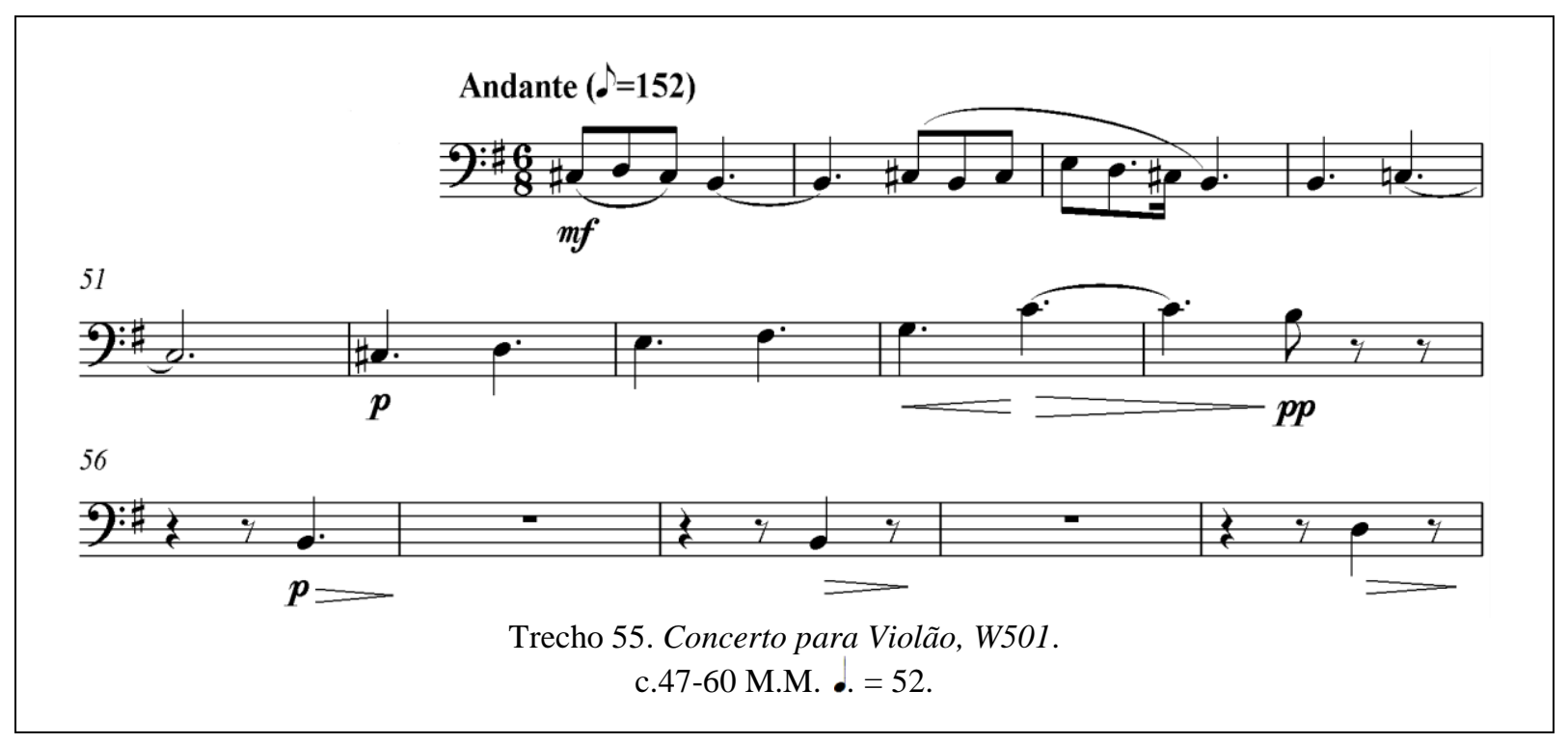

a. Principal desafio:

Analise de estilo: Neste trecho o trombone funcionará como uma $2^{\mathrm{a}}$. voz do Fagote, em diálogo ao tema exposto pelo Clarinete e a seguir com os Violinos num tutti orquestral sem a presença do solista.

Outros desafios:

b. Dinâmica: Cinco primeiros compassos (c.47-51) estão grafados em $\boldsymbol{m} \boldsymbol{f}$ e depois haverá uma queda para uma dinâmica mais suave $(\boldsymbol{p})$. O Trombone será mantido nessa dinâmica até o final do trecho.

c. Articulação: Os primeiros compassos (c.47-49) são ligados, o restante pode ser interpretado com articulação tratina/tenuta ( - ).

O trombone ficará em descanso por 18 compassos, não participando do término do movimento. No ultimo movimento, o Trombone entra pela primeira vez no c.31 e novamente em blocos harmônicos que servem de apoio em background ao tema exposto pelo solista e de mesma forma numa dinâmica muito suave e sem acentos nas notas. 
Trecho 56: Concerto para Violão e Pequena Orquestra - III. Allegro non troppo

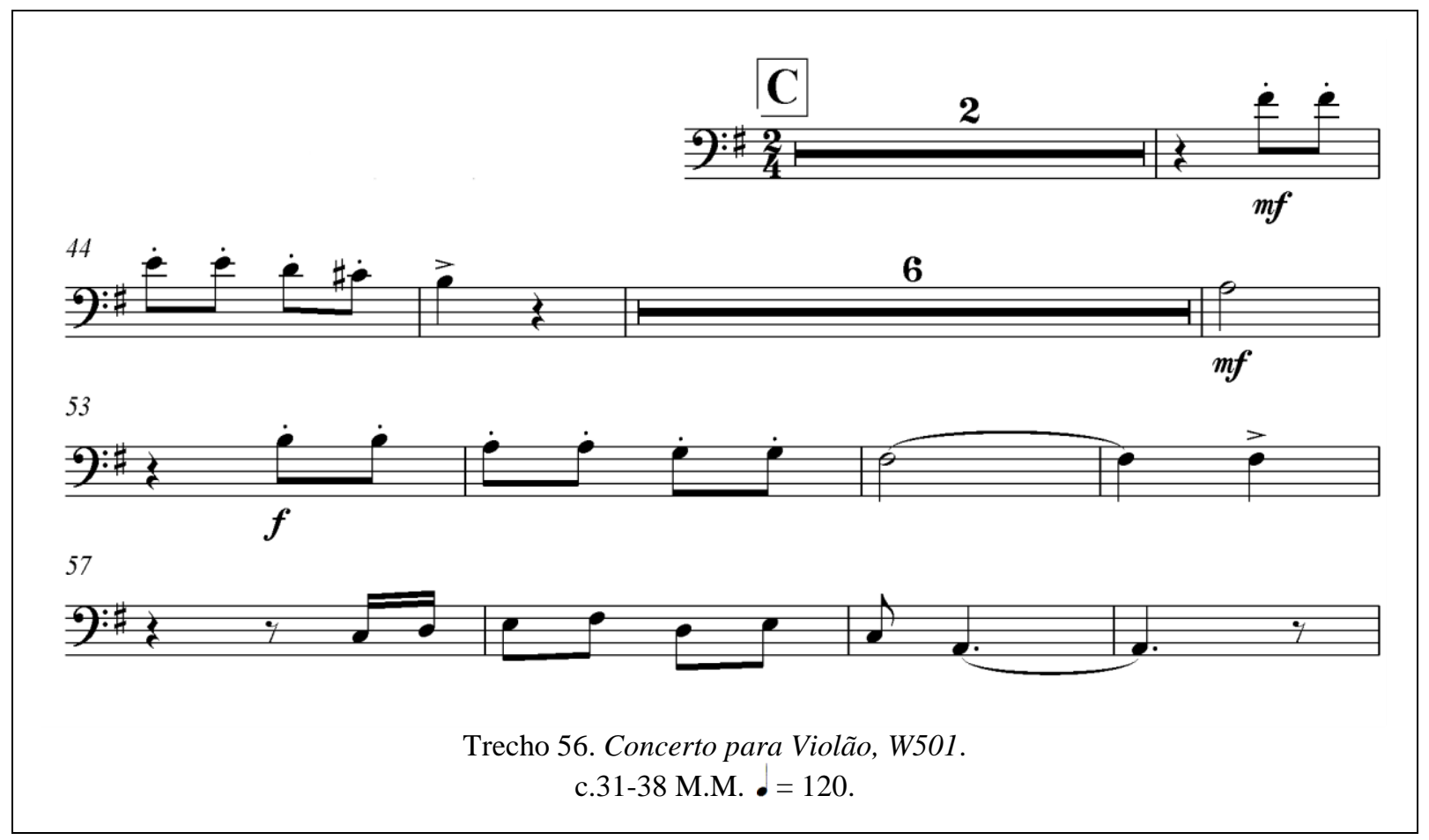

a. Principal desafio:

Analise de estilo: Em resposta ao inciso ascendente do Fagote, Violoncelo e contrabaixo, o Trombone fará outro descendente e em conjunto com Flauta, Oboé, Clarinete e Trompa. O próximo trecho será uma conversa entre a Flauta e um grupo formado pelo Oboé, Clarinete, Trompa, Trombone, Viola e Violoncelo e a finalização da frase ficou a cargo do Fagote, Trombone e Violoncelo.

Outros desafios:

b. Dinâmica: As madeiras estão em dinâmica $\boldsymbol{f}$, enquanto Trombone e Trompa estão em $m f$.

c. Articulação: A articulação geral é a mesma: colcheias em estacato e semínima acentuada.

d. Técnicas requeridas: Por conta da velocidade desse trecho (M.M. $•=120$ ) melhor será se o trombonista utilizar de estacato duplo no c.57. 
Trecho 57: Concerto para Violão e Pequena Orquestra - III. Allegro non troppo

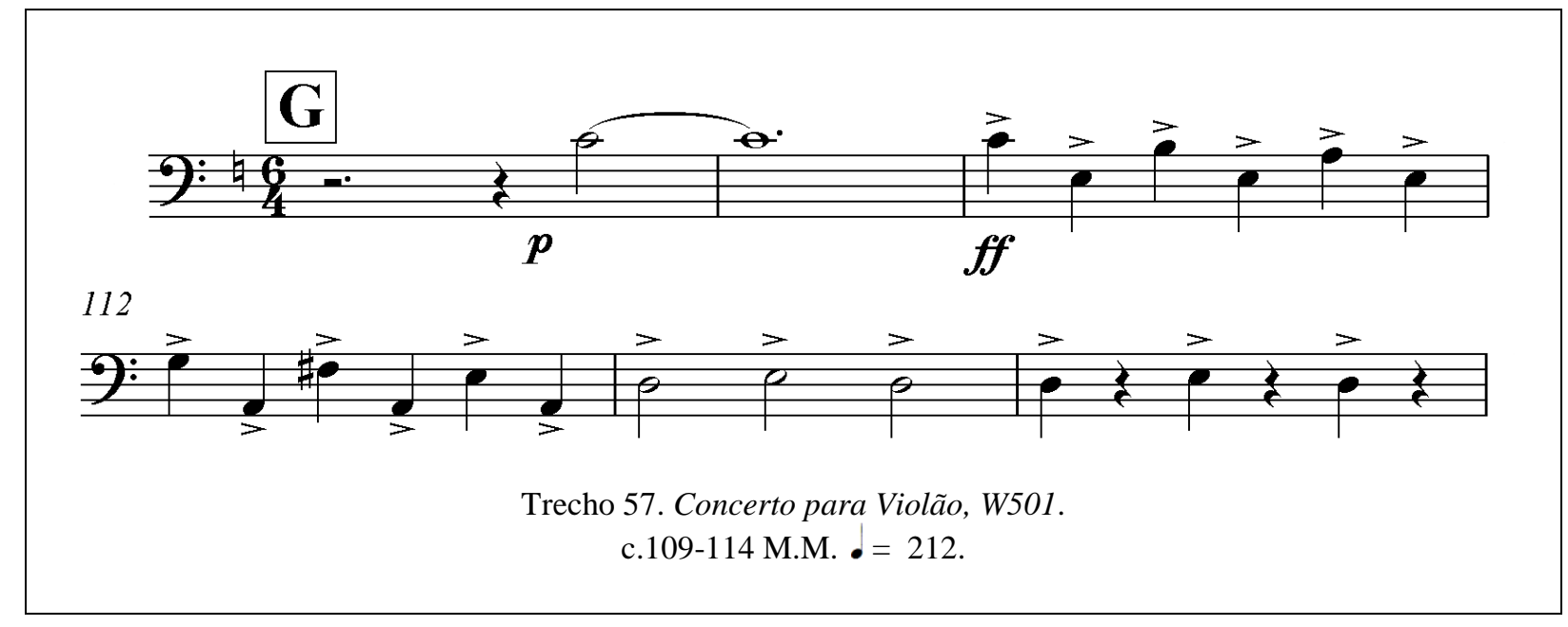

a. Principal desafio:

Articulação: Este é o único momento, em toda peça, onde o trombone foi grafado em dinâmica potente e com articulação acentuada ( > ). Deve-se ter cuidado para não extrapolar o níveis de volume das madeiras e do solista.

Outros desafios:

b. Intervalos: Trecho com seis intervalos longos. Atenção a este quesito em especial.

c. Dinâmica: Todos os sopros têm mesma dinâmica $\boldsymbol{p}$, porém as cordas iniciam um movimento escalar descendente mas com dinâmica $f$. A partir do c.111 todos têm mesma dinâmica em $f f$.

d. Complicações: A primeira nota está grafada em $\boldsymbol{p}$ dentro de um tutti orquestral e sem crescendo. Deve-se chegar súbito no ff no c.111. 
Trecho 58: Sinfonia $N^{o} .12$ - I. Allegro non troppo

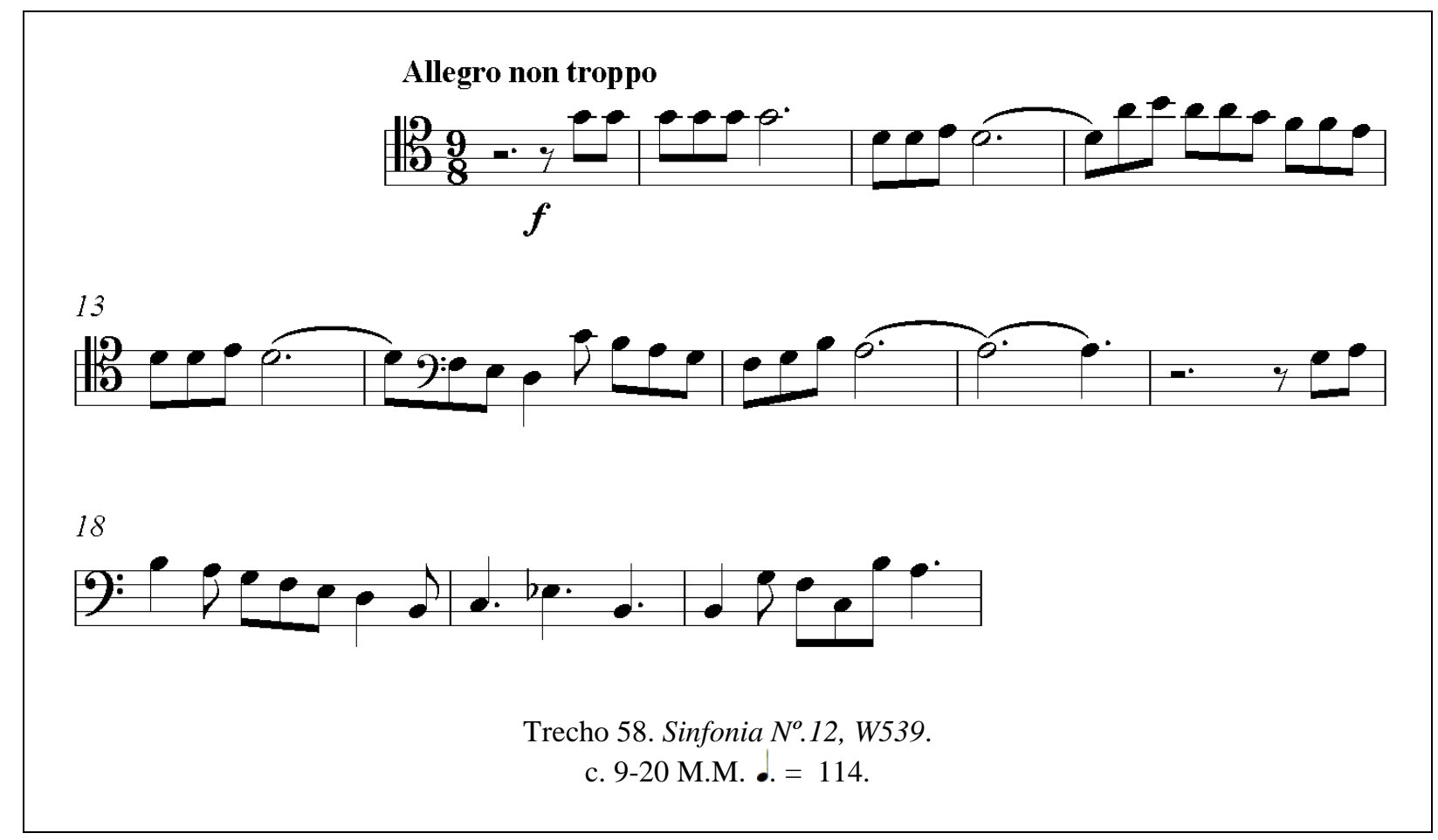

a. Principal desafio:

Sincronismo: Em conjunto com o Trombone, Villa-Lobos agrupou as Trompas e Trompetes em mesmo ritmo com papéis claros de foreground com independência rítmica dos metais onde a base contrapontística do trecho foi o diálogo em forma de responsório com madeiras e cordas respondendo ao inciso dos metais.

Outros desafios:

b. Intervalos: Villa-Lobos utilizou-se de intervalos grandes de $6^{\mathrm{a}}$. e $7^{\mathrm{a}} . \mathrm{m}$. Especial atenção com a afinação dentro dos saltos.

c. Dinâmica: Este trecho recebeu mesma dinâmica $(\boldsymbol{f})$ para todos os metais.

d. Extensão: O c.12 tem uma boa dose de dificuldade para o trombonista. Essa dificuldade é devido às notas estarem entre o $7^{\circ}$. e $9^{\circ}$. harmônicos (região onde as notas estão separadas por apenas 1 tom e o acerto das notas ficam mais comprometidos). 
Trecho 59: Sinfonia $N^{o} .12$ - I. Allegro non troppo

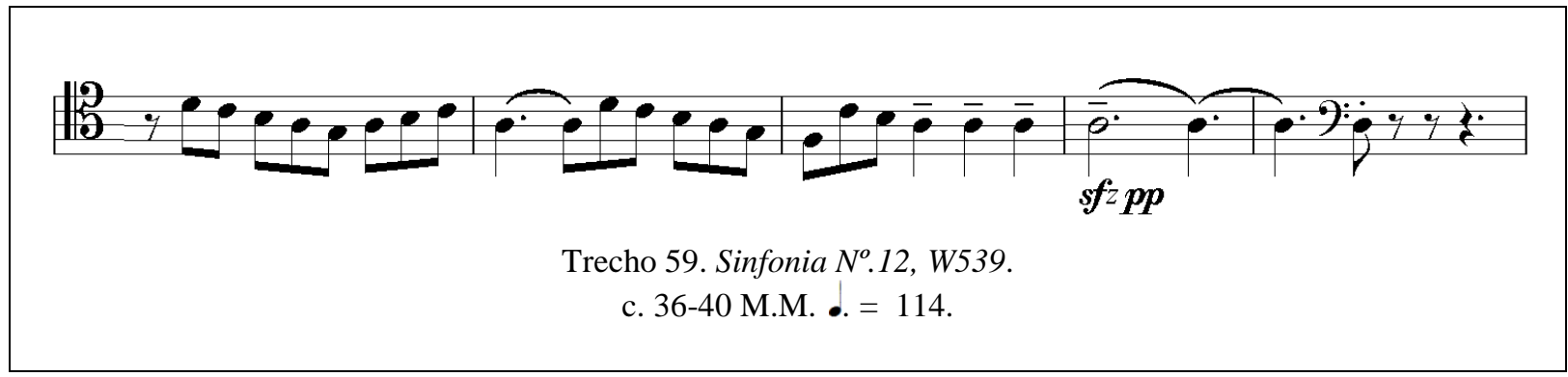

a. Principal desafio:

Articulação: O trombone inicia este trecho com articulação acentuada e levemente curta, mas precisa alterar rapidamente para tenuto em c.38. Especial atenção a essa troca de articulação.

Outros desafios:

b. Dinâmica: Trecho deve terminar com efeito de $\boldsymbol{s f} \boldsymbol{z} \boldsymbol{p p}$.

c. Analise de estilo: Semifrase finaliza com uma ideia feminina. Novamente o papel dos metais será o de foreground, pois estes estarão praticamente sozinhos - a única intervenção será dos Violinos e Violas.

\section{Trecho 60: Sinfonia $N^{o} .12$ - I. Allegro non troppo}

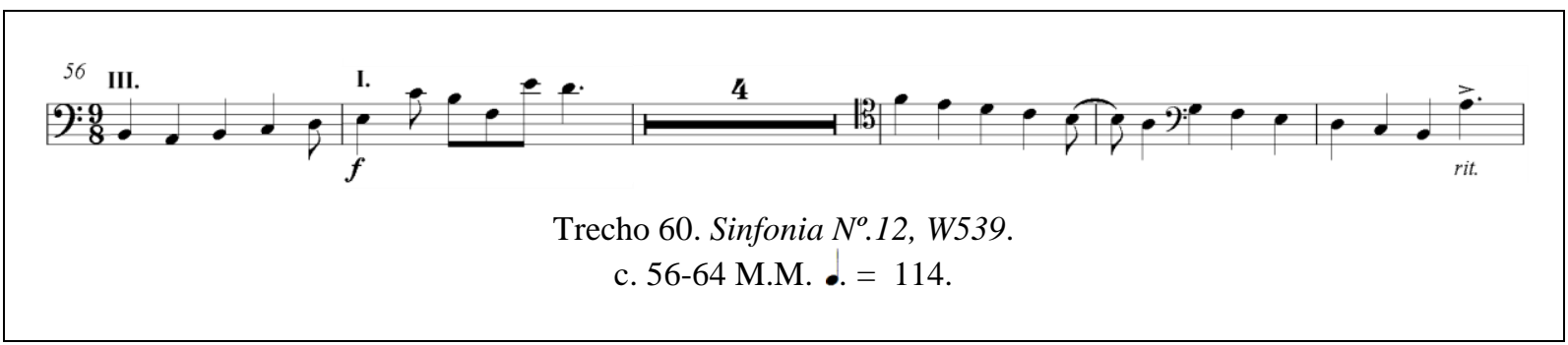

a. Principal desafio:

Ritmo: A base rítmica deste trecho é quartenário, mas estando em 9/8 o músico encontrará dificuldades em manter o pulso. Portanto muita atenção com as semínimas e seu comprimento. 
Outros desafios:

b. Intervalos: Especial atenção aos dois intervalos de 7a. durante o trecho.

c. Análise de estilo: Trecho em tópica Marcial. Os trombonistas devem acentuar as notas e manter o pulso durante o trecho.

Trecho 61: Sinfonia $N^{o} .12$ - I. Allegro non troppo (trecho a)

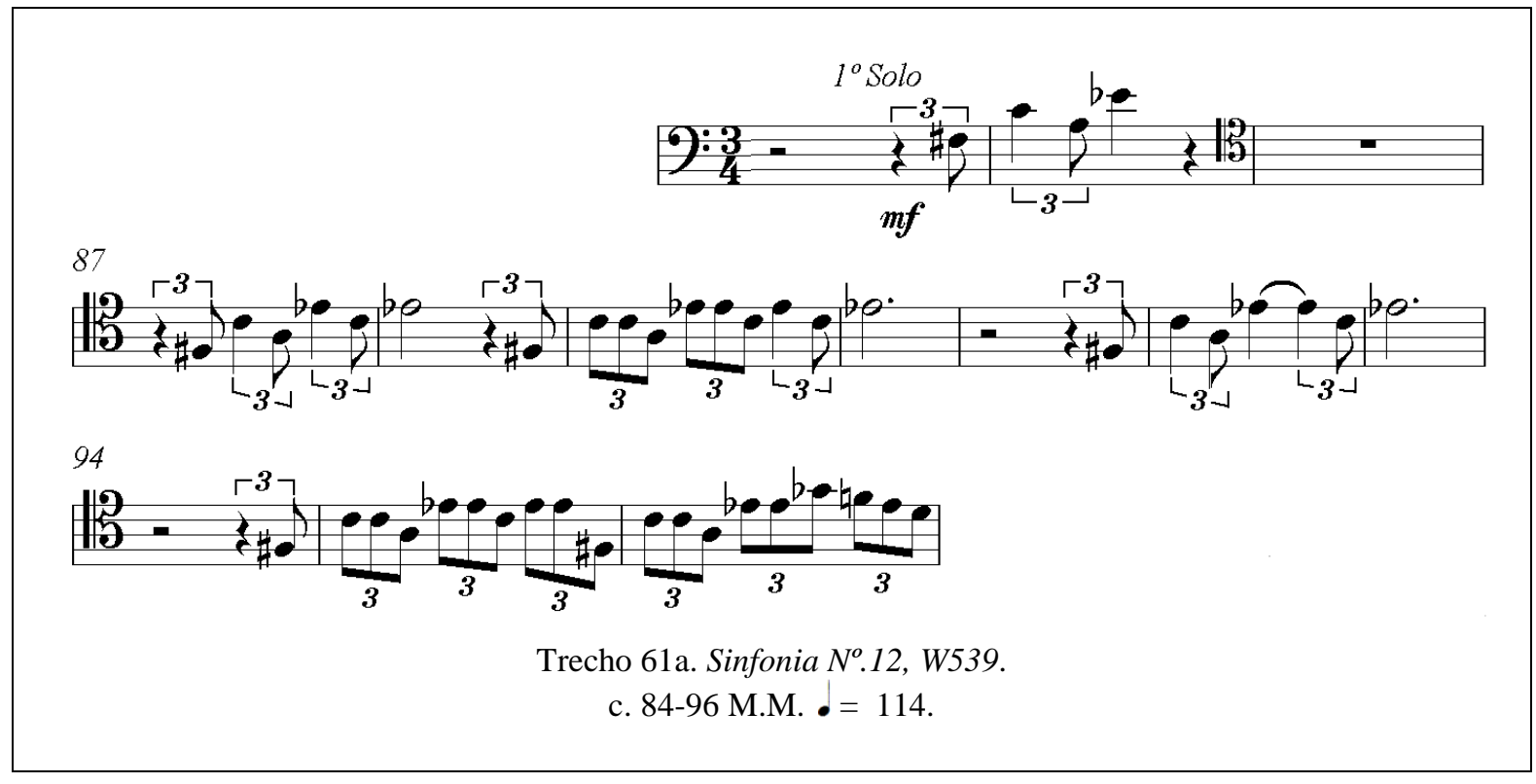

a. Principal desafio:

Ritmo: Trecho claramente poliritmico, onde os compassos do $1^{\circ}$. Trombone foram, de fato, compostos em 9/8 (9 colcheias por compasso), porém o $3^{\circ}$. Trombone está em 3/4 (6 colcheias por compasso - Trecho 61b). 


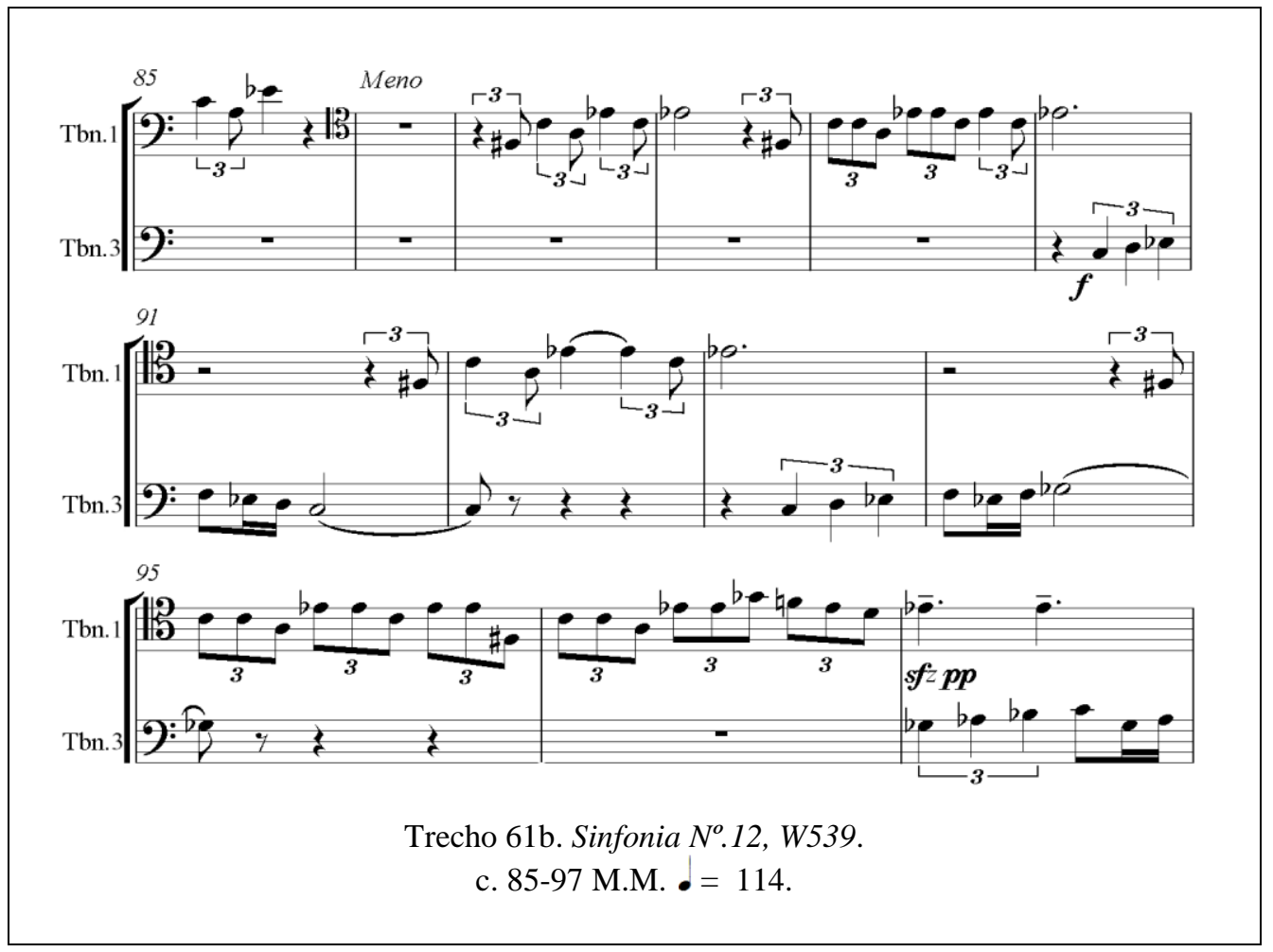

Outros desafios:

b. Intervalos: Trecho com abundância de intervalos de $5^{\mathrm{a}} \mathrm{s}$.

c. Dinâmica: Embora grafado com $\boldsymbol{m f}$, nas gravações ouvidas, o nível de dinâmica se aproxima do $f$;

d. Articulação: Trecho em Tópica Marcial, onde pra melhor clareza, as notas podem receber acentos $(>)$.

e. Afinação: Melodicamente a frase inicia-se num Fá\#2 e finda num Mib3. No Trombone tenor a posição para o Mib3 requer um ajuste em sua afinação, além do fato deste intervalo ser $7^{\mathrm{a}}$.dim. (intervalo com afinação delicada).

f. Técnicas requeridas: A queda melódica na $3^{\mathrm{a}}$. colcheia de cada tempo, gera um deslocamento na embocadura. Esse intervalo dificulta o retorno à $1^{\mathrm{a}}$. nota, possibilitando assim, uma falha momentânea de nota.

g. Complicações: Embora Villa-Lobos tenha grafado solo para o Trombone, também se encontrou a mesma designação para Flautim e Fagote. Desta forma, não é claro quem verdadeiramente é o solista dessa frase. No entanto, o Trombone fica sozinho do c.84 até o c.88. 
h. Análise de estilo: A partir do c.88, o Trompete entra em conjunto com Trombone no inciso ternário, confirmando a ideia de soli. As madeiras têm, nesse momento, movimentos melódicos em semicolcheia.

\section{Trecho 62: Sinfonia $N^{o} .12$ - I. Allegro non troppo}

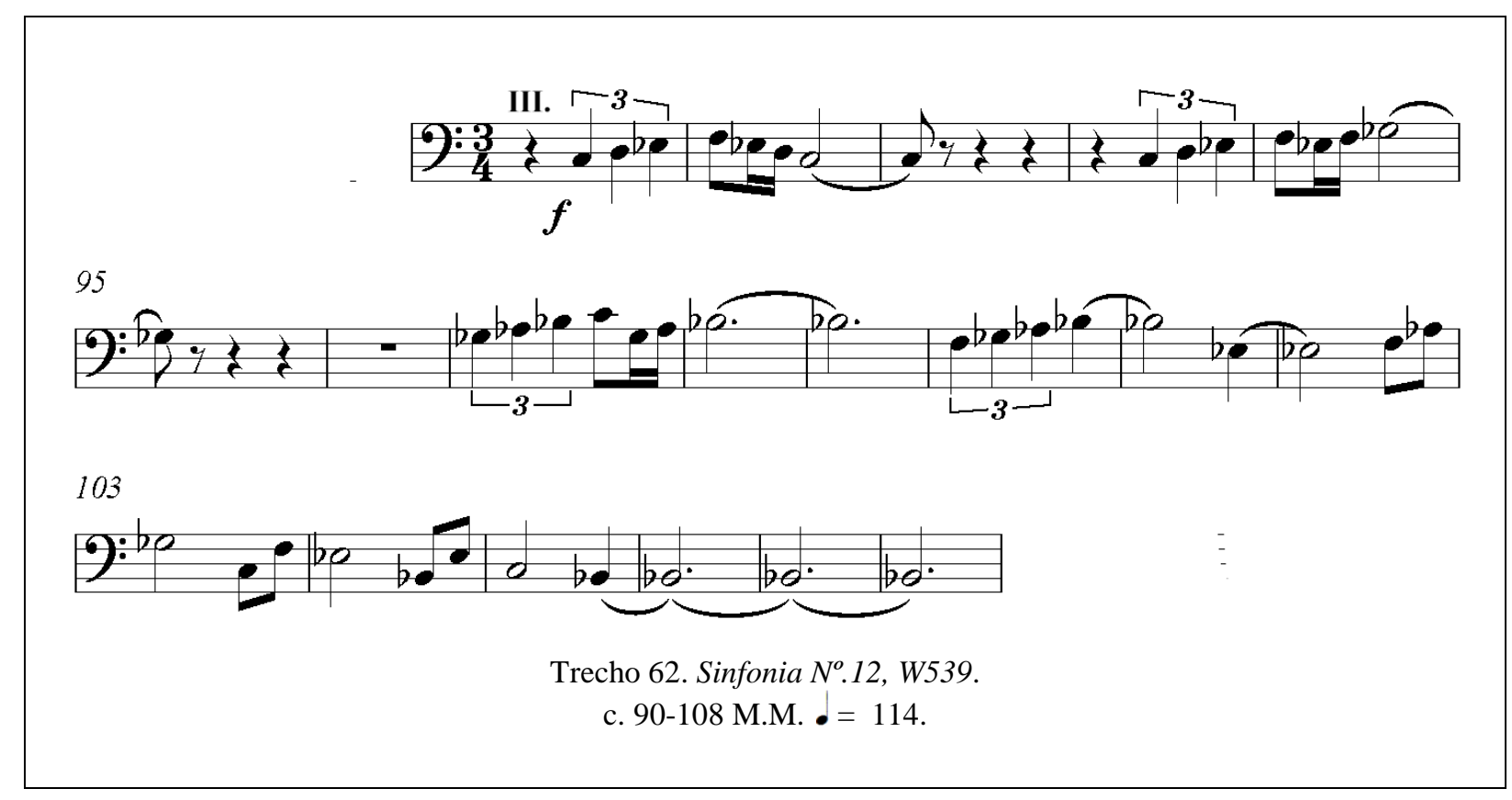

a. Principal desafio:

Afinação: Trecho longo, onde o $3^{\circ}$. Trombone estará em oitava com Oboés, Corne Inglês, Clarinetes, Clarone e Trompetes. A afinação precisa de ajustes em nível de perfeição.

Outros desafios:

b. Polirritmia: Trecho com complicações rítmicas. Villa-Lobos grafou tercinas de semínimas nos c.90,c.93, c.97 e c.100, porém os próximos dois compassos são grafados em subdivisão regular. Atenção criteriosa a esse quesito. 
Trecho 63: Sinfonia $N^{o} .12$ - I. Allegro non troppo

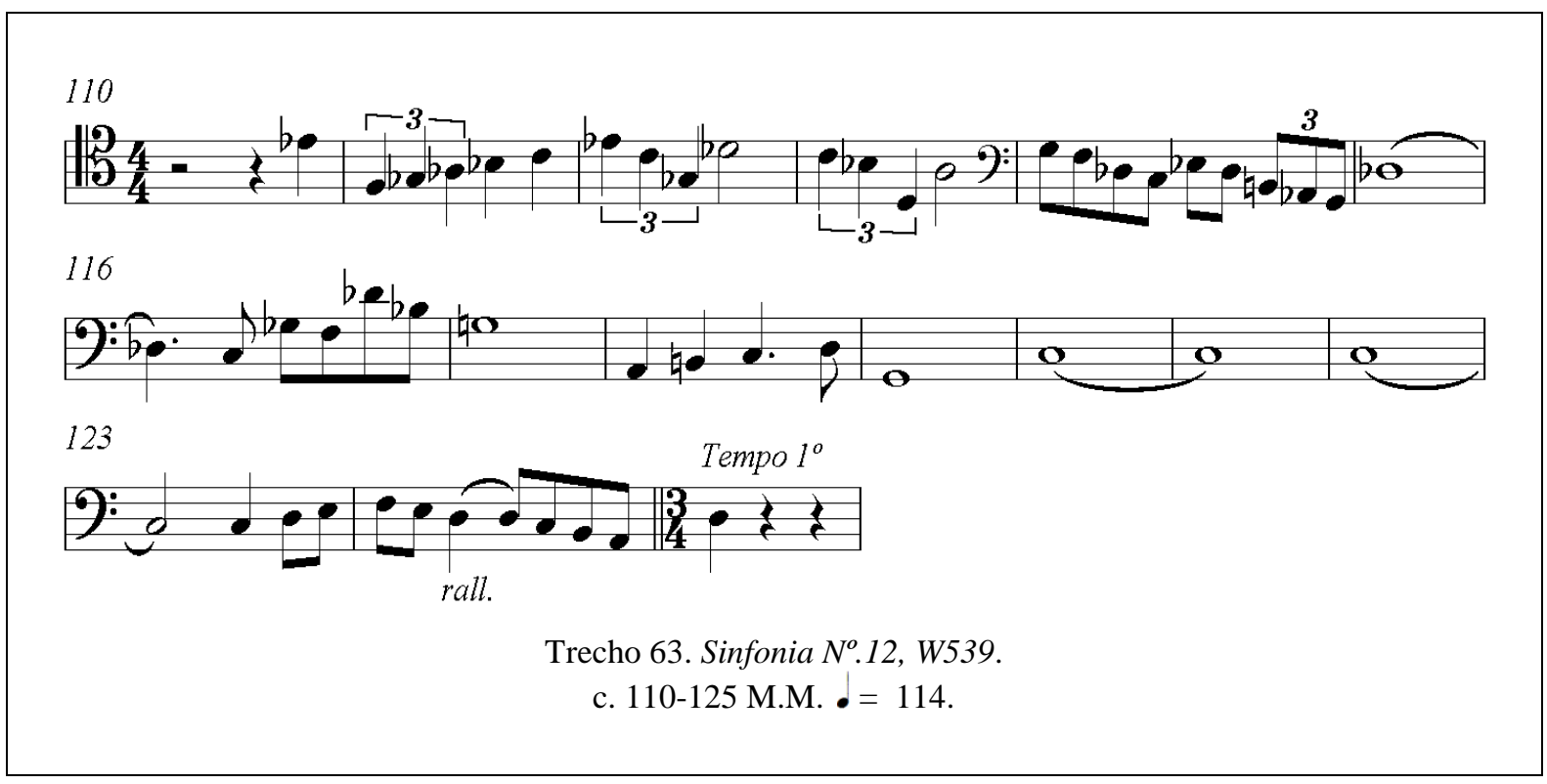

a. Principal desafio:

Oitavas e afinação: O tema será recapitulado pelo Trombone, num tutti orquestral em oitava com as Trompas, Trompetes e Cordas. Trombonistas fiquem atentos à afinação para esse trecho.

Outros desafios:

b. Intervalos: Um novo inciso contendo tercinas de semínima ao início e recheado de intervalos de $6^{\mathrm{a}}$. e $7^{\mathrm{a}}$. é recapitulado pelo Trombone. Atenção aos saltos melódicos.

c. Conjunto: Essa frase se divide em duas semifrases bem distintas em termos de utilização de figuras rápidas em contraponto às figuras mais longas, para a segunda semifrase.

d. Analise de estilo: Na primeira semifrase (c.110-119), o Trombone terá ação de foreground (solista), no entanto a segunda semifrase (c.120-125) este voltará à atitude de background (acompanhamento). 


\section{Trecho 64: Sinfonia $N^{o} .12$ - I. Allegro non troppo}

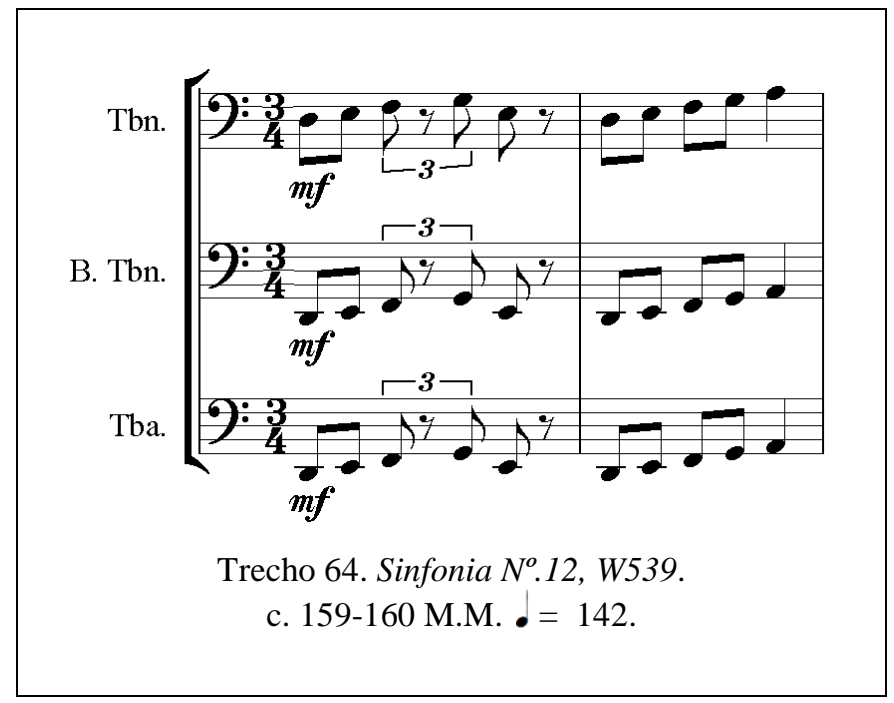

a. Principal desafio:

Complicações: Nesse trecho, os trombones fazem alusão a um movimento escalar ascendente (c.159-160) em eco para os Fagotes, Violoncelos e Contrabaixos. Villa-Lobos grafou $\boldsymbol{f}$ como dinâmica, no aguardo de equilíbrio sonoro entre os trombones e o grupo. Trombonistas devem buscar esse equilíbrio sonoro.

Outros desafios:

b. Ritmo: A tercina cria uma ideia de polirritmia no c.159. Trombonistas devem ter cuidado para que a resolução não seja com subdivisão quartenária de semicolcheias.

c. Analise de estilo: Concomitantemente a este trecho, haverá arpejos em semicolcheias nos violinos. Cuidado especial para que a subdivisão incutida pelos violinos não altere a subdivisão dos trombones. 


\section{Trecho 65: Sinfonia $N^{o} .12$ - II. Adagio}

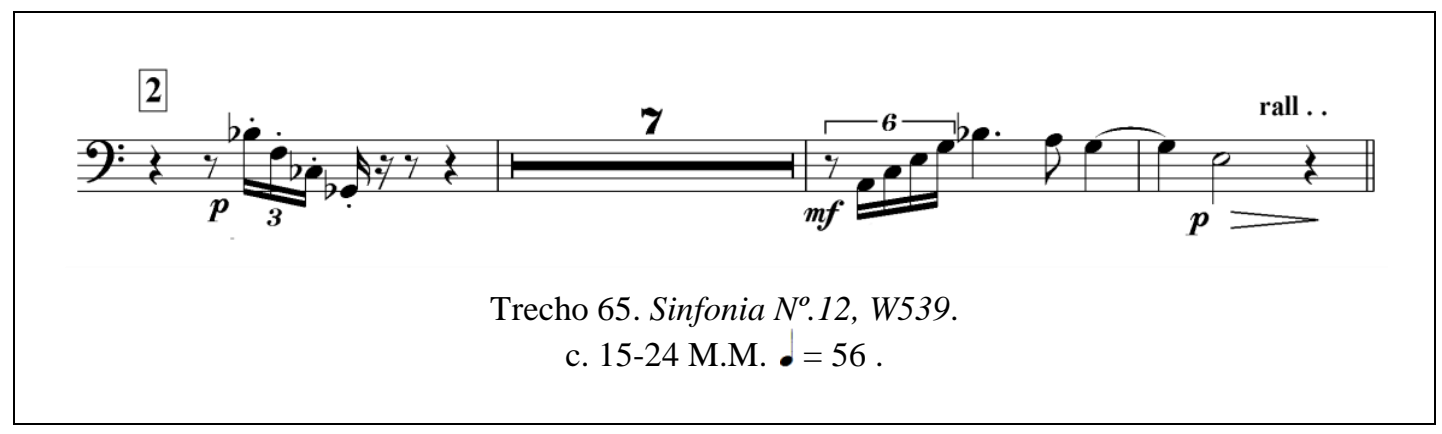

Estamos no segundo movimento. Neste, o Trombone entra no c.15, num motivo arpejado descendente, em sestinas, como finalização (pirâmide) da ideia melódica iniciada pelas cordas e madeiras no c.14. Em igual força (p) estão madeiras e metais, mas Villa-Lobos preferiu, seguramente por uma questão de equilíbrio sonoro, destinar uma dinâmica acima ( $\boldsymbol{m} f$ ) para as cordas. A articulação geral foi o estacato. A próxima entrada (c.23) será um eco do inciso apresentado pelas cordas em c.19-22 em conjunto com as Trompas.

\section{Trecho 66: Sinfonia $N^{o} .12$ - II. Adagio}

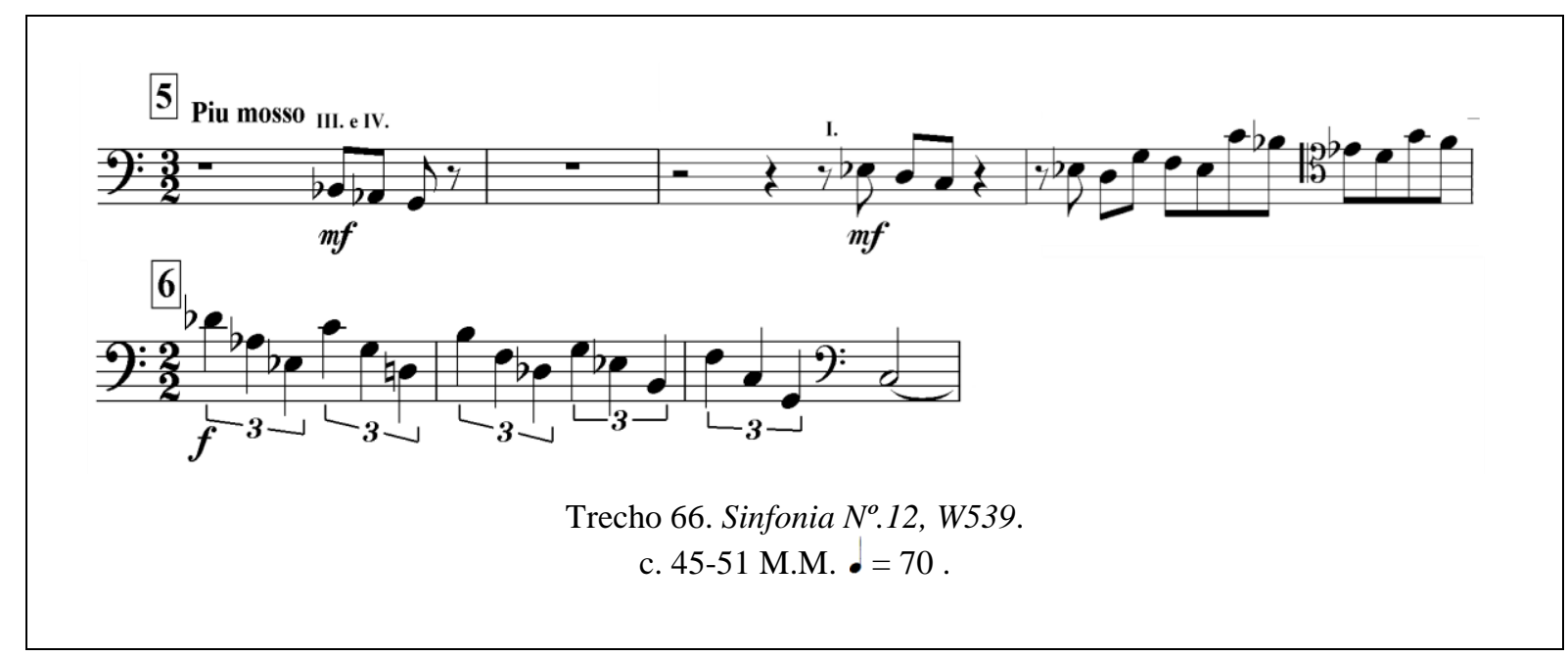

Em c.45-47, Villa-Lobos criou pirâmides de três colcheias onde o Trombone participa do segundo grupo, em conjunto com as Trompas. Em todos os grupos a dinâmica praticada foi a mesma $(\boldsymbol{m} \boldsymbol{f})$, porém em c.48 Villa-Lobos, apenas os metais graves foram incumbidos de executar a sequência completa de colcheias culminando em arpejos descendentes de tercinas em semínimas em conjunto com as cordas. Neste ponto a dinâmica será $f$. (Trecho 66). 


\section{Trecho 67: Sinfonia $N^{o} .12$ - II. Adagio}

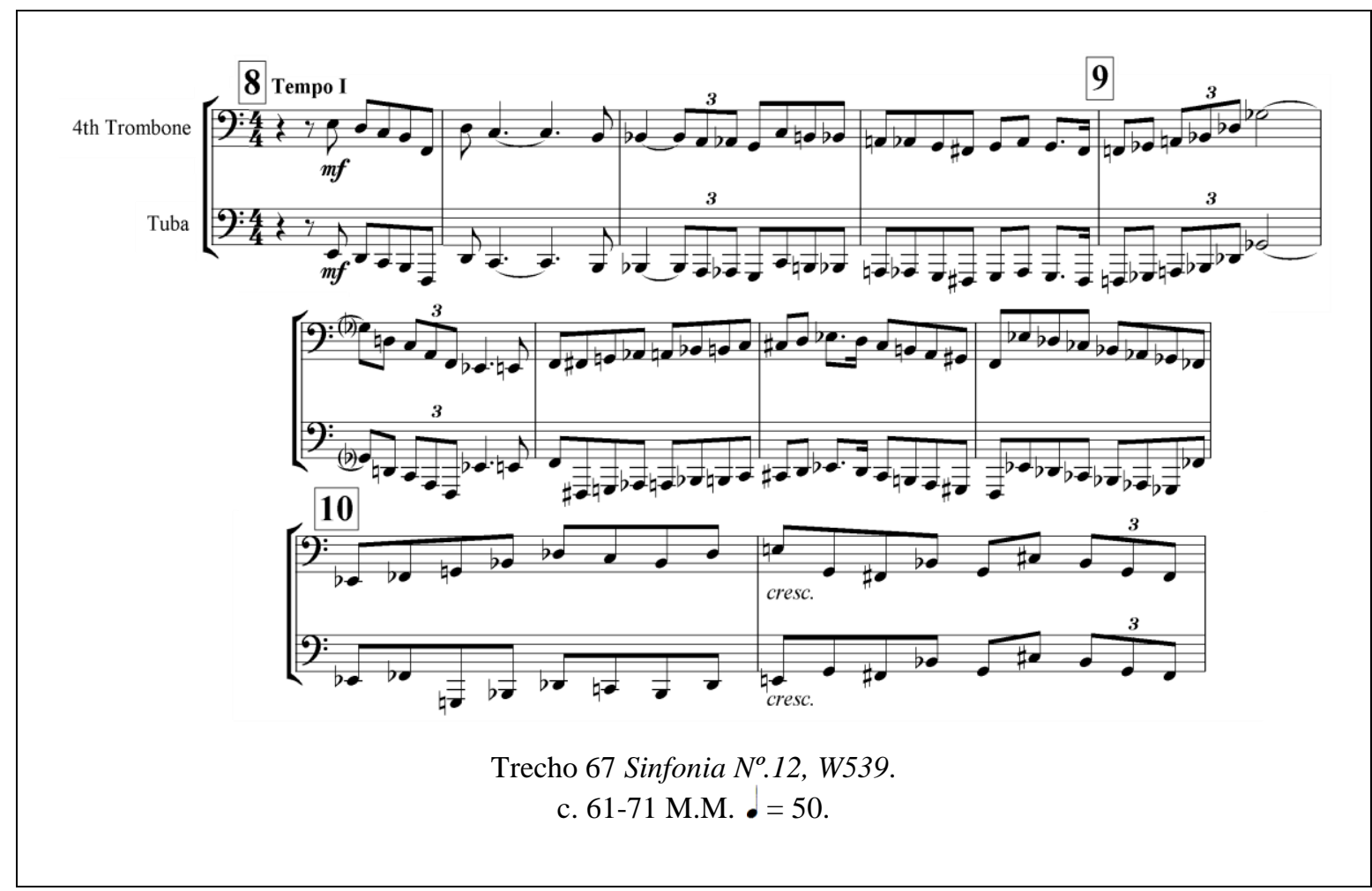

Em c.61 os metais graves fazem um contraponto, contendo dois intervalos de $6^{\mathrm{a}}$. e um de $7^{\text {a }}$, ao tema apresentado pelas Flautas, Trompa e cordas agudas (grupo 1). Junto aos metais graves estarão Clarone, Fagote, Contrafagote, Violoncelo e Contrabaixo ${ }^{109}$, num claro papel de background ao tema do grupo 1. (Trecho 67).

\section{Trecho 68: Sinfonia $N^{o} .12$ - III. Scherzo}

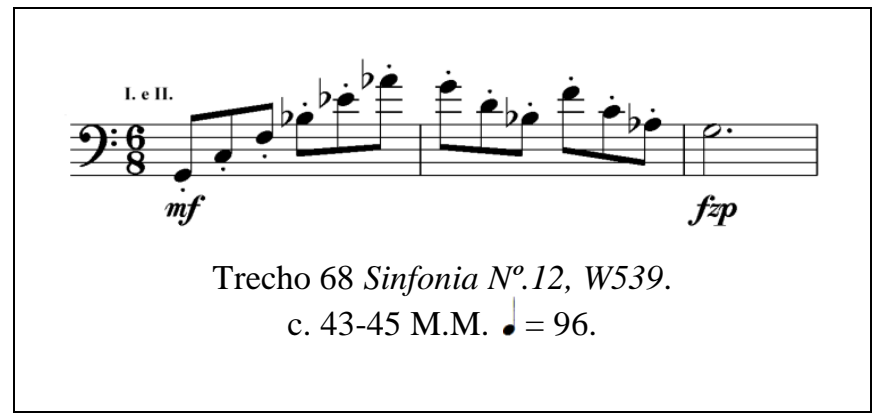

${ }^{109}$ Em verdade, os também graves das madeiras e cordas. 
No $3^{\circ}$. movimento, os Trombones fazem sua primeira participação em foreground no c.43-44. Nesse local, Villa-Lobos grafou uma resposta em forma de eco, ao inciso arpejado, apresentado pela Clarinete e Fagote (c.41-42) em dinâmica $f$. Estes mesmos instrumentos fazem acompanhamento ao eco dos Trombones com articulação em estacato e dinâmica $\boldsymbol{m f}$.

\section{Trecho 69: Sinfonia $N^{o} .12$ - III. Scherzo}

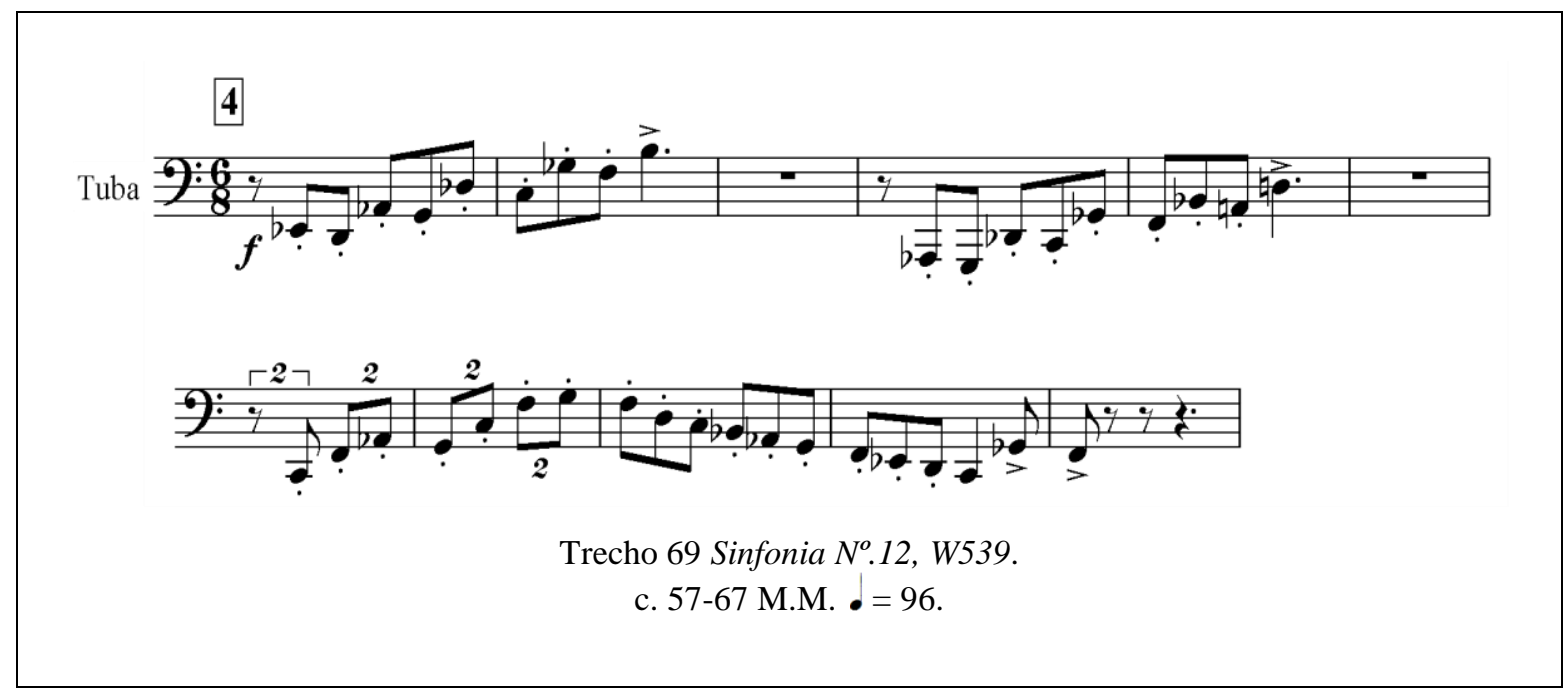

As madeiras fazem um inciso bem característico de 6/8 no c.55-56. Para esse inciso em região aguda, Villa-Lobos criou uma resposta em colcheias intermitentes onde os graves (Clarone, Fagote, Contrafagote, Tuba, Violoncelo e Contrabaixo) em clara ideia de contraste de cores, fazem três respostas ao inciso agudo (a terceira sofrerá mudança rítmica e uma ampliação). Nesse inciso dos graves teremos vários intervalos de $5^{\mathrm{a}}$. e $4^{\mathrm{a}}$. (Trecho 69).

Trecho 70: Sinfonia $N^{o} .12$ - III. Scherzo

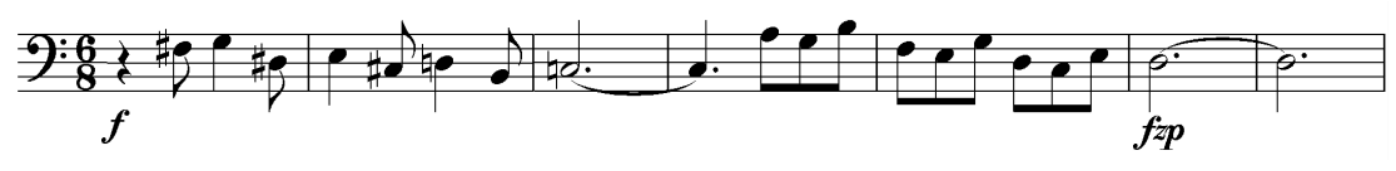

Trecho 70 Sinfonia $N^{o} .12$, W539.

III. mov. c.78-84 M.M. $\bullet=96$. 
Os Trombones fazem uma resposta com profusão de intervalos de $4^{\mathrm{a}}$. e em eco (c.7880) para o tema secundário ${ }^{110}$ exposto em c.74-77 pelas Trompas e Trompetes. Porém o fechamento da semifrase, os Trombones o fazem em conjunto com as Trompas graves (Trecho 70).

\section{Trecho 71: Sinfonia $N^{o} .12$ - III. Scherzo}

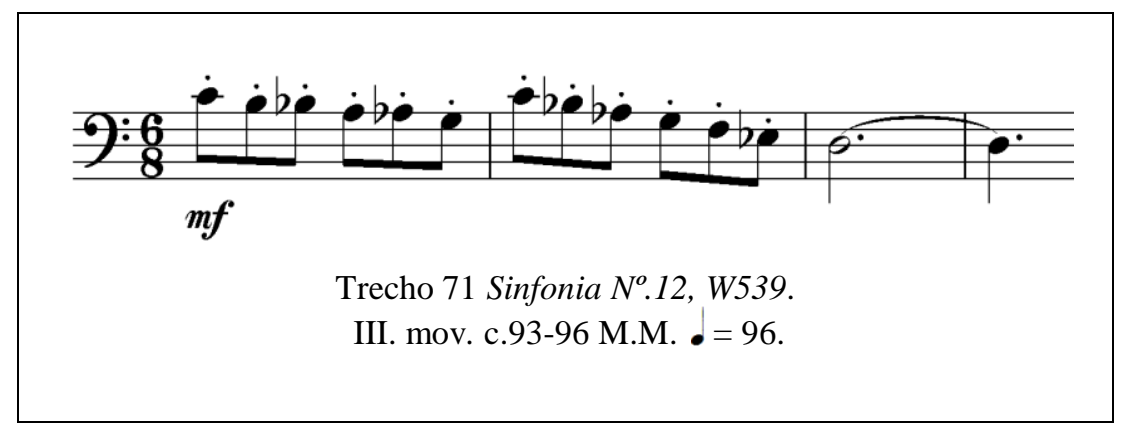

Numa sequência de incisos em forma de arpejos (c.89-103), Villa-Lobos criou um contraste melódico ao atribuir para os trombones, um inciso cromático descendente (c.93-94) em conjunto com as Trompas e em articulação estacato (Trecho 71).

\section{Trecho 72: Sinfonia $N^{o} .12$ - III. Scherzo}

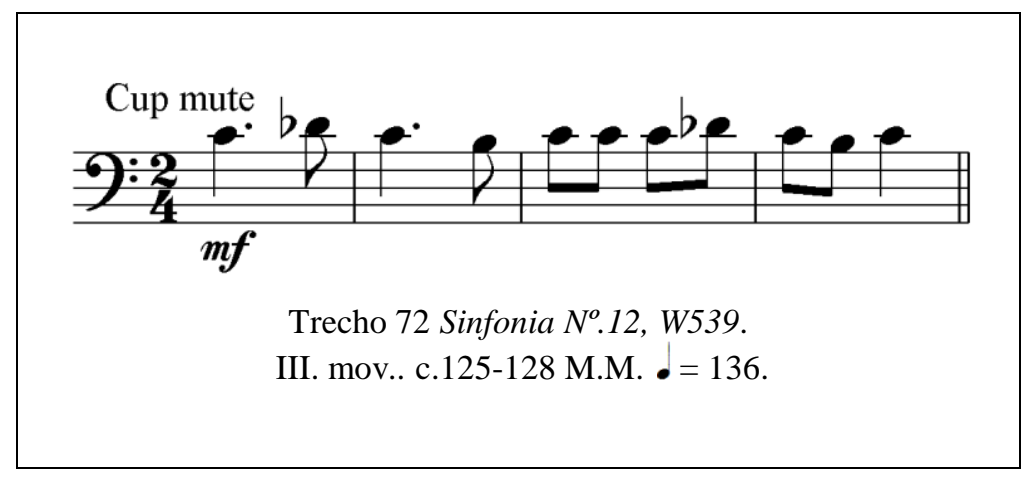

As madeiras têm o tema principal (c.117-140) em seu domínio. Villa-Lobos criou um inciso secundário polarizado na nota Dó e o designou para os Trombones (em surdina c.125-128) enquanto os Violinos fazem um eco ao tema das madeiras (Trecho 72).

${ }^{110} \mathrm{O}$ tema principal está a cargo das cordas. 
Trecho 73: Sinfonia $N^{o} .12$ - III. Scherzo

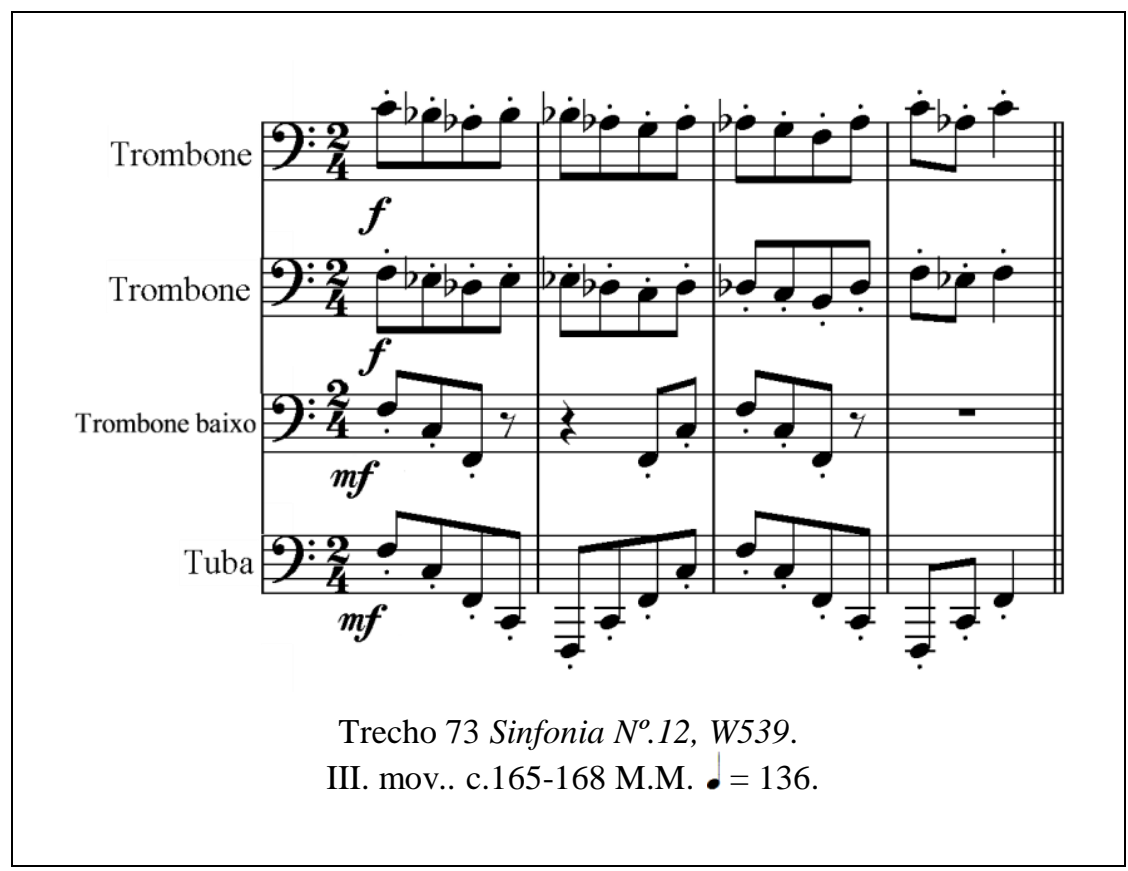

Os Fagotes iniciaram um tema secundário aos Violinos do c.141-189. Villa-Lobos repetiu o inciso para os metais graves em c.157-158 e c.165-168. Para equilíbrio sonoro, a dinâmica grafada foi $\boldsymbol{f}$ para os fagotes e $\boldsymbol{m} \boldsymbol{f}$ para os metais graves e Tímpanos. Todos têm articulação em estacato. Destaque deve ser dado à sequência de arpejos escrita para Tuba, de difícil execução. (Trecho 71).

\section{Trecho 74: Sinfonia $N^{o} .12$ - III. Scherzo}

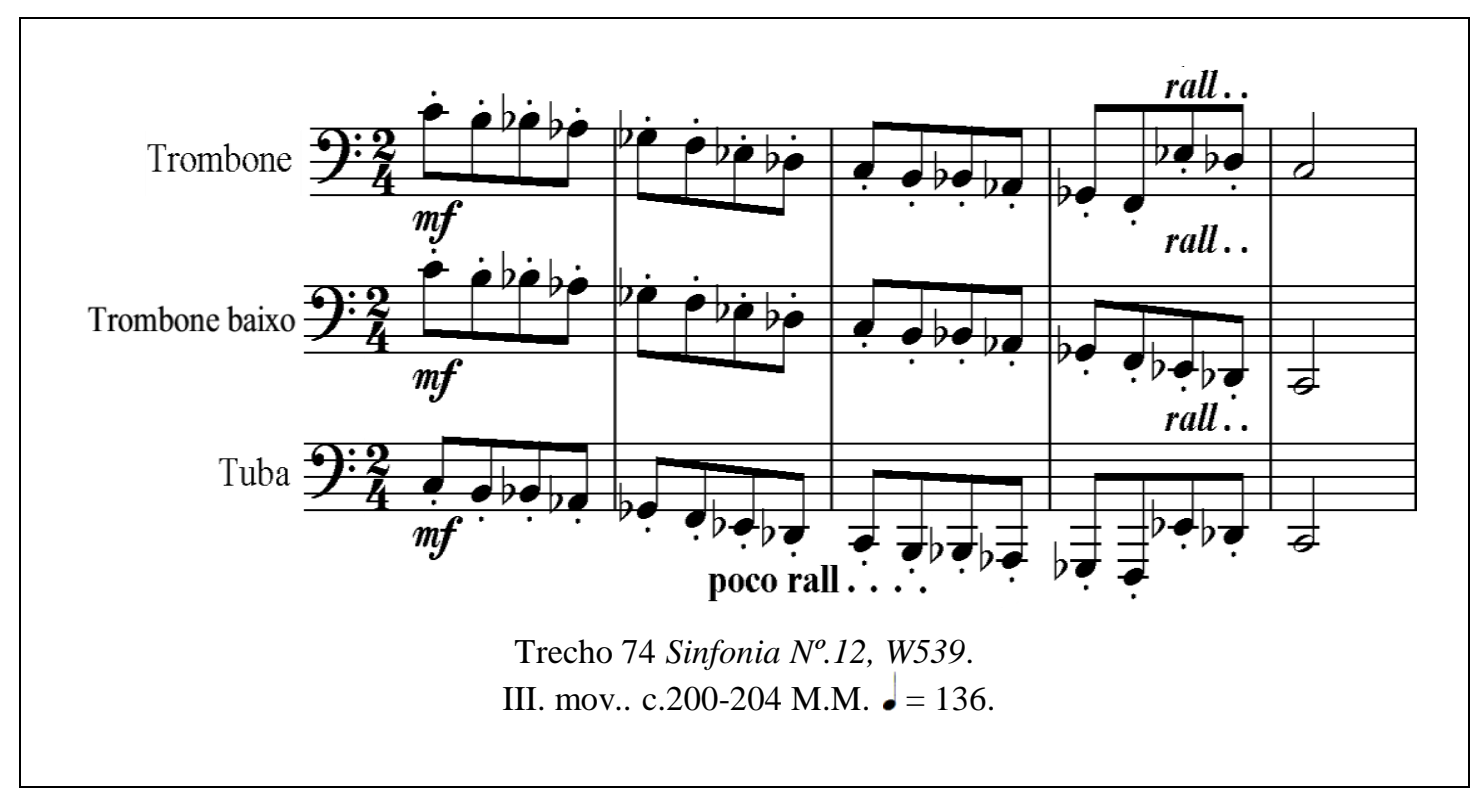


Com função de Coda, Villa-Lobos escreveu para os graves da orquestra (Contrafagote, metais graves, Violoncelos e Contrabaixos) um inciso em movimento escalar descendente, claramente no papel de foreground, nos c.200-204. A dinâmica ficou estabelecida em $\boldsymbol{m} \boldsymbol{f}$ e articulação estacato (Trecho 74).

\section{Trecho 75: Sinfonia $N^{o} .12$ - III. Scherzo}

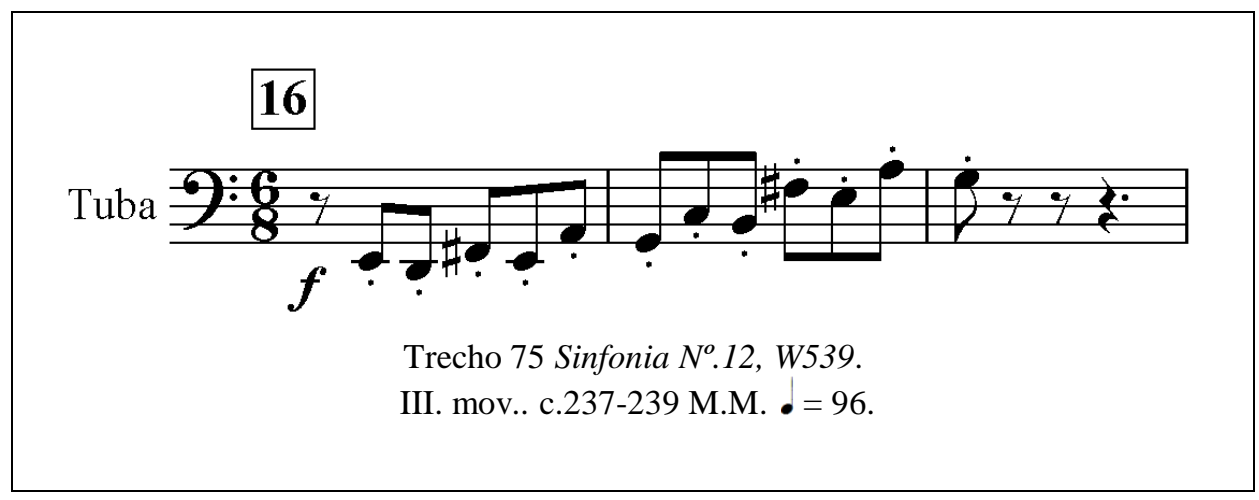

Villa-Lobos recapitula a fórmula 6/8 em c.205. A partir desse compasso, o compositor criou dois temas antecedentes (arpejos) e um consequente (intervalar e escalar descendente) exposto nas cordas e depois nas madeiras, e por fim retornando às cordas (ABA). Como possibilidade composicional, Villa-Lobos aproveitará essa ideia consequente para criar sua Coda à esse movimento, iniciando pelos graves orquestrais (Corne Inglês, Clarinete, Clarone, Fagote, Tuba, Viola, Violoncelo e Contrabaixo) e depois o consequente para os agudos (Flautim, Flauta, Trompete e Violinos), numa clara ideia de diálogo entre grave e agudo e o contraste de cores que essa técnica agrega. (Trecho 75). 


\section{Trecho 76: Sinfonia $N^{o} .12$ - IV. Molto Allegro}

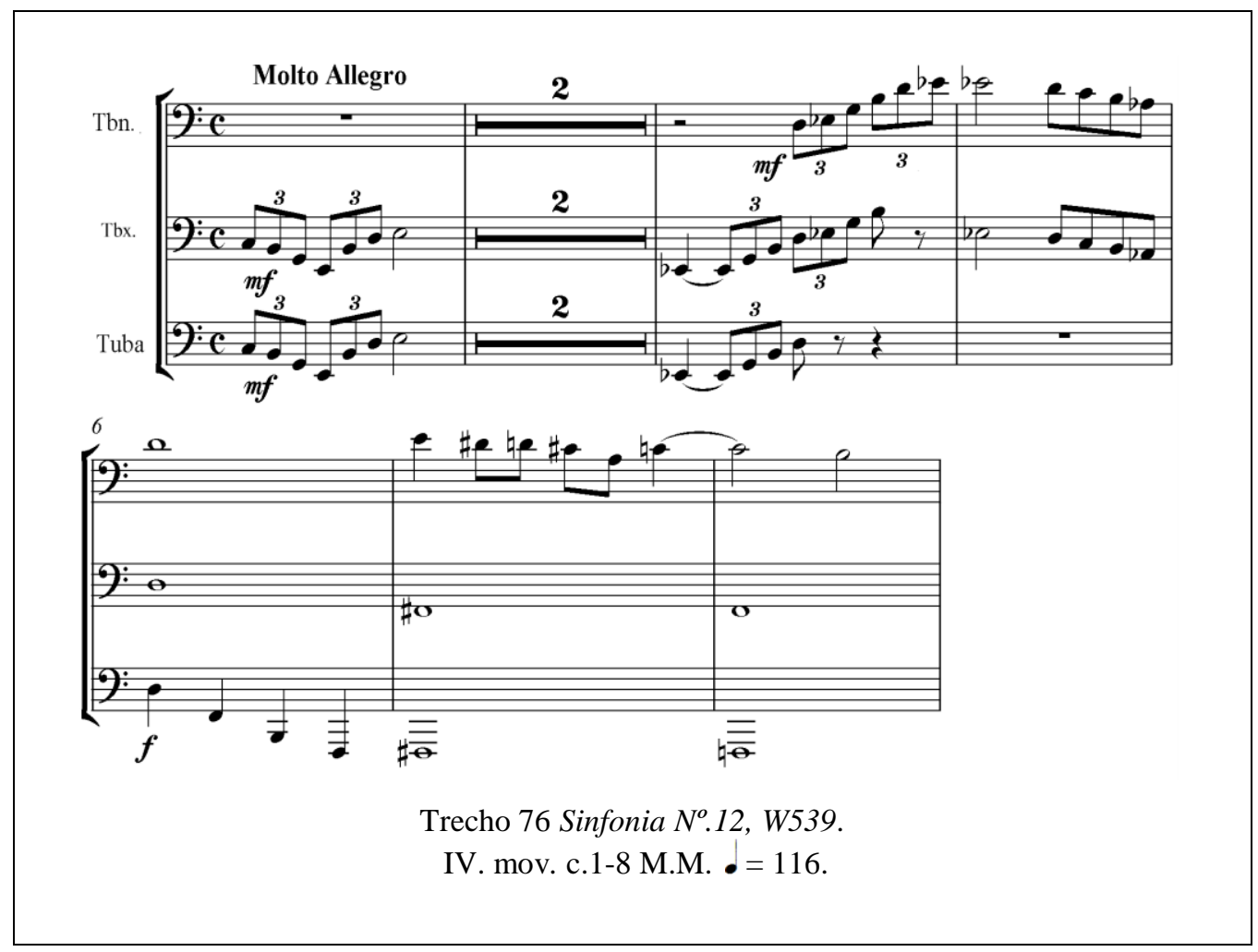

Apenas a Tuba e o Trombone baixo iniciam o $4^{\circ}$. e último movimento. Este movimento contém um inciso melódico em forma de arpejo, mas dentro de uma polirritmia simultânea onde os Violinos, Violas e Trompetes têm subdivisão binária sobre o Corne Inglês, Clarinete, Fagotes, Contrafagote, Trombone baixo, Tuba, Violoncelo e Contrabaixo com subdivisão em quiálteras de colcheia (c.1). Porém em c.4 com a entrada do restante do naipe de Trombones, a subdivisão por tercinas de colcheia será a base rítmica do compasso. Em c.7, o Trombone cita o $1^{\mathrm{o}}$. inciso exposto pelos Violinos, Violas e Trompete no c.2 (Trecho 76).

\section{Trecho 77: Sinfonia $N^{o} .12-I V$. Molto Allegro}

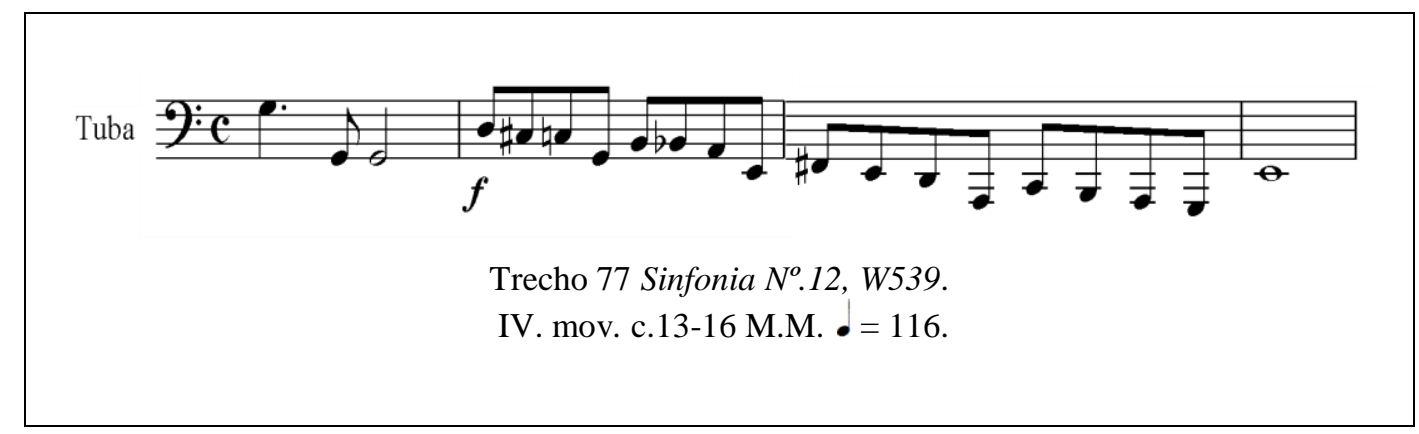


A partir do c.11, Villa-Lobos criou uma pirâmide com base no movimento escalar descendente (tetracorde) em semicolcheias, culminada no c.13. A terminação para essa semifrase será a mesma base intervalar, porém Villa-Lobos escreveu para os graves (Fagotes, Contrafagote, Trombone baixo, Tuba e Contrabaixo), mais lentos por natureza, a metade da velocidade: colcheias (Trecho 77).

\section{Trecho 78: Sinfonia $N^{o} .12$ - IV. Molto Allegro}
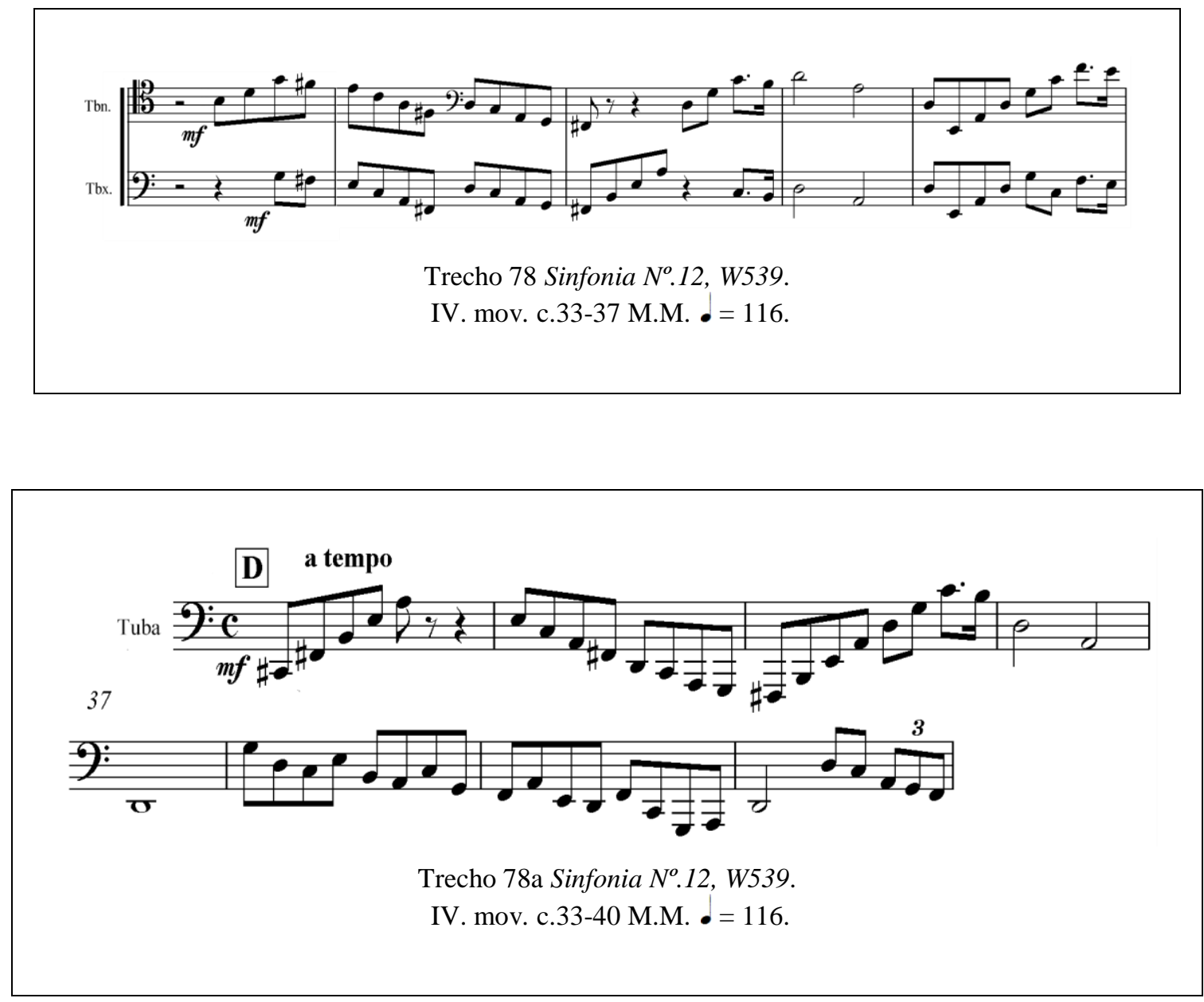

Em c.33, Villa-Lobos criou um novo tema para cordas e madeiras. A ideia de contraponto para esse novo tema, é uma ideia muito próxima ao tema (sequencia de arpejos em colcheias). Os metais graves fazem um contraponto em conjunto com Violoncelos, Contrabaixo, Fagotes e Contrafagote (Trecho 78 e 78a). 


\section{Trecho 79: Sinfonia $N^{o} .12$ - IV. Molto Allegro}

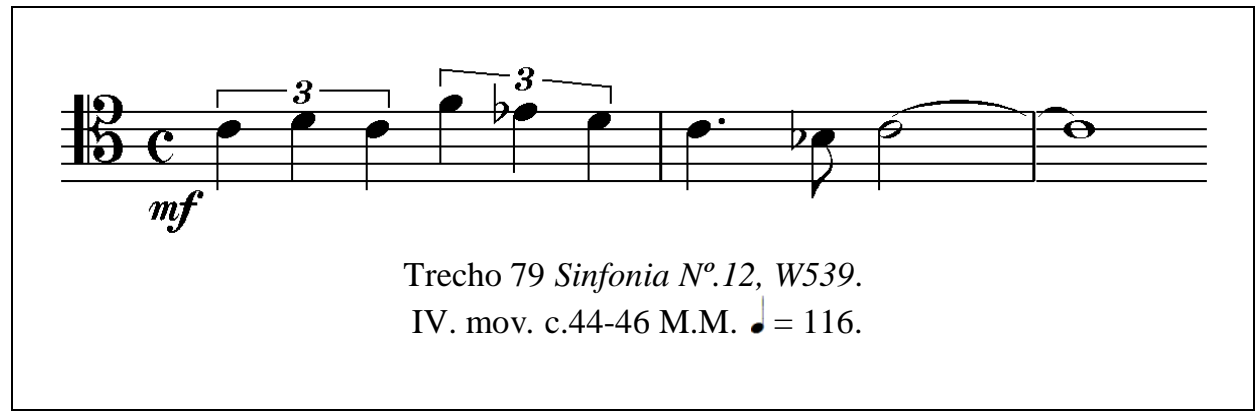

Em c.43 [5], Villa-Lobos criou para o conjunto Trompete, Violino e Viola um novo tema com base rítmica em tercina de semínima. Trombone, em solo, faz um eco a esse novo tema em c.44 e o mesmo primeiro grupo repete o mesmo tema pela $3^{\mathrm{a}}$. vez em c.45 (Trecho 79).

Trecho 80: Sinfonia $N^{o} .12$ - IV. Molto Allegro

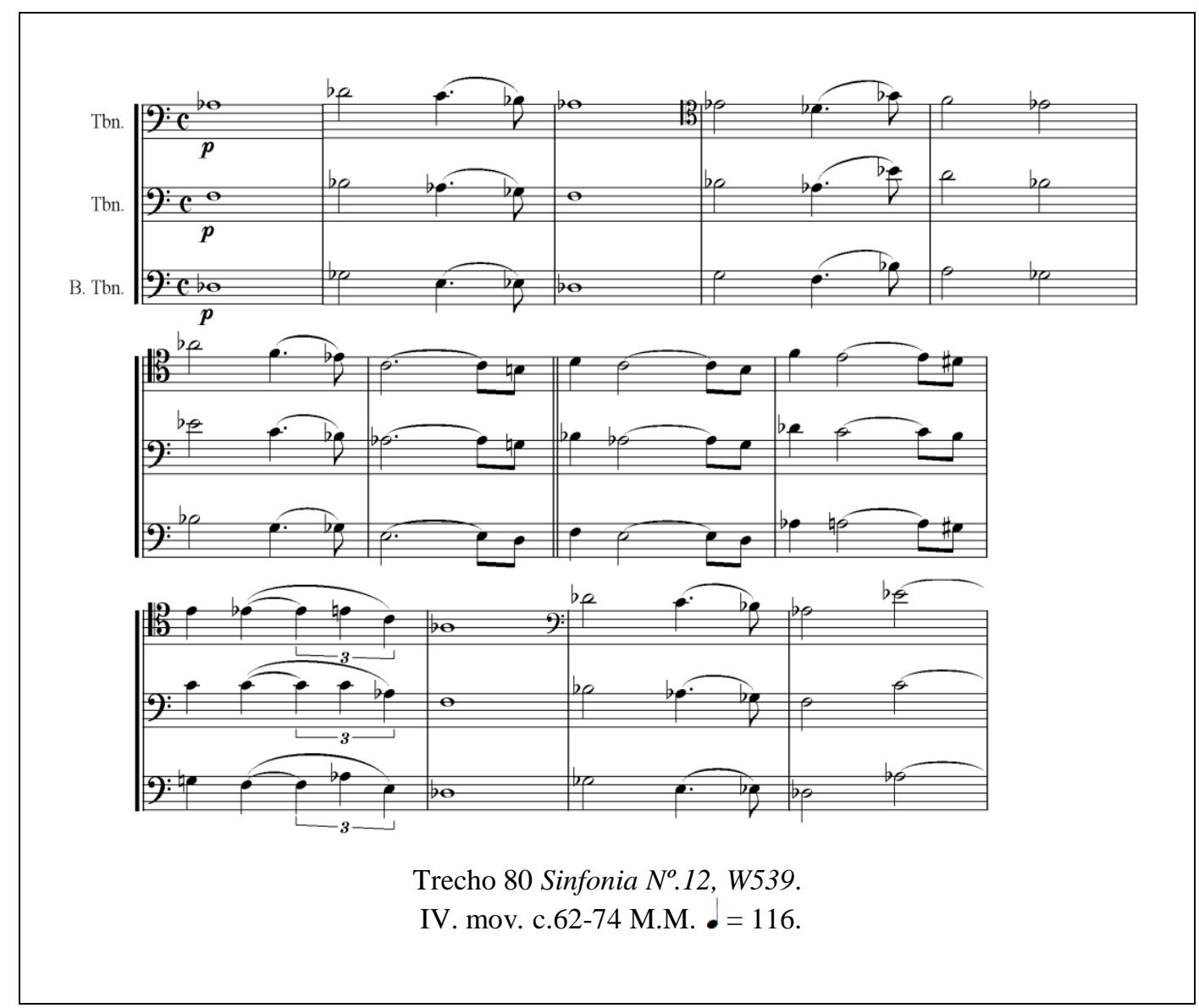


Após um pequena espera, os trombones farão um coral a três vozes escrito como base harmônica para o solo da Flauta (c.63-c.75). Um trecho onde tocam apenas Flautas, trombones e um ostinato em tercinas de semínimas feito pelos Tímpanos. Há também uma nota longa nas cordas, em forma pedal em tetracorde, com duração plena durante o coral. Nesse caso, percebe-se a técnica da separação entre o solista e o tutti pela independência rítmica (Trecho 80).

Trecho 81: Sinfonia $N^{o} .12$ - IV. Molto Allegro

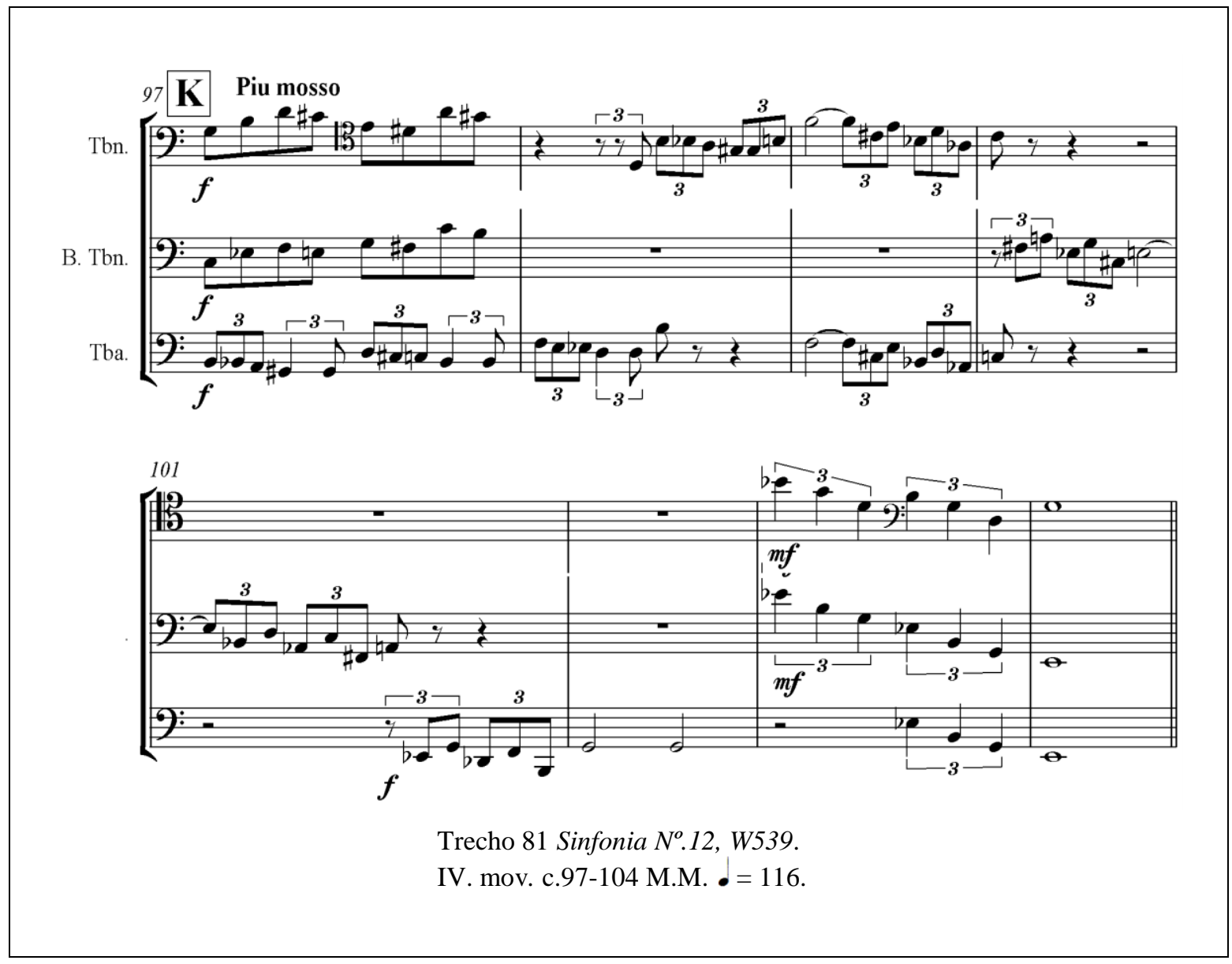

O início da Coda será marcado por polirritmias de semicolcheias (Violinos e Trompas) e tercinas de colcheia (o restante da orquestra). Como é sabido, os graves são mais lentos, logo Villa-Lobos dedicou colcheias simples e tercinas (ao invés de semicolcheias) para esse grupo mais lento. E será dentro desse caos rítmico que os Trombones participarão do inicio da Coda (Trecho 81). 


\section{Trecho 82: Sinfonia $N^{o} .12$ - IV. Molto Allegro}

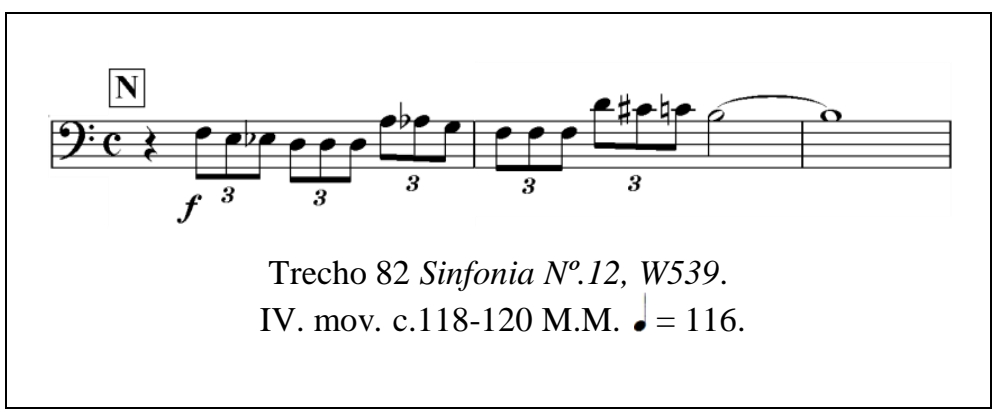

Em c.118 os Trombones fazem eco em resposta ao tema secundário exposto em c.117 pelo Clarone, Fagote, Contrafagote, Tuba, Violoncelo e Contrabaixo. Nesse trecho teremos a dificuldade técnica dos intervalos de $5^{\mathrm{a}}$. e $6^{\mathrm{a}}$. (Trecho 82 ).

Trecho 83: Sinfonia $N^{o} .12$ - IV. Molto Allegro

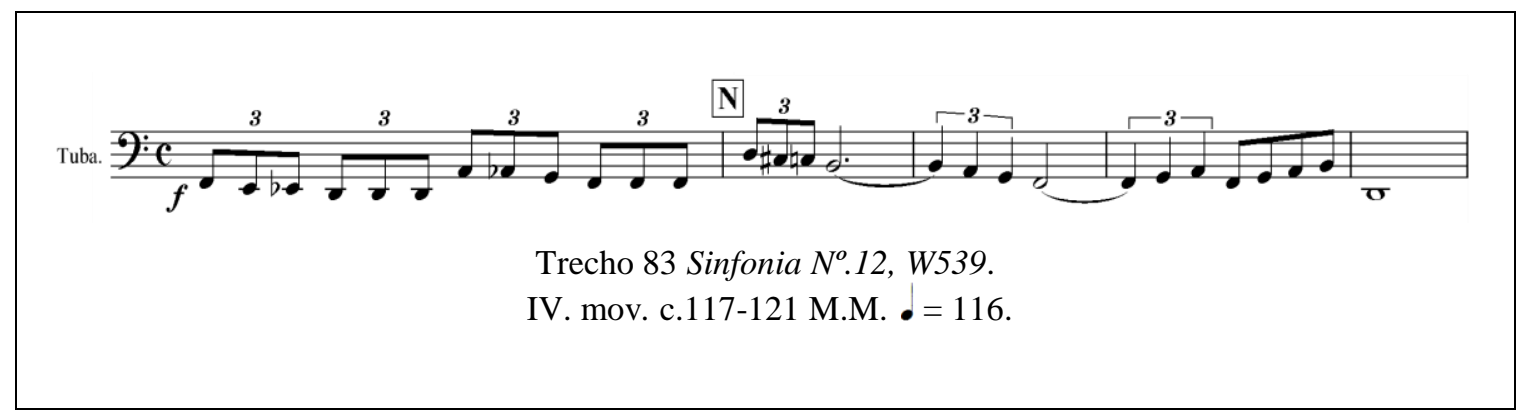

Em c.117 a Tuba estará com o tema secundário, em parceria com o Clarone, Fagotes, Contrafagote, Violoncelos e Contrabaixos. Nesse trecho teremos como dificuldade técnica, os intervalos de $5^{\mathrm{a}}$. e $6^{\mathrm{a}}$. (Trecho 83).

Trecho 84: Sinfonia $N^{o} .12$ - IV. Molto Allegro

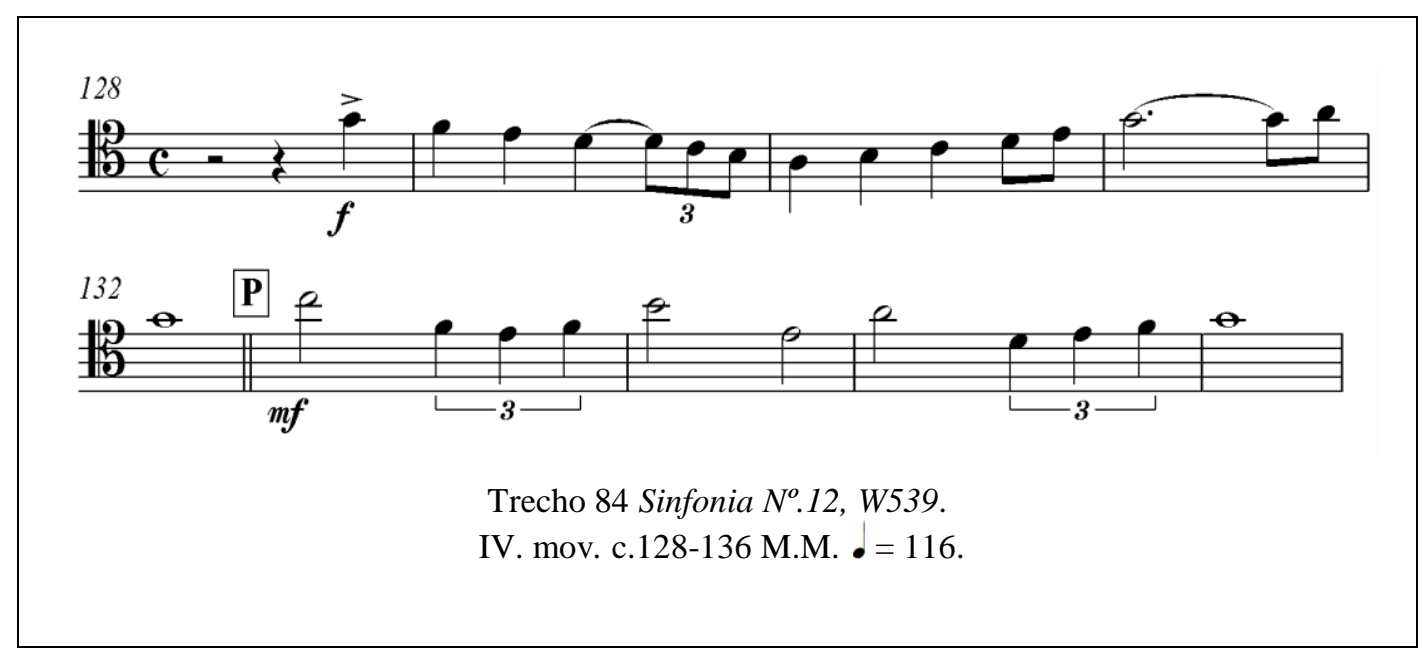


Um inciso novo, em semínimas, que se inicia em c.129 tem como base melódica o movimento escalar descendente. Trombones e Trompas terão o mesmo desenho melódico. O próximo inciso se inicia em c.132 e tem como base rítmica a tercina de semínima. O trombone no c. 133 estará junto à Trompa com ideia de tercina de semínima na segunda metade com compasso. Quem ficou responsável pela $1^{\circ}$. Grupo de tercinas, foram os tímpanos (Trecho 84).

\subsection{2 - TROMBONE BAIXO}

\section{Trecho 85: Uirapurú}

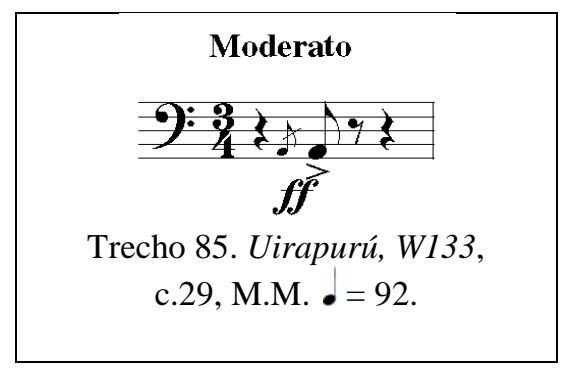

a. Principal desafio:

Ritmo: A apogiatura escrita antes do Lá1 (principal), não deve criar um atraso de pulsação. Deve-se atentar para um perfeito sincronismo ritmo deste motivo.

Outros desafios:

b. Articulação: O Segundo Lá1 receberá um acento ( $>$ ), logo os trombonistas devem se preparam para esconder um pouco a apogiatura para que a nota do bateri do tempo seja bem perceptível.

c. Complicações: Não deixar para se respirar no último instante. Essa atitude seguramente gerará atraso na nota acentuada. 


\section{Trecho 86: Uirapurú}

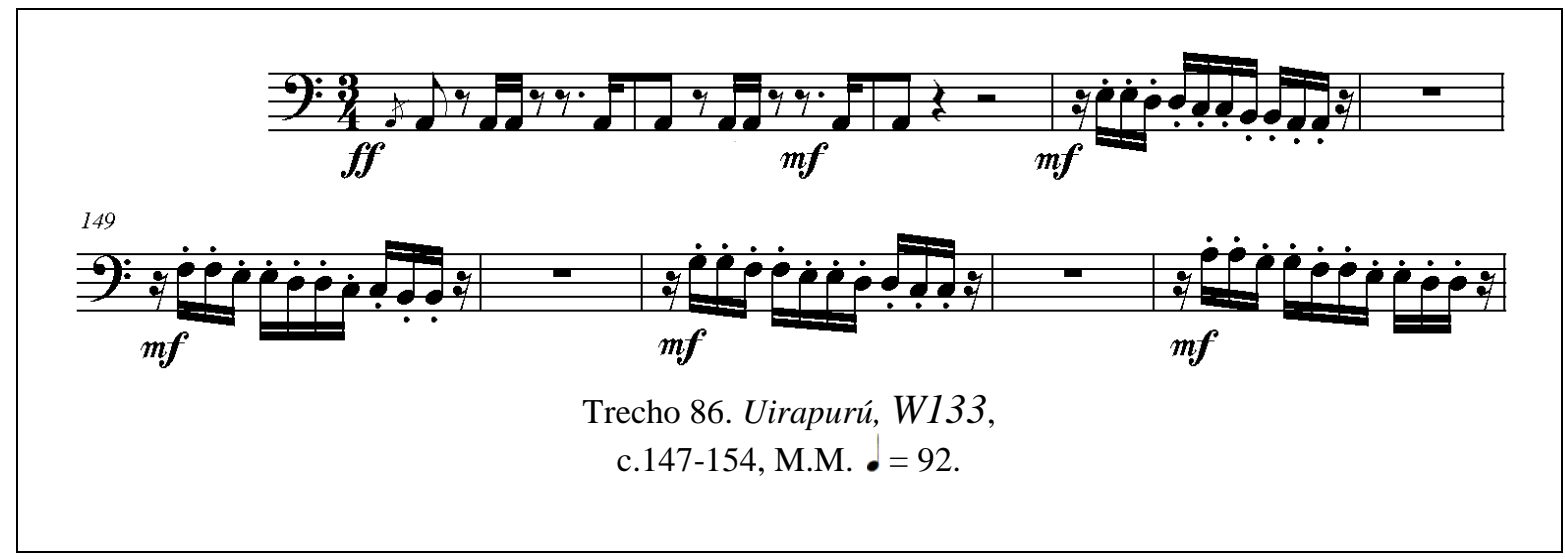

a. Principal desafio:

Ritmo: não atrasar a entrada do inciso rítmico do c.147, por conta da pausa de semicolcheia - o tímpano tem uma nota neste $1^{\circ}$. momento do compasso. Não permitir que o ato de respirar gere atrasos na entrada do inciso.

Outros desafios:

b. Articulação: sincronizar o estacato com a velocidade do êmbolo;

c. Dinâmica: não alterar a dinâmica durante a execução do inciso.

d. Afinação: por conta da troca constante de posição do êmbolo, a afinação poderá ser comprometida.

e. Analise de estilo: cuidado para não acentuar as notas que estão no início de cada tempo.

f. Técnicas requeridas: precisão de posicionamento do êmbolo em nível avançado e boa velocidade de estacato simples.

\section{Trecho 87: Uirapurú}

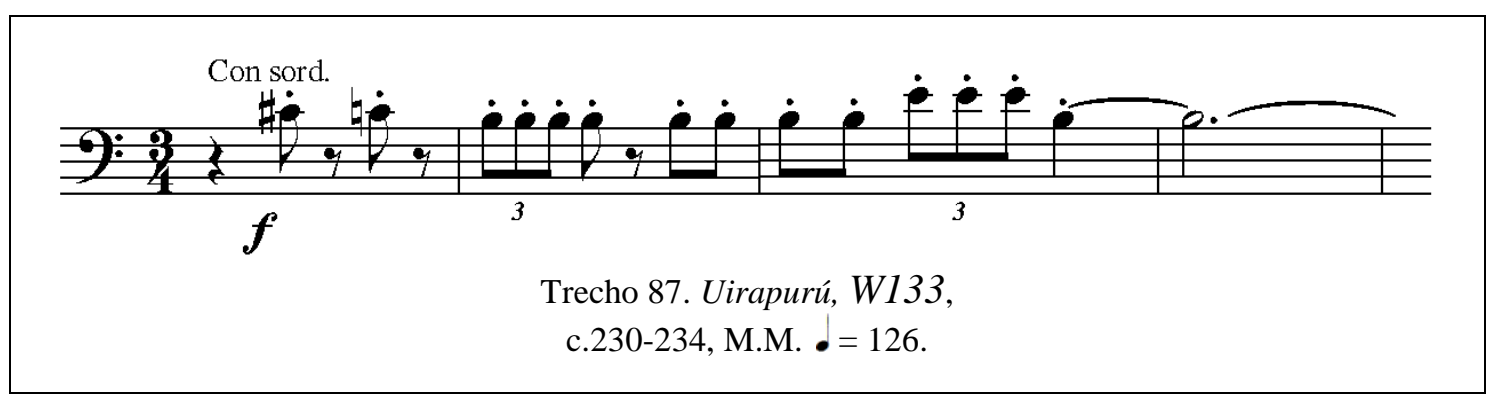


a. Principais desafios:

A colocação da surdina: o trombone terá nove tempos, onde o andamento da peça nesse momento estará a 126 no metrônomo, em verdade o trombonista terá 4 segundos para colocar a surdina - limite possível de colocação de surdina, ou seja a colocação deve ser rápida.

Projeção sonora: Villa-Lobos grafou a dinâmica forte $(\boldsymbol{f})$ para esse trecho. Estando com surdina, o trombonista necessariamente deve aumentar um grau na dinâmica $(\boldsymbol{f} f)$ para que a projeção sonora do instrumento, dentro da sala de concerto, aconteça no nível requerido pelo autor.

Outros desafios:

b. Afinação: a maioria das surdinas sobe a afinação das notas. Deve-se atentar para a afinação neste trecho.

c. Articulação: cuidado especial para que as notas - que estão grafadas na região aguda - em estacato e com surdina não saiam ríspidas demais.

d. Ritmo: a execução da tercina em meio a colcheias regulares deve ser precisa.

e. Analise de estilo: A sonoridade da última nota não deve extrapolar o restante do inciso. Temos claramente, neste trecho, uma terminação feminina.

\section{Trecho 88: Uirapurú}

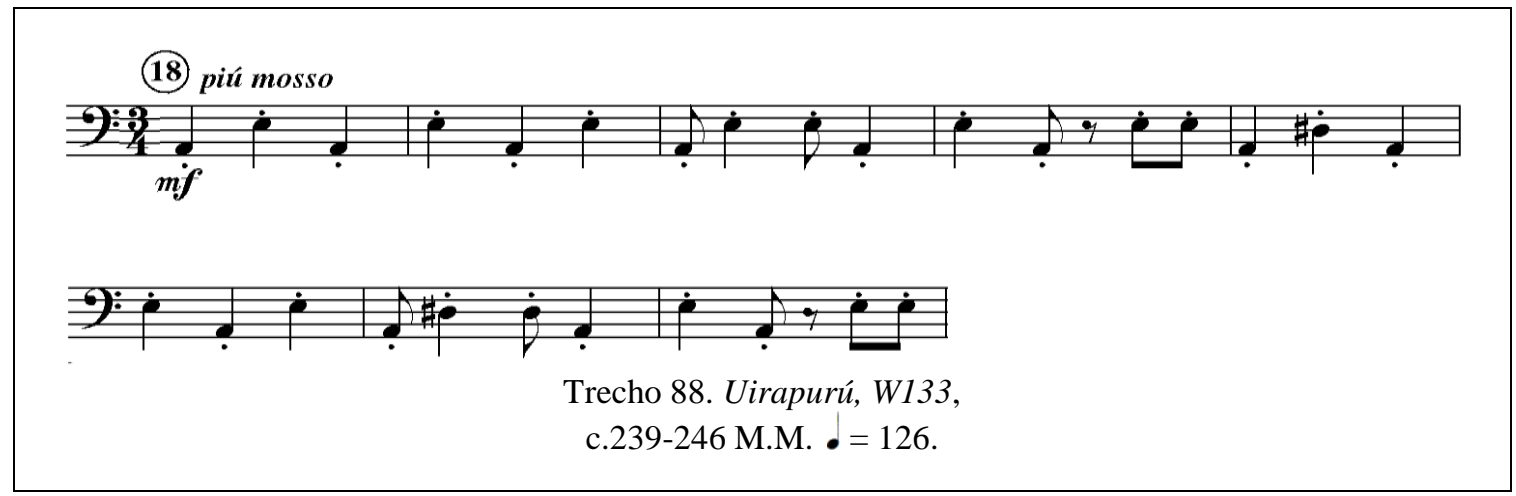


a. Principal desafio:

Concentração: A entrada da nota Ré\#2, no $5^{\circ}$. compasso do trecho, deverá ser preparada mentalmente para que não aconteça erro de nota por dúvida momentânea.

Outros desafios:

b. Articulação: O ponto de diminuição deve encurtar a nota, porém não deve torná-la mais agressiva. Embora em $\boldsymbol{m} \boldsymbol{f}$, este trecho deve soar leve e sem predomínio do trombone.

c. Afinação: O trombonista deve ter cuidado com a afinação da nota Ré\#2, pois ela é a única que não estará alocada na $2^{\mathrm{a}}$. posição.

d. Dinâmica: Deve-se manter a intensidade de $\boldsymbol{m} \boldsymbol{f}$ até o final da frase.

\section{Trecho 89: Amazonas}

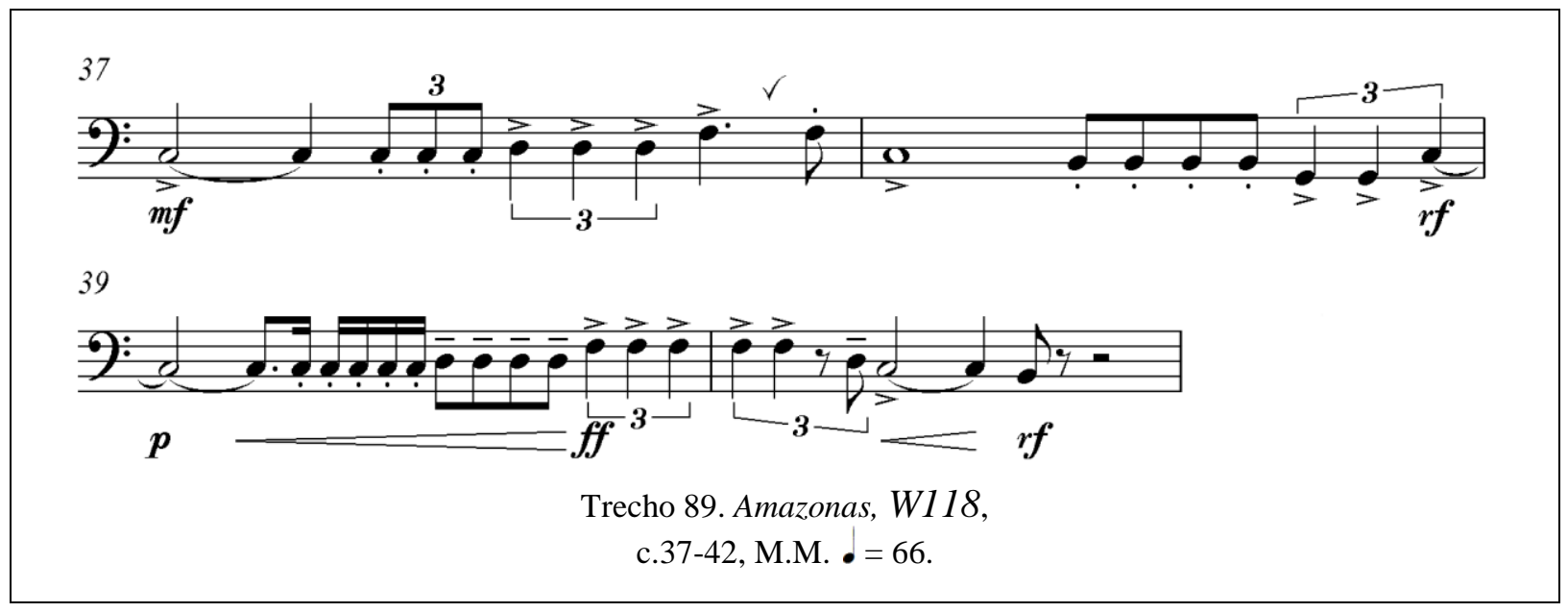

a. Principal desafio:

Ritmo: Os trombonistas devem ter especial atenção às tercinas existentes em todos os compassos desse trecho. Pela própria conformação da tercina, ela tende a deixar mais lento o tempo seguinte com base de 4 colcheias em subdivisão. 
Outros desafios:

b. Dinâmica: Trombonistas fiquem atentos às quedas de dinâmica no c.39 e c.41.

c. Articulação: Villa-Lobos grafou estacato logo após a nota longa e no tempo seguinte acentos ( > ). Muita atenção para o c.39: está escrito estacato no $2^{\circ}$. tempo, tenuto no $3^{\circ}$. tempo ( - ) e acento ( > ) no $4^{\circ}$. tempo.

d. Complicações: Villa-Lobos não deixou local para respiração, entre os c.39-c.42. Boa quantidade de ar deve ser armazenada nos pulmões para que esse trecho tenha sustentação sonora.

\section{Trecho 90: Amazonas}

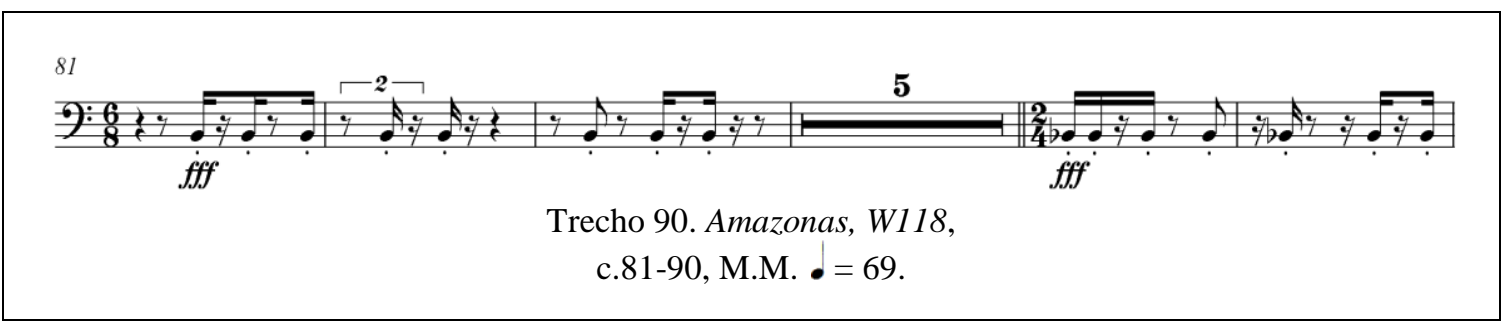

a. Principal desafio:

Ritmo: O trombonista deve estar muito seguro do local a ser tocado cada uma dessas semicolcheias entremeadas de pausa.

Outros desafios:

b. Articulação: Todas as notas deste trecho contém ponto de diminuição (estacato), portanto as notas deverão ser curtas o tempo todo.

c. Notação diferente: A grafia desse trecho não prioriza de forma alguma a leitura do trombonista. Anotações com relação ao tempo são bem vindas para uma melhor precisão do ritmo.

d. Complicações: - A alternância entre o 6/8 e as duínas deve ser precisa. 


\section{Trecho 91: Amazonas}

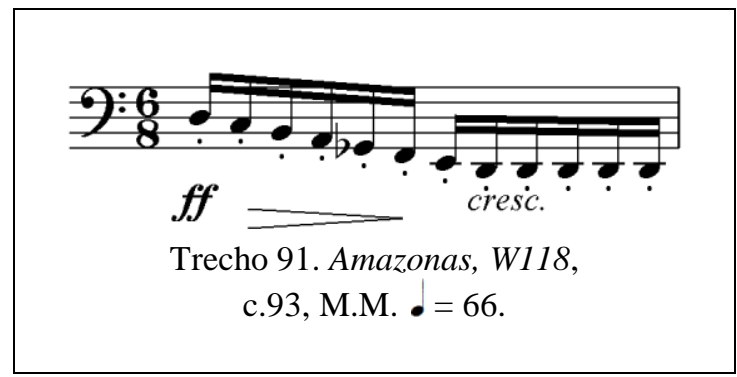

a. Principal desafio:

Complicações: Após dois compassos de um ritmo pouco perceptível nas cordas, o naipe de metais graves deverá entrar com segurança absoluta no $1^{\circ}$. tempo do c.93, juntamente com clarone, fagotes, contrafagotes e trompas.

Outros desafios:

b. Articulação: todas as notas estão grafadas em estacato (ponto de diminuição), portanto devem ser tocadas realmente curtas.

c. Dinâmica: Villa-Lobos grafou decrescendo no $1^{\circ}$. tempo e crescendo no $2^{\circ}$. tempo. Nesse local encontraremos uma dificuldade técnica de velocidade de ar.

\section{Trecho 92: Amazonas}

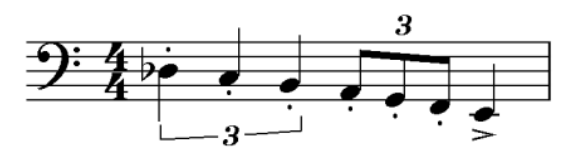

Trecho 92. Amazonas, W118, c.330, M.M. • = 112 .

a. Principal desafio:

Ritmo: Este trecho contém uma sequência de tercinas de mínimas e colcheias. Precisão rítmica deverá ser a meta nesse trecho. 
Outros desafios:

b. Articulação: Atenção especial à articulação, pois Villa-Lobos grafou estacatos do $1^{\circ}$. ao $3^{\circ}$. tempo, mas o $4^{\circ}$. tempo está grafado acento.

c. Complicações: sincronização rítmica necessária entre metais e madeiras graves. A tercina de colcheia necessita de sincronismo entre êmbolo e língua para que não saia atrasada.

\section{Trecho 93: Choros $N^{o} .4$}

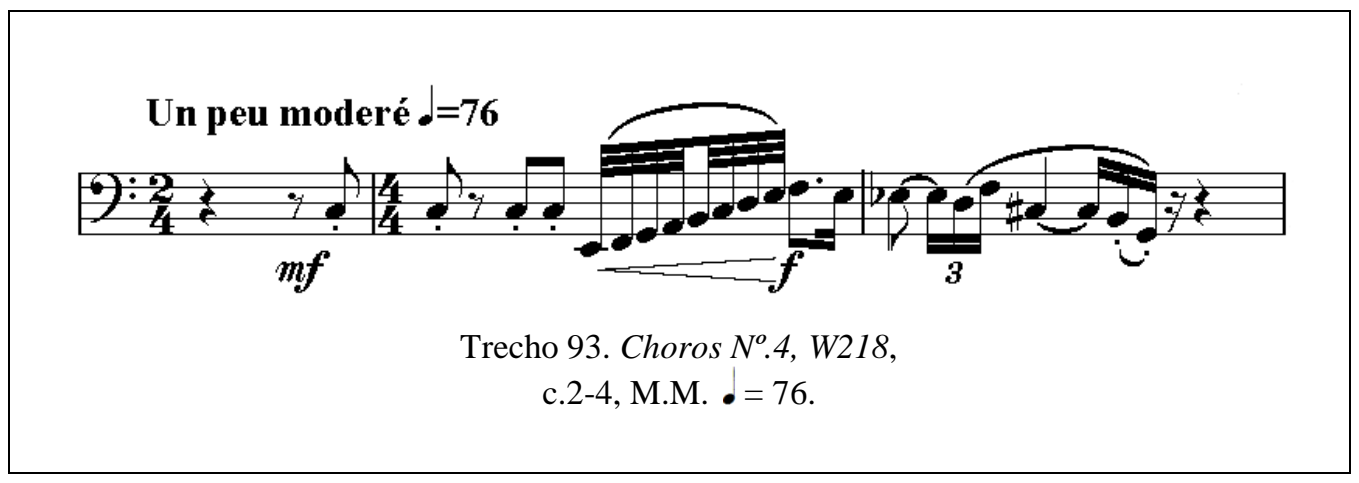

a. Principal desafio:

Complicações técnicas: Estão grafados no c.4 dois intervalos de Fá2-Dó\#2 e Si1-Sól1. Ambos são de grande dificuldade técnica para o trombonista baixo. O motivo é a distância entre as notas quando executadas no êmbolo: Fá2 (1 ${ }^{\mathrm{a}}$. pos.) para Dó\#2 (5 . pos.) significam quatro posições a serem suplantadas e o outro intervalo Si1 ( $7^{\mathrm{a}}$. pos. ou $2^{\mathrm{a}}$. posição na válvula) para Sól1 ( $4^{\mathrm{a}}$. pos.) que significam ( $1^{\circ}$. opção) três posições a se suplantar ou ( $2^{\mathrm{a}}$. opção) dois posições (Trecho 93a).

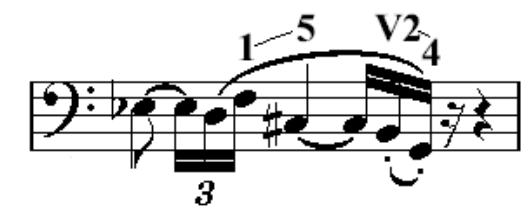

Trecho 93a. Choros $N^{o} .4, W 218$, c.4. 
Outros desafios:

b. Articulação: Sendo uma articulação recorrente em Villa-Lobos, as quatro primeiras notas (Dó2) devem ser bem curtas.

c. Afinação: A quinta posição do trombone é a mais complicada para se afinar, portanto o trombonista baixo deve concentrar-se para que a nota Dó\#2 seja bem posicionada no êmbolo.

d. Notação diferente: o glissando deve ser tocado de forma diferente (vide pg. 199).

\section{Trecho 94: Choros $N^{o} .4$}

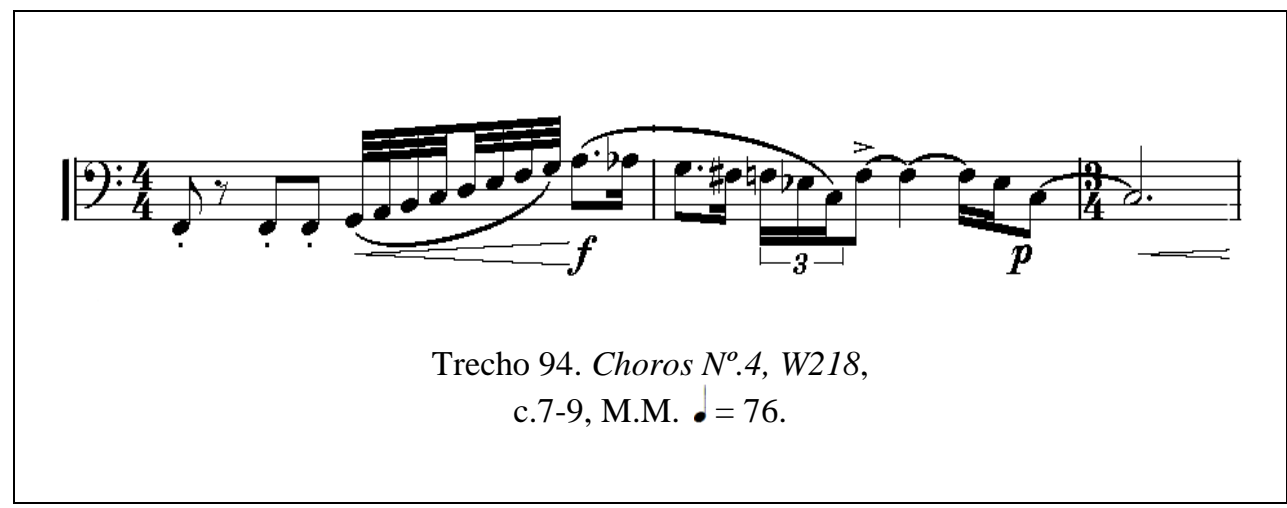

a. Principal desafio:

Complicações técnicas: Neste trecho o maior desafio será novamente a distância entre as posições do êmbolo. Está grafado no c.8 o semitom Fá\#2-Fá2. A altura não é problema alguma, porem o Fá\#2 é tocado na $5^{\mathrm{a}}$. pos. e logo a seguir teremos o Fá2 (1 ${ }^{\mathrm{a}}$. pos.). Isso significa um distanciamento de quatro posições. Essa é uma distância considerável para ser feita em tão curto espaço de tempo. Portanto, o trombonista baixo deve buscar a habilidade em percorrer essa distância no mais curto tempo possível, e ainda não transferir solavanco algum para a sonoridade (Trecho 94a).

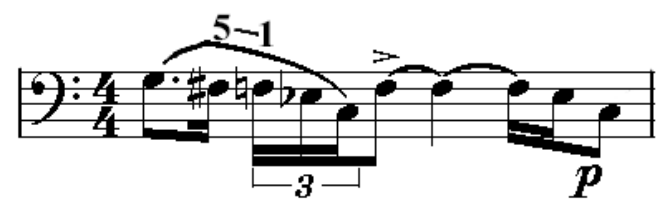

Trecho 94a. Choros $N^{\circ} .4$, W218, c.8. 
Outros desafios:

b. Dinâmica: Há uma diminuição de dinâmica na última colcheia do c.8 - Villa-Lobos grafou ump sub. e crescendo.

c. Articulação: As quatro primeiras notas (Fá1) devem ser bem curtas. Após o estacato, teremos duas ligaduras e ao final das ligaduras, Villa-Lobos grafou um acento ( $>$ ) na terceira colcheia do c.8.

d. Notação diferente: o glissando deve ser tocado de forma diferente (vide pg. 199).

\section{Trecho 95: Choros $N^{o} .4$}

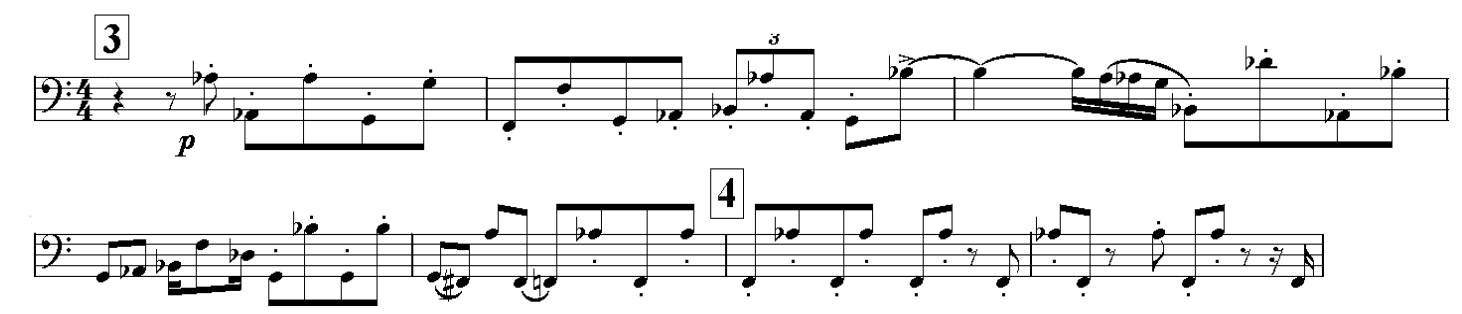

Trecho 95. Choros $N^{o} .4$, W218,

c.13-19, M.M. • = 76 .

a. Principal desafio:

Respiração: Villa-Lobos não reservou um ponto específico para a respiração do trombonista baixo. Deve-se localizar um local apropriado para respirar, sem que haja interferência melódica.

Outros desafios:

b. Intervalos: Há nesse trecho saltos melódicos grandes: doze intervalos de $10^{\mathrm{a}}$., apenas um de $9^{\mathrm{a}}$., três de $8^{\mathrm{a}}$. e finalmente um de $7^{\mathrm{a}}$. Saltos melódicos grandes são sempre uma dificuldade extra para a embocadura do trombonista-baixo. 
Trecho 96: Choros $N^{o} .4$

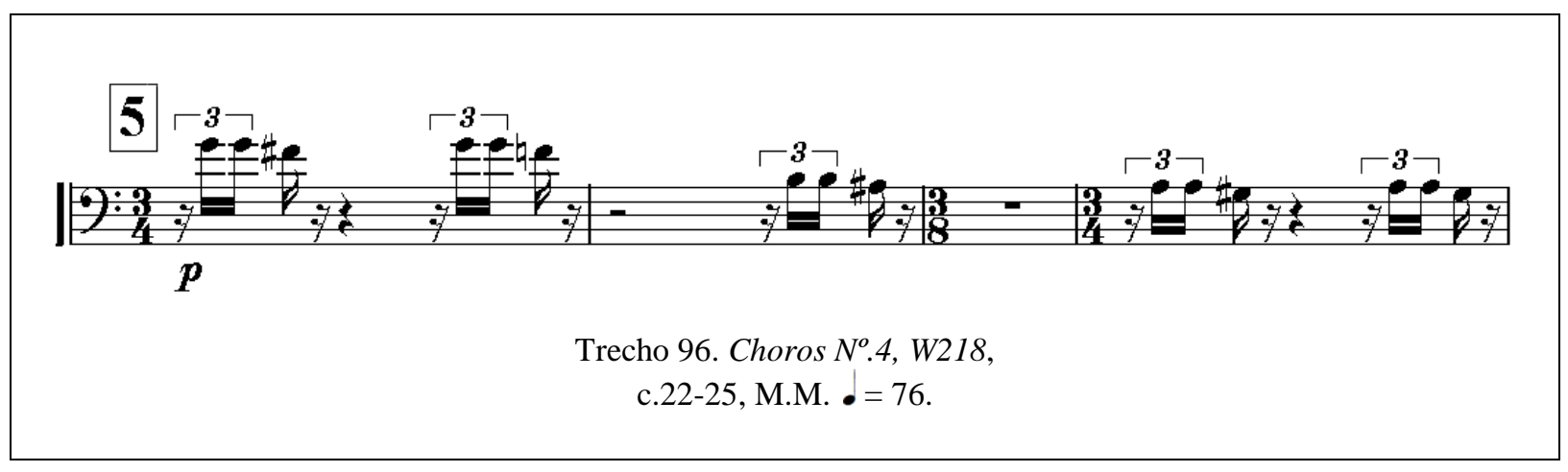

a. Principal desafio:

Técnica específica: Pelo andamento desse trecho, uma melhor opção será tocar utilizando-se da técnica de estacato duplo.

Outros desafios:

b. Sincronismo: Esse trecho é tocado em paralelo com a $2^{\text {a }}$. trompa. Deve-se buscar o melhor sincronismo entre esses dois instrumentos.

c. Complicações: Em região aguda, esse trecho está claramente grafado para ser tocado num trombone-barítono ou trombone tenor. Uma execução perfeita será de dificuldade quase máxima para um trombonista baixo.

\section{Trecho 97: Choros $N^{o} .4$}

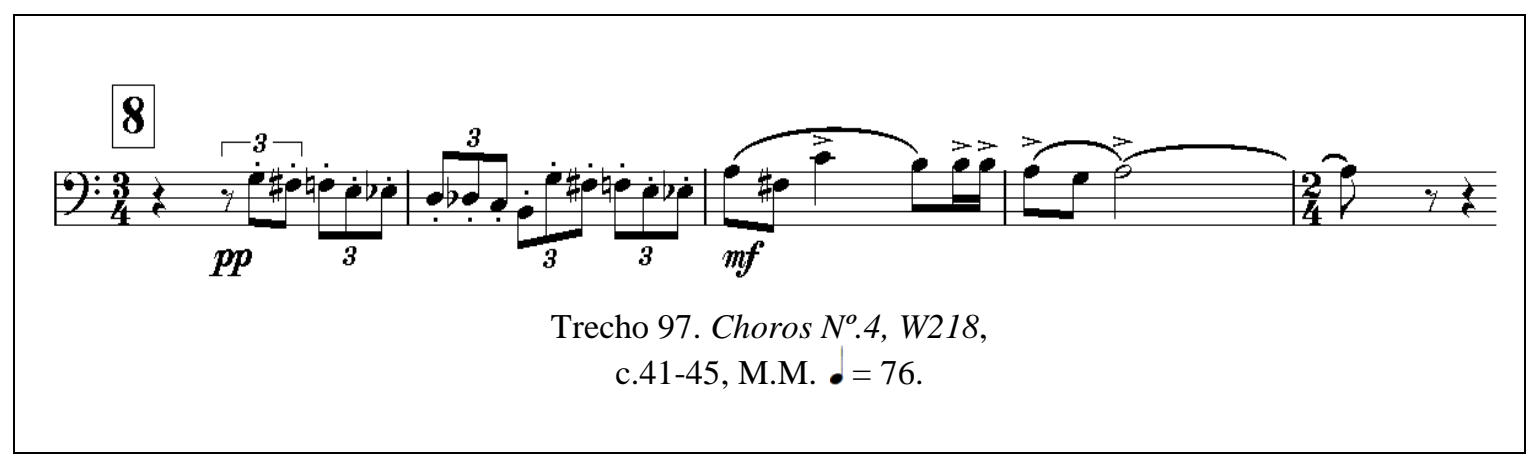


Principal desafio:

Analise de estilo: A troca de postura entre estar no acompanhamento (c.41-c.42) com dinâmica $\boldsymbol{p p}$ e no momento seguinte se tornar o solista (c.43-c.44) em dinâmica $\boldsymbol{m f}$ requer ao menos, uma habilidade técnica em nível avançada ao trombonista baixo.

Outros desafios:

a. Ritmo: No mesmo momento que se necessita dessa troca de postura de solista, VillaLobos fez a mesma troca no tópico rítmico: Villa-Lobos escreveu em 9/8 os dois primeiros compassos (c.41-c.42) e retoma a ideia de 3/4 nos dois últimos compassos desse trecho (c.43-c.44), portanto o trombonista baixo deve buscar total domínio da troca entre subdivisão ternária e binária para uma perfeita execução.

Trecho 98: Choros $N^{o} .4$

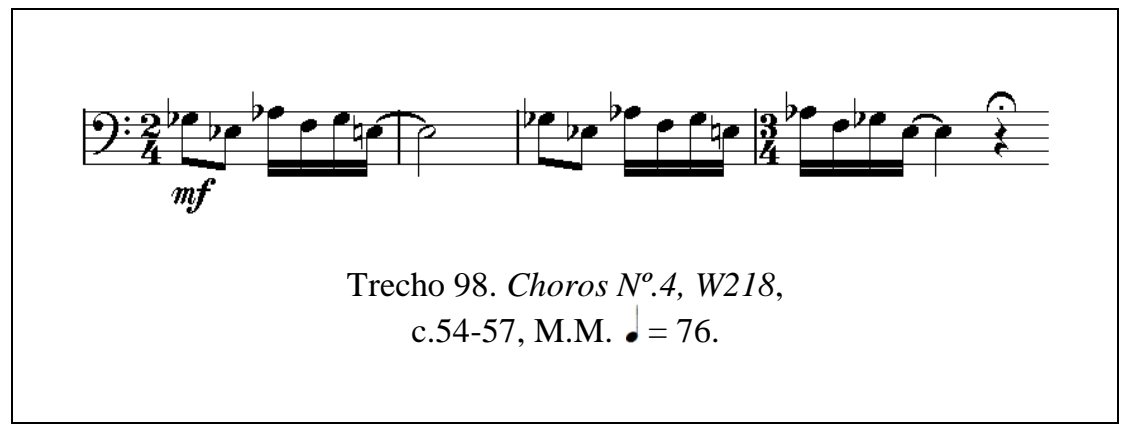

a. Principal desafio:

Complicações técnicas: O movimento do êmbolo entre a $1^{\mathrm{a}}$. posição (Fá2) e a $5^{\mathrm{a}}$. (Solb2) é longo o suficiente para gerar um atraso nas semicolcheias. O trombonista baixo deve estar atento a esse movimento do êmbolo e acelerar a troca de posição o mais rápido possível (Ex. 98a).

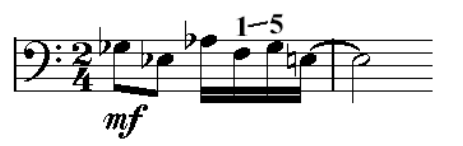

Trecho 98a. Choros $N^{o} .4$, W218, c.54. 
Outros desafios:

b. Afinação: Nesse local acima mencionado, teremos além da dificuldade da distância a ser percorrida pelo êmbolo, a afinação de chegada da nota Sólb2 ( $5^{\mathrm{a}}$. pos.). A $5^{\mathrm{a}}$. pos. é a mais complicada, em termos de afinação, para o trombonista baixo.

\section{Trecho 99: Choros $N^{o} .4$}

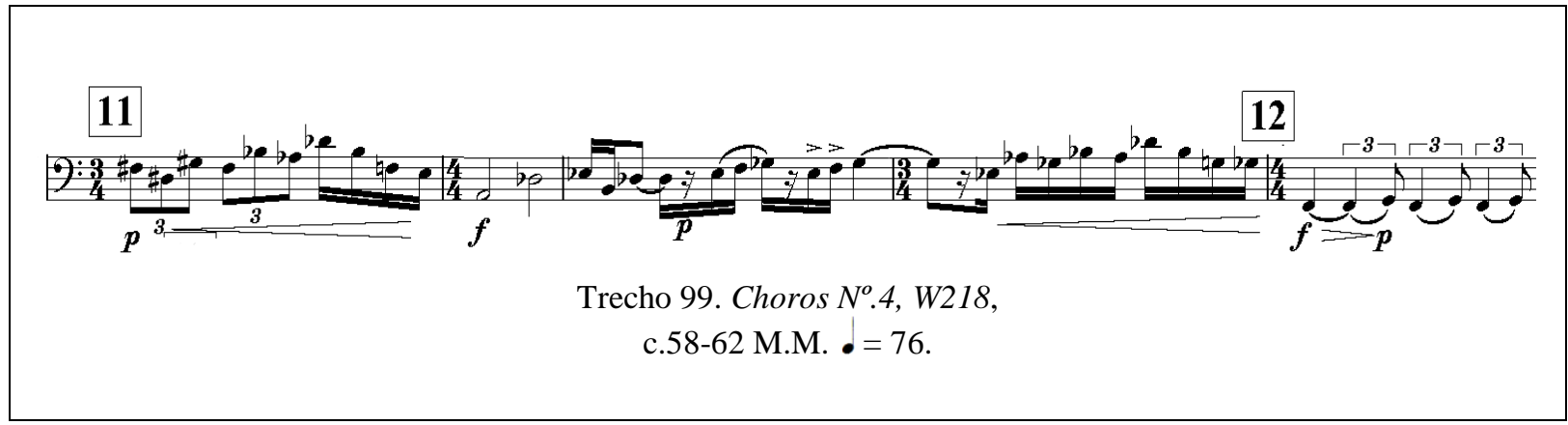

a. Principal desafio:

Intervalo grande: Na passagem do c.61-c.62,Villa-Lobos grafou um intervalo de $9^{\mathrm{a}} . \mathrm{m}$. É uma passagem realmente complicada e o trombonista baixo será obrigado a fazer um deslocamento de embocadura para conseguir nesse espaço de tempo (apenas uma semicolcheia) essa troca de registro. A maior dificuldade, ainda, recairá sobre o clímax atingido na nota Réb3 (Ex. 99a).

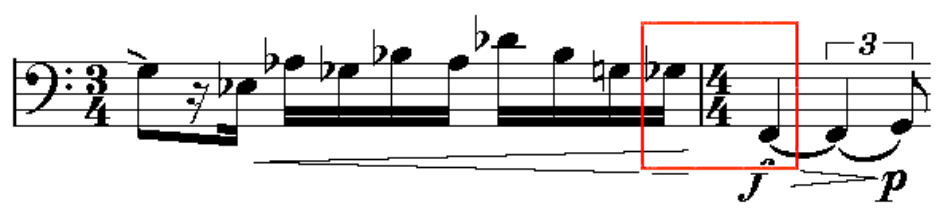

Trecho 99a. Choros $N^{o} .4$, W218, c.61-62.

Outros desafios:

b. Ritmo: A troca de tercina de colcheia com semicolcheia no c.58 cria uma dificuldade rítmica ao trombonista baixo. 
c. Dinâmica: A frase terá dois $\boldsymbol{p}$ (c. 58 e c.60) com seus respectivos cresc. (c.58 e c.61) para culminarem em dois $f$ (c.59 e c.62). Atenção especial para essas trocas de dinâmicas.

d. Afinação: Especial atenção às notas Sólb2 ( $5^{\mathrm{a}}$. pos.) durante esse trecho.

\section{Trecho 100: Choros $N^{o} .4$}

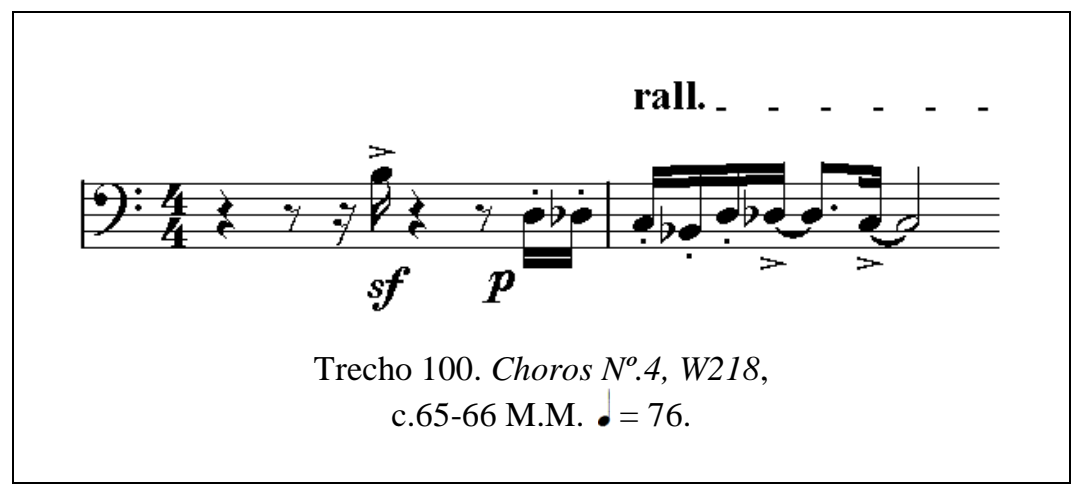

\section{Principal desafio:}

a. Ritmo: Em música popular é muito comum uma simples nota tocada como última semicolcheia do tempo. A dificuldade para o trombonista baixo reside no fato que ele precisará acertar perfeitamente o ritmo dessa semicolcheia precedida de uma pausa de colcheia pontuada e ainda sincronizar esse ataque com as outras três trompas.

Outros desafios:

b. Articulação: Villa-Lobos grafou para esse trecho acento $(>)$ na primeira nota, estacato nas próximas três notas e por fim, as duas últimas notas terão acento $(>$ ) novamente.

c. Complicações técnicas: Como a distância entre a nota Dó2 e Sib1 é muito grande, sugerimos que o trombonista baixo use a nota Dó2 feita no rotor ( $1^{\mathrm{a}}$. posição). 


\section{Trecho 101: Choros $N^{o} .4$}

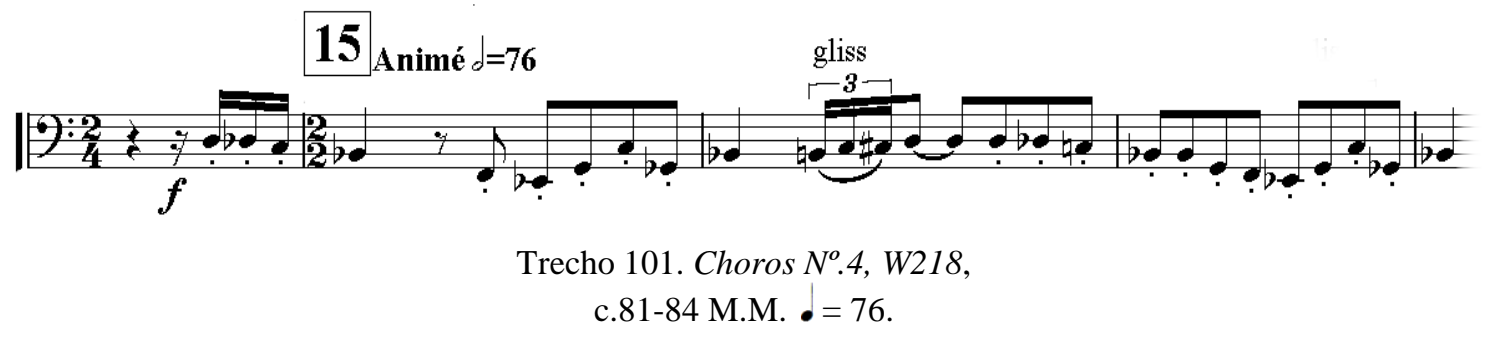

a. Principal desafio:

Ritmo: Intuitivamente, todo trombonista baixo acreditará que o glissando do c.83 o levará ao $3^{\mathrm{o}}$. tempo do compasso. No entanto, Villa-Lobos antecipou esse final do glissando para a $2^{\mathrm{a}}$. metade do $2^{\circ}$. tempo. Portanto, atenção especial deve ser dada a exatidão rítmica desse c.83 (Trecho 101a).

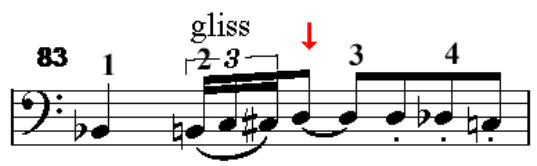

Trecho 101a. Choros $N^{o} .4$, W218, c.83.

Outros desafios:

b. Analise de estilo: A boa execução exige que o glissando finde-se em terminação feminina. Portanto os trombonista baixos não devem crescer em direção ao final desse glissando.

Trecho 102: Choros $N^{o} .4$

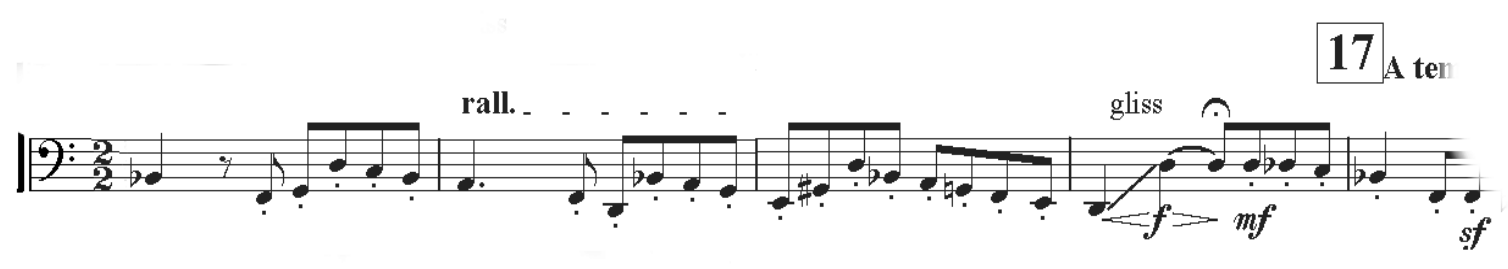

Trecho 102. Choros $N^{o} .4, W 218$, c.92-96 M.M. $\bullet=76$. 
a. Principal desafio:

Técnica específica requerida: Nesse trecho, Villa-Lobos não deixou espaço para respiração (c.93 até c.95). O ar não será suficiente se for feito de forma natural. O trombonista baixo deve localizar um local adequado para respiração em meio a esses compassos, sem que a ideia melódica seja interrompida.

Outros desafios:

b. Articulação: Especial atenção às notas curtas (ponto de diminuição) grafadas por Villa-Lobos para este trecho.

\section{Trecho 103: Choros $N^{o} .4$}

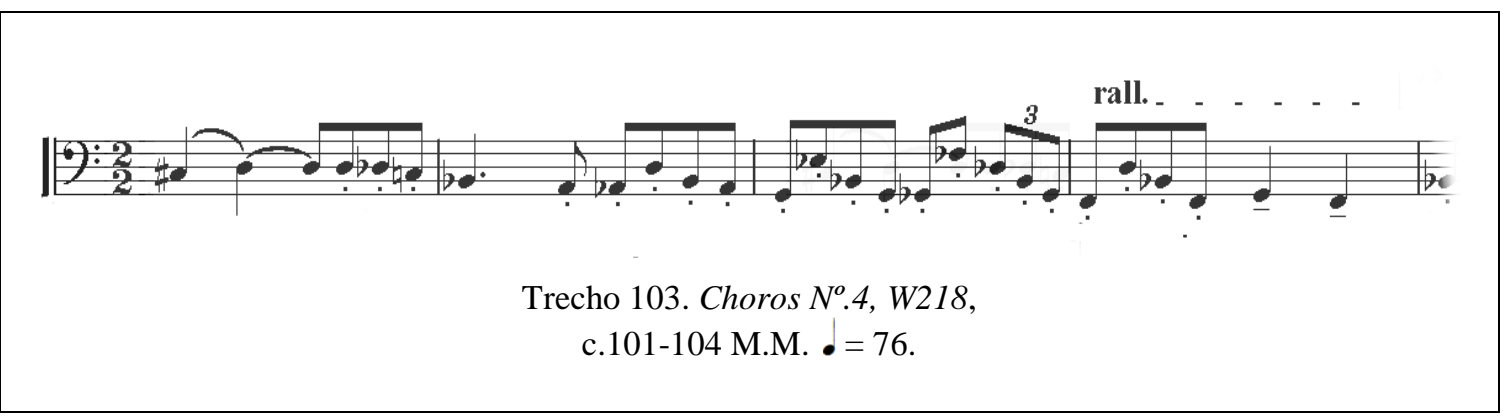

a. Principal desafio:

Técnica específica requerida: Villa-Lobos não deixou espaço para respiração nesse trecho (c.102 até c.104). Da mesma forma, o ar não será suficiente se feito de forma natural. Aconselhável será que o trombonista baixo encontre um melhor local para respiração em meio a esses compassos, sem prejuízo à melodia.

Outros desafios:

b. Força: Trombonistas-baixo devem ter especial cuidado para que as tercinas de colcheias escritas no c.103, não soem mais forte que o restante do trecho. 
Trecho 104: Choros $N^{o} .4$

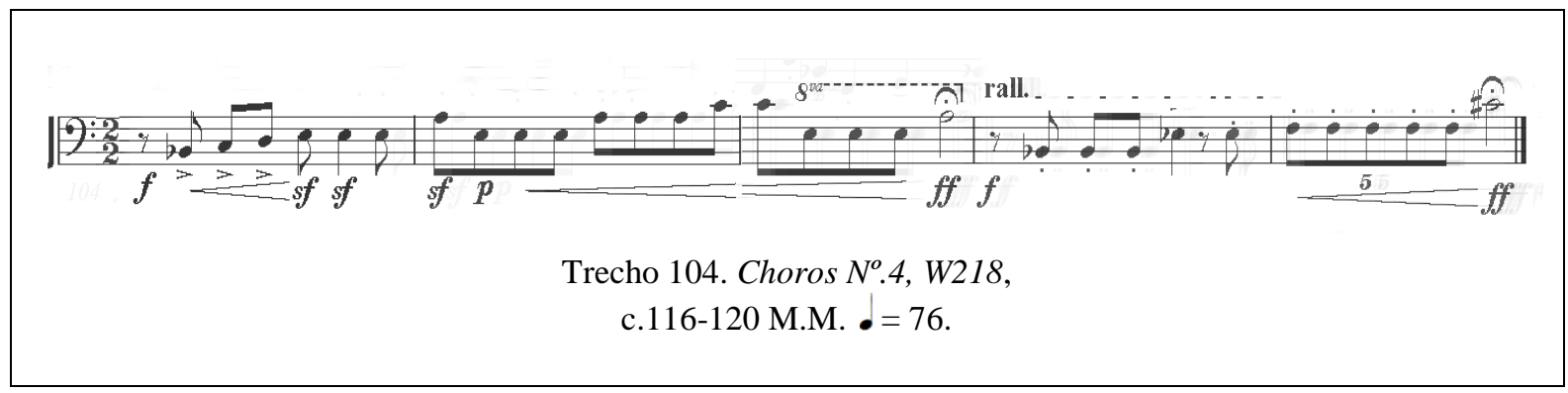

a. Principal desafio:

Ritmo: Dois locais deverão receber uma especial atenção: as duas colcheias da mudança do c.117-c.118 (as notas sempre estarão agrupadas em 3 repetições, porém nesse local, VillaLobos grafou apenas 2 Dó3 - Trecho 104a) e a quintina do c.120 deverá receber igual atenção pois além de ser uma das mais complexas divisões, não obstante o trombonista baixo deverá sincronizar perfeitamente com as outras trompas.

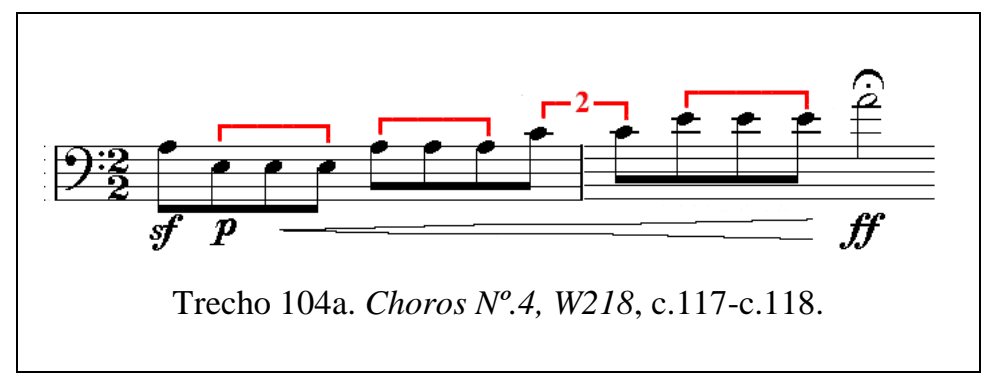

Outros desafios:

b. Intervalos: A dificuldade deste final de frase para trombonista baixo é clara: terminar a 1 ${ }^{\text {a }}$ semifrase na nota Lá3 (em fermata) e logo tocar um Sib1 (intervalo de uma oitava $+7^{\mathrm{a}} \cdot \mathrm{M}$, perfazendo 23 semitons de distância) exigirá uma embocadura em nível avançado. Especial atenção a esse intervalo problemático.

c. Complicações: A primeira semifrase terminará com a nota Lá3. Essa nota é realmente aguda para o trombone baixo. Portanto, essa finalização da semifrase está seguramente grafada para que seja tocada num trombone-barítono ou trombone tenor.

d. Dinâmica: Villa-Lobos grafou um crescendo durante a quintina. Essa alteração de dinâmica não é natural, mas deve ser executada. 
e. Articulação: Atentar para o fato que a $2^{\mathrm{a}}$. semifrase desse trecho final está grafada com ponto de estacato.

f. Sincronismo: Todo o trecho está em paralelo rítmico com as trompas. Trombonistas baixo devem manter a concentração para um perfeito equilíbrio rítmico.

Trecho 105: Choros $N^{o} .6$

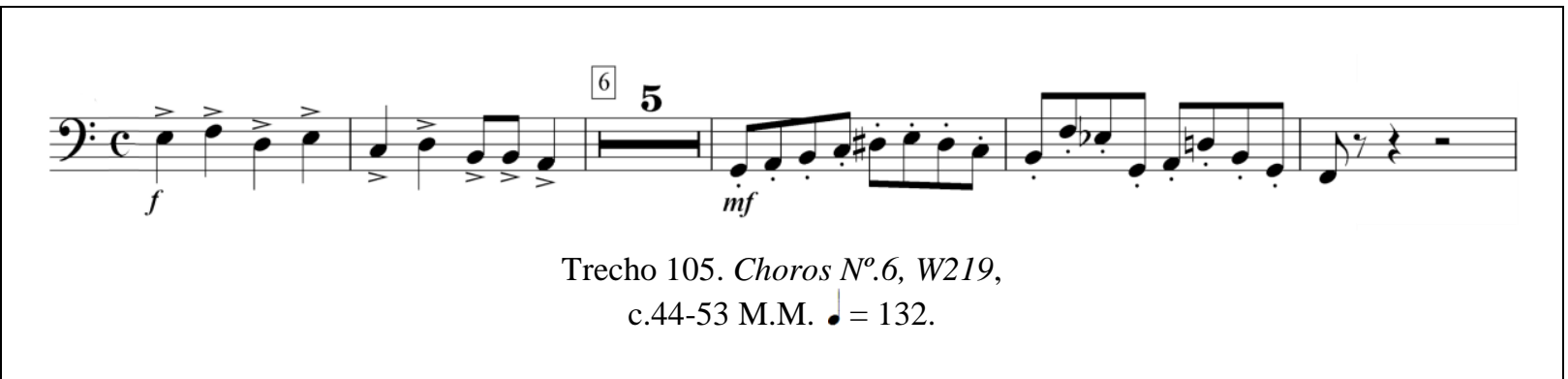

a. Principal desafio:

Sincronismo: Nos c.51-53, o compositor escreveu este inciso escalar para $3^{\circ}$. e $4^{\circ}$. Trombones em conjunto com a tuba. Portanto deve-se buscar unidade rítmica para essas três vozes do naipe.

Outros desafios:

b. Articulação: Trombonistas baixo devem demonstrar domínio técnico no quesito articulação fazendo com que os c.44-45 tenham articulação em acentos ( > ) e nos c.51-53 a articulação executada seja o estacato ( . ).

\section{Trecho 106: Choros $N^{o} .6$}

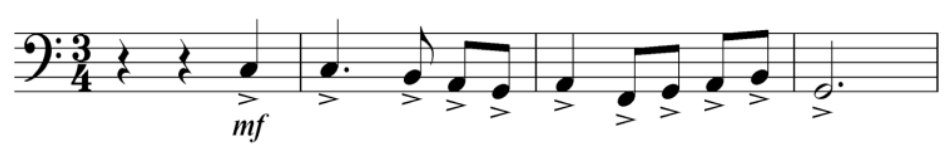

Trecho 106. Choros $N^{o} .6$, W219, c.120-123 M.M. • = 132 . 
a. Principal desafio:

Sincronismo: Esse soli, em conjunto com a tuba, é um eco para o mesmo inciso apresentado pelos violinos. Portanto a precisão rítmica da entrada deve ser uma meta a ser alcançada pelo trombonista baixo.

Outros desafios:

b. Articulação: Todo trecho compreendido pelos c.120-123 está grafado com articulação acentuada $(>)$.

c. Analise de estilo: Embora não grafado na parte, acredita-se que cada motivo tenha terminação feminina, logo não se deve crescer ao final de cada ideia melódica.

\section{Trecho 107: Choros $N^{o} .6$}

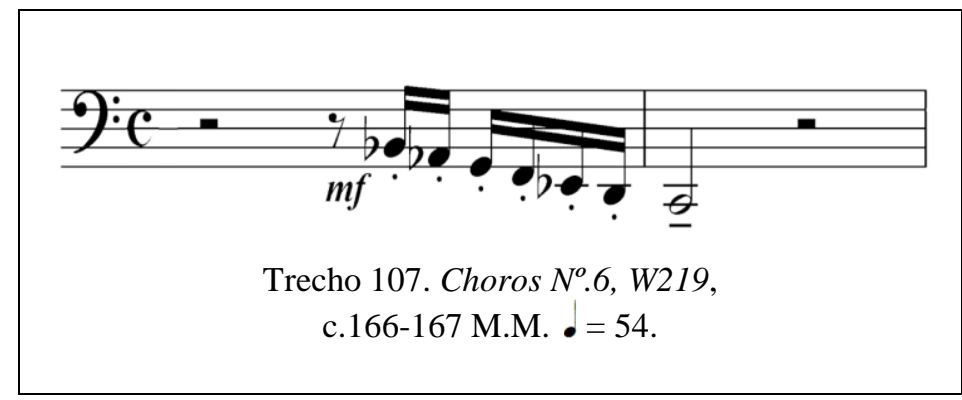

a. Principal desafio:

Analise de estilo: Embora esse movimento escalar descendente esteja escrito numa região de sonoridade fácil para o trombone baixo, este inciso deverá ser tocado de forma suave e com pouca intervenção no timbre dos outros instrumentos graves da orquestra.

Outros desafios:

b. Articulação: Estacato por todo o movimento escalar descendente (semicolcheias) e tenuto/tratina para a mínima. 
Trecho 108: Choros $N^{o} .6$

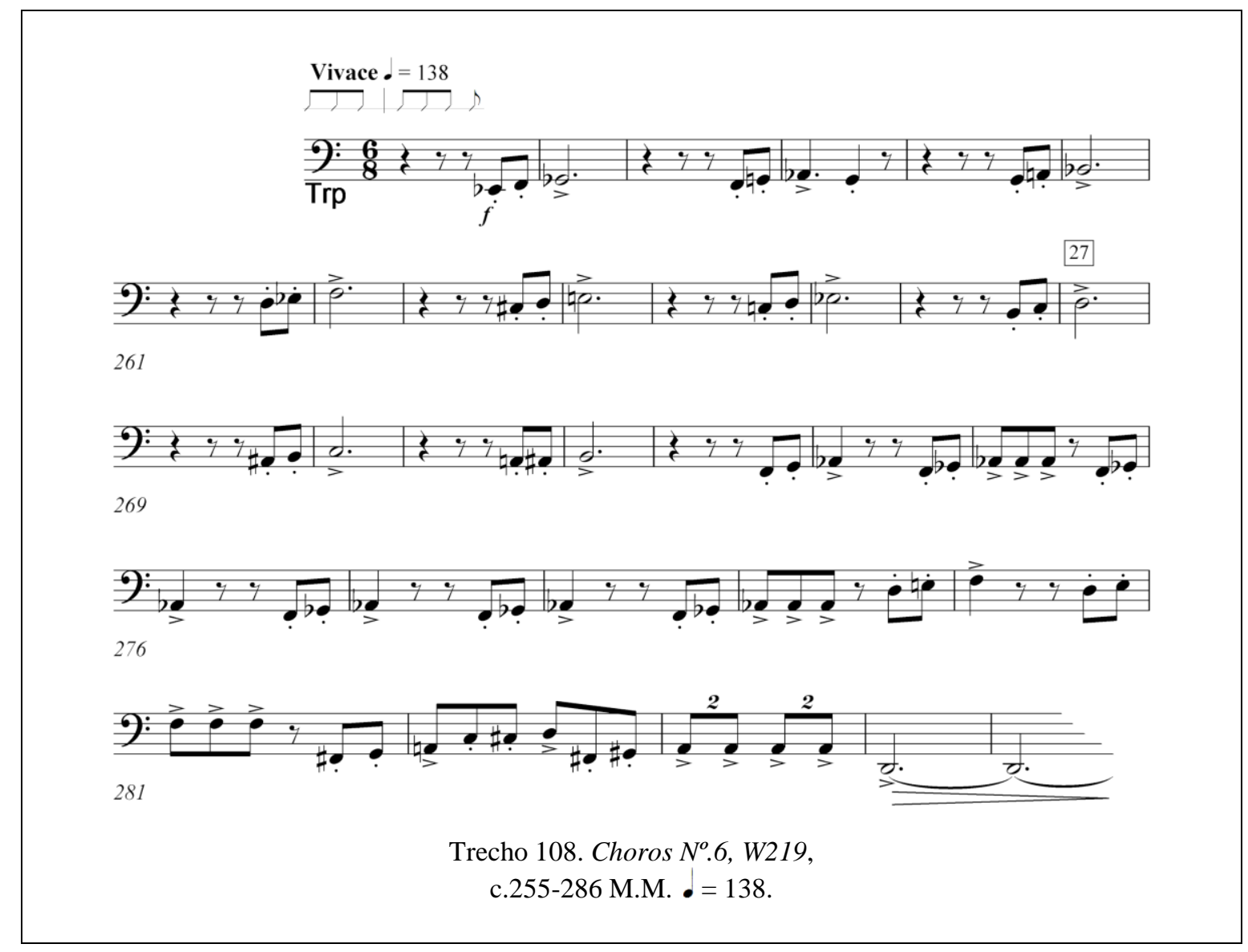

a. Principal desafio:

Ritmo: Os Trompetes entram no c. $254-2^{\circ}$. tempo, mas o ritmo dos Trompetes não ajudam aos trombones em seu inciso rítmico, portanto os trombonistas baixo precisam de máxima atenção para que não aconteça atrasos no momento de sua entrada.

Outros desafios:

b. Técnicas requeridas: Após 30 compassos em 6/8, Villa-Lobos grafou para os trombones um compasso em duínas (c.283). De maneira especial, o trombonista baixo deve reservar especial atenção para o ritmo desse trecho.

c. Respiração: Villa-Lobos não deixou um local em especial para uma respiração, entre os c.281-286, mas em compensação, termina a frase (c.284-286) em três mínimas pontuadas, ligadas e em decrescendo. E dessa forma, a escassez de ar ao final dessa frase será compensada pelo decrescendo em cada nota. 
Trecho 109: Choros $N^{o} .6$

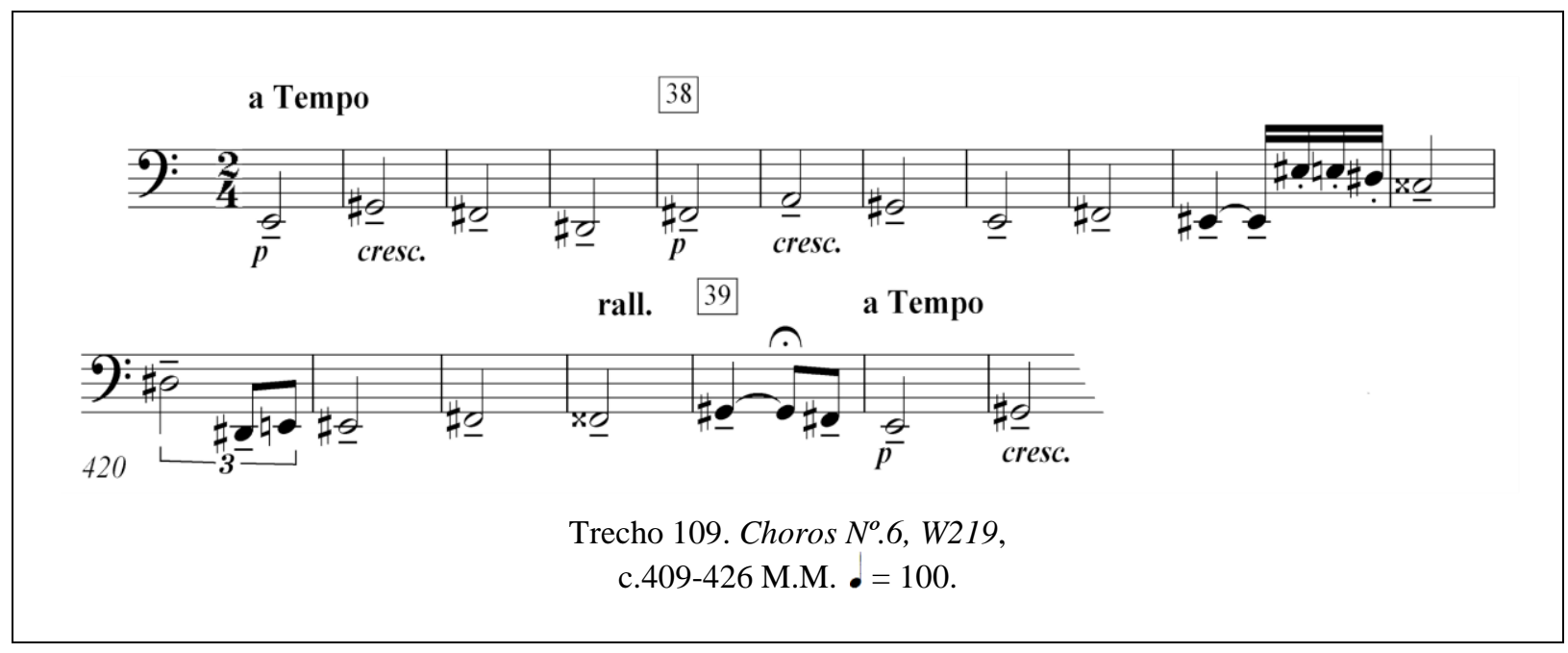

a. Principal desafio:

Ritmo: No c.418 Villa-Lobos grafou um movimento escalar cromático descendente para o trombone baixo e a tuba. Este trecho começa na segunda semicolcheia - posição largamente estudada por ser muito suscetível a atrasos. No c.420 o andamento não estará rápido, mas é aconselhável que o trombonista controle o tamanho das notas em quiálteras.

Outros desafios:

b. Articulação: Deve-se tocar tenuto/Tratina ( - ) por todo o trecho, porém Villa-Lobos grafou estacato ${ }^{111}$ para a escala cromática (c.418).

111 Da mesma forma que utilizada na técnica barroca: notas longas com duração cheia e notas curtas com estacato (grifo nosso). 
Trecho 110: Choros $N^{o} .6$

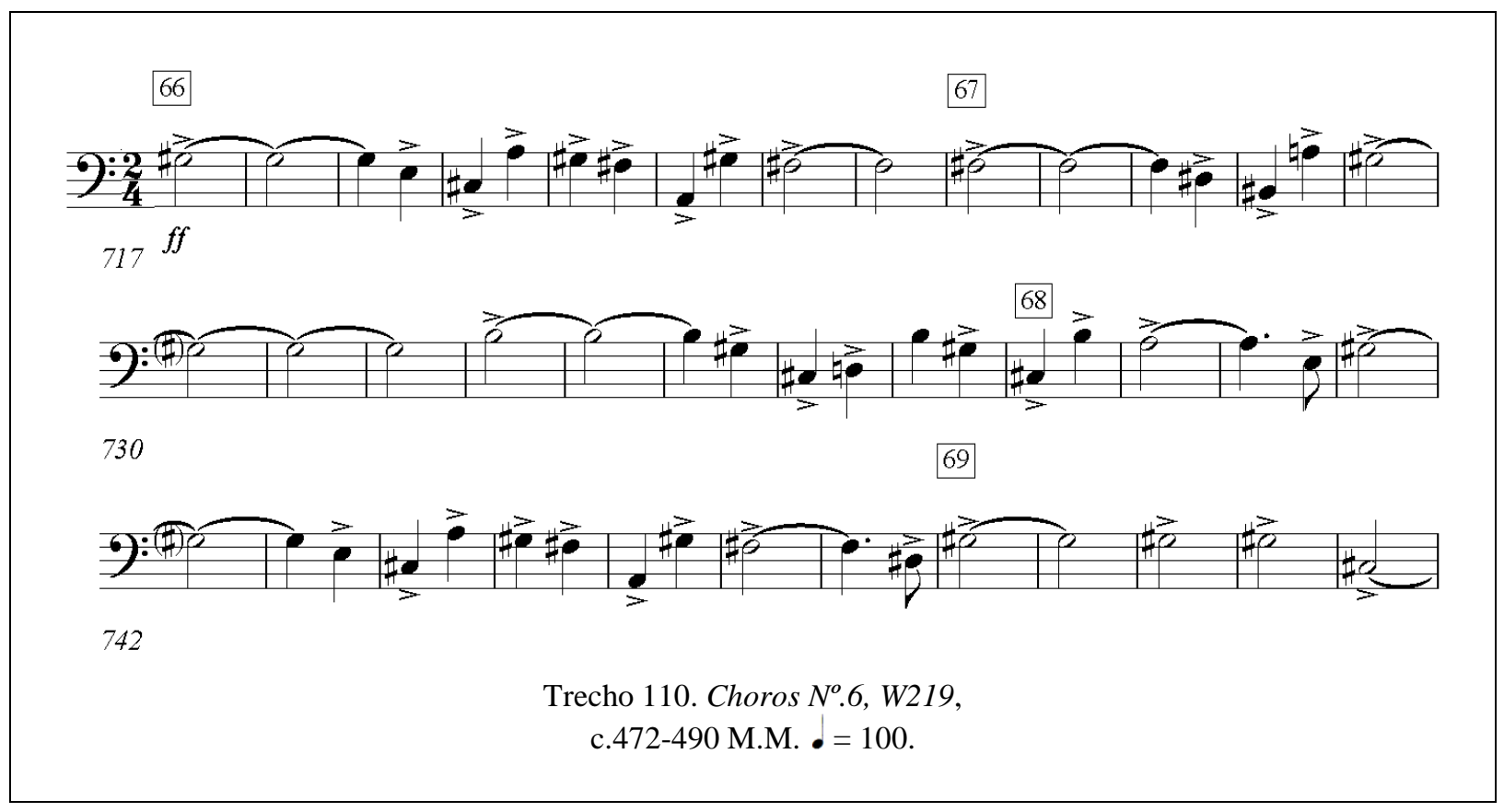

a. Principal desafio:

Análise de estilo: É o Cantus Firmus que embasará todo o final da peça. Os trombones estarão em oitavas. O maior desafio reside no domínio da manutenção das notas (sem decrescendo), articulação não exagerada (embora esteja marcado o acento) e por fim a manutenção sonora (sem tentativas femininas de terminações).

Outros desafios:

b. Respiração: Como todos os trombones estão em oitavas, deve-se buscar um local ideal para a respiração, que não interfira na continuidade sonora do naipe. Esta respiração pode ocorrer a qualquer momento. 


\subsection{3 - TUBA}

\section{Trecho 111: Uirapurú}

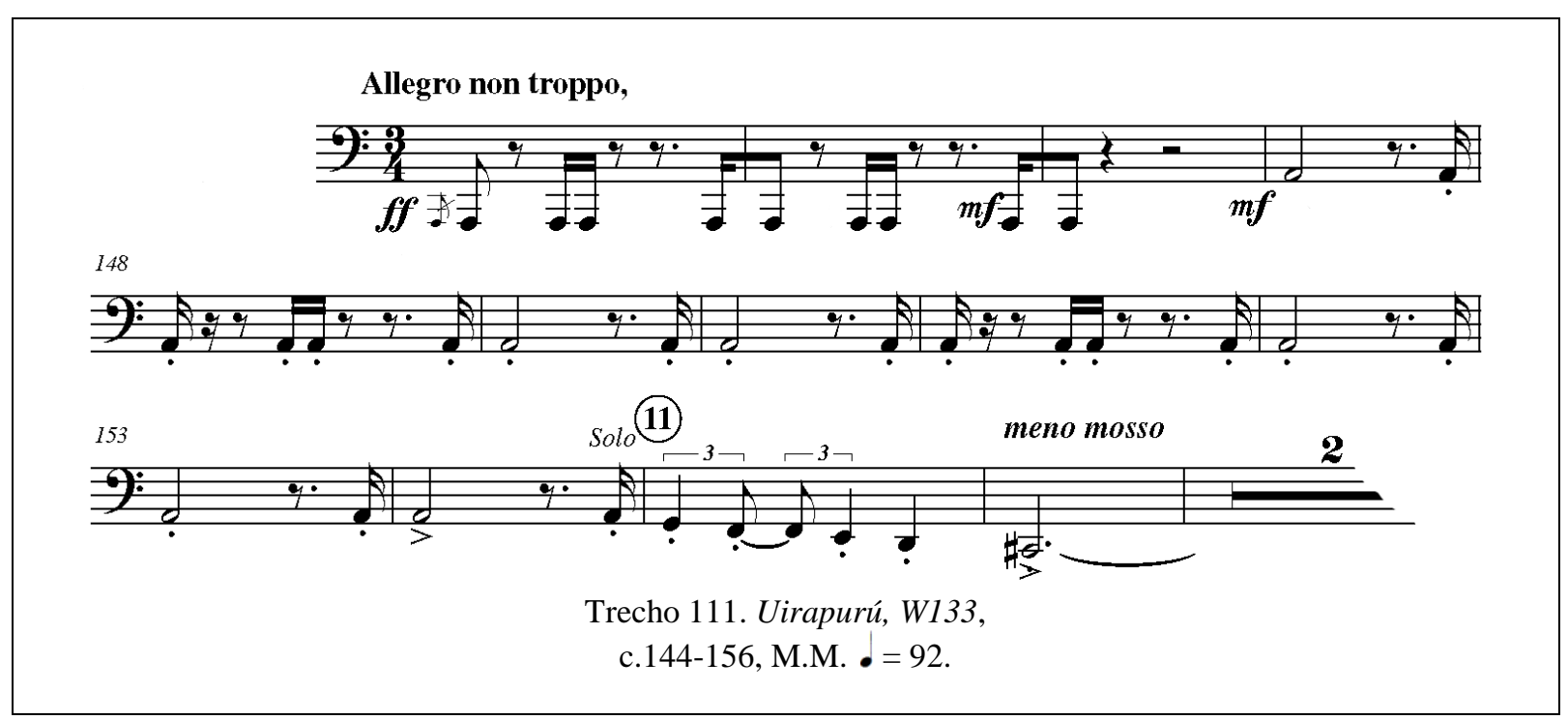

a. Principal desafio:

Ritmo: Mesmo sabendo da existência da apogiaturas fora do tempo, não atrasar a entrada do segundo Lá-1. A tuba juntamente com o tímpano garantirá o andamento dos compassos, pois sempre tocarão no $1^{\circ}$. momento do compasso. Não permitir que o ato de respirar atrase o início deste inciso.

Outros desafios:

b. Articulação: o tubista deverá manter sua língua em velocidade precisa; não esquecer de que a última nota do solo é acentuada ( > ) e as tercinas de semínima receberam um ponto de diminuição.

c. Dinâmica: A dinâmica no anacruse do c.146 é $\boldsymbol{m f}$. Deve-se manter essa dinâmica até o final da frase.

d. Ritmo: Durante o solo, tenha atenção especial à tercina de semínima. 


\section{Trecho 112: Uirapurú}

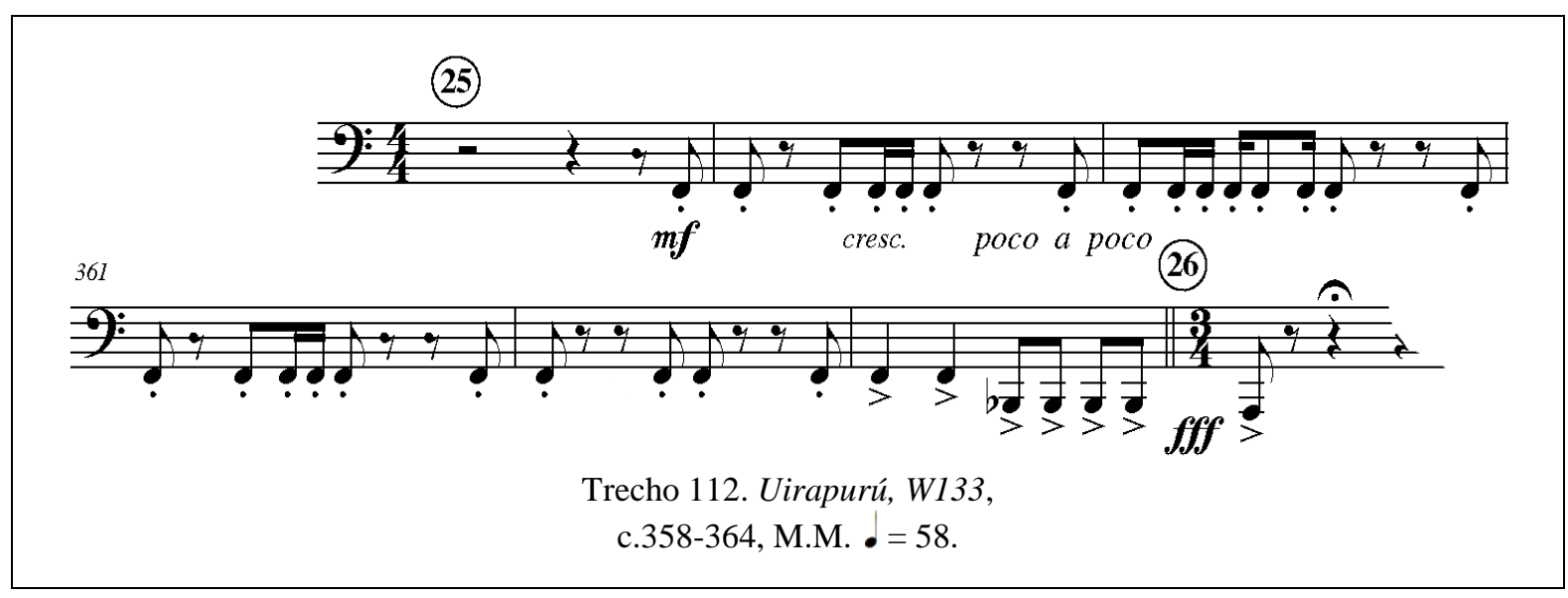

a. Principais desafios:

Ritmo: A resolução da sincopa do c. 360 - $2^{\circ}$. tempo deve ser em nível próximo a perfeição. Não se esquecer da polirritmia gerada pela duína (c.363) contra as tercinas que os agudos da orquestra estarão executando.

Outros desafios:

b. Dinâmica: Tubistas devem controlar seu ar para que o crescendo grafado por VillaLobos durante todo este trecho, aconteça gradativamente e não falte sonoridade (ar) ao final do trecho.

c. Articulação: Atenção especial pois a $1^{a}$. parte do trecho tem ponto de diminuição em todas as notas, porém o final do trecho (c.363) Villa-Lobos grafou acentos ( > ) nas semínimas e colcheias.

d. Complicações: Villa-Lobos grafou colcheia para tuba, fagote, contrafagote, tímpano piano, Violoncelos e contrabaixos na $2^{\text {a }}$. metade do c.363, porém o maestro regerá as tercinas de colcheias que as flautas, Trompetes, celesta, violinos, violas e Violoncelos estarão tocando nesse momento. 


\section{Trecho 113: Amazonas}

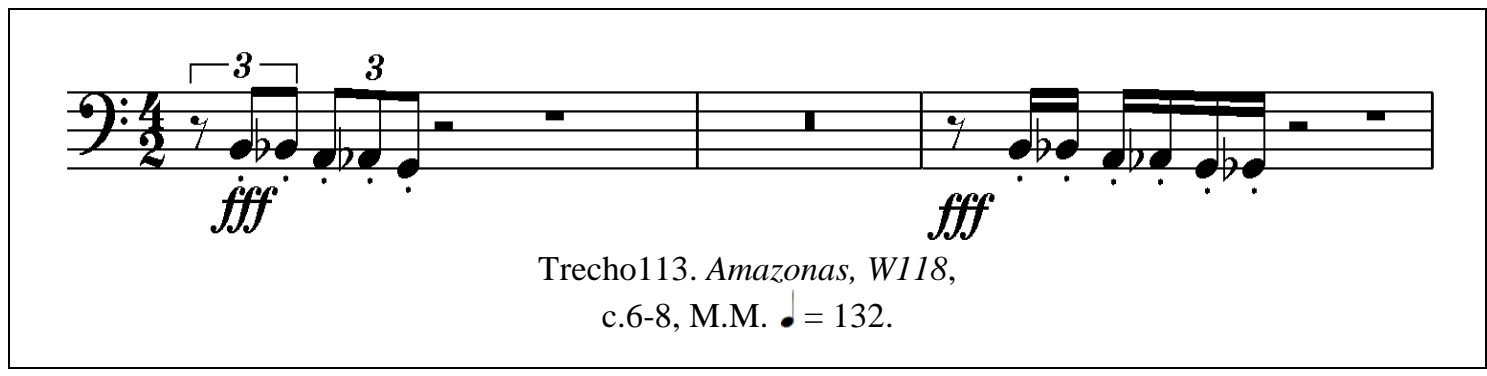

a. Principal desafio:

Ritmo: Villa-Lobos grafou tercinas de colcheia para a tuba (c.6). Essas tercinas serão tocadas contra um ritmo de 8 semínimas regulares. É necessário que se tenha uma perfeita precisão rítmica para compensar essa polirritmia.

Outros desafios:

b. Articulação: Villa-Lobos grafou todas as notas em estacato (ponto de diminuição), portanto não se devem unir as notas desse trecho.

c. Analise de estilo: Embora a direção do inciso seja descendente e nas gravações ouvidas se fez decrescendo, Villa-Lobos não deixou claro que esses incisos seriam femininos.

\section{Trecho 114: Amazonas}

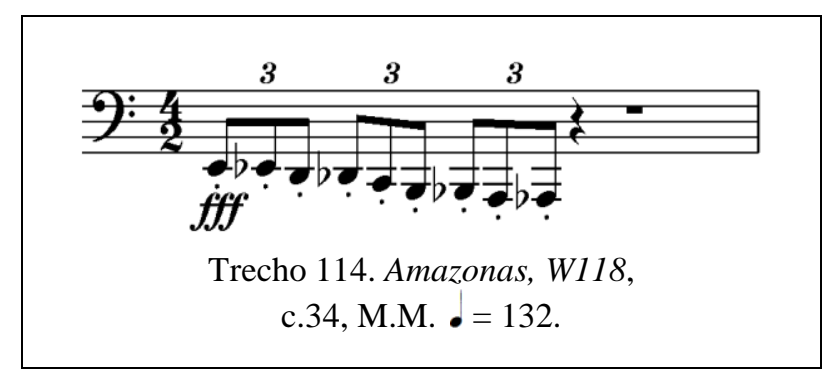

a. Principal desafio:

Ritmo: Villa-Lobos grafou para tuba no c.34 tercinas de colcheias para clarone, fagotes, contrafagote e trompas. Essas tercinas serão tocadas contra um ritmo de 8 semínimas regulares. É necessário que se tenha uma perfeita precisão rítmica para compensar essa polirritmia. 
Outros desafios:

b. Articulação: Villa-Lobos grafou todas as notas em estacato (ponto de diminuição), portanto as notas não devem receber valoração nesse trecho.

c. Analise de estilo: Como no trecho anterior, a direção do inciso é descendente e nas gravações ouvidas se os músicos fizeram decrescendo. Villa-Lobos não deixou claro que esses incisos receberiam interpretação feminina.

\section{Trecho 115: Amazonas}

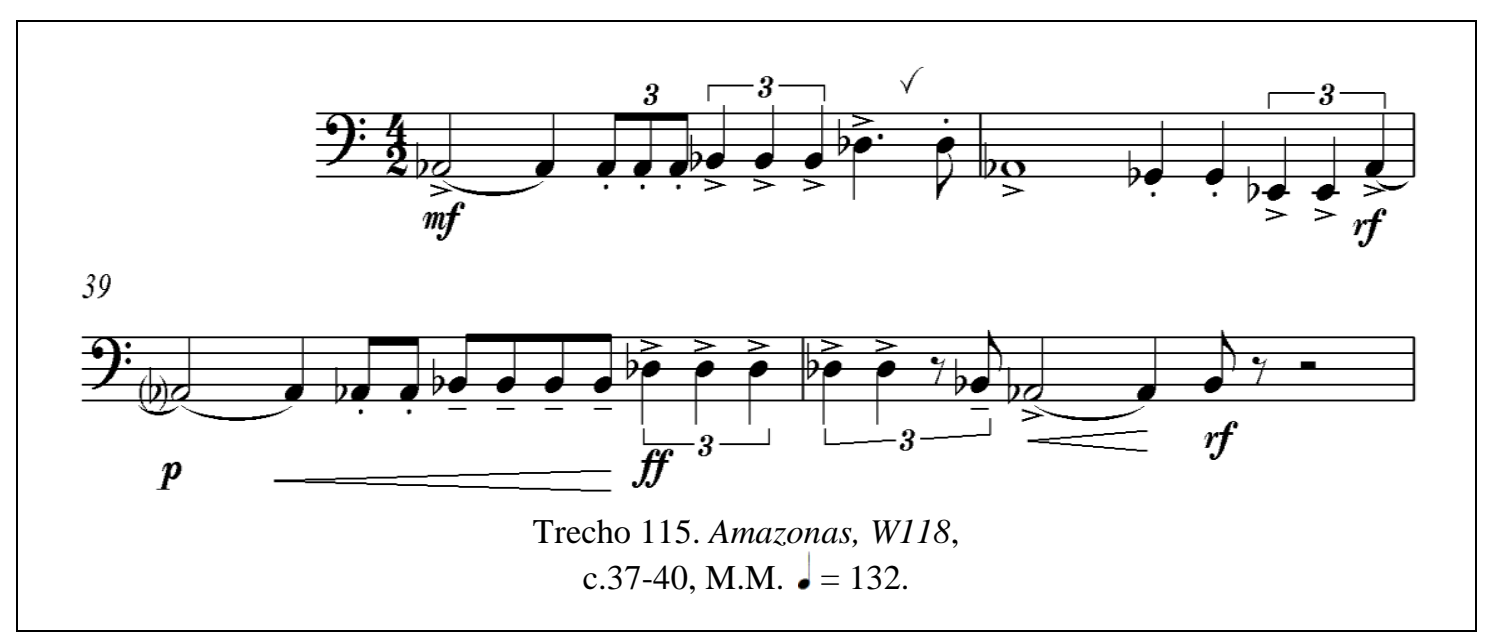

a. Principal desafio:

Ritmo: Atenção às tercinas que se posicionam em todos os compassos desse trecho. Pela própria conformação da tercina, ela tende a deixar mais lento o tempo seguinte com base de 4 colcheias em subdivisão.

Outros desafios:

b. Dinâmica: Tubistas fiquem atentos às quedas de dinâmica no c.39 e c.40.

c. Articulação: Villa-Lobos grafou estacato logo após a nota longa e no tempo seguinte acentos ( > ). Muita atenção para o c.39: está escrito estacato no $2^{\circ}$. tempo, tenuto no $3^{\circ}$. tempo ( - ) e acento ( > ) no $4^{\circ}$. tempo. 
d. Complicações: Villa-Lobos não deixou local para respiração, entre os c.39-c.42. Deve-se armazenar uma boa quantidade de ar nos pulmões para que esse trecho tenha sustentação sonora até o seu final.

\section{Trecho 116: Amazonas}

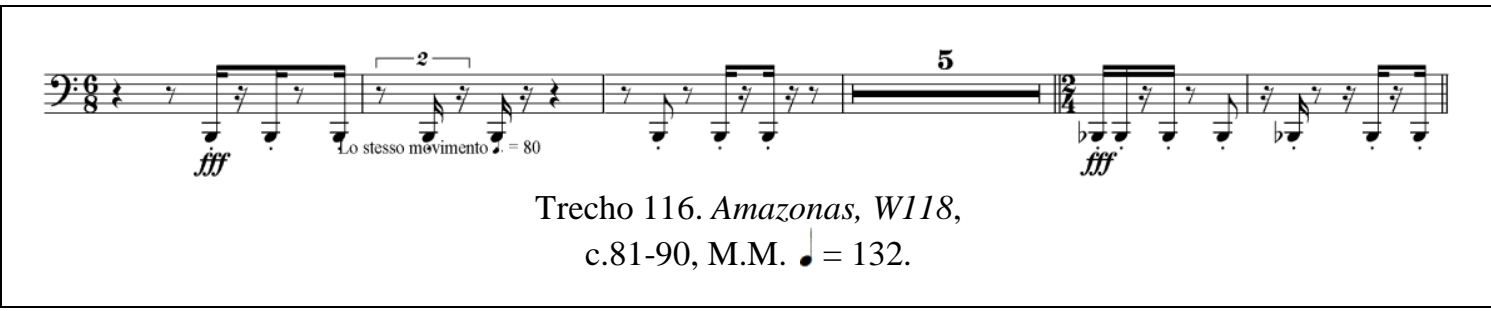

a. Principal desafio:

Ritmo: O tubista deve estar muito seguro do local a ser tocada cada uma dessas semicolcheias entremeadas de pausa.

Outros desafios:

b. Articulação: Todas as notas deste trecho contém ponto de diminuição (estacato), portanto as notas deverão ser curtas o tempo todo.

c. Notação diferente: A grafia desse trecho não prioriza de forma alguma a leitura do tubista. Anotações com relação ao tempo são bem vindas para uma melhor precisão do ritmo.

d. Complicações: - A alternância entre o 6/8 e a duína deve ser de extrema precisão.

\section{Trecho 117: Amazonas}

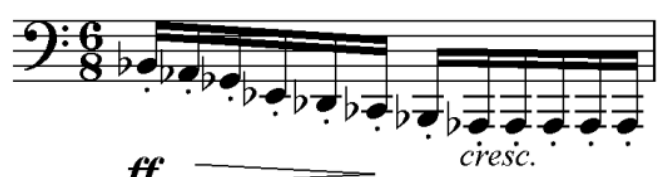

ff $=$

$$
\text { c.93, M.M. } \bullet=132 \text {. }
$$


a. Principal desafio:

Complicações: Após dois compassos de ritmo pouco perceptível nas cordas, a entrada do naipe de metais graves deve acontecer com segurança absoluta no $1^{\circ}$. tempo do c.93, juntamente com clarone, fagotes, contrafagotes e trompas.

Outros desafios:

b. Articulação: todas as notas estão grafadas em estacato (ponto de diminuição), portanto devem ser realmente curtas.

c. Dinâmica: Villa-Lobos grafou decrescendo no $1^{\circ}$. tempo e crescendo no $2^{\circ}$. tempo.

\section{Trecho 118: Amazonas}

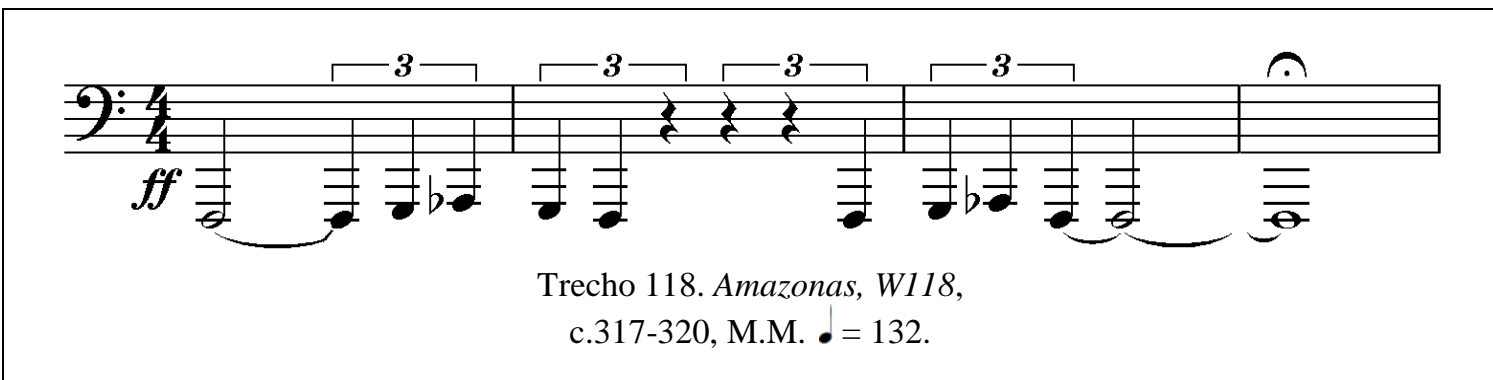

a. Principal desafio:

Ritmo e Polirritmia: Este trecho está escrito apenas para tuba e contrafagote. Nenhum outro instrumento estará tocando este ritmo de tercina, logo será necessário muita certeza rítmica, pois o maestro seguramente não regerá esse ritmo da tuba e contrafagote.

Outros desafios:

b. Dinâmica: Embora Villa-Lobos grafou $f f$ para este trecho, em virtude da extensão sonora extremamente grave, dificilmente será ouvido, mas toda potencia sonora será bem vinda à orquestração. 
c. Afinação: Em virtude da extensão grave do trecho, deve-se concentrar para uma afinação perfeita.

d. Analise de estilo: As notas na partitura não receberam articulação alguma, mas devido à extensão grave e a pouca instrumentação dedicada a esse trecho, sugeriríamos aos tubistas que acentuem ( > ) por conta própria.

\section{Trecho 119: Choros $N^{o} .6$}

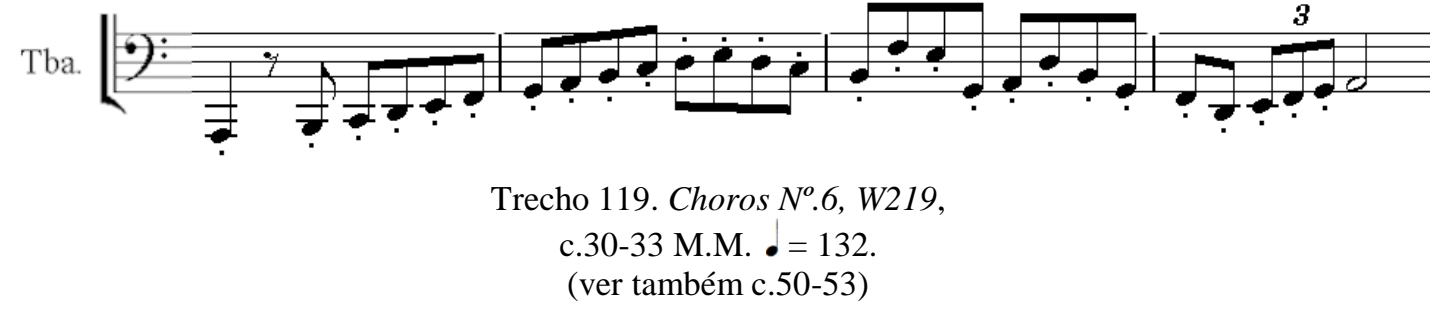

a. Principal desafio:

Respiração: Villa-Lobos seguramente transpôs a linha dos contrabaixos para a tuba. Logo não existiu repouso melódico ou mesmo um local para a respiração. Tubistas devem encontrar um local apropriado, em meio à sequência de colcheias, para sua respiração rápida nasal e silenciosa.

Outros desafios:

b. Articulação: As notas deverão soar realmente curtas - estacato ( . ) em toda semifrase (c.30-33).

c. Analise de estilo: Embora não grafado na parte, acredita-se que a finalização (c.53) tenha terminação feminina, logo não se deve executar a tercina de colcheia mais forte que as outras colcheias regulares. 


\section{Trecho 120: Choros $N^{o} .6$}

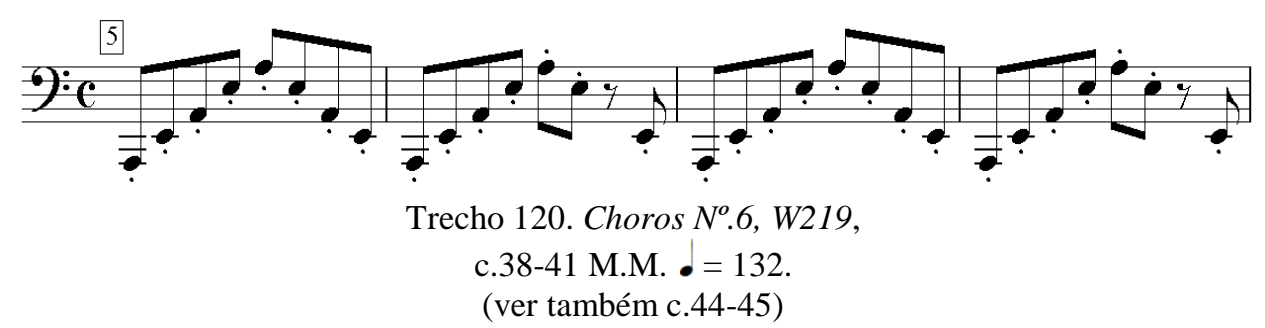

a. Principal desafio:

Intervalos: $\mathrm{Na}$ verdade, a sequência de $4^{\mathrm{a}}$. e $5^{\mathrm{a}}$. não gera dificuldade ao tubista, porém entre a nota mais grave do arpejos e a nota mais aguda, há um intervalo de duas oitavas, e isso sim requer domínio da embocadura do tubista em nível avançado.

Outros desafios:

b. Articulação: Villa-Lobos requer notas em estacato ( . ) nesse trecho por completo.

\section{Trecho 121: Choros $N^{o} .6$}

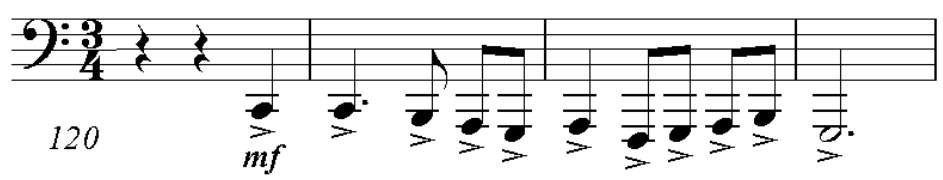

Trecho 121. Choros $N^{o} .6$, W219, c. $120-123$ M.M. $\bullet=132$.

a. Principal desafio:

Sincronismo: Esse soli, em conjunto com o trombone baixo, é um eco para o mesmo inciso apresentado pelos violinos. Portanto a precisão rítmica da entrada deve ser uma meta do tubista. 
Outros desafios:

d. Articulação: Todo trecho compreendido pelos c.120-123 está grafado com articulação acentuada $(>)$.

e. Analise de estilo: Embora não grafado na parte, acredita-se que cada motivo tenha terminação feminina, logo não se deve crescer ao final de cada ideia melódica.

Trecho 122: Choros $N^{o} .6$

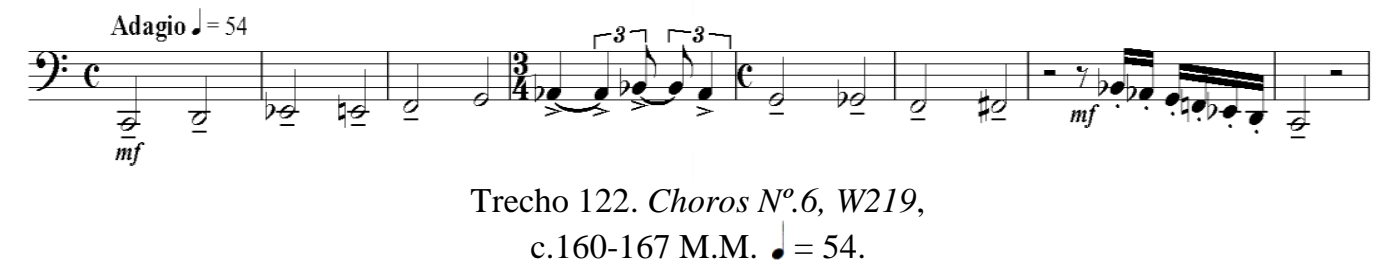

a. Principal desafio:

Analise de estilo: Embora esse movimento escalar descendente (c.166) esteja escrito numa região de sonoridade fácil para a tuba, este inciso deverá ser tocado de forma suave e com pouca intervenção no timbre orquestral neste momento.

Outros desafios:

b. Ritmo: Essa tercina escrita por Villa-Lobos no c.163 (o único trecho que tem articulação em acento) deve ser executada com precisão em conjunto com o naipe de trombones, pois a orquestra estará com outro ritmo e o maestro não regerá a tuba nesse momento.

c. Respiração: Villa-Lobos não deixou local algum para se respirar, porém esse trecho não tem função de soli, logo o tubista pode escolher qualquer mínima para sua respiração, desde que não atrapalhe o desenrolar das frases.

d. Articulação: Estacato por todo o movimento escalar descendente. 
Trecho 123: Choros $N^{o} .6$

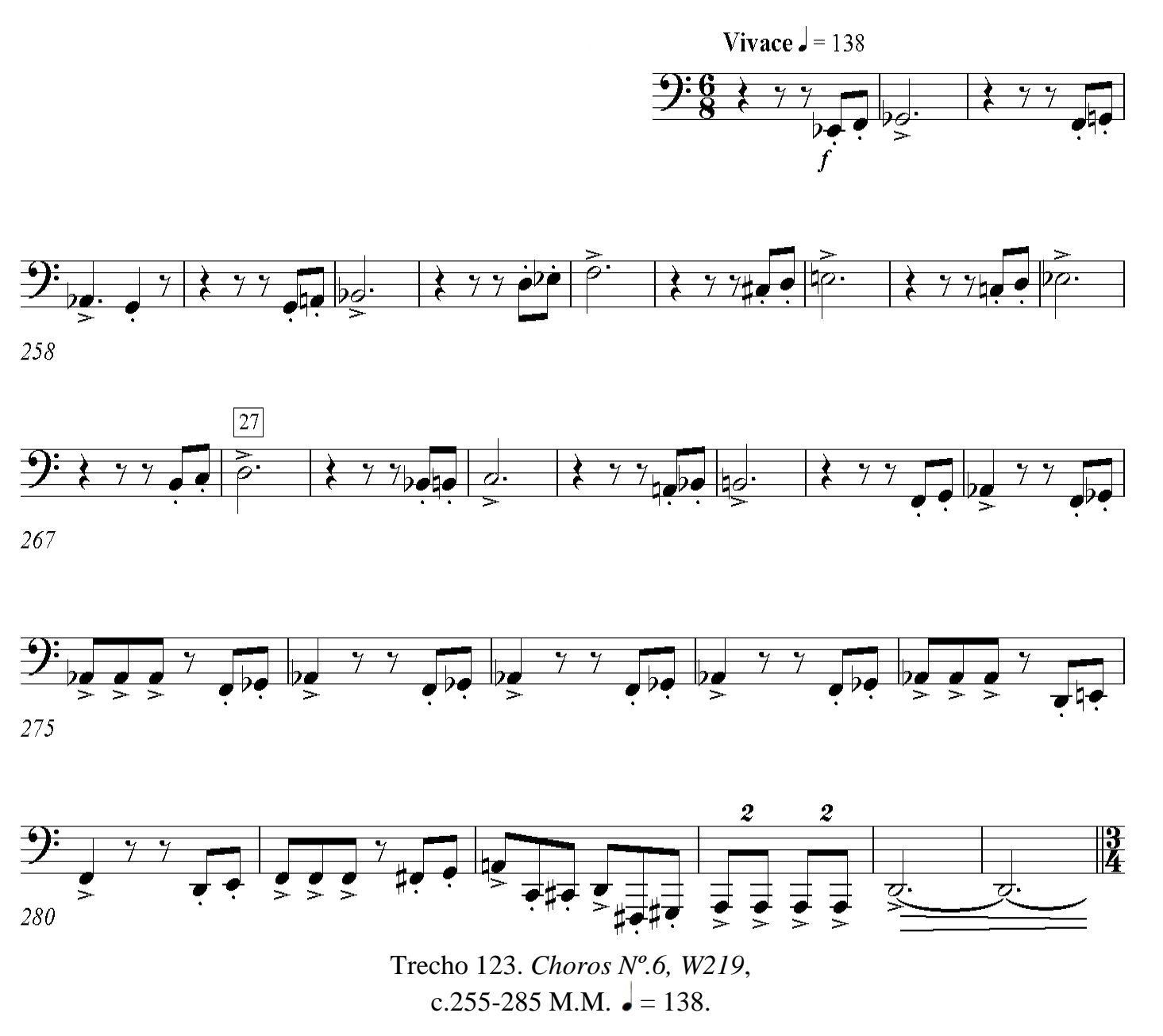

a. Principal desafio:

Ritmo: Os Trompetes entram no c. $254-2^{\circ}$. tempo, mas o ritmo dos Trompetes não ajudam a tuba em seu inciso rítmico, portanto os tubistas precisam de muita atenção para não atrasar na entrada ( $5^{\mathrm{a}}$ e $6^{\mathrm{a}}$ colcheias $)$.

Outros desafios:

b. Técnicas requeridas: Após 30 compassos em 6/8, Villa-Lobos grafou para a tuba um compasso em duínas (c.283). O tubista deve reservar especial atenção com o ritmo nesse local em especial.

c. Respiração: Villa-Lobos não deixou um local em especial para uma respiração, entre os c.281-286, mas em compensação, termina a frase (c.284-286) com três mínimas 
pontuadas, ligadas e em decrescendo. Dessa forma a escassez de ar ao final da frase será compensada pelo decrescendo das duas mínimas pontuadas e ligadas.

Trecho 124: Choros $N^{o} .6$

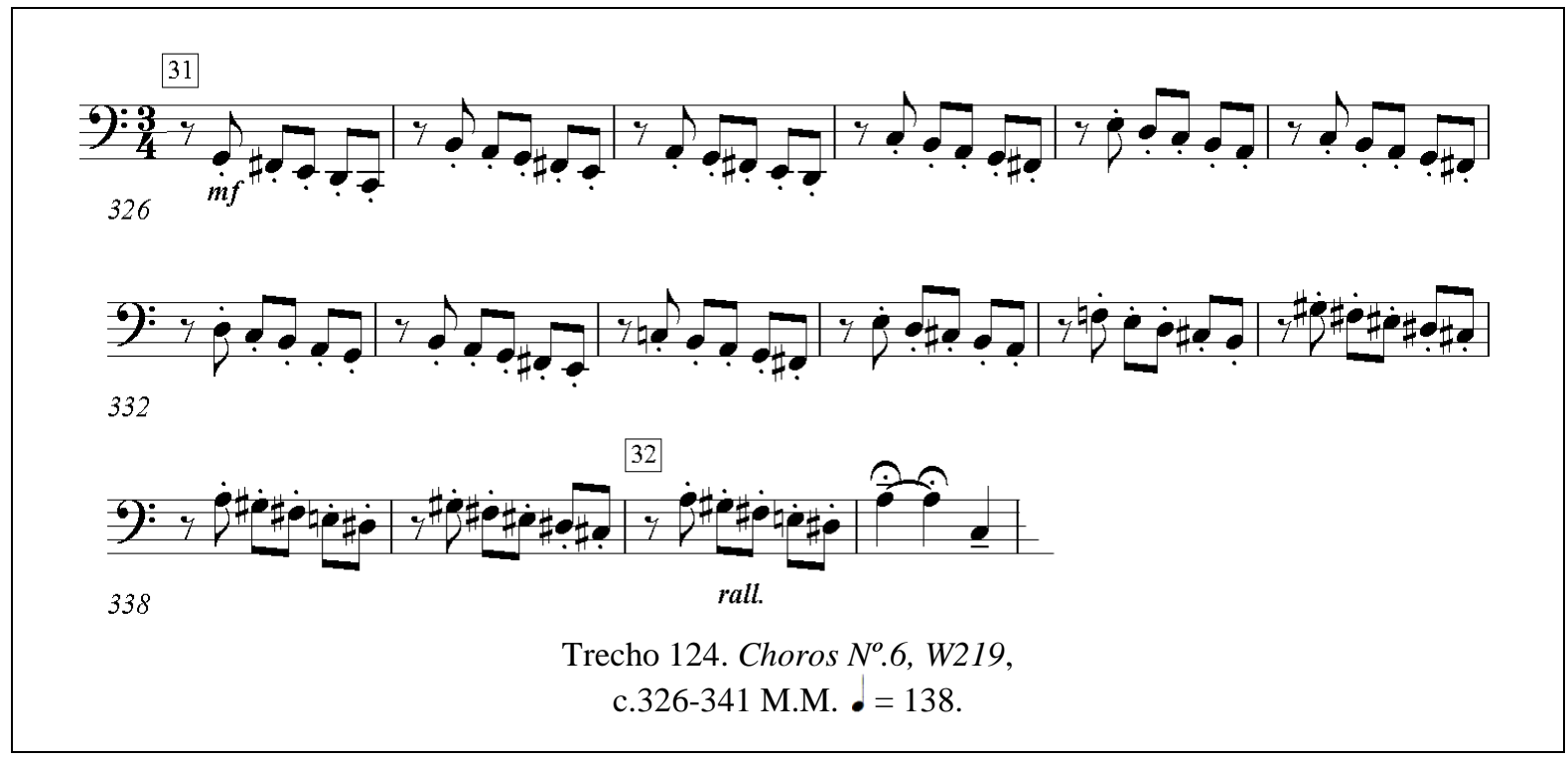

a. Principal desafio:

Extensão: Esse movimento escalar descendente que perdurará todo o trecho, não carrega consigo dificuldade alguma para o tubista. A dificuldade reside no fato que paulatinamente a nota mais aguda do inciso torna-se mais aguda que a anterior, gerando uma fadiga muscular e criando a possibilidade de uma falha em qualquer nota aguda.

Outros desafios:

b. Articulação: Villa-Lobos grafou esse trecho inteiramente em estacato.

c. Analise de estilo: Embora não grafado, mas a boa interpretação exige que todo final de movimento escalar descendente seja feito em terminação feminina. 
Trecho 125: Choros $N^{o} .6$

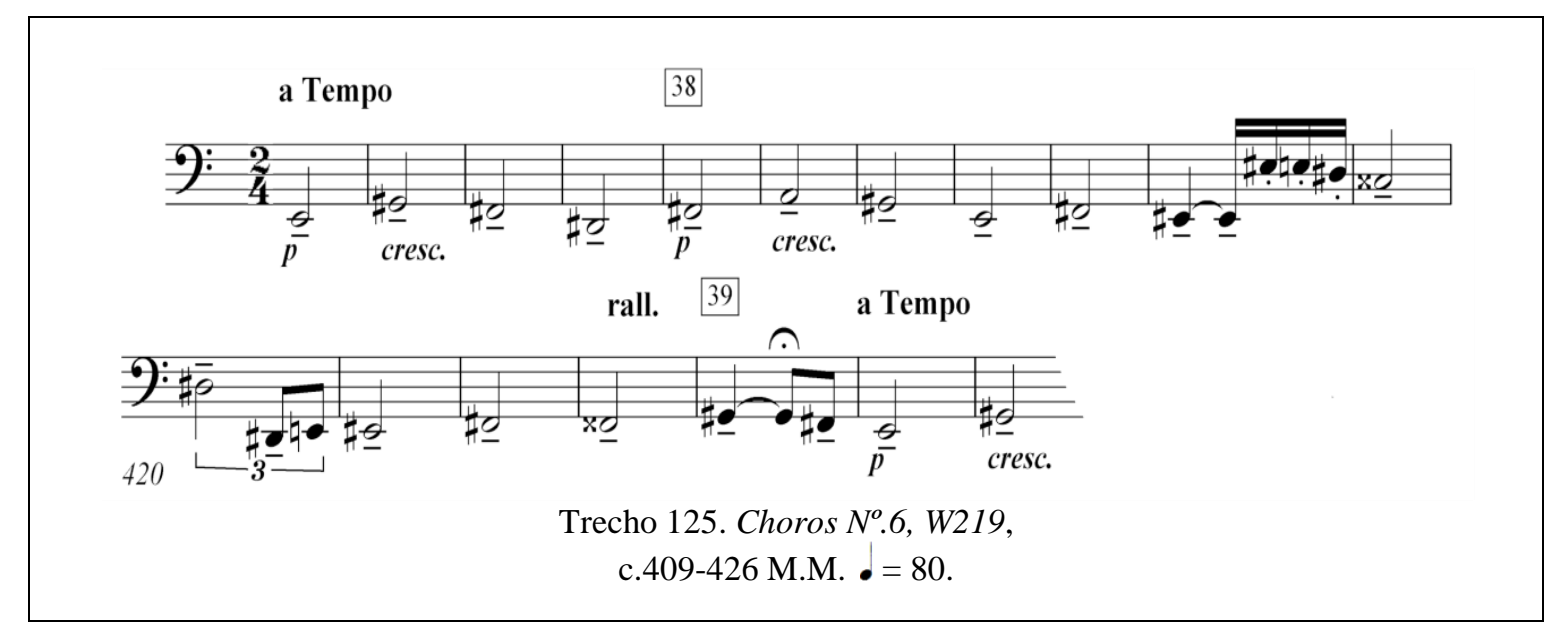

a. Principal desafio:

Ritmo: No c.418 Villa-Lobos grafou um movimento escalar cromático descendente para a tuba e o trombone baixo. Este trecho inicia-se na segunda semicolcheia - localização largamente estudada pelos músicos e por ser muito suscetível a atrasos. No c.420 o andamento não estará rápido, mas é aconselhável que o tubista controle o tamanho das notas em quiálteras.

Outros desafios:

b. Articulação: Deve-se tocar tenuto ( - ) por todo o trecho, porém Villa-Lobos grafou estacato para a escala cromática (c.418). 
Trecho 126: Choros $N^{o} .6$

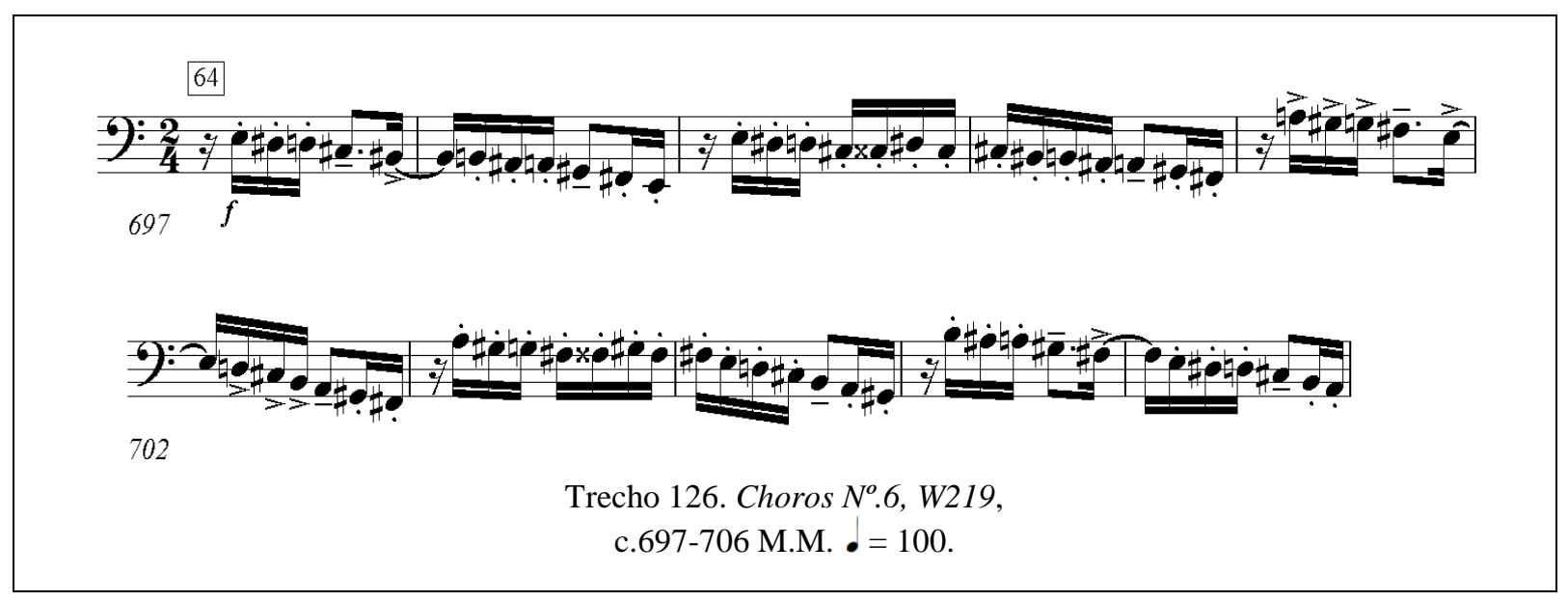

a. Principal desafio:

Complicações: Esse inciso escalar descendente, que por pouco não foi grafado como cromático. Mas por não ser realmente cromático, este inciso gera uma alta possibilidade de erro em alturas de notas, portanto o tubista deve se concentrar ao máximo durante esse trecho.

Outros desafios:

b. Ritmo: Ritmos iniciados por uma pausa de semicolcheia sempre estarão propensos à atrasos. Portanto o tubista deve buscar total concentração durante esse trecho.

c. Articulação: Villa-Lobos grafou para esse trecho, após uma pausa de semicolcheia, três semicolcheias em estacato ( . ), a colcheia pontuada em tenuto ( - ) e a próxima semicolcheia acentuada $(>$ ) e este será o padrão da articulação de todo o trecho. Ou seja, o tubista precisa estar atento à execução dessas três articulações dentro do mesmo compasso. 
Trecho 127: Choros $N^{o} .6$

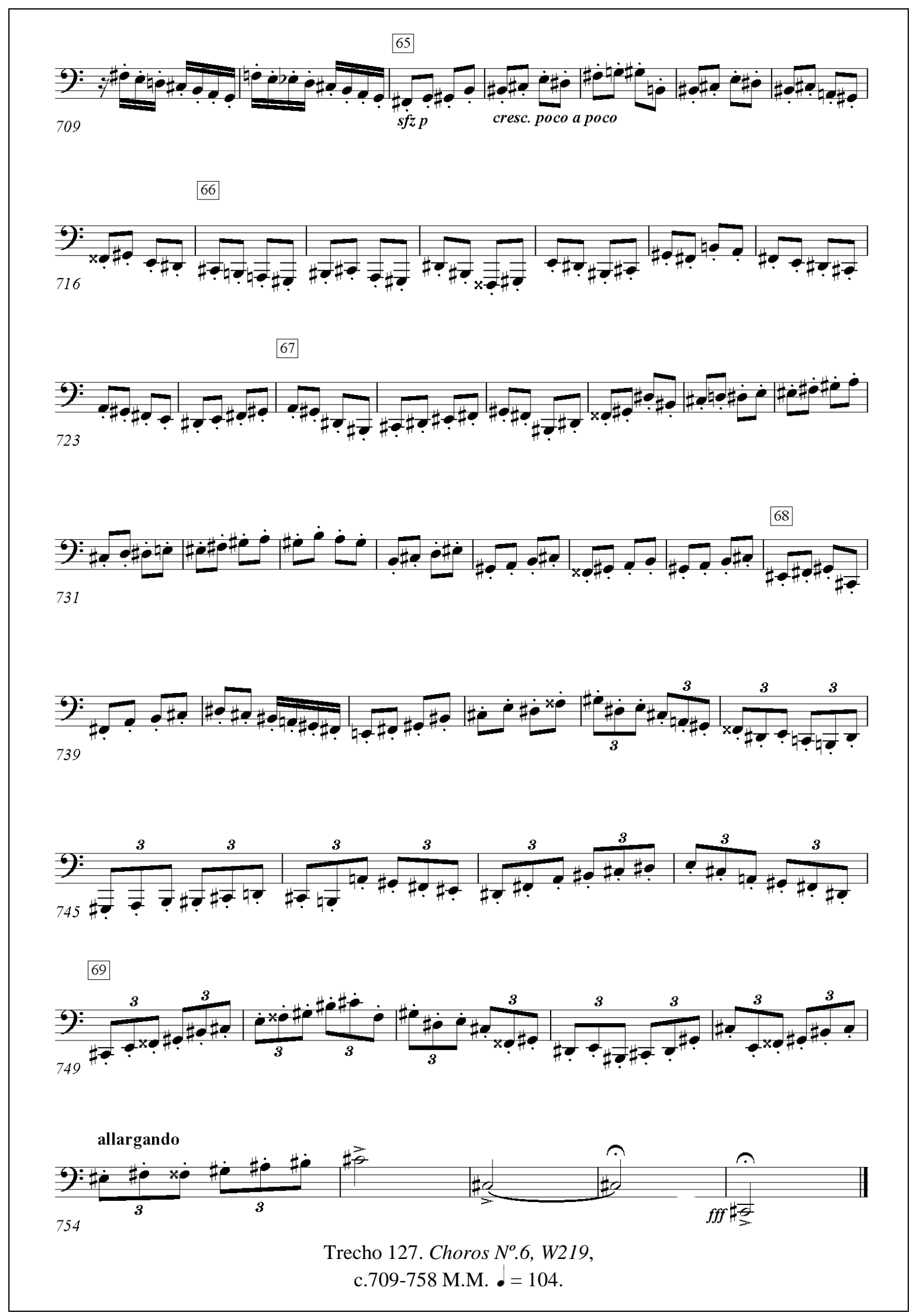


a. Principal desafio:

Respiração: Começando no c.709 e terminando em c.757 (48 compassos), esse trecho escrito por Villa-Lobos não contém lugar de respiração. Também não há opção de pausas ou notas longas. Devemos recorrer às duas últimas opções de respiração para os instrumentistas de sopro: busquemos respirar logo após o clímax agudo ou grave, e necessitando ainda, entre intervalos grandes (c.713, 719, 727, 734-738, 745, 746, 753, 755).

Outros desafios:

b. Articulação: Villa-Lobos grafou todo esse trecho em articulação estacato ( . ). Seguramente a língua de qualquer tubista sofrerá algum tipo de fadiga. A melhor solução para esse entrave é manter a concentração juntamente com um movimento ascendente de língua em sincronismo com um ar diafragmático curto em duração.

c. Ritmo: Tubistas devem estar atentos à mudança de subdivisão binária (c.709-742) para ternária (c.743-754). 
Villa-Lobos e os metais graves sinfônicos:

Um estudo dos elementos técnicos específicos

Os tópicos técnicos analisados estão contidos no quadro abaixo, porém conferiu-se que nos 3 instrumentos analisados a articulação foi a dificuldade mais recorrente.

\begin{tabular}{|c|c|c|c|c|}
\hline \multicolumn{2}{|r|}{ Tópico } & Trombone tenor & Trombone baixo & Tuba \\
\hline 1. & Afinação & 13 & 6 & 1 \\
\hline 2. & Análise de estilo & 22 & 7 & 7 \\
\hline 3. & Articulação & 33 & 17 & 15 \\
\hline 4. & Colocação da surdina & 2 & 1 & \\
\hline 5. & Complicações técnicas & 22 & 11 & 5 \\
\hline 6. & Concentração & 1 & 1 & \\
\hline 7. & Conjunto & 3 & & \\
\hline 8. & Dinâmica & 18 & 7 & 5 \\
\hline 9. & Extensão melódica & 2 & & 1 \\
\hline 10. & Força física & 2 & 1 & \\
\hline 11. & Intervalos grandes & 11 & 3 & 1 \\
\hline 12. & Notação diferente & 4 & 3 & 1 \\
\hline 13. & Polirritmia & 1 & & 1 \\
\hline 14. & Projeção sonora & 3 & 1 & \\
\hline 15 . & Respiração & 16 & 3 & 4 \\
\hline 16. & Ritmo & 29 & 13 & 13 \\
\hline 17. & Sincronismo & 5 & 4 & 1 \\
\hline 18. & Técnicas requeridas & 14 & 5 & 1 \\
\hline 19. & Valoração das notas & 1 & & \\
\hline
\end{tabular}

Quadro 14 - tabulação total dos tópicos técnicos analisados, demonstrados por incidência. 
Villa-Lobos e os metais graves sinfônicos:

Um estudo dos elementos técnicos específicos

Capítulo 8:

CONSIDERAÇÕES FINAIS

"De todas as artes, a que mais desperta a sensibilidade dos seres vivos, é a música. Ela é um dos milagres da arte e o artista concentra os mistérios

da natureza" (...), Villa. 


\section{CONCLUSÃO}

No presente trabalho realizou-se uma apreciação da orquestração elaborada por VillaLobos em relação ao trombone e tuba em algumas composições. Procurou-se localizar comparativamente com um pouco mais de detalhamento alguns elementos aventados aqui e ali na literatura a respeito do compositor brasileiro, que colaboram no mínimo para a internacionalização de sua obra.

Pelo exposto no capítulo 6, Villa-Lobos não suplantou em momento algum os limites de extensão dos instrumentos as quais a pesquisa se direcionou. Verificou-se que a maior extensão para os metais graves ficou entre 31 e 32 semitons, ou seja, algo em torno de 2,5 oitavas de extensão. Portanto concluiu-se que um aluno iniciante ou mesmo em nível médio de estudo não está apto a executar as peças analisadas ${ }^{112}$, permitindo apenas que profissionais em nível avançado de técnica e extensão as executem com perfeita destreza. Há algumas exceções possíveis de serem executadas por alunos em nível médio, tais como Amazonas (trombone tenor/14 semitons/ 9 ${ }^{\mathrm{a}} . \mathrm{M}$ ) e Uirapurú (trombone-baixo/5 semitons/4 ${ }^{\mathrm{a}}$.J e tuba/14 semitons $\left./ 9^{\mathrm{a}} \cdot \mathrm{M}\right)$.

Portanto esses trechos que foram apresentados, com técnicas específicas dos instrumentos, em paralelo com estudos teóricos direcionados às interpretações embasadas em pesquisas empírico-científicas, nos serviram para criar soluções para os entraves técnicos deixados por Villa-Lobos e, por conseguinte, obter melhoras na execução individual de cada músico participante da pesquisa. O trabalho de solução dos glissandos impossíveis, mesmo que de forma embrionária, receberam sugestões de resolução e locais opcionais para respiração foram determinados.

Após a análise de 127 trechos orquestrais, podemos concluir que o estudo direcionado e adaptado às realidades dos instrumentos envolvidos na pesquisa, melhora substancialmente

\footnotetext{
${ }^{112}$ Sabe-se que dentro da técnica de metais-graves, o músico necessita de pelo menos uma $4^{\mathrm{a}}$.J acima de seu limite de extensão na região dos agudos para que a nota saia a contento. Pela extensão máxima que Villa-Lobos escreveu um aluno iniciante necessitará de 7-8 anos de estudo para alcançar e de 3-4 anos um aluno em nível médio (grifo nosso).
} 
a execução de qualquer músico de metal grave orquestral, dentro do âmbito das peças pesquisadas, pois já se confirmou que a excelência da interpretação está diretamente relacionada à sua própria construção.

Entretanto, identificamos nove argumentos que até o presente momento não encontramos em outros trabalhos envolvidos na mesma temática:

1.) Utilização média dos metais graves em $50 \%$ das peças pesquisadas (exceção apenas para o Choros $N^{o} .4$ que obteve o índice de 95,87\%). Esse número se aproxima da média utilizada pelos compositores neoclássicos do início do século $\mathrm{XX}$;

2.) Os metais graves são instrumentos ativos em Villa-Lobos, pois em todas as peças pesquisadas sempre houve algum tipo de soli ou mesmo solo;

3.) Os glissandos, com facilidade ou dificuldade de execução não existiram no Concerto e na Sinfonia (coincidem com a fase madura de Villa-Lobos). O efeito caricaturado do glissando $^{113}$ não justificaria sua incursão nesses estilos de composição;

4.) Existe um comprometimento muito grande com a dinâmica, nas escritas de VillaLobos. Este se utilizou de toda a gama de volume, com exceção apenas do mezzopiano que não se localizou em peça alguma;

5.) No quesito articulação, localizou-se em maioria absoluta, o ponto de estacato ( . ) em 2104 notas. Com isso, pode-se afirmar que no estilo villalobiano, as notas no Trombone e na Tuba devem ser tocadas mais curtas em duração que a técnica específica prega.

6.) Ainda localizou-se 1490 notas sem articulação alguma. Essas necessitariam de um estudo musicológico para se identificar a articulação mais adequada;

7.) Embora a maioria dos músicos entrevistados indagasse a extensão sonora das peças analisadas como extrapolação técnica, esta, esteve perfeitamente dentro do padrão internacional dos instrumentos;

8.) Problema maior ficou dentro do âmbito da respiração e dos intervalos grandes. Estes quesitos sim justificaram essa pesquisa;

${ }^{113}$ Este efeito sonoro teve seu auge, dentro do repertório sinfônico, entre Debussy e Bartók (grifo meu). 
9.) A questão do Choros $N^{o} .4$, composto em 1926, confirmou-se ser apenas possível, na época, se executado por um trombonista-baixo. Testes com trombone tenor sem rotor foram feitos, e o resultado não condiz com a magnitude da peça, nem forneceu o baixo necessário para o trio de trompas. Atualmente possuímos o trombone tenor com rotor em fá, este com maior possibilidade de execução plena.

Acredito que pesquisas como esta proporcionam o conhecimento de soluções válidas durante a preparação de trechos orquestrais por músicos sinfônicos, já que estes poderão utilizar dos argumentos aqui apresentados para a solução de entraves técnicos. Espero ainda que o conhecimento aqui depositado agregue qualidade ao ensino do instrumento, uma vez que é baseado na minha vivência e na prática do instrumento por mais de 34 anos.

[...] "To satisfeito porque já bem aproximando o fim da minha vida, eu sinto perfeitamente que o Brasil encontrou o seu caminho. E tudo isso tá tão de acordo com a penitência da minha vida”, Villa-Lobos. 


\section{BIBLIOGRAFIA}

ALLEN, Jonathan Sayre: Mixed chamber music for trombone: an exploration of the genre through performance analyses of works by Roseman, Rush, and Kurtá. Tese. University of Iowa / EUA, 2011.

ALVES, Marcelo Eterno. Os instrumentos de metal no Choros $n^{\circ} 10$ de Villa-Lobos: Uma visão analítico-interpretativa. Dissertação de Mestrado. Brasil: UFG, 2003.

ALBUQUERQUE, Joel M. Bravo. Choros $N^{0} 4$ e $N^{07}$ de Villa-Lobos: dois procedimentos diferentes envolvendo o uso de eixo de simetria como fator estrutural. Artigo para $2^{\circ}$. Simpósio Villa-Lobos. ECA/USP, 23 a 25 de novembro de 2012.

ANDRADE, Mario de. Ensaio sobre a música brasileira. São Paulo: Livraria Martins Editora S.A., 1972.

ANDRADE, Mario de. Música Doce Música. $3^{\text {a }}$ ed. Belo Horizonte: Editora Itatiaia, 2006.

AQUINO, Felipe José A.: Villa-Lobos's Cello Concerto $N^{\boldsymbol{o}} .2$ A Portrait of Brazil. Tese. University of Rochester; Nova Iorque / EUA, 2000.

ARAÚJO, Marcos Vinícius. Estratégias de estudo utilizadas por dois violonistas na preparação para a execução musical da Elegy (1971) de Alan Rawsthorne. Dissertação (Mestrado em Música). Porto Alegre: Programa de Pós-Graduação em Música, Universidade Federal do Rio Grande do Sul, 2010.

BANDEIRA, Manuel. In: Ariel: revista de cultura Musical. Ano II, no. 13, SP, out. 1924.

BARROS, Roque Spencer Maciel de. A Ilustração Brasileira e a ideia de universidade. São Paulo: Convívio: Editora da Universidade de São Paulo, 1986.

BARROS, Luis Cláudio. A pesquisa empírica sobre o planejamento da execução instrumental: Uma reflexão crítica do sujeito de um estudo de caso. Tese. Porto Alegre: Programa de Pós-Graduação em Música, Universidade Federal do Rio Grande do Sul, 2008.

BLUM, David. Casals and the Art of Interpretation. Los Angeles, University of California Press, 1977.

BROWN, Keith. Orchestral Excerpts from the Symphonic Repertoire for trombone and tuba. New York: The International Music Company, 1965.

CANDÉ, Roland de. História Universal da Música. São Paulo: Martins Fontes, 2001.

CARDOSO, André. A Música na Capela Real e Imperial do Rio de Janeiro. $1^{\text {a }}$ ed. Rio de Janeiro: Academia Brasileira de Música, 2005. 
CARDOSO, Antônio Marcos Souza. O Trompete nos Choros de Heitor Villa-Lobos: possibilidades interpretativas no âmbito da orquestra sinfônica. Universidade Federal do Estado do Rio de Janeiro: Rio de Janeiro, 2009.

CARPENTIER, Alejo. Opiniones de Villa-Lobos. Obras completas de Alejo Carpentier esse músico que llevo dentro. México: Siglo XXI editores, 1987.

CARVALHO, Piedade. Villa-Lobos - Do Crepúsculo à Alvorada. Rio de Janeiro: Tempo Brasileiro, 1987.

CHAFFIN, R.; IMREH, G.; CRAWFORD, M. Practicing perfection: memory and piano performance. Mahwah. NJ: Erlbaum, 2002.

CHAUÍ, Marilena de Souza. Cultura e democracia. São Paulo: Editora Moderna, 1981.

DAMASCENO, André Álcman O. Villa-Lobos: negociações simbólicas na formação da moderna música brasileira. Fortaleza: Dissertação de Mestrado, Departamento de Sociologia, Centro de Humanidades/UFC, 2007.

DOMS, Johann. Orchesterstudien für Solo-Posaune. Berlin, Germany: Musikverlag/ Edition Johann Doms, 1985.

DUKE, Cason A.: A Performer's guide to theatrical elements in selected trombone literature. Tese. Louisiana State University, 2001.

EDMUNDO, Luiz. Rio de Janeiro de meu tempo. 2a . Edição. Jundiaí: Editora Conquista, 1957.

FERRER, Marcus. Suite retratos e Choros IV: o Choro visto por Radamés Gnattali e Heitor Villa-Lobos. Dissertação de Mestrado. Rio de Janeiro: UFRJ, 1996.

FLETCHER, ALLISON MARIE FLORES: Ten Orchestral Excerpts for Piccolo: An Historical and Stylistic Analysis. Tese. University of North Caroline / EUA, 2008.

FREITAS, Marcos F. de Aguiar: O Choro em Belo Horizonte. Artigo. UFMG, 2005.

FRIEDRICH, Otto. City of Nets: A Portrait of Hollywood in 1940's. New York: Harper \& Row. Reprinted, Berkeley and Los Angeles: University of California Press, 1986.

FORTE, Alen. Pitch-Class Set Genera and the Origin of Modern Harmonic Species. Journal of Music Theory, v. 32, n. 2, p. 187-270, 1988.

GERLING, C. C., DOS SANTOS, R. A. T. Pesquisas qualitativas e quantitativas em práticas interpretativas. In: FREIRE, W. (Org). Horizontes de pesquisa em música. Rio de Janeiro: Letras, 2010, p.96-138.

GIFFORD, Robert Marvin, Jr. A Comprehensive Performance Project in Trombone Literature with an Essay Consisting of a Survey of the Use of the Trombone in Chamber Music with Mixed Instrumentation Composed Since 1956. Tese. University of Iowa, 1978. 
GRAY, Robert E. The Treatment of the Trombone in Contemporary Chamber Music. Tese não publicada, University of Rochester, 1957.

GUÉRIOS, Paulo Renato. Heitor Villa-Lobos. $1^{\text {a }}$ ed. Rio de Janeiro: FGV, 2003. 1, n. 5 , março de 2004 . "A descoberta do Brasil por Villa-Lobos". Nossa História, ano

HALLAM, Susan. The development of metacognition in musicians: implications for education. British Journal of Music Education, v.18, n.1, p.27-39, 2001.

HEITOR, Luiz. 150 anos de música no Brasil (1800 - 1950). $1^{\mathrm{a}}$ ed. Rio de Janeiro: Livraria José Olympio Editora, 1956.

JARDIM, Gil. O Estilo antropofágico de Heitor Villa-Lobos. São Paulo: Editora Philarmonia Brasileira, 2005.

JOHNSON, Keith. The Art of Trumpet Playing. Denton, Texas: Gore Publishing, 1984.

KLEINHAMMER, Edward. The Art of Trombone Playing. Evanston, Illinois: SummyBirchard Co., 1963.

KRISTEVA, Júlia. A Palavra, O Diálogo, O Romance. Semiótica do Romance. Lisboa: Arcádia, 1977.

LACERDA Marcos Branda. "Aspectos harmônicos do Choros n. 4 de Villa-Lobos e a linguagem modernista”. Revista Brasileira de Música. Programa de Pós-Graduação em Música - Escola de Música da UFRJ, Rio de Janeiro, v. 24, n. 2, p. 277-297, Jul./Dez, 2011.

LAVILLE, Christian; DIONNE, Jean. A construção do saber: manual de metodologia da pesquisa em ciências humanas. Trad. Heloísa Monteiro e Francisco Settineri. Porto Alegre: Artmed; Belo Horizonte: Editora UFMG, 1999.

LEMIEUX, Anthony; CHEN, Colleen; CHAFFIN, Roger; IMREH, Gabriela. "Seeing the Big Picture”; Piano Practice as Expert Problem Solving. Music Perception. Califórnia: University of Califórnia, v.20, n. 4, p. 465-490, 2003.

LISBOA, Renato Rodrigues. A escrita idiomática para tuba nos dobrados Seresteiro, Saudades e Pretensioso de João Cavalcante. Belo Horizonte; UFMG, 2005.

MAGNANI, Sérgio. Comunicação e Expressão na Linguagem da Música. Belo Horizonte: UFMG, 1989.

MARIZ, Vasco. História da Música no Brasil. $6^{\mathrm{a}}$ ampl. e atual. ed. Rio de Janeiro: Nova Fronteira, 2005b.

MELLO, Ricardo C. Concerto para violão e pequena orquestra de H. Villa-Lobos: um estudo comparativo entre edições e manuscritos. Salvador: UFBA, 2009. 
MENKEN, Julian. Anthology of Symphonic and Operatic Excerpts for bass trombone. Nova Iorque / EUA: Carl Fischer Inc., 1957.

MOREIRA, Thais F. Rodrigues dos Santos. Solo do Choros $N^{\circ} 6$ de Villa-Lobos: construção da performance por flautistas profissionais. Dissertação. UFRS, 2013.

MOYER, Susan Elizabeth: A Detailed Study of Selected Orchestral Excerpts for Cello. Tese. University of Miami / EUA, 2009.

NADAI, Robson Alexandre de: Sonata para trombone e piano de Almeida Prado: uma análise interpretativa. Dissertação. Unicamp, 2007.

NEVES, José. Maria. Villa-Lobos, o Choro e os Choros. $1^{\text {a }}$ ed. São Paulo: Ricordi, 1977.

NIELSEN, S. G. Regulation of learning strategies during practice: a case study of a single Church organ student preparing a particular work for a concert performance. Psychology of Music, v. 27, p. 218-29, 1999.

NOBRE, Marlos. Villa-Lobos e a Série dos "Choros". Fórum Nacional - Sessão Especial Brasil: Estratégia de Desenvolvimento Industrial, com Maior Inserção Internacional e Fortalecimento da Competitividade. Rio de Janeiro, 18-19 de setembro de 2013.

NÓBREGA, Adhemar. As Bachianas Brasileiras de Villa-Lobos. $2^{\text {a }}$ ed. Rio de Janeiro: MEC, 1976.

NOGUEIRA, Eurico A evolução de Villa-Lobos na Música de Câmara. Rio de Janeiro: MEC/Museu Villa-Lobos, 1979.

OLIVEIRA, Rodrigo Eduardo. Flor-do-Cerrado: O Clube do Choro de Brasília. Dissertação. Universidade Federal de Uberlândia, 2006.

PEREIRA, Roberto. A Formação do Balé Brasileiro. 1 ${ }^{\text {a }}$. Ediçãa. Rio de Janeiro: Editora FGV, 2003.

PALMA, Enos da Costa, \& CHAVES JR., Edgard de Brito. As Bachianas Brasileiras de Villa-Lobos. $1^{\text {a }}$ ed. Rio de Janeiro: Companhia Editora Americana, 1971.

PEPPECORN, Lisa, "Villa Lobos", São Paulo: Ediouro, 2000.

PIEDADE, Acácio Tadeu de C. Tópicas em Villa-Lobos: o excesso bruto e puro, Anais do Simpósio Internacional Villa-Lobos. São Paulo: USP, 16 - 21 de nov. de 2009.

PINTO, Alexandre Gonçalves. O choro. Rio de Janeiro: Edição FUNARTE, 1978.

RATNER, Leonard G. Classic Music: Expression, Form and Style. New York: Schirmer Books, 1985.

ROSIN, Armin \& PLEYER, Eberhard. Orchester-Probespiel posaune. Frankfurt: Edition Peters, 1993. 
SALLES, Paulo de Tarso. Aberturas e Impasses. São Paulo: Editora UNESP, 2003.

SALLES, Paulo de Tarso. Villa-Lobos: Processos composicionais. São Paulo: Editora UNICAMP, 2009.

SCHOENBERG, Arnold. Style and Idea. California: California II, 1984.

SEINCMAN, Eduardo. Estética da Comunicação Musical. São Paulo: Editora Via Lettera, 2008.

SEIXAS, Guilherme Bernstein. Procedimentos composicionais nos Choros orquestrais de Heitor Villa-Lobos. Tese de Douturado. Rio de Janeiro: UNIRIO, 2007.

SMITH, Henry Charles. 20th Century Orchestra Studies for trombone. New York: G. Schirmer, Inc., 1969.

TARASTI, Eero. Paradigmas do estudo sobre Villa-Lobos. MUSIIIKI, 1979.

VILLA-LOBOS. Síntese crítica e biográfica. $3^{\text {a }}$ ed. Rio de Janeiro: MEC/DAC/Museu VillaLobos, 1978.

VILLA-LOBOS. O Homem e a Obra. 12 a ed. Rio de Janeiro, Francisco Alves, 2005.

VILLA-LOBOS. Biografia ilustrada do mais importante compositor brasileiro. (A. Sampson, Ed., \& T. M. Rodrigues, Trad.) Rio de Janeiro: Ediouro, 1991.

VILLA-LOBOS, Heitor. In: SADIE, Stanley (Ed.). Dicionário Grove de Musica - Edição concisa. Rio de Janeiro: Jorge Zahar Editor, 1994, p. 992-993.

WICK, Denis. Trombone Technique. London: Oxford Univ. Press, 1971.

WHITE, Eric Walter: Stravinsky: The Composer and His Works, 2a. edição. Berkeley e Los Angeles: The University of California Press. 1979.

ZANON, Fabio. Villa-Lobos. São Paulo: Publifolha, 2009.

ZULAR, Roberto. Criação em progresso: ensaios de crítica genética. São Paulo: Editora Iluminuras Ltda., 2002. 


\section{REFERÊNCIAS DISCOGRÁFICAS}

Uirapurú:

VILLA-LOBOS, Heitor. (1998). Villa-Lobos. Compact Disc. Orquestra Sinfônica Nacional, Ligia Amadio (regência), Universidade Federal Fluminense.

VILLA-LOBOS, Heitor. (2003). Villa-Lobos. Compact Disc. Odense Symphony Orchestra, Jan Wagner (regência).

VILLA-LOBOS, Heitor. (1989). A Brazilian Extravaganza. Compact Disc. Orquestra Sinfônica da Paraíba, Eleazar de Carvalho (regência), Delos International, Inc.

Amazonas:

VILLA-LOBOS, Heitor. (1997). Villa-Lobos Bachianas Brasileiras Nosl 2 \& 5, Concerto for guitar, Amazonas. Compact Disc. Orchestre National de Lyon, Maria Bayo (soprano) e Roberto Aussel (guitar), \& Emmanuel Krivine, Regente. Paris: Erato Disques S.A.

VILLA-LOBOS, Heitor. (1991). Heitor. Heitor Villa-Lobos Gênesis - Erosão - Amazonas. Compact Disc. Czecho-Slovak Radio Symphony Orchestra (Bratislava), \& Roberto Duarte, Regente. Alemanha: Marco Polo.

VILLA-LOBOS, Heitor. (1996). Heitor Villa-Lobos Symphony No. 4 "Victoria", Cello Concerto No. 2, Amazonas. Compact Disc. Simón Bolívar Symphony Orchestra of Venezuela \& Enrique Arturo Diemecke, Regente. Nova Yorque: Dorian Recordings.

VILLA-LOBOS, Heitor. (1997). Villa-Lobos. Compact Disc 0630-10704-2. Orchestre National de Lyon \& Emmanuel Krivine (regente). France: Erato.

Choros $N^{\circ}$ 4:

VILLA-LOBOS, Heitor. (2003). Villa-Lobos Choros 1 -7. Compact Disc. Gran Canaria Philharmonic Orchestra, ASV Living Area.

VILLA-LOBOS, Heitor. (1977). Os Choros de câmara. Compact Disc. Jessé Sadoc (trombone). Brasil: Kuarup Discos.

VILLA-LOBOS, Heitor. (2005). A obra de Câmara para sopros de Heitor Villa-Lobos. Compact Disc. João Areias (trombone). Brasil: ABM.

VILLA-LOBOS, Heitor. (1978). Villa-Lobos. Compact Disc. Victor Benglovski (trombone). Paris: Le Chant du Monde. 
Choros $N^{\circ} 6$ :

VILLA-LOBOS, Heitor. (1954). Villa-Lobos. Compact Disc. Rias Symphony Orchestra , \& Heitor Villa-Lobos (regente). Alemanha: Amadeo.

VILLA-LOBOS, Heitor. (2003). Villa-Lobos. Compact Disc. Orquestra Sinfônica Petrobras Pró Música \& Roberto Tibiriçá Villa-Lobos (regente). Brasil: independente.

VILLA-LOBOS, Heitor. (2003). Villa-Lobos. Compact Disc. Orquestra Filarmônica de Gran Canaria \& Adrian Leaper (regente). Espanha: ASV.

Choros $N^{\circ} 10$ :

VILLA-LOBOS, Heitor. (1996). Alma Brasileira. Compact Disc. New World Symphony \& Michael Tilson Thomas (regente). USA: RCA Victor.

VILLA-LOBOS, Heitor. (1996). Villa-Lobos. Compact Disc. Orquestra Sinfônica do Paraná \& Osvaldo Colarusso (regente). Brasil: independente.

VILLA-LOBOS, Heitor. (1992). Antônio Estévez \& Heitor Villa-Lobos. Compact Disc. Simón Bolívar Symphony Orchestra of Venezuela \& Eduardo Mata (regente). USA: Dorian Discovery.

Bachianas brasileiras $N^{o} 2$ :

VILLA-LOBOS, Heitor. (2005). Villa-Lobos. Compact Disc BIS-CD-1250. Orquestra Sinfônica do Estado de São Paulo \& Roberto Minczuk (regente). Sweden: BIS.

VILLA-LOBOS, Heitor. (1997). Villa-Lobos. Compact Disc 0630-10704-2. Orchestre National de Lyon \& Emmanuel Krivine (regente). France: Erato.

VILLA-LOBOS, Heitor. (1987). Villa-Lobos. Compact Disc CDCC 47901. Royal Philharmonic Orchestra \& Enrique Bátiz (regente). England: EMI Records Ltd.

VILLA-LOBOS, Heitor. (1995). American Portraits. Compact Disc 12471. Berlin Radio Orchestra \& Hans-Dieter Baum (regente). USA: Delta Music Inc.

VILLA-LOBOS, Heitor. (1995). Villa-Lobos. Compact Disc 80393. Cincinnati Symphony Orchestra \& Jesús Lópes-Cobos (regente). USA: Telarc.

Concerto para Violão e pequena Orquestra:

VILLA-LOBOS, Heitor. (1997). Villa-Lobos. Compact Disc 0630-10704-2. Orchestre National de Lyon \& Emmanuel Krivine (regente) \& Roberto Aussel (violão). France: Erato.

VILLA-LOBOS, Heitor. (1985). Villa-Lobos. Compact Disc CDCC 47901. Royal Philharmonic Orchestra \& Enrique Bátiz (regente) \& Alfonso Moreno (violão). England: EMI Records Ltd. 
VILLA-LOBOS, Heitor. (1971). Villa-Lobos. Compact Disc. London Symphony Orchestra \& André Previn (regente) \& Julian Bream (violão). England: EMI Records Ltd.

Sinfonia $N^{\circ} 12$ :

VILLA-LOBOS, Heitor. (2000). Heitor Villa-Lobos. Compact Disc cpo 999 525-2. SWR Radio-Sinfonieorchester Suttgart \& Carl St. Clair (regente). Alemanha: CPO.

\section{PARTITURAS}

VILLA-LOBOS, H. Uirapurú - Symphonic Poem, New York: Associated Music Publishers, 1948, 1 partitura (90 p.) Orquestra.

Amazonas - Poema Sinfônico, Rio de Janeiro: Academia Brasileira de Música, 2010, 1 partitura (73р.) Orquestra.

Choros $n^{\circ} 4$ pour Trois Cors Et um Trombone, Paris: Editions Max Eschig, 1928, 1 partitura (8 p.) Câmara.

Choros $n^{\circ} 6$ pour Orchestre, Paris: Editions Max Eschig, 1955, 1 partitura (178 p.) Orquestra.

Choros $n^{\circ} 6$ pour Orchestre, Rio de Janeiro: Academia Brasileira de Música, 2010, 1 partitura (38 p.) Orquestra.

Choros $n^{\circ} 10$ pour Orchestre et Choeur mixte, Paris : Editions Max Eschig, 1928, 1 partitura (92 p.) Orquestra e côro.

Bachianas brasileiras $N^{o} .2$ - Suite in 4 tempi per orchestra, Itália: G. Ricordi \& C., 1949, 1 partitura (86 p.) Orquestra.

Concerto para violão e pequena orquestra, Rio de Janeiro: Academia Brasileira de Música, 2010, 1 partitura (38 p.) Orquestra.

12 ${ }^{a}$. Sinfonia, 1 Partitura manuscrita, 1957, (129 p.) Orquestra.

\section{ACESSOS À INTERNET}

http://www.academia.org.br/abl/cgi/cgilua.exe/sys/start.htm?infoid=716\&sid=309 -

Academia Brasileira de Letras: Luis Edmundo. Acesso em 15/12/2013. 


\section{INDICE REMISSIVO}

\section{A}

A Sagração da Primavera, 68, 71

Amazonas, 8, 43, 45, 52, 68, 69, 74, 79, 80, 83, 89, 95, $97,98,99,100,101,102,103,104,191,192,193$, $195,196,198,200,201,204,211,212,223,224,225$, $226,301,302,304,324,325,326,328,344,385,389$

Aranha, 71

Arnold Schönberg, 67

\section{B}

Bach, 149

Bachianas:

$\mathrm{N}^{\circ} .10,8,43,138,139,141,142,143,144,145,146,147$, $148,192,193,195,196,200,202,205,207,214,246$, $247,249,250,252,253,254$

$\mathbf{N}^{\circ} .2,8,17,43,69,75,150,151,152,153,154,155,156$, $157,158,159,160,192,193,196,197,200,202,206$, $207,214,215,255,257,259,260,261,262,263,264$, 266

$\mathrm{N}^{\mathrm{o}} .6,8,43,45,59,73,117,119,120,121,122,123,124$, $125,126,127,128,129,130,131,132,133,134,135$, $136,137,138,191,192,193,195,196,198,200,202$, 204, 207, 210, 213, 214, 218, 219, 236, 237, 238, 240, $241,242,243,245,317,318,319,320,321,329,330$, $331,332,333,334,336$

Balé, 41, 42, 43, 45, 69, 139, 342

Balés, 8, 40, 82, 83

Bartók, 24, 68, 69, 70, 71, 72, 73, 74, 75, 76, 77

\section{C}

Calado, 106

Choros, 8, 10, 40, 41, 43, 45, 52, 55, 56, 57, 59, 60, 61, $62,70,72,73,74,78,79,83,105,107,108,109,110$, $111,112,113,114,115,116,117,118,119,120,121$, $122,123,124,125,126,127,128,129,130,131,132$, $133,134,135,136,137,138,139,140,141,142,143$, $144,145,146,147,148,149,150,151,163,191,192$, 193, 195, 196, 198, 200, 201, 202, 204, 205, 206, 207 , $210,212,213,214,215,217,218,219,227,228,229$, $230,231,232,233,234,235,236,237,238,240,241$, $242,243,245,246,247,249,250,252,253,254,305$, 306, 307, 308, 309, 310, 311, 313, 314, 316, 317, 318, $319,320,321,329,330,331,332,333,334,336,340$, $341,342,344,345$

Choros $\mathbf{N}^{\circ} .4, \mathbf{N}^{\mathrm{o}} .4,8,43,61,73,76,108,109,110,111$, $112,113,114,115,116,117,191,192,193,195,198$, $200,201,204,206,210,212,213,227,228,229,230$, $231,232,233,234,235,305,306,307,308,309,310$, $311,313,314,316,344,375$

Clarinete, 96, 97, 152, 153, 157, 162, 164, 165, 166, $167,170,178,181,267,270,271,272,285,289,290$

Concerto, 8, 25, 43, 45, 46, 57, 58, 73, 75, 76, 77, 78, 79, $161,162,163,164,165,166,167,168,169,192,193$, 194, 196, 197, 201, 202, 206, 207, 266, 267, 269, 270, $271,272,344,345,387,388$
Contrafagote, 87, 97, 172, 173, 175, 176, 177, 178, 180, $181,182,185,284,285,289,290,291,292,296$ Cordas, 69, 88, 97, 141, 152, 163, 171, 174, 281

\section{D}

Darius Milhaud, 69, 73

Debussy, 25, 53, 61, 67, 68, 69, 70, 72, 140, 344

\section{$\mathbf{E}$}

Extensão, 21

\section{F}

Fagote, 152, 153, 157, 159, 162, 164, 165, 167, 171, 173, $177,178,181,185,268,269,270,271,272,279,284$, $285,289,296$

Flexibilidade extrema, 27

\section{G}

Glissandos, 24, 200, 201, 202, 203

Gomes, 344

\section{I}

Igor Stravinsky, 68, 70, 71, 73

Intervalo, 232, 310

\section{$\mathbf{L}$}

Luiz Heitor, 149

\section{M}

Mário de Andrade, 70, 71, 77, 140

Metais, 1, 2, 5, 7, 8, 17, 18, 36, 37, 39, 40, 41, 42, 52, 56, $57,58,89,90,94,102,104,117,133,138,142,171$, $172,176,177,180,182,186,190,191,192,193,195$, $225,227,274,275,283,284,288,289,292,304,305$, $328,385,393$

Música de Câmara, 40, 342

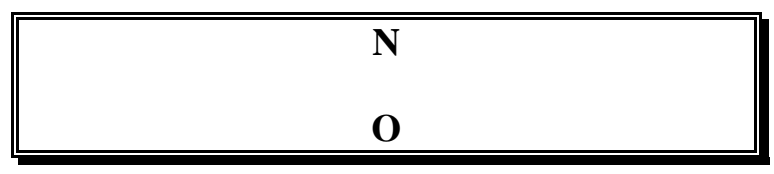

Orquestra, 5, 16, 25, 75, 77, 78, 117, 118, 139, 163, 169, $266,267,269,270,271,272,344,345,386,389,394$

Ostinato, 90, 91, 113, 114, 121, 126, 129, 131, 134, 144, $145,154,155,156,158,183,242,249,253,294$ 
Villa-Lobos e os metais graves sinfônicos:

Um estudo dos elementos técnicos específicos

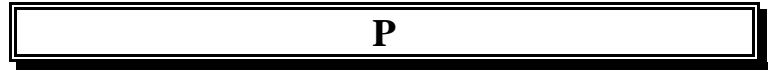

Petruschka, 72

\section{$\mathbf{R}$}

Ritmo, 221, 222, 223, 224, 226, 230, 232, 233, 235, 237, $238,241,242,243,249,254,260,261,263,264,265$, 266, 270, 277, 279, 282, 297, 299, 300, 302, 304, 309, $311,313,316,319,320,322,323,324,325,326,328$, $331,332,334,335,337$

Rotor, 215

\begin{tabular}{|c|}
\hline $\mathbf{S}$ \\
\hline
\end{tabular}

Sagração da Primavera, 72

Sinfonia, 8, 16, 22, 23, 41, 43, 44, 45, 46, 69, 70, 74, 75, $76,77,79,97,170,171,172,173,174,175,176,177$, $178,179,180,181,182,183,184,185,186,192,193$, 194, 196, 197, 198, 201, 203, 207, 210, 274, 275, 277 , $280,281,282,283,284,285,286,287,288,289,290$, 291, 293, 294, 296, 297, 347, 348, 393

Straight Mute, 218

\section{T}

Timbre, 53, 55, 56, 134, 154, 157, 218, 245, 318, 331, 396

Trombone baixo, 9, 11, 171, 173, 174, 181, 182, 204, 205, 206, 280, 290, 291

Trombone tenor, 9, 11, 171, 195, 196, 207, 208, 279

Trompa, 153, 154, 159, 162, 164, 165, 167, 177, 185, 270, 272, 284, 297

Trompete, 56, 121, 122, 137, 140, 147, 242, 340

Tuba, 9, 10, 45, 47, 56, 88, 97, 99, 170, 171, 172, 173 , $175,178,180,181,182,185,195,198,204,205,208$, $285,288,289,290,291,296,386,392$

\section{$\mathbf{U}$}

Uirapurú, 8, 43, 45, 68, 69, 79, 83, 85, 86, 88, 89, 90, 91 , $92,93,94,191,192,193,195,196,198,200,201$, $211,212,219,221,222,297,299,300,322,323,394$

\section{$\mathbf{V}$}

Violão, 8, 78, 163, 164, 165, 166, 167, 168, 169, 201 , 202, 206, 207, 266, 267, 269, 270, 271, 272

Violino, 152, 153, 154, 158, 183, 293

Violoncelo, 8, 43, 46, 53, 57, 58, 66, 68, 69, 77, 88, 89, $91,125,151,152,153,154,167,171,175,177,178$, $181,185,255,257,272,284,285,289,290,296$ 
Villa-Lobos e os metais graves sinfônicos:

Um estudo dos elementos técnicos específicos

\section{TRECHOS ORQUESTRAIS PARA TROMBONE E TUBA}

Universidade de São Paulo

Escola de Comunicação e Artes 


\section{INTRODUÇÃO: O TROMBONE E A TUBA NA ORQUESTRA SINFÔNICA}

Enquanto o trombone tenor ${ }^{114}$ conhecido na atualidade fixou-se em seu formato desde a última metade do século XVI, a tuba surgiu pôr volta de $1835^{115}$, em Berlim, inventada pôr Wilhelm Wieprecht e construída pôr Johann G. Moritz. Estes possuem seu lugar garantido na vida musical dos centros culturais tanto europeus quanto americanos, onde são utilizados em grande escala de gêneros. Historicamente o primeiro compositor que escreveu para o trombone em música de concerto foi Giovanni Gabrieli (1557-1612) e a partir de então tem participado ostensivamente de todo o repertório sinfônico praticado pelas orquestras.

Por volta de 1800, a orquestra atingiu o tamanho e as proporções que conhecemos na atualidade. Alguns compositores, como Berlioz, escreveram para grandes orquestras. Este inclusive introduziu novos instrumentos como o flautim e a tuba. Dentro da listagem de compositores que acreditaram numa orquestra maior, ainda podemos citar Verdi, Wagner, Mahler e Richard Strauss. Seus experimentos com larga orquestração mostraram o rumo que o séc. XX tomaria. Wagner foi tão longe que acabou por inventar um novo instrumento: a tuba wagneriana. Strauss criou o alphorn $^{116}$. Sabemos que Villa-Lobos também criara instrumentos, mas estes não pertenceram à família dos metais graves.

Para a execução das obras deste vasto repertório sinfônico, trombonistas e tubistas necessitam de um estudo direcionado e ainda especial em relação aos efeitos e mudanças na qualidade sonora - estas inerentes a qualquer compositor. Exemplos destas alterações são facilmente conferidos em: Mozart e Beethoven límpida, e nada gritante, porém Brahms mais ardente; brilhante para Bruckner ${ }^{117}$, Elgar e Holst; apaixonado para Mahler e Strauss, eriçado e pontiagudo para Stravinsky e imponente em se tratando de Ravel ${ }^{118}$. Contudo o

\footnotetext{
${ }^{114}$ Assumiremos a definição de Kleinhammer e Wick para trombone tenor: .500” de calibre e sem rotor.

115 Contudo, o modelo mais comum empregado na orquestra foi desenvolvido por volta de 1845, pelo belga, Adolphe Sax.

${ }^{116}$ um instrumento popular feito de madeira e com até 12 metros de comprimento. Este instrumento é tocado por uma tubista.

117 Também escreveu solos orquestrais para a tuba.

${ }^{118}$ WICK, Denis: TROMBONE TECHNIQUE, 19 - pp. 76-80.
} 
aspecto mais surpreendente é a dinâmica: Weber, muitas vezes, escreveu " $f f$ ", mas sabemos que esta foi escrita para uma orquestra de ópera, tocando num fosso, com trombone baixo pequeno, tenor e alto de pouca sonoridade, ou seja, toca-se uma dinâmica abaixo do grafado.

Na primeira metade do século XIX Berlioz deixou para os trombones as mais originais e variadas formas de sonoridade. Exemplos claros dessa faceta sonora estão em:Sinfonia Fantástica com terrificante poder ou com grande expressão na A infância de Cristo e com majestade e aterradora inspiração fazendo soar oito trombones em notas pedal e uníssono, na Grande Missa dos Mortos. Wagner, por sua vez inovou, utilizando trombones em efeitos dramáticos, particularmente no "Anel". Tanto Berlioz quanto Wagner deixaram solos escritos para a tuba. Essa faceta seria semelhante em Weber, que escreveu para uma orquestra de fosso.

Dvorak nos deixou belos efeitos harmônicos em "pp" ou mesmo ainda em frases completas. Em Dvorak, o trombonista necessita de uma qualidade sonora ardente, ainda que ressonante. No entanto, há exemplos de grafia em dinâmicas reversas dentro das peças do compositor Jean Sibelius. Sibelius por várias vezes escreveu dinâmicas mais suaves que o necessário para um equilíbrio, pois sua própria orquestra, a qual primeiramente executava suas peças, era mal equipada na seção de cordas. Exemplo desse argumento veremos no último movimento da Segunda Sinfonia a passagem para dois trombones (8 compassos antes de $[R])$ está grafada na parte em " $m p$ " mas deve ser tocada, no mínimo, com " $\boldsymbol{f}$ ".

Porém o fato em tirar o trombone de sua posição de coadjuvante ao fundo da orquestra e colocá-lo em destaque como solista só foi possível com Mahler. Exemplo dessa façanha pode-se conferir no primeiro movimento de sua Terceira Sinfonia, com partes para um naipe de três ou quatro trombonistas. Este em sua maestria escreveu, precisamente, tudo aquilo que pretenderia, ou seja, trombonistas e tubistas sabem, via a parte impressa, exatamente o que devem tocar a cada momento.

Em termos de técnica instrumental, Schöenberg escreveu as mais difíceis partes para trombone, as quais se acreditaram jamais serem possíveis de execução em concerto. Suspeita-se que foram escritas em estado de total ignorância e esperança, ou ainda a 
possibilidade da cooperação de um virtuoso trombonista em sua época. Atualmente a técnica necessária para a execução de suas peças oferecem poucas dificuldades a um bom executante.

Ainda na era moderna, Berg em sua Três Peças Orquestrais e nas óperas Wozzeck e Lulu escreveu para o trombone trechos como nunca ventilados anteriormente. Em seus extremos se vê tanto tessitura como na virtuosidade extrema. Há uma crença entre os trombonistas que suas obras foram concebidas ao piano, embasadas em conhecimento algum do instrumento. Têm sonoridade brilhante nos seus contextos, contudo, podem ser bem executadas mesmo que, a primeira vista, pareçam tanto fora da técnica do instrumento quanto impossíveis.

Com tantos argumentos técnicos, o que o instrumentista deve buscar dentro do repertório sinfônico é a justa e embasada interpretação de todos os compositores. Interpretar segundo Magnani é o ato de descobrir e comunicar os significados que estão ocultos numa série de significantes fundamentais, perante a atividade técnica em conjunto com a intuição que norteia o reconhecimento dos símbolos, no caso de músicos, sonoros (MAGNANI, 1989, p. 61). Seguindo esta premissa, interpretar significa tomar decisões interpretativas, técnicas ou intuitivas, que visam transformar em sons os símbolos grafados na partitura e/ou nas partes individuais. Em termos específicos, na interpretação o instrumentista se utiliza de técnicas e intuições aplicadas à sonoridade, articulação, dinâmica e ritmos.

Em última estância, as diferenças estéticas e filosóficas das correntes escolásticas serão unificadas pelas mãos e batuta do maestro. Este terá o direito em exigir uniformidade rítmica da obra executada ou até mesmo uma sonoridade que esteja fora das características físicas dos instrumentos. Os desafios para o instrumentista de orquestra ultrapassam os limites da técnica instrumental e da capacidade de trabalho em naipe.

Esta compilação de trechos seguiu o padrão internacional da linha de estudos de trechos orquestrais:

1.) Não se determinou os compassos entre os trechos exibidos;

2.) Cada trecho, em especial, tem clave, armadura de clave, fórmula de compasso, dinâmica, articulação e andamento; 
3.) A sequência de trechos não acompanha a mesma sequência da peça, nem se numerou os compassos.

4.) Se necessário, criou-se a guia melódica ou rítmica do instrumento solista, ou mais próximo, que serviria de orientação à contagem do músico;

5.) Informou-se a duração das fermatas a fim de proporcionar uma ideia da quantidade de ar necessária para a execução dessa nota longa.

6.) Os movimentos receberam numeração romana para sua identificação;

7.) Considerou-se o trombone tenor como sendo o $1^{\circ}$ e o $2^{\circ}$ do naipe. $\mathrm{O}$ trombone baixo seria o $3^{\circ}$ (ou $4^{\circ}$ se existir orquestração para 4 trombonistas). 
Trombone

\author{
Uirapuru \\ Poema Sinfônico
}

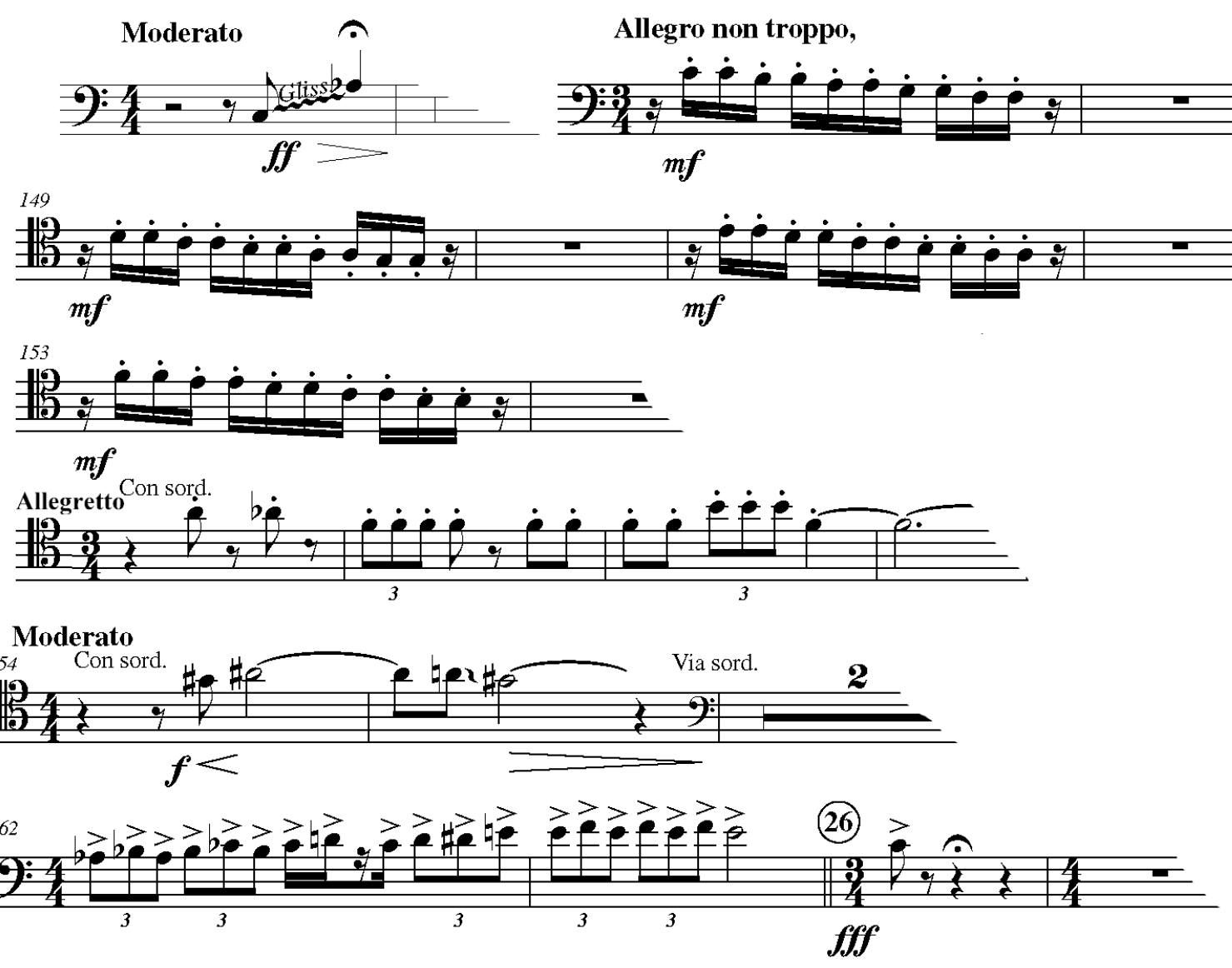


Trombone 3

Moderato
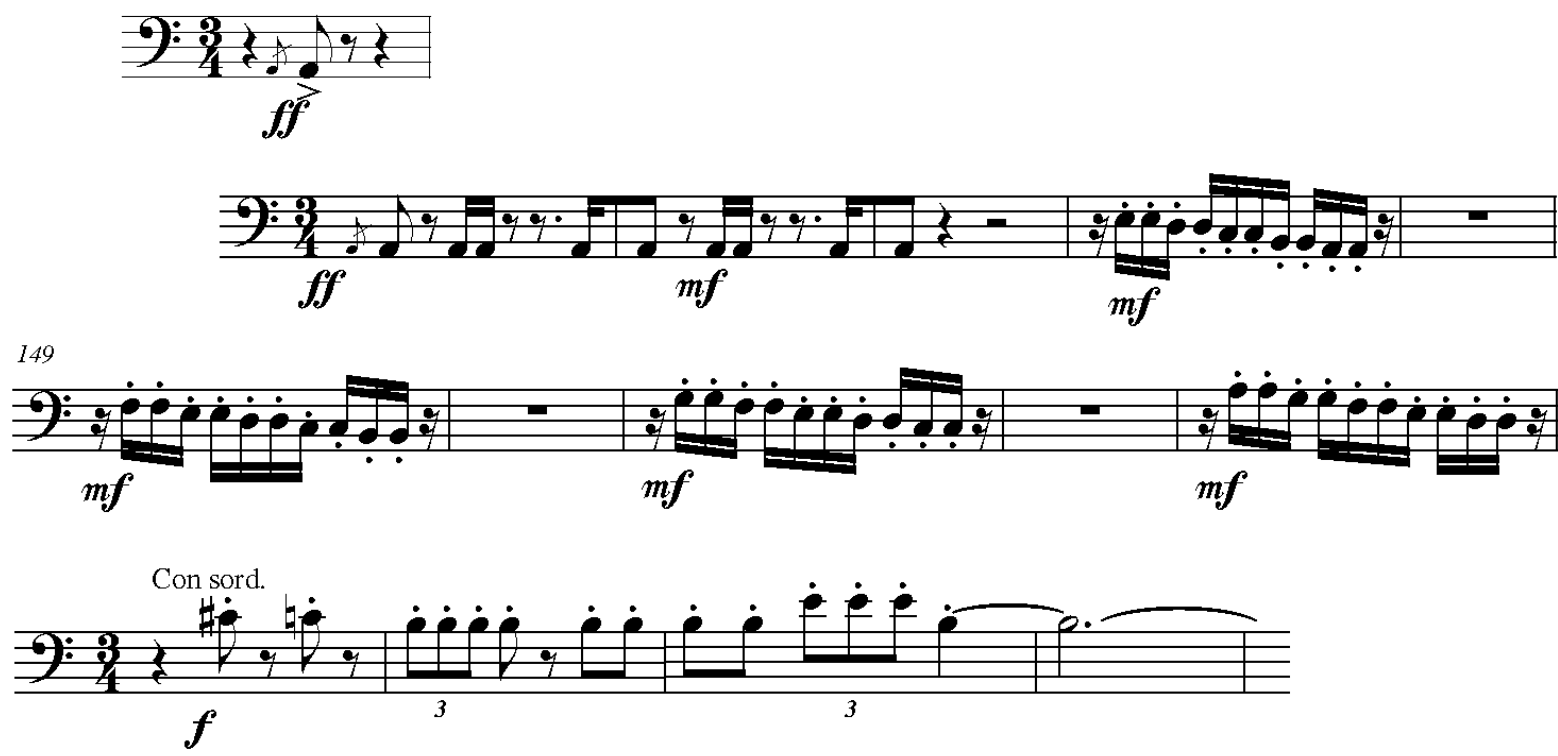

(18) piú mosso
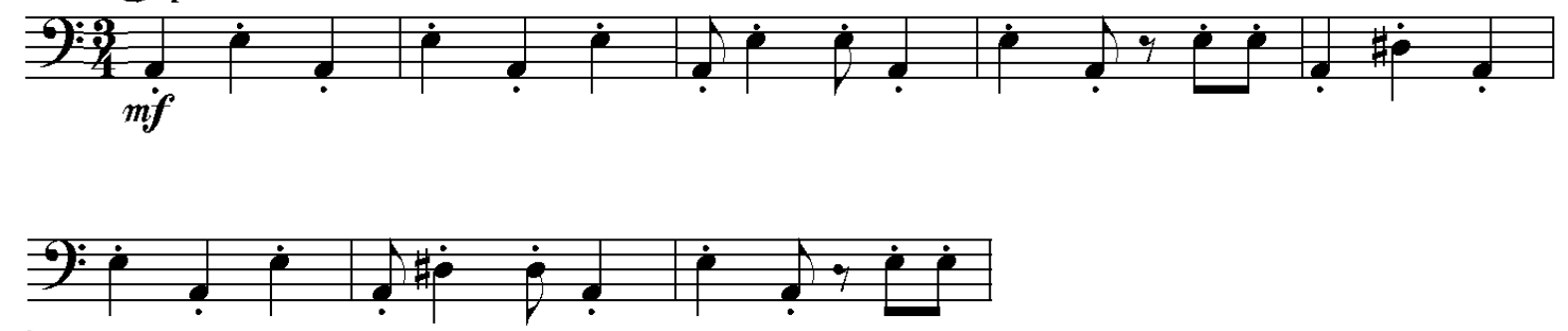

Universidade de São Paulo

Escola de Comunicação e Artes 
Villa-Lobos e os metais graves sinfônicos:

Um estudo dos elementos técnicos específicos

Tuba

Uirapuru

Poema Sinfônico

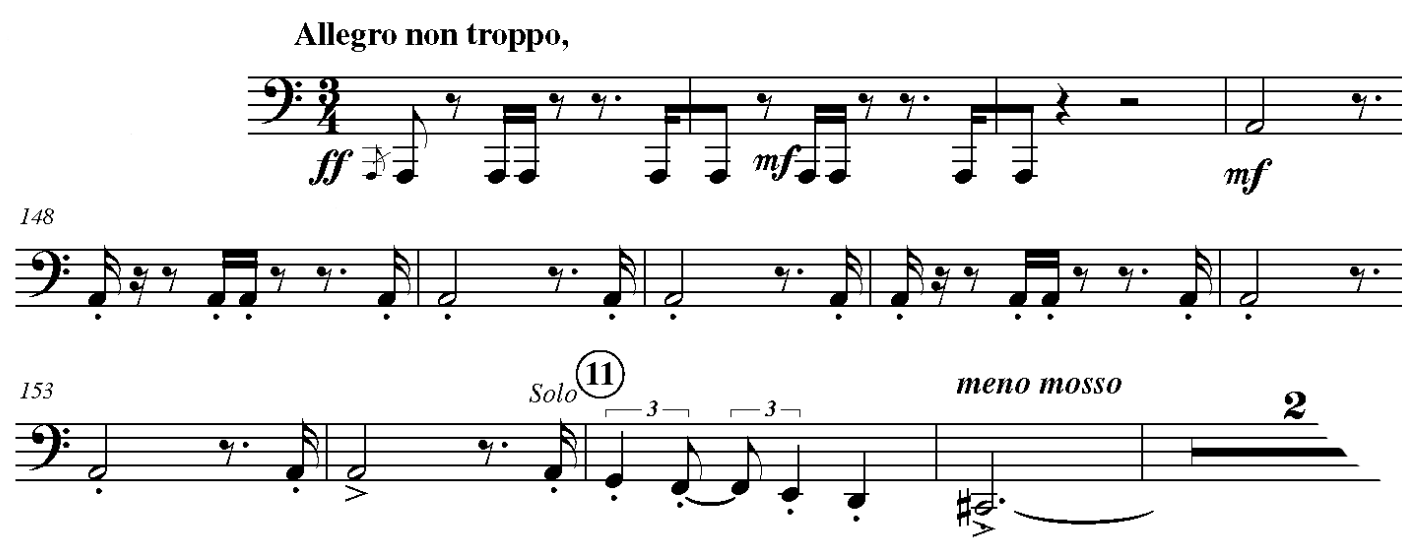

(25)

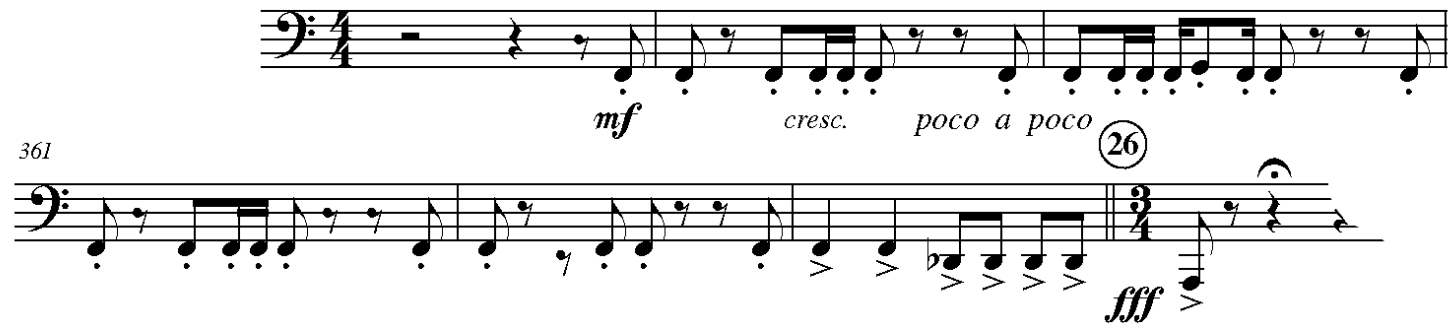


Villa-Lobos e os metais graves sinfônicos:

Um estudo dos elementos técnicos específicos

Trombone

\section{AMAZONAS}

Sobre um conto indigena de Raul Villa-Lobos

Heitor Villa-Lobos
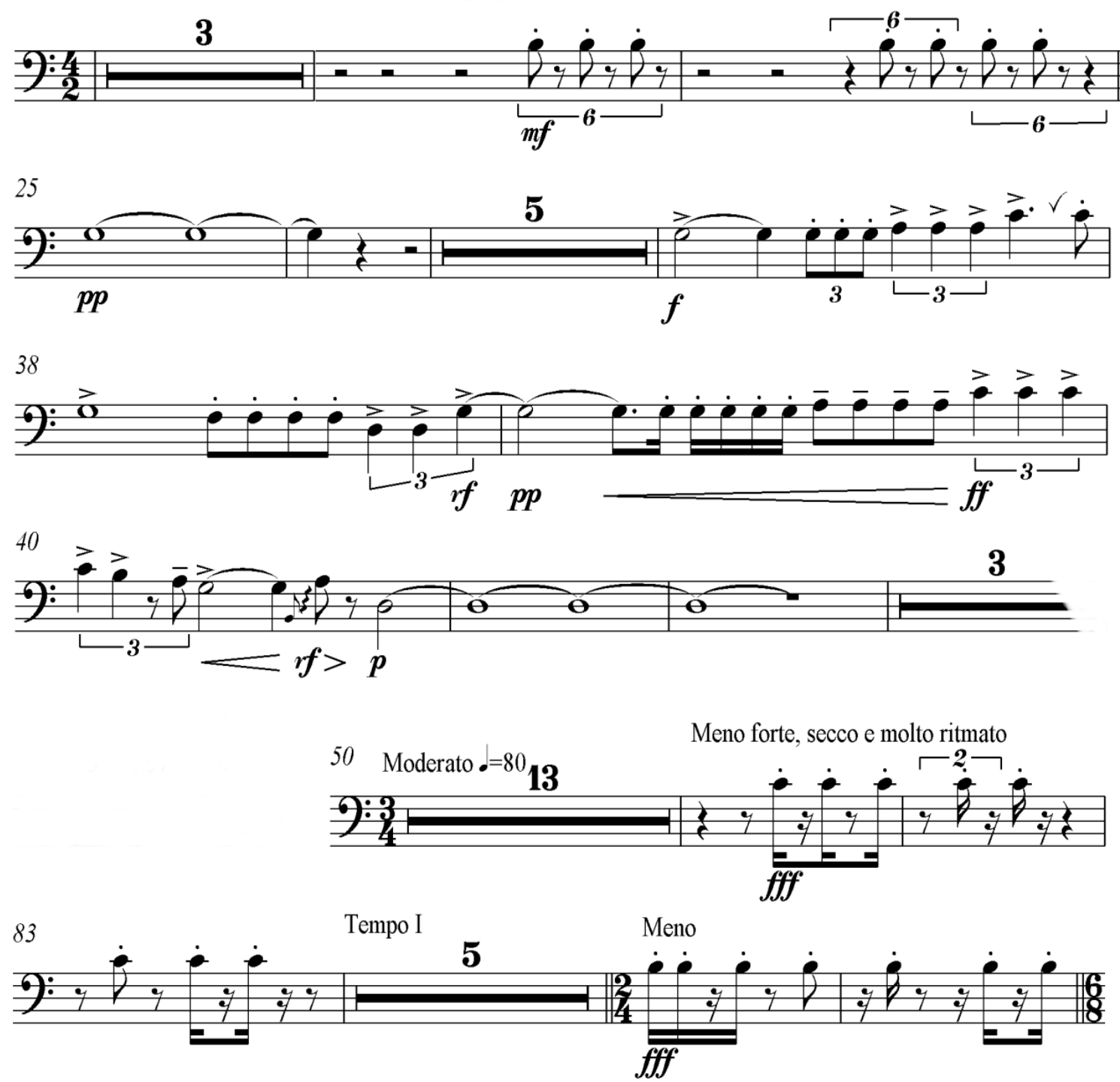

91 Tempo I

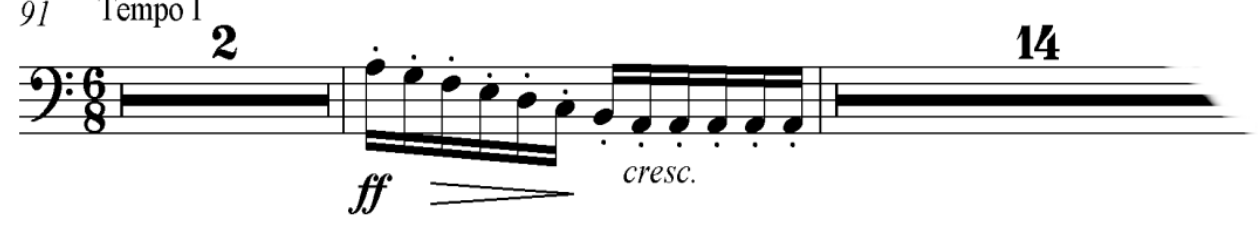


Villa-Lobos e os metais graves sinfônicos:

Um estudo dos elementos técnicos específicos

2

Trombone
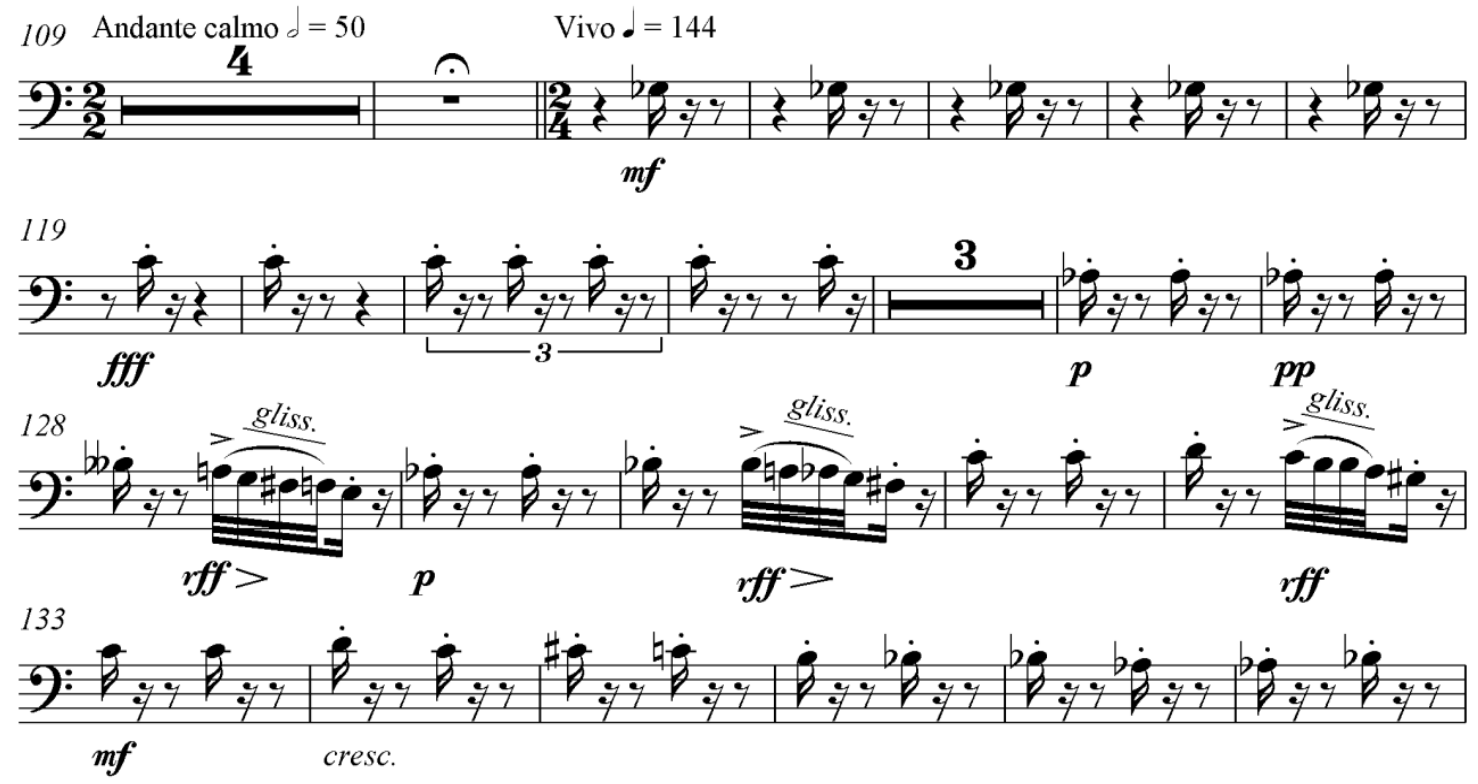
139
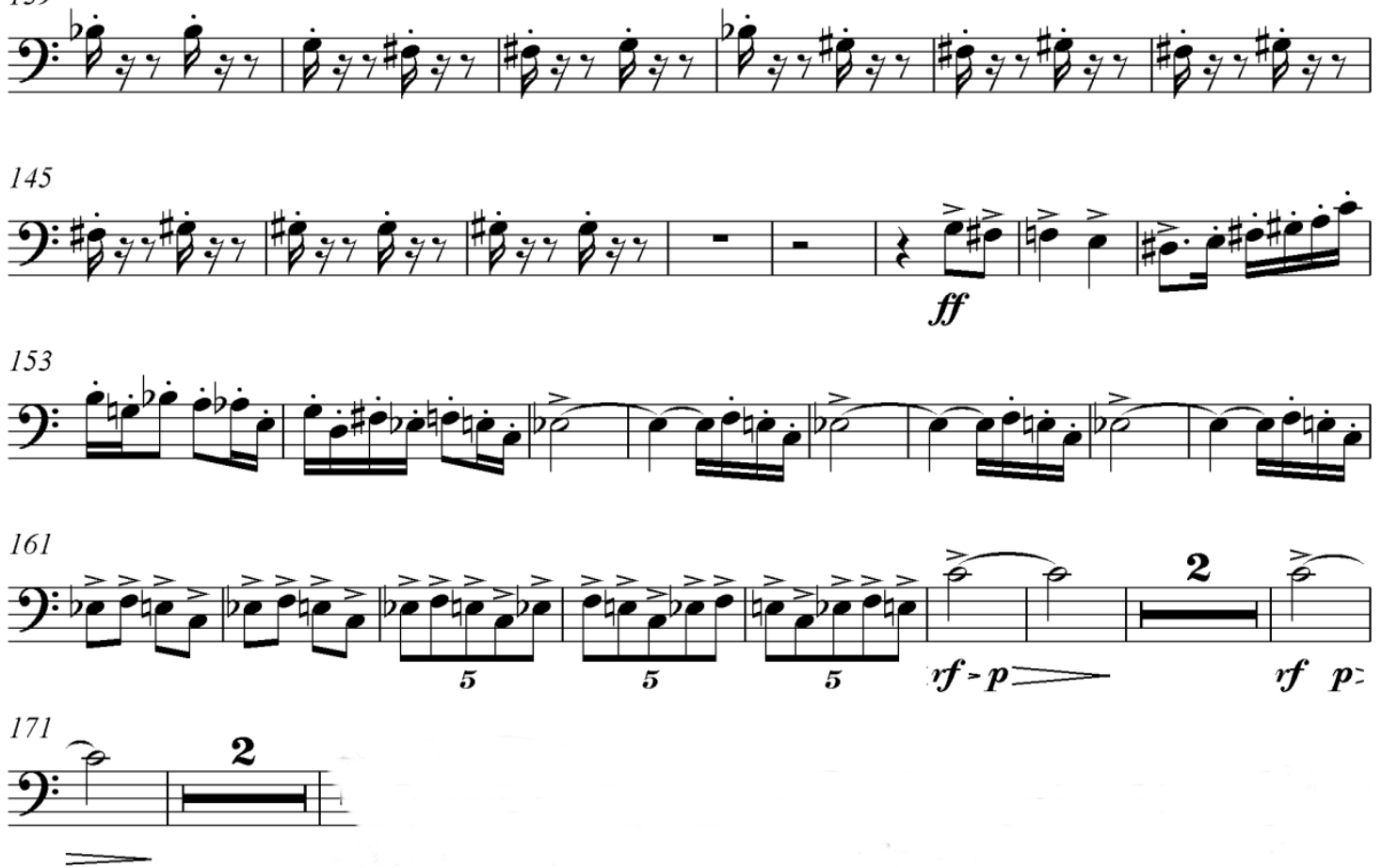
Villa-Lobos e os metais graves sinfônicos:

Um estudo dos elementos técnicos específicos
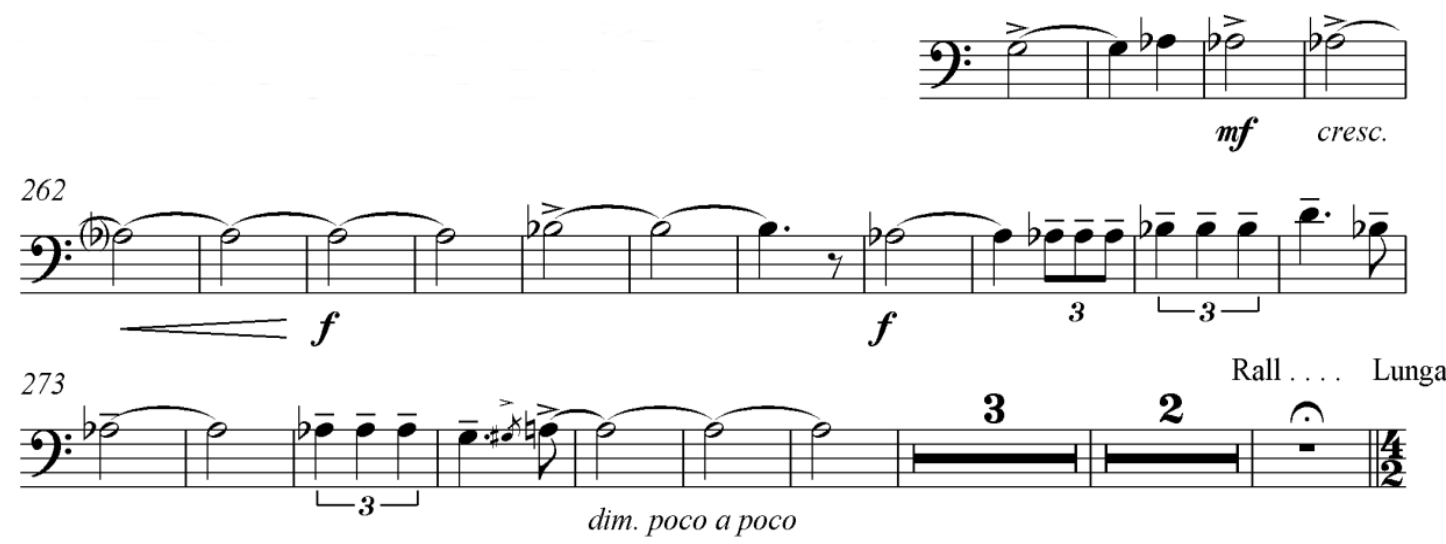

286 Adagio $d=60$

$\frac{6}{2}: \frac{4}{2}$

\section{3}
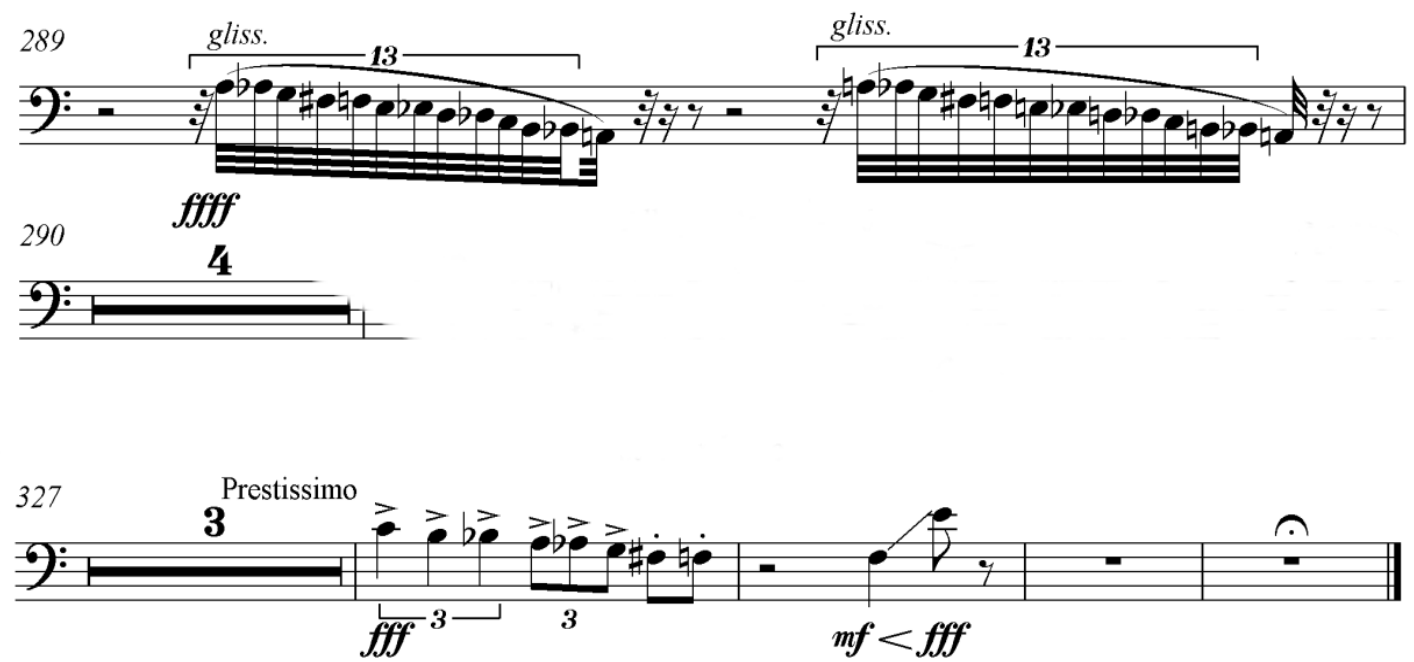

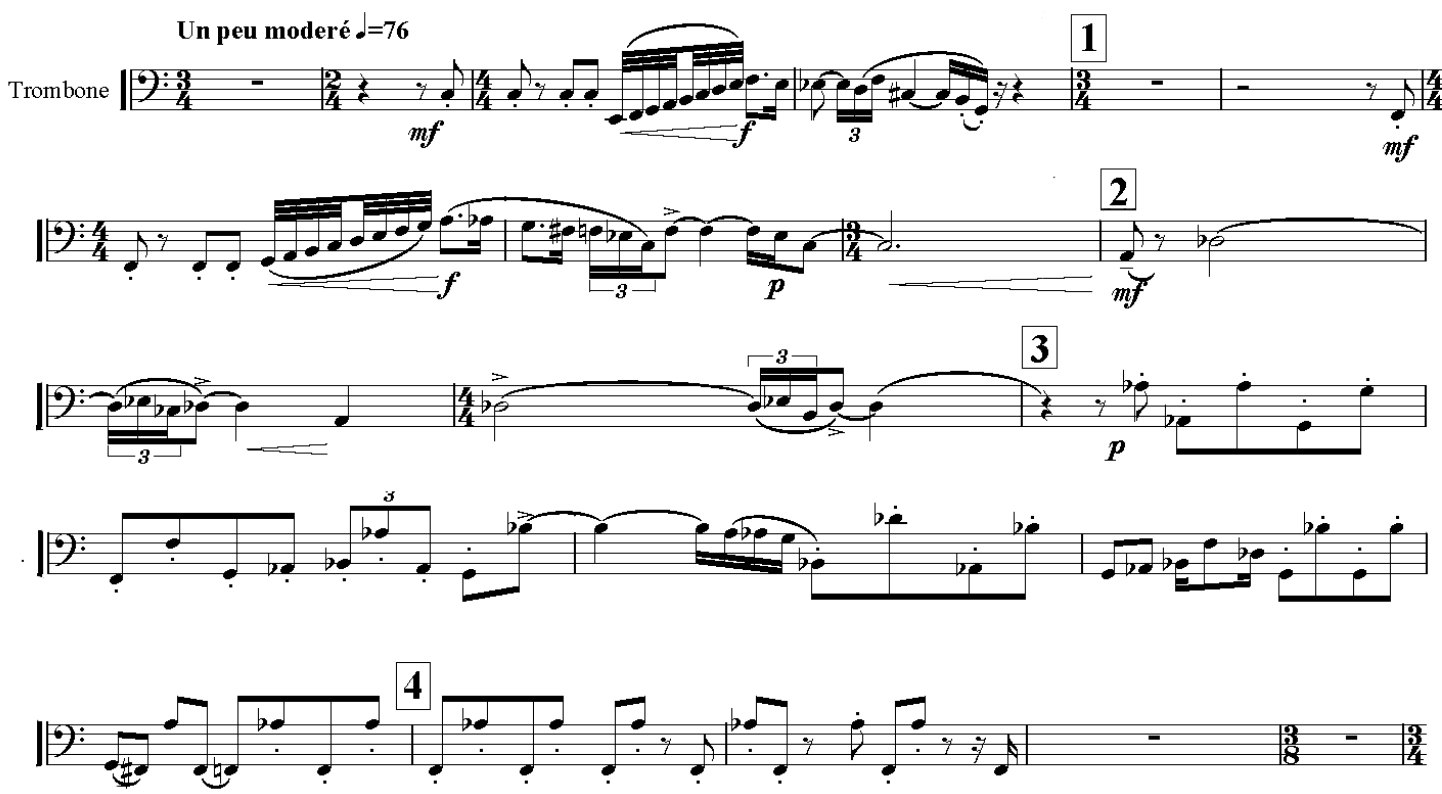

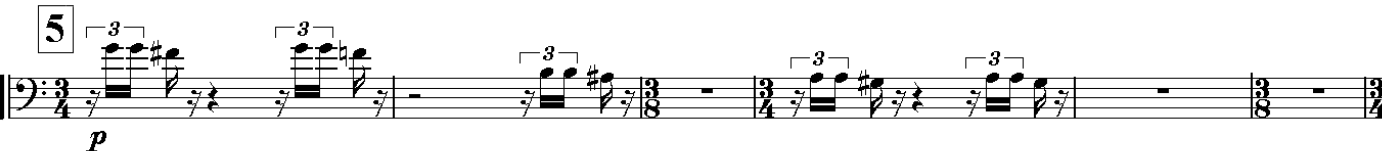

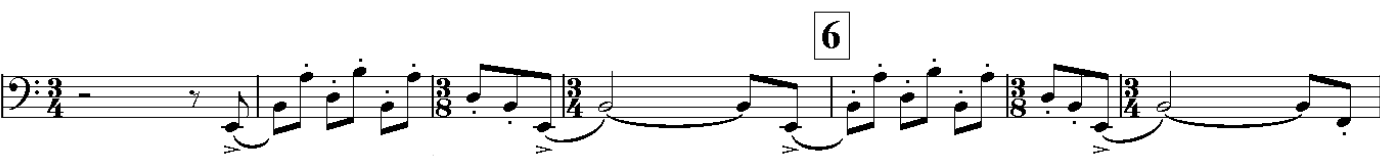

7

ए:

10 :

9

10

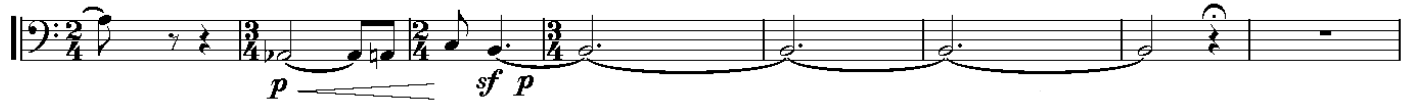

11

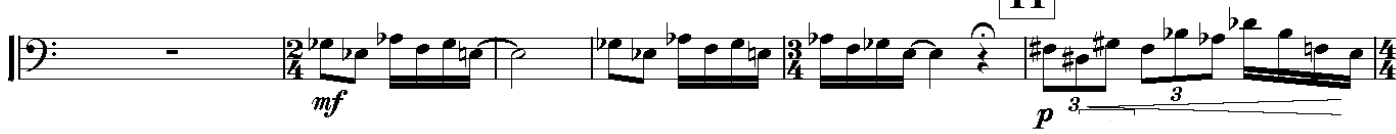

12

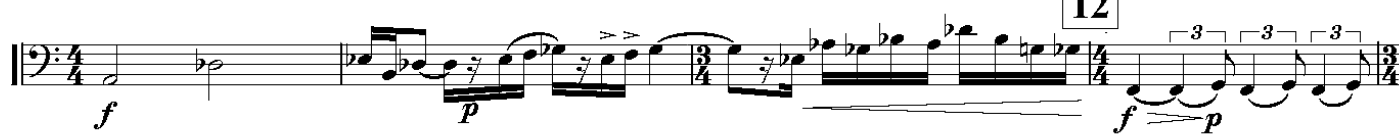


Villa-Lobos e os metais graves sinfônicos:

Um estudo dos elementos técnicos específicos

Choros $n^{\circ} 4$
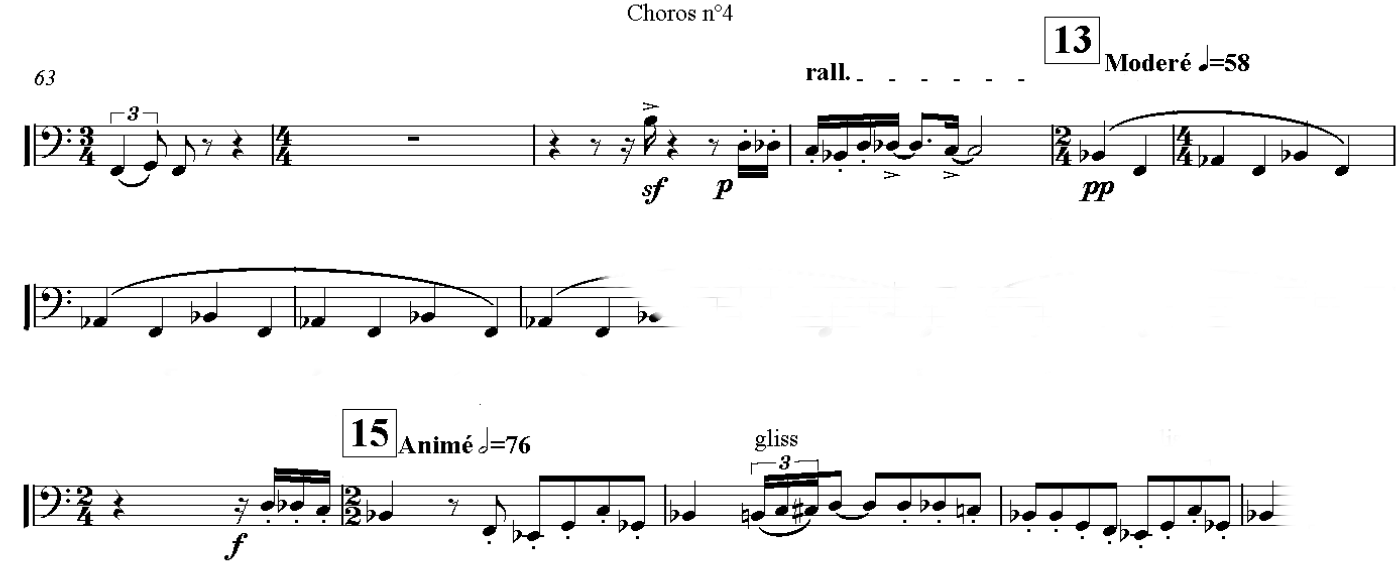

$177_{\text {A ter }}$
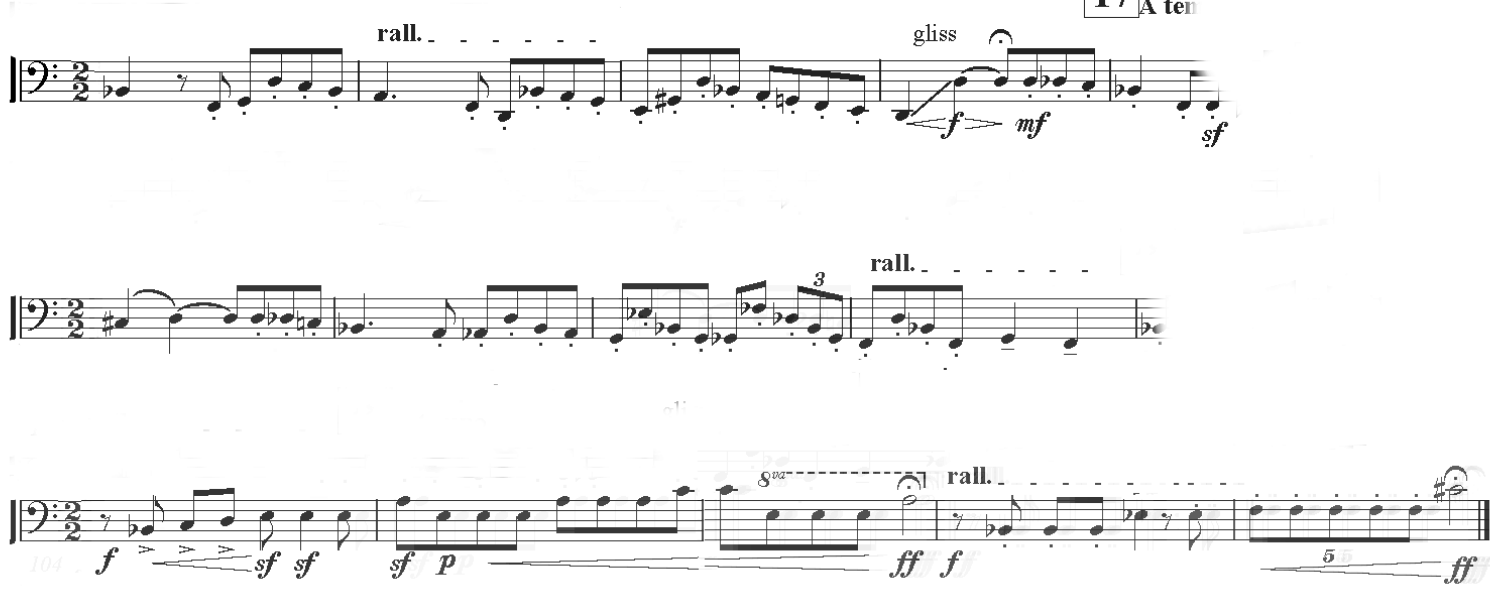

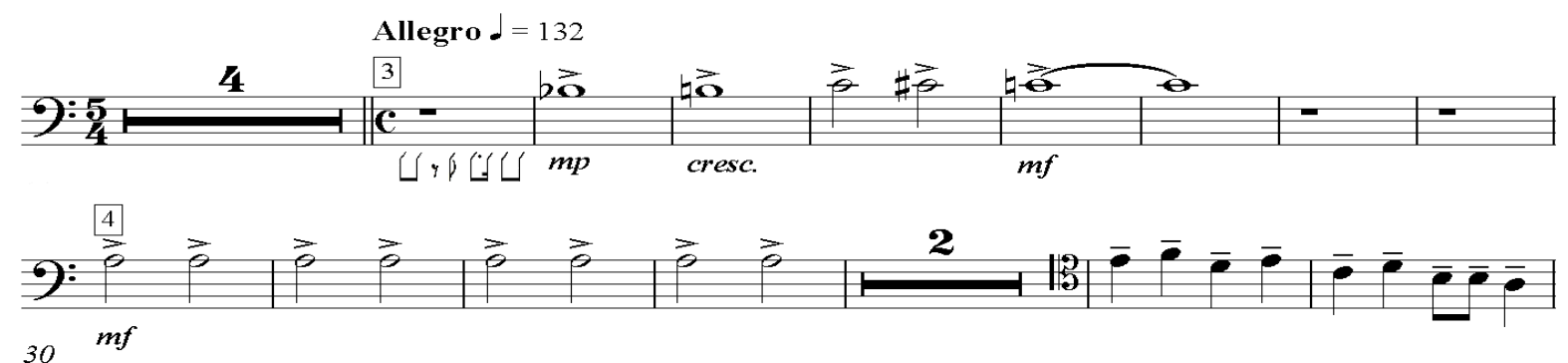
$30 \quad m f$
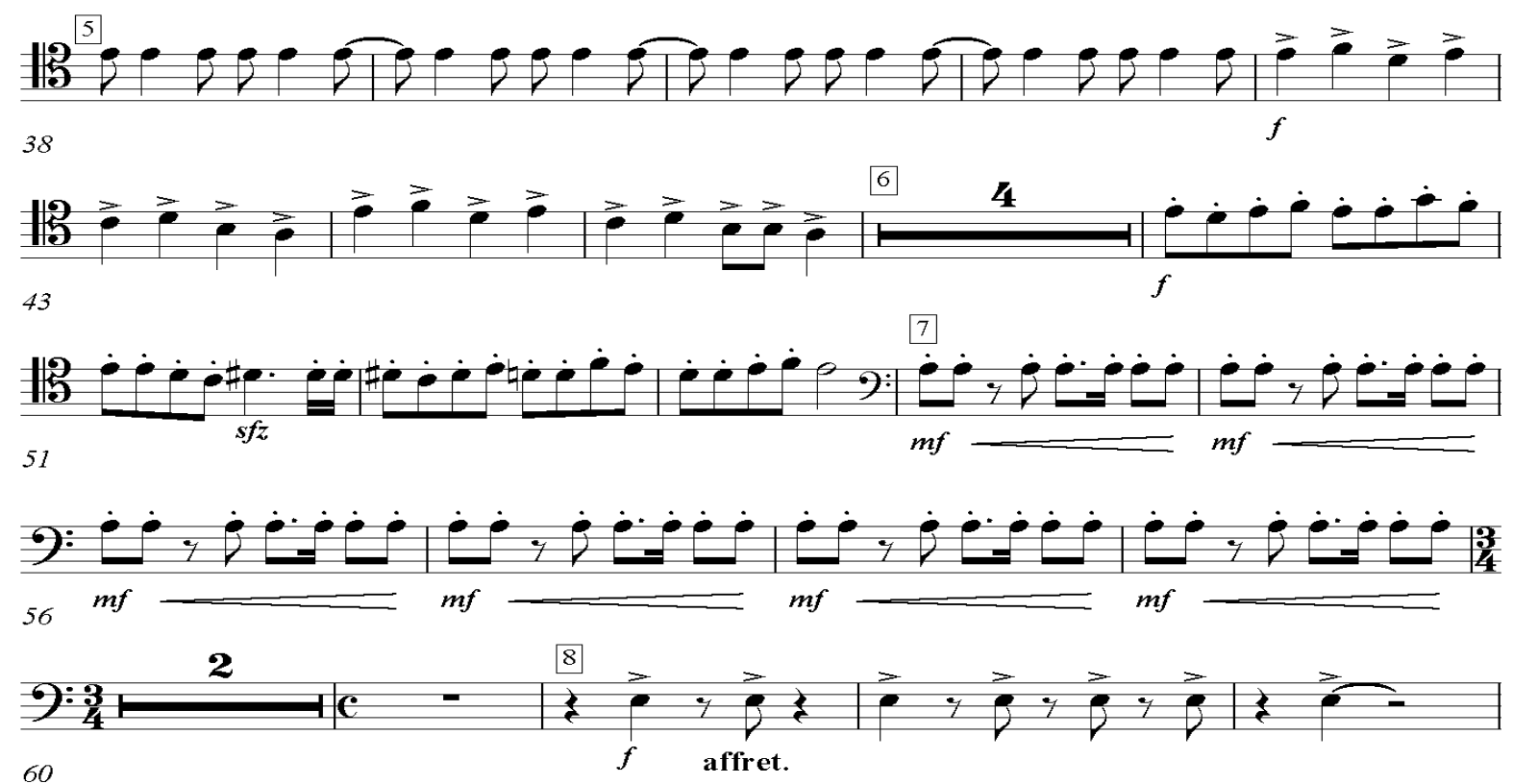
60
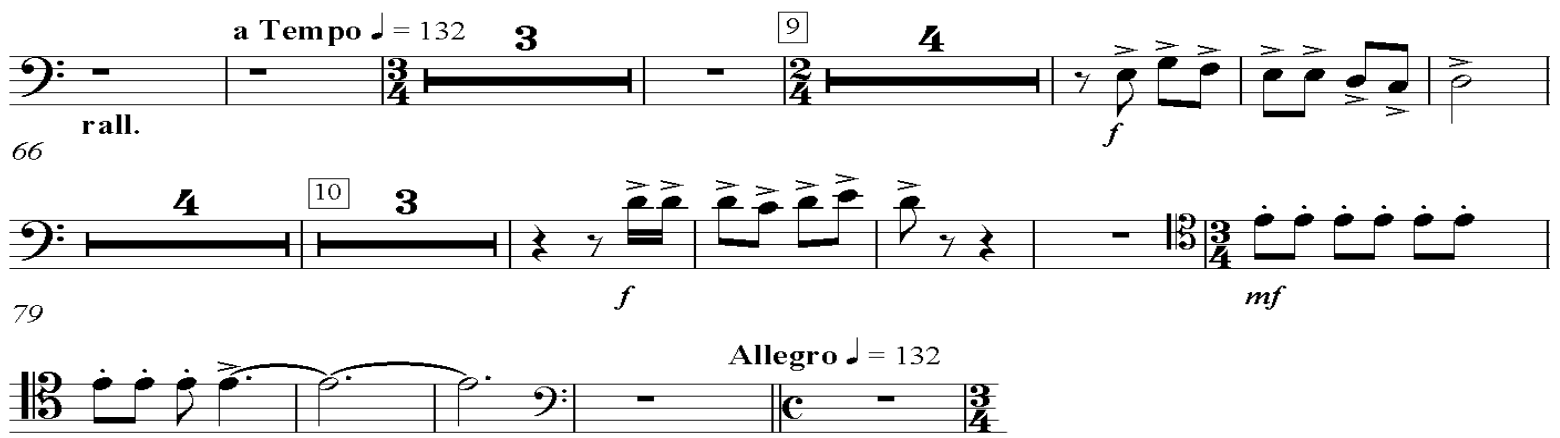

91

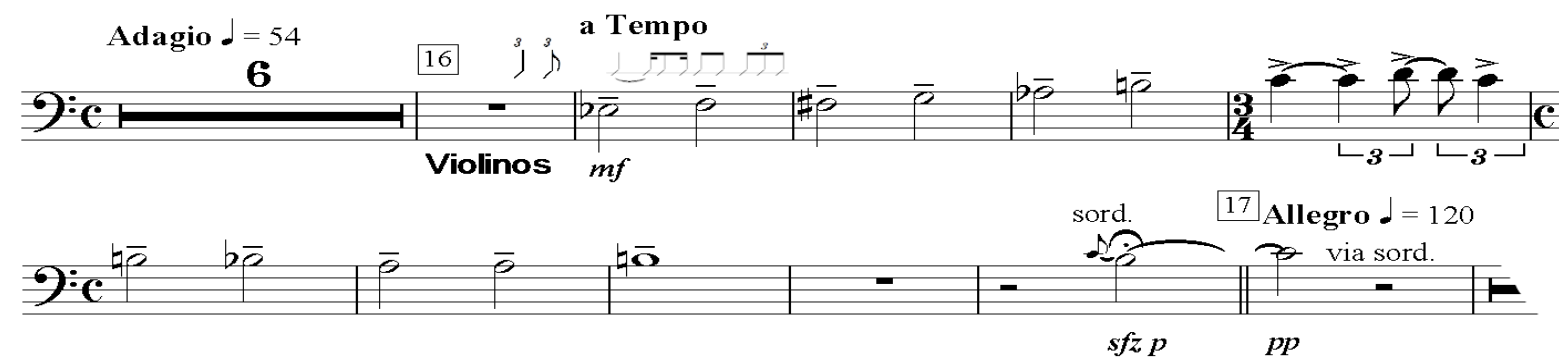


Villa-Lobos e os metais graves sinfônicos:

Um estudo dos elementos técnicos específicos

2

Chorus N.6 - Trombone 1
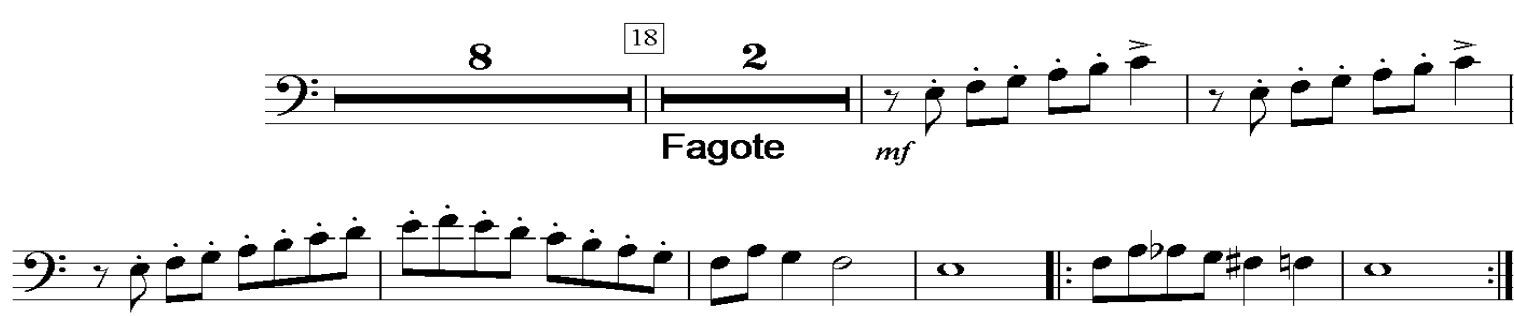

185

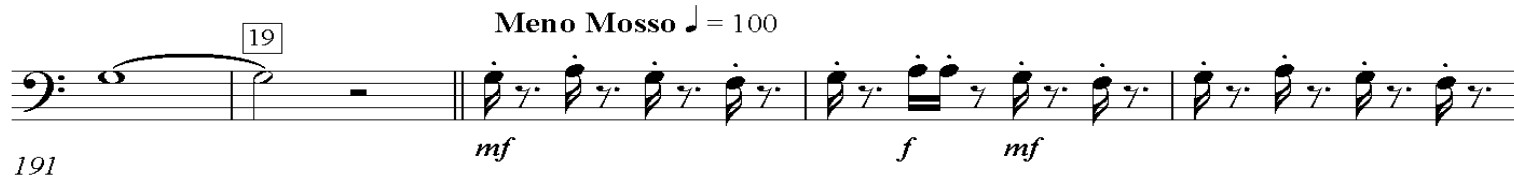

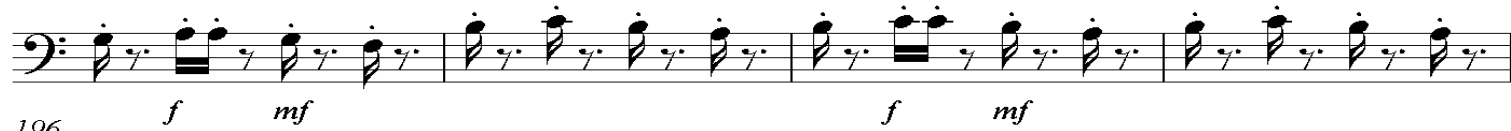
$19620 \mathrm{fm}$

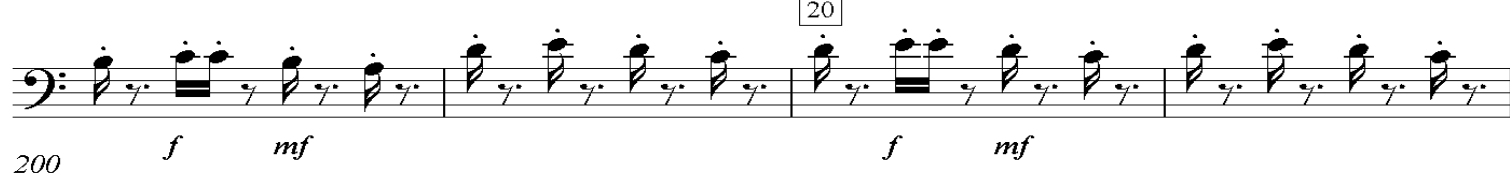

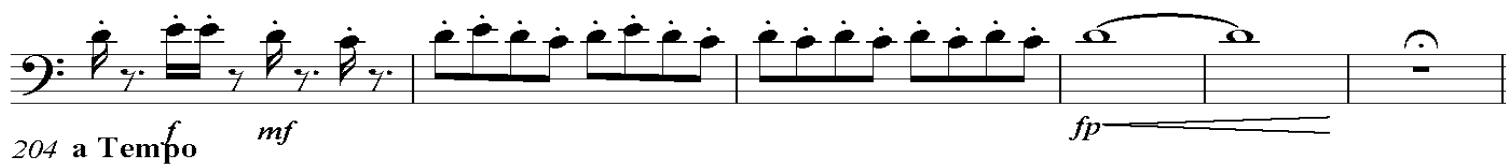

21

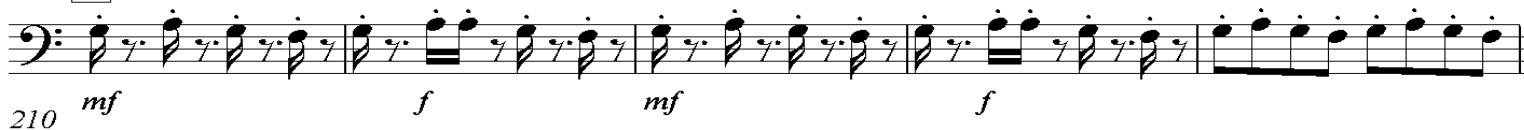

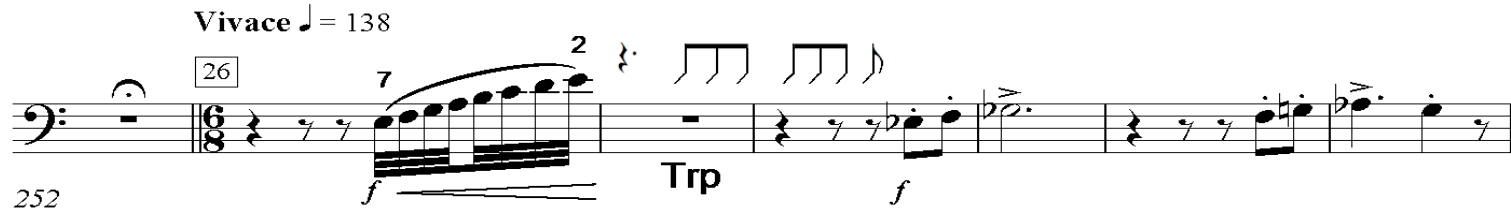

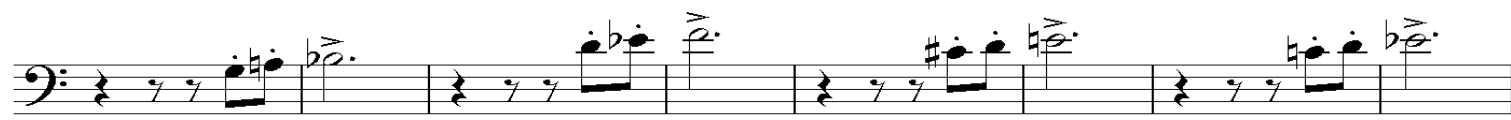
259

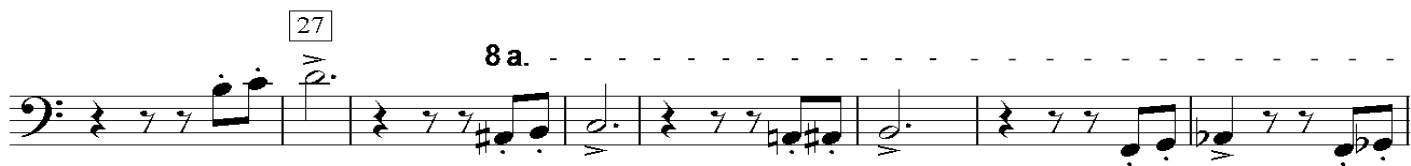
267

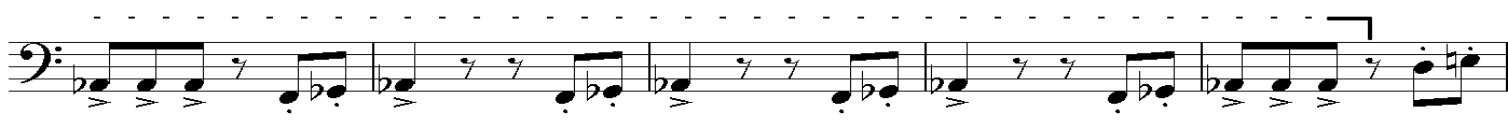
275

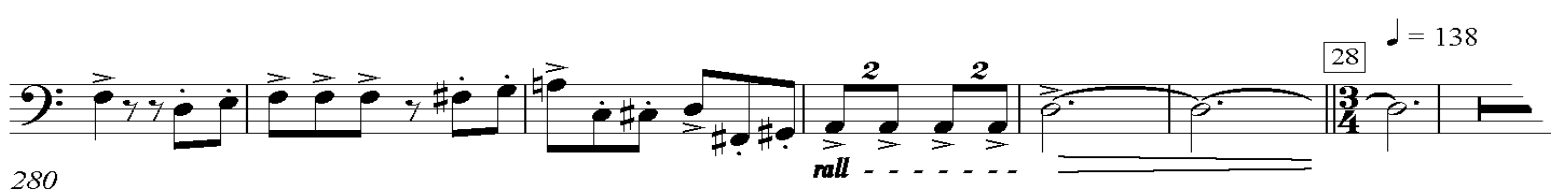

Universidade de São Paulo

Escola de Comunicação e Artes 


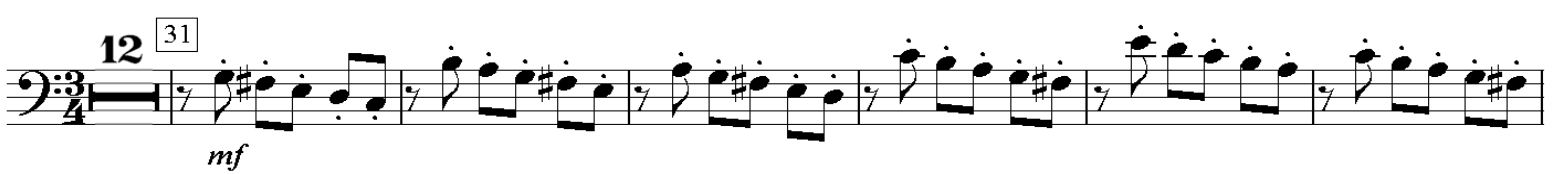

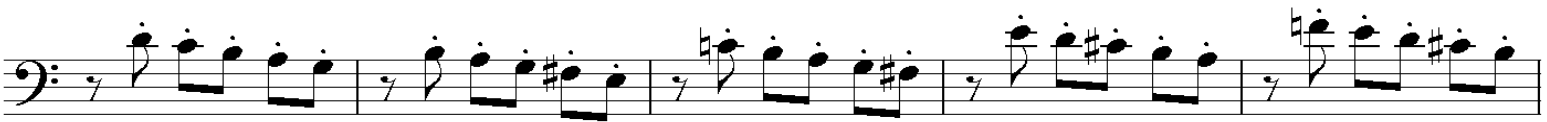

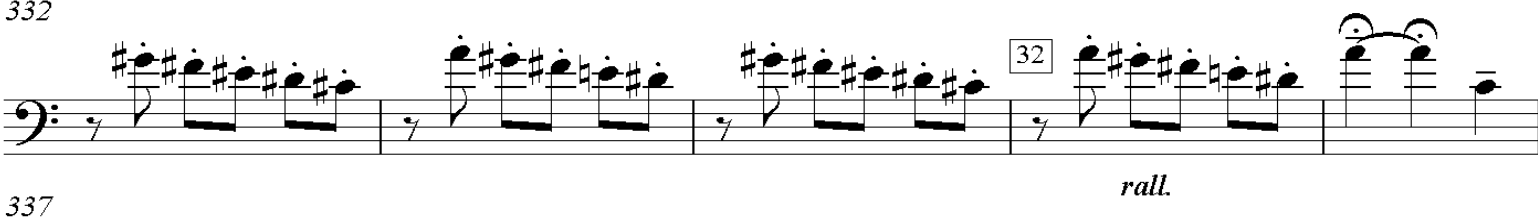

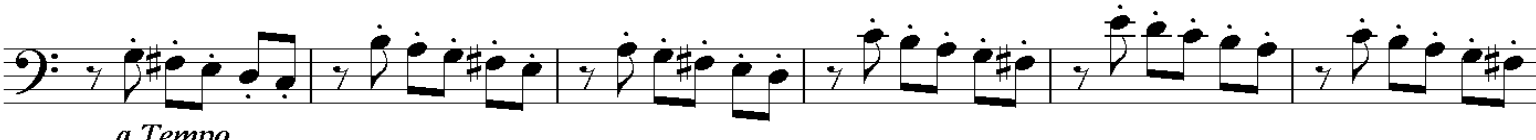
342

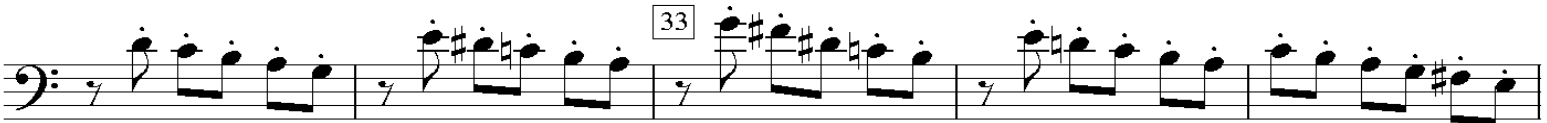
348
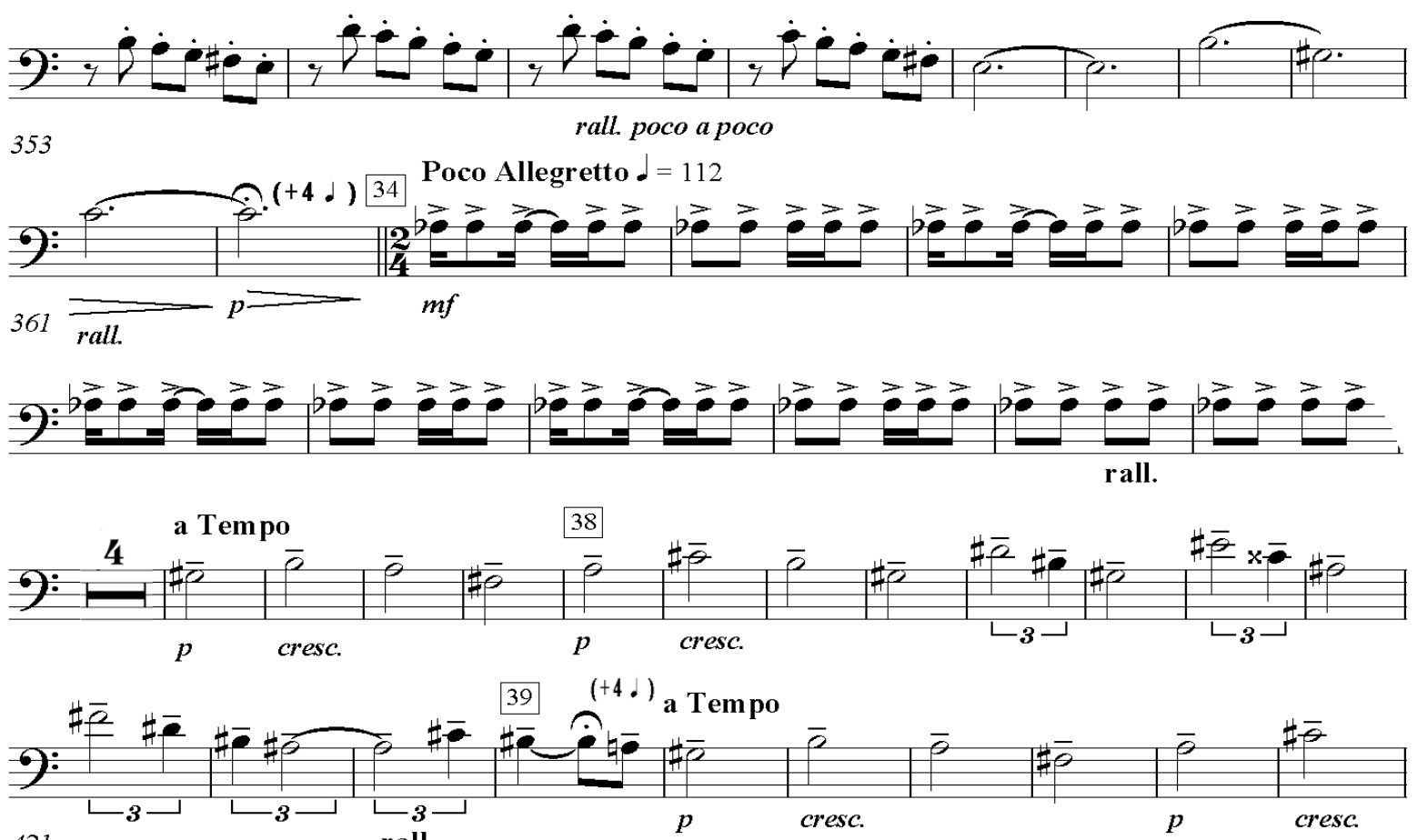

421 rall.
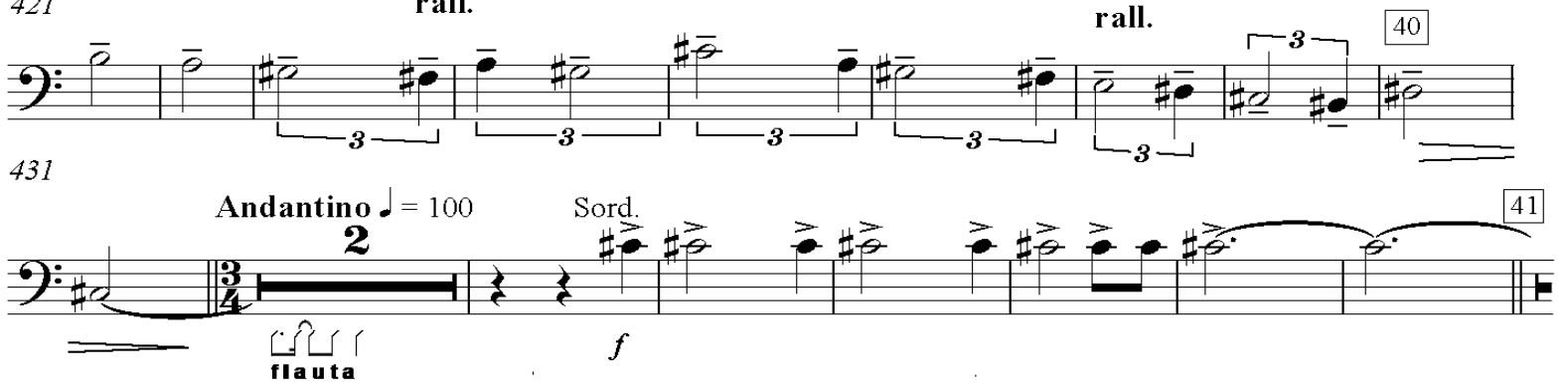

Universidade de São Paulo 
Villa-Lobos e os metais graves sinfônicos:

Um estudo dos elementos técnicos específicos

Chorus N.6 - Trombone 1
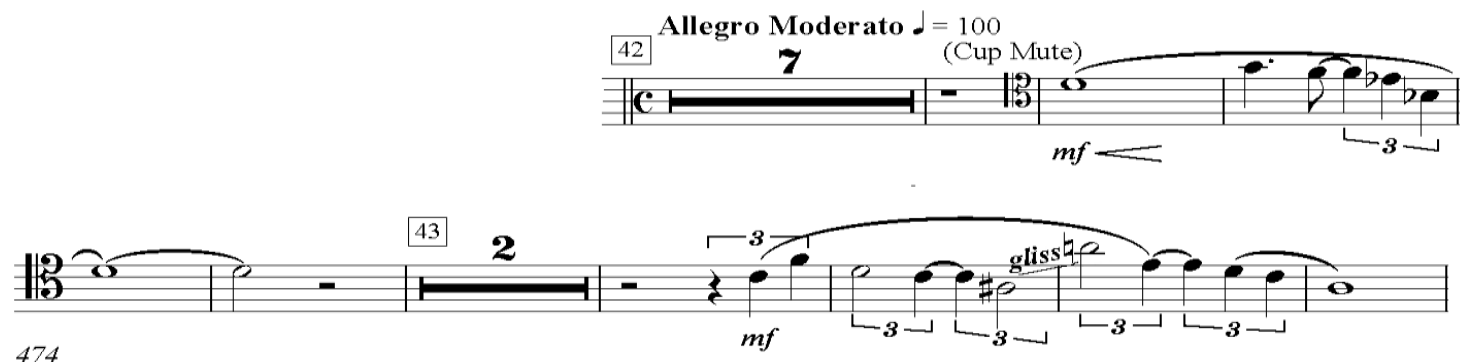

474

5

44

482

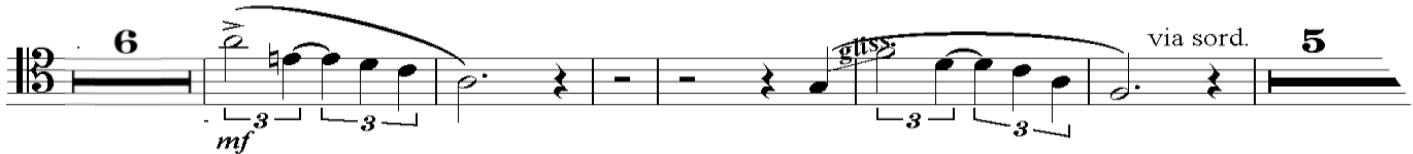

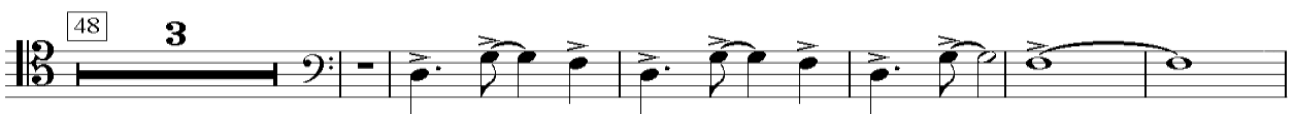
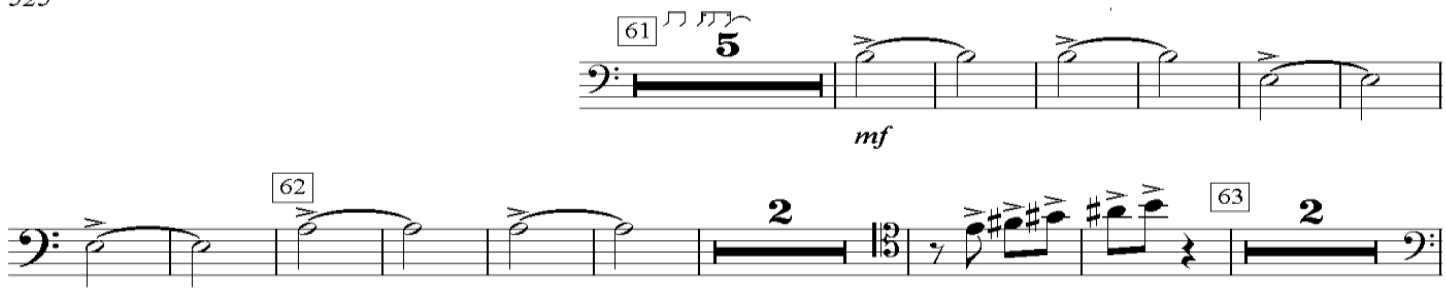

681

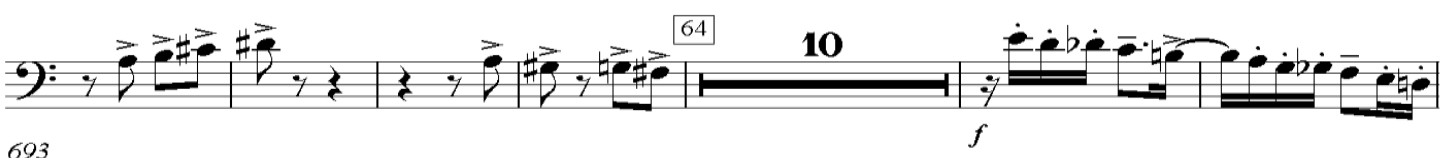
693

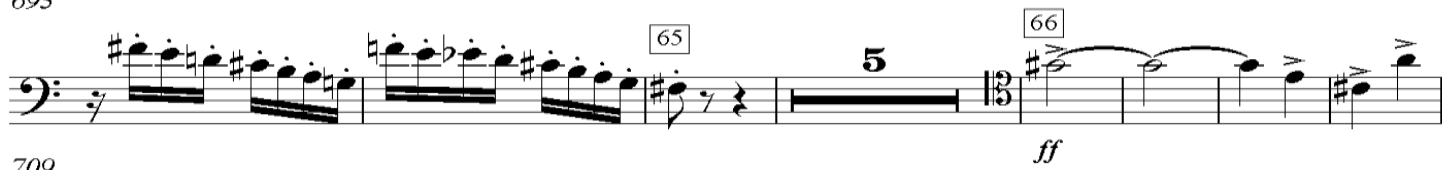
709

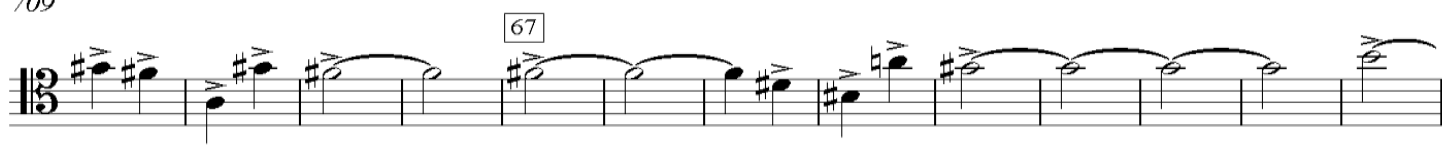
721
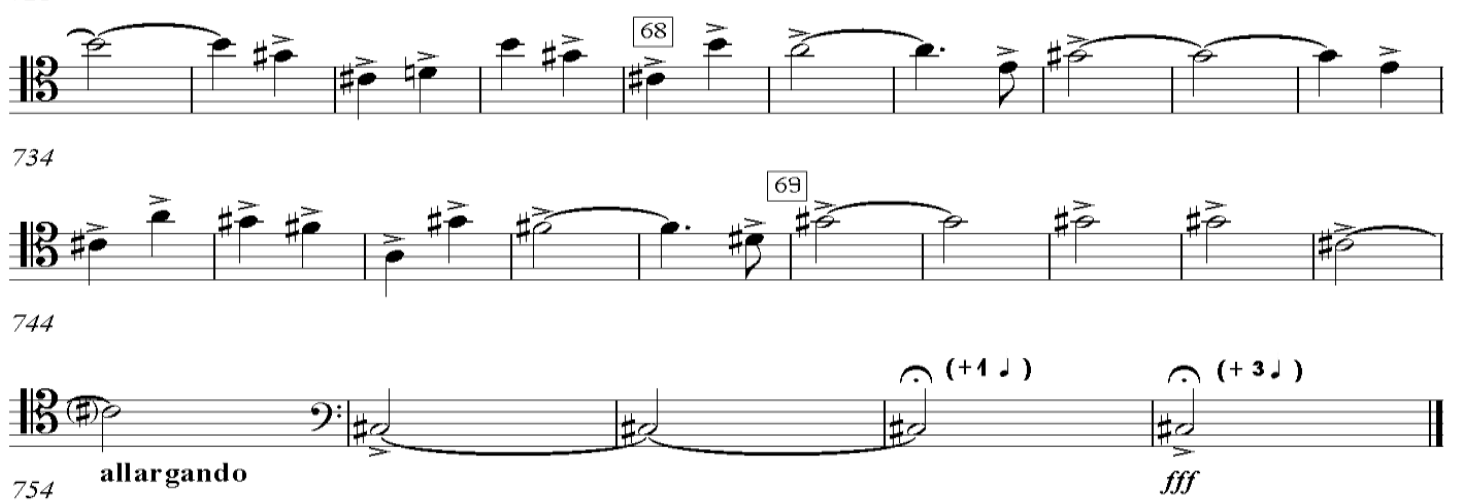


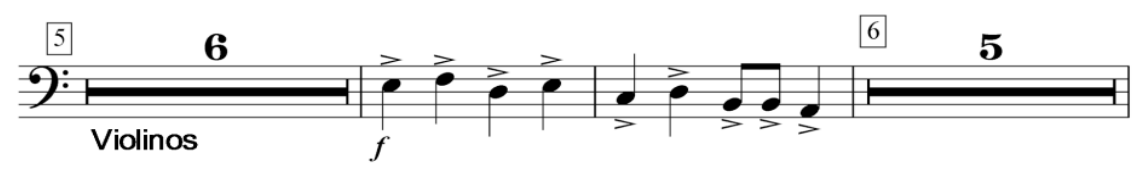

7
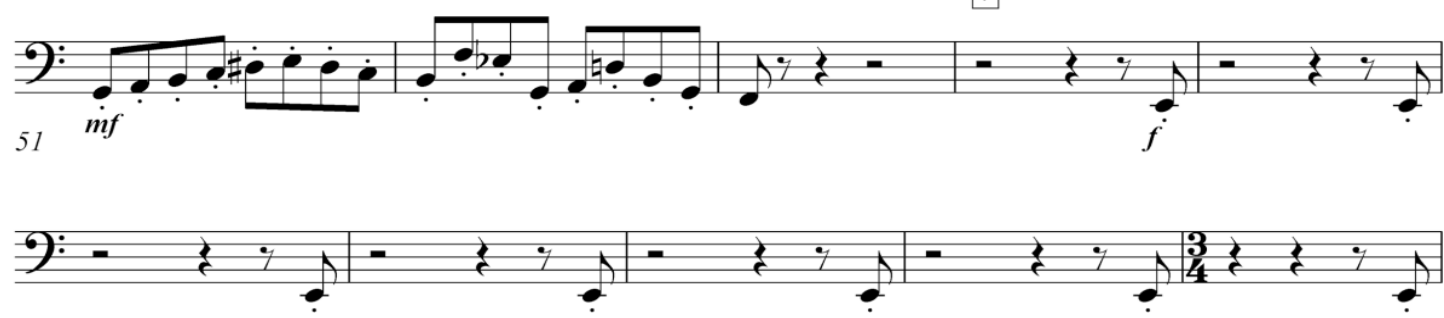
56
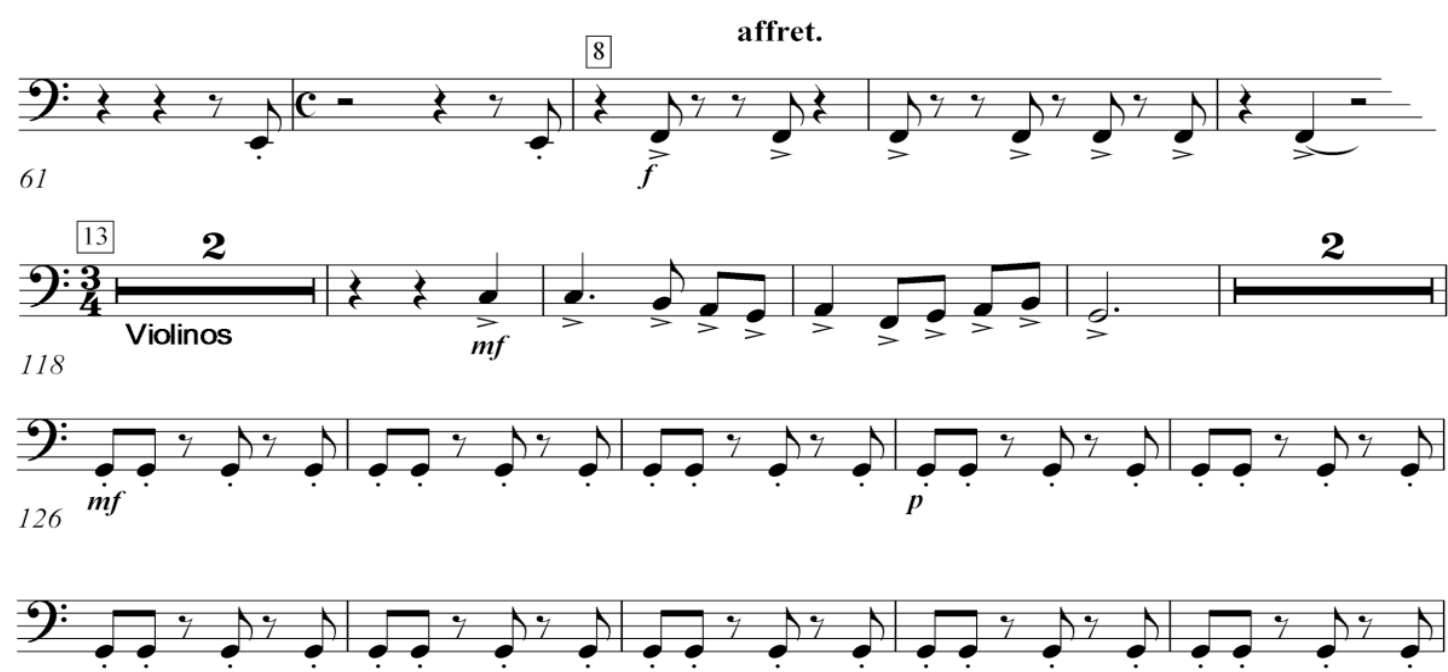
131

14
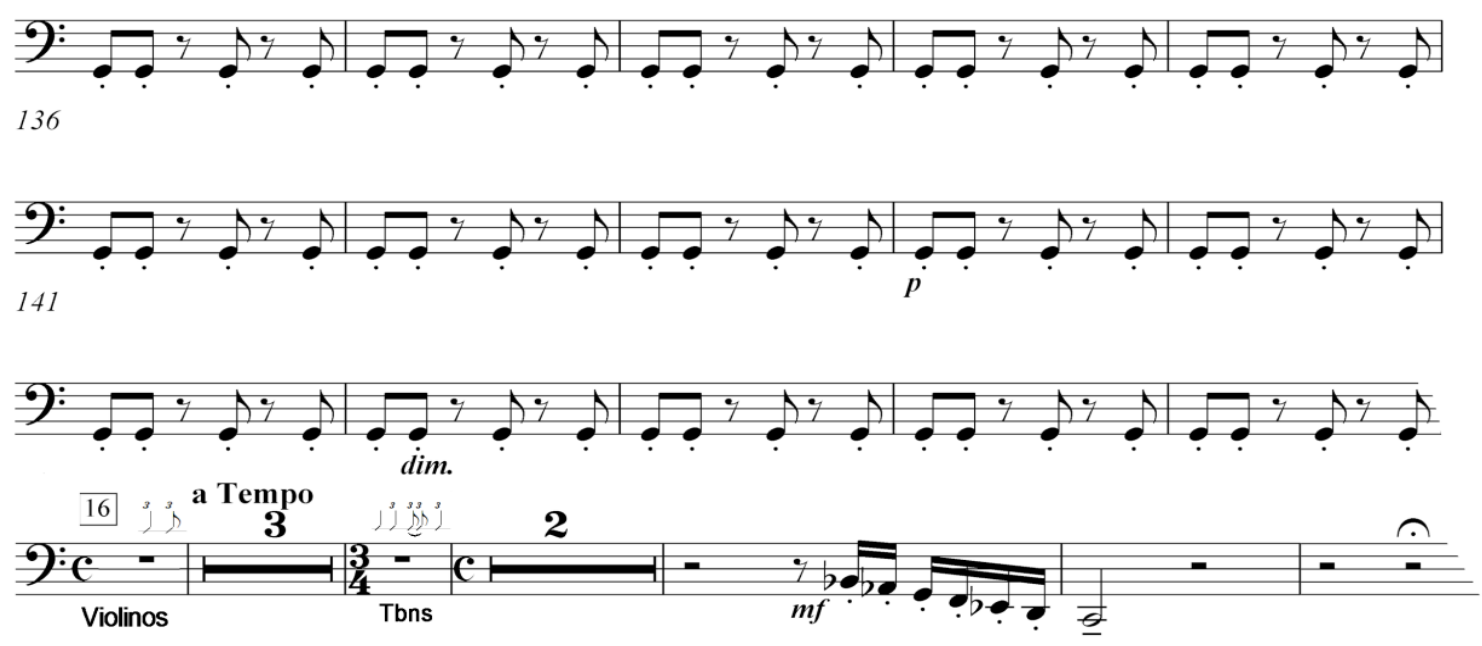
Villa-Lobos e os metais graves sinfônicos:

Um estudo dos elementos técnicos específicos

一)

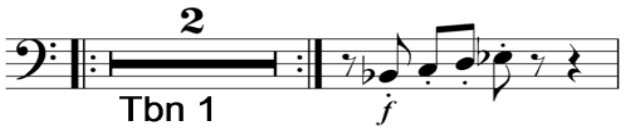

19 Meno Mosso $\bullet=100$
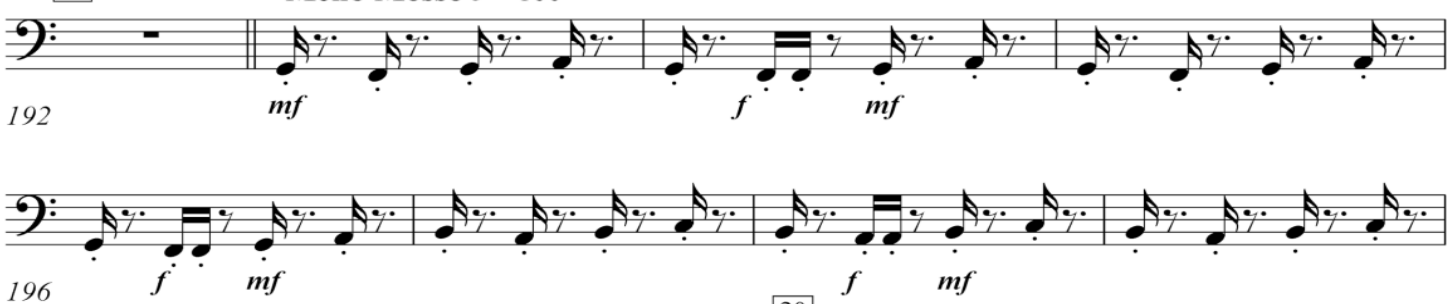

20

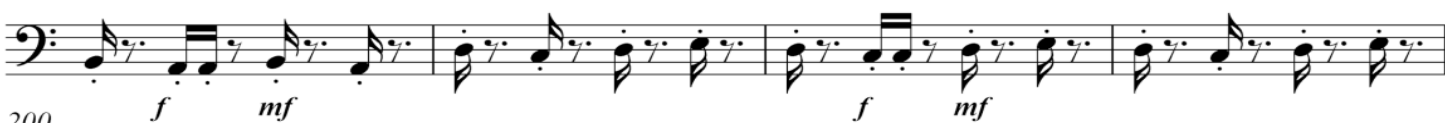
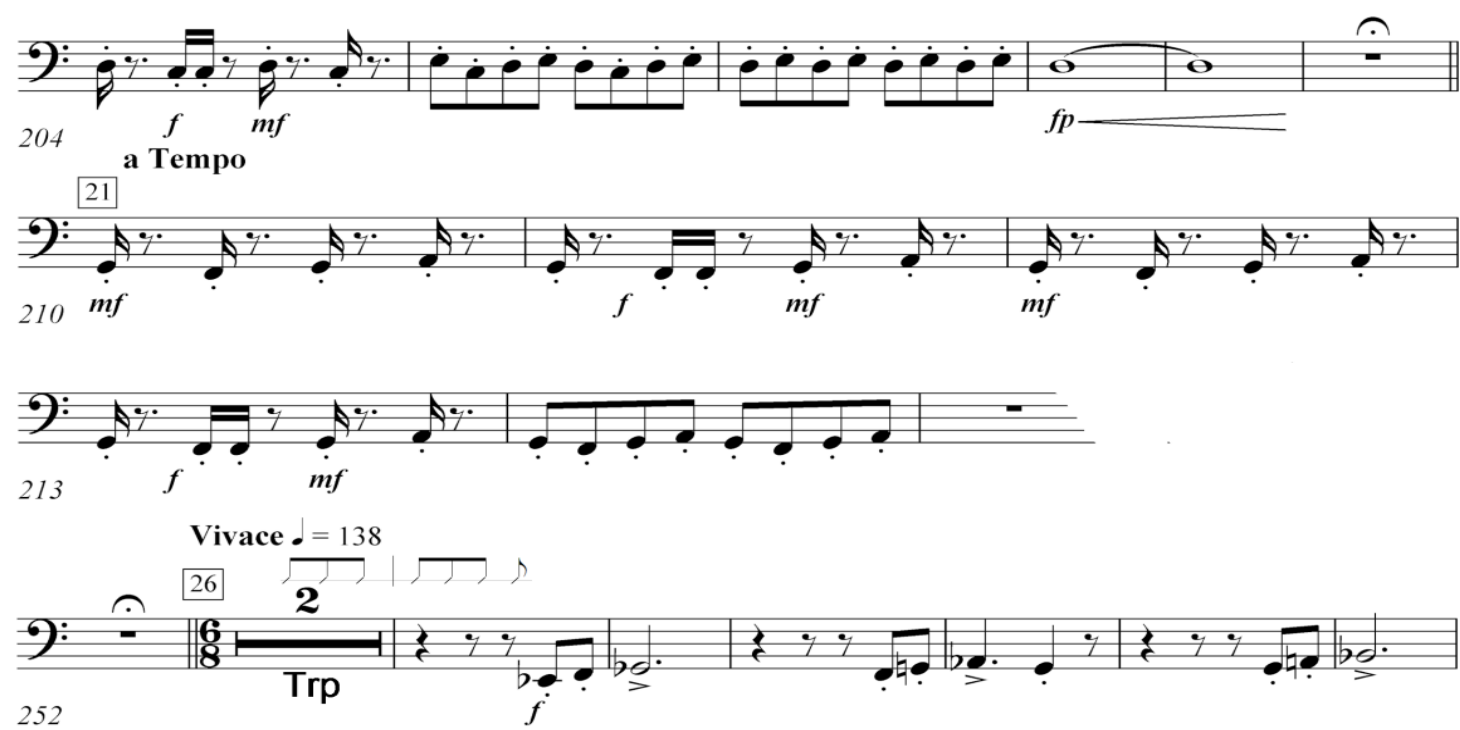

9:

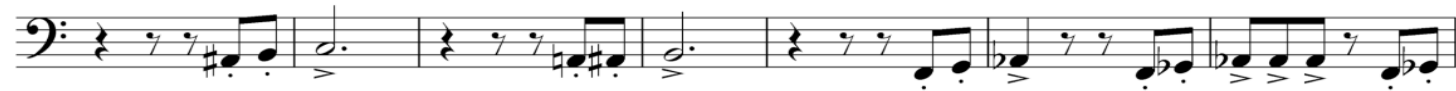
269
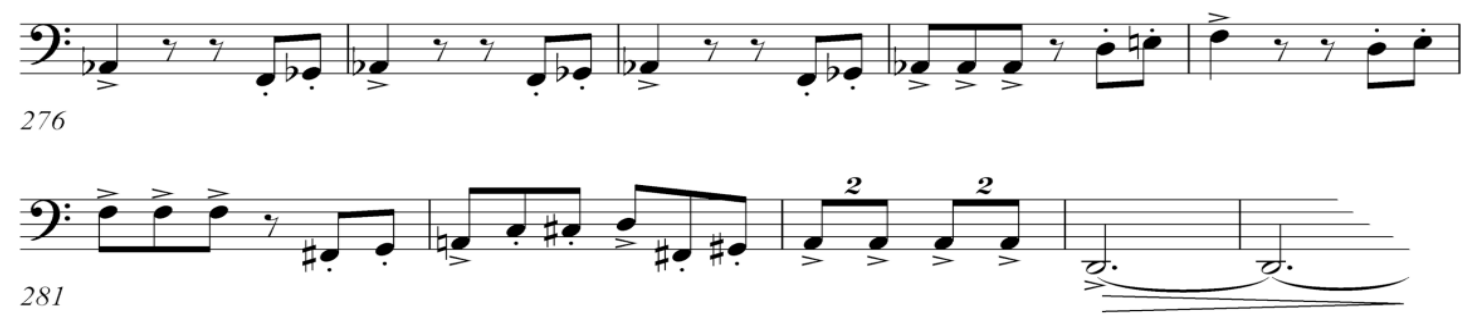
Villa-Lobos e os metais graves sinfônicos:

Um estudo dos elementos técnicos específicos

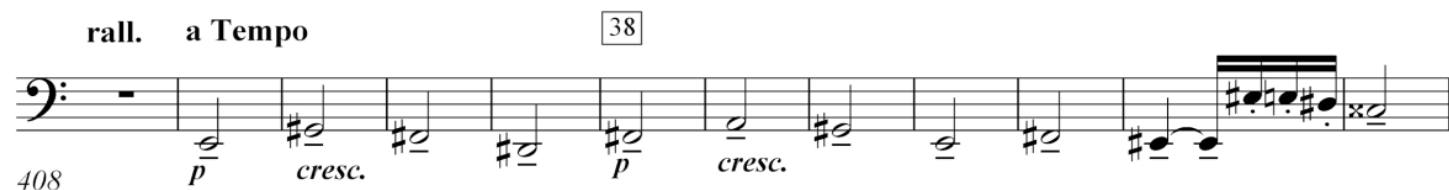

rall. 39 a Tempo
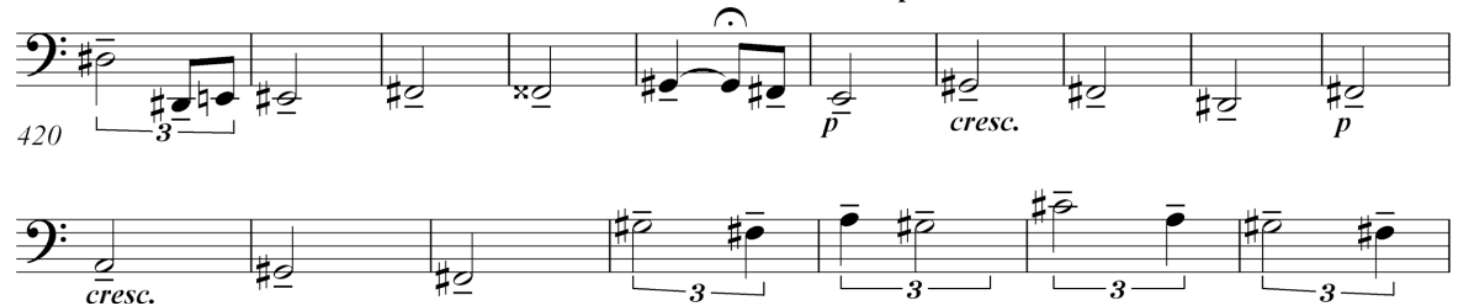
430
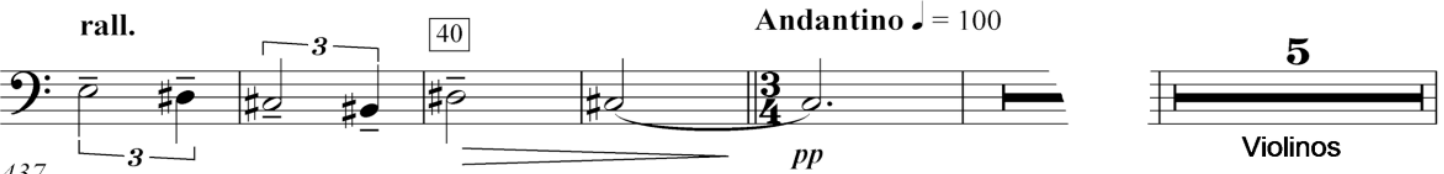

66

67

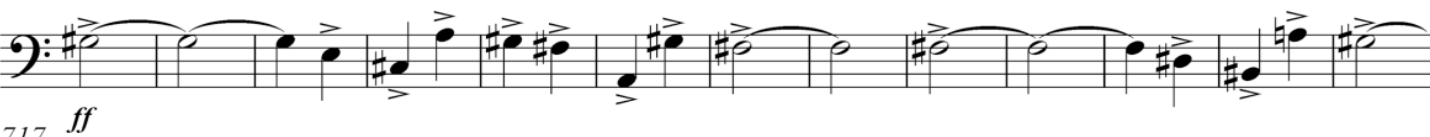
${ }_{717} \mathrm{ff}$

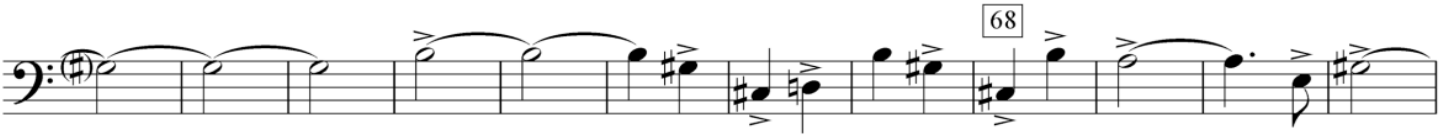
730

69

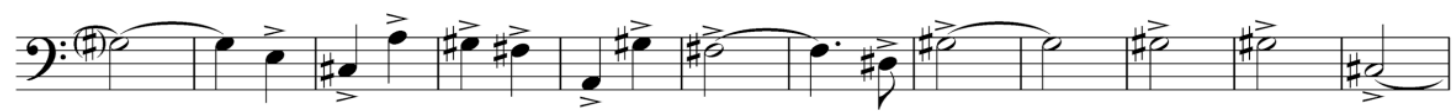
742

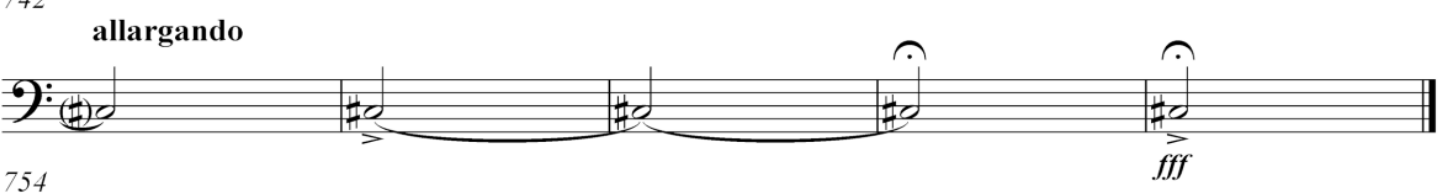


4 Allegro • $=132$
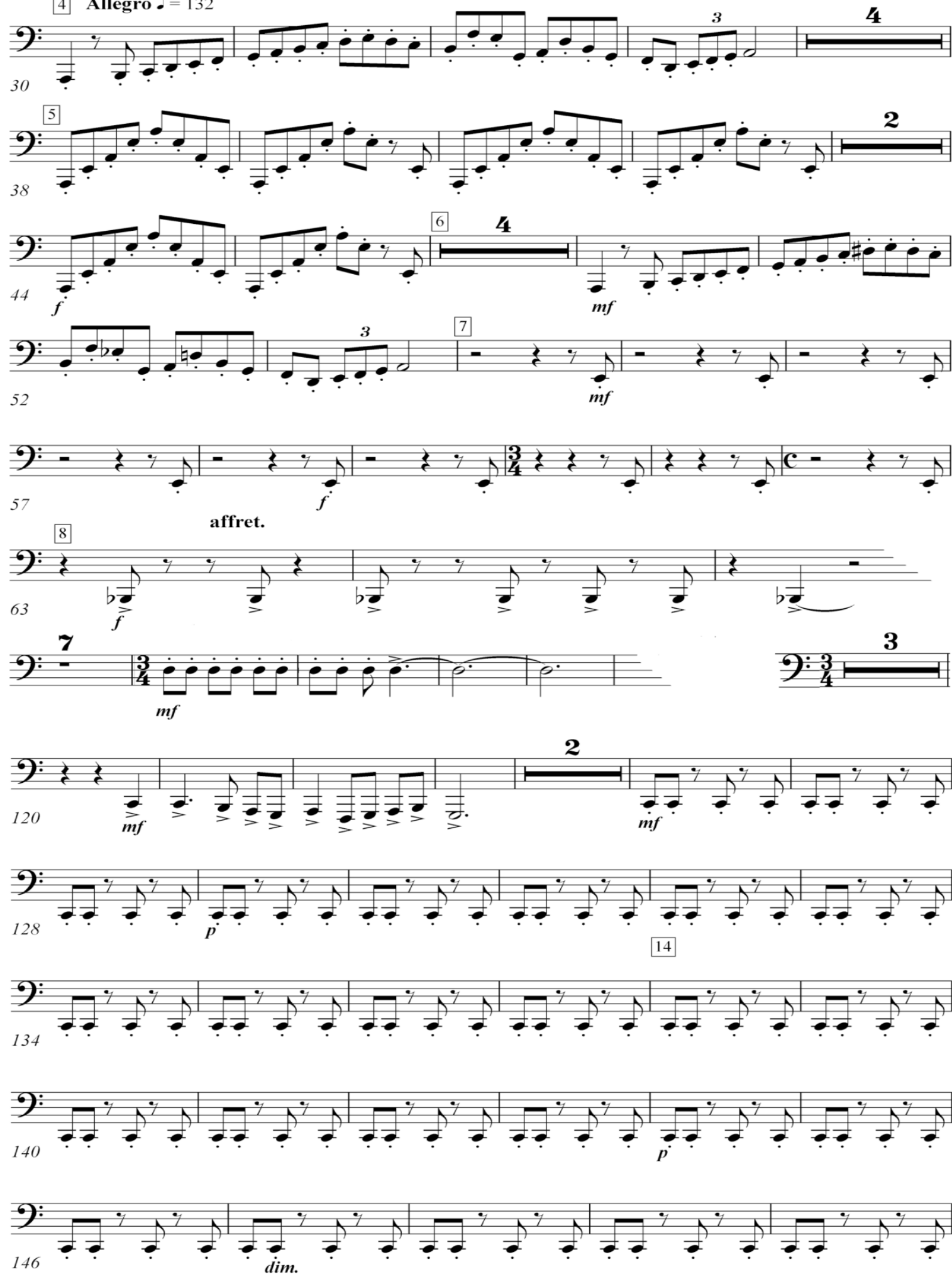

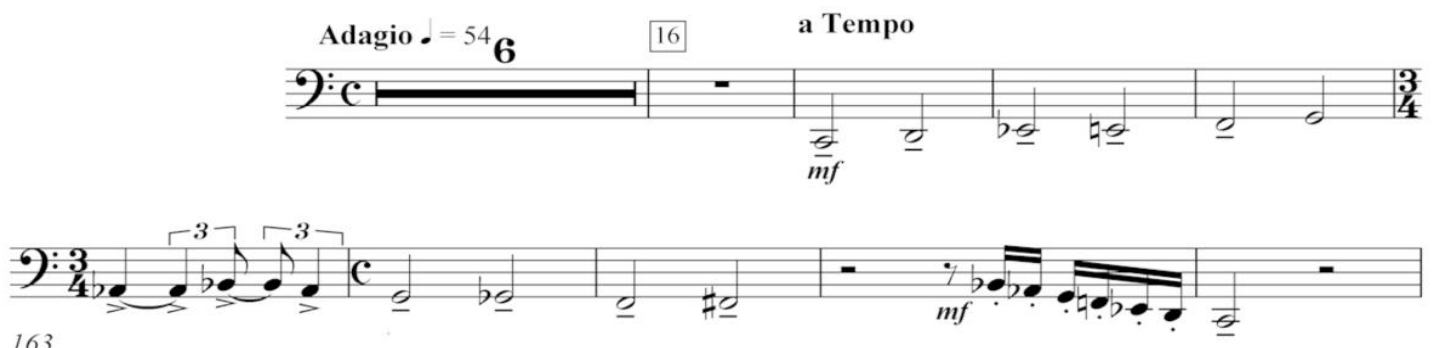
163
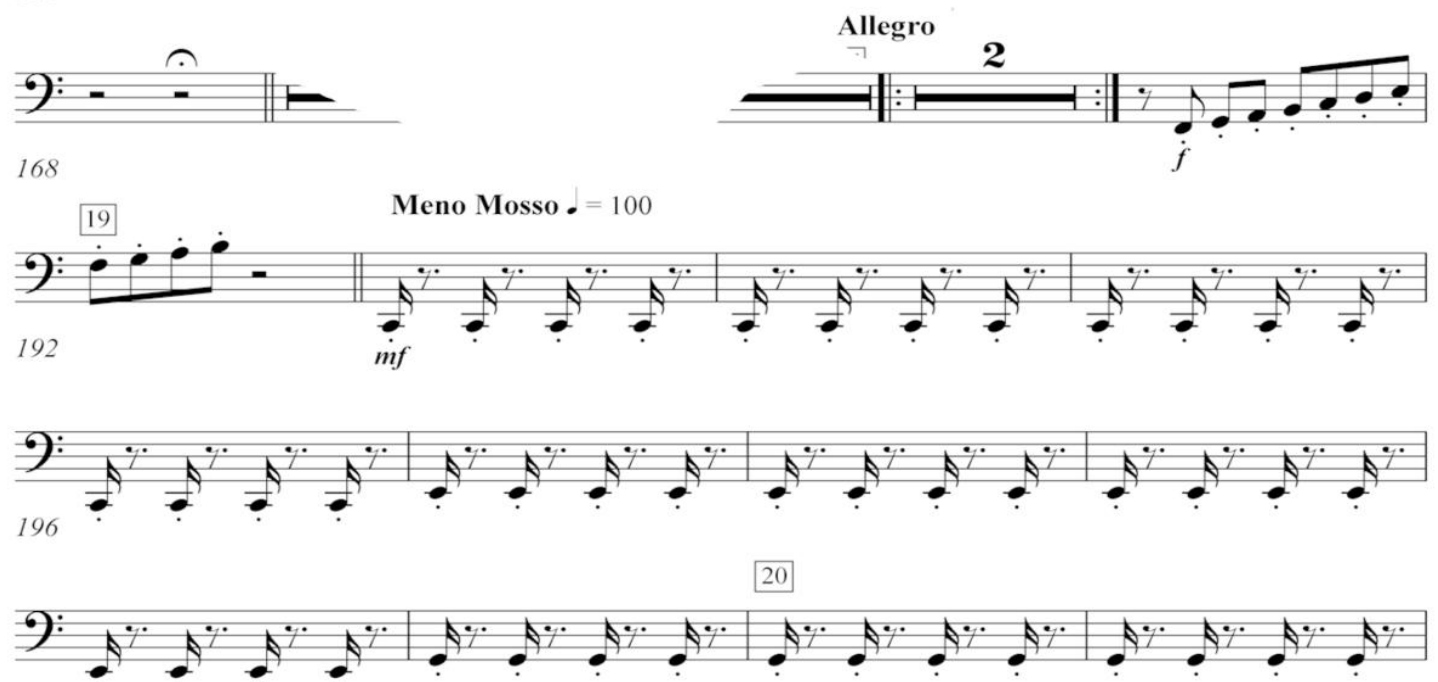
200

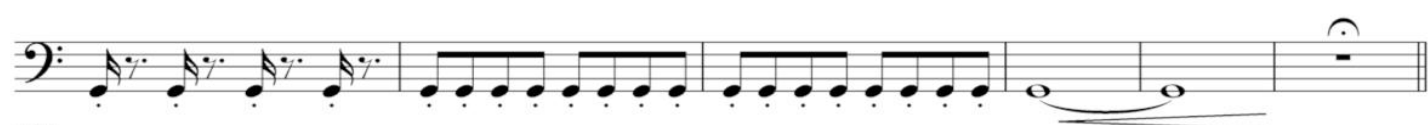
204 a Tempo $f p$

21
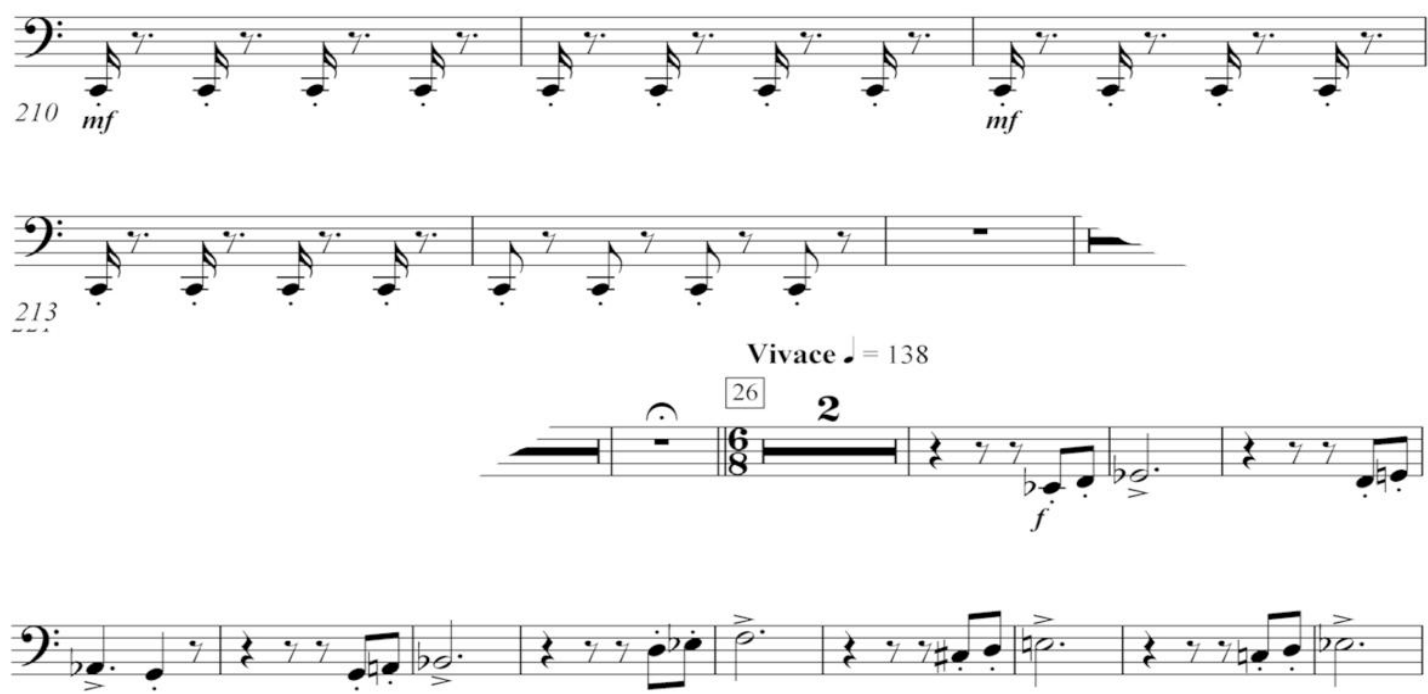
258

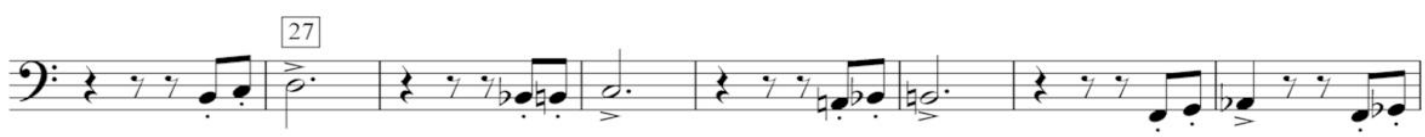
267

Universidade de São Paulo

Escola de Comunicação e Artes 

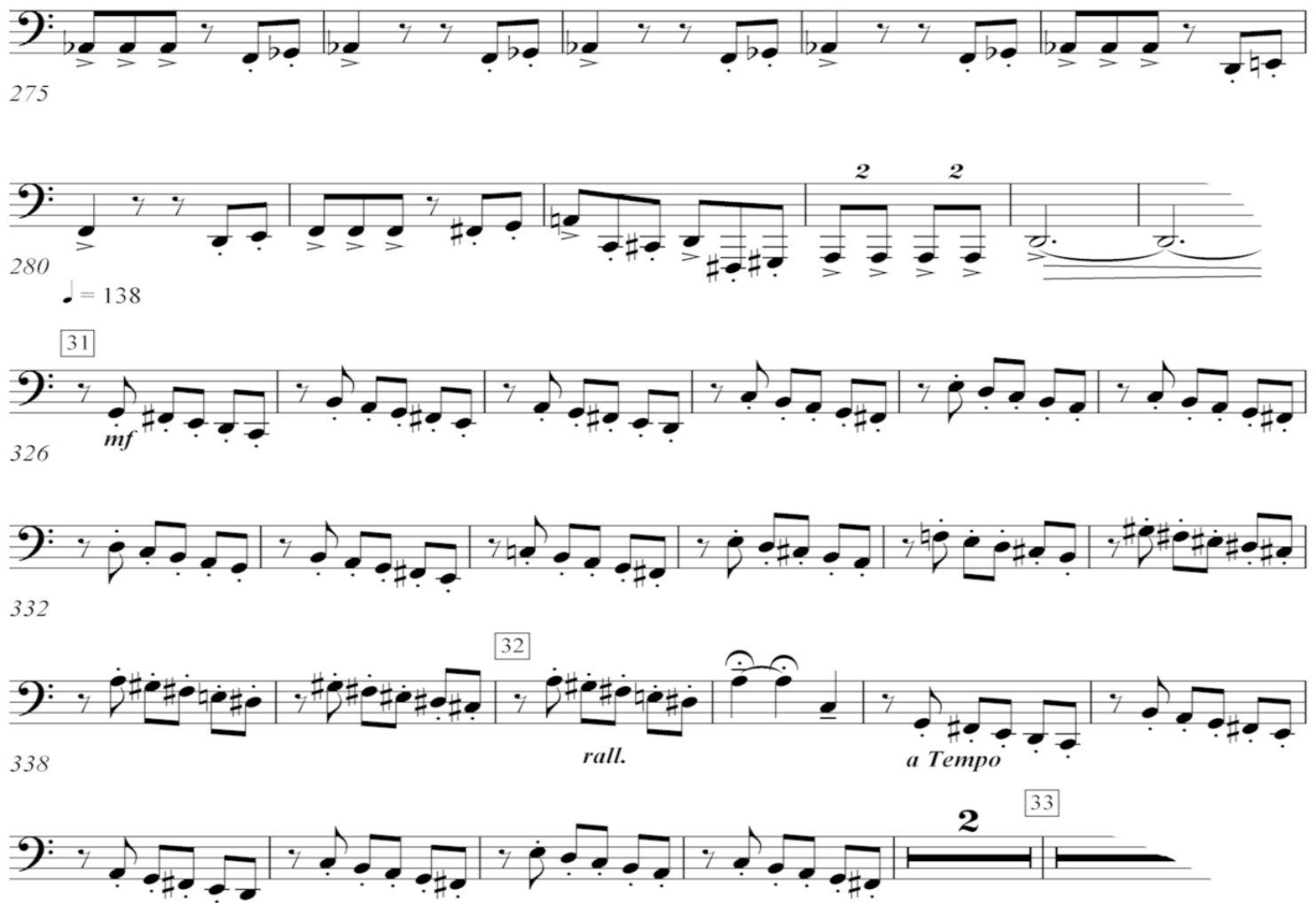

344 37

rall.

a Tempo

38
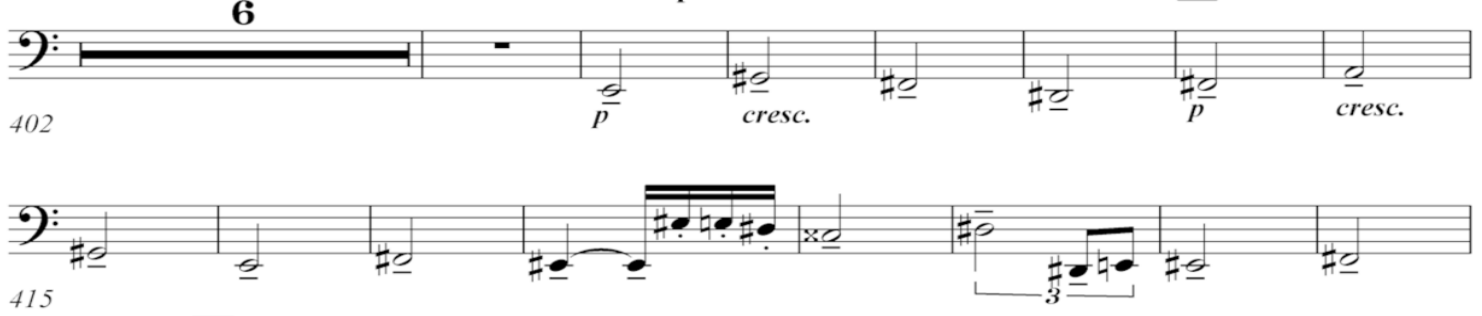
415 rall. 39 a Tempo

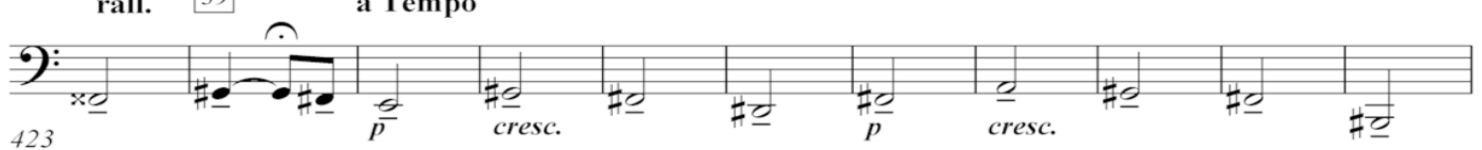

rall.

40

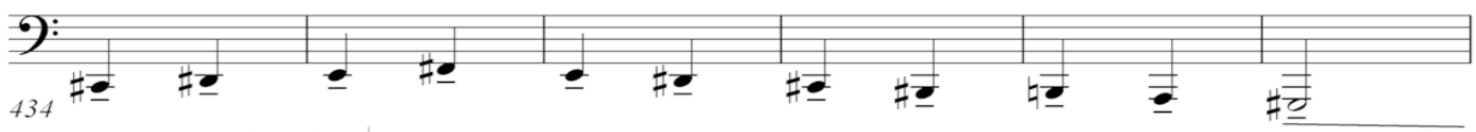

Andantino $\cdot=100$
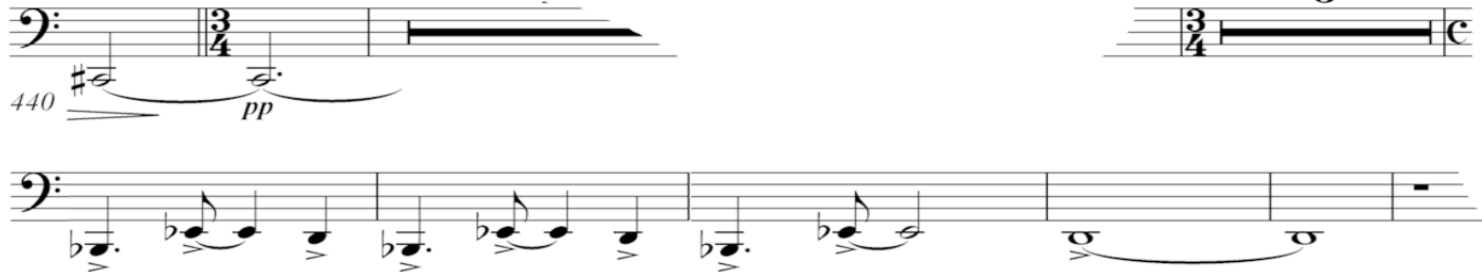


\section{Choros N.o 10}

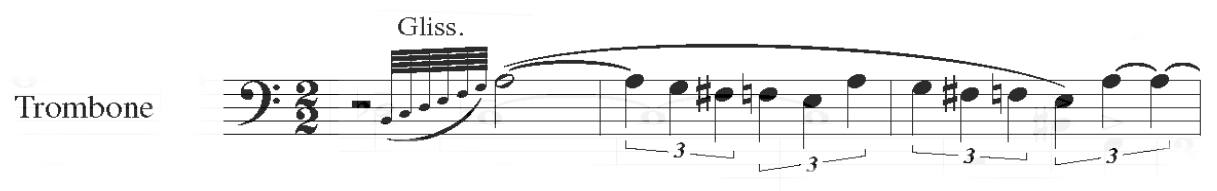

(D) Gliss.

$6: 0 \longdiv { 0 } 0$
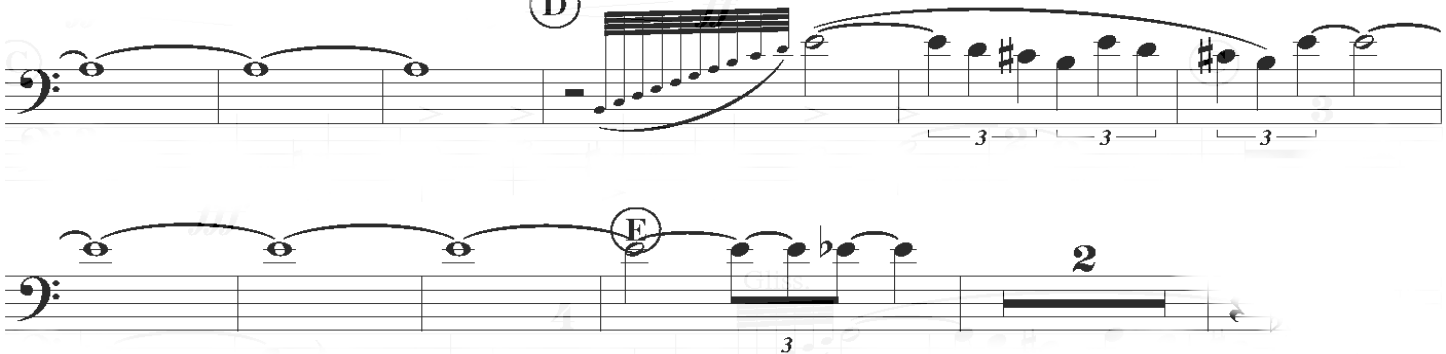

(F)
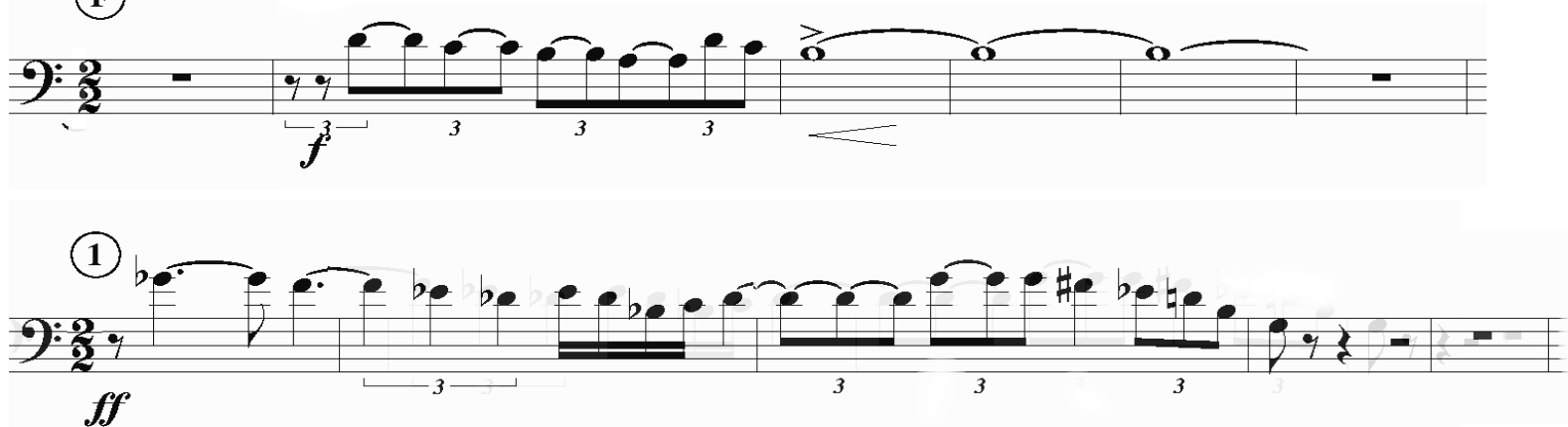

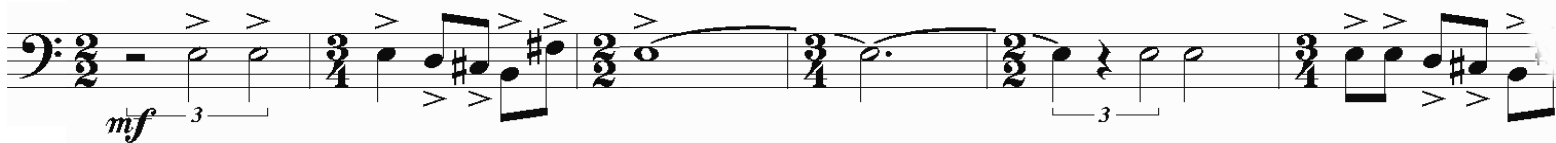
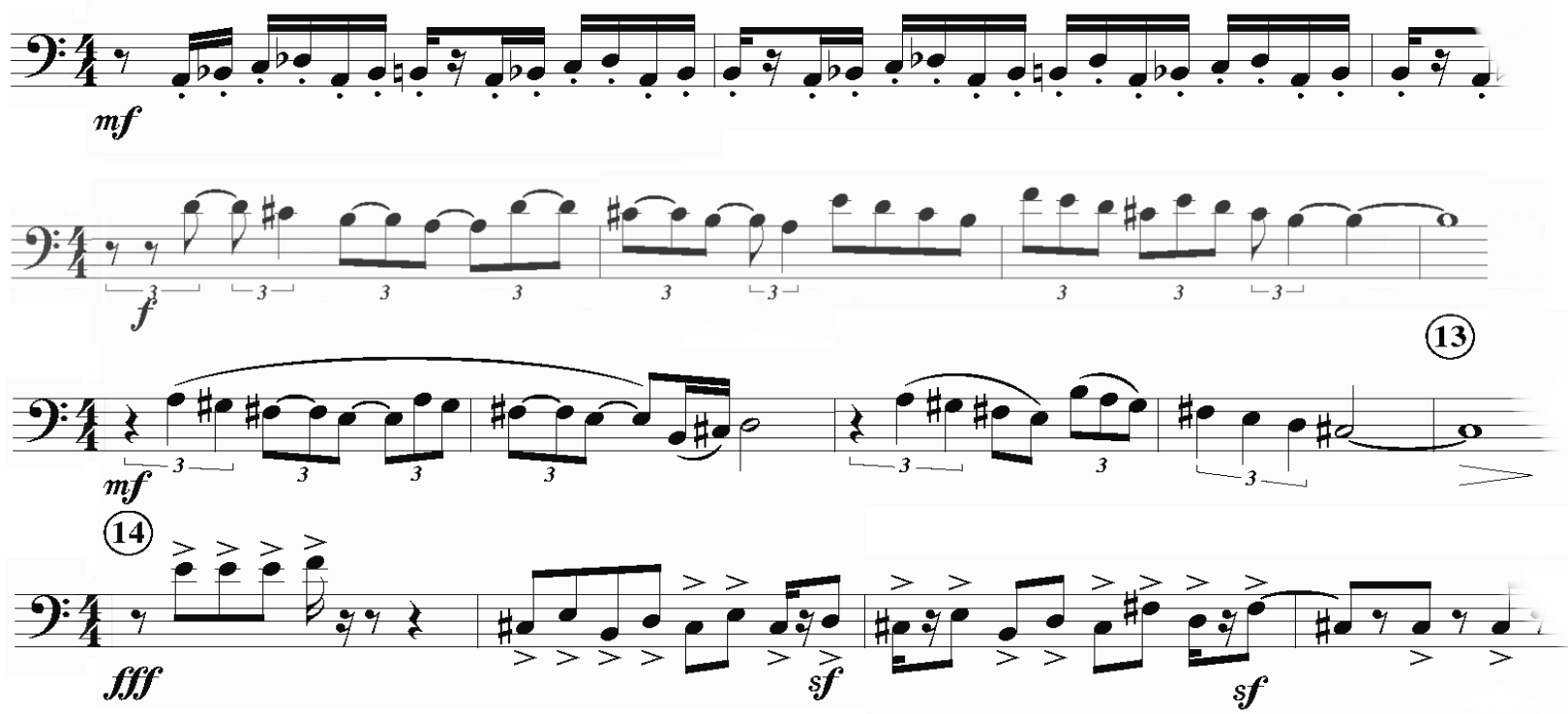


\section{Bachianas Brasileiras - $\mathrm{N}^{\mathrm{o}} 02$}

Preludio - O canto do capadocio

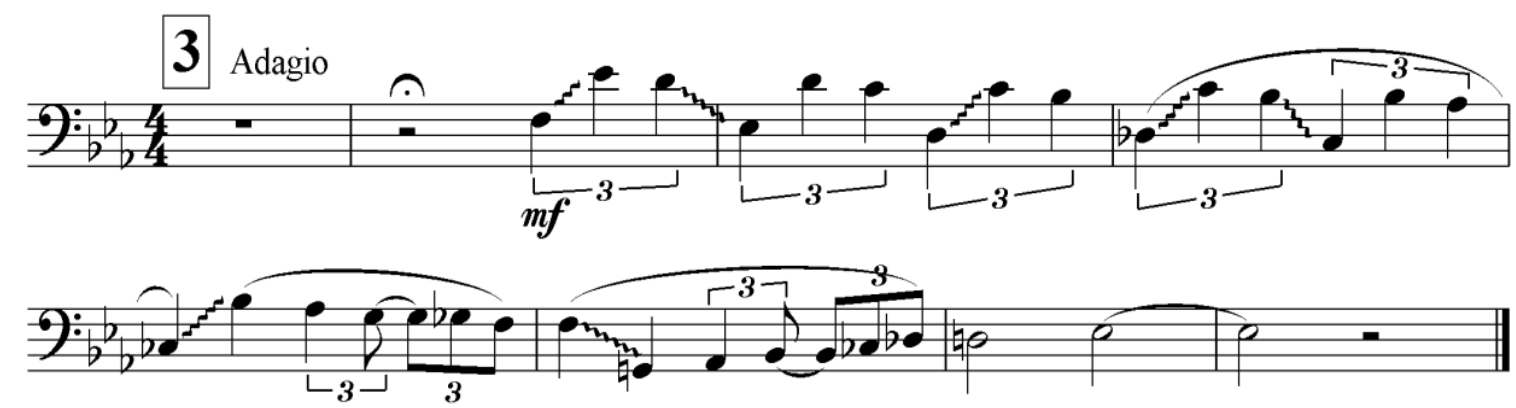

Aria - O canto da nossa terra
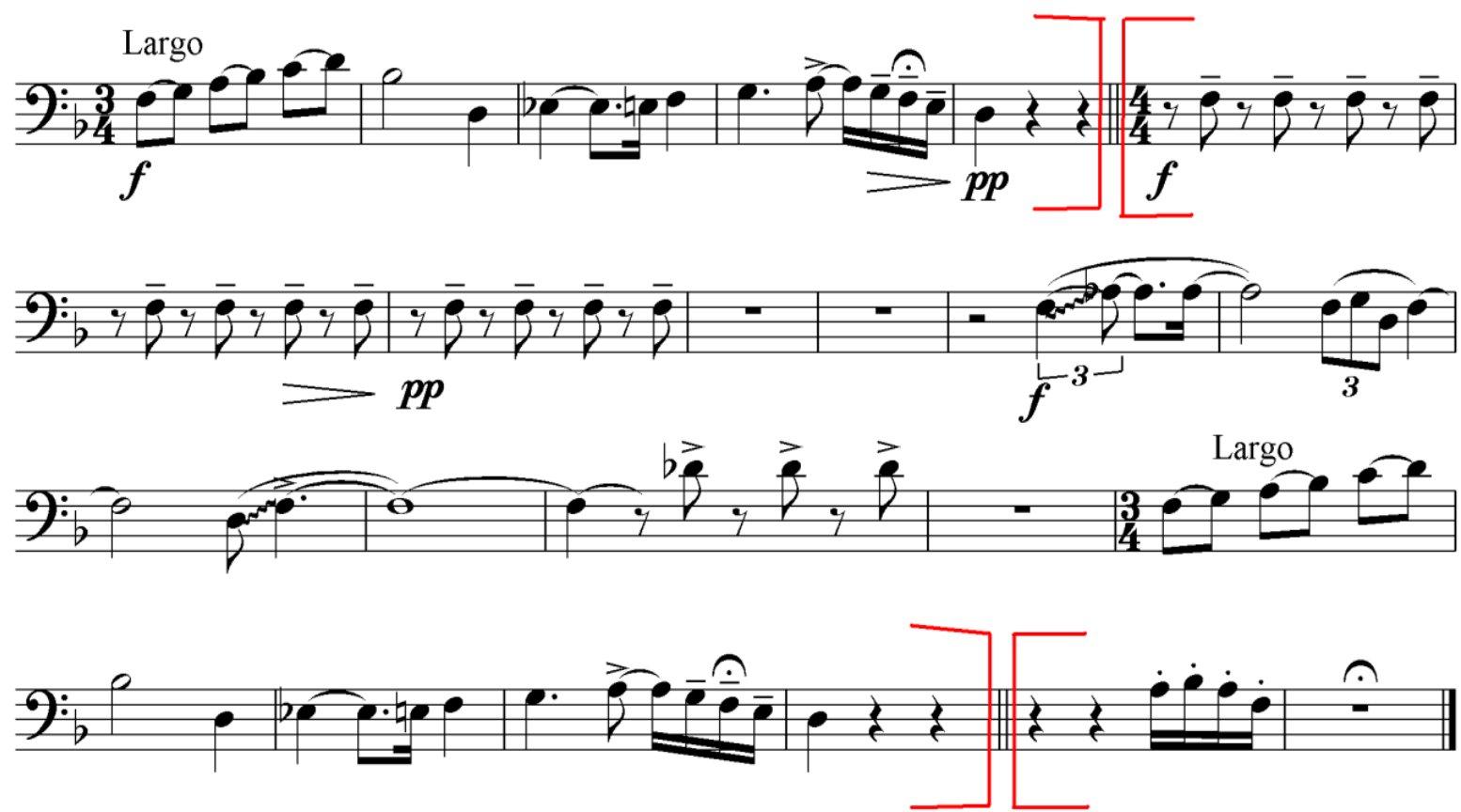
Villa-Lobos e os metais graves sinfônicos:

Um estudo dos elementos técnicos específicos

Dansa - Lembrança do sertão
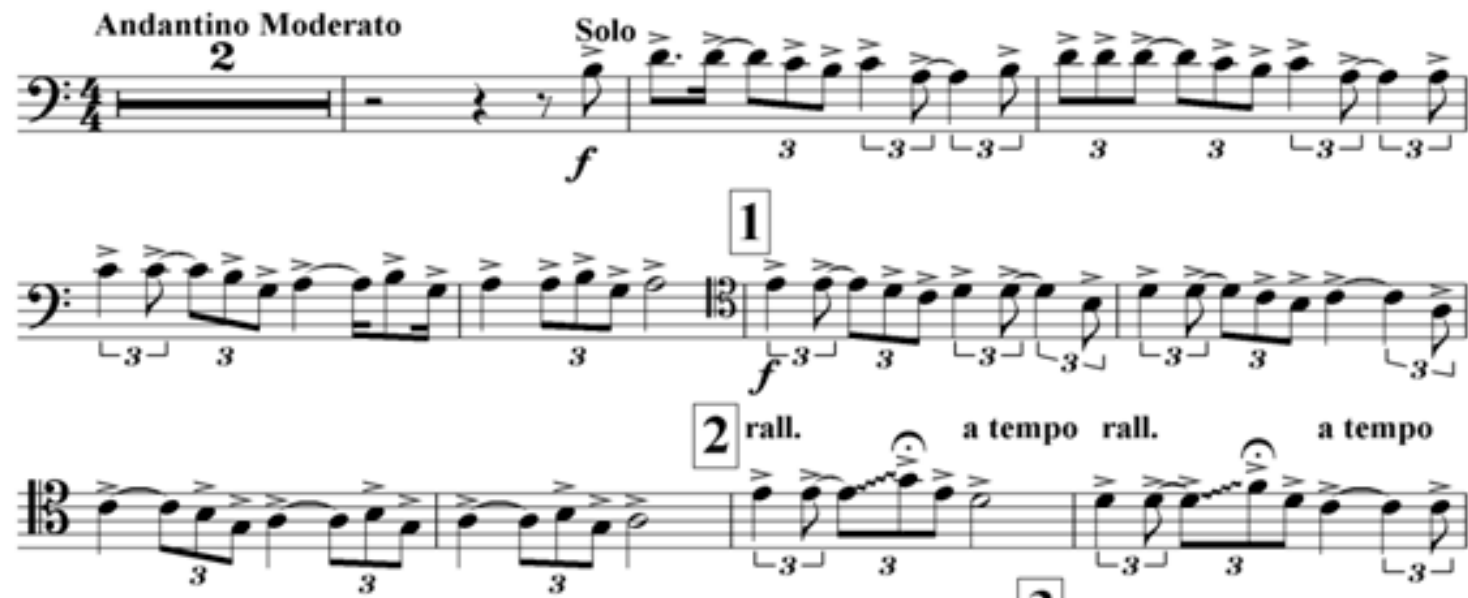

3
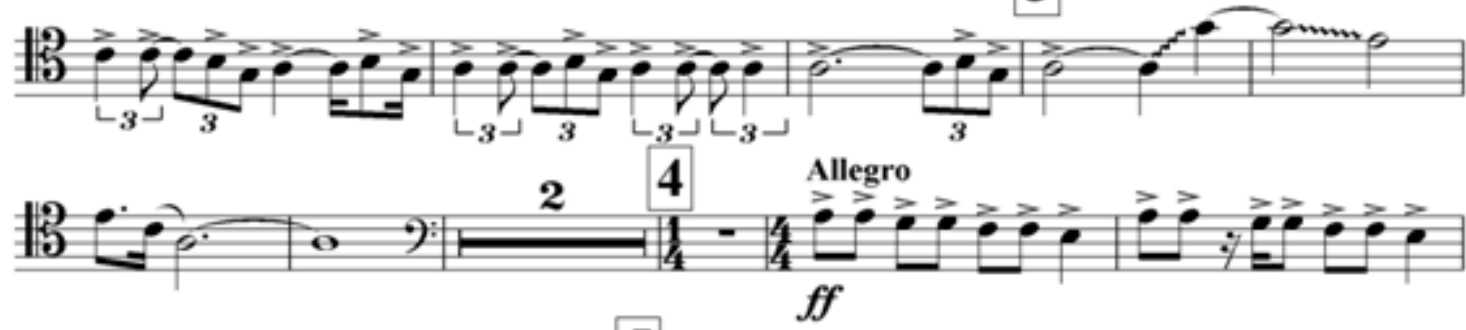

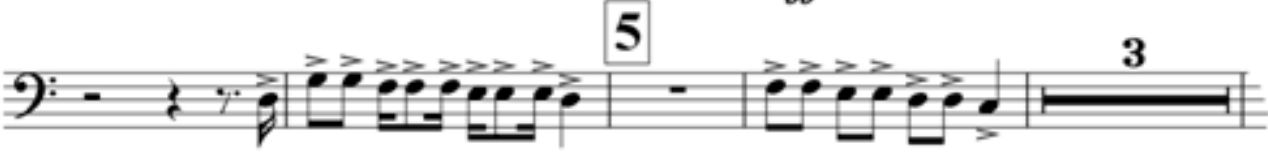
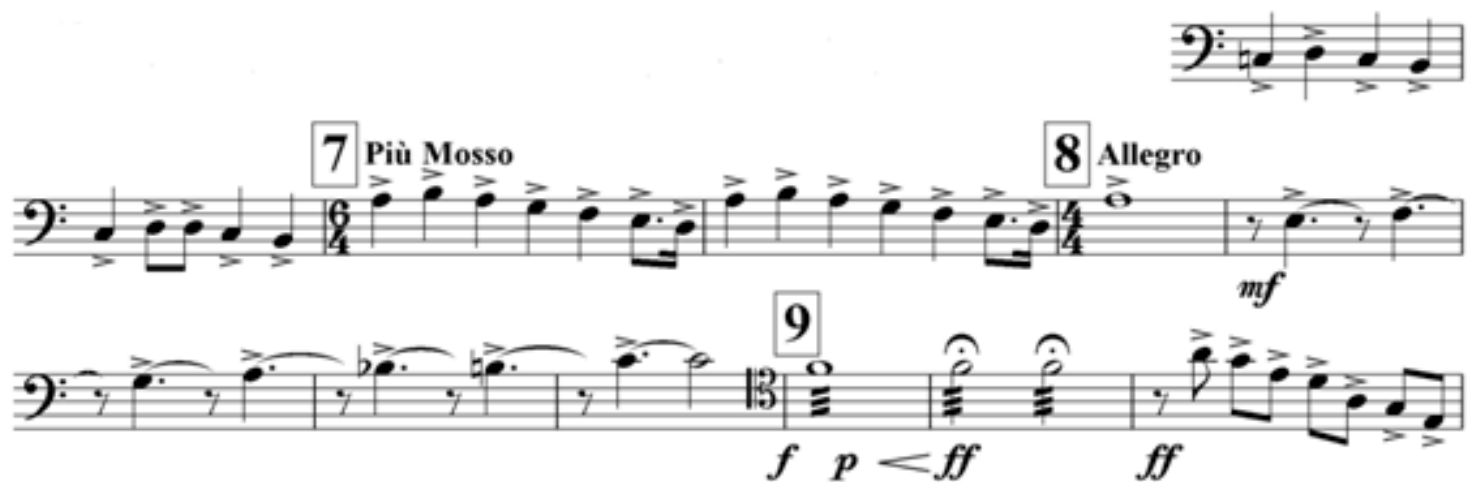

10
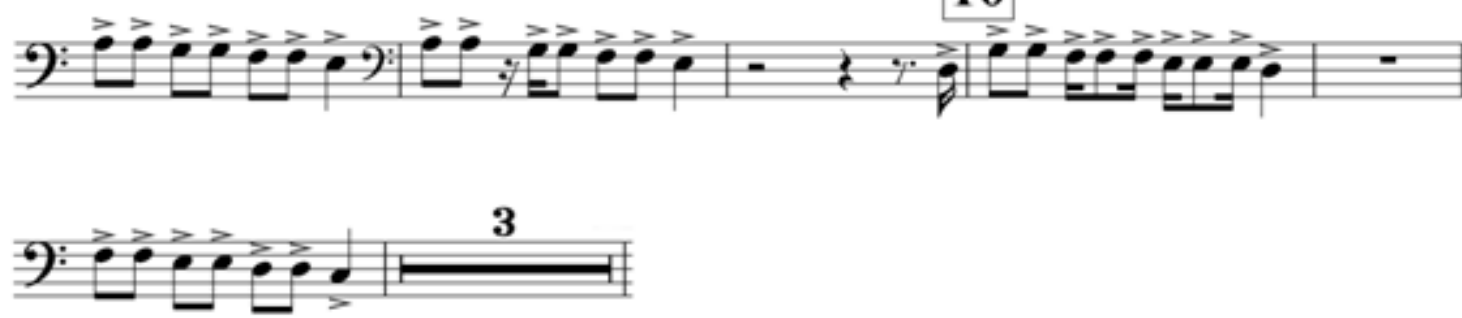
Trombone

\section{"O Trenzinho do Caipira"}

de Bachianas Brasileiras no2 para Orquestra

VI movimento - Tocccata

Heitor Villa-Lobos
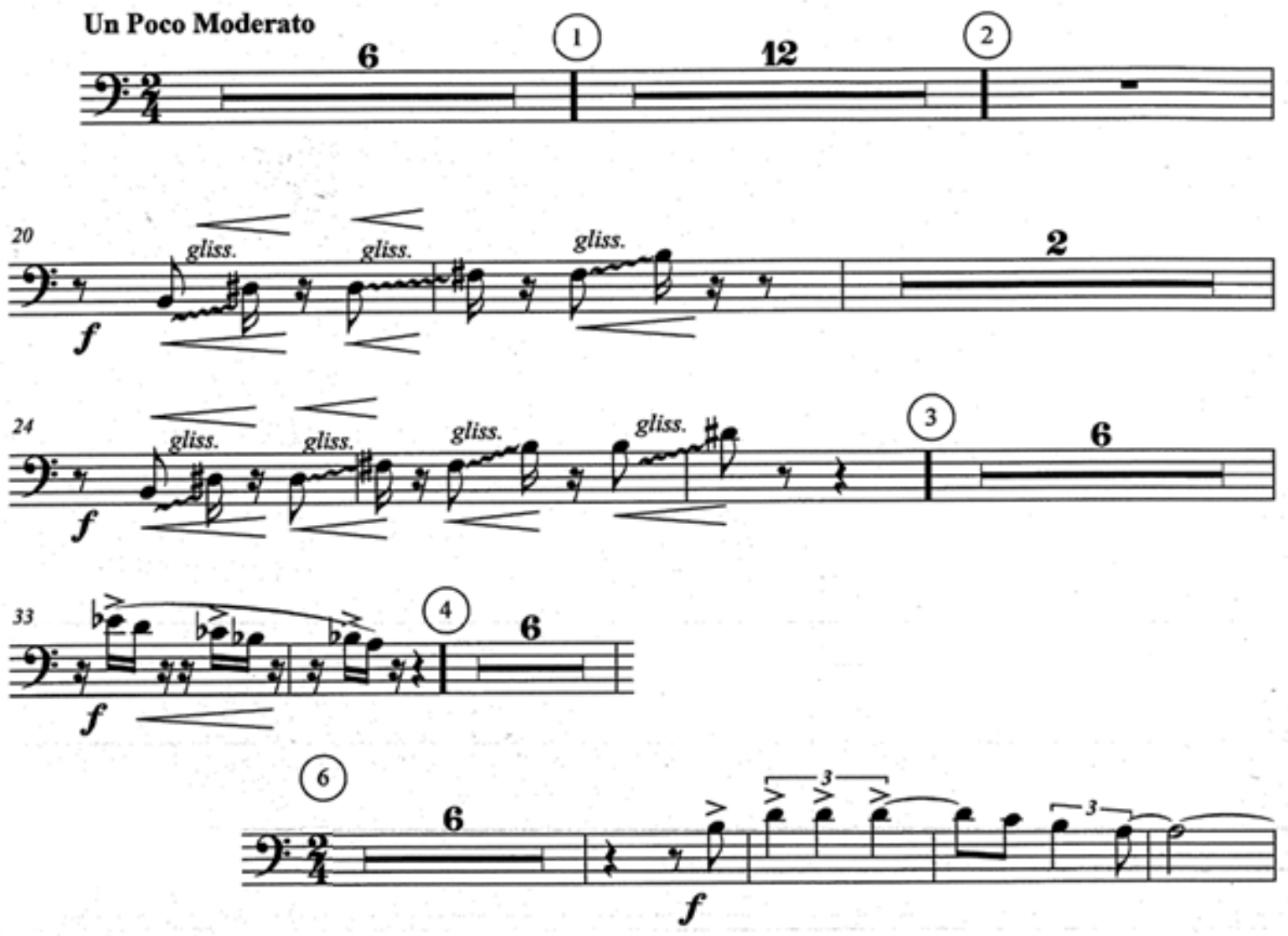

(7) (8)
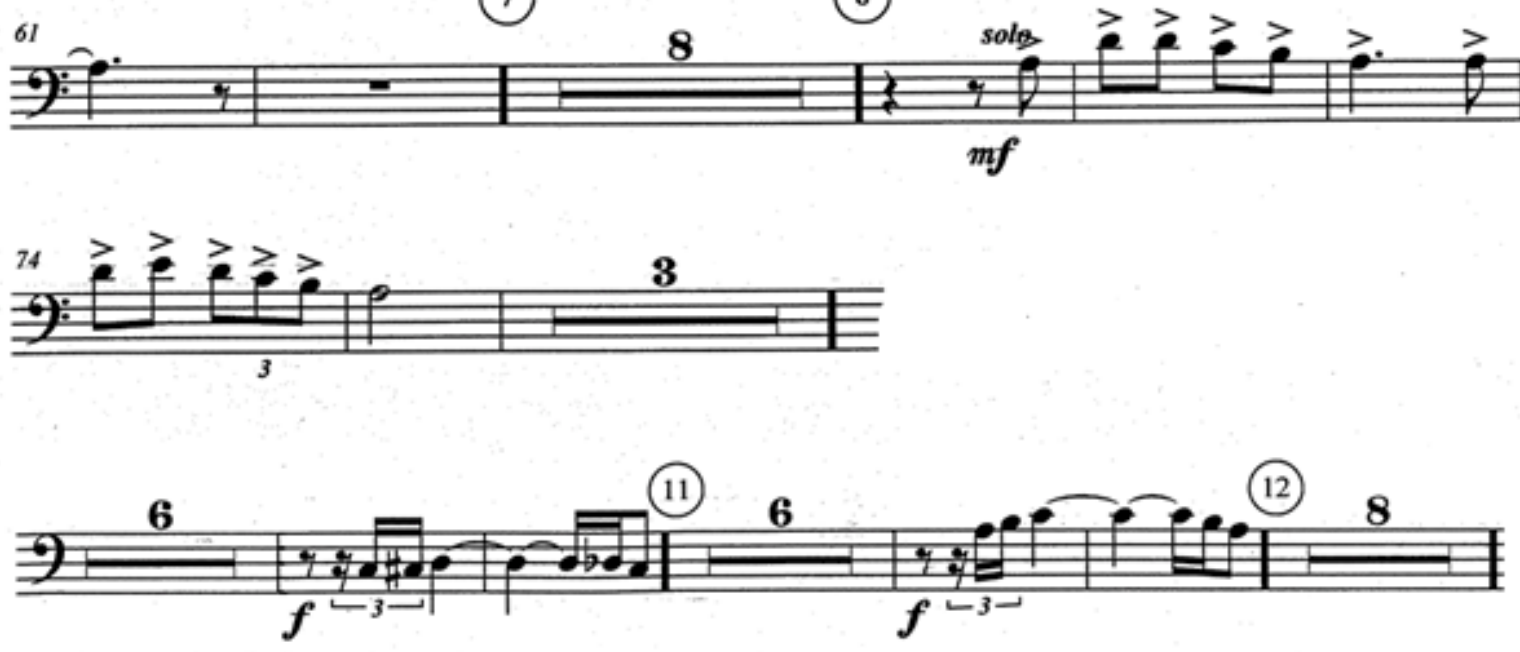


\section{Concerto Para Violão e Pequena Orquestra}

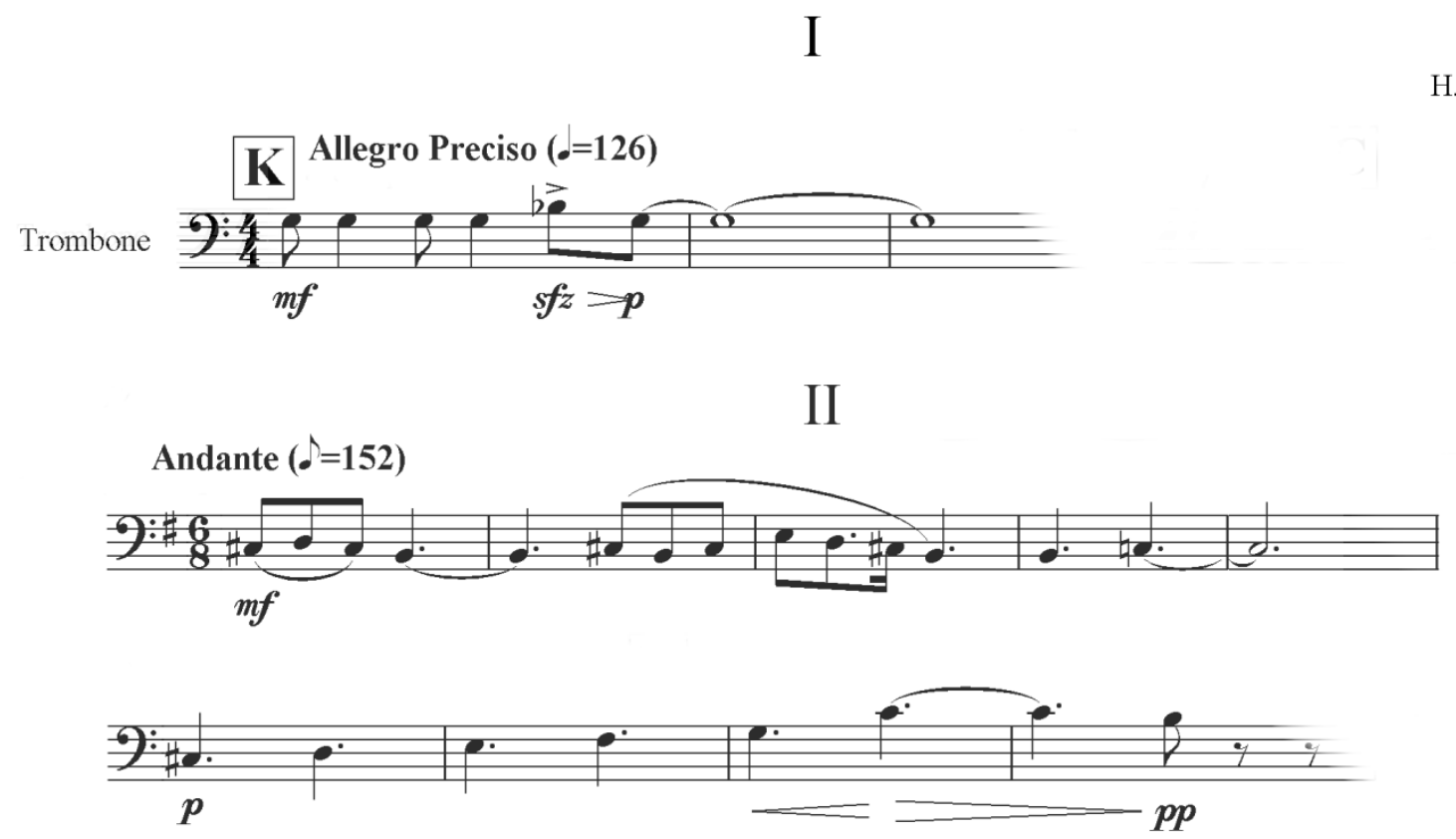

\section{III}

Allegro nom troppo
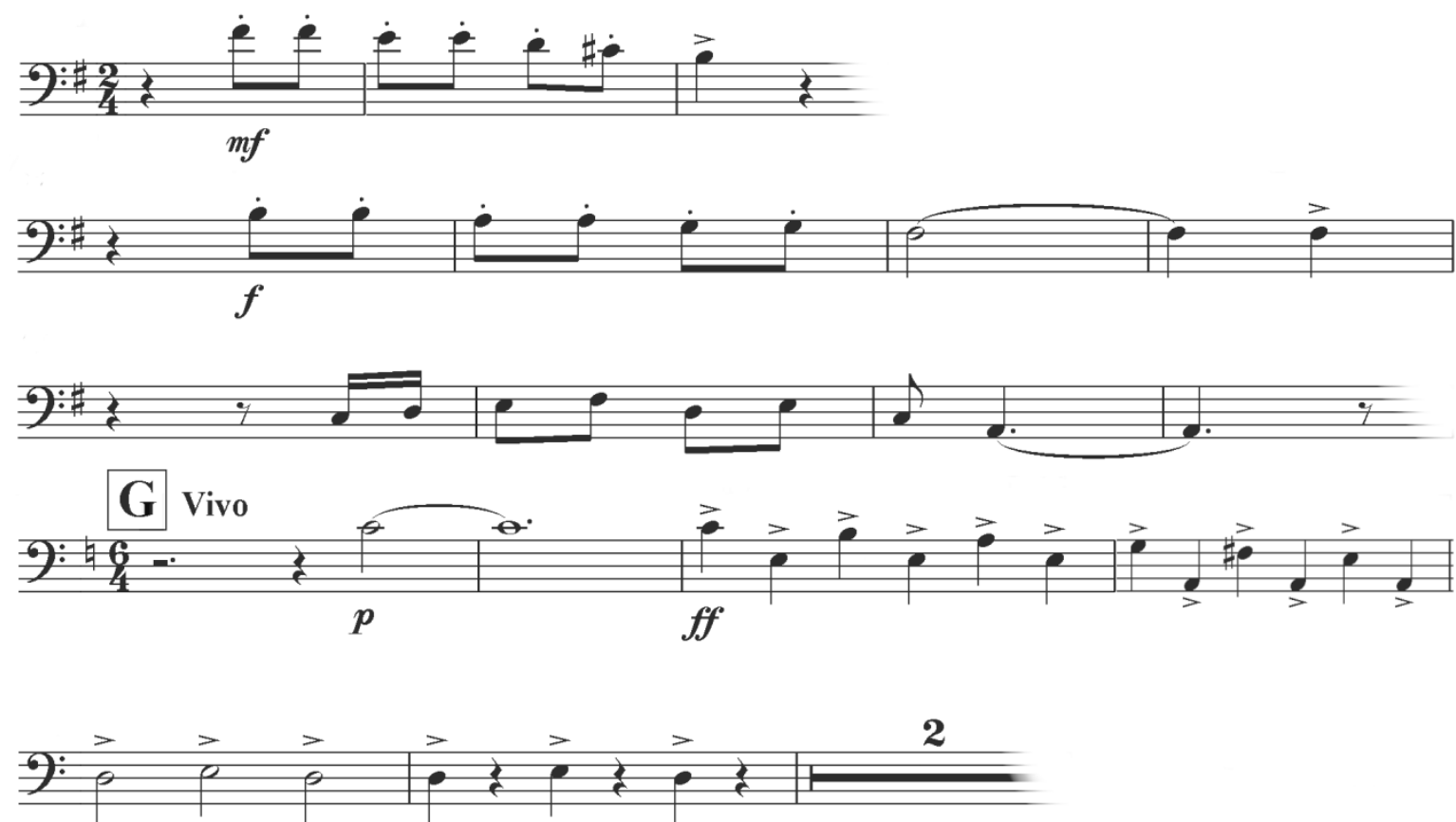
Trombone

\section{CONCERTO $\mathrm{N}^{\circ} 2$, I Movimento}

H . Vila Lobos

Allegro non Troppo d. $=84$
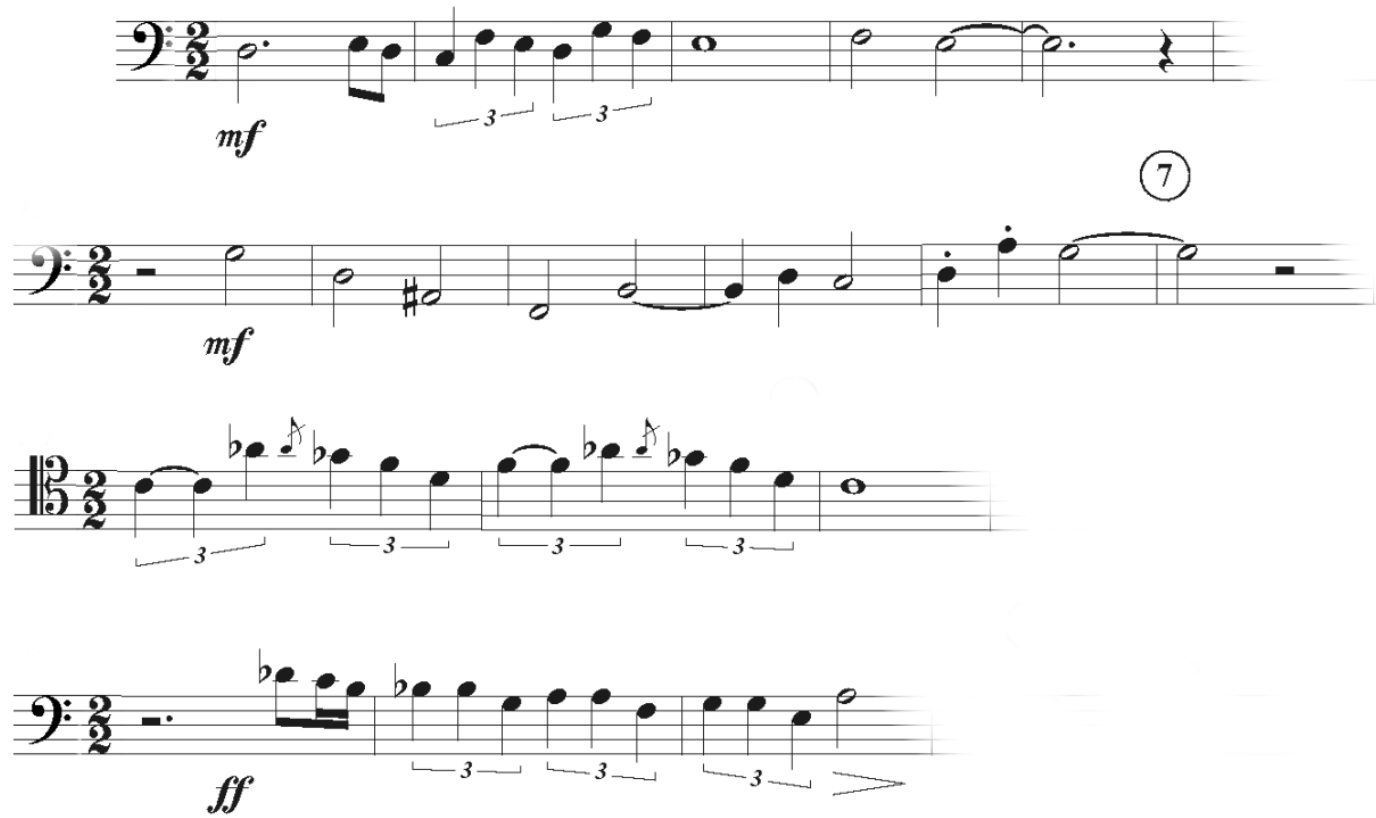

\section{Movimento}

Molto Andante Cantabile $\bullet=76$
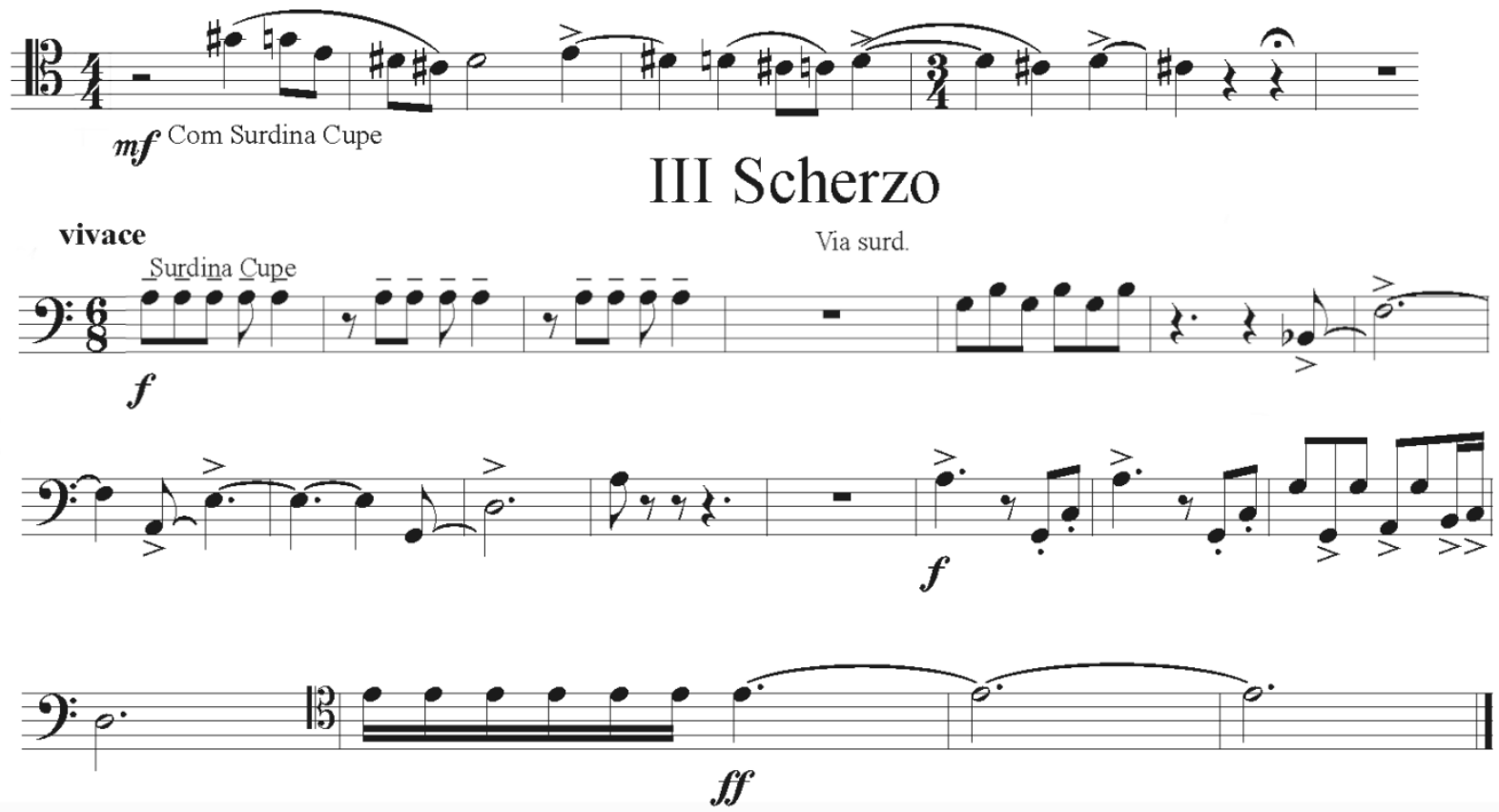
Villa-Lobos e os metais graves sinfônicos:

Um estudo dos elementos técnicos específicos

\section{CONCERTO $\mathrm{N}^{\mathrm{o}}$ 2, I Movimento}

Trombone 3
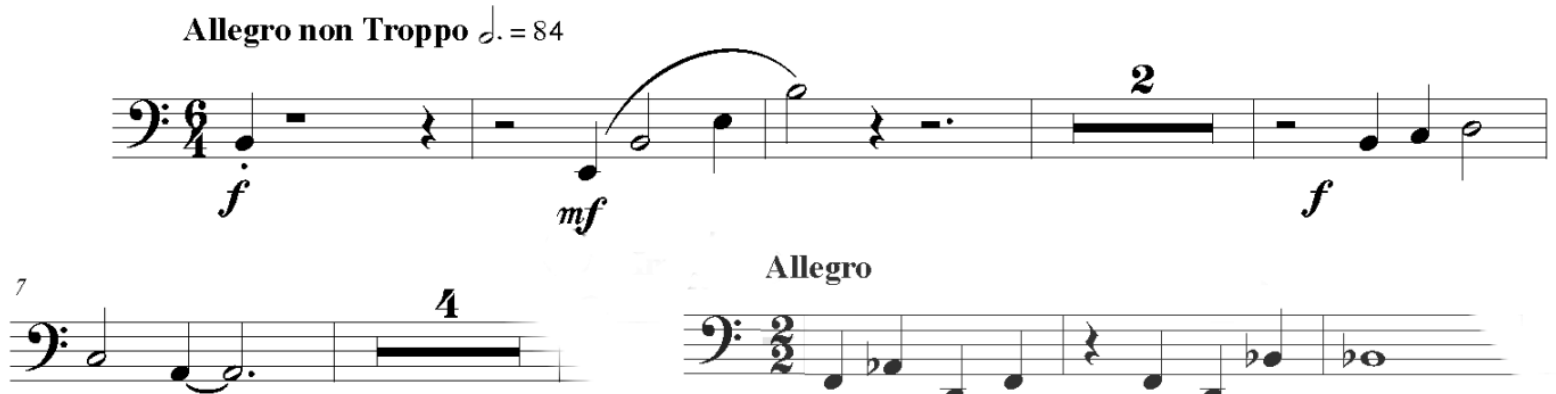

Allegro

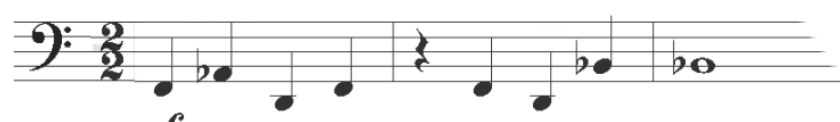

$m f$

\section{Movimento}

(4) Molto Andante Cantabile $\bullet=76$

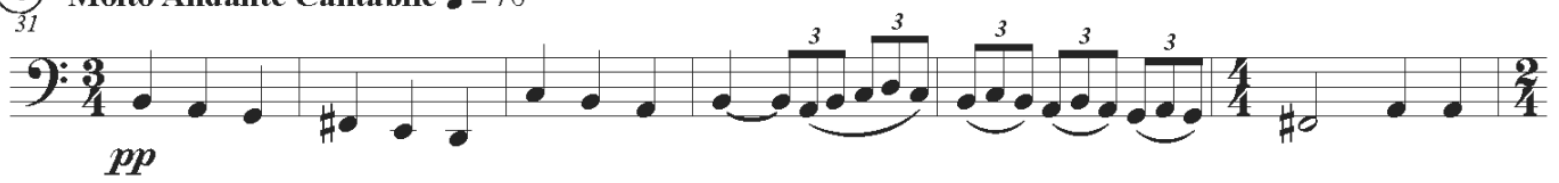

III Scherzo

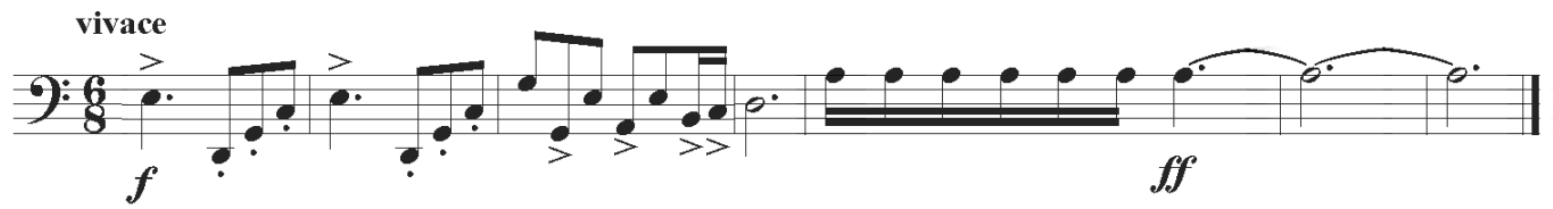


snor Trombone

Allegro non troppo
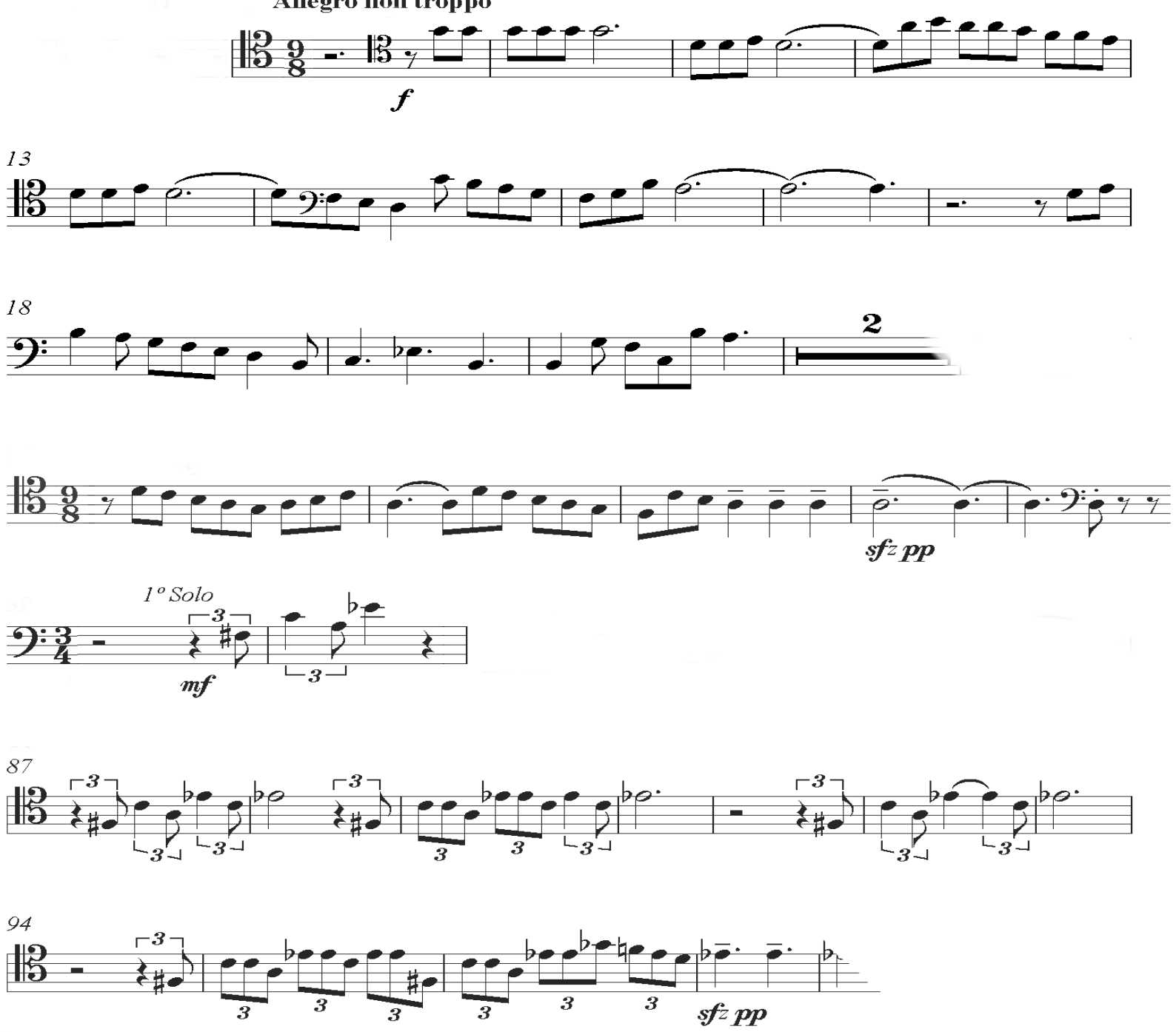

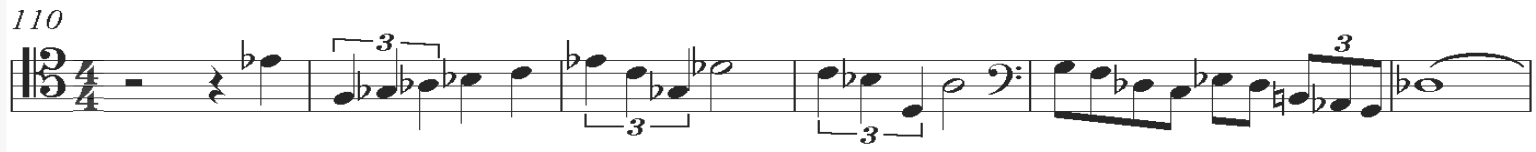
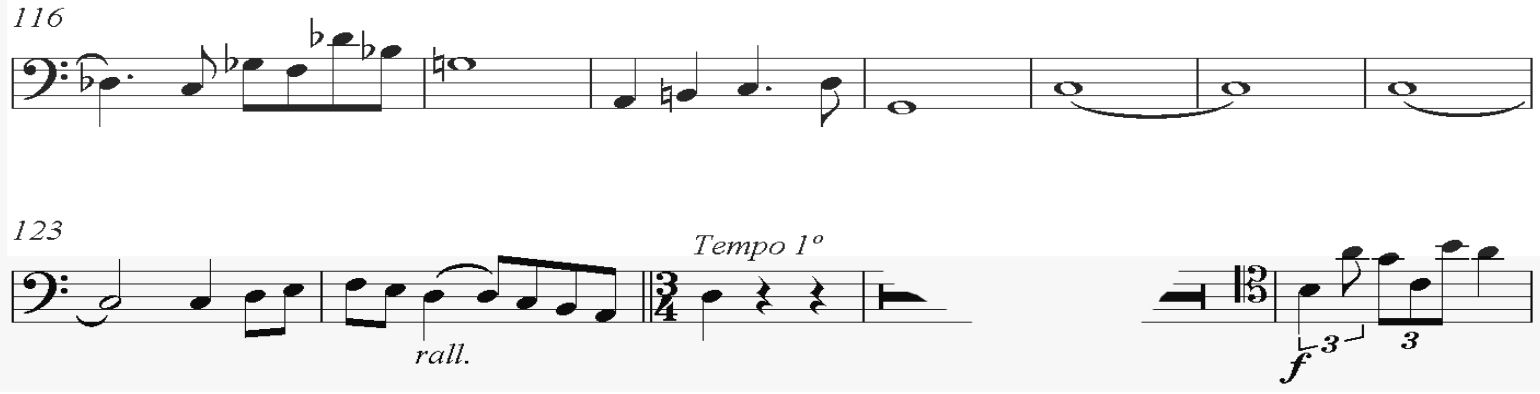

Universidade de São Paulo

Escola de Comunicação e Artes 


\section{Apêndice A}

\section{Lista das composições de Villa-Lobos para metais graves}

Abaixo encontraremos uma lista das composições que contém metais graves em sua orquestração, ordenadas alfabeticamente. Os metais graves estão presentes em 135 peças de Villa-Lobos. A divisão por gênero pode ser conferida na tabela em exibição.

\section{Listagem das composições por gênero}

\begin{tabular}{|c|c|}
\hline Bachianas - 5 & $\begin{array}{l}\text { Bachianas brasileiras No. } 2 \text { (W247) } \\
\text { Bachianas brasileiras No. } 3(\mathrm{~W} 388) \\
\text { Bachianas brasileiras No. 4: } \\
\text { Bachianas brasileiras No.7: } \\
\text { Bachianas brasileiras No. } 8 \\
\end{array}$ \\
\hline Balé - 6 & $\begin{array}{l}\text { Amazonas } \\
\text { Caixinha de boas festas (W265) } \\
\text { Rudá (Ballet) } \\
\text { Uirapuru (W133) } \\
\text { Gênesis } \\
\text { Imperador Jones }\end{array}$ \\
\hline Banda - 15 & $\begin{array}{l}\text { A canôa virou (W266) } \\
\text { Brasil novo (W186) } \\
\text { Canção do operário brasileiro (W405) } \\
\text { Canto do pajé (W324) } \\
\text { Constância (W268) } \\
\text { Desfile aos heróis do Brasil (W367) } \\
\text { Lá na ponte da vinhaça (W290) } \\
\text { Na Bahia tem (W297) } \\
\text { Nesta rua (W300) } \\
\text { Ó ciranda, ó cirandinha (W301) } \\
\text { O pião (W361) } \\
\text { Pro-pax (W049) } \\
\text { Sertanejo do Brasil (W401) } \\
\text { Teresinha de Jesus (W314) } \\
\text { Vem cá, siriri (W317) }\end{array}$ \\
\hline Câmara - 6 & $\begin{array}{l}\text { Canções indígenas (W248) } \\
\text { Chôros No. } 4 \text { (W218) } \\
\text { SuiteNo.1 para orquestra de câmara } \\
\text { SuiteNo.2 para orquestra de câmara } \\
\text { Suíte sugestiva (W242) } \\
\text { Suíte (Pitoresco) W566: } 2 \text { trombones, tuba }\end{array}$ \\
\hline Choros - 7 & $\begin{array}{l}\text { Chôros No. } 3 \text { (W206) } \\
\text { Chôros No. } 6 \text { (W219) } \\
\text { Chôros No. } 8 \text { (W208) } \\
\text { Chôros No. } 9 \text { (W232) } \\
\text { Chôros No. } 10(\mathrm{~W} 209) \\
\text { Chôros No. } 11 \text { (W228) } \\
\text { Chôros No. } 12 \text { (W233) }\end{array}$ \\
\hline
\end{tabular}




\begin{tabular}{|c|c|}
\hline Cinema - 1 & Floresta do Amazonas (W118) \\
\hline Concertante - 13 & $\begin{array}{l}\text { Concerto Grosso } \\
\text { Concerto para Harmônica e orquestra } \\
\text { Concerto para Harpa e orquestra } \\
\text { Concerto para Piano No.1 } \\
\text { Concerto para Piano No.2: } \\
\text { Concerto para Piano No.3: } \\
\text { Concerto para Piano No.4: } \\
\text { Concerto para Piano No.5: } \\
\text { Concerto para violão } \\
\text { Concerto para violoncelo e orquestra No.2 } \\
\text { Fantasia para Cello e Orquestra } \\
\text { Momoprecoce (W240) } \\
\text { Suíte para piano e orquestra (W068) } \\
\end{array}$ \\
\hline Sinfonia - 13 & $\begin{array}{l}\text { Sinfonia No.1, Op. } 112(\mathrm{~W} 114) \\
\text { Sinfonia No.2, Op. } 160 \text { (W132) } \\
\text { Sinfonia No.3 (W152) } \\
\text { Sinfonia No.4 (W153) } \\
\text { Sinfonia No.6: } \\
\text { Sinfonia No.7 } \\
\text { Sinfonia No.8 } \\
\text { Sinfonia No.9 } \\
\text { Sinfonia No.10 (ameríndia) } \\
\text { Sinfonia No.11 } \\
\text { Sinfonia No.12 } \\
\text { SinfoniettaNo.1 (W115) } \\
\text { SinfoniettaNo.2 }\end{array}$ \\
\hline Ópera - 6 & \begin{tabular}{|l|} 
Izaht $($ W055) \\
A menina das nuvens \\
Magdalena \\
Magdalena (SuiteNo.1) \\
Magdalena (Suite No.2) \\
Yerma: 3 trombones, tuba (1955-56).
\end{tabular} \\
\hline Orquestral - 47 & $\begin{array}{l}\text { Abertura de l'homme tel (W508) } \\
\text { Alvorada na floresta tropical } \\
\text { Big Ben } \\
\text { Canção da imprensa } \\
\text { Canções típicas brasileiras (W158) } \\
\text { Dança dos mosquitos (W187) } \\
\text { Dança frenética (W144) } \\
\text { Danses africaines (W107) } \\
\text { Descobrimento do Brasil (SuiteNo.1 - W377) } \\
\text { Descobrimento do Brasil (SuiteNo.2 - W378) } \\
\text { Descobrimento do Brasil (SuiteNo.3 - W379) } \\
\text { Descobrimento do Brasil (SuiteNo.4 - W380) } \\
\text { Élégie (W094) } \\
\text { Epigramas irônicos e sentimentais (W173) } \\
\text { Erosão } \\
\text { Fantasia de movimentos mistos (W174) } \\
\text { Fantasia e fuga no.6 (W394) } \\
\text { Fantasia em três movimentos } \\
\text { Floresta do Amazonas } \\
\text { Folia de um bloco infantil (W146) } \\
\end{array}$ \\
\hline
\end{tabular}




\begin{tabular}{|c|c|}
\hline & $\begin{array}{l}\text { Francette e Piá } \\
\text { Historiettes (W164) } \\
\text { Introdução aos chôros (W239) } \\
\text { Invocação em defesa da pátria } \\
\text { Louco (W079) } \\
\text { Madona } \\
\text { Manduçarará: } 4 \text { trombones, tuba (1940) } \\
\text { Marquesa de Santos (W395): } 1 \text { trombone (1938) } \\
\text { Marcha solene No.6 (W167) } \\
\text { Marcha religiosa No.3 (W138) } \\
\text { Martírio dos insetos (W213) } \\
\text { Memorare (W128) } \\
\text { Naufrágio de Kleônicos (W111) } \\
\text { Modinhas e canções: } 1 \text { trombone, tuba } \\
\text { Modinhas e canções: } 2 \text { trombones, tuba (1939) } \\
\text { New York Skyline Melody (W408): } 1 \text { trombone (1939) } \\
\text { Odisséia de uma raça: } 3 \text { trombones, tuba (1953) } \\
\text { Papagaio do moleque (W302) } \\
\text { Prelúdio e fuga no.6 (W398): } 2 \text { trombones, tuba (1938) } \\
\text { Rudepoêma (W310) } \\
\text { Saudade da juventude: } 2 \text { trombones, tuba (1940) } \\
\text { Serestas (W215) } \\
\text { Tédio de alvorada (W116) } \\
\text { Tocata e fuga no.3 (W404) } \\
\text { Três poemas indígenas (W224) } \\
\text { Verde velhice (W189) } \\
\text { Vidapura (W155) }\end{array}$ \\
\hline Voz e orquestra - 16 & $\begin{array}{l}\text { Cair da tarde (W545) } \\
\text { Canção da folha morta (W571) } \\
\text { Canção das águas claras (W529) } \\
\text { Canção do poeta do século XVIII (W564) } \\
\text { Canções de cordialidade } \\
\text { Eu te amo } \\
\text { Hino à vitória (W429) } \\
\text { Magnificat alleluia: } 1 \text { trombone, tuba } \\
\text { Melodia sentimental (W555): } 4 \text { trombones, tuba } \\
\text { Pátria (W348): } 3 \text { trombones, tuba (1934). } \\
\text { Poema de Itabira: } 4 \text { trombones, tuba (1943) } \\
\text { Poema de palavras: } 2 \text { trombones, tuba } \\
\text { Samba classico: } 4 \text { trombones, tuba (1950) } \\
\text { Sete vezes (W552): } 2 \text { trombones, tuba } \\
\text { Veleiros (W561): } 4 \text { trombones, tuba } \\
\text { Xangô (W591): } 1 \text { Trombone }\end{array}$ \\
\hline
\end{tabular}

Quadro 15 - Listagem das composições por gênero 


\section{Listagem por gênero e suas porcentagens}

Abaixo encontraremos um quadro com o numeral geral para cada gênero das composições que contém metais graves em sua orquestração. A ordenação desses gêneros está em forma decrescente.

\begin{tabular}{|c|c|c|}
\hline GÊNERO & $\mathrm{n}^{\circ}$. de peças & porcentagem \\
\hline Orquestral & $\mathbf{4 7}$ & $\mathbf{3 4 , 8 1}$ \\
\hline Voz e orquestra & $\mathbf{1 6}$ & $\mathbf{1 1 , 8 5}$ \\
\hline Banda & $\mathbf{1 5}$ & $\mathbf{1 1 , 1 1}$ \\
\hline Concertante & $\mathbf{1 3}$ & $\mathbf{9 , 6 3}$ \\
\hline Sinfonia & $\mathbf{1 3}$ & $\mathbf{9 , 6 3}$ \\
\hline Choros & $\mathbf{7}$ & $\mathbf{5 , 1 9}$ \\
\hline Balé & $\mathbf{6}$ & $\mathbf{4 , 4 4}$ \\
\hline Câmara & $\mathbf{6}$ & $\mathbf{4 , 4 4}$ \\
\hline Ópera & $\mathbf{6}$ & $\mathbf{4 , 4 4}$ \\
\hline Bachianas & $\mathbf{5}$ & $\mathbf{3 , 7 0}$ \\
\hline Cinema & $\mathbf{1}$ & $\mathbf{0 , 7 4}$ \\
\hline & & \\
\hline Total $=>$ & $\mathbf{1 3 5}$ & \\
\hline
\end{tabular}

Quadro 16 - Numeral geral para cada gênero das composições

Pode-se concluir que o trombone é um instrumento essencialmente Orquestral, na visão de Villa-Lobos, e as soluções interpretativas foram grafadas como proposição no decorrer deste trabalho. 


\section{Listagem das composições por ordem alfabética}

\section{A}

Abertura de l'hommetel: 1 trombone (1952)

A canôa virou (W266): trombone, barítono, 2 trombones-contrabaixo (Mi b eSi b - 1932 Banda).

Alvorada na floresta tropical: 3 trombones, tuba (1953)

Amazonas (W118): 3 trombones, tuba (1917 - Orquestral)

1. Contemplação do Amazonas

2. Ciúme do Deus dos ventos

3. O espelho da jovem índia

4. Traição do Deus dos ventos

5. A prece da jovem índia

6. Dança ao encantamento das florestas

7. A dança sensual da jovem índia

8. Região dos monstros

9. A marcha dos monstros

10. A alegria da índia

11. Um monstro se destaca

12. A ânsia do monstro

13. O espelho enganador

14. A descoberta

15. O abismo

16. O precipício.

A menina das nuvens: 1 trombone, tuba

B

Big Ben: 2 trombones, tuba (1948)

Bachianas brasileiras No. 2 (W247): 1 trombone (1930 - Orquestral).

1. Prelúdio (O canto do capadócio)

2. Ária (O canto da nossa terra)

3. Dansa (Lembrança do sertão)

4. Toccata (O trenzinho do caipira). 
Bachianas brasileiras No. 3 (W388): 4 trombones, tuba (1938)

1. Prelúdio (Ponteio)

2. Fantasia (Devaneio)

3. Ária (Modinha)

4. Tocata (Pica-Pau)

Bachianas brasileiras No. 4: 2 trombones, tuba (1941)

Bachianas brasileiras No.7: 4 trombones, tuba (1942)

1. Prelúdio (Ponteio)

2. Giga (Quadrilha caipira)

3. Tocata (Desafio)

4. Fuga (Conversa)

Bachianas brasileiras No.8: 4 trombones, tuba (1944)

1. Prelúdio

2. Ária (Modinha)

3. Tocata (Catira batida)

4. Fuga

Brasil novo (W186): Tuba barítono, Trombone, Tuba-tenor, 2 Trombones-contrabaixo (Mi b eSi b - 1922 - Banda).

Cair da tarde: 3 trombones, tuba.

Caixinha de boas festas (W265): 2 trombones, tuba (1932 - Ballet).

Canção da folha morta: 1 Trombone

Canção da imprensa: 2 trombones, tuba (1940)

Canção das águas claras: 2 trombones, tuba (1956)

Canção do operário brasileiro (W405): 1 trombone, bombardino, eufônio, trombonecontrabaixo (Mib, Sib), (1939)

Canção do poeta do século XVIII: 2 trombones, tuba

Canções indígenas (W248): 1 trombone (1930 - Orquestra de Câmara). 
Canções de cordialidade: 3 trombones (1945)

1. Feliz aniversário

2. Boas-festas

3. Feliz ano novo

4. Boas-vindas

Canções típicas brasileiras (W158): 1 trombone (1919/35 - Orquestral + voz solo)

1. Mokocê-cê-maká

2. Nozani-ná

3. Xangô

4. Estrela é lua nova

5. Itabaiana

6. Onde o nosso amor nasceu

7. Xangô

8. Estrela é lua nova.

Canto do pajé (W324): 1eufônio, 2 trombones-contrabaixo (Mi b and Si b -1933 - Banda)

Chôros No. 3 (W206): 1 trombone (1925 - Coral).

Chôros No. 4 (W218): 1 trombone (1926 - Quarteto).

ChôrosNo.6 (W219): 4 trombones, tuba (1926 - Orquestral).

Chôros No. 8 (W208): 3 trombones, tuba (1925 - Orquestral).

ChôrosNo.9 (W232): 4 trombones, tuba (1929 - Orquestral).

Chôros No. 10 (W209): 2 trombones (1925 - Orquestral).

ChôrosNo.11 (W228): 4 trombones, tuba (1928 - Orquestral).

ChôrosNo.12 (W233): 4 trombones, tuba (1929 - Orquestral).

Concerto grossoConcertino: 4 trombones, 2 trombones baixo, tuba

Concerto para Harmonica e orquestra: 1 trombone (1955)

Concerto para Harpa e orquestra:2 trombones, tuba (1953)

Concerto para Piano No.1: 4 trombones, tuba (1945)

Concerto para Piano No.2: 4 trombones, tuba (1948)

Concerto para Piano No.3: 2 trombones, tuba (1952-7)

Concerto para Piano No.4: 2 trombones, tuba (1952) 
Concerto para Piano No.5: 3 trombones, tuba (1954)

Concerto para violão: 1 trombone (1951)

Concerto para violoncelo e orquestra No.2: 3 trombones, tuba, (1953)

Constância (W268): barítono, trombone, 2 trombones-contrabaixo (Mi b e Si b - 1932 Banda).

$\mathrm{D}$

Dança dos mosquitos (W187): 4 trombones, tuba (1922 - Orquestral).

Dança frenética (W144): 3 trombones, tuba, timpani (1919 - Orquestral).

Danses africaines (W107): 3 trombones, tuba (1916 - Orquestral).

Descobrimento do Brasil (SuiteNo.1 - W377): 3 trombones, tuba (1937)

1. Introdução (Largo)

2. Alegria

Descobrimento do Brasil (SuiteNo.2 - W378): 3 trombones, tuba (1937)

1. Impressão moura (Canção)

2. Adágio sentimental

3. Cascavel

Descobrimento do Brasil (SuiteNo.3 - W379) 4 trombones, tuba 1937

1. Impressão ibérica

2. Festa nas selvas

3. Ulalocê (Visão dos navegantes)

Descobrimento do Brasil (SuiteNo.4 - W380): 4 trombones, tuba (1937)

1. Procissão da cruz

2. Primeira missa no Brasil

Desfile aos heróis do Brasil (W367): 3 trombones, eufônio, trombone-contrabaixo (Si b ), barítono (1936).

$E$

Élégie (W094): 2 trombones, tuba (1915 - Orquestral).

Epigramas irônicos e sentimentais (W173): 2 trombones (1921 - Orquestral). 
Erosão: 4 trombones, tuba (1950)

Eu te amo: 2 trombones, tuba (1956)

$\mathrm{F}$

Fantasia de movimentos mistos (W174): 2 trombones, tuba (1921 - Orquestral)

1. Alma convulsa

2. Serenidade

3. Contentamento.

Fantasia e fuga no.6 (W394): 2 trombones, tuba (1938)

Fantasia em três movimentos: 4 trombones, 2 trombones baixo, tuba

Fantasia para Cello e Orquestra: 3 trombones, tuba (1945)

Floresta do Amazonas: 4 trombones, tuba

Folia de um bloco infantil (W146): trombone (1919- Orquestral + solo).

Francette e Piá: 1 trombone

G

Gênesis: 3 trombones, tuba (1954)

$\mathrm{H}$

Hino à vitória: 4 trombones, tuba (1941)

Historiettes (W164): 3 trombones, tuba (1920 - Orquestral + solo voz)

1. Solitude

2. Le petitpeloton de fil

3. Hermione et les bergers

4. Car vite s'écoule la vie

5. Le marché. 
Imperador Jones: 4 trombones, tuba (1956)

Introdução aos chôros (W239): 4 trombones, tuba (1929 - Orquestral).

Invocação em defesa da pátria: 2 trombones, tuba (1943)

Izaht (W055): 4 trombones, tuba (1912/4 - Ópera).

$\mathrm{L}$

Lá na ponte da vinhaça (W290): barítono, trombone, eufônio, 2 trombones-contrabaixo (Mi b e Si b - 1932 - Banda).

Louco (W079): 3 trombones, tuba (1917 - Orquestral + voz solo).

M

Madona: 4 trombones, tuba (1945)

Magdalena: 2 trombones, tuba (1947)

Magdalena (SuiteNo.1): 3 trombones, tuba (1947)

1. My Bus and I

2. Scene of Paris

3. Food for Thought

Magdalena (Suite No.2): 3 trombones, tuba (1947)

1. The Singing Tree

2. The Emerald Song

3.Valse d'Espagne

Magnificat alleluia: 1 trombone, tuba

Manduçarará: 4 trombones, tuba (1940)

Marcha solene No.6 (W167): 3 trombones (1920 - Orquestral).

Marcha religiosa No.3 (W138): 3 trombones (1918 - Orquestral). 
Marquesa de Santos (W395): 1 trombone (1938)

1. Lundu

2. Valsinha brasileira

3. Gavota-choro

Martírio dos insetos (W213): 2 trombones, tuba (1925 - Orquestral)

1. A cigarra no inverno

2. O vagalume na claridade

3. Mariposa na luz (1916).

Melodia sentimental: 4 trombones, tuba

Memorare (W128): 2 trombones (1917 - Orquestral).

Modinhas e canções: 1 trombone, tuba

1. Pobre peregrino

2. Nésta rua

3. Manda tiro, tiro lá

Modinhas e canções: 2 trombones, tuba (1939)

1. Canção do marinheiro

2. Lundu da Marquesa de Santos

3. Cantilena

4. Remeiro de São Francisco

5. Nhapopê

6. Evocação

7. A gatinha parda

Momoprecoce (W240): 1 trombone (1929 - Orquestral).

$\mathrm{N}$

Na Bahia tem (W297): 1 trombone, barítono, 2 trombones-contrabaixo (Si b e Mi b - 1932 Banda).

Naufrágio de Kleônicos (W111): 4 trombones, tuba (1916 - Orquestral).

Nesta rua (W300): 1 trombone, barítono, 2 trombones-contrabaixo (Mi b e Si b - 1932 Banda).

New York Skyline Melody: 1 trombone (1939) 
Ó ciranda, ó cirandinha (W301): saxhorn, 1 trombone, 3 trombones-contrabaixo (Mi b , Si b e Fá) (1932 - Banda).

Odisséia de uma raça: 3 trombones, tuba (1953)

O pião (W361) 1 trombone, barítono, 2 trombones-contrabaixo (Mi b and Si b - 1935 Banda).

$\mathrm{P}$

Papagaio do moleque (W302): 4 trombones, tuba (1932 - Orquestral).

Pátria (W348): 3 trombones, tuba (1934).

Poema de Itabira: 4 trombones, tuba (1943)

Poema de palavras: 2 trombones, tuba

Prelúdio e fuga no.6 (W398): 2 trombones, tuba (1938)

Pro-pax (W049): Tuba-contralto, trombone, Tuba barítono (1912 - Banda).

$\mathrm{R}$

Rudá (Ballet): 4 trombones, tuba (1951)

1. Os maias

2. Os aztecas

3. Os incas

4. Os marajoaras

5. La vittoria dell' amorenel tropico

6. Epílogo

Rudepoêma (W310): 4 trombones, tuba (1932 - Orquestral). 
Samba classico: 4 trombones, tuba (1950)

Saudade da juventude: 2 trombones, tuba (1940)

1. Vida formosa

2. O ciranda, ó cirandinha

3. A gatinha parda

4. O sim

5. Mando tiro, tiro lá

6. Condessa

7. Nésta rua

8. A cotia

9. Na corda da viola

10. De flor em flor

Serestas (W215): 2 trombones, tuba (1925 - Orquestral)

1. Pobre cega

2. Canção da folha morta

3. Saudades da minha vida

4. Modinha

5. Na paz do outono

6. Cantiga do viúvo

7. Canção do carreiro

8. Abril

9. Desejo

10. Redondilha.

Sertanejo do Brasil (W401): 1 trombone, bombardino, eufônio, trombone-contrabaixo (Mi b e Si b ) (1938)

Sete vezes: 2 trombones, tuba

Sinfonia No.1, Op. 112 (W114): 3 trombones, tuba (1916 - Orquestral).

Sinfonia No.2, Op. 160 (W132): 4 trombones, tuba (1917 - Orquestral).

Sinfonia No.3 (W152): 4 trombones, tuba, fanfarra de metais(1919 - Orquestral)

1. Allegro quasi giusto (A vida e o labor)

2. Como scherzo (Intrigas e cochichos)

3. Lento e marcial (Sofrimento)

4. Allegro impetuoso (A batalha).

Sinfonia No.4 (W153): orquestra:4 trombones, tuba; banda externa: tuba-tenor, tuba-contralto, trombone-baixo, trombone-contrabaixo em Mi b , trombone-contrabaixo em Si b ;(1919 Orquestral). 
Sinfonia No.6: 4 trombones, tuba (1944)

Sinfonia No.7: 4 trombones, tuba (1945)

Sinfonia No.8: 4 trombones, tuba (1950)

Sinfonia No.9: 4 trombones, tuba (1952)

Sinfonia No.10 (ameríndia): 4 trombones, tuba (1952)

Sinfonia No.11: 4 trombones, tuba (1955)

Sinfonia No.12 (W539): 4 trombones, tuba (1957)

SinfoniettaNo.1 (W115): 2 trombones (1916 - Orquestral).

SinfoniettaNo.2: 2 trombones, tuba (1947)

Suíte Pitoresca: 2 trombones, tuba

SuiteNo.1 para orquestra de câmara: 2 trombones, tuba

1. Abertura (Allegro)

2. Pitoresca (Poco andantino, quasi animato)

3. Uma fuga para brincar (Allegro)

4. Pastoral

5. Dança

SuiteNo.2 para orquestra de câmara: 2 trombones, tuba (1959)

1. Lamento (Andante cantábile)

2. Scherzo (Vivace)

3. Passeio (Promenade) (Andantino quasi Allegretto)

4. Canção lírica (Poco Moderato)

5. Macumba (Evocação dos espíritos)

Suíte para piano e orquestra (W068): 2 trombones, tuba (1913 - Orquestral + solo).

Suíte sugestiva (W242): 1 trombone (1929 - Orquestra de câmara)

1. Ouverture de l'homme tel

2. Prélude, choral et funèbre (ciné journal)

3. Cloche pied au flic (comédie)

4. Le recit du peureux (drame)

5. Charlot aviateur (comique)

6. l'Enfant et le iouroupari (tragédie)

7. La marche finale. 
Tédio de alvorada (W116): 3 trombones (1916 - Orquestral).

Teresinha de Jesus (W314): barítono, 1 trombone, 2 trombones-contrabaixo (Mi b e Si b 1932 - Banda).

Tocata e fuga no.3 (W404): 2 trombones (1938)

Três poemas indígenas (W224): 4 trombones (1926 -Orquestra + Coro).

U

Uirapurú (W133): 3 trombones, tuba (1917 - Ballet).

$\mathrm{V}$

Veleiros: 4 trombones, tuba

Vem cá, siriri (W317): 1 trombone, barítono, 2 trombones-contrabaixo (Mi b e Si b - 1932 Banda).

Verde velhice (W189): 3 trombones, tuba (1922 - Orquestral).

Vidapura (W155): 2 trombones, tuba (1919 - Orquestral + Coro).

$X$

Xangô: 1 Trombone

Y

Yerma: 3 trombones, tuba (1955-56). 